

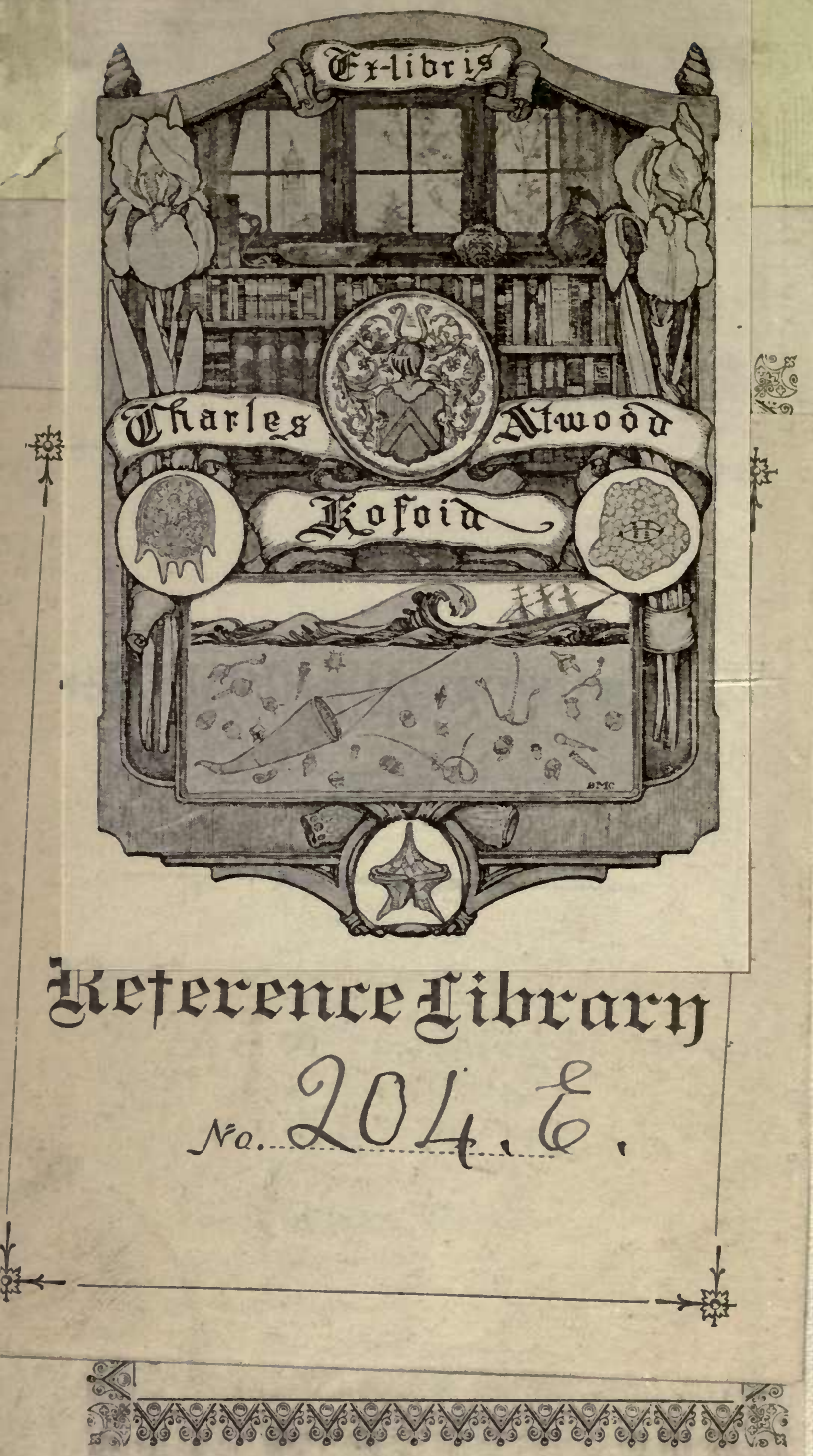




$$
204,2 .
$$




$$
\text { is }
$$

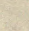




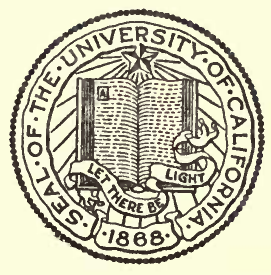

THE LIBRARY OF

\title{
THE UNIVERSITY OF CALIFORNIA
}

\author{
PRESENTED BY
}

PROF. CHARLES A. KOFOID AND MRS. PRUDENCE W. KOFOID 



\section{$M A N U A L$ \\ OF}

\section{BRITISH BOTANY,}

CONTAINING THE

FLOWERING PLANTS AND FERNS

ARRANGED. ACCORDING TO

THE NATURAL ORDERS.

BY

CHARLES CARDALE BABINGTON, M.A., F.R.S., F.L.S. ETC. ETC.

FOURTH EDITION.

WITH MANY ADDITIONS AND CORRECTIONS.

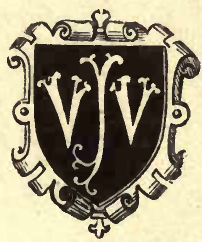

L O N D O N :

JOHN VAN VOORST, PATERNOSTER ROW. MDCCCLVI. 
PRINTED BY TAYLOR AND FRANCIS, RED LION COURT, FLEET STREET.

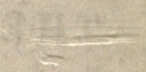




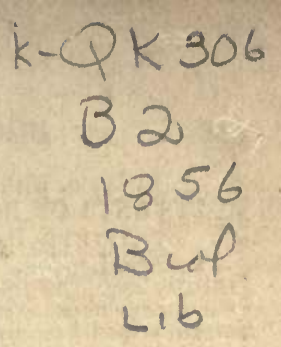

Just published, 1

\section{THE MICROGRAPHIC DICTIONARY;}

A Guide to the Examination and Investigation of the Structure and Nature of Microscopic Objects.

By Dr. Griffith and Professor Henfrey.

Illustrated by 41 Plates, each with numerous Figures, some Coloured, and 816 Woodcuts. 777 pp. 8 vo, $22: 5 s$.

"It contains an amount of well-digested and authentic information upon the wide variety of subjects it is devoted to, which is nowhere else to be found in any one work or set of works. We find it an admirable volume for reference. The articles on the subjects we are familiar with are correct and well worked up as far as they go; and the bibliographical citations at the end of each considerable article direct us to the best and latest sources of fuller information. But it is to the general student or amateur of natural history, and to the medical student, who can rarely be expected to possess a general scientific library rich in works of original investigation, that this volume will be invaluable; and to these we cordially recommend it."-Professor As A GRAY in Silliman's American Journal, March 1856.

John Van Voorst, 1 Paternoster Row. 


\section{BOOKS ON BOTANY.}

In $16 \mathrm{mo}$. with Illustrative Woodcuts, price $3 s .6 d$. THE RUDIMENTS OF BOTANY. A familiar Introduction to the Study of Plants. By Arthur Henfrey, F.R.S., F.L.S., Professor of Botany in King's College, London.

"Admirably adapted for general use in Collegiate Institutions, and, indeed, for all those who are commencing the study of Botany."-Pharmaceutical Journal.

"Designed to furnish the beginner with a simple and practical introduction to the study of plants, and admirably adapted for their purpose."-Medico-Chirurgical Review.

"Written in simple language, so as to be easily understood by those who are totally without botanical knowledge."-Annals of Natural History.

\section{By the same Author.}

OUTLINES OF STRUCTURAL AND PHYSIOLOGICAL BOTANY. With 18 plates, fcap. 8 vo. 10 s. $6 d$.

A SET OF SIX COLOURED DIAGRAMS ILLUSTRATIVE OF THE RUDIMENTS OF BOTANY; for Schools and Lectures, price 158.

VEGETATION OF EUROPE, its Conditions and Causes. With a Map. Foolscap 8ro. $5 s$.

PRINCIPLES OF THE ANATOMY AND PHYSIOLOGY OF THE VEGETABLE CELL. By Hugo Von MoHL. Translated, with the Author's permission, by Professor Henfrey. 8vo. with an lllustrative Plate and numerous Woodcuts, 7s. $6 d$.

"It is an invaluable treatise, extremely weil translated."-The Gardener's Chronicle.

ON THE GROWTH OF PLANTS IN CLOSELY GLAZED CASES. By

N. B. WARD, F.R.S., F.L.S. Second Edition, post 8 vo. price $6 s$. illustrated.

"The great beauty of the vegetation in Ward's Cases, and their real use, which is becoming daily more and more acknowledged, render a history of this curious invention, and remarks as to its various modes of use, at once valuable and desirable. Hence the entertaining volume before us." -The Guardian.

WALKS AFTER WILD FLOWERS; or, The Botany of the Bohereens. By Richard Dotwden (Richard). Foolscap 8vo. price 4s. $6 d$.

"His volume is redolent of genius throughout, and is certainly one of the most charming works on Botany we have ever met with." - English Review.

A MANUAL OF THE BRITISH MARINE ALGE; containing Generic and Specific Descriptions of all the known British Species of Sea-weeds. With Plates to illustrate all the Genera. By W. H. HARvEY, M.D., M.R.I.A., Keeper of the Herbarium of the University of Dublin, and Professor of Botanyto the Royal Dublin Society. In 8 vo. price 21s. (coloured copies, $£ 111$ s. 6d.)

THE SEA-WEED COLLECTOR'S GUIDE; containing Plain Instructions for Collecting and Preserving, and a List of all the known Species and Localities in Great Britain. By J. Cocks, M.D., Devonport. Fcap. 8vo. 2s.6d.

a Historiy of bRitish forest trees. By Prideaux John Selby of Twizell, Esq. With nearly 200 engravings, price $28 s$.

TERRA LINDISFARNENSIS. The Natural History of the Eastern Borders. By George Johrston, M.D. \&c. \&c. This volume embraces the Topography and Botany; and gives the Popular Names and Uses of the Plants, and the Customs and Beliefs which have been associated with them. 8vo. 10s. $6 d$.

"If any one should ask for what class of readers this volume is adapted, we answer, that, with exception of the very cold-hearted and worldly, it is difficult to say for whom it is not adapted." -Scottish Ecclesiastical Journul.

JoInN VAN Voorst, 1 Paternoster Row. 


\section{P R E F A C E.}

IN this work it has been the Author's wish to adopt in all cases those names which have the claim of priority, unless good cause could be shown for a contrary proceeding, and with this object he has carefully examined nearly all the best European Floras, comparing our plants with the descriptions contained in them, and in very many cases with foreign specimens of undoubted authenticity. In the adoption of genera and species an endeavour has been made, by the examination of the plants themselres, to determine which are to be considered as truly distinct, thus, it is hoped, taking Nature as a guide, and not depending upon the authority of any name, however distinguished. Still let it not be supposed that any claim is made to peculiar accuracy, nor that the Author considers himself qualified to dictate to any student of botany, for he is well aware that there are many points upon which persons who have carefully studied 
the subject may form different conclusions from those to which he has been led.

This volume being intended as a field-book or travelling companion for botanists, it is advisable to restrict the space allotted to each species as much as possible, and accordingly the characters and observations are only such as appear to be necessary for an accurate discrimination of the plants. Synonyms have been almost wholly omitted, but usually one British and often a foreign figure of each plant is quoted. Localities are only given for new or rare plants, the existence of so complete a work as Mr. Watson's New Botanist's Guide having made it unnecessary inconveniently to swell the present volume by their introduction; but in order to convey some idea of the distribution of plants throughout the United Kingdom, the letters E., S., and I. have been appended to the descriptions of such species as have, it is believed, been only found in England, Scotland, or Ireland respectively, - all plants without such an addition and not inclosed in brackets having been observed in each of them. The descriptions of a considerable number of plants which only occur in the Channel Islands ; or, although included in our lists, there is reason to suppose have never been really detected in Britain; or have been added to our Flora by previous writers but are not now to be found; or, although decidedly naturalized, have very slender claims to be considered as aboriginal natives, are included within []; and notices of a few plants concerning which more accurate information is requisite are distinguished in a similar manner. It is hoped that by this arrangement the truly indigenous species will be clearly distinguished from those which have little or no claim to be 
considered as aboriginal or even thoroughly naturalized. The attempt to do this is necessary for two seemingly contradictory reasons; namely, the great tendency of many collectors to consider as native any plant found growing upon a spot where it is not cultivated; and the peculiar scepticism of some of our botanists concerning the claims of many local or thinly scattered species to be considered as indigenous, even when their distribution upon the European continent is not unfavourable to the belief that they may inhabit Britain. It has been recommended that the descrip. tions of these excluded species should be placed in an Appendix, but as some of them are not unlikely to be observed by collectors, it is more convenient that they should be arranged with their allies. Those who desire to obtain a complete knowledge of the distribution of our plants should consult Watson's Cybele Britannica.

A very concise Synopsis of the genera, according to the Linnæan method, is given for the convenience of those botanists who may not be quite familiar with the Natural Orders.

Dr. Lindley's Vegetable Kingdom being accessible to nearly all the readers of this little work, it has not been considered advisable to introduce detailed descriptions of the Orders; but in the preparation of the short distinctive characters the author has availed himself of that work, of Dr. Arnott's elaborate treatise contained in the Encyclopedia Britannica, of Endlicher's Genera Plantarum, Koch's Synopsis Flora Germanica, and other works.

To his botanical friends and correspondents too numerous to record here, he takes this opportunity of returning most fincere thanks for the great assistance they have rendered 
to him by the communication of valuable suggestions, observations, and specimens.

The present edition has been carefully revised, so as, if possible, to keep pace with the rapidly advancing knowledge of British plants; the descriptions of several of the more difficult groups, such as Hieracium and Carex, and the whole Order Graminea, have been remodelled.

In accordance with the wishes of several gentlemen who have favoured the author with advice, many more English names are inserted. All the genera could not be thus named owing to the absence of any recognized English terms that have been applied to them, or the sereral species possessing different names. It does not seem desirable to invent. new names for the few genera that have them not, the Latin name being usable in those cases.

The portability of the volume being one of its most valuable qualities, it has been found impossible to accord to the wishes of some young botanists by prefixing to it a short Introduction to Botany, or a Glossary of botanical terms; since sufficient space could not have been afforded to them to admit of their possessing that fulness and detail without which they would be worse than useless. Students are recommended to make themselves well acquainted with the contents of some good introductory work, such as Balfour's Class-Book of Botany, which contains a copious glossary; Henfrey's Outlines; or Gray's Botanical Text-Book; or persons totally unacquainted with the science may advantageously study Henfrey's Rudiments and Lindley's Ladies' Botany.

It is hoped that those who use this book will favour the author with information of any (even the slightest) addi- 
tion, correction or alteration that may appear to be necessary, in order that it may be employed in the preparation of a future edition, as it is only through such assistance that the Flora of an extensive country can attain to even a moderate degree of perfection.

A few terms are used in this book which may not have become familiar to botanists, and it is therefore advisable to direct attention to them and explain their meaning. This is done nearly in the words employed by Mr. Joseph Woods in the introduction to his useful Tourist's Flora.

The word Phyllaries is used for the parts in Compositce which were considered by Linnæus as the leaves of a common calyx, and by later writers as the bracts or scales of an involucre.

Botanists have used the word Joint (articulus) as signifying the point of union of two different parts, or the space between such points. Joining is here employed in the former of these senses ; and Joint is used as in common speech for the parts so joined.

In the Orchidacea the term Label is used for that appendage to the flower which was called the Terminal division of the lip in former editions of this book.

St. John's College, Cambridge,

May 1, 1856. 


\section{NATURAL ORDERS OF BRITISH PLANTS.}

Class I. Dicotyledones.

Subclass I. ANGIOSPERME.

Subdivision I. THALAMIFLORA.

Order I. RANUNCULACEßE.

II. BERBERIDACE无.

III. NYMPHZEACEXE.

IV. PAPAVERACEZE.

V. FUMARIACEZE.

VI. CRUCIFERE.

VII. RESEDACE压.

VIII. CISTACEZ.

IX. VIOLACER.

X. DROSERACEX.

XI. POLYGALACEZE.

XII. FRANKENIACEX.

XIII. ELATINACE IE.

XIV. CARYOPHYLLACEE.

XV. MALVACE无.

XVI. TILIACEE.

XVII. HYPERICACEZE.

XVIII. ACERACE压.

XIX. GERANIACE E.

$X X$. LINACEX.

XXI. BALSAMINACE压.

XXII. OXALIDACE无.

Subd. II. CALYCIFLORÆ.

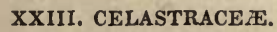

XXIV. RHAMNACEE.

XXV. LEGUMINOS 2 .
Order XXVI. ROSACE王.

XXVII. LYTHRACE压.

XXVIII. TAMARISCACE王.

XXIX. ONAGRACEE.

XXX. HALORAGACE王.

XXXI. CUCURBITACEE.

XXXII. PORTULACEE.

XXXIII. PARONYCHIACE E.

XXXIV. CRASSULACE王.

XXXV. GROSSULARIACE正.

XXXVI. SAXIFRAGACE理.

XXXVII. UMBELLIFERAE.

XXXVIII. ARALIACE无.

XXXIX. CORNACE.E.

Subd. III. COROLLIFLORE.

XL. LORANTHACEZ.

XLI. CAPRIFOLIACEZE.

XLII. RUBIACE E.

XLIII. VALERIANACEE.

XLIV. DIPSACEA.

XLV. COMPOSIT

XLVI. CAMPANULACEE.

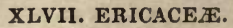

XLVIII. AQUIFOLIACEAE.

XLIX. OLEACE无.

L. APOCYNACEE.

LI. GENTIANACEEE.

LII. POLEMONIACEE.

LIII. CONVOLVULACEXE.

LIV. BORAGINACEIE.

LV. SOLANACEXE. 
Order LVI. OROBANCHACEÆE. LVII. SCROPHULARIACEE. LVIII. LABIATE.

LIX. VERBENACEE.

LX. LENTIBULARIACEE.

LXI. PRIMULACER.

LXII. PLUMBAGINACE无.

LXIII. PLANTAGINACEZE.

Subd. IV. MONOCHLAMYDEE LXIV. AMARANTHACE无. LXV. CHENOPODIACEE. LXVI. POLYGONACEAE. LXVII. ELIEAGNACE压. LXVIII, THYMELACEA. LXIX. SANTALACEF. LXX. ARISTOLOCHIACEAE. LXXI. EMPETRACE死. LXXII. EUPHOREIACE E. LXXIII. CERATOPHYLLACER. LXXIV. CALLITRICHACEX. LXXV. URTICACE王.

LXXVI. ULMACEE. LXXVII. AMENTIFER在.

Subclass II. GYMNOSPERMÆE. LXXVIII. CONIFER在.

Class II. Monocotyledones. Subdivision I. DICTYOGENE. LXXIX. TRILLIACEE. LXXX. DIOSCOREACEA.
Subdivision II. FLORID E.

LXXXI. HYDROCHARIDACEÆ. LXXXII. ORCHIDACEE. LXXXIII. IRIDACEXE. LXXXIV. AMARYLLIDACEE. LXXXV. ASPARAGACE压. LXXXVI. LILIACEEE. LXXXVII. COLCHICACEIE. LXXXVIII. ERIOCAULACE E. LXXXIX. JUNCACEA.

XC. ALISMACE正.

XCI. TYPHACEX. XCII. ARACEXE.

XCIII. LEMNACER.

XCIV. POTAMOGETONACEE. XCV. NAIADACE $Z$.

Subd. III. GLUMIFER E.

XCVI. CYPERACEE.

XCVII. GRAMINEA.

Class III. Cryptogamea.

XCVIII. EQUISETACEE. XCIX. FILICES.

C. MARSILEACEE.

CI. LYCOPODIACEZE.

- CII. CHARACE EE. 


\section{ABBREVIATIONS.}

In the descriptions.

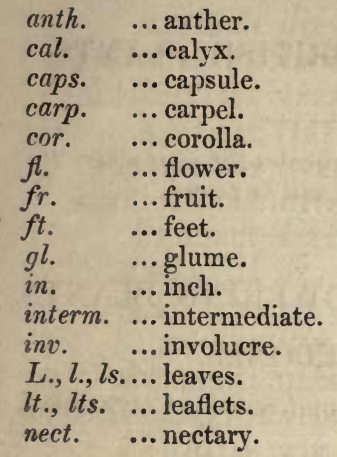

Books.

A.N.H. ... Annals of Natural History.

E.B. ... English Botany.

E.B.S. ... Supplement to E. B. G.F.G. ... Nees von Esenbeck's Genera Plantarum Floræ Germanicæ.

$H$. ... Hoppe, in Sturm's Deutschlands Flora.

N. ... Newman's History of British Ferns, ed.2.

P. $\quad$... Parnell's Grasses of Britain.

R. ... Reichenbach'sIcones Floræ Germanicæ.

R. I. ... Reichenbach'sIconographia Botanica.

Schk. ... Schkuhr's Riedgräser.

St. $\quad$... Sturm's Deutschlands Flora.
pan. $\quad .$. panicle.
ped. ... peduncle.
pet. ... petal.
phyll. ...phyllary.
segm. ... segment.
sep. ... sepal.
st. $\quad$... stem.
stam. ... stamen.
stig. ... stigma.
stip. $\quad$... stipule.
$t$. $\quad$...plate.
term. ...terminal.
Tr. ... Tribe.
var. ...variety.

\section{Duration.}
A. ... Annual.
B. ... Biennial.
P. ... Perennial.
Sh. ... Shrub.
T. ... Tree.

\section{Native country.}

E. ... England.

S. ... Scotland.

I. ... Ireland.

†... Possibly introduced but now having the appearance of being a true native.

* ... Certainly naturalized.

!... After the name of a plant shows that an authentic specimen has been seen.

I. II. III. \&c. represent the months of flowering, viz. Jan., Feb., March, \&c.

When the Initial letter of the generic name is prefixed to that of a variety, it is intended to show that the anthor quoted considered it to be a species. 


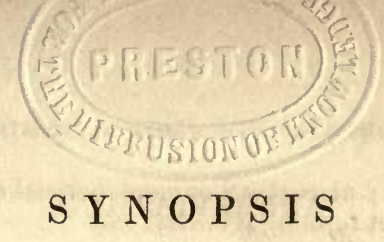

OF THE

\section{NATURAL ORDERS OF BRITISH PLANTS.}

The number prefixed to each Order indicates the page where the description of the Genera will be found.

\section{PHANEROGAME E or FLOWERING PLANTS.}

\section{Class I. DICOTYLEDONES.}

Wood of stem youngest at the circumference. Cotyledons 2 or more.

\section{Subclass I. ANGIOSPERMA.}

Seeds inclosed in seed-vessels.

Subdivision I. Fl. with a calyx and corolla, polypetalous, inferior.

A. Ovaries many, distinct or united, each bearing a style ; or solitary with 1 lateral placenta.

I. Corolla regular.

a. Sepals distinct. Stam. hypogynous.

1. Ranunculacez. Anth. opening by 2 longitudinal clefts.

13. Berberidacese. Anth. opening by a valve from the bottom to the top. Carpel solitary.

b. Sepals more or less combined below.

125. Crassulace $x$. Stam. as many as, or twice the number of, the pet., on the base of the calyx.

87. Rosacex (part). Stam. 20 or more, on the calyx.

II. Corolla irregular.

34. Resedaces. Cal. persistent. Ovary 3-lobed, 1-celled, open at the end. Stam. 10-24.

69. Leguminos As. Ovary 1-celled, closed. Fr. a pod. Stam. $10,1-2$-adelphous.

2. Ranunculace (part). Ovaries l ormore, closed, follicles. Stam. many, free. 
B. Ovary one ; placentas 2 or more, parietal or on the dissepiments, not forming a central axis.

I. Corolla regular. Pet. 4.

14. Papaveraces. Sepals 2. Stam. many.

18. Crucifera. Sepals 4. Stam. tetradynamous.

II. Corolla regular. Pet. 5.

39. Droseraceat. Sep. 5, equal, distinct, imbricate. Seeds without an arillus.

35. Cistace ax. Sep. 5, distinct; 3 inner with a twisted æstivation; 2 outer smaller or wanting. Seeds without an arillus.

115. Tamariscacea. Sep. 5, combined below. Seeds comose.

III. Corolla regular. Pet. many.

13. Nyмрнжасеж. Pet. gradually passing into the stamens.

IV. Corolla irregular.

16. Fumariaces. Sep. 2 or 0 . Stam. 6 , in two bundles.

36. Vrolacede. Sep. 5. Stam. 5; filaments free at the base.

C. Ovary 1 ; placentas central.

I. Estivation of calyx valvate or with distant lobes.

56. Malvacea. Stam. monadelphous.

58. Trliaces. Stam. distinct, hypogynous.

69. RHAMNACEA. Stam. distinct, opposite the pet. and equalling them in number, perigynous.

115. LYTHRACEA. Stam. distinct, alternating with the pet. or twice as many.

II. Estivation of calyx imbricate. Cal. and cor. irregular.

67. Balsaminaces.

III. Estivation of gamosepalous calyx imbricate. Cor. regular.

87. Rosace a (Tr. Amygdaleæ). Fruit a drupe. Stam. epigynous.

42. Caryophyllace Stam. hypogynous.

IV. Estivation of cal. imbricate; sep. distinct or slightly connected below. Cor. regular.

* Ovary 1-celled.

121. Portulacex. Sep. 2. Stam. opposite the petals.

43. Caryophy llaceas (Subord. Alsineæ). Sep. 3-5. Stam. 10 or fewer, opposite the sepals. Stipules 0.

122. Paronychiaceas. Sep. $3-5$. Stam 5, opposite the sepals. Stipules present. 
** Ovary many-celled. Stam. polyadelphous.

59. HYPERICACEA.

*** Ovary many-celled. Stam. monadelphous.

66. Linaceas. Ovary with $4-5$ complete and $4-5$ incomplete dissepiments.

67. OxALIDACEA. Ovary 5-celled; cells many-seeded.

62. Geraniacede. Ovary 5-celled; cells 1-seeded.

**** Ovary many-celled. Stam. free. Style 1.

62. Acerace e. Stam. usually 8. Pet. 5. Fr. winged, separating into 2 capsules.

289. Empetraces. Stam. 3. Pet. 3. Fr. fleshy.

41. Frankeniaceze. Stam. 5 or more. Pet. 5. Caps. 3valved.

68. Celastraceze. Stam. and pet. 4-5, inserted in an hypogynous disk.

211. Ericacex (Tr. Pyroleæ and Monotropeæ). Stam. 10. Hypogynous disk 0 .

***** Ovary many-celled. Stam. free. Styles 3-5.

41. Elatinacea. Pet. 3-5. Stam. 3-5 or 6-8.

Subdivision II. Fl. with a calyx and corolla, polypetalous, superior.

A. Ovary 1-celled; placentas parietal.

128. Grossulariacese. Stam. and pet. 4-5, alternating.

B. Ovary 2-many-celled; placentas central.

a. Stamens many.

87. Rosace es (Tr. Pomeæ). Fr. a 1-5-celled pome.

$b$. Stam. as many as, and alternating with, the petals, or twice as many.

133. Umbelliferes. Styles 2, from a bifid epigynous disk. Fr. of 2 carpels pendulous from a common axis and adhering by their face.

151. Araliaces. Pet. valvate in æstivation. Fr. a berry.

152. Cornaceze. Pet. valvate in æstivation. Fr. a drupe.

116. Onagracese. Pet. imbricate or twisted in æstivation. Style 1.

129. Saxifragacke. Pet. imbricate in æstivation. Styles 2 or more. (Fl. sometimes inferior.) Caps. 2-valved.

120. Haloragace (in part). Pet. imbricate in æstivation. Styles 4. Caps. not bursting. 
C. Stam. as many as, and opposite to, the petals.

153. Loranthaces. Filaments or anthers adnate to the petals.

Subdivision III. Fl. with a calyx and corolla, gamopetalous, superior.

A. Stam. inserted in an epigynous disk.

2il. Ericace (Tr. Vaccinieæ).

B. Stam. inserted with the corolla.

208. Campanulacex. Filaments free.

121. Cucurbitacea. Stam. 5, triadelphous.

C. Stam. inserted on the tube of the corolla or between its lobes.

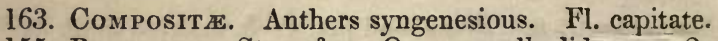

155. Rubiacez. Stam. free. Ovary usually didymous, 2-celled, with 2 ovules. Cal. simple.

159. VAlerianacez. Stam. free. Ovary with 1 perfect cell and 1 ovule. Cal. simple.

153. Ca prifoliaces. Stam. free. Ovary 3-5-celled. Cal. simple.

162. Dipsacaceze. Stam, free. Cal. double.

Subdivision IV. Fl. with a calyx and corolla, gamopetalous, inferior.

A. Ovary 4-parted, 4-seeded. Style 1. Fr. of 4 nuts. 226. Boraginacese. Stam. 5 .

249. Labiatæ. Stam. 4, didynamous, or 2.

B. Ovary simple, 1-celled, 1-seeded.

270. Plumbaginacex. Stam. 5 .

C. Ovary simple, 1-celled, many-seeded; placenta central, free, simple.

264. Lentibulariacez. Cor. irregular. Stam, 2.

265. Primulacez. Cor. regular. Stam. 4-5, opposite to the segments of the corolla.

D. Ovary simple, 1-celled, many-seeded; placenta central, free, winged.

271. Plantaginacede. Cor. 4-fid, scarious. Stam. 4.

E. Ovary simple, 2- or more-celled, with central placentas; 1-celled with a parietal placenta; or 2 ovaries with parietal placentas.

I. Stam. hypogynous, scarcely attached to the corolla, distinct. 211. Ericacex (Tr. Arbuteæ and Ericeæ). 
II. Stam. on the corolla, filaments connected.

40. Polygalacese. Filaments monadelphous, separating into 2 bundles above.

III. Stam. on the corolla, distinct.

a. Stam. 2. Cor. regular.

218. Oleaceas.

b. Stam. 2, or 4 and didynamous. Cor. irregular.

234. Oróanchaces. Ovary l-celled, with 2 or more parictal placentas, in a fleshy disk.

237. Scrophulariacex. Ovary 2-celled; placentas central. 263. Verbenacese. Ovary 2-4-celled. Capsule dividing into 4 nuts.

c. Stam. 4-5, not didynamous. Cells of the ovary with $1-2$ ovules.

218. Aquifoliaces. Cor.4-6-parted. Hypogynous disk 0. Fr. fleshy, not bursting.

224. Convolvulaces. Cor. 4-5-lobed. An hypogynous disk surrounding the ovary. Fr. a capsule, bursting.

d. Stam. 4-5, not didynamous. Cells of the ovary with many ovules.

223. Polemoniacex. Ovary 3-celled. Caps. 3-valved.

220. Gentranaces. Ovary 1-2-celled. Caps. 2-valved.

232. Solanacex. Ovary 2-celled.

290. Apocynaces. Ovaries 2, 1-celled.

Subdivision V. Perianth single or none.

A. Flowers not in catkins. Perianth superior.

288. Aristolochiacea. Stam. 6 or 12, epigynous. Ovary 3-6-celled.

120. Haloragace es (part). Stam. 1. Perianth very minute. 287. Santalaceas. Stam.4-5. Ovary 1-celled.

B. Flowers not in catkins. Perianth inferior.

I. Fr. separating into several carpels.

120. Haloragace e (part). Carp. 4, not bursting. Stam. 8. 293. Callitrichacea. Carp. 4, not bursting. Stam. 1. 289. Euphorbiaces. Carp. 3 or 2, opening with elasticity.

II. Fruit indehiscent.
$a$. Leaves with stipules.

280. Polygonace the stem. 
87. Rosace (part of Tr. Sanguisorbeæ). Stipules adnate to the petiole.

294. Urticaces. Stipules free, deciduous. Ovary 1-celled. 295. Ulmaces. Stipules free, deciduous. Ovary 2-celled.

b. Stipules 0. Fl. monœcious. Perigone 0. 293. Ceratophyllacee.

c. Stipules 0. Fl. hermaphrodite or polygamous. Embryo straight.

287. Thymelaces. Fr. a nut or drupe. Radicle superior. 286. Elafagnacese. Fr. clothed with the berry-like perigone. Radicle inferior.

d. Stipules 0. Fl. hermaphrodite or polygamous. Embryo curved or spiral.

124. Paronychiacex (Scleranthus). Fr. inclosed in the hardened calyx-tube.

274. Chenopodiacez. Cal. not hardened. Stam. from the base of the perianth.

273. Amaranthace a. Cal. not hardened. Stam. hypogynous.

C. Male flowers always in catkins.

296. Amentifere.

Subclass II. GYMNOSPERME.

Seeds quite naked.

309. Conifera.

\section{Class II. MONOCOTYLEDONES.}

Wood of stem youngest at the centre. Cotyledon single.

Subdivision I. Dictyogenæ. Leaves net-veined, deciduous. Floral envelopes whorled.

311. Trilliacez. Perianth inferior.

311. Dioscoreacea. Perianth superior.

Subdivision II. Florid A. Leaves parallel-veined, persistent. Floral envelopes whorled.

A. Ovaries several, each bearing a style or stigma.

344. Alismacese. Perianth 6-parted. Caps. not bursting. 349. Potamogetonacex. Perianth 4-parted.

335. Colchicaces. Perianth 6-7-parted. Caps. opening at the inner edge. 
B. Ovary 1, inferior.

313. OrChidaces. Stam. and style united in a central column. 312. Hydrocharidace as. Stam. free. Sep. 3. Pet. 3.

324. IrIdacese. Stam. free, 3. Anth. bursting outwards. Perianth coloured.

326. Amaryllidacez. Stam. free, 6. Anth. bursting inwards. Perianth coloured. Fr. a 3-valved capsule.

C. Ovary 1 , superior.

I. Perianth like a corolla of 6 petals.

329. Liliaceas. Fr. dry, bursting with 3 valves.

327. Asparagaceas. Fr. succulent, not bursting.

II. Perianth more or less glumaceous, or partly coloured, or none.

337. Juncaces. Perianth 6-parted. Stam. 6. Fl. bermaphrodite.

336. Eriocaulacese. Perianth 4-5-parted. Stam. 2-6. Fl. monœcious.

346. Typhacex. Fl. monœcious on a spadix. Anth. wedgeshaped, erect; filaments long.

348. Araceze. Fl. monœcious, on a spadix. Anth. ovate; filaments very short.

349. LemNaCE E. Fl. monœcious, 2 in a spath; no spadix.

355. Naiadacese. Perianth 0 . Fl. in 2 rows upon one side of a spadix, or solitary.

Subdivision III. Glumiferes. Leaves parallel-veined, persistent. Floral envelopes imbricated.

356. Cyperaceze. Leaves with entire sheaths. Anth. entire at the end.

381. Graminex. Leaves with split sheaths. Anth. notched at both ends.

\section{CRYPTOGAMEA or FLOWERLESS PLANTS.}

\section{Class III. CRYPTOGAMEA DUCTULOSE.}

414. Equisetace as. Leafless branched plants with a fistular stem, with sheaths at the joinings.

417. Filices. Leafy plants. Caps. from the veins on the underside or at the end of the leaves.

429. Marsileaces. Creeping plants with slender leaves. Caps. globular, 2-4-celled.

430. Lyco podraceas. Leafy plants. Caps. axillary, sessile. 431. Char ace es. Leafless branched plants with a fistular stem, not sheathed at the joinings. 
xviii

\section{CLASSES AND ORDERS}

\section{IN THE \\ LINNAAN ARTIFICIAL SYSTEM.}

\section{CLASSES.}

* Flowers perfect, each with stamens and pistils.

Cl. 1. Monandria, stam. 1.

2. Diandria, stam. 2.

3. Triandria, stam. 3.

4. Tetrandria, stam. 4.

5. Pentandria, stam. 5 .
Cl. 6. Hexandria, stam. 6.

7. Heptandria, stam. 7.

8. OCTANDRIa, stam. 8 .

9. ENNEANDRIA, stam. 9.

10. Decandria, stam. 10 .

11. Dodecandria, stam. 12-19.

12. ICOSANDRIA, stam. 20 or more, inserted on the calyx.

13. Polyandria, stam. 20 or more, inserted on the receptacle.

14. Didynamia, stam. $4 ; 2$ long and 2 sliort.

15. Tetradynamia, stam. $6 ; 4$ long and 2 short. Fl. cruciform.

16. Monadelphia, filaments united below in 1 set.

17. Diadelphia, filaments united in 2 sets. Fl. papilionaceous.

18. Polyadelphta, filaments united in 3 or more sets.

19. Syngenesia, stam. 5, anth. united. Fl. compound.

20. Gynandria, stamens and pistils combined.

** Stamens and pistils in different flowers.

21. Monecra, stam. and pistils on the same individual.

22. Diøera, stam. and pistils on different inclividuals.

23. Polygamia, fl perfect and unisexual on the same or on different individuals.

*** Fructification concealed.

24. Cryptogamia.

\section{ORDERS.}

The Orders in the first 13 Classes are founded on the number of styles or stigmas in each flower; viz. MoNOGYNIA, 1 style; Digynia, 2 styles; \&c. The Orders of the other Classes are explained in the Svnopsis of Genera. 


\title{
xix \\ SYNOPSIS
}

oF

\section{THE GENERA OF BRITISH PLANTS,}

\author{
ARRANGED ACCORDING TO \\ THE LINNAEAN SYSTEM.
}

The number prefixed to each Genus indicates the page where the description of the Species will be found. Where the Group is a natural one the Order is referred to for the generic characters.

\section{Class I. MONANDRIA. Stamen 1.} Order I. MONOGYNIA. Style 1.

277. Salicornia. Perianth single, tumid. Fr. included in the enlarged perianth.

120. HIPpURIs. Perianth single with a very indistinct rim crowning the ovary.

160. Centranthus. Perianth double.

(See Alchemilla, Nat. Ord. 26.)

\section{Order II. DIGYNIA.}

293. Callitriche.

\section{Class II. DIANDRIA. \\ Order I. MONOGYNIA.}

* Fl. inferior. Perianth single or none.

355. Ruppia. Perianth 0 . Nuts 4.

349. Limma. Perianth single, urn-shaped.

358. Cladicm. Perianth single, a chaffy glume. 
** Fl. injerior, monopetalous, regular. Perianth double.

219. Ligustrum. Cor. 4 -cleft. Berry with 2 cells and 4 seeds. 219. Fraxinus. Cor.4-cleft or 0. Caps. compressed, 2-celled, 2-seeded.

*** Fl. inferior, monopetalous, irregular. Perianth double. Carp. simple.

264. Pinguicula. Cal. 5-fid. Cor. ringent. Caps. 1-celled. 265. Utricularia. Cal. of 2 sepals. Cor. ringent. Caps. 1celled.

246. Veronica. Cor. 4-cleft, rotate. Caps. 2-celled.

**** Fl. inferior, monopetalous, irregular. Perianth double. Carp. 4-lobed.

254. Lycopus. Filaments simple. Anthers 2-celled.

254. Sa lvia. Filaments bifid; 1 branch barren. Anth. 1-celled.

***** Fl. superior. Perianth double.

119. Circas. Cal. of 2 sepals connected below. Cor. of 2 petals.

(Pet. 0. Salicornia, Nat. Ord.65. Fraxinus, N. O. 49. Rhynchospora, N. O. 96.)

(Pet. 4. Lepidium and Senebiera, N. O. 6.)

\section{Order II. DIGYNIA.}

390. Anthoxanthum. Perianth glumaceous. A grass.

\section{Class III. TRIANDRIA.}

\section{Order I. MONOGYNIA.}

* Fl. superior, with calyx and corolla.

159. Nat. Order 43. Valerianaceas.

** Fl. superior. Perianth single, petal-like.

324. Nat. Order 83. IrIdaces.

$$
\text { *** Fl. inferior, glumaceous, chaffy. }
$$

356. Nat. Order 96. Cyperacese (in part). Sheaths of the leaves entire. Stem angular. Cor. 0.

393. Nardus. Cor. of 2 valves. Cal. 0 . A grass.

(Juncus, N. O. 89.)

\section{Order II. DIGYNIA.}

381. Nat. Order 97. Graminex. Fl. glumaceous. Grasses. 


\section{Order III. TRIGYNIA.}

121. Montia. Cal. of 2 leaves. Cor. of 1 petal. Caps. 3valved, 3-seeded.

124. Polycarpon. Cal. of 5 leaves. Pet. 5. Caps. 1-celled, 3-valved.

52. Holosteum. Cal. of 5 leaves. Pet. 5. Caps. 1-celled, opening with 6 teeth at the end.

(Tillaa, N. O. 34.)

\section{Class IV. TETRANDRIA.}

\section{Order I. MONOGYNIA.}

* Perianth double. Cal. double; inner adnate to the fr. Cor. monopetalous.

162. Nat. Order 44. Dipsacacex.

** Perianth double. Cal. single. Cor. monopetalous, inferior. 272. Plantago. Segments of cor. reflexed. Stam. very long. 222. Cicendia. Cor. salvershaped, spreading. Stam. included. Caps. opening at the top by two valves.

269. Centunculus. Cor. tubular, spreading. Stam. included. Caps. bursting transversely.

(Gentiana, N. 0.51.)

*** Perianth double. Cal. single. Cor. monopetalous, superior.

155. Nat. Order 43. Rubiacese. Limb of the cal. often obsolete.

**** Perianth double. Pet. 4.

13. Epimedium. Cor. inferior.

152. Connus. Cor. superior. Cal. 4-cleft.

(Cardamine, N. O. 6. Senebiera, N. 0.6. Euonymus, N. O. 23.)

155. Linnata. Cor. superior. Cal. 5-cleft.

$$
\text { ***** Perianth single. }
$$

328. Maianthemum. Perianth petal-like, 4-parted, inferior.

92. Alchemilla. Perianth a calyx, inferior, 8-parted; 4 segments larger than the alternate ones.

91. Sanguisorba. Perianth a calyx, inferior, 4-parted. Stam. inserted on a ring closing the tube.

292. Parietaria. Perianth inferior, 4-parted, bellshaped. Stam. at its base.

119. Isnardia. Perianth superior, 4-parted, persistent. 


\section{Order II. DIGYNIA.}

48. Buffonia. Cal. of 4 persistent sepals.

(Cuscuta, N. O. 53.)

\section{Order III. TETRAGYNIA.}

218. Ilex. Cal. 4-toothed. Cor. rotate. Berry with four 1seeded nuts.

54. Moenchia. Pet. 4. Caps. 1-celled, opening at the top with 8 teeth.

49. Sagina. Pet. 4. Caps. 1-celled, opening with 4 valves. 66. Radiola. Cal. 4-fid; lobes 2-3-fid. Pet.4. Caps. with 8 cells and 8 valves.

125. Tillea. Cal. 3-4-parted. Caps. several, each 2-seeded. 350. Potamogeton. Perianth single, of 4 scales. Drupes 4. (Cerastium, N. O. 14.)

\section{Class V. PENTANDRIA. \\ Order I. MONOGYNIA.}

* Cor. monopetalous, inferior. Ovary 4-lobed. Fr. 4 nuts. 226. Nat. Order 54. BoraginaCese.

** Cor. monopetalous, inferior. Caps. 1-celled. Stam. opposite to the segments of the corolla.

265. Nat. Order 61. Primulace es (in part).

*** Cor. monopetalous, inferior. Stam. and cor.-segments alternate.

220. Nat. Order 51. Gentranaceas (in part). Fr. 1- or imperfectly 2 -celled, many-seeded.

232. Nat. Order 55. Solanace . Fr. 2-celled, many-seeded. Stam. on the corolla, equal.

238. Verbascum. Fr. 2-celled, many-seeded. Stam. on the corolla, unequal; 2 or more hairy at the base.

224. Polemonium. Fr. 3-celled. Stam. on the cor.-tube. 224. Nat. Order 53. Convolvulaces. Fr. 2-3-celled, nostly few-seeded. Stam. on the base of the corolla.

216. Azalea. Fr. 2-3-celled. Stam. on the receptacle. 219. Vinca. Fr. consisting of 2 follicles.

**** Cor. monopetalous, superior.

208. Nat. Order 46. Campanulace the corolla. Fr. a capsule. 
154. Lonicera. Stam. on the irregular cor. Fr. a berry. 269. Samolus. Stam. on the half-inferior bellshaped cor. and opposite to its segments; 5 scales (barren stam.) above. Fr. a capsule.

***** Cor. of 4 or 5 petals, inferior.

67. Impatiens. Fl. irregular. Sep. 3, unequal, deciduous. Pet. 3.

36. Vrola. Fl. irregular. Sep. 5, persistent. Pet. 5. 69. Rhamnus. Fl. regular. Stam. opposite to the petals. 69. Euonymus. Fl. regular. Stam. alternate with the petals.

******* Petals distinct, superior.

128. Rries. Pet. and stam. on the limb of the calyx. Pet. clawed.

152. Hedera. Pet. and stam. below the margin of an epigynous disk. Pet. sessile with a broad base.

******* Perianth single.

269. Glaux. Perianth inferior, bellshaped, coloured.

288. Thesium. Perianth superior, persistent.

(Illecebrum and Herniaria, N. O. 33.)

\section{Order II. DIGYNIA.}

* Perianth single, or pet. resembling abortive stamens.

295. Ulmus. Caps. compressed, winged all round. L. with stipules.

274. Nat. Order 65. Chenopodiacese (in part). Caps. not winged. Stip. 0.

123. Herriaria. Cal. 5-cleft; segments plane-concave. Pet. (or abortive stam.) 5, setaceous.

123. IlLECEBRUM. Cal. of 5 thick laterally compressed hooded sepals. Pet. (or abortive stam.) 5, subulate.

** Perianth double. Cor. monopetalous, inferior.

222. Gentiana. Caps. 1-celled, 2-valved. Cor. without nectariferous pores.

225. Cuscuta. Caps. 2-celled, bursting transversely. Cor. bellshaped.

*** Perianth double, superior. Cal.-limb often obsolete. Pet. 5. 133. Nat. Order 37. UmbelliferA. 


\section{Order II. DIGYNIA.}

283. Oxyrria. Perianth 4-leaved.

\section{Order III. TRIGYNIA.}

336. Colchicum. Perianth funnelshaped; tube very long.

336. Tofieldia. Perianth 6 -leaved. Caps. 3 , connected up to the middle.

346. Scheuchzeria. Perianth 6-leaved. Caps. 3 , inflated.

346. Triglochin. Perianth 6-leaved. Caps. $3-6$, united to a longitudinal receptacle.

281. RumeX. Perianth 6-leaved. Caps. 1, triquetrous. Styles feathery.

Order IV. HEXAGYNIA.

345. Actinocarpus. Caps. combined at the base, radiating, $6-8$.

\section{Order V. POLYGYNIA.}

345. Alisma. Caps. many, clustered, distinct.

Class VII. HEPTANDRIA.

269. Trientalis. Cal. and cor. 7-parted. Style 1. Caps. l-celled, 7-valved.

Class VIII. OCTANDRIA.

\section{Order I. MONOGYNIA. \\ * Flowers with calyx and corolla.}

62. ACER. Cal. inferior, 5-parted. Pet. 5. Fr. 2-winged.

119. CEnothera. Cal. superior, 4-parted. Pet. 4. Seeds without hairs.

116. Epilo bivm. Cal.superior, 4-parted. Pet.4. Seeds hairy at the end.

221. Chlora. Cal. inferior, 8-fid.

213. Nat. Order 47. Ericacex (in part). Cal. and cor. inferior, 4-5-fid.

216. Vaccinium. Cal. and cor. superior, 4-5-fid.

$$
\text { ** Perianth single. }
$$

287. Daphne. Limb of the perianth 4-fid, deciduous, inferior. 


\section{Order II. DIGYNIA.}

283. Polygonum. Perianth single, inferior.

133. Chrysos plenium. Perianth single, half-superior-

\section{Order III. TRIGYNIA.}

286. FAGOPYRUM.

(Polygonum, N. O.66.)

Order IV. TETRA- PENTA-GYNIA.

152. AdoxA. Cal. 2-fid, cor. 4-fid in the terminal fl.; cal. 3fid, cor. 5-fid in the lateral flowers.

42. Elatine. Cal. 3-4-parted. Pet. 3-4. Anth. terminal.

311. Paris. Sep. and pet. 4. Filaments continued beyond the anthers.

\section{Class IX. ENNEANDRIA.}

346. Вuтомus. Perianth of 6 coloured leaves. Stigmas 6 .

Class X. DECANDRIA.

Order I. MONOGYNIA.

211. Nat. Order 47. Ericacese (in part). Cor. 5-cleft or of 5 petals.

\section{Order II. DIGYNIA.}

124. Scleranthus. Cal. 5-cleft. Pet. 0.

129. Saxifraga. Cal. 5-toothed or 5-parted. Pet. 5. Fr. with 2 beaks.

45. Saponaria. Cal. 5-toothed, naked below. Pet. 5.

44. Dranthus. Cal.5-toothed, with scales at the base. Pet. 5. (Chrysosplenium, N. 0.36. Polygonum, N. O.66.)

\section{Order III. TRI- TETRA- PENTA- GYNIA.}

42. Nat. Order 14. Caryophyllaces (in part). Caps. opening by teeth at the end or valves. Stipules none.

124. LePigonum. Caps. opening by valves alternate with the sepals. With stipules.

124. Spergula. Caps. opening by valves opposite to the sepals. With stipules.

44. Cucubalus. Fr, a berry. Styles 3.

67. Oxalis. Caps. 5-celled, opening at the angles. Pet. connected below. 
126. StDum. Caps. 5 or more. Pet. usually 5.

128. Cotyledon. Caps. 5. Cor. tubular, 5-cleft.

(Adoxa, N. 0.38.)

\section{Class XI. DODECANDRIA.}

89. Asarum. Perianth 3-fid, superior. Style 1.

115. Lythrum. Cal. tubular, inferior, with 10 teeth. Pet. 6.

Style 1.

91. Agrimonia. Cal. turbinate, with hooked bristles. Pet.5. Styles 2.

34. Reseda. Pet. irregular. Styles 3. Caps. open at the eud. 127. Sempervivum. Pet. and styles 12 or more.

(Styles 3. Euphorbia, N. O. 72.)

(Styles 4. Potentilla, N. O. 26.)

Class XII. ICOSANDRIA.

87. Nat. Order 26. Rosacese (in part).

Class XIII. POLYANDRIA.

Order I. MONOGYNIA.

14. Nat. Order 4. Papaveraces. Sep. 2. Pet. 4.

12. Act zea. Sep. 4. Pet. 4.

35. Helianthemum. Estivation of cal. twisted. Pet. 5.

58. Truia. Estivation of cal. valvate. Pet. 5.

13. Nat. Order 3. Nymphasers. Pet. many.

Order II. DI- POLY- GYNIA.

1. Nat. Order 1. Ranunculace E. Cal. and cor. inferior. (Reseda, N. O.7.)

\section{Class XIV. DIDYNAMIA.}

Order I. GYMNOSPERMIA.

[Fr. deeply 4-lobed, resembling 4 seeds.]

249. Nat. Order 58. La Biat Ai.

(Verbena, N. O.59.) 


\section{Order II. ANGIOSPERMIA.}

[Seeds in a distinct capsule.]

234. Nat. Order 56. Orobanchacez. Caps. 1-celled, manyseeded. Placentas parietal.

273. Limosella. Caps. I-celled (except at the bottom). Placentas central, free.

237. Nat. Order 57. Scrophulariaces (in part). Caps. 2celled.

155. LinNasa. Ovary 3-celled. Fr. 1-seeded.

263. Verbena. Ovary 4-celled. Seeds 2-4; pericarp evanescent.

\section{Class XV. TETRADYNAMIA.}

18. Nat. Order 6. Cruciferea.

\section{Class XVI. MONADELPHIA.}

Order I. PENT- DEC- ANDRIA.

[Stam. 5-10.]

62. Nat. Order 19. Geraniaceas.

(Lysimachia, N. O. 61. Linum, N. O. 20. Oxalis,

N. O. 22. Part of Leguminosa, N. 0.25.)

\section{Order II. POLYANDRIA.}

56. Nat. Order 15. Malvacees.

\section{Class XVII. DIADELPHIA.}

16. Nat. Order 5. Fumariaceas. Stam. 6.

40. Nat. Order 11. Poly galaceas. Stam. 8.

69. Nat. Order 25. Leguminos $x$. Stam. 10.

Class XVIII. POLYADELPHIA.

59. Nat. Order 17. Hypericacex. Stam. many.

\section{Class XIX. SYNGENESIA.}

163. Nat. Order 45. Compositak. 


\section{Class XX. GYNANDRIA.}

313. Nat. Order 82. Orchidacese. Stam. 1 or 2.

288. Aristolochia. Stam. 6 . Stigma with 6 lobes.

\section{Class XXI. MONGECIA.}

\section{Order I. MONANDRIA.}

[Stam. 1.]

290. EUPHORBIA. Involucre bellshaped, inclosing many male fl. and 1 female flower. Cor. and cal. wanting.

348. Arum. Spath of 1 sheathing leaf, inclosing many female fl. and many male fl. above them. Cal. and cor. wanting.

293. Callitriche. Bracts 2 petal-like, or 0. Involucre, spath, cal. and cor. wanting.

355. Zannichellia. Involucre 0. Male fl. without cal. or cor. Fem. fl. with a perianth of 1 leaf. Nuts 4 , stalked. Stigma peltate.

355. Zostera. Fl. aggregate in 2 rows on one side of a spadix. Spath ending in a leaf.

356. NAIAS. Fl. solitary, sheathed. Perianth 0.

Order II. DIANDRIA.

(Callitriche, N. 0.73. Carex, N. O.96.)

\section{Order III. TRIANDRIA.}

347. Typнa. Spikes male and female, cylindrical. Ovary surrounded with bristles. Perianth 0 .

347. Sparganium. Spikes male and female, globose. Perianth single, 3-leaved.

364. CAREx. Fl. in 1 or more imbricated scaly spikes. Perianth 0. Perigone urn-shaped.

364. Kobresia. Fl. in a compound spike. Perianth and perigone 0 .

\section{Order IV. TETRANDRIA.}

273. Litrorella. Cor. of male fl. with a cylindrical tube and 4-parted limb. Stam. very long.

290. Buxus. Cor. of male fl. of 2 petals, fem. of 3 pet. Caps. with 3 beaks. 
295. Urtica. Perianth 4-leaved. Perigone 2-leaved. Stam. equalling the perianth.

308. Alnus. Fl. in imbricated catkins. Scales of male fl. 3 lobed, 3-flowered. Perianth 4-fid. Perigone 0.

\section{Order V. PENT- POLY-ANDRIA.}

* Fl. not in catkins, with cal. and corolla.

120. Myriophyllum. Pet. of male fi. 4 , deciduous. Stam. 8 . Germ. inferior.

345. SagitTaria. Pet. 3. Stam. about 24. Carp. many, upon a globose receptacle.

121. Bryonia. Cal. with 5 teeth. Cor. 5 -cleft. Filaments 3. Anth. 5. Fr. an inferior berry.

** Fl. not in catkins, imperfect.

208. Xамтhium. Involucre of male many-leaved, with a 5toothed perianth ; of female 1-leaved, inclosing 2 flowers.

293. Ceratophyllum. Perianth many-leaved. Stam. 16-20. Nut ending in a spine.

337. Eriocaulon. Perianth 4-6-cleft. Stam.4-6. Caps. 2-3-lobed, 2-3-celled.

274. Amaranthus. Perianth 3-4-leaved. Stam. 3 or 5. Caps. opening all round.

91. Poterium. Perianth 4-cleft. Fr. 2 nuts, invested with the hardened quadrangular tube of the perigone.

*** Fl. in catkins.

296. Nat. Order 77. Amentiferas (in part).

\section{Order VI. MONADELPHIA.}

[Filaments of stam. united below into one set.]

310. Pinus. Male fl. in racemose catkins. Fr. in cones.

\section{Class XXII. DICECIA.}

297. Salix. Perianth 0. Stam. and pistils with 1 or 2 glands at the base. Anth. 1-5, usually 2 .

289. Empetrum. Cal. 3-parted. Pet. 3. Stam. 3.

329. Ruscus. Sep. 6. Pet. 0. Stam. 3.

287. Hif pophas. Male fl. with a perianth of 2 deep roundish lobes. Stam. 4. Fem. fl. with a tubular bifid perianth. Stigma elongate. 
153. Viscum. Cor. 4-parted. Cal. of male fl. 0 , of fem. fl. an obscure free margin. Stam. 4. Stigma obtuse, sessile.

307. Mrrica. Fl. in catkins. Perianth 0. Stam. 4, at the base of the scales.

295. Humulus. Female $\mathrm{fl}$. in a catkin formed of large persistent scales. Stam. 5 .

312. Tamus. Perianth 6-parted, superior. Stam. 6. 306. Populus. Fl. in imbricated catkins. Stam. 8.

292. Mercurialis. Perianth single, 3-parted. Stam. 9.

312. Hy drocharis. Cal. 3-parted, superior. Pet. 3. Stam.9.

313. Stratiotes. Cal. 3-parted, superior. Stam. 12.

313. Axacharis. Cal. 3-parted, inferior, with a long tube. Filaments 3. Caps. 1-celled. Male with 9 stamens with combined filaments.

310. Juniperus. Stam. 5, combined. Fl. in catkins. Fem. fl. 3, scales ultimately fleshy and united.

310. TAxus. Stam. 5, combined. Fl. in catkins. Fem. fl. 1, scaly below. Perigone ultimately fleshy, cupshaped.

(Stam. 3. Valeriana, N. O.43. Stam. 4. Rhamnus, N. O. 24. Urtica, N. O.75. Stam. 8. Sedum, N.0.34. Stam. 12. Stratiotes, N.0.81.)

\section{Class XXIII. POLYGAMIA.}

278. Atriplex. Perigone 2-lobed or 2-parted. Pericarp free. Testa crustaceous.

280. Овгоne. Perigone 2-lobed. Pericarp adhering to the perigone. Testa membranous.

294. Parietaria. Perigone 4-parted.

\section{Class XXIV. CRYPTOGAMIA.}

414. Nat. Order 98. EQuisetaces. Leafless branched plants with sheathed joinings. Fructification in terminal catkins.

417. Nat. Order 99. Filices. Leafy plants. Fructification attached to the veins, either on the back or edge of the leaves.

429. Nat. Order 100. Marsileace . Creeping plants with slender leaves. Fructification consisting of globular nearly sessile coriaceous 3-4-celled capsules.

430. Nat. Order 101. Lycopodiaces. Plants with imbricated leaves. Capsules axillary, solitary.

431. Nat. Order 102. Characes. Leafless branched plants with a fistular stem, not sheathed at the joinings. 


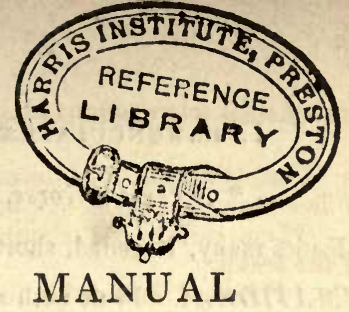

OF

\section{B R I T I H B O T A N Y.}

\section{FLOWERING PLANTS.}

Substance composed of cellular tissue, woody fibre and spiral vessels. Epidermis with stomata. Embryo with cotyledons.

\section{Class I. DICOTYLEDONES.}

Stems formed of bark, wood and pith. The wood furnished with medullary rays and increasing by the addition of concentric layers externally. Leaves mostly with netted veins. Cotyledons 2 or more, opposite or whorled.

\section{Subclass I. ANGIOSPERM E.}

Plants with an ovary, style and stigma. Seeds inclosed in a seed-vessel.

\section{Subdivision I. THALAMIFLORAE.}

Petals distinct (rarely 0 ), and as well as the stamens hypogynous.

\section{Order I. RANUNCULACEE.}

Sep. 3-6. Pet. 5 or more, rarely 0. Stam. indefinite : anth. adnate, opening longitudinally. Carp. many, distinct, or rarely united into a single pistil. Seeds erect or pendulous. 
* Anthers extrorse.

$\dagger$ Fruits many, 1-seeded, short (achenes).

Tribe I. CLEMATIDEAE. Fruit with a feathery awn. Seed pendulous. Astivation valvate or induplicate. Leaves opposite.

1. Clematis. Cal. of 4 or 5 sepals. Pet. 0 . Carp. not bursting, awned. Stam. and styles many.

Tr. II. ANEMONEAE. Seed pendulous. Estivation imbricate. Leaves radical or alternate.

2. Thalictrum. Cal. of 4 or 5 sepals. Pet. 0 . Carp. not bursting, without awns. Stam. and styles many.

3. Axemone. Cal. petaloid, sep.5-9. Pet. 0. Carp. not bursting, tipped with the persistent sometimes feathery styles, inserted upon a thickened hemispherical or conical receptacle. Stam. and styles many.

4. Adonis. Cal. of 5 sepals. Pet. 5-10, without a nectary. Carp. not bursting, without awns. Stam. and styles many.

Tr. III. RANUNCULEAE. Seed erect (except in Myosurus). Estivation imbricate. Pet. with a nectariferous pore at their base.

5. Mrosurus. Cal. of 5 sepals, prolonged into a spur at the base. Pet. 5, with a filiform tubular claw. Stam. 5 . Styles many. Carp. not bursting, closely imbricated upon a long filiform receptacle. Seed pendulous. Embryo inverted, with the radicle superior.

6. Ranunculus. Cal. of 5 , rarely 3 , sepals. Pet. 5 , rarely many; nectariferous pore naked or covered by a scale. Carp. not bursting, collected into a globular or elliptical head. Stam. and styles many.

†† Fruits many-seeded, bursting, long (follicles).

Tr. IV. HELLEBOREAE. Estivation imbricate. Stam. many.

7. Caltha. Cal. of 5 petaloid deciduous sepals. Pet. 0 . Follicles 5-10, many-seeded.

8. Trollius. Cal. of 5 or many petaloid deciduous sepals. Pet. small, linear, flat, clawed. Follicles many, sessile.

[9. Eranthis. Cal. of $5-8$ petaloid deciduous sepals. Pet. 
small, tubular, with a long claw, 2-lipped, inner lip very short. Follicles many, stalked.]

10. Helleborus. Cal. of 5 petaloid persistent sepals. Pet. small, tubular, 2-lipped, clawed. Follicles 3-10 sessile.

11. Aquilegia. Cal. of 5 petaloid deciduous sepals. Pet.5, funnel-shaped, with a long horn-like spur. Follicles 5.

12. Delphinium. Cal. of 5 petaloid deciduous sepals, upper sep. with a long spur at its base. Pet. 4; 2 upper ones with spurs included in the spurred sepal, or all combined into one spurred petal. Follicles 1, 3 or 5.

13. Aconitum. Cal. of 5 petaloid sepals, upper one helmetshaped. Two upper pet. tubular, on long stalks, concealed in the helmet-shaped sepal. Follicles 3-5.

** Anthers introrse. (Stam. arising from a glandular disk.)

Tr. V. PAEONIEAE or spurious Ranunculaceæ.

14. Act asa. Cal. of 4 petaloid deciduous sepals. Pet. 4. Carp. 1, baccate, indehiscent, many-seeded.

15. P年onia. Cal. of 5 persistent sepals. Pet. 5 or more. Follicles 2-5, many-seeded, bursting inwards, crowned with the bilaminated stigmas.

\section{Tribe I. Clematidea.}

\section{Cuematis Linn. Traveller's Joy.}

1. C. Vitalba (L.); st. climbing, 1. pinnate, leaflets ovate acuminate entire coarsely serrate or incise-lobate rounded or cordate below, petioles twining, sep. oblong downy on both sides, fr. with long feathery awns.-E.B. 612. R. iv. 64.-St. woody, angular, branched. Petioles acting as tendrils.-Hedges and thickets on a calcareous soil. Sh. VI.

E. S.

\section{Tribe II. Anemonea.}

\section{Thalictrum Linn. Meadow-Rue.}

1. T. alpinum (L.); st. perfectly simple and nearly leafless, cluster terminal simple, fruitstalks reflexed, carp. shortly stalked tipped with the hooked style.-E.B. 262. R. iii. 26.-St. 3-6 in. high, quite smooth. L. mostly radical, upon long stalks, twice ternate.-Higher parts of mountains. P. VI. VII.

2. T. minus (L.); st. zigzag striated branched leafless but sheathed at the base, stip. with inflexed auricles, 1.2-3-pinnate, lts. ternate 3-cleft glaucous, petioles with angular ascending 
branches, fl. in a branched divarieate leafless panicle drooping, carp. fusiform 8-ribbed subcompressed ventricose below externally. - E. B. 11. R. iii. 27.-St. 1-2 ft. high, usually solid; sheatlss at its base rather lax.- $\beta$. T. pubescens (Schreb.); st. petioles and lts. beneath or on both sides clothed with stalked glands.-Stony pastures and sand hills. P. VI. VII.

3. T. flexuosum (R., Fries); st. zigzag striated branched leafy to the base, stip. with reflexed auricles, 1. 2-3-pinnate, lts. 3-5-cleft paler beneath, petioles with patent divaricate branches, ti. drooping in an elongated leafy panicle with patent or reclinate branches, carp. narrowly oblong gibbous above within below without. - R. iii. 28. T. majus $\sin$. E. B. 611 , not Jacq. -St. often 3 feet high, solid. Lower 1 . with rather close sheaths and broad lts. with blunt cuspidate lobes; upper narrower and more acutely lobed.-Bushy and stony places. P. VII.

4. T. saxatile (DC.); st. rather zigzag smooth but striated below the sheaths leafy to the base, "stip. with horizontal auricles," 1. 2-3-pinnate, lts. ternate 3-5-cleft paler beneath, petioles subterete with patent not divarieate branches, fl. drooping in a branehed leafless erect pyramidal panicle with patent straight branches, carp. regularly oval. $-R$. iii. 34. T. Kochii Fries.St. often 4 feet high, hollow. L. broad, lobes blunt or on the upper l. aeute.-Damp places in the Lake District.

E.

5. T. flavum (L.); st. erect furrowed, l. bipinnate, lts. broadly obovate or wedge-shaped trifid, panicle coinpact corymbose. $f$. erect, carp. short oval.-E. B. 367. R. iii. 44.-L. rather paler benenth. Root creeping.-In wet fields. P. VI. VII. Common Meadow Rue.

\section{ANEMONe Linn.}

1. A. Pulsatilla (L.); fl. solitary erect, involuere sessile in deep linear segments, 1 . doubly pinnate, leatlets pinnatitid, lobes linear, carp. with feathery tails.-E. B. 51.-Fl. violet-purple, externally silky. Involuere silky, close to the flower, but, by the elongation of the stalk, distant from the fruit.-Open calcareous pastures. P.IV. V. Pasque flower:

E.

2. A. nemorosa (L.); fl. solitary, sep. 6 elliptical, involuere of 3 ternate or quinate stalked leaves with lobed and cut leaflets, 1. similar, carp. pubescent keeled.-E. B. 355. R. iv, 47.-Fl. white or purplish. Beak about as long as the carp., not tailed. Root (rhizome) horizontal. Sep. glabrous on both sides.-Groves and thickets; common. P. III.-V. Wood Anemone.

[*3. A. apennina (L.) ; fl. solitary, sep. many lanceolate, involucre of 3 ternate stalhed deeply eut leares, 1. similar, "carp. 
pointed without tails."-E. B. 1062. R. iv. 47.-Fl. bright blue. Root similar to the last.-Scarcely naturalized. P. IV.] E.

[*?4. A. ranunculoides (L.); fl. solitary or in pairs, sep. 5 elliptical, involucre of 3 nearly sessile ternate deeply cut leaves, 1. similar often quinate, carp. pointed downy without tails. $-E$. B. 1484. $R$. iv. 47.-Fl. bright yellow. Sep. extemally pubescent. Root similar to the last. - A very doubtful native. P. IV.] E.

\section{Adovis Linn. Pheasant's Eye.}

+1. A. autumnalis (L.); cal. glabrous patent, pet. connivent, carp. without teeth collected into an ovate head and tipped with a straight beak.-E. B. 308 R. iii. 24. - Pet. scarlet, black at the base, scarcely exceeding sepals. L. triply and copiously pinnatifid, segments linear.-Corn-fields, rare. A. VII. E. S.

\section{Tribe III. Ranunculea.}

\section{Myosurus Linn. Mousetail.}

1. M. minimus (L.)-E. B. 435. R. iii. 1.-St. simple, leafless, single-flowered, $2-5$ in. high. L. linear, fleshy. Receptacle ultimately very long, with many oblong carpels. Seed attached to the upper part of the carp. and pendulous, the radicle pointing upwards.-In damp places in fields. A. V.VI. E.

\section{Ranunculus Linn. Crowfoot.}

A. Fr.-st. arching, carp. transversely, wrinkled, pet. white (with a yellow claw in all our plants). BatrachiUm Fries. Water Crowfoot.

* Submersed 1. 2-3ce 3-furcate with filiform segments spreading in the section of a sphere, rarely wanting. Receptacle hispid.

1. R. trichophyllus (Chaix); submersed l. closely trifurcate, segments short rigid not collapsing into a pencil when taken from the water, no floating l., ped. not narrowing upwards about equalling the l., fl. small, pet. obovate 5-7-veined not contiguous evanescent, stig. oblong, receptacle oblong, carp. $\frac{1}{2}$-obovate laterally apiculate compressed.-St.67.11.-St. not rising out of the water. Upper l. sessile, all dense. Stip. $\frac{1}{2}$-adnate, large. round, auricled. Buds globose. Fl. starlike. Stam. exceeding the pistils. Stig. short but lengthening. Recentacle as thick as pedunele. Carp. a little narrowed at the end.-Ponds and ditches. P. V. VI. 
2. R. Drouetii (F. Schultz?); submersed l. rather closely trifurcate, segments rather rigid but collapsing, floating 1 . (rare) tripartite with subsessile or stalked wedgeshaped bifid lts., ped. not narrowing about equalling the 1., fl. small, pet. obovate $5-7$ veined not contiguous evanescent, stig. oblong, receptacle oblong, $\operatorname{carp} . \frac{1}{2}$-obovate sublaterally apiculate inflated at the end.-St. not rising out of the water. Upper 1. nearly or quite sessile. Floating 1 . usually 0 ; lateral lts. stalked and in a different plane from the usually sessile middle leaflet. Stip. $\frac{1}{2}-\frac{2}{3}$-adnate, large, auricled. Buds oblong. Fl. starlike. Stam. exceeding the pistils, fewer than 10. Fr.-receptacle as thick as peduncle. Carp. with the edge flattish at the end, base of style small often subcentral.-Ponds and ditches. P. V. VI.

E.

3. R. heterophyllus (Fr.); submersed l. loosely trifurcate, segments long collapsing, floating l. subpeltate tripartite with sessile or stalked wedgeshaped 3-5-lobed lts., ped. not narrowing scarcely exceeding the $1 ., \mathrm{fl}$. large, pet. broadly obovate-cuneate 7-9-veined not contiguous persistent, stig. oblong, receptacle conical, carp. $\frac{1}{2}$-obovate laterally pointed. $-R$. aquatilis E. B. 101.-St. not rising out of the water. Floating l. nearly circular, sometimes 0 . Stip. much adnate. Buds slightly depressed and rather 5-agonal. Fl. becoming starlike. Stam. many, exceeding pistils. Style hooked. Carp. blunt, inner edge straight.-Ponds and streams. P. V. VI.

E.

4. R. confusus (Godr.); submersed $l$. loosely trifurcate, segments long rather rigid not collapsing, floating $l$. long-stalked subpeltate subtripartite with sessile obovate 3-5-lobed segments, ped. slender narrowing gradually exceeding the l., fl. large, pet. obovate-cuneate 7-9-veined not contiguous persistent, stig. tongue-shaped, receptacle ovate-conical, carp. $\frac{1}{2}$-ovate compressed and narrowed upwards. - St, 82.2.-St. rising out of the water. Floating l. semicircular, flat, nearly tripartite, outer base of lateral segments rounded. Stip. oblong, much adnate. Buds globular. Fl. starlike. Stam. many, exceeding pistils. Style recurved.Ponds and ditches, especially near the sea, often in brackish water. P. VI.-IX.

E.

5. R. Baudotii (Godr.); submersed 1. closely trifurcate, segments rather rigid not collapsing, floating 1 . long-stalked tripartite with sessile or stalked wedgeshaped 3-4-lobed segments, ped. thick narrowed at the top exceeding l., fl. moderate, pet. 7 -veined not contiguous persistent, stam. not exceeding pistils, stigma tongue-shaped, receptacle long-conical, $\operatorname{carp}$. $\frac{1}{2}$-obovate inflated at the end.-St. rising out of the water (?). Floating 1. nearly or quite tripartite, the base of all the segments wedgeshaped; or often of many linear blunt segments. Stip. much adnate. Buds globular but depressed (?). Fl. starlike. Stam. 
15-20. Style recurved. Receptacle thicker than ped., very tall. Carp. very many. - Slightly brackish water or near the sea. P. V.-VIII.

6. R. floribundus (Bab.) ; submersed l. closely trifurcate, segments rather rigid divaricate not collapsing, floating l. longstalked subpeltate $\frac{1}{2}$-trifid or tripartite with sessile obovate $3-5$ lobed segments, ped. not narrowed scarcely exceeding the l., fl. large, pet. obovate-cuneate 9-many-veined not contiguous persistent, stam. many exceeding pistils, stig. tongue-shaped, receptacle spherical, carp. $\frac{1}{2}$-obovate very blunt. $-A$. N. H. ser. 2 . xvi. 397.- St. often rising out of the water. Floating l. convex, divided more than halfway down, more than semicircular; outer base of lateral segments much rounded. Stip. broad, with a free rounded end. Buds depressed. Fl. starlike. Stam. 20-30. Style recurved. Receptacle as thick as peduncle. Inner edge of carp. nearly straight.-Ponds. P. V.-IX.

7. R. peltatus (Fr.); submersed l. loosely trifurcate, segments rather rigid divaricate not collapsing, floating 1 . long-stalked subpeltate nearly half 3 - 5 -fid with obovate $3-4$-crenate segments, ped. narrowing gradually from floating $l$. and exceeding them, fl. large, pet. round becoming obovate-cuneate 9 -veined contiguous persistent, stam. many exceeding pistils, stigma club-shaped, receptacle ovate, carp. $\frac{1}{2}$-obovate very blunt. - St.67.7. - St. often rising out of the water. Floating $1 . \frac{2}{3}$-circular, convex, outer base of lateral segments much rounded. Stip. adnate nearly throughout. Buds globular. Fl. sweet-scented, very large. Stam. about 30 . Style curved. Receptacle small. Inner edge of carp. nearly straight. Rarely a fl. springs with a divided leaf. -Ponds. P. V. -IX.

8. R. tripartitus (DC.); "submersed l. divided into capillary segments collapsing," floating l. long-stalked subpeltate deeply trifid with cuneate-obovate $2-4$-fid segments, ped. not narrowing falling short of 1 ., $\mathrm{fl}$. very small, pet. oblong 3 -veined not contiguous, stam. few exceeding the pistils, stig. small on long subulate terminal style with a slender base, receptacle globose, carp. unequally obovate much inflated with a nearly terminal point.-E. B. S. 2946.-St. rising out of the water. Floating 1. $\frac{3}{4}$-circular; outer edge straight below; lateral segments with 3 , middle with 2-4 crenatures. Upper stip. free. Buds globular. Pet. very small, scarcely exceeding sep., pinkish. Stam. 5-10. Style deciduous. Receptacle globose. Inner edge of carp. much rounded. No divided l. have been seen in Britain. - Streams. P. V.-VIII.

** Submersed 1. not as in Section*. Receptacle hispid.

9. R. circinatus (Sibth.); 1. all submersed and sessile trifurcate 
with repeatedly and closely forked rigid segments all placed in one roundish plane not collapsing, ped. much narrowing exceeding l., fl. large, pet. obovate many-veined nearly contiguous persistent, stam. exceeding pistils, stigm. cylindrical, receptacle oblong, carp. $\frac{1}{2}$-ovate compressed rather acute.-E. B. S. 2869.St. submersed. L. sheatbing, not auricled, remarkably flat rigid and formal. Buds depressed. Stam. 15-20. Receptacle narrower than ped. Inner edge of carp. nearly straight.-Streams and ponds. P. VI.-VIII.

10. R. fluitans (Lam.); l. all submersed about twice trifureate with very long linear twice or thrice forked nearly paralleb segments, ped. narrowing, fl. large, pet. broadly obovate manyveined contiguous persistent, stam. falling short of pistils, stig. cylindrical, receptacle conical,carp. obovate inflated much rounded at the end laterally apiculate.-E. B.S. 2870.-St. submersed, usually very long. Petioles and segments of 1 . often very long, together a foot in length. Stip. broadly lanceolate. Buds shortly pyramidal, pentagonal. Pet. often more than five. Stam. very short, many. Inner edge of carpels slightly rounded.-Rivers. P. VI. VII.

\section{*** No submersed leaves. Receptacle not hispid.}

11. R. conosus (Guss.); 1. all roundish cordate with $3-5$ rather deeply divided lobes which widen from their base, pet. exceeding cal., style terminal upon the ovate-conical ovary, carp. unequally obovate with a terminal point. $-R$. Lenormandi E.B.S. 2930. - St. floating or creeping upon mud. L. not spotted; lobes very broad at the top, mostly with $2-3$ notches. Upper stip. very broad, $\frac{1}{2}$-adnate. Pet. narrow, obovate, 5-veined. Stam. 8-10. Style nearly central on the ovary and usually so on the carpel. Inner edge of carp. much rounded towards the top.-Shallow ponds or mud:- P. VI.-VIII.

12. $R$. hederaceus (L.) ; 1. all roundish reniform with $3-5$ shallow rounded lobes widening to their base, pet. scarcely exceeding cal., style prolonging the inner edge of the ovary, carp. $\frac{1}{3}$-oval or $\frac{1}{2}$-obovate with a lateral point. - E. B. 2003. - St. floating or creeping upon mud. L. usually spotted; lobes usually entire or with a central notch, often rather triangular. Stip. narrow, much adnate. Pet. narrow, 3-veined. Stam. 6-8. Style lateral upon both ovary and carpel. Inner edge of carpel nearly straight.-Shallow ponds or mud. P. VI.-IX.

\section{B. Fr.-st. straight, carp. transversely wrinkled on the middle of each side, nect. naked.}

13. R. sceleratus (L.) ; root fibrous, lower l. stalked tripartite, segments blunt crenate, upper l. trin̂d linear entire or incise- 
dentate, calyx reflexed, head of fr. oblong, carp. minute.-E. B. 681. R. iii. 11.-Fl. very small, pale yellow. Nect. round, open, bordered all round, rarely not bordered above. Lower 1 . broad, glabrous, shining. Stem 1-2 feet high, thick.-By ditches and ponds. A. VI.-IX. Celery-leaved Crowfoot.

C. Fr.-st. straight, carp. not transversely wrinkled.

$\dagger$ L. divided, fl. white, nectary naked.

[14. R. alpestris (L.); root fibrous, l. smooth, radical l. somewhat heart-shaped deeply $3-5$-lobed, lobes incise-crenate at the extremity, stem-l. 1 or 2 simple linear or trifid with linear lobes, fl. almost solitary, ped. furrowed, calyx glabrous, carp. obovate with a straight beak hooked at the end.-E. B. 2390.-Pet. obcordate. St. $4-5$ in. high.-Clova mountains. Mr. G. Don. P. V.]

S.

†† L. undivided, fl. yellow, nectary nearly or quite naked, bordered.

[15. R. gramineus (L.); root fibrous, the fibres thickening towards the end, l. linear-lanceolate striated entire, st. and ped. glabrous few-flowered, carp. obliquely obovate rugose with a short revolute point, nectary tubular.-E. B. 2306.-Wales? P. V. VI.]

F.?

16. R. Flammula (L.); root fibrous, $l$. ovate- or linear-lanceolate nearly entire stalked, stem. reclining at the base and rooting, carp. obovate minutely pitted with a short point.-E.B. $387 . R$. iii. 10.-Stems 6-18 in. high. L. sometimes serrate, hairy or glabrous.- $\beta$. reptans; st. procumbent filiform rooting, l. linear. -In wet places. P. VI.-VIII. Lesser Spearwort.

[17. R. ophioglossifolius (Vill.); root fibrous, lower l. cordateovate stalked, upper l. oblong sessile amplexicaul, stem erect hollow, carp. obliquely ovate margined tubercled with a short terminal point. -E. B. S. 2833. R. iii. 2].-Glabrous. Fl. small. St. about 1 foot high, branched, many-flowered, tapering below. -St. Peter's Marsh, Jersey. A. VI.]

18. R. Lingua (L.); root fibrous, $l$. elongate-lanceolate acute somewhat serrate sessile amplexicaul, stem erect, carp. margined minutely pitted with a broad sword-shaped beak.-E. B. 100.R. iii. 10.-Fl. large. St. 2-3 feet high. St. and 1. glabrous or with adpressed hairs.-In marshy places, rather rare. P. VI. VII. Great Spearwort. 
t+十 L. undivided, fl. yellow, nectary with a scale.

19. R. Ficaria (L.); root with fasciculate knobs, $l$. cordate stalked angular or crenate, st. with $1-31$. single-flowered, sep. usually 3 ,'carp. smooth blunt.-E. B. 584. R. iii. l.-Pet. usually 8 , but varying from 6 to 11 . St. $3-8$ in. long, weak, often producing bulbs in the axils of its leaves.-Damp shady places, common. P. IV. V. Pilewort.

$++\dagger$ L. divided, fl. yellow.

+ Nectary without a scale, carp. smooth.

20. R. auricomus (L.); root fibrous, radical l. reniform $3-7-$ partite with crenate or cut lobes stalked, stem-l. sessile digitate with linear or lanceolate more or less toothed segments, peduncles round, calyx pubescent, carp. downy ventricose, beak slender hooked. - E. B. 624. R. iii. 12.-Pet. often wanting. Sep. yellow. St. about one foot high.-Woods and thickets, common. P. IV. V. Wood Crowfoot. Goldilocks.

++ Nectary with a scale, carpels smooth.

21. R. acris (L.); root fibrous, radical 1. palmately tripartite, segments trifid and deeply cut, uppermost stem-l. tripartite with linear segments, peduncles round, calyx pubescent erect-patent, carp. oval glabrous margined, beak short marginal recurved, receptacle glabrous. - E. B. 652. R. iii. 17.-Hairy. St. $2-3$ fect high. Beak about $\frac{1}{4}$ the length of the carpel.- Sometimes dwarf and 1-fl. on mountairs.-Meadows and pastures, common ; mountains. P. VI. VII. Upright Crowfoot.

22. $R$. repens $(\mathrm{L}$.); stoles creeping, 1. with 3 stalkerl leaflets which are 3-lobed, lobes 3-fid and cut, peduncles furrowed, calyx pubescent erect-patent, carp. oval glabrous margined minutely pitted, beak longish slightly curved, receptacle hairy.-E.B. 516 . -Primary stem erect, 10-12 in. high.-Meadows and pastures, common. P. V.-VIII. Creeping Crowfoot.

23. $R$. bulbosus (L.); stem bulblike at the base, radical l. with 3 stalked leaflets which are tripartite, segments trifid and cut, peduncles furrowed, calyx hairy reflexed, carp. round margined smooth, beak short, receptacle hairy. $-E$. B. 515. R. iii. 20.St. about 1 foot high. Upper l. cut into narrow segments.Meadows and pastures. P. V. Bulbous Crowfoot.

+++ Nectary with a scale, carp. rugose or tubercular.

24. R. hirsutus (Curt.); root fibrous, radical l. with 3 stalked trifid and cut leaflets, peduncles furrowed, calyx reflexed, carp. round margined with a series of tubercles near the margin, beak short curved, receptacle hairy.-E. B. 1504. R. iii.23. R. Phi- 
lonotis (Ehrh.) Koch.-St. 4-18 in. high ; the smaller specimens are $R$. parvulus L. Upper l. in narrow acute segments. Fl. pale yellow.-Waste land and corn-fields, rare. A. VI.-X. E. S.

†25. $R$. arvensis (L.); root fibrous, radical l. 3-cleft dentate, stem-l. once or twice ternate with linear-lanceolate segments, calyx erect-patent, carp. margined beaked and spinous.-E. B. 135. $R$. iii. 21.-Fl. pale yellow. Known by its spinous fruit.Corn-fields. A. VI. Corn Crowfoot.

26. $R$. parviflorus (L.); root fibrous, stems spreading, 1. roundish-cordate 3-5-lobed cut, upper l. oblong undivided or 3-lobed, calyx at first erect afterwards reflexed, carp. orbicular muricated. -E. B. 120. R. iii. 22.-Peduncles opposite the leaves. Pet. narrow.-Corn-fields and dry banks, rare. A.V. VI. E. I.

\section{Tribe IV. Helleborea.}

\section{Caltha Linn. Marsh Marigold.}

1. C. palustris (L.); st. ascending, l. heart-shaped rounded crenate. $-E$. B. 506. $R$. iv. 101.-Fl. large. Sep. roundish-ovate, bright yellow.- $\beta$. minor (DC.); smaller in all its parts and with the l. considerably shorter in proportion, but the posterior lobes greatly produced.-Marshy places, common. $\beta$. in more mountainous situations. P. III.- - V.

2. C. radicans (Forst.); st. creeping, 1. triangular serrate-crenate. -E. B. 2175.-Fl. half the size of those of C. palustris, sep. narrower, hinder angles of the leaves scarcely produced. I have only seen cultivated specimens. - "In a ditch that runs from the farm-house called Haltoun, on the estate of C. Gray, Esq. of Carse, Forfarshire. 1790." Mr. G. Don. All the other stations probably belong to $C$. palustris $\beta$. minor. P. V. VI. S.

\section{Trollius Linn. 'Globe Flower.}

1. T. europaus (L.); sep. $10-15$ concave converging into a globe, pet. 10 about equalling the stam., l. palmately 5 -parted, segments rhomboid 3-partite incise-serrate.-E. B. 28. R. iv. 101. -Fl. bright yellow. Pet. ligulate. St. $1-2 \frac{1}{2}$ feet high.-Damp mountain pastures. P. VI. VII.

\section{Eranthis Salisb. Winter Aconite.}

[*1. E. hyemalis (Salisb.); sep. 6-8 oblong. - R. iv. 101. Helleborus Linn.-Radical 1. upon long stalks, 5-7-parted, deeply cut into linear-oblong segments. St. $4-6$ in. high, with 2 opposite sessile l. just below the solitary yellow $\mathrm{fl}$. Root (rhizome) tuberous.-Naturalized in thickets. P. II. III.] E. S.? 


\section{Helleborus Linn. Hellebore.}

1. H. viridis (L.); radical $l$. digitate stalked, stem-l. sessile at the ramifications, st. few-flowered, calyx spreading.-E. B. 200. $R$. iv. 105.-Veins of the 1. prominent beneath. Stigma erect. St. 1 foot high, annual. Fl. greenish-yellow.-Thickets on a calcareous soil. P. III. IV. Green Hellebore.

2. H. fæetidus (L.); l. pedate stalked, st. leafy many-flowered, caly $x$ converging. $-E$. B. 613. R. iv. 103.-L. successively contracting upwards into bracts. St. 2 feet high. Fl. globose, drooping, greenish tipped with purple.-Thickets in chalky districts. P. III. IV. Stinking Hellebore.

\section{Aquilegia Linn. Columbine.}

1. A. vulgaris (L.); spur of the pet: incurved, limb obtuse falling short of the stamens, 1 . biternate, leaflets 3 -lobed crenate. -E. B. 297. R. iv. 114. - St. 2-3 feet high, slightly leafy. Caps. hairy. Inner stam. frequently imperfect.-Woods and thickets. P. V. VI.

\section{Delphinium Linn. Larkspur.}

†1. D. Consolida $($ L. $)$; st. erect branched, racemes few-flowered, spur longer than the calyx, pet. combined.-E. B. 1839.-Pedicels usually longer than the bracts. Caps. downy. Fl. of a vivid and permanent blue, rarely red, pink or white. L. deeply multifid.-Sandy or chalky corn-fields. A. VI. VII. E. S.

\section{Aconitum Linn. Monk's-hood.}

†I. A. Napellus (L.); nectaries horizontal upon curved stalks, spurs bent down, fl. racemose, young carpels diverging. $-E$. $B$. S. 2730. $R$. iv. 92.-Filaments slightly hairy, with cuspidate wings. Nectary inflated above, its lip broad. Helmet open, hemispherical. Pedicels erect, downy.-Banks of rivers and brooks, rare. VI. VII.

E. $\mathrm{S}$.

\section{Tribe V. Preniea.}

\section{Aстха Linn. Bane-berry.}

I. A. spicata (L.); raceme simple elongate, pet. as long as the stamens, berries oval. $-E . B .918$. R. iv. 121.-L. stalked biternate; leaflets ovate, trifid, deeply cut. St. $1-2$ feet high. -Mountainous limestone tracts in the north. P. V. E. S. 


\section{Pasonia Linn. Pæony.}

*1. P. corallina (Retz.); l. biternate, leaflets ovate entire glaucous beneath, caps. downy recurved from the base.-E.B. 1513 . R. iv. 128.-Root fleshy, knobbed. Herb 2 feet high. Fl. large, crimson with yellow anthers.-On the Steep Holmes Island in the Severn. P. V. VI.

E.

\section{Order II. BERBERIDACEÆ.}

Sep. 3, 4 or 6 , in a double row. Pet. the same or double that number. Stam. opposite to the petals. Anth. opening by valves from the bottom to the top. Carpel 1, 1-celled, seeds attached to the bottom or on a lateral placenta.

1. Berberis. Sep. 6, deciduous. Pet. 6 , each with 2 glands at the base within. Stam. 6. Berry 2-3-seeded.

[2. Epimedium. Sep. 4, deciduous. Pet. 4. Nectaries 4, cupshaped. Stam. 4. Caps. podlike, many-seeded.]

\section{Berberis Linn. Barberry.}

1. B. vulgaris (L.); spines 3-parted, 1. obovate ciliate-serrate, racemes pendulous many-flowered, petals entire.-E. B. 49 . $R$. iii. f. 4486.-Fl. yellow. Berries red, oblong, slightly curved. Filaments curiously elastic.-Hedges and thickets. Sh. V. VI:

\section{Epimedium Linn. Barren-wort.}

[1. E. alpinum (L.) ; root-leaves 0, stem-1. twice ternate.E. B. 438. R. iii. f. 4485. - Lts. heartshaped, serrate. Pan. shorter than the 1. and appearing to grow from the petiole. Fl. red with yellow nectaries. - Subalpine woods. Not a native. P. V.] E. S.

\section{Order III. NYMPHAACEસ.}

Sep. 4-6, passing gradually into the petals, and these into the many stamens, all inserted on a fleshy disk more or less completely surrounding the ovary. Stigma peltate. Fruit manycelled : seeds many, in a gelatinous aril. Embryo in a bag on the outside of the base of the albumen.

1. Nyмрнжа. Cal. of 4 sepals. Pet. many, inserted together with the stamens upon a fleshy disk enveloping the germen. Berry many-celled, many-seeded. Stigma sessile, of many rays. 
2. Nuphar. Cal. of 5 sepals. Pet. many, inserted together with the stamens upon the receptacle. Berry many-celled, many-seeded. Stigma sessile, of many rays.

\section{Nумрна Linn. White Water Lily.}

1. N. alba (L.); l. roundish deeply cordate entire with approximate lobes even beneath, stigna of $12-20$ rays. $-E$. $B$. 160. R. vii. 67.-Fl. large, white, floating. Stigmas yellow. Ovary covered with the stamens almost to its summit. Caps. dissolving into a mass of pulp. Notch in the leaves with parallel sides.-Slow rivers, lakes and elear ditches. P. VII.

\section{Nuphar Sm. Yellow Water Lily.}

1. N. lutea (Sm.); 1. oblong cordate, sep. 5 , stigma with 10 20 rays not extending to the entire margin, anthers linear. $-E . B$. 159. R. vii. 63.-Fl. yellow, smelling like brandy. Caps. bursting irregularly. Submersed l. thin, transparent, wavy, oblongcordate.-Lakes and ditches. P. VII.

2. N. pumila (DC.); l. ovate deeply cordate with distant lobes, sep. 5, stigma with 8-10 rays extending to the margin and forming acute teeth, anth. subquadrate.-E. B. 2292. R. vii. 65.-Fl. yellow, small. Caps. furrowed upwards. Anth. not twice as long as broad. Much smaller than N. lutea. Submersed 1. thin, transparent, wavy, reniform.-In small Highland lakes. P. VII. VIII.

\section{Order IV. PAPAVERACEA.}

Sep. 2, deciduous. Cor. regular, of 4 petals. Stam.generally many, free. Ovary free; placentas parietal, usually projecting; seeds many. Stigmas as many as the placentas, simple or lobed, the lobes of adjoining stigmas combining, thus appearing (falsely) to be opposite to the placentas.

* Fruit not linear, stigmas radiant.

1. Papaver. Pet. 4. Stam. many. Style 0. Stigmas 4-20, sessile. Caps. opening by pores beneath the stigma. Placentas like dissepiments. Seeds not crested.

2. Meconopsis. Pet. 4. Stam. many. Style short. Stigmas 5-6, free. Caps. obovate, opening by pores beneath the style. Placentas filiform. Seeds not crested.

** Fruit linear, stigmas 2-4.

3. Roemeria. Pet. 4. Stam. many. Stigmas 2-4, ses- 
sile. Caps. 2-4-valved, I-celled, placentas distinct. Seeds not crested.

4. Glaucrum. Pet. 4. Stam. many. Stigmas 2, sessile. Caps. 2-valved, placentas connected by a spongy dissepiment. Seeds not crested.

5. Chelidonium. Pet. 4. Stam. many. Stigmas 2. Caps. 2-valved, 1-celled, placentas distinct. Seeds crested.

\section{Papaver Linn. Poppy.}

1. P. Argemone (L.); filaments dilated upwards, caps. clavate hispid with erect bristles, stem leafy many-flowered, l. bipinnatifid.-E. B. 643. R. iii. f. 4475.-Fl. small. Pet. pale scarlet, black at the base. Bristles sometimes spreading.-In corn-fields, rather rare. A. VI. VII.

2. P. hybridum (L.); filaments dilated upwards, caps. ovate hispid with spreading bristles, stem leafy many-flowered, 1. bipin-

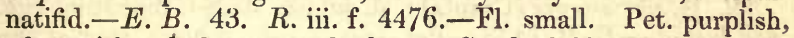
often with a dark spot at the base.-Sandy fields, rare. A. VI. VII.

E. I.

3. P. Rhœas (L.); filaments subulate, caps. nearly globular without bristles, margin of the stigma with overlapping lobes, stem bristly many-flowered, 1. pinnatifid cut.-E. B. 645. $R$. iii. f. 4479.- Fl. large. Pet. deep scarlet, often nearly black at the base. Peduncles with spreading hairs, or. ( $\beta$. strigosum Boenningh.) with adpressed hairs.-In corn-fields, common. A. VI. VII. Common red Poppy.

4. P. dubium (L.); flaments subulate, caps. clavate without bristles, margin of the stigma with distinct crenatures, stem hispid many-flowered, l. pinnatifid.-E.B. 644. R. iii.f. 4477.Fl. large. Pet. light scarlet. Peduncles with adpressed hairs. - Corn-fields, common. A. VI. VII.

†5. P.somniferum (L.); filaments dilated upwards, caps. truly globular without bristles, l. oblong unequally toothed amplexicaul.-E. B. 2145. R. iii. f. 4481.-Fl. large. Pet. bluish white with a violet spot at the base. Whole herb smooth, except sometimes a few rigid spreading bristles on the flower-stalk and a bristle tipping many of the teeth of the leaves, in which case it probably is the $P$. setigerum DC.-On sandy ground near the sea, and in the fens. A. VII.

E.

\section{Meconopsis Vig. Welsh Poppy.}

1. M. cambrica (Vig.) ; caps. smooth, l. stalked.-E. B. 66.Caps, oblong, beaked. Stem many-flowered, about 1 foot high. 
L. pinnate, cut, glaucous beneath. Fl. large, orange-yellow, on long stalks.-Rocky and shady places, rare. P. VI.

\section{Roemeria Cand.}

†1. R. hybrida (DC.); pod 3-valved erect with a few rigid hairs at its top. - E. B. 201. - Pod 2-3 in. long. L. twice or thrice pinnatifid with linear nearly smooth bristle-pointed segments. St. about 1 foot high, usually slightly hairy. Fl. violetblue. Pet. falling before noon.-Chalky corn-fields in Cambridgeshire and Norfolk. A. VI.

\section{Glaucium Tourn. Horned Poppy.}

1. G. luteum (Scop.); st. smooth, stem-l. amplexicaul sinuate, pod minutely tubercular-scabrous.-E. B. 8.-Glaucous. St. $1-3$ feet high, glabrous or slightly hairy. Root-l. stalked, lyrate, lobed and cut, hairy. Pet. large, golden yellow. Pods 6 -12 in. long, curved.-Sandy sea-shores. B. VI.-VIII.

[2. G. phœniceum (Crantz); st. pilose, stem-1. pinnatifid cut, pod hispid.-E. B. 1433.- Pet. scarlet with a black spot at the base.-Said to have been found in Norfolk. A. VI. VII.] E.

\section{Chelidonium Linn. Celandine.}

1. C. majus (L.); peduncles umbellate, 1. deeply pinnatifid, segments rounded and bluntly lobed.-E. B. 1581.-Fl. yellow, small. Pod long. St. 1-2 feet high. All parts full of an orange juice.- $[\beta$. C. laciniatum (DC.); segments of the leaves deeply pinnatifid, lobes incise-serrate.] -Waste places and old walls. $\beta$, a very doubtful native. P. V.-VIII.

\section{Order V. FUMARIACEA.}

Sep. 2 or 0 . Cor. irregular, of 4 parallel petals, one or both of the two outer saccate at the base. Stam. 6, in 2 bundles opposite to the outer petals : lateral stam.in each bundle 1-celled. Ovary free, 1-celled. Style filiform. Stigma with 2 or more points.

1. Corydalis. Cal. of 2 sepals or wanting. Pet. 4 , the upper one spurred at the base. Stam. diadelphous. Pod 2-valved, many-seeded, compressed.

2. Fumaria. Cal. of 2 sepals. Pet. 4 , the upper one spurred at the base. Stam. diadelphous. Fruit a nut, indehiscent, l-seeded.

\section{Corydalis Cand.}

[*?1. C. solida (Hook.); root tuberous solid, 1. biternate cut, lowest petiole a leafless scale, bracts palmate.-E. B. 1471.- 
Lobes of the 1. obtuse. Fl. purplish. St. a span high.-A very doubtful native. P. IV. V.]

*2. C. lutea (DC.) ; root fibrous, 1. triternate, bracts minute oblong cuspidate, seeds shining granulate-rugose with a patent denticulate crest. - E. B. 588.-Lts. obovate, trifid. Bracts shorter than pedicels. Fl. yellow. St. $1 \mathrm{ft}$. high, brittle.-Naturalized on old walls. P. V.-VIII. Yellow Fumitory.

3. C. claviculata (DC.); root fibrous, leaves pinnate, pinnæ ternate, footstalks ending in tendrils, bracts oblong acuminate.E. B. 103.-Leaflets entire, elliptical. Bracts rather longer than the pedicels. Fl. small, pale yellow or nearly white. St. slender, climbing, $1-4$ feet long.-Bushy places in hilly districts. P. VI. VII. White Climbing Fumitory.

\section{Fumaria Linn. Fumitory.}

1. F. capreolata (L.); sep. ovate toothed as broad as the cor.tube, fr. subglobose blunt, bracts rather shorter than the fruitstalks, lts. flat.-E.B.943.-St. erect, climbing, or diffuse. Sep. sometimes entire, about $\frac{1}{2}$ as long as the corolla. Pet. creamcoloured or pinkish ; lower linear, gradually dilated in its upper half. Fr. slightly compressed, smooth or rugose, rounded at the end and sometimes slightly apiculate, with 2 apical hollows, usually longer than broad.- $\beta$. Leightonii; sep. broader and longer, fr. broader than long. F. capreolata $\gamma$. Parl. ?- - . media; sep. narrower and longer, fr. rugose apiculate especially when young. $F$. agraria Bab.-Common. A. VI.-IX.

2. F. officinalis (L.); sep. ovate-lanceolate acute toothed narrower than the cor.-tube, fr. globose-retuse, bracts much shorter than the fruitstalks, lts. flat.-E. B. 589.-St. erect or diffuse. Sep. broader than the pedicel, about $\frac{1}{3}$ the length of the corolla. Pet. rose-coloured; lower spathulate, its haft linear. Fr. rugose, broader thau long.-Common. A. V.-IX.

3. F. micrantha (Lag.); sep. large roundish dentate broader than the cor.-tube, fr. subglobose subapiculate, bracts longer than the fr.-stalks, lts. linear channelled.-E.B.S.2876.-St.branched, diffuse. Pet. pale purple; lower spathulate, its haft linear. Fr. rather longer than broad.-Fields. A. VI.-IX.

4. F. parviflora (Lam.); sep. minute ovate acute cut, fruitstalk shorter than the obovate pointed $f r$. and equalling the bract, lts. linear channelled.-E. B. 590. R. iii. 1.-Foliage yellowish green glaucous. Lts. ascending. Fl. whitish, afterwards pale purple ; lower pet. linear widened at the end, sides of its haft inflexed.-Fields in Kent, Essex, Camb. A. VI.-IX.

5. F. Vaillantii (Lois.) ; sep. very minute triangular, fr.st. longer than obovate pointed fr. and twice longer than bract, 
lts. narrow flat.-E. B. S. 2877. R. iii. 1.-Foliage greyish green glaucous. Lts. spreading. Fl. purplish, afterwards whitish ; lower pet. spathulate, sides of haft scarcely inflexed.-Fields. A. VI.-IX.

\section{Order VI. CRUCIFER}

Sep. 4. Cor. cruciform of 4 petals. Stam. 6, tetradynamous ; 2 shorter opposite the lateral petals. Ovary free, with marginal placentas meeting in the middle. Stigmas 2, opposite to the placentas (or rather, alternate with them, lobed and combining). Fruit a silique or silicle, the valves opposite the shorter stamens.

\section{Suborder I. SILIQUOSA.}

Pod (silique) linear or linear-lanceolate, opening by 2 valves, dissepiment narrow but in its broadest diameter.

Tribe I. ARABIDEAE. Cotyledons accumbent parallel to the disscpiment, radicle lateral, seed compressed.

1. Matrinola. Pod round or compressed. Stigma 2-lobed, lobes erect gibbous or horned at the back.

2. Cheiranthus. Pod compressed or 2-edged, with an elevated longitudinal rib upon each valve. Stigma 2-lobed, lobes patent. Seeds in a single row in each cell.

3. Nasturtium. Pod subcylindrical; valves convex, veinless. Stigma capitate. Seeds irregularly in 2 rows.

4. BARBAREA. Pod terete; valves convex with a prominent longitudinal rib. Stigma capitate. Seeds in a single row.

5. TURRITIs. Pod compressed; valves slightly convex with a prominent longitudinal rib. Stigma capitate. Seeds in 2 rows.

6. Arabis. Pod compressed; valves nearly flat with a prominent longitudinal rib, or with numerous longitudinal veins. Stigma obtuse. Seeds in a single row.

7. Cardamine. Pod compressed; valves flat, veinless. Stigma capitate. Seeds in 1 row ; seed-stalk simple, filiform.

8. Dentaria. Pod lanceolate, compressed; valves flat, veinless. Stigma capitate. Seeds in a single row; seed-stalk dilated, winged.

Tr. II. SISYMBRIE $E$. Cotyledons incumbent contrary to the dissepiment, radicle dorsal, seed compressed. 
9. Hesperis. Pod quadrangular or subcompressed; valves keeled, somewhat 3-veined. Stigma of 2 closely converging erect elliptical obtuse lobes. Seeds in a single row.

10. Sisymbrium. Pod terete or rarely tetragonal; valves convex, with 3 longitudinal veins. Stigma entire. Seeds in a single row, smooth; seed-stalk filiform.-S. thatianum has a tetragonal pod and valves with 1 strong conspicuous rib.

11. Alliaria. Pod terete; valves convex, with 3 longitudinal veins, the middle one prominent and strong, the 2 lateral slender and branching. Stigma entire. Seeds in a single row, striated; seed-stalk flattened, winged.

12. Erxsimum. Pod tetragonal; valves prominently keeled, with 1 longitudinal vein. Stigma obtuse, entire or slightly emarginate. Seeds in a single row; seed-stalk filiform.

Tr. III. BRASSICEAE. Cotyledons conduplicate longitudinally folded in the middle ; radicle dorsal, within the fold.

13. Brassica. Cal. erect. Pod terete or angular. Seeds globose, in a single row.

14. Sinapis. Cal. patent. Pod terete or angular. Seeds in a single row.

15. Diplotaxis. Cal. patent. Pod compressed. Seeds oval or oblong, in 2 rows.

\section{Suborder II. LATISEPTE.}

Pouch (silicle) short, opening with two valves : dissepiment in its broadest diameter.

Tr. IV. ALYSSINEAE. Cotyledons accumbent.

16. Alyssum. Pouch roundish or oval, compressed. Seeds $2-4$ in each cell. Filaments toothed or the shorter ones with a gland or subulate process on each side at the base.

17. Koniga. Pouch oval, compressed. Seeds $1-2$ in each cell. Filaments simple. Hypogynous glands 8. Carpophorum 0.

18. Draba. Pouch oval or oblong, slightly convex. Seeds many in each cell, not margined, in two rows. Filaments simple.

19. Cochlearia. Pouch globose ; valves very convex, dorsal vein prominent. Seeds many. Filaments simple.

20. Armoracia. Pouch elliptical or globose; valves very convex, no vein. Seeds many. Filaments simple. 
[Tr. V. CAMELINEAE. Cotyledons incumbent.

21. Camelina. Pouch subovate; valves ventricose with a linear prolongation at the end which is confluent with the persistent style.]

[Tr. VI. VELLEAE. Cotyledons conduplicate.

22. Vella. Pouch ovate with a dilated winged flat style longer than the convex valves.]

\section{Suborder III. ANGUSTISEPTÆ.}

Pouch (silicle) short, laterally compressed, opening with 2 boat-shaped valves keeled or winged on the back; dissepiment narrow, linear, or lanceolate.

Tr. VII. THLASPIDEAE. Cotyledons accumbent.

23. Thlaspr. Pouch roundish, notched; valves boatshaped, winged at the back. Seeds many. Pet. equal. Filaments simple.

24. Hutchinsia. Pouch elliptical, entire; valves boatshaped, keeled not winged at the back. Seeds 2 in each cell. Pet. equal. Filaments simple.

25. Teesdalia. Pouch roundish, notched; valves boatshaped, their back keeled below narrowly winged above. Seeds 2 in each cell. Pet. equal or 2 outer ones larger. Filaments with a little scale at the base of each within.

26. IBERIS. Pouch ovate or roundish, notched; valves boatshaped, winged at the back. Seeds 1 in each cell. Pet. unequal, 2 outer ones much larger. Filaments simple.

Tr. VIII. LEPIDINEAE. Cotyledons incumbent.

27. Lepidium. Pouch roundish or oblong, entire or notched; valves compressed, keeled or winged at the back. Seeds 1 in each cell.

28. Capsella. Pouch triangular-obcordate; valves compressed, keeled but not winged. Seeds many.

Tr. IX. SUBULARIEA. Cotyledons incumbent, long, linear, curved back above their base. Cells many-seeded.

29. Subularia. Pouch oval-oblong, laterally subcompressed; valves boatshaped.

Tr. X. SENEBIEREAE. Cotyledons incumbent, long, linear, curved back above their base. Cells one-seeded. 
30. Senebiera. Pouch broader than long, somewhat kidneyshaped, entire at the end, or notched above and below and almost 2-lobed, not bursting. Cells 1-seeded.

Suborder IV. NUCUMENTACE

Pouch (silicle) scarcely dehiscent, often 1-celled, owing to the absence of the dissepiment.

Tr. XI. ISATIDEAE. Cotyledons incumbent.

31. Is atis. Pouch laterally compressed, 1-celled, 1-seeded; valves keeled, eventually separating.

\section{Suborder V. LOMENTACEE.}

Silicle or silique dividing transversely in single-seeded cells, the true silique often barren, all the seeds being in the beak.

Tr. XII. CAKILINEAE. Cotyledons accumbent.

32. Cak lle. Silicle angular, of two 1-seeded indehiscent joints, upper joint deciduous with an erect seed, lower persistent seedless or with a pendent seed.

Tr. XIII. RAPHANEAE. Cotyledons conduplicate.

33. Crambe. Silicle 2-jointed, upper joint globose with 1 seed pendent from a long curved seed-stalk springing from the bottom of the cell, lower joint barren stalklike.

34. Raphanus. Silique linear or oblong, tapering upwards, smooth and indehiscent, or moniliform and dividing transversely into l-seeded cells, lowermost cell barren imperfectly 2-valved stalklike.

\section{Suborder I. Siliquosa. Tribe I. Arabidea.}

\section{Matthiola $R$. Br. Stock.}

1. M. incana (R. Br.) ; st. shrubby upright branched, l. lanceolate entire hoary, pods "cylindrical without glands." $-E$. B. 1935. $R$. ii. 45.-Fl. of a full purple.-Cliffs in the Isle of Wight. P. V. VI. Hoary Stock.

E.

2. $M$. sinuata (R. Br.); st. herbaceous diffuse, l. oblong downy, lower $l$. sinuate, pods compressed muricated with glands. $-E$.B. 462. R. ii. 45.- Fl. purple.-Sandy sea-coasts of Wales, Cornwall, Wexford and Jersey. B. VI.-VIII. Sea Stock. E. I.

\section{Cheiranthus Linn. Wallfower.}

†1. C. Cheiri (L.); st. shrubby, l. lanceolate acute entire with bipartite adpressed hairs, pods tetragonal. $-E . B .1934$. R. ii. 45. -Fl. yellow or tinged with red.-Old walls. P. IV. V. 


\section{Nasturtium $R . B r$. Water Cress.}

1. N. officinale (R. Br.); 1. pinnate, lts. ovate or oblong subcordate sinuate-dentate, pet. twice as long as calyx (white), pods linear.-E. B. 855. R. ii. 50.-Pods patent. Very variable. When growing out of water it is slender with small leaves and is N. microphyllum (R.); when remarkably luxuriant, many feet in length, the stem often nearly an inch thick and the leaves very large and resembling those of a Sium, it is N. siifolium (R.).Brooks and ditches. P. VI. VII. Water Cress.

2. N. sylvestre (R. Br.); root creeping, 1. deeply pinnatifid, lts. oblong or lanceolate cut, uppermost 1 . often nearly entire, pet. twice as long as the calyx (yellow), pods linear.-E. B. 2324.Fr.-stalks patent; pods patent or ascending, variable in length usually as long as their stalks sometimes shorter.-N. anceps (Bab.) is not separable from this species.-River banks and wet places. P. VI.-VIII.

3. N. palustre (DC.); root fibrous, lower 1. lyrate, upper 1. deeply pinnatifid, lts. oblong toothed, pet. as long as the calyx, pods oblong turgid. - N. terrestre Sm., E. B. 1747.-Fl. small. Fr.-stalks patent or even deflexed; pods ascending, short, about as long as their stalks. - Wet places. P. VI.-IX.

\section{Barbarea $R$. Br. Rocket.}

1. B. vulgaris (R. Br.); lower l. lyrate, upper pair of lobes equalling the breadth of the large roundish subcordate terminal lobe, uppermost 1 . undivided toothed, young pods obliquely erect. -E.B.443. R. ii. 47.-Pet. twice as long as the calyx. Flowering raceme lax. Pods straight. $-\beta$. arcuata; young pods patent upon nearly horizontal pedicels.-In damp places. B.? V.-VIII. Yellow Rocket.

2. B. stricta (Fries); lower l. lyrate, upper pair of lobes small much shorter than the breadth of the large oblong-ovate terminal lobe, uppermost l. undivided toothed, porls adpressed, styleslender. $-R$. ii. 47. B. parviflora Fries.-Pet. half as long again as the calyx. Flowering raceme close. Fl. much smaller than in $B$. vulgaris. Pods straight. Lateral lobes of the lowermost l. very small, often obsolete.-Between Sheffield and Halifax and between Weedon and Blisworth, plentifully. Mr. Borrer. York. B.? V.-VIII.

E.

3. B. precox (R. Br.) ; lower l. imparipinnate with large lobes, upper pair of lobes equalling the breadth of the subeordate terminal lobe, uppermost l. pinnatifid with linear-oblong entire lobes, style short and thick.-E.B. 1129. R. ii. 49. B. patula Fries.Fl. moderate. Raceme close. Pods patent. Lower 1. usually iuterruptedly pinnate.-South of England. B. V.-VII. E. 


\section{Turritis Linn. Tower-wort.}

1. T. glabra (L.); radical 1. toothed hairy, stem-l. glabrous entire amplexicaul with a sagittate base, pods straight erect.E. B. 777. R. ii. 44.-Plant very erect and straight, $1-3 \mathrm{ft}$. high. Fl. whitish-yellow.-Banks, particularly in Norf. and Suff. Cliffs in Glen Devon, Scotland. B. VI. VII.

E. S.

\section{Arabis Linn. Rock-cress.}

1. A. hirsuta (R. Br.); 1. hispid dentate, stem-l. truncate-auricled or cordate at the base, auricles patent, pods erect narrow straight.-E. B. 587.- St. 1 foot high, clothed with spreading mostly simple hairs and many erect leaves. Sometimes the hairs on the stem are adpressed and branched. Root-l. narrowed into a footstalk. Koch and Reich. divide this into two or more species which I have not been able to determine.-Walls and banks. B. VI.-VIII.

2. A. ciliata (R. Br.) ; l. glabrous and ciliated or hispid somewhat toothed nearly sessile, stem-l. sessile with a rounded base, pods erect narrow straight.-St. erect. Seeds without wings.a. st. glabrous, 1. glabrous ciliated. E. B. 1746.- $\beta$. st. and 1. hispid. Often taken for $A$. hirsuta.-Rocks by the sea, Cunnamara, Ireland. $\beta$. Lidstep, Pembrokeshire. B. VII. VIII. E. I.

3. A. stricta (Huds.); $l$. hispid and ciliated deeply sinuatedentate narrowed into a footstalk, stem-l. sessile, pods few distant erect-patent straight.-E. B. 614.-St. erect, glabrous, hispid below, $6-8$ in. high. Fl. rather large. "Seeds with a narrow margin and winged at the apex."-Limestone cliffs near Bristol. P. IV. V.

E.

4. A. petraa (Lam.); l. glabrous or with forked hairs lyratepinnatifid or oblong-ovate nearly entire with long stalks, stem-l. narrow nearly entire stalked, pods spreading slender straight.E. B. 469. - St. erect or decumbent, 3-8 in. long, glabrous. Fl. large, white tinged with purple. Seeds oblong with a narrow margin and slight wing at the end.-Alpine rocks in E. and S. Ben Bulben, Ireland. Mr. Wynne. P. VII. VIII.

*5. A. Turrita (L.); 1. clothed with short forked hairs dentate elliptical narrowed into a stalk, stem-l. deeply cordate-amplexicaul elongate, pods flat with a thickened margin recurved from an erect stalk, seeds with a membranous margin.-E. B. 178. $R$. ii. 44. - St. 1 foot high, erect, hairy. Fl. yellowish. Pods 3-4 in. long, without any central vein but with many prominent longitudinal anastomosing veins.-On walls at Oxford, Cambridge, and Cleish Castle, Kinross. B. V.

E. S. 


\section{Cardamine Linn. Bitter-cress.}

1. C. impatiens (L.); l. pinnate, leaflets of the lower 1 . ovate 3 -fid, of the upper l. oblong lanceolate toothed or entire, petioles of the stem-l. with slender sagittate auricles, pet. linear or wanting.-E. B. 80. R. ii. 26.-Pet. erect, white. Distinguished by having auricles at the base of its petioles.-Hilly districts, preferring limestone. A. VII. VIII.

2. C. sylvatica (Link); 1. pinnate, leaflets of the lower $\ell$. roundish angled or toothed, of the upper 1 . narrower, pet. twice as long as the calyx, pods erect upon patent pedicels, stam. 6, style long. - R. ii. 26. C. hirsuta, E. B. 492. St. 45. 13. C. flexuosa With.-Fl. small. Pet. erect, white. St. flexuose, more leafy than in C. hirsuta. Root oblique, covered with fibres.Common, especially in woody places. A. IV.-IX.

3. C. hirsuta (L.); 1. pinnate, leaflets of the lower 1. roundish angled or toothed, of the upper l. narrower, pet. twice as long as the calyx, pods and pedicels erect, stam. 4, style short. $-R$.ii. 26 . St. 45. 14.-Fl. small. Pet. erect, white. St. nearly straight, rather leafy.-Rather common in damp places. A. IV.-VIII.

4. C. pratensis (L.); 1. pinnate, leaflets of the lower l. roundish slightly angled, of the upper $l$. linear-lanceolate entire, pet. 3 times as long as the calyx spreading, stam. half the length of the petals, st. terete. $-E . B .776$. R. ii.28.-Fl. large, lilac. Anth. yellow. Style short.- $\beta$. C. dentata (Schult.); leaflets of the lower 1. and lower stem-1. acutely angular--Moist meadows, common. $\beta$. near Cambridge. P. IV. Common Bitter-cress.

5. C. amara (L.); 1. pinnate, leaflets of the lower 1. roundishovate, of the upper l. oblong, all angular, pet. 3 times as long as the calyx erect, stam. nearly as long as the petals, st. angular.E. B. 1000. R. ii. 27.-Fl. large, white. Anthers purple. Style long, slender. Stigma small. Stoloniferous.-Moist meadows near streams, rare. P. V. VI.

[C. bellidifolia (L.) which has simple entire l. has been erroneously considered as a native of Britain. E. B. 2355.]

\section{Dentaria Linn. Coralwort.}

1. D. bulbifera (L.); st. simple, 1. alternate, lower 1. pinnate, upper 1. simple, axils of the l. producing bulbs. $-E$. B. 309.

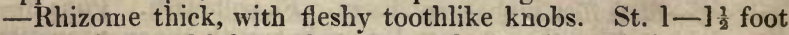
high. Lts. and l. lanceolate, serrated or entire. Fl. large, rosecoloured or purple.-Woods and shady places, rare. P.V. VI. 


\section{Tribe II. Sisymbriea.}

\section{Hesperis Linn. Dame's Violet.}

†l. H. matronalis (L.) ; st. erect branched above, l. ovatelanceolate acuminate toothed, pedicels about as long as the calyx, pet. obovate obtuse with an apiculus, pods erect froin a patent pedicel terete torulose.-H. inodora, E. B. 731.-Fl. lilac, " fragrant," large and handsome.-Hilly pastures, very rare. B. V. VI.

[Malcolmia maritima (R. Br.) has been found in Kent, but is not a native.]

\section{Sisymbrium Linn. Hedge Mustard.}

1. S. officinale (Scop.); pods subulate adpressed to the stem, 1. runcinate-pinnatifid with 2 or 3 pairs of oblong dentate lobes and a large hastate terminal lobe. $-E$. B. 735. R. ii. 72.-St. I - 2 feet high with divaricate branches, upper part leafless. Fl. small, pale yellow. Pods on very short stalks, pubescent sometimes glabrous-Common. A. VII. VII. Hedge Mustard.

[*2. S. polyceratium (L.); pods subulate spreading sessile axillary about 3 together, 1. lanceolate repand-dentate or subhastate.-R. ii. 73.-St.leafy throughout, branched, "prostrate." Fl. small.-Bury St. Edmunds, naturalized. A. VII. VIII.]

3. S. Irio (L.); pods terete 4 times as long as their pedicels erect-patent, the young pods exceeding the fl., seeds oblong, $l$. runcinate-pinnatifid, lobes dentate oblong the terminal lobe angular, lobes of the upper l. lanceolate with the terminal hastate. $-E$. B. 1631. R. ii. 75. - Erect, branched, st. and l. glabrous. Fl. yellow. Pods narrow, linear. Pedicels slender.-Near old towns, rare. A. VII. VIII. London Rocket.

4. S. Sophia (L.); pods terete 3 times as long as their pedicels erect-patent, seeds oblong, $l$. doubly or trebly pinnatifid, segments linear or linear-lanceolate.-E. B. 963. R. ii. 74.-St. erect, branched, and as well as the l. slightly downy. Fl. yellow. Pet. short. Pods linear, narrow. Pedicels slender.--Waste places, not common. A. VI.-VIII. Flixweed.

5. S. thalianum (Gaud.); pods 4-angular linear ascending twice as long as their patent pedicels, seeds oblong not striated, l. oblong-lanceolate undivided toothed.-Arabis Sm., E. B. 901 . Conringia $R$. ii. 60.-St. erect, slender, much branched, with few leaves which are nearly all radical. Fl. small, white. Pods angular on the back of the valves (tetragonous), not convex as in the other species (terete), nor with the lateral longitudinal veins so strongly marked.-On walls and banks. A. IV. V, and IX.X. 


\section{Alliaria Adans. Sauce-alone.}

1. A. officinalis (Andrzj.); l. heartshaped the lower ones reniform sinuate-dentate all stalked, pods erect-patent much longer than their stalks, seeds oblong subcylindrical striated.-E. $B$. 796. R. ii. 60. Sisymbrium Alliaria Sm., Koch.-St. erect, 1-3 feet high, slightly branched. L. large, thin, veined, smelling like garlic when bruised. Fl. white--Hedgebanks. B. V. VI. Jack-by-the-Hedge.

\section{Erysimum Linn. Worm-seed.}

1. E. cheiranthoides (L.); l. oblong-lanceolate slightly toothed with stellate-tripartite hairs, all narrowed into a slight footstalk, pedicels longer than the calyx 2 or 3 times shorter than the pods, pods patent ascending, seeds small many.-E. B. 942 . R. ii. 83 . -Seeds very small, so many in the pod as to be nearly 2-rowed. Fl. small. Pods always diverging from the stem. - Cultivated ground. Wild in the Fens. B. VI.-VIII.

E. I.

*2. E. orientale (R. Br.); l. elliptical heartshaped obtuse clasping the stem, radical l. obovate, all smooth glaucous undivided entire.-E. B. 1804. R. ii. 61.-Fl. white or cream-coloured. - "Fields and cliffs near the sea." A. V.-VII.

\section{Tribe III. Brassicece.}

\section{Brassica Linn.}

* Valves of pod 1-ribbed.

1. B. oleracea (L.); 1. glabrous glancous waved and lobed, lower 1. lyrate, upper l. oblong sessile.-E. B. 637. R. ii. 97.L. thick and somewhat fleshy. Stam. all erect. Fl. large, creamcoloured. Raceme elongated before the fl. expand. Cal. erect, adpressed. The wild state of the garden Cabbage.-Cliffs by the sea. B. VI.-VIII. Wild Cabbage.

2. B. campestris (L.); lower l. lyrate dentate somewhat hispid, upper $l$. ovate acuminate deeply cordate amplexicaul glabrous. -E. B. 2234.- "Raceme close, the open fl. rising above the buds." Fl. yellow.- $\beta$. B. Rapa (L.), root caulescent fleshy. E. B. 2176 . R. ii. 96 .-Borders of fields. A. or B. VI. VIİ. Wild Navew. $\beta$. Turnip.

3. B. Napus (L.); lower l. lyrate dentate glabrous, upper $l$. oblong somewhat narrowed below with a dilated cordate semiamplexicaul base.-E. B. 2146. R. ii. 93.-" Raceme elongated at the time when the fl. expand. Shorter stam. patent, ascending." Fl. yellow. It is difficult to find any character by which to di- 
stinguish this plant from the preceding.-Borders of fields. A. or B. V. VI. Rape, or Coleseed.

** Valves of pod 3-ribbed; beak 1-3-seeded.

4. B. monensis (R. Br.) ; 1. stalked all deeply pinnatifid, lobes obiong unequally toothed those of the upper l. linear. -E.B. 962 . - Fl. yellow. St. usually prostrate, glabrous. L. glabrous. - $\beta$. $B$. Cheiranthus (Vill.); st. $1-3 \mathrm{ft}$. high erect leafy hispid below, 1. hispid. Sinapis, E. B. S. 2821.-On the western coasts. B. or P.VI.-VIII.

E. S.

\section{Sinapis Linn. Mustard.}

1. S. nigra (L.); pods quadrangular adpressed, beak short sterile subulate, valves 1 -veined, lower 1 . lyrate, terminal lobe large and lobed, upper l. lanceolate entire.-E.B.969. R. ii. 88. -Fl. yellow. Lower 1. large, rough.-Willowy riverbanks. A. VI.-VIII. Black Mustard.

2. S. arvensis (L.); pods subcylindrical knotty longer than the conical compressed beak, valves 3-veined, l. ovate the lowermost sublyrate stalked, upper l. sessile.-E. B. 1748. $R$. ii. 86 . -Fl. large, yellow. Whole plant scabrous. Pods glabrous or rough with deflexed bristles; beak usually with 1 seed; valves with faint intermediate veins. Stem $1-1 \frac{1}{2}$ foot high.-Cornfields. A, VI.-VIII. Charlock.

3. S. alba (L.); pods cylindrical knotty shorter than the swordshaped beak, valves 5-veined, 1 . lyrate pinnatifid irregularly lobed. -E. B. 1677. R. ii. 85.-Fl. large, yellow. Pods hispid. St. 1-2 feet high.-Cultivated and waste land. A. VII. White Mustard.

[4. S. incana (L.); pods adpressed turgid prominently veined with a short 1 -seeded beak, l. lyrate hispid, stem-l. linear-lanceolate, st. much branched.-E. B. S. 2843.-St. 1-3 feet high, branches divaricate with few very small leaves. Pods very short, glabrous or hairy, often scarcely longer than their glabrous beak.-Sandy places in Jersey and Alderney. B. VII.-VIII.]

\section{Diplotaxis Cand. Wall-Mustard.}

1. D. tenuifolia (DC.); st.woody below branched subglabrous leafy, l. glaucous linear-lanceolate very acute sinuate-dentate or pinnatifid, segments linear remotely dentate, pet. roundish-obovate with a short claw. $-E$. B. 525. Sinapis Sm.-Pedicels usually twice as long as the sepals. Fl. large, pet. blunt but

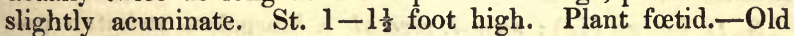
walls. P. VII.-IX.

E. S. 
2. D. muralis (DC.) ; st. herbaceous simple hispid and leafy at the base, l. almost glabrous ovate-lanceolate sinuate-dentate or pinnatifid, pet. roundish ovate with a short claw.-E. B. $10 \subseteq 0$. Sinapis Sm.-Pedicels as long as the flowers. Pet. abrupt or emarginate. L. often blunt, never very acute, usually all collected about the base of the stem. Branches all springing from the base-Waste ground. A. VIII. IX.

\section{Suborder II. Latisepta. Tribe IV. Alyssinea.}

\section{Alyssum Linn. Madwort.}

1. A. calycinum (L.); herbaceous hoary with starry pubescence, 1 . obovate-lanceolate attenuate below, pods orbicular stellate-pubescent, calyx persistent, filaments all toothless, shorter ones from between 2 setaceous processes. - E. B. S. 2853. R. ii. 18.-Cells of the pod 2-seeded. Pet. yellow, becoming at length white.-Grassy commons, S.; ploughed land, E. See Phytol. ii. 284. A. V. VI.

[Farsetia incana (R. Br.); seerls 6 or more in each cell, pods pubescent subventricose.-Near Lewes.]

\section{Koniga Adans., $R$. Br.}

[*1. K. maritima (R. Br.); procumbent, hairs bipartite, l. linear-lanceolate acute, pods oval pointed glabrous. - E. B. 1729. R. ii. 18. Alyssum Sm. - St. rather woody below. Fl. white, sweet-scented.-Naturalized near the sea. P. VIII. IX.]

\section{Draba Linn. Whitlow-grass.}

1. D. aizoides (L.); scape_leafless glabrous, l. linear rigid acute keeled glabrous ciliate, stam. equalling the slightly notched petals, style as long as the breadth of the pouch. $-E . B .1271$. $R$. ii. 15.-Fl. bright yellow. L. fringed with rigid hairs densely collected into cushion-like tufts.-On rocks and walls at Pennard Castle near Swansea. P. III. IV.

E.

2. D. rupestris (R. Br.); scape leafless or with 1 or 2 leaves pubescent, $l$. lanceolate flat stellately pubescent, stam. shorter than the slightly notched petals, style short.-E. B. 1338. D. hirta Sm.-Pouch oblong-oval, slightly hairy. St. very short, branched, each branch bearing a dense tuft of leaves and 1-3 short scapes. Fl.small. L. mostly entire.-Tops of the Highland mountains, rare. P. VII.

S. I.

3. D. incana (L.); stem-l. several, 1. lanceolate stellately pubescent toothed, pet. twice as long as the calyx entire, pouch 
longer than its pedicel twisted, style short slender.-E. B. 388. $R$. ii. 14.-Pouch nearly or quite glabrous, erect, lanceolate-oblong. St. 4-12 in. high, simple or branched. Fl. white.Mountains. Sand-hills by the sea in Islay, S. P. VI. VII.

4. D. muralis (L.); st. leafy branched, I. ovate amplexicaul toothed hairy, pet. " entire," pedicels spreading horizontally rather longer than the glabrous pouch.-E. B. 9l2. R. ii. 12.Pouch elliptical. St. 5-12 in. high. Fl. white. Pubescence branched. Root-l. narrowed below.-Limestone mountains. A. IV. V.

5. D.verna (L.); scape leafless glabrous above, l. lanceolate acute narrowed below hairy, pet. deeply cloven, pouch oblong shorter than its pedicel.-E. B. 586. R. ii. 12.- Pouch compressed, acute or rounded at the end. Fl. white. L. entire or toothed. Scape sometimes rather pilose.- $\beta$. inflata (Hook.); pouch inflated. D. spathulata (Lang.) Hoppe in St. 65. 1. D. pracox R. ii. 12. The pouches when transversely cut present a nearly circular section.-Very common on walls, banks, \&e. $\beta$. Ben Lawers. A. III.-V. Common Whitlow-grass.

\section{Cochlearia Linn. Scurvy-grass.}

1. C.officinalis(L.); radical l. cordate-reniform stalked, stem-l. sessile oblong sinuate semiamplexicaul, pouch globose or obovate.-E. B. 551.- Petioles long. Lower l. entire or sinuate. Seeds large. Style short. St. occasionally rooting and proliferous.- $\beta$. alpina ; pouch obovate, leaves smaller. C. groenlandica Sm., E. B. 2403. - Sea-coast, mostly in muddy places. $\beta$. on the higher parts of mountains. B. ? VI.-VIII. Common Scurvy-grass.

2. C.danica (L.); l. stalked, radical l. cordate somewhat lobed, stem-1. 3-5-lobed subdeltoid uppermost subsessile, pouch ovate. $-E$. B.696. R. ii. 16.-Petioles of the root-l. very long, gradually shortening as they become more distant from the root. Seeds small. Style short.-Sea-coast. B. V.-VIII.

3. C. anglica (L.); radical l. stalked ovate-oblong entire, stem-l. oblong entire or toothed mostly sessile the upper ones amplexicaul, pouch ovate-oblong. - E. B. 552.- Pouch twice as large as that of $C$. officinalis, much compressed laterally. Seeds large. Style rather long. Lower l. rounded below or narrowed into a footstalk. Fl. large.- $\beta$. gemina (Hort MS.); pouch coriaceous deeply furrowed on each side, dissepiment very narrow. - Sea-shores. $\beta$. on the mud of the Severn, Wye, \&c. A. V. English Scurvy-grass. 


\section{Armoracia Rupp.}

1. A. rusticana (Rupp.); roots long and thick, radical l. oblong crenate-serrate on long stalks, stem-1. elongate-lanceolate incise-serrate or entire subsessile, pet. (white) twice as long as cal., pouch oval "4-seeded," "stigma peltate."-Cochlearia $\mathrm{Ar}$ moracia (L.) E. B. 2323. R. ii. 17.--St. 2-3 feet high. Roots running deep into the ground.-Wastes and pastures near Swansea, abundant. Mr. Borrer. Elsewhere, scarcely wild. P. V. Horse Radish.

2. A. amphibia (Koch); root fibrous, 1. oblong narrowed at both ends serrate or pinnatifid, pet. (yellow) twice as long as the cal., pouch oval, "stigma capitate."-E. B. 1840. Nasturtium ed. 2. - St. 2-3 ft. high. Submersed 1. deeply pinnatifid. Ped. usually deflexed.-Watery places. P. VI.-VIII.

\section{Tribe V. Camelinea.}

21. Camelina Crantz. Gold-of-pleasure.

[C. fœetida (Fr.); pouches obovate inflated flaccid. In fields of flax and corn, introduced but not naturalized. I have not met with C. sylvestris (Fr.) nor C. sativa (Fr.).]

\section{Tribe VI. Vellea.}

\section{Vella Linn.}

[1. V. annua (L.); "l. doubly pinnatifid, pouches deflexed." $-E$. B. 1442.- Found in the time of Ray on Salisbury Plain, but has not since been noticed: A. VI.]

E.

Suborder III. Angustisepta. Tribe VII. Thlaspidea.

23. Thlaspi Linn. Penny Cress.

1. T. arvense (L.); fruitbearing raceme elongate, pouch orbicular with a broad longitudinal wing, seeds concentrically rugose and striated 5-6 in each cell, stem-l. oblong sagittate toothed. -E.B. 1659. R. ii. 5.-Pouch very large with remarkably broad wings. Stigma subsessile. St. often a foot high.-Fields and road-sides. A. V.-VII. Penny Cress.

2. T. perfoliatum (L.); fruitbearing raceme elongate, pouch obcordate broadly winged above, style very short included within 
the notch, seeds $3-4$ in each cell smooth, stem -l. cordate-oblong. -E. B. 2354. R. ii. 5.-About 6 in. high.-Limestone pastures in Oxfordshire and Gloucestershire. A. V.

E.

3. T. alpestre (L.); fruitbearing raceme elongate, pouch oblong-obovate narrowed below, style equalling or exceeding the notch, seeds $4-8$ in each cell, stem-1. oblong cordate. $-R$. ii. 5 . -Fl. white, often tinged with rose, small. Pet. about twice as long as the calyx. Terminal lobes of pouch rounded. L. usually entire. $-\beta$. T. occitanum (Jord.); fruitbearing raceme rather shorter, pouch triangular-obcordate with almost divaricate lobes, style much exserted. L. usually slightly toothed.-Mountain pastures. Teesdale; Thornhaugh, Northumb. ; Glen Isla, Forfar. $\beta$. Settle, York; Llanrwst, N. Wales. P. VI.-VIII. E. S.

4. T. virens (Jord.); fruitbearing raceme oval or oblong, pouch oboval with a shallow notch, style much exserted, seeds $4-5$ in each cell, stem-1. oblong-cordate.-Jord. Obs. Pl. de Fr. iii. t. 1. T. alpestre Sm., E. B. 81.?-Fl. white, small. Pet. about thrice as long as the calyx. Pouch with a very broad and shallow notch often almost truncate. L. usually entire.-Mountain pastures near Matlock. P. VI.-VIII.

E.

\section{Hutchinsia $R$. Br.}

1. H. petraa (R. Br.) ; l. pinnate, st. branched leafy, pet. scarcely longer than the calyx, pouch obtuse at both ends.E. B. 111. R. ii. 6.-St. $2-4$ in. high. Fl. small. Teesdalia has scales at the base of the filaments; Noccra (R.), incumbent cotyledons.-limestone rocks, rare. A. III.-V.

E.

\section{Teesdalia $R$. Br.}

1. T. nudicaulis (R. Br.); petals unequal.-E. B. 327. R. ii. 6 . -L. many, spreading on the ground, lyrate-pinnatifid, rarely orbicular-spathulate and entire. St. $2-4$ in. high, solitary or several from the crown of the root, sometimes bearing 1 or 2 small leaves. Stam. with remarkable scales within. Pouch emarginate.-Sandy and gravelly places. A. V.VI. E.S.

\section{Iberis Linn. Candytuft.}

1. I. amara (L.); herbaceous, l. lanceolate somewhat toothed, pouches racemose orbicular notched, lobes triangular porrect.E. B. 52. R. ii. 7.-L. usually with $1-3$ obtuse teeth on each side. St. often 1 foot high, diffuse, branched. Fl. at first corymbose, afterwards in lengthened clusters. Outer pet. radiant. -Chalky fields. A. VII. Bitter Candytuft.

E. 


\section{Tribe VIII. Lepidinea.}

\section{Lepidium Linn. Pepper-wort.}

* Pouch cordate with turgid valves, style filiform.

[*1. L. Draba (L.); l. oblong entire or toothed lower ones narrowed into a footstalk, stem-l. sagittate and amplexicaul, style as long as the dissepiment.-E.B.S.2683. R. ii. 9.-One foot or more in height, branched. Fl. many, small, white, upon long pedicels in a subumbellate corymb.-Kent; near Swansea; and other places. Introduced. P. V. VI.] E.

** Pouch ovate or roundish winged notched. † Style manifest.

2. L. campestre (R. Br.); 1. downy toothed lower ones oblong narrowed into a footstalk, stem-l. lanceolate sagittate and amplexicaul, pouch ovate rough notched and rounded at the end, style scarcely longer than the notch.-E. B. 1385. R. ii. 9.Scales on the pouch only minute globular blisters when fresh. St. one, upright, about a foot high, branched in the upper part. -Dry gravelly soil. B. VI.-VIII.

3. L. Smithii (Hook.); 1. hairy toothed lower ones obcordate stalked, stem-1. lanceolate-sagittate amplexicaul, pouch ovate glabrous notched and rounded at the end, style twice as long as the notch.-L. hirtum, Sm., E. B. 1803.-Seeds $\frac{1}{2}$ as long as in L. campestre. Pouch sometimes with a few scales, never hairy. St. several, 6-12 in. long; central st. erect, others diffuse.Hedge-banks. P. VI.-VIII.

\section{+ Style minute.}

[L. sativum (L.); lower 1. lobed pinnate or bipinnate, upper 1. sessile linear entire, pouch roundish oval, obtuse. $-R$. ii. 9.Escaped from cultivation in many places.]

*** Pouch oval or roundish notched, style minute.

4. L. ruderale (L.); lower 1. pinnatifid, upper l. linear entire, pouch patent, diandrous, petals $0 .-$ E. B. 1595 . R. ii. 10.-End of pouch narrowly winged. St. branched, often a foot high. Radicle dorsal. - Waste places near the sea. A. V. VI.

**** Pouch oval or roundish scarcely notched wingless, style minute.

5. L. latifolium (L.); 1. ovate-lanceolate serrate or entire undivided, pourh oval entire downy.-E. B. 182. $R$. ii. 10.-Fl. many, small, in compound leafy panicled clusters. St. 3 feet high, erect, branched. L. large, the lower ones upon long stalks, the upper nearly sessile and narrower.-In salt marshes and sandy places near the sea. P. VII. VIII. 


\section{Capselda Vent. Shepherd's Purse.}

1. C. Bursa-pastoris (DC.); radical 1. lanceolate pinnatifid or undivided toothed, upper l. amplexicaul auricled, pouch triangular-obcordate.-Thlaspi Sm., E. B. 1485.-Varying greatly in size and the division of its leaves. Known by its peculiar pouches. -A common weed. A. III.-X.

\section{Tribe IX. Subulariea.}

\section{Subularia Linn. Awl-wort.}

1. S. aquatica (L.); E. B. 732. R. ii. 12.-Cotyledons only once folded, but curved back upon themselves above their base, therefore incumbent not bicrures. Plant small, subaqueous. L. linear-subulate, radical. Root of many long white fibres. Fl. small, often perfected under water--Margins of alpine lakes. P. VII.

\section{Tribe X. Senebierea.}

30. Senebiera Pers. Wart-cress.

1. S. Coronopus (Poiret); pouch undivided reniform crested with little sharp points, style prominent, l. pinnatifid.-E. B. 1660. $R$. ii. 9. - St. much branched, prostrate. Fl. small, white, in lateral clusters opposite to the leaves. Pouches large, in dense clusters. Cotyledons in this genus curved back upon themselves above their base, not at it as is usual in Crucifera.Waste ground, common. A. VI.-IX.

2. S. didyma (Pers.); pouch notched of two wrinkled lobes, style very short, l. pinnatifid.-E. B. 248. R. ii. 9.-St. spreading, prostrate, a foot or more in length. Fl. small white in long slender lax clusters.-Waste ground near the sea in the south and south-west. A. VII.-IX.

\section{Suborder IV. Nucumentacea. Tribe XI. Isatidea.}

\section{Isatis Linn. Dyer's Woad.}

†1. I. tinctoria (L.); " radical leaves oblong crenate," pouch abrupt smooth thrice as long as broad.-E. B. 97. R. ii. 4.Cultivated and waste land, rare. B. VII.

\section{Suborder V. Lomentacea. Tribe XII. Cakilinea.}

The fruit consists of a very small 2-celled, stalklike, usually sterile pod, with a long moniliform beak bearing the seeds and dividing transversely into as many indehiscent cells as there are seeds. 


\section{Cakile Gaert. Sea-Rocket.}

1. C. maritima (Scop.); joints of the pouch 2-edged, the upper one with 2 teeth at the base, l. fleshy piunatifid or somewhat toothed.-E. B. 231. R. ii. 1.-Fl. purplish. Pouches an inch long, erect, with 4 sharp angles, swordshaped in the upper part. - Sandy sea-shores. A. VI. VII. Purple Sea-Rocket.

\section{Tribe XIII. Raphanea.}

\section{Crambe Linn. Sea-kale.}

1. C. maritima (L.); longer filaments forked at the end, pouch without a style, l. roundish sinuate wavy toothed glaucous and as well as the st. glabrous. $-E$. B. 924 . R. ii. 2.-Root thick, fleshy. St. 2 feet high. FI. white--Sandy sea-shores. P. VI.

\section{Raphanus Linn. Radish.}

1. R. Raphanistrum (L.); pods moniliform striated shorter than the very long beak, l. simply lyrate.-E. B. 856.-Root slender. Lobes of the leaves quite distinct. Pet. veined, white or lilac-Corn-fields. A. VI. VII. Jointed Charlock.

2. R. maritimus ( $\mathrm{Sm}$.); pods moniliform striated beak shorter, radical $\iota$. interruptedly pinnate.-E. B. 1643.-Root thick. Lobes of the l. usually so close as to overlap each other. Pet. yellow.-Sea-coasts, rare. B.? VI. FIII. Sea Radish.

\section{Order VII. RESEDACEÆ.}

Sep. 4 or 5 or 6 , persistent. Cor. irregular, pet. $4-6$ entire or lacerated. Stam. 10-24, filaments rariously united, inserted on a glandular irregular 1-sided disk. Ovary 3 or 4-lobed, l-celled, with 3 or 4 parietal many-seeded placentas; or of several l-celled carpels. Fruit opening nearly at the end.

1. Reseda. Cal. many-parted. Pet. entire or variously cut, unequal. Stam. many. Fruit of one cell opening at the top. Styles 3-6.

\section{Reseda Linn. Mignonette.}

1. R. lutea (I..); sep. 6 linear, pet. 6 very unequal, ped. longer than the cal., l.3-cleft or pinnatifid- -E. B. 321. R. ii. 100.St. 2 feet high, branched, smooth. L. very variable. Two upper pet. with 2 winglike lobes, lateral pet. with a single wing, lower ones nearly entire. Fl. yellow. Fr. oblong, wrinkled.Waste places in chalky and limestone districts. B. VI.-VIII. 
†2. R. suffruticulosa (L.); sep. 5 linear-lanceolate, pet. 5 nearly equal 3 -fid longer than the calyx, ped. shorter than the cal., l. all pinnatifid, segments linear acute sometimes wavy.E. B. S. 2628. R. ii. 101.-St. $1 \frac{1}{2}-2$ feet high, rather shrubby below. Fl. white. Fr. oblong, wrinkled. This plant is sometimes found with 6 sep. and pet. when it appears to be $R$. alba (L.). -Waste sandy places near the sea, rare. B. or P. VII. VIII.

3. R. Luteola (L.); sep. 4 , pet. 4 or 5 very unequal longer than the calyx, $l$. elongate-lanceolate undivided.-E. B. 320. R. ii. 99.-St. 2 feet high. Pet. usually 4 , upper one $3-$, 4-, or 5-cleft, 2 lateral 3-cleft, segments linear, lower one (or 2) linear entire. Fr. broad, depressed.-Waste places, particularly on chalk or limestone. A. VII. VIII. -Weld.

\section{Order VIII. CISTACEÆ.}

Sep. 5, two outer smaller sometimes wanting, 3 inner with a twisted æstivation. Pet. 5, corrugated and twisted in æstivation the contrary way to the sepals. Stam. many. Ovary l, 1- or many-celled. Style and stigma simple. Fruit capsular, with 3, 5 or 10 valves. Embryo spiral or curved, in the albumen.

1. Helianthemum. Cal. of 5 sepals, 2 outer smaller. Pet. 5, deciduous. Stam. many. Caps. 3-valved.

\section{Hedianthemum Gaert. Rock-rose.}

1. H. guttatum (Mill.); erect herbaceous, l. oblong-lanceolate or linear, lower 1. opposite without stipules, upper 1. alternate, racemes without bracts, stigma subsessile.-E. B. 544.-Upper 1. usually with small stipules. Fruitstalks patent. Pubescence of long simple and short stellate hairs. Fl. yellow, usually with a deep red spot at the base of each petal.-Very rare. ThreeCastle Head, Cork. Jersey. A. VI.-VIII.

2. H. Breweri (Planchon); erect herbaceous, $l$. obovate obtuse rosulate without stip., upper l. linear, racemes with bracts.Lond. Journ. of Bot. iii. 618. t. 21. - St. mostly simple or branching from the base. Pet. narrow, yellow, not spotted. Fruitstalks erect-patent.-Very rare. Holyhead Mountain and near Amlwch, Anglesea. A. VI.-VIII.

E.

3. H. canum (Dun.); shrubby, without stipules, l. opposite ovate or oblong stalked flat hoary beneath, racemes terminal bracteated, "style twisted at the base reflexed, at the apex inflexed."-Cistus marifolius Sm., E. B. 396.-St. decumbent. L. hoary beneath, hairy above. Fl. yellow, small. "Anth. emarginate at both ends. Style longer than the stigma." - On limestone rocks, rare. P. V.-VII.

E. I. 
[4. H. ledifolium (Willd.); herbaceous, with stipules, downy, 1. lanceolate opposite, upper 1. alternate subsessile pubescent, ped. solitary opposite the l. shorter than cal., styles straight.E. B. 2414.-Brent Down, Somerset, not found for muny years and probably an error. A. VI. VII.]

E.

5. H. vulgare (Gaert.); procumbent, shrubby, with stipules, 1. oval or linear-oblong opposite nearly flat green above hoary beneath, racemes bracteated, style longer than the germen bent at the base, sep. subglabrous inner ones obtuse apiculate.-Cistus Helianthemum (L.) E. B. 1321.-Fruitstalks contorted and deflexed. Varying much in the size and shape of its leaves and the amount of hoariness and pubescence. Fl.yellow.-C. tomentosus E. B. 2208. does not differ essentially from this plant.-C. surrejanus E. B. 2207. (from Mr. Dickson's garden) is not the Croydon plant (Dill. Hort. Elth. t. 145.) which was again found there by the late Mr. Christy and is a monstrosity of $H$. vulgare.Common on dry hilly places. P. VII.-IX. Common Rockrose.

E. S. I.?

6. H. polifolium (Pers.); shrubby, procumbent, hoary, with stipules, $l$. opposite ovate-oblong or oblong-linear more or less revolute at the edges, racemes bracteated, style bent at the base longer than the germen, sep.tomentose inner ones obtuse.-E. B. 1322. H. apenninum DC. - Fl. white-Very rare. Brean Downs, Som.; Torquay, Devon. P. VII. VIII.

E.

\section{Order IX. VIOLACEÆ.}

Sep. 5, imbricate. Pet. 5, regular or irregular. Stam. 5, filaments dilated, connective elongated beyond the anthers into a flat membrane. Ovary 1 -celled with 3 parietal placentas. Style with a hooded stigma. Caps. with 3 valves. Embryo straight, in fleshy albumen.

1. Viola. Sep. 5, extended at the base. Pet. 5, unequal, the lower one produced into a hollow spur behind. Stam. 5 . Anth. combined into a cylinder, 2 lower ones spurred behind.

1. Viola Linn. Violet.

d. Two interm. pet. patent laterally. Style nearly straight from a slender base.

* Stigma flat above. St. creeping. Fr.-st. erect. Caps. nodding.

1.V.palustris (L.); anth.-spurs short thick rounded, spur of the cor. very short obtuse, $l$. reniform-cordate glabrous.-E. $B$. 444. $R$. iii.-Anth.-cells nearly parallel. Fl. pale lilac with purple 
streaks.-Bogs in mountainous districts. P. IV.-VI. Marsh Violet.

** Stigma hooked; beak deflexed. Nearly stemless. Fruitstalks prostrate.

2. V.odorata (L.); anth.-spurs lancet-shaped decurved blunt, spur of the cor. obtuse straight, lateral pet. entire lower one emarginate, 1. cordate, stoles creeping.-E.B. 619. R. iii.-Anth.spurs narrowed to an obtuse point. Anth.-cells diverging below. Spurs of the pet. inflated towards the end, slightly channeled above. Fl. purple, often white, sweet-scented. Bracts above the middle of the flowerstalk. Petioles with deflexed hairs. Lateral pet. usually with a hairy line, or without when it is $V$. imberbis Leight. Caps. globose, downy.-Common. P. III. IV. Sweet Violet.

3. V. hirta (L.) ; anth.-spurs nearly linear blunt, spur of the cor. obtuse hooked at the end, pet. entire or slightly emarginate, 1. cordate, stoles wanting.-E. B. 894. R. iii.-Anth.-spurs scarcely broader at the base than at the apex. Anth.-cells diverging below. Spur of the petals compressed, not channeled. Fl. pale blue, sometimes white, scentless. Lateral pet. usually with a hairy line. Bracts below the middle of the flowerstalk. Stip. not hispid at the margin. Petioles with spreading hairs. Caps. globose, downy.- $\beta$. calcarea (Bab.); fl. smaller, ped. much longer than the leaves, sep. oblong-ovate-Common on limestone. $\beta$. Gogmagog Hills. Portland. P. IV. V. Hairy Violet.

*** Stigma hooked; beak horizontal. Having a stem. Fruitstalks erect.

+ Root not rhizomatous.

4. V. sylvatica (Fries); anth.-spurs narrowly lancet-shnped ( 5 times as long as broad), cor.-spur blunt, 1. broadly cordate, st.-l. longer subacuminate, stipules ${ }^{1}$ lanceolate fimbriate much shorter than the petioles, flowering branches axillary from a short flowerless central rosette of leaves. $-R$. iii. 12 . V. canina E. B. 620.-Fl. lilac, spur paler, scentless. Cor.-spur 3-6 times exceeding the cal.-appendages. Lower pet. cuneate-spathulate.V.riviniana (R.) is a large-flowered form. V.flavicornis (Forst.), E. B. S. 2736 , is a dwarf form having small 1 . and large flowers with a pale or sometimes yellow spur.-Common on hedgebanks or in thickets. P. IV. V.

5. V.canina (L.); anth.-spur lancet-sbaped (3 times as long as broad), cor.-spur blunt, 1 . cordate-oblong roundedly acute,

1 The stipules on about the middle of the stem should always be exanined in determining the species of Viola. 
stip. ovate or lanceolate ciliate or dentate much shorter than the petioles, primary and lateral stems flowering and elongated.- $R$. iii. 10. V. pumila H. and A. (not Vill.).-Rather cæspitose. L. always roundedly acute, longer than those of No. 4. Fl. bluish purple, spur yellow, scentless. Cor.-spur $1-3$ times longer than cal.-appendages. Lower pet. spathulate. $-V$. flavicornis (Sm.) is a small form with cordate leaves. When the 1 . are cordateoblong it is perhaps $V$.montana (Linn.).- $\beta$. V.lancifolia(Thore); $l$. ovate-lanceolate rounded below, stip. lanceolate incise-serrate. $V$. pumila Fries (not Vill. which is $V$. pratensis Fr. and is rhizomatous). V. lactea Sm. E. B. 445. H. and A. (in part). L. narrowing gradually from near their base to a narrow but rounded point.-Sandy and peaty places. $\beta$. in turf bogs, rare. P. IV. V. Dog Violet.

\section{† Rhizome slender.}

6. V. stagnina (Kit.); anth.-spur short broadly lancet-shaped acute (not twice as long as broad), cor.-spur very short blunt, 1 . ovate-lanceolate subcordate below, petioles winged at the top, stip. linear-lanceolate incise-serrate shorter than the petioles, primary and lateral st. flowering and elongated.- $V$. lactea $\mathrm{R}$. iii. 16. not $S m$., V. stricta Bab.-Rhizome threadlike. St. erect. L. narrowing gradually from the base which in the lowest is sometimes rounded not cordate. Fl. pale blue, nearly white. Cor.-spur scarcely longer than the cal.-appendages.-Rare. Turf bogs. P. V. VI.

B. Four upper pet. directed upwards and imbricate. Style clavate. Stigma inflated.

7. V. lutea (Huds.); anth.-cells nearly parallel, anth.-spurs long filiform, spur of the cor. as long or longer than the calycine appendages, sep. acute, l. crenate-serrate lower ones ovatecordate, upper 1. ovate or lanceolate, stip. palmate-pinnatifid, terminal lobe linear or linear-lanceolate entire, st. ascending diffuse and filiform underground.-E. B. 721.-Fl. wholly yellow, yellow with the 2 upper petals purple or wholly purple, varying greatly in size. Caps. globose. All the lobes of the stip. of nearly equal size, lateral ones (usually 3 on one side and $l$ on the other) all springing from near the base of the stip., the terminal lobe narrow and always I believe quite entire but sometimes considerably larger than the others.- $\beta$. V. Curtisii (Forst.); stems angular rough, lower part of the stip. somewhat elongated so as slightly to separate the lateral lobes. E.B.S. 2693.-Mountainous pastures. $\beta$. Sands near the sea. P. VI. VII.

8. V. tricolor (L.); anth.-cells diverging below, anth.-spurs long subclavate-filiform, spur of the corolla about equalling 
the calycine appendages, 1 . crenate-serrate lower ones ovatecordate, upper l. ovate or ovate-lanceolate, stip. lyrate-pinnatifid, terminal lobe spathulate crenate, st. ascending. $-E . B .1287 . R$. iii. 21. V. Curtisii (Mack.) from Portmarnock.-Root simple. Fl. with the upper pet. purple, lateral ones bluish, lower one yellow. Caps. ovate. Terminal lobe of the stip. often having only one tooth on each side. $-\beta$. $V$. arvensis (Murr.); pet. shorter than the calyx whitish, caps. nearly globular. E. B. S. 2712.-Common. A. V.-IX. Heartsease. Pansy.

\section{Order X. DROSERACEA.}

Sep. 5, imbricate. Pet. 5, regular. Stam. 5 or 10, free. Styles 3 or 5. Ovary free. Caps. 3-5-valved; valves bearing the seeds along their middle. Seeds without an arillus.-L, with a circinate vernation.

1. Drosera. Cal. deeply 5-cleft. Pet. 5. Stam. 5, hypogynous. Styles $3-5$, deeply bifid. Caps. 1-celled with $3-5$ valves, many-seeded.

2. Parnassia. Cal. deeply 5-cleft. Pet.5. Stam.5, perigynous, with 5 scales fringed with glandular setæ interposed. Stigmas 4, sessile. Caps. 1-celled, with 4 valves.-Differs from this Order by wanting the circinate vernation.

\section{Drosera Linn. Sundew.}

1. D. rotundifolia (L.) ; l. round spreading, petioles hairy, fl.stalks erect, seeds with a loose chaffy coat. $-E . B .867$. R. iii. 24 . -Flower-stalks 2-6 in. high. "Stignas white, clubbed, entire. Anth. white." Borr. L. covered, as in all other species, with hairs terminating in large glands secreting a viscid fluid which retains insects that settle upon them.-Common in boggy places. P. VII. VIII. Round-leaved Sundew.

2. D. intermedia (Hayn.); 1. spathulate obtuse erect, petioles glabrous, fl.-stalks arcuate or decumbent at the base, seeds with a close rough not chaffy coat. $-R$. iii. 24 . D. longifolia $S m$. E. B. 868. - "Stig. pink, bifid. Anth. yellow." Borr. A variety with shorter leaves and the flower-stalks shorter than the leaves is sometimes found.-Common in boggy places. P. VII. VIII.

3. D. anglica (Huds.) ; l. obovate-lanceolate obtuse erect, petioles glabrous, fl.-stalks erect, seeds with a loose chaffy coat.E. B. 869. D. longifolia $R$. iii. 24, Koch, Fries.-Much larger and taller than the last. A variety, D. obovata (M. and K.), is common in Scotland with broader leaves and the styles often, 
though not always, emarginate.-In bogs, rather rare, eommon in Ireland. P. VII. VIII.

\section{Parnassia Linn.}

1. P. palustris (I.) ; filaments of the petaloid scales $9-13$, pet. with a short claw, radical l. cordate stalked, stem-l. amplexicaul. $-E$. B. 82.-Pet. white, veined. Glands of the scales yellow. L. mostly rarlical.-Wet and boggy places, particularly in the north. P. VIII. $-X$.

\section{Order XI. POLYGALACEÆ.}

Sep. 5, imbricate, irregular, 2 interior much larger petaloid. Pet. unequal, usually 3,1 anterior and larger than the rest. Stan. monadelphous, separating above into 2 equal opposite bundles. Anth. 1-celled, opening by a pore at their apex. Caps. 1-2-celled, with placentas in the axis. Seeds pendulous, usually with an arillus at the base.

1. Polygala. Sep. 5, persistent, 2 inner (wings) broader and often petaloid. Cor. irregular. Pet. $3-5$, connected together, the lower one keelshaped. Caps. compressed. Seeds solitary, with a 3-pointed basal arillus.-Fl. crested.

\section{Polygala Linn. Milkwort.}

1. P. vulgaris (L.); lower l. smaller oblong, upper 1. linearlanceolate, cal.-wings obovate mucronate their veins branched the lateral joining a branch of the central vein, caps. obcordate, lateral bracts shorter than the pedicels. $-E$. B. 76.-St. prostrate, ascending. L. scattered. Racemes terminal. Fl. blue, pink, or white. Central vein of wings nearly simple ending in a mucro; lateral only branched externally; branches joining in loops and also with the upper ones of the central vein. Lobes of arillus unequal, blunt, lateral ones $\frac{1}{2}$ as long as the seed which is a little stalked within the arillus. $-\beta$. P. depressa (Wend.); lower 1. mostly opposite and crowded, st. long prostrate wiry, racemes ultimately lateral. $P$. serpillacea Weihe.-P. oxyptera (R.); fl. smaller, fr. broader than the wings. E. B. S. 2827.A plant from Ben Bulben, Sligo, has oblong smallish lower l., large lanceolate upper l., elliptical apiculate cal.-wings whose lateral veins rejoin the mostly simple central vein near its tip and have many netlike veins externally; deep blue flowers. It is probably a fine state of this species and may be the var. grandiflora (W. and G.).-Dry pastures and peaty fens. P. VI.-IX.

2. P. calcarea (F. Sch.); $l$. chiefly in an irregular terminal tuft large obovate obtuse, upper 1. smaller lanceolate, cal.-wings 
oblong their veins branched the lateral looping with a branch from near the middle of the central vein, caps. oblong-obcordate, lateral bracts shorter than the pedicels.-P. amara Don, E.B.S. 2764. P. amarella Coss. et Germ. Atl. t. 7.-St. weak, procumbent or ascending, nearly naked below. Fl.-st. from the axils of the term. rosette, simple, short; racemes terminal. Fl. blue. Lobes of arillus unequal, lateral $\frac{1}{2}$ as long as seed.-Chalk hills of the S.E. of England. P. V.

E.

3. P. austriaca (Cr.); lower l. larger obovate obtuse in a basal rosette, upper l. oblong-lanceolate, cal.-wings oblong or obovate obtuse their veins simple or slightly branched free, caps. wedgeshaped below roundish broader than the wings, lateral bracts shorter than the pedicels. $-P$. uliginosa R. I. i. f. 40. 4l. $P$. amara Sv. Bot. t. 484.- Rosette at the crown of the rootstock; 1. much the largest, broad, rounded at the end. Fl.-st. from the axils of the rosette, simple, short; upper l. acute; racemes terminal. Cal.-wings longer than caps. (in our plant). Lobes of arillus nearly equal, blunt, $\frac{1}{2}$ as long as seed.-Cronkley Fell, Yorkshire (1500 ft.). Mr. James Backhouse. P. VI. VIII.

\section{Order XII. FRANKENIACE\&.}

Sep. 4-5, in a furrowed tube below. Pet. 5, clawed, with appendages at the base of the limb. Stam. 5 or more, free, 2celled, opening by 2 terminal pores or longitudinally. Caps. 1celled, 2-4-valved; placentas 3, parietal. Style slender, simple or trifid. Seeds many, minute. Embryo in the albumen.

1. Frankenia. Style 3-fid; lobes oblong with the stigma on their inner side. Caps. 1-celled, 3-4-valved.

\section{Frankenia Linn. Sea-heath.}

1. F. lavis (L.); 1. linear revolute at the margin glabrous ciliated at the base.-E. B. 205.-St. slightly downy, prostrate, wiry. Cal. slightly hispid between its prominent angles. Fl. terminal or from the forks of the stem, sessile, rose-coloured. L. sometimes pulverulent, truly oblong but with much revolute edges.-Salt marshes on the east coast. P. VIII.

E.

2. F. pulverulenta (L.); l. obovate retuse glabrous above pulverulent beneath, petiole ciliated.--E. B. 2222.-St. similar to the last.-Formerly on the Sussex coast, now lost. A. VII. E.

\section{Order XIII. ELATINACEA.}

Sep. 3-5, distinct, or slightly connate. Pet. 3-5. Stam. equal to or twice as many as the pet., free. Caps. 3-5.celled, 
3-5-valved, loculicidal, with central placentas. Styles $3-5$, stigmas capitate. Seeds many, albumen 0 , embryo curved with the seed.-L. without stipules, opposite.

1. Elatine. Cal. 3-4-parted. Pet. 3-4. Stam. 3-4 or 6-8. Styles 3-4. Caps. 3-4-celled, many-seeded. Seeds cylindrical, straight or bent.

\section{Elatine Linn. Water-wort.}

1. E. hexandra (DC.); 1. opposite longer than their petioles, fl. slightly stalked with 6 stam. and 3 obovate pet., caps. turbinate concave at the summit 3-celled, seeds nearly straight ascending $8-12$ in each cell. $-R$. I. f. 599. E. Hydropiper $E$. B. 955. E. tripetala $S m$.-Plant ininute, procumbent. Fl. alternate, axillary. Cal. 3-fid.-Forming small matted tufts under water, rare. A. VIII.

2. E. Hydropiper (L.); 1. opposite shorter than their petioles, fl. stalked or nearly sessile with 8 stam. and 4 ovate pet., caps. roundish depressed 4-celled, seeds bent almost double pendulous 4 in each cell. - E. B. S. $\leq 670$. E. Schkuhriana (Hayne) Reich. -Fl. quite sessile in our plant. Cal.4-fid.-Very rare, growing under water. A. VIII.

E. I.

\section{Order XIV. CARYOPHYLLACEÆ.}

Sep. 5 or 4 , distinct or connected in a tube. Pet. 5 or 4 , clawed. Stam. usually twice as many as, sometimes equal to, the petals, free or connected at the base. Anth. opening longitudinally. Ovary one, often stalked. Stigmas 2-5, sessile, filiform. Caps. 1-or imperfectly 2-5-celled, opening by twice as many teeth as stigmas, sometimes valvular. Placenta central. Embryo generally curved round mealy albumen.-L. without stipules, opposite.

\section{Suborder I. SILENEA.}

Sep. united into a tube. Stam. united below into a tube which is connate with the stalk (carpophore) of the ovary. Caps. stalked.

1. Diantuus. Cal. 5-toothed, with 2 or more imbricate opposite scales at the base (except in D. prolifer). Pet. 5, clawed. Stam. 10. Styles 2. Caps. I-celled, many-seeded, opening at the top with 4 valves. Seeds peltate, convex above, concave beneath and more or less keeled.

2. Saponaria. Cal.5-toothed, naked at the base. Pet. 5, 
clawed. Stam. 10. Styles 2. Caps. 1-celled, opening at the top with 4 valves. Seeds globular or reniform.

[3. Cucubalus. Cal. 5-toothed, naked. Pet. 5, clawed. Stam. 10. Styles 3. Caps. a globose 1-celled berry. Seeds reniform.]

4. Silnne. Cal.5-toothed, naked. Pet. 5, clawed. Stam. 10. Styles 3. Caps. more or less completely 3-celled, opening at the top with 6 valves. Seeds reniform.

5. Lychnis. Cal. 5-toothed, naked. Pet. 5, clawed. Stam. 10. Styles 5. Caps. 1- or half 5-celled, opening at the top with 5 or 10 teeth.

\section{Suborder II. ALSINEE.}

Sep. distinct. Stam. free, inserted into a more or less evident hypogynous ring. Caps. sessile.

* Valves of caps. the same number as the styles.

[6. Buffonia. Sep.4. Pet. 4, entire. Stam.4. Styles 2. Caps. flattened, 2-valved, 2 -seeded.]

7. Sagina. Sep., entire pet., styles and valves of caps. $4-5$. Seeds reniform, wingless. Stam. 4-10.

8. Honkeneja. Sep. 5. Pet. 5, large. Stam. 10, alternating with glands. Styles and valves 3. Seeds few, large.

9. Alsine. Sep. and pet. 5 or 4 . Styles and valves 3 (or 4 ). Seeds many, with a naked hilum.

10. Cherleria. Sep. 5. Pet. 0 or 5, minute. Stam. 10, outer ones opposite to the sep. and springing from an oblong emarginate glandular base. Styles and valves 3 . Seeds few, small.

** Valves of the caps. twice as many as the styles.

11. Moenringia. Sep. 5. Pet. 4-5, entire or slightly emarginate. Stam. 8 or 10. Styles 2-3. Caps. opening with 4 or 6 valves. Seeds many, with an appendage at the hilum.

12. Arenaria. Sep. 5. Pet. 5, entire, or slightly emarginate. Stam. 10. Styles 3. Caps. opening with 6 valves. Seeds many, with a naked hilum.

13. Holosteum. Sep. 5. Pet. 5, toothed at the end. Stam. 5 or 3 or 4 . Styles 3. Caps. subcylindrical, many-seeded, opening at the end with 6 teeth. 
14. Stellaria. Sep. 5. Pet. 5, bifil. Stam. 10. Styles 3. Caps. opening with 6 valves or teeth, many-seeded.

15. Moenchia. Sep. 4, erect. Pet. 4, entire. Stam. 4. Caps. many-seeded, opening at the end with 8 or 10 teeth.

16. Malachium. Sep. 5. Pet. 5, bifid or entire. Stam. 10. Styles 5. Caps. opening with 5 bifid valves.

17. Cerastium. Sep. 5. Pet. 5, bifid. Stam. 10 or 5 or 4. Styles 5 or 4 . Caps. tubular, opening at the end with 10 teeth. - In C. trigynum the styles are mostly 3.

\section{Suborder I. Silenea.}

\section{Dianthus Linn. Pink.}

* Fl. capitate or clustered.

1. D. prolifer (L.); fl. in a clustered head, cal.-scales membranous pellucid the 2 outer ones shorter mucronate, inner ones obtuse about equalling the calyx, st. glabrous, l. all linear, seeds boatshaped with a longitudinal membrane in the hollow rough pointed at one end.-E. B. 956. R. vi. 247.-St. $1-1 \frac{1}{2} \mathrm{ft}$. high, erect, usually simple. Fl. expanding one at a time, small. Pet. rose-coloured, obcordate. Head quite inclosed by brown dry scales.-Sandy and gravelly places, rare. A. VII.

E.

2. D. Armeria (L.); fl. aggregate tufted, cal.-scales and bracts lanceolate-subulate downy herbaceous ribbed equalling the tube, st. downy, l. linear downy, seeds nearly flat one side slightly hollowed and with a longitudinal keel in its middle rough pointed at one end. $-E . B$. 317. R. vi. 249.-St. $1-2$ feet high, erect, branched. Pet. rose-coloured, speckled with white dots, crenate. -Waste places, rare. A. VII. VIII. Deptford Pink. E.

$$
\text { ** Fl. solitary or panicled. }
$$

†3. D. plumarius (L.); st. 2-5-flowered, fl. solitary, cal.scales roundish-ovate shortly mucronate 4 times shorter than the tube, $l$. rough at the margin linear-subulate, pet. digitate multifid as fur as the middle with the central entire part obovate downy, barren st. procumbent rooting much branched, seeds flat orbicular with a point on one side. $-R$. vi. 257.-Flowering stems $6-12$ in. high. Calyx teeth ciliated at the margin, slightly shorter than the capsule. Fl. pale pink, sometimes white, fragrant.Old walls and ruins. P. VI.

†4. D. Caryophyllus (L.); fl. solitary, cal.-scales broadly obovate pointed 4 times shorter than the tube, $l$. with smooth margins linear, pet. crenate-dentate ovate glabrous, barren st. elon- 
gated procumbent branching, seeds pyriform nearly flat.-E. $B$. 214. $R$. vi. 268 . -Fl. stems $12-18$ in. high. Calyx teeth not ciliated, longer than the capsule. Fl. pale pink, fragrant. Seeds half the size of those of the preceding.-Old walls, Kent, Norwich (?). P. VII. VIII. Clove Pink.

E. S. ?

5. D. casius $(\mathrm{Sm}$.$) ; st. mostly single-flowered, cal.-scales$ adpressed ovate obtuse shortly pointed 4 times shorter than the tube, $l$. with rough margins linear, pet. obovate crenately-cut bearded, barren stems elongated procumbent branching, seeds ovate pointed at one end.-E. B. 62. R. vi. 265.-Flowering stem 6.8 in. high. Fl. pale rose-colour, fragrant.-On limestone cliffs at Cheddar, Som. P. VI. VII. Cheddar Pink. E.

6. D. deltoides (L.); fl. solitary, cal.-scales usually 2 ovate aristate $\frac{1}{2}$ the length of the tube, l. linear-lanceolate the lower ones obtuse rough at the edges and keel, stem-l. acute and as well as the st. pubescent-scabrous, pet. obovate dentate, barren st. short procumbent simple (?), seeds obovate flat reticulate-rugose. $-E$. B. 61. R. vi. 263.-Flowering-stems 6-12 in. high, branched. Calyx teeth lanceolate, minutely ciliated. Fl. rosecoloured, with a darker circle round the mouth, scentless.- $\beta$. D. glaucus (L.); l. glaucous, cal.-scales usually 4 , fl. nearly white with a purple circle.-Hilly pastures. $\beta$. King's Park, Edinburgh. P. VI.-IX. Maiden Pink.

\section{Saponaria Linn. Soapwort.}

1. S. officinalis (L.); fl. fasciculate-corymbose, cal. cylindrical, pet. retuse crowned, l. elliptic-lanceolate ribbed, st. erect. $-E$. $B$. 1060. R. vi. 245 . St. 6 . 10.-St. $1-3$ feet high, stout, leafy. Fl. flesh-coloured or pale pink, large, handsome.- $\beta$. hybrida (L.) ; some of the upper l. combined and sheathing, pet. combined.-Hedges, mostly near villages. Banks of streams on the borders of Wales. P. VIII.

\section{Cucubalus Linn.}

[1. C. bacciferus (L.); st. branched spreading, l. ovate acute, cal. campanulate, pet. distant.-E. B. 1577.-Fruit fleshy.-Isle of Dogs near London, scarcely native. P. VIII.]

\section{Silene Linn. Catchfly.}

1. S. anglica (L.); racemes terminal, fl. alternate, cal. hairy with setaceous teeth ovate when in fruit, pet. slightly cloven or entire obovate, 1. lanceolate lower ones spathulate.-E. B. 1178. - Hairy and viscid. St. simple or branched, erect. Fl. solitary, secund, axillary, white or reddish.-Fr.-st. often reflexed.- $\beta . S$. 
quinquevulnera (L.); fl. white with a large crimson spot upon the disk of each usually entire petal. E. B. 86.-Sandy and gravelly fields. $\beta$. Duppas Hill, Surrey, and Wrotham, Kent. A. VI.-X. English Catchfly.

2. S. nutans (L.); pubescent, glandular-viscid above, panicle secund with drooping trichotomous opposite 3-7-flowered branches, cal. ventricose with acute teeth, pet. bifid crowned, segments linear, lower 1. spathulate, stem-1. sessile lanceolate, carpophore scarcely half as long as the capsule, teeth of the caps. reflexed.-E. B. 465. -St. $1 \frac{1}{2}$ foot high. Fl. white, most expanded and sweetest in the evening. - $\beta$. S. paradoxa (Sm.); 1 . broader.-On limestone and chalky places. $\beta$. Dover Cliffs. P. VI. VII. Nottingham Catchfly.

E. S.

[3. S. italica (Pers.); pubescent, panicle nearly erect with opposite trichotomous viscid branches, cal. long clavate with obtuse teeth, pet. bifid not crowned, segments broad, lower l. lanceolatespathulate, stem-l. linear-lanceolate, carpophore as long as caps., teeth of the capsule reflexed (?). -S. patens (Peete) E. B. S. 2748. - St. about 2 feet high.-An escape from cultivation. The station at Dover is an error. P. VI. VII.] E. S.

4. S. Otites (Sm.) ; panicle elongate with opposite tufted verticillate-racemose branches, whorls many-flowcred, peduncles glabrous, cal. faintly veined smooth with obtuse teeth, pet.linear undivided not crowned, 1. lanceolate-spathulate, stem-l. small linear erect.-E. B. 85.-Fl. imperfectly dicecious, small, yellowish. Caps. sessile. St. viscid at about the middle, 1 foot high. - Sandy and gravelly places in the east of England. P. VI. E.

5. S. inflata (Sm.); panicle terminal, fl. many drooping, cal. inflated reticulated, pet. deeply cloven scarcely ever crowned, seginents narrow, l. elliptical lanceolate, stem erect.-E. B. 164. - Glabrous, smooth. St. 2-3 feet high. Inflorescence between corymbose and panicled. Pet. white. Cal. intlated especially below, mouth narrower than the base. Bracts scarious. Branches of panicle unequal. Scented at night. Sometimes the st. and 1. are rough with hairs, and cal. downy.-Fields and roadsides. P. VI.-VIII. Bladder Campion.

6. S. maritima (With.); panicle terminal, fl. few usually solitary erect, cal. inflated reticulated, pet. crowned, segments broad, l. lanceolate or ovate-lanceolate, st. spreading decumbent, $\mathrm{fl}$. shoots ascending.-E. B.957.-Barren procumbent shoots forming a cushion. Fl. larger than those of No. 5. Cal. elliptical, mouth broader than base, most inflated above the middle. Bracts herbaceous. - Near the sea, also by alpine rills. P. VI.-VIII.

7. S. conica (L.); st. erect forked, fl. from the forks or terminal, cal. with 30 furrows conical in fruit, teeth subulate acute, pet. 
obcordate crowned, 1. linear subulate downy, caps. oblong-ovate. -E. B. 922. S. conoidea R.-St. 3-12 in. high, simple or branched. Cal. of the flowers conical-tubular, rounded below, of the fruit very broad at the base. Carpophore very short. Fl. reddish.-Sandy fields, rare. A. V. VI.

8. S. noctiflora (L.); st. erect repeatedly forked, ft. from the forks or terminal, cal. veined and with 10 hairy glandular ribs in fruit ellipicic-oblong, teeth long subulate, pet. deeply bifid crowned, l. lanceolate lower ones obovate, caps. ovatc.-E. B. 291. St. 3. 10.-Resembling Lychnis vespertina. St. about 1 foot high, downy and glandular. Caps. opening with 6 patent teeth. Carpophore very short. Fl. reddish-white, rather large, sweetscented in the evening; pet. rolled up by day ; peduncles glandular.-Sandy and gravelly fields. A. VII. VIII.

[9. S. Armerix (L.); "panicles forked many-flowered leveltopped, pet. cloven each with a double awlshaped scale, cal. and 1. smooth, caps. not longer than its stalk." Sm.-E. B. 1398. St. 21. 4.-Chester, now lost. Yalding, Kent. A. VII.] E.

[10. S. alpestris (Jacq.); cal. topshaped short, st. dichotomous, fl. axillary and terminal, calyx-teeth ovate-obtuse, pet. crowned, limb with 4 teeth, caps. oblong twice as long as the calyx, seeds cristate-ciliate, 1. lanceolate.- "On a rock on a mountain to the east of Clova, Angus-shire, Mr. G. Don." !]

11. S. acaulis (L.); st. densely tufted and much branched, fhe solitary, peduncles and cal. glabrous, cal. bellshaped with 10 . strix, teeth ovate-obtuse, pet. slightly notched crowned, 1 . linear ciliated 'below.-E. B. 1081 . R. 5084.-Forming broad dense tufts 2-3 in. high. Fl. purple or white, upon longish solitary stalks, sometimes nearly sessile. Caps. twice as long as the calys. Plants somewhat diœcious.-Summits of the higher mountains. P. VII. VIII. Cushion-pink.

\section{Lychnis Linn. Campion.}

1. L. Viscaria (L.); pet. emarginate crowned, st. glabrous viscid below the joinings, 1 . lanceolate glabrous the margins woolly at the base, fl. racemose-panicled somewhat whorled, carpophore 1.: the length of the capsule.-E. B. 788.-St. simple, 1 foot high. El. large, rose-coloured. Caps. 5-celled when young. Seeds ;eniform, minute, acutely tubercled.-Dry rocks, rare. P. VI.

E. S.

2. L. alpina (L.) ; pet. cloven scarcely crowned, st. glabrous not at all viscid, l. linear-lanceolate glabrous sometimes minutely ciliated at the base, $\mathrm{fl}$. corymbose, carpophore $\frac{1}{3}$ of the length of the capsule.-E.B.2254.-St. simple, 5-6 in. high. Fl. small, 
rose-coloured, crown scarcely more than 2 small tubercles upon each petal. Caps. 5-celled when young. Seeds reniform, minute, bluntly tubercled.-Mountains. Glen Isla, Forfar. (3200 ft.). Hobcarten Crag, Cumb. (2000 ft.). P. VI. VII. E. S.

3. L. Flos-cuculi (L.); pet. deeply 4-cleft crowned, segments linear palmately diverging, cal. with short teeth, st. with deflexed hairs, 1. lanceolate the lower ones narrowed below, $\mathrm{fl}$. loosely panicled, caps. 1-celled, teeth 5 , carpophore very short.-E. B. 573. - St. viscid and brownish above, $1-2$ feet high. Pet.rosecoloured, the crown bipartite; segments subulate erect and usually with an acute tooth on the middle of the outer margin. Cal. 10-ribbed.-Moist places. P. V. VI. Ragged Robin.

4. L. vespertina (Sibth.); pet. half bifid crowned, st. villose, 1. peduncles and cal. hairy, 1 . ovate-lanceolate, $\mathrm{fl}$. dichotomously panicled diœcious, calyx-teeth of the fertile fl. linear lanceolate long, caps. conical, teeth 10 straight.-St. 23.9. R. vi. 304. I. dioica $\beta$. (L.) E. B. 1580.-Fl, white, very rarely reddish. Calyx of barren $\mathrm{fl}$. obovate-oblong; of fertile fl. ovate, teeth twice as long as those of L. diurna. Carpophore broad, short. -Fields. B. (?) VI.-IX. White Campion.

5. L. diurna (Sibth.); pet. half bifid crowned, st. 1. and cal. villose, l. ovate acute, fl. dichotomously panicled, diceious, caly $x$ teeth of the fertile fl. triangular, caps. nearly globular, teeth 10 recurved.-St. 23.8. R. vi. 304. L. dioica $\alpha$. (L.) E. B. 1579.Fl. red, very rarely nearly white. Carpophore narrow, short. The E. B. figures are not accurate in the form of the calyx-teeth. Both No. 4 and 5 vary in colour from red to white and white to red.-Damp hedgebanks. B. (?) V. VI. Red Campion.

6. L. Githago (Lam.); pet. entire or emarginate crowiless, calyx-teeth longer than the tube exceeding the petals, 1 . solitary upon long stalks.-Agrostemma (L.) E. B: 741. St. 5. 6.-FI. large, purple. St. dichotomous, $2-3$ feet high. Cal. coriaceous, ribbed, with 5 linear-lanceolate constantly erect-patent very long segments. Caps. 5-toothed.-Corn-fields. A. VI.-VIII. Corn Cockle.

\section{Suborder II. Alsinea.}

\section{Buffonia Linn.}

[1. B. апnиa (DC.); "st. loosely panicled from the hase, branches spreading short firm, striæ on the ealyx straight parallel, caps. scarcely equalling the calyx, 1 . subulate spreading at the base." DC.-B. tenuifolia Sm., E. B. 1313. - Said to have been found near Boston, Linc. and on Hounslow Heath. A. VI.] L. 


\section{Sagina Linn. Pearlwort.}

* Sep., pet., stam., styles and valves of caps. 4.

1. S. procumbens (L.); central st.very short, branches elongated procumbent, $l$. linear awned, sep. blunt much longer than the petals and slightly shorter than the capsule, apex of the peduncles reflexed after flowering ultimately erect.-E. B. 880. R. v. 201. St. 30. 3.-Glabrous. Central st. very short, barren and erect. Branches elongated, procumbent, often rooting. Pet. blunt, often wanting. A fifth part is occasionally added to the fl. in which case it is distinguished from $S$. saxatilis by its cal. spreading when in fruit and styles reflexed during flowering. A fleshy maritime form is often taken for S. maritima. - $\beta$. spinosa (Gibs.); 1. longer and narrower very minutely spinose-ciliated on the edges.-Waste ground. P. V.-IX.

2. S. apetala (L.); st. elongated forked, branches ascending, l. linear mucronate, sep. blunt much longer than the petals and shorter than the capsule hooded ultimately spreading in the form of a cross, peduncles always erect.-E. B. 881. R. v. 200. - Pale green; upper part of the stem, peduncles and calyx more or less clothed with granular hairs. Central st. elongated and flowering. Branches often quite erect, sometimes prostrate. Pet. very minute, inversely wedgeshaped and truncate. Caps. conical-ovate, subpeltate below, stalked.-S. debilis (Jord.) has awnless l., sep. equalling and spreading from the ripe caps., and may be a maritime state of $S$. apetala. It is often called $S$. maritima in. England. S. maritima (Gren.) has a central rosette and may be a form of $S$. procumbens.-Walls and dry places. A. V. - IX.

3. S'. ciliata (Fr.); st. elongated, branches diffuse or spreading, J. linear awned, outer sep. pointed exceeding and adpressed to th s mature caps., their tips patent.-R. v. 200. S. patula Jord., S. apetala $\gamma$. Bab.-Glabrous. Central st. elongated and flowering. Cal. and tips of ped. sometimes with gland-tipped hairs. Caps. ovate-attenuate, rounded below, stalked.-Dry places. A. V. VI.

E. I.

4. S. maritima (Don); central st. elongated forked, branches ascending, $l$. fleshy blunt or apiculate rounded at the back glabrous, sep. blunt about equalling the capsule, peduncles always erect.-E. B. 2195 . S. stricta Fries. - St. often purple, brittle. The central stem produces flowers and is erect, or in luxuriant p.ants more or less procumbent. Sep. concave with incurved tiu)s. Caps. ovate, rounded below, sessile.-On the sea-shore. (lies states that his plant sometimes occurs upon mountains in Norway.) A. V.-IX. Sea Pearlwort. 
[S. densa (Jord.) has rery mueh branched st. forming dense tufts, with short joints and shorter linear plane-convex l., caps. ovate rounded below but stalked. It grows near Christchurch, Hants, and probably at Wisbeeh, Camb. Apparently a distinet species allied to S. maritima.]

** Sep., pet., styles and valves 5. Stam. 10. Spergella Reich.

5. S. saxatilis (Wimm.); central st. short and barren, 1. linear mucronate smooth, st. peduncles and cal. glabrous, pet. shorter caps. longer than the calyx. - Spergula saginoides Sm., $E$. B. 2105.-St. prostrate, slightly rooting, many. Peduncles long, their tips reflexed after flowering ultimately ereet. Caps. rather longer than the calyx, sometimes twice the length. Closely resembling $S$. procumbens but distinguished by the valves of its capsule being much more narrowed npwards, sep. adpressed and narrower, pet. longer, styles not reflexed.-Highland mountains. P. VI.-VIII.

S.

6. S. subulata (Wimm.); l. awned linear often ciliated, peduncles and calyx glandular hairy, pet. about as long caps. longer than the calyx. - Spergula Sm., E. B. 1082.-St. procumbent. Peduncles very long, the tip slightly reflexed after flowering ultimately ereet. Caps. ovate-attenuate, rounded below, sessile. -Dry gravelly and sandy places. P. VI.-VIII.

7. S. nodosa (E. Meyer); 1. subulate glabrous, upper l. shorter fasciculate, pet. muci longer than the calyx, pedinneles always erect.-Spergula Sm., E. B. 694.-Primary stem abbreviated, not flowering; lateral stems procumbent at the base then ascending, 2-6 in. long. Fl. terminal, 1, 2 or 3 together, white, conspicuous. Whole plant often quite glabrous. Sometimes (S. glandulosa Bess.) the upper parts of the st., the connecting membrane of the 1. and the base of the cal. are glandular-hairy.Wet and sandy places. P. VII. VIII. Knotted Spurrey.

\section{Honkeneja Ehrh. Sea-Pimpernel.}

1. H. peploides (Ehrh.) ; 1. sessile ovate acute fleshy glabrous 1-veined, pet. obovate, sep. ovate obtuse 1-veined sliorter than the petals.-Arenaria E. B. 189.-St. dichotomous, procumbent, rhizomatous. Fl. from the furks of the stem, frequently diocious. Caps. large, globose. Seeds few, large.-Sandy sea-coasts. P. VI.-IX.

\section{Alsine Wahl.}

1. A. stricta (Wahl.); $\boldsymbol{l}$. filiform veinless, fl.-shoots crect naked above, pet. equalling the cal. oblong-oval attenuated below, sep. ovate-lanceolate acute 3-veined (when dry), ped. ter- 
minal 1-3 very long. - Aren. uliginosa $E$. B. S. 2890. Alsinanthe R.v. 209.-St. prostrate, cæspitose.-Teesdale moors, very rare. Mr. J. Backhouse. P. VI.

E.

2. A. verna (Jacq.); l. linear-subulate acute 3-veined, pet. exceeding the caly $x$ rounded-obovatc attenuated below, sep. ovatelanceolate acute 3 -veined with a membranous margin, peduncles 1- or many-flowered.-Arenaria Sm., E. B. 512. Triphane $R$. v. 207.-L. usually not adpressed and mostly with a minute point.- $\beta$. A. Gerardi (R.); l. subulate bluntish not apiculate, pet. elliptical shortly clawed scarcely longer than the calyx. L. usually pressed close to the stem.-Rocky places in mountainous districts. $\beta$. On the hills above Kynance Cove near the Lizard Point, Cornwall. P. V.-IX.

3. A. rubella (Wahl.); $l$. linear-subulate blunt 3-veined, pet. obovate attenuated below shorter than the calyx, sep. ovate-lanceolate acute 3 -veined with a membranous margin, peduncles l-flowered. - E. B. S. 2638. Wahl. Lap. t. 6. - St. many. Flowering shoots terminal, downy, nearly always single-flowered, about an inch long, with $1-3$ pairs of leaves. Ped. longer than the calyx. Styles and valves of the capsule 3-5.-Summits of the Scotch mountains, very rare. P. VII. VIII.

$\mathrm{S}$.

4. A. tenuifolia (Wahl.); l. subulate acute 3-veined, pet. ovate attenuated below shorter than the calyx, sep. lanceolate-subulate 3 -veined with a membranous margin.-Arenaria Sm., E. B. 219. Sabulina $R$.-St. slender, 4-6 in. high, much branched, dichotomous, with flowers in the forks. Glabrous. $-\beta$. A. viscosa (Schreb.); upper parts, or cal. alone, covered with patent glandtipped hairs.-Sandy and chalky places. A. V. VI. E.

[5. A. fastigiata; $l$. subulate acute 3-veined, pet. oblong obtuse half the length of the calyx, sep. lanceolate acute equal (white) with 2 central (green) ribs.-Arenaria Sm., E. B. 1744. "Mountains of Fifeshire and westward of Clova." Mr. G. Don. A. VI.]

\section{Cherleria Linn.}

1. C. sedoides (L.).-E. B. 1212.-Pet. generally wanting. Fl. solitary, on short stalks. St. very many, forming a dense mass close to the ground. L. very many, linear-subulate, finely ciliated.-Summits of mountains. P. VI.-VIII.

\section{Moehringia Linn.}

1. M. trinervis (Clairv.); 1. ovate acute stalked 3-5-veined the upper ones sessile, pet. shorter than the calyx, sep. lanceolate acute 3-ribbed the intermediate rib strongest and rough.- $R$. v. 216. Arenaria Sm., E. B.1483.-St. about a foot high, weak, 
branched, downy. Fl. solitary from the forks of the stem and axils of the upper leaves. Ped. ultimately spreading and curved just below the fruit. Lateral veins of the sep. often obsolete. Distinguished from Arenaria and Alsine by the appendages to the hilum of its seeds.-Damp shady places. A. V.VI.

\section{Arenaria Linn. Sandwort.}

1. A. serpyllifolia (L.): l. ovate acute subscabrous sessile, pet. shorter than the calyx, sep. lanceolate acute 3-ribbed hairy.E. B. 923. R. v. 216.-St. prostrate or ascending, dichotomous. Fl. from the forks of the stem or the axils of the upper leaves. Pet. narrowly ovate, narrowed below. Clothed all over with minute hairs which are sometimes glandular. According to Hooker (Br. Fl. 68.) Wilson finds a plant at Bangor with 5 stam., the pet. only $\frac{1}{4}$ as long as the cal. and the sep. with prominent ribs.- $\beta$. tenuior (Koch); stems much more slender, fl. and fr. of half the size.-Dry places and walls. A. VI.-VIII.

2. A. ciliata (L.); spathulate ciliated, pet. exceeding the calyx, sep. ovate-lanceolate with 3 prominent ribs. - E. B. 1745. R. v. 217.-St. much branched, prostrate, rough. Fl. 1-5, terminal, somewhat panicled. Pet. ovate, slightly clawed.-Limestone cliffs on Ben Bulben, \&c., Sligo. P. VI. VII.

I.

3. A. norvegica (Gunn.); l. spathulate obovate fleshy not ciliated, pet. exceeding the calyx, sep. ovate acute obscurely 3-ribbed glabrous.-E. B. S. 2852.-St. much branched, procumbent, nearly smooth. Fl. $1-3$, terminal. Pet. ovate, slightly clawed. Seed dark brown, tuberculated.-On Serpentine Hill, Unst, Shetland. P. VII. VIII.

S.

\section{Holosteum Linn.}

1. H. umbellatum (L.); fl. umbellate, peduncles pubescent viscid, pedicels reflexed after flowering, 1 . elliptical or elongate acute. $-E$. B. 27. R. v. 221. - On old walls and dry places at Norwich, Bury, Eye and Yarmouth. A. IV.

E.

\section{Stellaria Linn. Stitchwort. \\ * Seeds on a linear long columella.}

1. S. nemorum (L.); st. ascending downy above, 1. stalked heartshaped, upper l. ovate sessile, panicle dichotomous, peduncles alternately pubescent, pet. deeply bifid twice as long as the lanceolate sepals, caps. longer than the calyx.-E. B.92. $R$. v. 252. - St. $1-1 \frac{1}{2}$ foot high. L. large, rough on the upper surface, ciliated. Sep. with narrow scarious margins.-Damp woods, chiefly in the north. P. V. VI. Wood Stitchwort. 
** Caps. rounded below or scarcely if at all narrowed; columella very short.

2. S. media (Wither.); st. procumbent and ascending with an alternate hairy line, $l$. ovate shortly pointed stalked, upper $l$. sessile, $\mathrm{H}$. axillary and terminal, pet. deeply bifid not exceeding the ovate-lanceolate single-ribbed glandular-pilose sepals, caps. oblong longer than the calyx.-E.B. 537. R. v. 222.-Very variable in length of st., size of 1 , number of stam. (3-10), and length of joints. Sep. with a narrow scarious margin, glabrous or with long hairs. Pet. sometimes wanting. Fr.-st. reflexed, often scarcely exceeding the leaves. L: glabrous with broad ciliated petioles. - $\beta$. S. neglecta (Weihe); 1. larger with longer stalks, upper l. sessile and subcordate slightly clasping, stam. 10. $-\gamma$. S. umbrosa (Opitz); l. narrowed gradually into long points, cal. more narrowed below, sep. lanceolate acute glabrous but tubercular, valves of the caps. narrower, seeds with prominent acute tubercles. St. much branched, slender. Fr.-st. much exceeding the leaves. S. grandiflora (Ten.) Woods.-Common. $\gamma$. Sussex. A. III.-IX. Common Chickweed.

3. S. Holostea (L.); st. ascending angular with rough angles, l. lanceolate-attenuate acute with a rough margin and keel all sessile, $\mathrm{fl}$. in a forked panicle, pet. half bifid twice as long as the lanceolate veinless sepals, caps. globose about as long as the calyx, bracts leaflike.-E.B.511. R.v. 223.-St. $1-2$ feet high, slender and procumbent at the base, thicker upwards. L. gradually narrowing from a little above the base to the very acute point. Fl. large, white, few, in a leafy panicle.-Woods and hedges. P. IV.-VI. Greater Stitchwort.

4. S. glauca (Wither.); st. erect weak angular smooth, l. linearlanceolate acute quite smooth sessile, lower l. broader, fl. solitary or in a few-flowered lax corymb, pet. bipartite exceeding the lanceolate 3-veined sepals, caps. oblong-ovate about as long as the calyx, bracts with scarious and glabrous margins. - E. B. 825 . R. v. 223. S. palustris Retz.-Usually glaucous. St. 6-12 in. high, leafy. Fl. rarely solitary. Pet. white, sometimes much exceeding the cal., segments linear.-Marshy places. P. V.VII.

5. S. graminea (L.); st. diffuse angular smooth, $l$. linear-lanceolate acute quite smooth ciliated below sessile, fl. in a dichotomous panicle, pet. bipartite equalling or exceeding the 3-veined sepals, caps. oblong longer than the calyx, bracts scarious ciliated. -E. B. 803.-St. $1-2$ feet high. Fl. smaller than those of the last 2, white. Shorter or longer pet. accompany an imperfection of the stam. or germen, $-[$ S. longifolia (Fr.), S.Friesiana (Koch), has the upper part of its stem and the edges and keel of its leaves 
scabrous.]-Dry heathy and bushy places. P. V.-VIII. Lesser Stitchwort.

[6. S. scapigera (Willd.); st. shorter than the peduncles erect, 1. linear-lanceolate slightly pubescent on the margins, peduncles long rising far above the leaves slender glabrous simple or once forked, pet. deeply divided equalling the lanceolate acute slightly fringed 3-ribbed sepals.-E. B. 1260 .-No wild specimens are known. I can scarcely believe that this is a state of S. graminea. - By the sides of rivulets between Loch Ereachd and Loch Laggan, Scotland. Mr. G. Don. P. VI.]

\section{*** Caps. narrowed below, hence the cal. has a funnelshaped} base. Larbrea St. Hil. not Ser.

7. S. uliginosa (Murr.); st. diffuse angular glabrous, $l$. oblonglanceolate acute with a callous tip glabrous slightly ciliated below sessile, fl. irregularly panicled lateral and terminal, pet. bipartite shorter than the lanceolate 3 -veined sepals, caps. ovate nearly cqualling the calyx, bracts scarious with glabrous margins. $-E$. $B$. 1074.- Very variable in size, usually about a foot long. F. in small panicles mostly axillary. On the summits of the Clova mountains ( 3200 feet) it is about $2 \mathrm{in}$. long, with minute leaves and usually solitary flowers.-In damp places. A. V. VI.

\section{Moenchia Ehrh.}

1. M. erecta (Sm.); stam. 4.-E. B. 609. R. v. 227.-Glaucous. St. erect, glabrous, $1-4$ in. high. L. opposite, linear-lanceolate, acute, rigid. Sep. with broad white membranous margins, acute.-Dry gravelly and sandy places. A. V. VI. E.

\section{Malachium Fries. Water-Chickweed.}

1. M. aquaticum (Fr.); st. decumbent and ascending angular covered with glandular hairs, 1. cordate-ovate acuminate sessile the lowest one stalked, fl. scattered solitary in the forks of the stem, pet. bipartite rather exceeding the calyx, caps. exceeding the calyx.-R vi. 237. Cerastium Sm. E. B. 538.-Closely resembling Stellaria nemorum.-Usually in wet places. P. V1I. VIII.

\section{Cerastium Linn. Mouse-ear.}

* Root fibrous. Pet. not exceeding the calyx.

+ Caps. curved, pet. about equalling the calyx.

1. C. glomeratum (Thuil.); l. ovate, sep. lanceolate acute with a narrow membranous margin and as well as the herbaceous bracts hairy throughout, caps. cylindrical ascending twice as long 
as the calyx, fruitstalks about equalling the calyx.-C. vulgatum S'm., E. B. 789. R. v. 229. C. viscosum Fries.-St. erect. Fl. aggregated or in dichotomous panicles, longer than their stalks. -3. C. apetalum (Dum.); pet. 0 , whole plant usually much more slender.-Fields and banks. A. IV.-IX.

2. C. triviale (Link); l. oblong-lanceolate, sep. oblong-ovate bluntish and as well as the bracts membranous at their margins and glabrous tips, caps. cylindrical ascending twice as long as the calyx, fruitstalks at least as long as the calyx. $-R$. v. 229 . C. viscosum Sm., E. B. 790. C. vulgatum Fries.-St. mostly procumbent. Fl. larger than those of the last, in small terminal panicles the branches of which become much elongated as the fruit advances to maturity. - $\beta$. holosteoides (Fries); glabrous, the sides of the stem alternately pubescent. St. 63.9.-In fields. $\beta$. Near Newcastle on Tyne; and Perth. A. or B. IV.-IX.

†† Caps. nearly straight, pet. mostly shorter than the calyx.

3. C. semidecandrum (L.); l. broadly orate, sep. lanceolate broadly membranous at their margins and tips, bracts with their upper half membranous, caps. cylindrical slightly inflated erect longer than the calyx, fruitstalks longer than the calyx at first reflexed afterwards erect.-E. B. 1630. R. v. 228.- St. erect or decumbent, downy, sometimes viscid. Distinguished by its half-membranous bracts.-Common in dry places. A. IV. V.

4. C. pumilum (Curt.); l. ovate or oblong, sep. lanceolate acute with their tips and margins narrowly membranous, bracts herbaceous with an extremely narrow membranous margin, caps. slightly curved upwards longer than the calyx, fruitstalks short curved at the top declining from their base ultimately erect.-Curt. Lond. ii. 92.-Viscid. St. branched at the root, afterwards nearly simple, prostrate, or ascending. Fl. in small terminal dichotomous corymbs. The curve at the top of the fruitstalks is rather doubtful; my authentic specimens and the figure do not clearly show its presence or absence. I know but little of this plant.Near Croydon, Surrey. Mr. Dickson! A. V.?

E.

5. C. tetrandrum (Curt.); l. oval or oblong, sep. lanceolate acute their tips and margins narrowly membranous, bracts herbaceous, caps. a little exceeding the cal. straight, fruitstalks $2-4$ times as long as the caps. straight ultimately erect.-E. B. 166. Curt. Lond. ii. 93. C. pumilum Gren. C. atrovirens and C. tetrandrum Bab.-Viscid. St. repeatedly forked from the very base with $a$ fl. in each fork. Bracts very broad, oval, rather acute or apiculate, or nearly round, leaflike.-Walls and sandy places near the sea. A. V.-VII. 
** Root truly perennial, with prostrate leafy shoots. Pet. longer than the calyx.

6. C. arvense (L.); st. ascending prostrate below, $l$. linearlanceolate, fl. many, sep. and bracts lanceolate slightly acute with membranous margins and tips, caps. at last longer than the calyx, seeds small acutely tubercled.-E. B. 93.-St. long. Fl.7-14, in dichotomous panicles. Fruitstalks erect, bent just under the calyx. St. and I. hairy or glabrous.-In sandy and gravelly and chalky places. P. IV.-VIII.

7. C. latifolium (L.); pubescence short, st. prostrate caspitose, 1. elliptical or lanceolate, fl. $1-3$, sep. blunt with membranous margins, bracts herbaceous, caps. slightly narrowing straight, seeds large rugose, fruitstalks obliquely patent.-E. B. 473.Pubescence short, rigid, yellowish. Barren shoots usually long. L. variable in shape.- $\beta$. Edmondstonii (Wats.); l. roundishovate dark green, st. short densely leafy.-Alpine parts of Wales and Scotland. $\beta$. Unst, Shetland. Mr. T. Edmondston. P. V. E. $S$.

8. C. alpinum (L.); hairy, st. ascending, l. ovate ovate-oblong or lanceolate, $\mathrm{fl}$. few, sep. bluntish with membranous margins, bracts herbaceous their margins often narrowly membranous, caps. nearly cylindrical curved at the end, seeds small acutely tubercled, fruitstalks obliquely patent.-E. B. 472. St.64.3.Pubescence long, silky. St. much branched below then simple, elongated, prostrate or ascending. Fl. 1, 2 or 3 together, in a forked panicle, shorter than their stalks.-Alpine parts of Scotland and the north of England. P. VI.-VIII.

9. C. trigynum (Vill.); st. decumbent with an alternate hairy line, 1. elliptic-oblong, ped. pubescent 1-3-flowered terminal, bracts herbaceous, styles mostly 3 , caps. rather longer than the calyx.-Stellaria cerastoides L, E. B. 911.-St. 4-8 in. long, slender, leafless and much branched below. L. light green, glabrous (or hairy in C. nivale Don), subsecund and subfalcate. Fl. large, white. Teeth of caps. 6-10.-Highland mountains. P. VII. VIII.

S. I.

\section{Order XV. MALVACE}

Sep. 5 or 3 or 4 , more or less connected below, often double, restivation valvate. Pet. as many as the sepals, æstivation twisted. Stam. monadelphous, indefinite; anth. l-celled, reniform, bursting transversely. Ovary formed by the union of several carpels round a common axis. Carp. 1- or many-seeded. Embryo curved with twisted or doubled cotyledons, albumen variable in quantity.-L. alternate, with stipules. Fl. axillary. 
1. Malva. Styles many. Cal. double, outer 3-leaved, inner 5-fid. Caps. orbicular, many-celled: cells 1 -seeded and circularly arranged.

2. AlthaAa. Styles many. Cal. double, outer 6-9-fid, inner 5.fid. Caps. orbicular, many-celled: cells 1-seeded and circularly arranged.

3. Lavatera. Styles many. Cal. double, outer 3-lobed, inner 5-fid. Caps. orbicular, many-celled: cells 1-seeded and circularly arranged.

\section{Malva Linn. Mallow.}

1. M. moschata (L.); st. erect, l. kidneyshaped with 5 or 7 deep pinnatifid lobes, lower 1 . incise-crenate, stipules lanceolate acute, fruitstalks erect, outer sep. linear-lanceolate, fruit hairy. -E. B. 754. R. v. 169.-Fl. large, rose-coloured, on axillary single-flowered peduncles, crowded at the extremity of the stem and branches. Cal. hairy. St. 1-2 feet high.-Gravelly places. P. VII. VIII. Musk Mallow.

[M. Alcea (L.) ; outer sep. oval acute, fr. glabrous; should be found in England.]

2. M. sylvestris (L.); st. erect, l. kidneyshaped with 5-7 deep crenate lobes, stipules lanceolate, fruitstalks erect, outer sep. lanceolate, fruit glabrous reticulate-rugose.-E. B. 671. R. v. 168 . -Fl. large. Pet. much longer than the hairy calyx, purple, on axillary aggregated peduncles. St. $2-4$ feet high.-Road-sides and waste places. P. VI.-IX. Common Mallow.

3. M. rotundifolia (L.); st. decumbent, 1. roundish-heartshaped with $5-7$ shallow acutely crenate lobes, stipules ovate-acute, fruitstalks reflexed, outer sepals linear-lanceolate shorter than the ovate-acuminate stellately hairy inner ones, pet. 2 or 3 times longer than the calyx, fruit pubescent, carp. rounded on the edge smooth.-E. B. 1092. M. vulgaris Fries, $R$. v. 167.-Fl. small, purple. Carp. meeting each other with a straight line. Central disk of the fr. rather large.-Waste places. P.? VI.-IX. Dwarf Mallow.

[4. M. borealis (Wallm.); st. decumbent, 1. roundish-heartshaped with 5-7 rather shallow crenate-dentate lobes, stipules lanceolate, fruitstalks reflexed, outer sep. linear as long as the ovate-acute glabrous but strongly ciliated inner ones, pet. about equalling the calyx, fr. pubescent, carp. margined reticulaterugose. $-M$. pusilla Sm. E. B. 24l. M. rotundifolia Fries, R.! v. $167 .-$ Fl. very small. Carpels meeting each other with a toothed edge. Central disk half as large as in the preceding plant.-Hythe, Kent. Huds. Not found since. A. VII.?] E. 
[5. M. verticillata (L.); st. erect, 1. cordate with 5 deep crenate-dentate triangular acute lobes, fl. axillary clustered nearly sessile, outer sep. linear half as long as the reticulated diaphanous pilose enlarged inner ones, pet. about as long as the calyx, fr. glabrous, carp. rounded on the edge reticulated. $-E$. B. S. 2953. -Fl. small. Carpels separated by a deep furrow into which the elevate-reticulated surface extends. Central disk very small. Stem quite erect like a little hollyhock. Petioles several times longer than the clusters.-Near Llanelly, S. Wales. A.] E.

\section{Althea Linn.}

1. A. officinalis (L.); l. soft on both sides crenate or crenateserrate cordate or ovate 3-5-lobed, peduncles axillary manyflowered shorter than the leaves, st. downy.-E. B. 147. R.v. 173. -St. 2-3 feet high. Covered with soft velvety pubescence.Marshes, particularly near the sea. P. VIII. IX. Marsh Mallow.

†2. A. hirsuta (L.) ; 1. hispid cordate, lower 1. reniform obtusely 5 -lobed, upper 1 . palmate with 5 or 3 acute lobes, peduncles axillary 1-flowered longer than the leaves, st. hispid.-E.B.S. 2674. $R$. v. 172.-Stem and calyx very hispid.-Between Cobham and Cuxton, Kent. A. VI. VII.

E.

\section{Lavatera Linn. Tree-Mallow.}

1. $L$. arborea (L.); st. woody, 1. 7-angled plaited velvety, ped. axillary aggregated $\mathrm{l}$-flowered shorter than the petioles.- $\boldsymbol{E}$. $\boldsymbol{B}$. 1811.-Fi. large, purplish rose-coloured with darker veins. St. 3-8 feet high.-Maritime rocks, rare. B. VII. - IX.

\section{Order XVI. TILIACEA.}

Sep. 4-5, æstivation valvate. Pet. 4-5. Stam. distinct, indefinite, or (in exotics) polyadelphous; anth. 2-celled, bursting longitudinally. Glands $4-5$ at the base of the petals. Carp. 4 -10-celled, several seeds in each cell or by abortion 1-celled 1-seeded. Embryo erect in the axis of fleshy albumen; cotyledons flat, leafy.-L. alternate, with stipules.

1. Trlia. Sep. 5, deciduous. Pet. 5, with or without a scale at the base. Stam. indefinite, free, or polyadelphous. Ovary 5-celled, cells 2-seeded. Style 1. Fr. 1-celled, with 1 or 2 seeds. - No scale to the pet. in our plants.

\section{Trlia Linn. Lime Tree.}

*1. T. europaa (L.); $l$. obliquely cordate glabrous except a woolly tuft at the origin of each vein beueath, ped. manyflowered, fr. not oblique nearly smooth coriaceous downy. $-E$. B. 
610.-Fl. in a naked cyme springing from a lanceolate leaflike bract. L. twice the length of their petioles.-In many old plantations. T. VII.

2. T. parvifolia (Ehrh.); l. obliquely cordate glabrous except a woolly tuft at the origin of each vein beneath, ped. manyflowered, fr. oblique angular thin and brittle.-E.B. 1705.-L. usually scarcely longer than their petioles, with stellate hairs beneath. Lobes of the stigma ultimately spreading horizontally.In woods. Probably the only truly native species. T. VIII.

*3. T. grandifolia (Ehrh.); l. obliquely cordate downy beneath with a woolly tuft at the origin of each vein beneath, ped. mostly 3-flowered, fr. with 5 prominent angles woody downy turbinate. -E. B. S. 2720.-Young shoots hairy. L. longer than their petioles with solitary hairs beneath. Lobes of the stigma erect. -T. rubra (Lindl.) is stated to have globose and smooth fruit and to be T. corallina Sm. I have not seen it.-In old plantations. T. VI. VII.

E. I.

\section{Order XVII. HYPERICACEA.}

Sep. 4-5, distinct or cohering, persistent, with glandular dots, imbricate. Pet. 4-5, twisted in rstivation. Stam. indefinite, polyadelphous, connected in 3 or 4 bundles at the base. Anthers versatile. Styles several, rarely connate. Fruit a dry or fleshy capsule of many cells and many valves, the valves curved inwards. Seeds minute, indefinite, on a central axis or the incurved margins of the valves, embryo straight with no albumen.-L. mostly opposite, with pellucid dots. Fl. yellow.

1. Hypericum. Cal. 5 -parted or of 5 sepals. Pet. 5. Styles 3 (in nearly all our plants) or 5 . Caps. more or less perfectly 3-celled, many-seeded.-Fl. yellow.

\section{Hypericum Linn. St. John's Wort.}

\section{* Styles 5. Pet. unequal-sided.}

*1. H. calycinum (L.); st. shrubby square, l. oblong, fl. solitary, sep. unequal obovate obtuse, pet. often lobed on one side. -E. B. 2017.-Fl. very large.-Naturalized in bushy places in Wicklow and Cork; Scotland; England. P. VII.-IX.

** Styles 3, stam. in 5 sets, pet. deciduous. Andros Amum.

2. H. Androscemum (L.); st. shrubby compressed, l. broadly subcordate-ovate blunt, cymes trichotomous few-flowered, sep. broad unequal, pet. oval blunt, styles much falling short of stam., caps. pulpy imperfectly 3-celled blunt.-Curt. Lond. i. 164.-St. 
very little branched, $2 \mathrm{ft}$. high. L. large, with a strong aromatic smell when rubbed. Fl. large in term. cymes. Pet. short. Styles much shorter than the black capsule, finally hooked.Thickets and hedges. P. VII. VIII. Tutsan.

3. H. anglicum (Bert.); st. shrubby 2-edged, ped. 2-winged, 1. subcordate-ovate subacute, cymes few-flowered, sep. broad unequal $\frac{1}{2}$ as long as petals, styles exceeding the stam., caps. oval. -H. Androsamum E. B. 1225. - St. tall, much branched. Fl. like those of $H$. hircinum which is naturalized in Ireland.Hedges and thickets? P. VII.-IX.

*** Styles 3, stam. shortly united in 3 sets, pet. persistent.

4. H. quadrangulum (L.); st. erect with 4 wings, l. ovate with pellucid dots, sep. erect lanceolate acuminate entire, pet. lanceolate, styles half as long as the capsule.-E. B. 730. H. tetrapterum Fries, Koch, $R$. vi. 344. - St. $1-2$ feet high. Fl. in terminal forked close many-flowered cymes, pale. This is certainly the plant of Linn. Hort. Cliff. 380. No. 5.-In wet places. P. VII.

5. H. perforatum (L.) ; st. erect 2-edged, I. oblong with pellucid dots, sep. erect lanceolate acute, pet. obliquely oblong, styles as long as the capsule.-E. B. 295. R. vi. 343-St. $1-2$ feet high. L. elliptic-oblong, they vary much in form, and the number and size of the pellucid dots; chief veins pellucid, but not forming a network as in the next. Sep. exceeding the ovary, usually denticulate near the apex. $-\beta$. angustifolium; 1 . linearoblong, sep. lanceolate acute denticulate (not "entire").-Woods, hedgebanks, \&c. P. VII. VIII.

6. H. dubium (Leers); st. erect quadrangular, I. elliptic-orate obtuse with a few pellucid dots netted with pellucid veins, sep. reflexed with many black dots on the outside, pet. elliptical, styles half as long as the capsule.-E.B.296. H. quadrangulum Fries. -St. 1-2 ft. high. Fl. in forked terminal cymes. Sep. elliptical, nearly entire. Caps. longitudinally striated. - $\beta$. maculatum; sep. oblong-lanceolate minutely denticulate, l. narrower. $H$. $m a-$ culatum Bab.-Moist places by ditches, \&c. P. VII.

7. H. humifusum (L.); st. prostrate somewhat 2-edged, l. ovaloblong obtuse minutely pellucid-punctate the margins with black dots beneath, fl. subcymose, sep. unequal, 3 oblong obtuse mucronate, 2 lanceolate, all entire or glandular-serrate and having a few black dots beneath, stam. $15-20$, styles very short. $-E . B$. 1226. $R$. vi. 342.-St. slender, $3-6$ in. long.-Gravelly and heathy places. P. VII.

S. H. linariifolium (Vahl); st. erect or ascending terete, 1. linear obtuse with revolute margins, fl. cymose, sep. rather 
unequal lanceolate acute with glandular serratures and many black dots beneath, stam. about 30, styles half as long as the capsule.-E. B. S. 2851.-St. wholly erect or procumbent below. Fl. larger than in the last.-Channel Isles. Cape Cornwall. Banks of the Teign, Tamar and Tavy, Devon. P. VII.

[9. H. barbatum (Jacq.); st. erect slightly 2 -edged, l. oblonglanceolate with revolute margins and scattered black dots, sep. lanceolate fringed with gland-tipped hairs as long as the diameter of the sepals, pet. obovate minutely ciliated and copiously dotted. -E. B. 1986.- "Aberdalgy in Strathearn, Perthshire." Mr. G. Don. P. IX. X.]

10. H. hirsutum (L.); st. erect round hairy, l. oval-oblong slightly stalked pellucid-punctate pubescent, sep. lanceolate acute fringed with shortly stalked glands, pet. linear oblong tipped with stalked glands, styles deciduous.-E. B. 1156. R. vi. 349.-St. about 2 feet high, nearly simple. Fl. in axillary and terminal forked panicles. Seeds longitudinally papillose.-Woods and thickets. P. VII. VIII.

11. H. montanum (L.); st. erect round glabrous, l. ovate-oblong sessile pellucid-punctate with glandular dots near the margin, sep. lanceolate acute fringed with shortly stalked glands, pet. elliptical entire without dots or glands, styles half the length of the capsule.-E. B. 371. R. vi. 347.-Fragrant. St. two feet high, simple. Fl. in terminal dense panicles. Seeds with longitudinal crenate ridges.-Bushy limestone hills. P. VII. VIII. E.

12. H. pulchrum (L.); st. erect round glabrous, l. cordate amplexicaul pellucid-punctate glabrous, sep. broadly ovate obtuse fringed with sessile glands, pet. ovate-lanceolate fringed with glands.-E. B. $1227 .-$ St. $12-18$ in. high, nearly simple. Fl. in loose, axillary, opposite, and terminal panicles. Buds tipped with red. Anth. red.-Dry heaths, banks, woods. P. VI. VII.

\section{**** Styles 3 ; stam. united in lower half in 3 sets, a scale between each set; pet. equal-sided.}

13. H. elodes (L.); st. ascending round shaggy rooting below, l. roundish-ovate sessile pellucid-punctate shaggy, sep. ovate bluntish glabrous fringed with shortly stalked glands, pet. ovate entire, styles nearly as long as the capsules.-E. B. 109. Elodes palustris $R$. vi. 342 .- St. prostrate below, then ascending and leafy. Fl. in terminal and axillary few-flowered panicles. "Seeds longitudinally furrowed." Leight. Spongy bogs. P. VII. VIII. 


\section{Order XVIII. ACERACEÆ.}

Cal. 5-, rarely 4-9-parted, imbricated. Pet. the same number, inserted round a hypogynous disk. Stam. generally 8 , inserted on the hypogvnous disk. Ovary 2-lobed, 2-celled. Style 1. Stigmas 2. Fruit winged, separating into 2 indehiscent nuts each with 1 cell and $1-2$ seeds. Embryo curved, albumen 0.Trees with opposite leaves.

1. Acer. Fl. polygamous. Calyx 5-parted. Pet. 5. Stam. usually 8 , longer in the male flowers.

\section{Acer Linn. Maple.}

1. A. campestre (L.); 1. 5-lobed, lobes entire or slightly cut, corymbs erect, sep. and pet. linear hairy, wings of the fruit horizontally diverging, ovary downy, stam. of the male flowers as long as the corolla. $-E$. B. 304. R. v. 162.-A small tree with corky fissured bark.-Woods and hedges. T. V. VI. Maple.

†2. A. Pseudo-platanus (L.); 1. 5-lobed unequally serrated, racemes pendulous, ovary downy with spreading wings, stam. of the male flowers twice as long as the corolla. $-E . B .303 . R$. v. 164.-A large handsome tree.-In hedges and plantations. T. V. VI. Sycamore.

\section{Order XIX. GERANIACEE.}

Sep. 5, persistent, imbricated. Pet. 5, clawed, twisted in xstivation. Stam. generally monadelphous, 2 or 3 times as many as the petals, some often abortive. Fruit of 5 carpels cohering round a long beaked torus, each terminated by an indurated style which finally twists up, separating from the torus, and carrying with it the carpel. Seeds solitary, without albumen. Cotyledons convolute, plaited.

1. Geranium. Sep. 5. Pet. 5. Stam. 10, monadelphous, alternately larger and with glands at their base. Carp. rounded at the top; the long ultimately recurved awn glabrous internally.

2. Erodium. Sep. 5. Pet. 5. Stam. monadelphous, 5 sterile, 5 fertile with glands at their base. Carp. with 2 lateral depressions at the top; the long ultimately spirally twisted awn bearded internally.

1. Geranium Linn. Cranesbill.

* Root consisting of long fibres springing from a pramorse rhizome, perennial.

1. G. phaum (L.); peduncles 2-flowered, pet. roundish wedge- 
shaped rather longer than the mucronate sepals, carp. hairy below transversely wrinkled above, seeds punctate-striate.-E. $B$. 322. R.v. 197.- St. erect, 2 feet high. L. 5-lobed : lobes acute, cut, serrated. Fl. purplish-black, very rarely white.-In woods and thickets, rare. P. V. VI.

E. S.

[2. G. nodosum (L.) ; peduncles 2-flowered, pet. obcordate long, sepals awned, carp. even downy, 1. 3-5-lobed, lobes ovate acuminate serrate.-E. B. 1091.-St. 18 in. high, slender, erect. Fl. pale purple.-In Cumberland and Hertfordshire. P. V.VIII.-G. striatum which resembles this but has a hairy stem was found near Filby, Cumb., and Chepstow. Planted?] E.

3. G. sylvaticum (L.); peduncles 2-flowered, pet. obovate slightly notched long, sepals awned, carp. even hairy, hairs spreading glandular, seeds dotted, 1. palmate 7-lobed, lobes cut and serrated, st. erect glandular-hairy above, filaments of stam. subulate, fruitstalks erect.-E. B. 121.- - St. erect, 2-3 feet high. Fl. purplish-blue, claws of the petals bearded, lower half of filaments hairy. When the fl. are pale rose-coloured, pet. smaller and nearly entire, and st. more decidedly hairy, it may be the B. fastigiatum (Fries).-Woods and thickets, rare. P. VI. VII.

4. G. pratense (L.) ; ped. 2-flowered, pet. obovate entire or slightly notched long, sepals awned, carp. even hairy, hairs spreading glandular, seeds minutely reticulated,1.palmate 7-lobed, lobes cut aud serrated, st. diffuse glandular hairy above, hairs deflexed, filaments of stam. filiform with a triangular-ovate base, fr.-st. deflexed. - E. B. 404.-St. $1-2$ feet high. Fl. large, purple, claw of pet. ciliated. Base of filaments slightly hairy.Moist pastures. P. VI.-VIII.

5. G. sanguineum (L.); peduncles mostly single-flowered, pet. obcordate long, sepals awned, carp. smooth crowned with a few bristles, seeds ininutely wrinkled and dotted, 1. nearly round 7-lobed, lobes deeply 3-fid und cut, st. diffuse hairy, hairs spreading horizontally.--E. B. 272. R. v. 168.-Fl. large, purple; filaments dilated at the base.- $\beta$. G. prostratum (Lindl.); st. dwarf tufted nearly simple decumbent, fl. flesh-coloured. G. lancastriense With.- In dry places. $\beta$. Sands in Walney Island, Lancashire. P. VII.

\section{** Root fusiform, rhizome wanting, perennial.}

6. G. pyrenaicum (L.); peduncles 2-flowered, fruitstalks deflexed, pet. obcordate twice as long as the mucronate sep., claws densely ciliated. carp. smooth with adpressed hairs, seeds smooth, 1. reniform 7-9-lobed, lobes oblong obtuse trifid and toothed at the end, st. erect villose.-E. B. 405. R.v. 191.-Fl. light purple or nearly white. Claws of the pet. with a dense tuft of hairs 
on each side. Fertile anth. 10. Segments of the upper leaves more acute. St. spreading, 1-3 feet high, clothed with dense short down and long hairs intermixed.-Roadsides and pastures. P. VI. VII.

\section{*** Root fusiform annual, ped. 2-flowered.}

7. G. pusillum (L.); pedicels deflexed after flowering, pet. notched a little exceeding the mucronate sepals, claws slightly ciliated, carp. smooth with adpressed hairs, seeds smooth, 1. reniform palmate with $5-7$ trifid lobes, st. diffuse downy. $-E . B$. 385. R. v. 190. G. rotundifolium Fries.-St. usually prostrate, clothed only with short down. Fl. small, bluish-purple. Claws of the pet. only slightly ciliated. Fertile anth. 5. Ped. shurter than the leaves. - Waste places. A. VI.-IX.

8. G. dissectum (I.) ; pet. bifid about equalling the awned sepals, claws slightly ciliated, carp. smooth with erect hairs, seeds reticulated, 1 . in $5-7$ deep laciniated segments with linear lobes, st. diffuse hairy. - E. B. 753. R. v. 189.-Fl. small, bluish-purple. L. divided almost to the base, longer than the peduncles.Waste places. A. VI.-VIII.

9. G. columbinum (L.); pet. obovate emarginate with a short obtuse tooth in the notch about equalling the awned sepals, claws ciliated, carp. smooth with a few minute scattered hairs, seeds reticulated, 1 . in $5-7$ deep laciniated segments, st. diffuse with adpressed hairs. $-E$. B. 259. R. v. 198.-Fl. small, rosecoloured. L. divided almost to their base. Peduncles longer than the leaves, pedicels very long.-On gravelly and limestone soils. A. VI. VII.

10. G. rotundifolium (L.); pet. spathulate entire obtuse rather longer than the shortly awned sepals, claws glabrous, carp. smooth with spreading hairs, seeds reticulated, 1. reniform in $5-7$ broadly wedge-shaped incise-crenate segments, st. diffuse pubescent.E. B. 157. R. v. 190 . G. viscidum Ehrh.-Fl. small, flesh-coloured. Peduncles shorter than the leaves.-Old walls and waste places, rare. A. VI. VII.

11. G. molle (L.) ; pet. oblong deeply bifid $\frac{1}{2}$ as long again as the mucronate sepals, claws ciliated, carp. transversely wrinkled glabrous, seeds smooth, 1. roundish-reniform in 7-9 deep wedgeshaped segments trifid at the end, st. diffuse pubescent. $-E$. $B$. 778. R. v. 191.-Fl. small, purple. Softly pubescent, glandular above.-Dry places. A. IV.-VIII.

12. G. lucidum (L.); pet. obovate entire, claws glabrous very long nearly equalling the transversely rugose pyramidal calyx, carp. reticulated triply keeled glandular-hairy at the summit, seeds smooth, 1. reniform in 5 obtuse incise-crenate mucronate 
segments, st. spreading ascending.-E. B. 75. R. v. 187.-Fl. small, rose-coloured. St. and 1. glabrous and shining, often strongly tinged with red.-Lindley considers his G. Raii as most allied to this species, differing by its "shaggy calyx and simply keeled fruit." South coast of England.-Walls and hedge-banks. A. V.-VIII.

13. G. robertianum (L.); pet. obovate entire or slightly emarginate, claws glabrous very long nearly equalling the long-awned hairy and slightly glandular sepals, carp. transversely wrinkled downy, seeds smooth, l. ternate or quinate, leaflets stalked trifid incise-pinnatifid, st. spreading erect.-E. B. 1486. R. v. 187.Fl. purple, sometimes white. Cal. with a very few glandular hairs, not transversely rugose. $-\beta$. maritimum; carp. glabrous with $1-2$ deep transverse wrinkles at the top. $-\gamma$. G. purpureum (Forst.) ; pet. narrower, sep. giandular-hairy, carp. glabrous and more wrinkled, l. in narrower segments. E.B. S. 2648.-Hedgebanks. $\beta$. and $\gamma$. Southern sea-coast. A. V.-IX.

\section{Erodium L'Herit. Storksbill.}

I. E. cicutarium ( $\left.\mathrm{Sm}_{\mathrm{.}}\right)$; st. procumbent hairy, peduncles many-flowered, perfect stam. dilated not toothed below glabrous, beak hairy, a concentric furrow below the circular glandless depression on the carpel, l. pinnate, leaflets sessile pinnatifid cut, stip. lanceolate.-E. B. 1768. - Very hairy. Fl. purplish or white. Leaflets very deeply divided, their segments lanceolate or linear, acute. In Jersey specimens the 1. are ovate and short, and their segments short broad and bluntish.-Waste ground. A. VI.-IX.

2. E. moschatum (Sm.); st. procumbent hairy, peduncles many-flowered, perfect stam. toothed at the base glabrous, beak downy, a concentric furrow below the circular glandular depression on the carpel, l. pinnate, leaflets nearly sessile orate unequally cut, stip. oval.-E. B. 902.-Much larger than the preceding and diffusing a strong musky scent when handled. Leaflets less deeply cut.-Waste places, rather rare. A. VI. VII.

3. E. maritimum $(\mathrm{Sm}$.$) ; st. prostrate slightly hairy, peduncles$ 1-2-flowered, pet. very minute, a transverse furrow below the semicircular depression on the carpel, 1. simple ovate-cordate stalked lobed and crenate.-E. B. 646r-St. often very fleshy. Fl. very small. Pet. pale red, very minute, often wanting.Sandy and gravelly places, particularly near the sea, rare. $P$. V.-IX. 


\section{Order XX. LINACEE.}

Sep. 4-5, persistent, imbricate. Pet. 4-5, twisted in æstivation, clawed, fugitive. Stam. as many as the pet., connected into a hypogynous ring with intermediate teeth (abortive stamens). Ovary with about as many cells and styles as the sepals, stigmas capitate. Caps. generally tipped with the hardened base of the styles, with $3-5$ complete dissepiments (of 2 membranes), and $4-5$ incomplete dissepiments. Seeds 1 in each spurious cell, pendulous, with albumen.-L. without stipules, alternate.

1. Linum. Cal. of 5 sepals. Pet. 5. Stam. 5 . Styles 5. Caps. with 10 cells and 10 valves.

2. Radrola. Cal. of 4 sepals, connected below, deeply trifid. Pet. 4. Stam. 4. Styles 4. Caps. with 8 cells and 8 valves.

\section{Linum Linn. Flax.}

* Leaves scattered. Margins of the sep. not glandular.

1. L. angustifolium (Huds.); caps. downy within, sep. elliptical pointed ciliated, l. linear-lanceolate, st. many.-E. B. 381 . -Fl. pale blue. St. $1-2$ feet high, lax, branching irregularly. - Sandy and chalky places. P. VII.

E. I.

*2. L. usitatissimum (L.); caps. glabrous within, sep. ovate pointed ciliated, 1. lanceolate, st. solitary.-E. B. 1357. St. 26. 12.-Fl. blue. St. 1-1 $\frac{1}{2}$ foot high. Sep. 3-veined. $-\beta$. crepitans (Schub.); smaller and more branched, caps. opening with elasticity, seeds paler.-In cultivated fields. A. VII. Common Flax.

3. L. perenne (L.); sep. obovate obtuse obscurely 5 -veined glabrous, l. linear-lanceolate, st. many, fruitstalks erect. $-E$. $B$. 40.-Fl. blue. St. l-2 ft. long, erect or decumbent. - Chalky places. P. VI. VII.

E. I.

\section{** ILeaves opposite.}

4. L. catharticum (L.); sep. elliptical pointed, l. opposite obovate, upper l. lanceolate.-E. B. 382.-Fl. white, small; sep. serrated; pet. acute. St. one or more, slender. Panicle forked, spreading.-In dry pastures. A. VI.-VIII.

\section{Radiola Gmel. Flax-seed.}

1. R. millegrana (Sm.).-E. B. 893. R. linoides DC., Koch. -St. 1-2 in. high, repeatedly forked, with solitary $\mathrm{fl}$. in the axils as well as at the extremities of the branches. Fl. minute, 
white. Sep. deeply and acutely 3-cleft, connected below into a tube.-Damp sandy places. A. VII. VIII.

\section{Order XXI. BALSAMINACEA.}

Sep. 5 (2 upper usually wanting), irregular, deciduous, lower spurred, imbricate in rstivation. Pet. 5, irregular, united in pairs. Stam. 5. Anth. 2-celled, opening at the apex by a longitudinal fissure, more or less connected. Ovary 5-celled. Fr. capsular with 5 elastic valves. Seeds solitary or many, pendulous; albumen 0.-L. without stipules. Plant succulent.

1. Impatiens. Sep. 3, the lower one cucullate with a spur. Pet. 3, upper one symmetrical, lateral unequally 2-lobed or each formed of 2 combined. Anth. cohering.

\section{Impatiens Linn. Balsam.}

1. I. Noli-me-tangere (L.); l. ovate coarsely serrate, peduncles many-flowered solitary, spur loosely recurved not emarginate. -E. B. 937. R. v. 198. b. St. 5. 15.-Fl. large, yellow spotted with orange. Serratures of the leaves not glandular. St. 1-2 feet high, tumid at the joinings.-Damp woody places in mountainous districts. A. VII.-IX. Yellow Balsam.

E.

[*2. I. fulva (Nutt.); l. ovate coarsely serrated, peduncles about 4-flowered solitary, spur closely reflexed emarginate.E. B. S. 2794.-Fl. orange-yellow spotted with red. Serratures of the 1. with a reflexed glafidular tooth. St. $2-3$ feet high.An American plant quite naturalized by the Wey and other rivers in Surrey. A. VIII.]

E.

\section{Order XXII. OXALIDACEÆ.}

Sep. 5, equal, persistent, imbricate in æstivation. Pet. 5, equal, often cohering at the base, twisted in rstivation. Stam. 10, more or less monadelphous, those opposite to the pet. longer than the others. Anth. 2-celled, not connected. Ovary 5-celled. Styles 5. Caps. 5-10-valved. Seeds several; testa fleshy, bursting elastically. Embryo straight, in cartilaginous albumen.

1. Oxalis. Sep. 5, connected below. Pet. 5, often connected below. Stam. 10, monadelphous, 5 outer ones shorter. Styles 5.

\section{Oxalis Linn. Wood-Sorrel.}

1. O. Acetosella (L.); stemless, rhizome creeping toothed, 1. 
ternate, leaflets obcordate hairy, peduncles with 2 scaly bracts at about the middle 1-flowered, caps. ovoid, seeds longitudinally ribbed.-E. B. 762. R. v. 199.-Fl. white with purple veins or rarely purple or blue. Cor. about 4 times as long as the calyx. -Woods and shady places. P. V. Wood Sorrel.

2. O. corniculata (L.); st. diffuse with procumbent branches pubescent, 1. ternate, leaflets obcordate, stipules oblong united to the base of the petioles, peduncles about 2 -flowered shorter than the leaves, partial fruitstalks reflexed, caps. narrowly oblong, seeds transversely ribbed, root fibrous.-E. B. 1726. R. v. 199. -Fl. yellow. L. mostly in pairs. - Waste ground in Devon and Cornwall. A. VI.-IX.

E.

[3. O. stricta (L.) ; st. erect, stipules 0 , peduncles 2-8flowered longer than the 1 ., fruitstalks erect, stoloniferous. R. v. 199.- Naturalized in Cornwall, Devon, Glamorgan, \&c. B. VII. VIII.]

\section{Subdivision II. CALYCIFLORA.}

Pet. distinct. Stam. perigynous.

\section{Order XXIII. CELASTRACEA.}

Sep. 4-5, rstivation imbricate. Pet. 4-5, inserted into the margin of a hypogynous fleshy disgk. Stam. alternate with the petals, inserted in the disk. Ovary sunk in the disk, more or less connected with it, $3-4$-celled; cells $1-2$-seeded; ovules erect. Embryo straight.

[1. Staphylea. Cal. 5-parted, coloured; disk urceolate. Pet. 5. Stam. 5, inserted round the disk. Stvles 2-3. Caps. membranous, 2 -3-celled, dehiscing internally. Seeds few, bony, truncate at the hilum.-Leaves compound.]

2. Euonymus. Cal. flat, 4-5-lobed; disk peltate. Pet. $4-5$, inserted in the margin of the disk. Stam. 4-5, inserted in the disk. Style 1. Caps. 3-5-celled, 3-5angled, dehiscence loculicidal. Seeds solitary in each cell, with a fleshy arillus, not truncate at the hilum.-Leaves simple.

\section{Staphylea Linn. Bladder-nut.}

[1. S. pinnata (L.); 1. pinnate, leaflets $5-7$, petioles without glands, fl. racemose, styles 2 , caps. bladdery. $-E$. B. 1560.-Fl. yellowish-white.-A very doubtful native. S. VI.] 


\section{Euonymus Linn. Spindle-tree.}

1. E. europaus (L.) ; pet. oblong, fl. mostly 4-cleft and 4-androus, branches tetragonal smooth and even, l. elliptic-lanceolate minutely serrate, caps. obtusely angular not winged.-E.B. 362 . $R$. vi. 309. St. 27. 3.-Arillus inclosing the seed. Bark green. L. glabrous. Fl. few together forming a small umbel, greenishwhite. Fruit rose-coloured.-Hedges and woods. Sh. V. VI.

\section{Order XXIV. RHAMNACEÆ.}

Cal. 4-5-cleft, æstivation valvate. Pet. distinct, inserted into the throat of the calyx. Stam. opposite to the pet. and equalling them in number. Ovary wholly or in part superior, 2-34-celled, surrounded by a glandular disk. Seeds solitary, erect. Embryo straight. Fruit fleshy or dry.

1. Rhamnus. Cal. urceolate, $4-5$-cleft. Pet. 4 or 5 , or sometimes 0 , inserted with the stam. on the margin of the tube of the calyx. Fruit fleshy, with $2-4$ cells and as many seeds.

\section{Rhamnus Linn. Buckthorn.}

1. R. catharticus (L.) ; thorns terminal, fl. 4-cleft diœcious, petioles much longer than the stipules, $l$. roundish-oval sharply toothed, fr. with 4 seeds.-E. B. 1629.-Branches opposite. Serratures of the 1. incurved, glandular. Notch in the seeds shut. Styles 4, united half way up.-Hedges and thickets. Sh. V.-VII. Buckthorn.

2. R. Frangula (L.); spineless, fl. 5-cleft perfect, l. elliptical acuminate narrowed below entire, fr. with 2 seeds, style simple.E. B. 250.-Branches alternate. Fl. in small clusters, greenishwhite, small.-Hedges and thickets. Sh. V. VI.

\section{Order XXV. LEGUMINOS $\$$.}

Cal. inferior. Sep. 5, more or less combined, odd one anterior. Cor. papilionaceous (in our plants), inserted into the base of the calyx. Pet. 5, odd one superior. Stam. 10 (in our plants), monadelphous or diadelphous. Ovary free, 1-celled. Fruit a legume; placenta on the upper suture; style from the upper suture. Embryo bent over the edge of the cotyledons, or straight. -All our plants have papilionaceous flowers and 10 stamens in one bundle or in two bundles of 9 and 1 .

Tribe I. LOTE $A$. Pod continuous. Cotyledons rising above the ground and becoming green leaves. Leaves of 1 or 3 leaflets or pinnate with an odd one. 
* Leaflet solitary. Stamens monadelphous.

1. Ulex. Cal. of 2 parts, the upper with 2, the lower with 3 teeth, a bract on each side at the base. Pod turgid, fewseeded, scarcely longer than the calyx.

2. Genista. Cal. 2-lipped, upper bifid, lower 3-toothed. Style subulate, ascending. Stigma terminal, oblique, introrse.-Many foreign species have trifoliate leaves.

** Leaf of 3 leaflets. Stamens monadelphous.

3. Sarothamnus. Cal.2-lipped, the upper with 2, the lower with 3 teeth. Style long, curved, thickened upwards, channeled within. Stigma terminal, capitate, small. Pod flat.

4. Ononis. Cal.5-cleft, campanulate, segments narrow, the lower ones longer. Keel beaked. Style filiform, ascending. Stigma terminal, subcapitate.

*** Leaf of 3 leaflets. Stamens diadelphous.

5. Medicago. Cal. with 5 vearly equal teeth. Keel obtuse. Filaments of the stamens filiform. Ovaries curved. Pod I-celled, falcate or spiral. Seeds 1 or many.

6. Melilotus. Cal. with 5 nearly equal teeth. Keel obtuse. Filaments filiform, not united with the claws of the petals. Ovary straight. Pod subglobose or oblong, 1-celled, 1-4seeded, longer than the calyx. Pet. distinct, deciduous.

7. Trifolium. Cal. with 5 unequal teeth. Keel obtuse. Filaments slightly enlarged upwards and more or less united with the claws of the petals. Pod oval, $1-4$-seeded, included in the calyx or slightly protruding. Pet. slightly combined, persistent.-In T. ornithopodioides, scarcely a true Trifolium, the pod is 8-seeded and the filaments are filiform.

8. Lotus. Cal. with 5 nearly equal teeth. Keel ascending, with a narrowed point (beak). Wings connivent at their upper margin. Longer filaments dilated upwards. Style kneed at the base, filiform-subulate. Pod linear, manyseeded, 2-valved, imperfectly divided by transverse partitions.

**** Leaf pinnate with an odd one. Stamens monadelphous.

9. Antry luis. Cal. tubular, inflated, 5-cleft, segments unequal. Keel not beaked. Style filiform. Stigma capitate.

***** Leaf pinnate with an odd one. Stamens diadelphous.

10. Oxytropis. Cal. with 5 teeth. Keel with a narrow 
straight point. Pod imperfectly 2-celled, cells formed by the inflexed margin of the upper suture.

11. Astragalus. Cal. with 5 teeth. Keel obtuse. Pods imperfectly 2-celled, cells formed by the inflexed margin of the lower suture.

Tr. II. VICIEAE. Pod continuous. Stam. diadelphous. Cotyledons remaining under ground. L. abruptly pinnate or apparently simple.

* Tube of stam. very obliquely truncate.

12. Vicia. Cal.5-fid or 5-toothed. Style filiform, its upper part hairy all over, or bearded on the under side and at the same time hairy or glabrous. Pods 1-celled, 2-valved.

** Tube of stam. transversely truncate.

13. Lathyrus. Cal. 5-fid or 5-toothed. Style dilated upwards, plane on the upper side, hairy beneath the stigma. Pods 1-celled, 2-valved.

Tr. III. HEDYSAREAE. Pod divided transversely into 1seeded joints. L. pinnate with an odd one.

14. Ornithopus. Cal. elongated, tubular, with 5 nearly equal teeth, 2 upper ones slightly combined and converging. Keel obtuse. Pod elongated, compressed, of many 1-seeded indehiscent joints equally narrowed at both sides at the joinings.-Apex of the common peduncles bearing a small pinnate leaf just below the flowers.

15. Arthrolobium. Cal. elongated, tubular, with 5 nearly equal teeth, 2 upper ones combined up to their middle and straight. Keel obtuse. Pod elongated, cylindrical, of many l-seeded indehiscent joints scarcely narrowed at the joinings. -No leaf at the apex of the peduncles.

16. Hippocrepis. Cal. short, campanulate, with 5 nearly equal teeth, 2 upper ones combined up to their middle. Keel narrowed into a beak. Pod elongated, compressed, of many 1-seeded crescent-shaped joints, so that each pod has many notches on one side.

17. ONoвrychis. Cal. with 5 nearly equal subulate teeth. Keel obliquely truncate, longer than the wings. Pod 1-celled, compressed, indehiscent, l-seeded, upper suture straight, lower curved toothed winged or crested. 


\section{Tribe I. Lotece.}

\section{Ulex Linn. Furze. Whin. Gorse.}

1. U. europaus (L.); young l. shaggy beneath furrowed, primary spines strong terete-polygonal furrowed minutely scabrous, st. hairy, $f$. lateral, bracts ovate lax, cal. shaggy, wings longer than keel.-E.B.742.-St. 4-6 feet high, very much branched spreading. Fl. bright yellow, springing from both the primary and secondary spines. Spines branching at their base and up to about their middle, not exceeding the flowers. "Seeds 10."Heaths. Sh. II.-VI.

2. U.strictus (Mack.); young l. shaggy beneath thin, primary spines small slender tetragonal minutely scabrous, st. hairy, $f$. terminal, bracts ovate lax, cal. shaggy, wings longer than keel.Plant $1-2$ feet high, with upright branches. Fl. rarely produced, springing from the summit of the stem, not from the spines, which branch as in $U$. europaus but are peculiarly small. The pet. slightly different in form from the last. Distinguished from the other species by its peculiar habit.-In Lord Londonderry's park, Down, Ireland. Sh. IV.

3. U. nanus (Forst.); young l. glabrous ciliated furrowed, primary spines slender terete striated smooth, st. hairy, fl. lateral and terminal, bracts very minute adpressed, cal. finely downy, wings shorter than keel.-E. B. 743.-St. procumbent. Primary spines short, spreading, branched at their base only. Fl. half the size of those of $U$. europaus, springing from the primary spines and exceeded by them, pale; pet. scarcely separated when full blown. "Seeds 5."- $\beta$. U. Gallii (Planch.); primary spines strong, wings rather longer than keel. St. $2-5$ feet high. Primary spines deflexed. Wings not straight and thus often seeming shorter than keel. Fl. orange, pet. more or less divaricate. A dwarf form is often taken for $U$.nanus. Probably a distinct species.-Heaths. Sh. VIII.-XI.

\section{Genista Linn.}

1. G. pilosa (L.); st. procumbent without thorns, l. obovatelanceolate obtuse, stipules ovate blunt, branches peduncles calyx standard keel and underside of the 1. silky, peduncles lateral accompanied by a tuft of leaves, pods hairy.-E. B.208.-Fl. small, yellow, collected towards the extremity of the branches. St. much branched, furrowed, woody, tortuose.-Dry sandy and gravelly heaths, rare. Sh. V.

2. G. tinctoria (L.); st. depressed with erect branches without thorns, l. lanceolate or elliptical hairy at the edges, stipules mi- 
nute subulate, fl. racemose, cor. and pods glabrous. - E. B. 44.Branches erect, $1-2$ feet high, elevate-striate, glabrous, downy above. Fl. yellow. Keel as long as the standard.- $\beta$. G. humifusa (Dicks. MSS.); st. and branches procumbent, l. orate or oblong, pods hairy on the back of each valve. St. angular, 610 in. long. - In pastures and thickets. $\beta$. Near Kynance Cove, Cornwall. Sh. VII.-IX. Dyers-weed. Woad.

3. G. anglica (L.); st. ascending spinous leafless below, flowering branches unarmed glabrous, l. ovate-lanceolate, stipules $0, f$. solitary in the axils of the upper 1., corolla and pods glabrous. -E. B. 132.-St. 1 foot high, round, leafless, with short leafy branches bearing the yellow flowers. Keel longer than the standard.-Moist peaty heaths. Sh. V. VI. Needle Whin. E. S.

\section{Sarothamnus Wimm. Broom.}

1. S. scoparius (Koch).-E. B. 1339. Spartium L., Sm. Cytisus Link.-St. 2-3 feet high, angular, glabrous. L. ternate or simple, leaflets obovate. Fl. axillary, solitary or in pairs, shortly stalked, large, bright yellow. Pods dark brown, hairy at the edges; seeds many.-Dry hills and heaths. Sh. V.VI.

\section{Ononis Linn. Rest-harrow.}

1. O. arvensis (L.) ; st. procumbent uniformly hairy, fl. axillary solitary stalked, leaflets broadly oblong, pods ovate erect falling short of the calyx.-E. B. S. 2659 . O. repens Koch.-Usually without spines. St. rooting at their base. Wings equalling the keel; standard a little longer. Seeds tubercular-scabrous.Barren sandy places. P. VI.-IX.

2. O. campestris (Koch); st. erect or ascending, bifariously hairy, fl. axillary solitary stalked, leaflets oblong, pods ovate erect exceeding the calyx.-E. B. 682. O. antiquorum Benth. (not L.). O. spinosa Koch.-Usually spinous. St. mostly erect. Wings falling short of the keel which falls short of standard. Seeds tubercular-scabrous.-Barren places. P. VI.-IX. E. S.

[O. hircina (Jacq.) differs by having its $\mathrm{fl}$. axillary in pairs and densely spiked at the ends of the branches.]

3. O. reclinata (L.); viscid, pubescent, st. ascending, $\mathrm{fl}$. axillary, pedicels l-flowered shorter than the l. fl. or pod without bracts, cor. about equal to the calyx, leaflets obovate-cuneate serrated at the lip, stipules ovate, pods cylindrical reflexed, seeds 14-18 tuberculated.-E. B. S. 2838.-St. 5-6 in. high, much branched.-Sandy places. Galloway. Channel Isles. A. VII. S. 


\section{Medicago Linn.}

*1. M. sativa (L.); st. erect, racemes many-flowered, pods compressed loosely spiral with 2 or 3 turns downy with adpressed hairs unarmed, pedicels shorter than the calyx or bract, leaflets obovate-oblong dentate above emarginate mucronate.-E. $B$. 1749. - St. angular when young, Pods twisted into a loose open spiral. Fl. yellow or violet.-Hedge-banks and borders of fields, scarcely naturalized. P. VI. VII. Lucerne.

2. M. sylvestris (Fries); st. rather quadrangular pithy ascending, racemes many-flowered, pod of one flat turn annular, pedicels shorter than the cal. longer than the bract, lts. obovate-oblong dentate above emarginate mucronate.-Fl. yellow or blackishgreen with darker streaks.--Sandy and gravelly places in Norfolk and Suffolk. P. VI. VII.

E.

3. M. falcata (L.); st. usually terete nearly solid prostrate, racemes many-flowered, pod straightly sickle-shaped twisted not annular, pedicels shorter than the cal. longer than the bract, lts. obovate-oblong dentate above emarginate mucronate.-E. $B$. 1016.-Fl. vellow.-Sandy and gravelly places in Norfolk and Suffolk. P. VI. VII.

4. M. lupulina (L.); spikes many-flowered dense oval, pods compressed unarmed kidney-shaped with a spiral point rugged with longitudinal branched prominent veins, stip. obliquely ovate slightly toothed, leaflets roundish-ohovate denticulate above emarginate mucronate.-E. B. 971.-St. procumbent or ascending, spreading widely. Pods scarcely spiral, glabrous or slightly hairy. Fl. yellow.-Waste ground. A. V.-VIII. Black Medick.

5. M. maculata (Sihth.); peduncles 1-4-flowered, pods compactly spiral compressed consisting of 2 or 3 turns veined with 4 ridges on the edge and a central furrow, spines in 2 rows divergent subulate curved, leaflets- triangular-obcordate, stip. toothed. -E. B. 1616.-Leaflets with a purple spot in the centre. Edge of the pods broad; spines arising from the margin and the ridge next to it on each side, compressed and furrowed on both sides, varying considerably in length.-On a gravelly soil. A.V.-VIII.

6. M. minima (Lam.); peduncles 1-6-flowered, pods compactly spiral consisting of 4 turns smooth with a thin edge, spines in 2 rows divergent subulate hooked, leaflets obovate, stip. nearly entire.-E.B.S. 2635.-Edge of the pods with 3 ridges, the central one so prominent as to be easily taken for the true margin, no central furrow but the central ridge common to the 2 rows of spines. Sides of the pods smooth. Spines varying considerably in length and the whole plant in bairiness. This is probably Ray's Orford plant.-In sandy fields, rare. A. V. E. 
7. M. denticulata (Willd.); peduncles 1-5-flowered, pods rather loosely spiral consisting of 2 or 3 turns deeply reticulated with a thin edge, spines in 2 rows divergent subulate hooked, leaflets obcordate, stip.laciniated.-E. B. S. 2634.-Edge of the pods as in M. minima. Spines about equalling the diameter of the pod. Glabrous.- $\beta$. M. apiculata (Willd.); spines very short without hooks, often scarcely longer than their own breadth so as to appear little more than tubercles, ped. 3-10-flowered.On sandy ground near the sea. A. V.-VIII.

\section{Melilotus Lam.}

1. M. officinalis (Willd.) ; racemes lax, wings keel and standard equal, pods ovate acute compressed transversely wrinkled hairy, leaflets serrate truncate narrowly ovate, stip. setaceous entire.E. B. 1340. M. macrorrhiza Pers., Koch.-St. erect, 2-3 feet high. Fl. in lateral racemes, yellow.-Waste places. B.? VI. - ViII. Melilot.

2. M. arvensis (Willd.); racemes lax, wings and standard equal longer than the keel, pods ovate obtuse mucronate rounded and slightly keeled on the back transversely plicate-rugose glabrous, lts. obcordate or oblong serrate, uppermost lanceolate, stip. awlshaped entire.-E. B. S. 2960. M. officinalis Koch.-St. erect. Fl. yellowish, in long racemes. Pods brown.-Waste places. Cambridge; Thetford; \&c. B. VI. VII. E. I.

3. M. vulgaris (Willd.); racemes lax, wings and keel equal but shorter than the standard, pods ovate obtuse mucronate reticulaterugose glabrous, leaflets obovate the upper ones oblong serrate obtuse, stip. awlshaped entire.-M. leucantha Koch, E. B. S. 2689. M. alba Koch.-St. erect. Fl. white.-Sandy and gravelly places near the sea, rare. B. VII. VIII.

\section{Trifolium Linn. Clover.}

* Fl. sessile; cal. with an elevated thickened often hairy line or ring of hairs in its throat, not inflated.

1. T. pratense (L.); heads ovate dense sessile, cal. 10-veined hairy not half so long as the corolla, teeth setaceous ciliated, stip. ovate abruptly bristle-pointed, leaflets oval emarginate upper ones entire apiculate.-E. B. 1770. St. 15. 11.-In the cultivated plant the leaflets are usually all quite entire. Cal.-teeth 5, 4 nearly equal in length to the tube, the lower one twice as long. Heads of fl. sometimes slightly stalked. Fl. purplish, sometimes white. St. erect.- $\beta$. parviflorum; heads stalked, calyx-teeth as long or longer than the corolla.-Mountainous pastures, fields. $\beta$. in dry places. P. V.-IX. Purple Clover. 
2. T. medium (L.); heads subglobose lax stalked, calyx 10 -veined glabrous not half as long as the corolla, teeth setaceous hairy, stip. linear-lanceolate acuminate, leaflets elliptical or lanceolate apiculate.-E. B. 190. St. 15.13.-Four of the calyxteeth equalling, or rather longer than the tube, the fifth $\frac{1}{3}$ longer. Heads of fl. large. Fl. purplish. St. ascending, zigzag.-Dry elevated pastures. P. VI.-IX.

3. T. ochroleucum (L.); heads subglobose dense stalked solitary terminal, cal. 10-veined pubescent about half as long as the corolla, teeth erect in fruit subulate lower one rather longer than the tube the others two-thirds shorter, stip. lanceolate-subulate, leaflets elliptic-oblong the lower one emarginate or cordate.E.B. 1224. St. 15.15.-Cal. with acute teeth having 1 strong vein. St. $1 \frac{1}{2}$ foot high, erect. Lower l. on very long stalks. Fl. cream-coloured, at length turning brown.-Dry gravelly soils and clays of the east of England. P. VI. VII.

4. T. incarnatum (L.); heads ovate at length cylindrical stalked solitary terminal, cal. 10-veined hairy, teeth patent in fruit lanceolate-subulate nearly equal rather longer than their tube and falling short of the cor., stip. ovate obtuse, leaflets obovate retuse or obcordate, st. erect and together with the 1 . and stip. villose. -E. B. S. 2950.-Stip. sometimes rather acute especially the lower ones. Fl. reddish purple on the cultivated, nearly white on ("T. Molinerii Balb." T. noeanum $R$.) the wild plant. Mouth of the calyx of the fr. hairy.- Near the Lizard Point, Cornwall (with pale flowers). Rev. W. S. Hore. A. VI. VII. E.

†5. T. stellatum (L.); heads globose stalked terminal, calyx 10-veined hairy, teeth subulate from a broad base equal exceeding the corolla patent in fruit 3-veined and reticulated, throat closed with hairs, stip. ovate rather acute denticulated, leaflets obcordate, st. spreading and together with the 1 . and stip. villose.- $E$. $B$. 1545. St. 16. 5.-Fl. cream-coloured, small. Calyx of the fruit remarkably large, its teeth spreading in a stellate manner. St. short.-Shingly beach near Shoreham. A. VI. VII. E.

6. T. arvense (L.); heads nearly cylindrical stalked very hairy, cal. 10-veined, teeth subulate-setaceous hairy nearly equal veinless exceeding the cor. at length slightly spreading, stip. ovate or lanceolate acuminate, leaflets linear-oblong.-E. B. 944 . St. 16. 3.-St. erect, or in a maritime form (Ray Syn. t. 14. f. 2.) procumbent with globose heads, st. and 1. finely hairy. Points of the lower stip. sometimes very slender. Fl. small, almost concealed by the very hairy calyx. Seeds oval, greenish yellow; radicle not prominent.-Sandy fields. A. VII.-IX. Hare'sfoot Trefoil.

7. T. striatum (L.); heads ovate or oblong sessile terminal and 
lateral solitary or the terminal in pairs, calyx 10-veined hairy, teeth subulate unequal straight mucronate about equalling the cor., tube ventricose in fruit, stip. ovate cuspidate, leaflets obcordate or obovate, veins equal and straight at the margins. $-E$. $B$. 1843. St. 16. 6. 7.-St. procumbent, 4-10 in. long and as well as the l. silky. Stip. with reddish veins. Fl. small. Seeds oval, brownish yellow ; radicle not prominent.- $\beta$. erectum (Leight.); st. erect, heads elongated subconical lateral shortly stalked, cor. longer than the calyx.-Dry and sandy places. A. VI. VII.

8. T. scabrum (L.); heads ovate sessile terminal and lateral solitary, cal. 10-veined hairy, teeth lanceolate mucronate about equalling the cor. with 1 strong prominent vein at length patent, tube cylindrical in fruit, stip. ovate cuspidate, leaflets obovate, veins thickened and curved at the margins.-E. B. 903.-St. procumbent, spreading. Fl. small. Cal. of the fruit very rigid. Seeds oblong, reddish yellow; radicle not prominent.-Dry sandy places. A. V.-VII.

9. T.Bocconi (Savi); heads oblong-ovate sessile terminal usually 2 together, cal. 10-veined hairy, teeth lanceolate-subulate mucronate about as long as the cor. with 1 strong prominent vein erect, tube cylindrical in fruit, stip. oblong with a long subulate point, leaflets oblong-obovate in the lower leaves roundish-obovate, veins equal and straight at the margins, seeds with the radicle slightly prominent.-E.B.S. 2868.-St. 2-6 in. high, erect. Fl. small, pale yellow. Seeds oval, brownish yellow. Heads dense, somewhat conical.-In dry places, near the Lizard Point, Cornwall. A. VII.

E.

10. T. maritimum (Huds.) ; heads ovate-globose stalked terminal, cal. strongly veined, teeth ciliated at first subulate erect falling short of the cor. afterwards broad leaflike acute spreading 1-veined the lower one longest and 3-veined, tube hairy above obconical in fruit, stip. broadly subulate very long, leaflets oblongobovate.-E. B.220.-St. spreading, usually procumbent. F1. pale red, small.-Muddy salt marshes. A. VI. VII. E. I.

** Fl. sessile; throat of the calyx naked within; heads fewflowered, at length producing thick stellated fibres (abortive calyces) from their centre which ultimately fold over the fruit.

11. T. subterraneum (L.); heads $2-5$-flowered erect deflexed in fruit, calyx glabrous, teeth filiform hairy nearly equal shorter than the corolla, tube inflated in fruit and at length split longitudinally, abortive calyces numerous slender stellate with 5 points, stip. ovate pointed, leaflets obcordate.-E. B. 1048.-St. prostrate and as well as the l. hairy. Fl. white, considerbly longer than the calyx. The curious abortive calyces are remarkably characteristic of this species.-Dry gravelly places. A. V. VI. 
*** Fl. sessile or stalked; throat of the calyx naked within, not inflated: pods 2-4-8-seeded.

12. T. glomeratum (L.); heads globose sessile terminal and axillary, calyx sessile 10 -veined, teeth ovate very acute veiny nearly equal reflexed, stip. ovate taper-pointed, leaflets obcordate the upper ones obovate, seeds $2 .-E . B .1063$. - St. procumbent. Fl. rose-coloured; standard persistent, striated. Seeds transversely ovate-reniform, radicle prominent.-Gravelly places in the east and south of England. A. VI.

13. T. strictum (L.); heads globose axillary, calyx sessile 10veined, teeth subulate unequal somewhat spreading, stip. broad pointed serrated, leaflets obovate the upper ones oblong, seeds 2 . -E. B.S.2949.-St. diffuse, short. Ped. short. Pods slightly exserted; seeds ovate, radicle slightly prominent.-Jersey. Near the Lizard Point, Cornwall. A. VI.-VIII.

E.

14. T. suffocatum (L.); heads roundish sessile axillary, cal. sessile, teeth lanceolate acute falcate recurved longer than the corolla, stip. ovate pointed, leaflets obcordate, seeds 2.-E. B. 1049.-St. short, usually buried in the sand. Fl. small, erect. Cal. scarcely striated. Seeds roundish, radicle prominent.Sandy sea-shores, rare. A. VI.

E.

15. T. repens (L.); heads roundish, peduncles axillary longer than the leaves, fl. stalked at length deflexed, calyx glabrous half as long as the corolla, teeth lanceolate unequal erect, stip. orate abruptly cuspidate, leaflets obovate or obcordate, seeds 4 , stems creeping. - E. B. 1769. St. 15. 6.-Fl. white, standard striated, sometimes pink. L. often with a dark spot at their base. Pod included. In damp seasons the pod is often protruded in the form of a horn or changed into a small leaf.-Meadows and pastures. P. V.-IX. Dutch or White Clover.

16. T.? ornithopodioides (-L.); clusters stalked axillary of 13 stalked fl., calyx glabrous, teeth slender acute nearly equal erect, stip. ovate with long taper points, leaflets obcordate, seeds 8 . -E.B. 1047.-St. prostrate. FI. small, pet. all distinct. Pod exserted, compressed, obtuse, transversely furrowed, slightly hairy, curved, longer than the calyx, opening with 2 valves. This plant is scarcely a Trifolium or Trigonella.-Dry gravelly places. A. VI. VII.

**** Fl. sessile; throat of the calyx naked within, inflated after flowering and arched above.

17. T. fragiferum (L.); heads globose, peduncles axillary exceeding the leaves, involucre multifid equalling the calyx, calyx of the fruit membranous reticulated downy, stip. ovate with a long attenuated point, leaflets obovate emarginate minutely serrate, 
seeds 2.-E. B. 1050. St. 16.8.-St. creeping. Fl. purplish red. Heads large, remarkable when in fruit for their curious calyces. Pod included.-Damp pastures. P. VII. VIII.

[18. T. resupinatum (L.); heads hemispherical at length globose, peduncles axillary short, bracts minute, calyx of the fruit membranous reticulated woolly, stip. subulate-lanceolate from an ovate base, leaflets obovate minutely serrate, seeds 2.-E. B. S.2789. (bad) St. 16.9.-St. prostrate or ascending. Fl. small, resupinate. Pod included.-Near Bristol, Poole, New Brighton and Everton. A. VII.]

E. I.

***** Fl. stalked; throat of the calyx naked within, not inflated; cor. persistent; standard deflexed and covering the pod.

19. T. procumbens (L.); heads oval dense with about $40 \mathrm{fl}$., ped. axillary equalling or exceeding the leaves, fl. at length reHexed, style much shorter than the pod, stip. ovate acute entire, lts. obovate emarginate, central petiole longest, seeds elliptical, radicle scarcely prominent.-E. B. 945. St. 15. 15.-Primary stem erect, branches procumbent or ascending. Pod pointed at both ends. Peduncles sometimes shorter at others longer than the leaves. Fl. yellow. Radicle causing a slight irregularity in the otherwise regularly elliptical seeds. [T. patens (Schreb.), style as long as the pod, radicle prominent through $\frac{1}{2}$ the length of the seed, stip. half-cordate usually denticulate; will probably be found in England.]-Dry pastures. A. VI.-VIII.

20. T. minus (Sm.); heads close about 12-flowered, peduncles axillary, pedicels very short, $f$. at length reflexed, standard furrowed truncate quite covering the pod, style much shorter than the pod, stip. ovate, leaflets obcordate intermediate one stalked. -E. B. 1256. T. filiforme Koch.-Dry places. A. VI.-VIII.

21. T. filiforme (L.) ; fl. few (3-5) in lax racemes, peduncles axillary, pedicels as long as the calyx-tube, fl. at length reflexed, standard not furrowed deeply notched scarcely covering the pod. -E. B. 1257. T. micranthum Koch.-Standard much narrower in proportion than in T. minus. See Phyt. i. 293.-Dry places near the sea. A. VI. VII.

\section{Lotus Linn. Bird's-foot Trefoil.}

1. L. corniculatus (L.); claw of the standard obovate transversely vaulted, calyx-teeth straight in the bud subulate from a triangular base, points of the 2 upper ones converging, heads 5-10-flowered.-E. B. 2090.-Glabrous or slightly hairy. St. ascending. Leaflets obovate. Stip. ovate. Angle between the 2 upper calyx-teeth rounded. $-\beta$. villosus (Ser.); upper part of 
st. 1 . and cal. hairy with long spreading hairs. $-\gamma$. crassifolius (Pers.); pilose, st. cæspitose, leaflets obovate fleshy, stip. ovate. - $\delta$. L. tenuis (Sm.) ; glabrous or slightly hairy, st. filiform elongated procumbent or ascending, leaflets linear or linear-obovate, stip. $\frac{1}{2}$-ovate. E. B.S.2615.-Pastures, dry banks, \&c. P. VII. VIII.

2. L. major (Scop.?); claw of the standard linear, calyx-teeth spreading like a star in the bud subulate from a triangular base, two upper ones diverging, heads 8-12-flowered, leaflets obovate, stip. roundish-ovate.-E. B. 2091. L. uliginosus Schkuhr.Hairy. St. usually erect, $1-3$ feet high. Angle between the 2 upper calyx-teeth acute.- $\beta$. glabriusculus (Bab.); glabrous, the margins and veins of the l. stip. bracts and sep. ciliated, st. erect or procumbent.-In damp places. $\beta$. on drier spots. P. VII. VIII.

3. L. angustissimus (L.) ; claw of the standard linear, calyxteeth straight in the bud subulate, pod linear straight 6 times longer than the calyx, beak straight, heads about 2-flowered.E. B. 925. L. angustissimus (L.!), L. diffusus (Ser.).-Peduncle of the fl. as long as the l., of the fr. twice as long; leaflets and stip. ovate-lanceolate acute; st. procumbent. $-\beta$. Seringianus (Bab.); peduncle of the $\mathrm{fl}$. and fr. as long as the leaves, leaflets obovate-oblong, stip. ovate acute, st. ascending. L. angustissimus (Ser.). - South of England near the sea. A. VII. VIII. E.

4. L. hispidus (Desf.); claw of the standard subulate, calyxteeth straight in the bud subulate, podrugose terete twice as long as the calyx, beak elongate setaceous bent downwards, heads few (3-4)-flowered, leaflets obovate-lanceolate, stip. half-cordate, st. procumbent.-E. B. S. 2823.-Near the sea in Devon and Cornwall. A. VII. VIII.

E.

\section{Anthyllis Linn. Lady's Fingers.}

1. A. Vulneraria (L.); herbaceous, 1. pinnate, leaflets unequal, heads of $\mathrm{fl}$. in pairs, calyx of 5 ovate pointed teeth.E.B. 104. St. 49. 4.5.-Pod semiorbicular, long-stalked, upper suture arched outwards, 1-seeded. St. $6-12$ in. high, silky. Root-l. simple, oval. Fl. yellow, in terminal pairs of crowded many-flowered heads. - $\beta$. Dillenii; plant smaller, $\mathrm{Al}$. red. Dill. Elth. 320.-Dry pastures. P. VI.-VIII.

\section{Oxytropis Cand.}

1. O. Halleri (Bunge); stemless, leaflets ovate acute in about 12 pairs, peduncles exceeding the leaves erect silky, bracts equalling the calyx, pods erect ovate-oblong inflated silky 2-celled.- 
Astragalus uralensis Sm. E. B. 466.-Root, or more correctly stem, woody, branched. Pods abrupt with a very oblique acute point. Fl. bluish purple. "Pl. uralensis ab europæa differt." Koch.-Dry hilly pastures in Scotland. P. VII.

S.

2. O. campestris (DC.) ; st. short procumbent, leaflets lanceolate in about 12 pairs, peduncles rather exceeding the 1 . ascending hairy, bracts equalling the calyx, pods erect ovate inflated hairy imperfectly 2-celled.-Astragalus Sm. E. B. 2522. St. 19. 12.-Root woody, producing short procumbent stems. Pods narrowed upwards with a slightly oblique point. Fl. yellowish tinged with purple.-Clova Mountains. P. VII. S.

\section{Astragalus Linn. Milk-vetch.}

1. A. hypoglottis (L.); st. prostrate, stip. united, leaflets blunt in 8-10 pairs, spikes ovate, peduncles exceeding the leaves, pods ovate hairy stalked in the calyx erect.-E. B. 274.-Stip. opposite to the leaves. St. a few inches long, slender. Leaflets small. Fl. in rather large heads, ascending, purple. Ovary twice as long as its stalk.-Chalky and gravelly places. P. VI. VII.

2. A. alpinus (L.); st. procumbent, stip. ovate free, leaflets elliptical blunt in 10-12 pairs, spikes capitate, peduncles equalling the leaves, pods oblong hairy narrowed at both ends stalked in the calyx pendulous.-E. B. S. 2717. St. 19.13.-Stip. sometimes slightly connected at the base. St. elongated, slender. Fl. few, drooping, white tipped with purple.-Lofty mountains. Glen Dole, Clova. Little Craigindal,'Braemar. P. VII. S.

3. A. glycyphyllos (L.); st. prostrate, stip. ovate-lanceolate free, leaflets ovate in 5-6 pairs, spikes ovate, peduncles much falling short of the leaves, pods linear incurved erect glabrous.E. B. 203.-St. 2-3 feet long, scarcely branched, nearly glabrous. Fl. in short dense spikes, dull yellow. Pods an inch long.-Thickets on a chalky or gravelly soil. P. VI.

\section{Tribe II. Viciea.}

\section{Vicia Linn. .Vetch.}

* Upper part of the style equally hairy all over.

+ Peduncles elongated, few-flowered; cal. not gibbous at the base on the upper side. Ervum. Tares.

1. V. hirsuta (Koch); peduncles $1-6$-flowered about equalling the leaves, leaflets in 6-8 pairs linear-oblong. truncate mucronate, calyx-teeth equal as long as their tube the 2 upper ones 
converging, pods oblong 2-sceded hairy.-Ervum Sm., E. B. 970. Cracca minor Godr. - Stip. 2-lobed, outer lobe trifid with setaceous segments, inner lanceolate. Fl. small, pale blue, standard entire. Calyx-teeth subulate. Porl obliquely truncate; its upper suture nearly straight and prominent at the end. Seeds globose, compressed, red with darker spots, smooth; hilum long, linear.- $\beta$. angustifolia (Fries); ped. 1-2-flowered, pods glabrous.-Corn-fields and hedges. A. VI.-VIII. Harry 'Tare.

2. V. tetrasperma (Moench); peduncles 1-2-flowered about equalling the leaves, leaflets linear-oblong blunt mueronate in 4 6 pairs, calyx-teeth unequal shorter than their tube the 2 upper ones shortest " diverging," pods linear-oblong about 4-sceded glabrous.-Ervum Sin., E. B. 1223. St. 32. 14.-Stipules halfarrowshaped. Fl. small, pale blue; standard with blue streaks, emarginate. Calyx-teeth elongate-triangular. Pod rounded; its upper suture decurved at the end. Seeds 3-5, globose, dull brown, slightly rough; hilum oblong.-Fields and hedges. A. VI.-VIII. Smooth Tare.

3. V. gracilis (Lois.); peduncles $1-4$-flowered at last twice as long as the leaves, leaflets linear acute in 3-4 pairs, calyxteeth unequal shorter than their tube the 2 upper ones shortest, pods linear 5-8-seeded glabrous.-E. B. S. 2904.- Stip. halfarrowshaped. Fl. twice as large as those of $V$.tetrasperma, pale blue; standard emarginate. Calyx-tecth elongate-triangular, "two upper slightly eonverging." Pod with its upper suture slightly decurved at the end. Seeds globose, variegated with dark hrown and yellow, smooth; hilum short, oval, half as long as that of the last.-Fields and hedges. A. VI.-VIII.

†† Peduncles elongated, many-flowered; calyx gibbous at the base on the upper side.

4. V. sylvatica (L.); peduncles exceeding the leaves, leaflets elliptical obtuse mucronate in about 8 pairs, stip. lunate deeply toothed at the base, teeth setaceous, calyx-teeth shorter than their tube subulate.-E. B. 79. St. 31. 3. - St. many feet long, climbing by their branched tendrils. Fl. many, cream-coloured and streaked with blue. Hilum extending about half round the seed. -Woods and thickets. P. VII. VIII. Wood Vetch.

5. V. Orobus (DC.); leaflets ovate-oblong or ovate-lanceolate mucronate in many $(7-10)$ pairs, stip. half-arrowshaped slightly toothed at the base, calyx-teeth longer than their tube, 2 upper ones triangular, the others triangular-subulate.-Orobus sylvaticus, Sm., E. B. 518. - St. ascending, $1-1 \frac{1}{2}$ foot long. Tendrils reduced to a short slender point. Fl. many, creamcoloured streaked with purple. Porls linear-oblong. Hilum extending about $\frac{1}{8}$ round the seed.-Rocky woods. P. V. VI. 
** Upper part of the style hairy all over, the hairs rather longer below the stigma but scarcely bearded. Calyx gibbous at the base.

6. V. Cracca (L.); peduncles long many-flowered, leaflets lanceolate mucronate silky in about 10 pairs, stip. half-arrowshaped entire, calyx-teeth shorter than their tube, upper pair minute, the others subilate, standard sinuated at about the middle of each side, its limb and claw equally long, pods linear-oblong smooth. - E. B. 1168. St. 31. 6.-St. 3-4 feet long. F1. blue variegated with purple. Seeds subglobose, black. Hilum linear, extending $\frac{1}{d}$ round the seed.-Hedges. P. VI.-VIII.

\section{*** Style bearded below the stigma, in other respects glabrous} or uniformly hairy all over in its upper part; calyx gibbous at the base on the upper side.

7. V. bithynica (L.); peduncles falling short of the leaves 1-2-flowered, lts. of upper l. in 2 pairs elliptic-lanceolate mucronate or linear-lanceolate acute, stip. half-arrowshaped toothed, calyx-teeth longer than their tube lanceolate-subulate, pods linearoblong hairy.-E. B. 1842. St. 32. 5.-St. 12-18 in. long. F1. almost always solitary, purple. "Seeds globose, speckled with black and grey; hilum oval." Upper part of the style hairy all over. The inland plant has broader leaflets and more cut stip. than the maritime one.-Bushy places on a gravelly soil. P. VII. VIII.

8. V. sepium (L.) ; fl. 4-6 in small axillary nearly sessile clusters, leaflets in 4-8 pairs ovate obtuse mucronate gradually smaller upwards on the petiole, stip. half-arrowshaped undividerl or lobed, calyx-teeth unequal shorter than their tube, 2 upper ones curved upwards, pods linear-oblong glabrous.-E. B. 1515. St. 31. 16. - St. about 2 feet high. Fl. purplish. Calyz hairy. IIlum linear, extending about $\frac{2}{5}$ round the seed. Upper part of the style nearly or quite glabrous, bearded. L. more or less hairy, leaflets sometimes ovate-lanceolate truncate. - Woods and hedges. P. VI.-VIII.

9. V. lavigata (Sm.); fl. solitary axillary, leaflets ellipticoblong rounded mucronate in 4 pairs, stip. cloven, calyx-teeth nearly equal as long as the tube subulate, standard glabrous, pods compressed oblong glabrous. - E. B. 483. - St. suberect, 3-4 in. to 1 foot long. F1. pale purple. Seeds oblong, brown, attached by one end. I have not seen specimens. - On the pebbly beach at Weymouth formerly, but now lost. P. VII. VIII. E.

10. V. hybrida (L.) ; fl. solitary axillary, leaflets obovate emarginate apiculate in 5-7 pairs, calyx-teeth unequal spreading subulate longer than their tube, standard hairy, pod ovate-oblong 
hairy.-E. B. 482. St. 32. 3.-St. ascending, 1 foot long. Fl. reddish yellow. Hairs on the pods simple. "Seeds round with a short hilum." I have seen no native specimens.-On Glastonbury Tor Hill. Swan Pool, Lincoln. P. VI. VII. E.

11. V. lutea (L.); $\mathbb{f}$. solitary axillary, leaflets elliptic-lanceolate acute or rounded at the end apiculate in 5-8 pairs, calyxteeth unequal, upper ones very short and curved upwards, lower one longer than the tube, standard glabrous, pods elliptic-oblong hairy.-E. B. 481. St.31. 13.-St. procumbent, 1-2 feet long. Fl. sulphur-coloured. Hairs on the pods bulbous. Seeds round, compressed, with a short hilum. L. varying greatly in hairiness. - Pebbly ground near the sea. P. VI.-VIII. E. S.

12. V. sativa (L.); fl. axillary solitary or in pairs, leaflets in 5-7 pairs elliptic-oblong retuse or obcordate mucronate, upper ones narrower or linear truncate mucronate, calyx-teeth equal lanceolate-subulate long equalling their tube, standard glabrous, pods linear slightly silky, seeds globose smooth.-Seeds slightly compressed; hilum linear, occupying about $\frac{x}{4}$ of the circumference. $-\alpha$. V. sativa $(\mathrm{Sm}$.) ; leaflets all elliptic- or obovateoblong, the lower ones shorter and broader, fl. usually in pairs, pods erect, st. $1-1 \frac{1}{2}$ foot high. E. B. 334. St. 31. 10.- 3 . V. angustifolia (Sm.); leaflets of the upper 1. linear-lanceolate, lower ones obovate retuse or obcordate, fl. solitary or in pairs, pods mostly patent, st. slender. E. B. S.2614. St. 31. 11.$\gamma$.V. Bobartii (Forst.); leaflets of the upper l. linear truncate or retuse, fl. solitary, pods patent, st. prostrate. E. B. S. 2708.$\beta$. and $\gamma$. in dry places. $a$. is a doubtful native, perhaps only an escape from cultivation. A. V. VI. Common Vetch.

**** Style bearded below the stigma; calyx not gibbous.

13. V. lathyroides (L.) ; fl. axillary solitary, leaflets in $1-3$ pairs obovate or oblong retuse mucronate, calyx-teeth subulate straight as long as their tube, pods linear glabrous, seeds nearly cubical tubercular, bilum short elliptical.-E. B. 30. St. 31. 12. -St. procumbent, $3-5$ in. long. Fl. small, purple.-Dry gravelly and sandy places. A. V. VI.

\section{Lathyrus Linn. Vetchling.}

1. L. Aphaca (L.); peduncles single-flowered, petioles leafless forming tendrils, stip. very large leaflike cordate-sagittate.E. B. 1167.-St. weak, climbing. Fl. yellow, on long stalks. Remarkable for its total want of 1 . which are replaced by the stipules; rarely 1 or 2 lanceolate leaflets may be found. Pods subfalcate; seed smooth, compressed.- Sandy and gravelly fields in the south. A. V.-VIII. 
2. L. Nissolia (L.); peduncles 1-2-flowered, petioles leaflike linear-lanceolate without lts. or tendrils, stip. minute subulate.E. B. 112.-St. mostly erect. L. grasslike. Fl. purple, on long stalks. Pods cylindrical; seeds tubercular, round; hilum small, oval.-Bushy grassy places, rare. A. VI.

E.

3. L. hirsutus (L.); peduncles 2-flowered, 1. of one pair of linear-lanceolate leaflets, pods hairy, seeds globose tubercular. E. B. 1255.-St. winged, climbing to the height of 1 or 2 feet. Pods linear-oblong, covered with bulbous hairs. Fl. sometimes solitary, pale blue with a crimson standard. Hilum oblong.Rare. Essex. Somerset? A. VI. VII.

E.

4. L. pratensis (L.); st. angular, peduncles many-flowered, 1. of one pair of lanceolate mucronate slightly silky leaflets, stip. arrowshaped like the lts., calyx-teeth subulate, pods obliquely veined, seeds globose smooth.-E. B. 670.-St. $2-3$ feet high, climbing, not winged. Pods linear-oblong. Fl. racemose, drooping, bright yellow. Hilum small, oblong.-Moist meadows and pastures. P. VII. VIII.

5. L. sylvestris (L.); st. winged, peduncles many-flowered, 1. of one pair of linear-lanceolate or lanceolate leaflets, stip. halfarrowshaped narrow, calyx-teeth triangular-subulate, 2 upper ones short, pods reticulated with veins, seeds compressed smooth half surrounded by the hilum.-E. B. 805.-St. climbing to the height of 5-6 feet. Pods linear-oblong, curved. Fl. greenish yellow variegated with purple. Broader-leaved varieties often pass for L. latifolius. - Woods and thickets. P. VII.-IX. F. S.

[6. L. latifolius (L.); st. winged, peduncles many-flowered, 1. of one pair of elliptical pointed leaflets, stip. half-arrowshaped triangular-ovate broad, "pods reticulated with veins, seeds tubercular rugose $\frac{2}{3}$ surrounded by the hilum." -E. B. 1108.-St. climbing 5 or 6 feet. "Pods linear oblong." Fl. rosy purple, large.-A very doubtful native. P. VII. VIII.] E. S.

7. L. palustris (L.); st. winged, peduncles many-flowered, l. of 2 or 3 pairs of linear-lanceolate acute leaflets, stip. half-arrowshaped lanceolate, "pods linear-oblong compressed ; seeds round compressed smooth $\frac{1}{4}$ surrounded by the hilum." - E. B. 169.St. $2-3$ feet high. Fl. bluish purple.-Boggy meadows, rare.
P. VI. VII.

8. L. maritimus (Big.); st. angular not winged, peduncles many-flowered, 1. of $3-4$ pairs of oval leaflets, stip. large oval cordate-hastate, pods oblong obliquely reticulated, seeds globose $\frac{1}{8}$ surrounded by the hilum.-Pisum Sm., E. B. 1046.-St. prostrate. Leaflets large, obtuse but apiculate; petioles often recurved. Fl. purple, variegated.- $\beta$. acutifolius (Bab.); leaflets elliptic-lanceolate acute, petioles straight, stems slender strag- 
gling.-Pebbly sea-shores, rare. $\beta$. Burrafirth, Unst, Shetland. P. VII. VIII. Sea Pea.

9. L. macrorrhizus (Wimm.); st. simple winged, peduncles 2-4-flowered, 1. of 2-3 pairs of oblong or lanceolate blunt apiculate leaflets without tendrils, stip. half-arrowshaped broad, pods cylindrical, seeds globose $\frac{1}{3}$ surrounded by the hilum.-Orobus tuberosus $\mathrm{Sm}$. E. B. 1153.-Root tuberous. L. glaucous beneath. Fl. purple, variegated with red and blue. $-\beta$. tenuifolius; lts. linear.-Woods and thickets in hilly countries. P. VI. VII.

10. L. niger (Wimm.); st. branched not winged, ped. manyflowered, 1. of 3-6 pairs of lanceolate or oblong leaflets without tendrils, stip. linear-subulate the lower ones half-arrowshaped, pods slightly compressed, seeds oval $\frac{1}{3}$ surrounded by the hilum. -Orobus Sm., E. B. S. 2788.-Turns black in drying. Fl. variegated with red, blue and purple. Pods linear. Seed dark brown, perfectly smooth.-Rocky woods in Scotland, rare. P. VI. VII.

S.

\section{Tribe III. Hedysarea.}

\section{Ornithopus Linn. Birdsfoot.}

1. O. perpusillus (L.); ped. exceeding the leaves, calyx-teeth triangular acute $\frac{T}{3}$ the length of their tube, beak scarcely as long as a joint of the pod.-E. B. 369.-A small prostrate plant, $3-12$ in. long. L. with $5 \frac{1}{2}-12 \frac{1}{2}$ pairs of elliptical downy leaflets. Fl. small; calyx hairy, cor. white with crimson veins. Pods curved, joints beadlike wrinkled lengthwise.-Dry sandy and gravelly places. A. V.-VII.

\section{Arthrolobium Desv.}

1. A. ebracteatum (DC.); ped. about equalling the 1.2-4flowered, stip. minute distinct, l. pinnate with many pairs of elliptic-oblong leaflets, the lowest pair remote from the stem.E.B.S. 2844.-St. prostrate, filiform. Fl. small, yellow, standard red externally. Pod curved upwards, joints cylindrical rugose. -Channel aud Scilly Islands. A. VI. VII.

\section{Hippocrepis Linn. Horseshoe Vetch.}

l. H. comosa (L.); pods umbellate, their joints rough curved neither dilated nor bordered, joinings glabrous, peduncles longer titan the leaves. - E. B. 31.-St. procumbent, often a foot long. Fl. yellow. Leaflets $7-13$, obovate, obtuse or emarginate, apiculate.-Dry calcareous banks. P. V.-VIII. 


\section{ONobrychis Gaert. Saintfoin.}

1. O. sativa (Lam.); wings shorter than the calyx, keel about as long as the standard, st. ascending, pods with reticulated spinous elevations on the disk and short sharp flat teeth on the lower suture.-E. B.96. St. 19. 10.-St. often 2 feet long. Fl. in long dense terminal racemes, crimson, variegated. Tube of the calyx silky, short; teeth very long. Leaflets elliptic-oblong, mucronate, entire, glabrous above, in about $12 \frac{1}{2}$ pairs. - On chalky and limestone hills. P. VI. VII.

\section{Order XXVI. ROSACEE.}

Cal. 4-5-parted, or twice as many in 2 rows, lined with a disk below, odd lobe superior. Pet. 5, equal. Stam. usually indefinite. Carp. several or solitary, distinct or combined with each other or with the calyx. Styles distinct, often lateral. Fruit various. Seeds nearly without albumen, embryo straight.-L. alternate, usually compound, with stipules.

\section{Suborder I. AMYGDALEE.}

Fruit a drupe. Calyx deciduous, quite free from the solitary ovary. Stipules free.

1. Prunus. Drupe fleshy, indehiscent; its nut smooth or furrowed.

Suborder II. ROSEE.

Carpels several, distinct from each other and from the calyx. Stipules united to the petiole.

Tribe I. SPIRAEA. Follicles several ; seeds 1--6, suspended from the inner edges of the follicles. Calyx persistent.

2. Spirza. Cal. 5-cleft. Stam. many, inserted with the pet. on a disk adhering to the calyx. Follicles 1 or more, usually distinct. Seeds $2-6$.

Tr. II. SANGUISORBEAE. Carpels $1-3$, inclosed in the dry calyx-tube which is narrowed at the top.

3. Sanguisorba. Fl. perfect. Cal. 4-cleft, with 2 or 3 external scales at its base, tube quadrangular. Pet. 0. Stam. 4, opposite to the segments of the calyx. Nuts. 1-2. Style terminal. Stigma capitate, covered with oblong spreading papillæ. Seed suspended.-G. F. G. Monochl. 78.

4. Poterium. Fl. monocious or polygamous. Cal. 4-cleft, with 3 external scales at its base, tube quadrangular. Pet. 0 . 
Stam. 20-30. Nuts 2-3. Style terminal. Stigma brushlike with filifoim divisions. Seed suspended.-G. F. G. Monochl. 79.

5. Agrimonia. Calyx 5-cleft, without external scales; tube turbinate, armed with hooked bristles above. Pet. 5. Stam. 15 , inserted with the pet. into a glandular ring in the throat of the calyx. Nuts 2. Style terminal. Seed suspended.

6. Alchemilla. Cal.8-parted, the alternate parts smaller; tube obconical, contracted at the throat. Pet.0. Stam. $1-4$, inserted into a ring in the throat of the calyx and opposite to the smaller segments. Nuts $1-2$. Style from near the base of the nut. Seed ascending.-G. F.G. Monochl. 80.

Tr. III. DRYADEAE. Fruit formed of 5 or more small dry (in Rubus succulent) nuts inserted on a dry or succulent receptacle. Calyx persistent, open.

* Attachment of the seed near to that of the style, radicle superior.

7. Si baldia. Cal. concave, 10 -parted, in 2 series, 5 exterior parts smaller. Pet. 5. Stam. 5. Style lateral. Fr. of 5-10 small nuts placed on a dry receptacle. Seed ascending.

8. Potentilla. Cal. concave, 8-10-parted, in 2 series, 5 exterior parts smaller. Pet. 4-5. Stam. many. Style lateral or nearly terminal. Fr. of many small nuts placed upon a flattish dry receptacle. Seed pendulous or ascending.

9. Comarum. Cal. cor. stam. and pistils as in Potentilla. Receptacle ultimately large spongy persistent. Style lateral near the top of the nut. "Seed pendulous.

10. Fragaria. Cal. cor. stam. and pistils as in Potentilla. Receptacle large succulent pulpy deciduous. Style lateral near the base of the nut. Seed ascending.

11. Rubus, Cal. concave or flattish, 5-parted. Pet.5 Stam. many. Styles nearly terminal. Carp. many, succulent, drupaceous, placed upon a hemispherical or conical spongy receptacle. Seed pendulous.

** Attachment of the seed distant from that of the style, radicle inferior. Seed with a long awn.

12. Dryas. Cal.8-10-cleft, in one row. Pet.8-9. Stam. many. Fr. of many small nuts, tipped with the persistent hairy styles which are straight at the extremity. Receptacle flat, dry. Seed ascending. 
13. Geum. Cal. 10-cleft, in 2 rows, the outer parts smaller. Pet. 5. Stam. many. Fr. of many small nuts, tipped with the persistent jointed styles hooked at the joining. Receptacle elongated, dry. Seed ascending.

Tr. IV. ROSEAE. Fruit formed of many small dry nuts inclosed in the fleshy tube of the calyx.

14. RosA. Cal. urceolate, contracted at the mouth, ultimately fleshy, 5-fid. Pet. 5. Stam. many, inserted with the petals on the rim of the tube of the calyx.

\section{Suborder III. POMEE.}

Calyx-tube thick and fleshy, in fruit forming a 1-5-celled pome.

15. Crategus. Calyx-segments 5, acute. Pet. 5. Styles 1-5. Fr. oval or round, concealing the upper end of the 1-5 bony 1-2-seeded carpels.

16. Cotoneaster. Calyx-segments 5. Pet. 5. Styles 2-5. Fr. turbinate, its nuts adhering to the sides of the calyx but not cohering at the centre.-Stam. erect, as long as the teeth of the calyx.

17. Mespilus. Calyx-segments 5, leaflike. Pet. 5. Styles $2-5$. Fr. turbinate with the upper end of the bony carpels exposed; disk dilated, almost as broad as the fruit.

18. Pykus. Cal. 5-toothed. Pet. 5. Styles 2-5. Fr. fleshy with 5 cartilaginous or membranous distinct 2 -seeded cells. Testa cartilaginous.

\section{Suborder I. Amygdalea.}

\section{Prunus Linn.}

\section{* Young leaves convolute.}

1. P. communis (Huds.); ped. solitary or in pairs, 1. elliptic or ovate-lanceolate rather downy beneath.-a. P. spinosa (L.); branches spinous, ped. glabrous, 1 . usually glabrous, fr. globose. E. B. 842.- 3. P. insititia (L.); branches slightly spinose, ped. and under-side of 1 . usually downy, fr. globose. E. B. 841.$\gamma$. P. domestica (L.); branches without spines, ped. glabrous, 1 . hairy about the midrib beneath, fr. oblong. $E$. B. 1783.-The characters of these varieties are not constant: $a$. is usually a shrub with crooked and much armed branches; $\beta$. is a taller shrub with straight and slightly armed branches; $\gamma$. is a small tree.-Sh. IV. T. a. Sloe. Blackthorn. $\beta$. Bullace. 
** Young leaves conduplicate. CERAsus.

2. P. Padus (L.); arborescent, l. obovate-lanceolate finely serrate glabrous, $f$. in pendulous racemes, fr. roundish-oblong.E. B. 1383.-A small tree. L. minutely doubly serrate. Fl. white, many, in a lax raceme. Fr. black, harsh and bitter, with a corrugated nut.-Woods and hedges. T. V. Bird Cherry.

3. P. Avium (L.); arborescent, $l$. drooping oblong-obovate suddenly cuspidate incise-serrate downy beneath, calyx-tube contracted below the entire sepals, "fr. heartshaped."-E. B. 706. -A tree of $20-30$ feet high. Outer scales of the leaf-buds deflexed. Flower-buds not leafy. Fl. in umbels. Pet. bifid, with a minute claw. " Fr. firm, bitter, black or red." Borr.-Woods. T. V. Wild Cherry.

4. P. Cerasus (L.) ; fruticose, $l$. not drooping oblong-obovate or ovate-lanceolate doubly crenate-serrate glabrous, calyx-tube not contracted, fruit round.-E.B.S.2863.-An erect bushy shrub, 3-8 feet high. Umbels scattered. Outer scales of the leaf-buds erect. Inner scales of the flower-buds leafy. Sep. crenate-serrate. Pet. subemarginate, with a claw. "Fr. juicy, acid, always red."-Hedges. Sh. V.

\section{Suborder II. Rosea. Tribe I. Spirca.}

\section{Spirata Linn.}

†1. S. salicifolia (L.); shrubby, stip. 0, 1. elliptic-lanceolate unequally serrate glabrous, racemes terminal compound, stam. exceeding the petals. $-E$. B. 1468.-A shrub of $4-5$ feet high with smooth round wandlike branches. Fl. flesh-coloured, in dense erect racemes.-Damp woods in the north and in Wales. Sh. VII.

E. S. *I.

2. S. Ulmaria (L.); herbaceous, stip. rounded toothed, 1. interruptedly pinnate, leaflets ovate undivided, the terminal one larger palmately 3 -5-lobed, $\mathrm{fl}$. in compound proliferous cymes, caps. glabrous contorted.-E. B. 960. St. 18. 8.-St. about 3 feet high, angular, branched. L. with a few large serrated leaflets and very minute intermediate ones, downy beneath. Peduncles downy. Fl. yellowish, sweetscented. Pet. roundish.Meadows and by water. P. VI.-VIII. Meadow-sweet.

3. S. Filipendula (L.); herbaceous, stip. of the root-leaves linear acute entire, those of the stem rounded and cut, l. interruptedly pinnate, leaflets all oblong deeply cut and serrate, $\mathrm{fl}$. in a panicled cyme, caps. hairy parallelly adpressed.-E. B. 284. St. 18. 7.- Root producing tubers. St. $1-1 \frac{1}{2}$ foot high, rourd, simple, panicled at the top. L. mostly radical, spreading; leaf- 
lets small, many, intermediate ones much smaller. Fl. yellowish white tinged with red. Pet. obovate-Dry chalky and limestone pastures. P. VI. VII. Dropwort.

\section{Tribe II. Sanguisorbea.}

\section{Sanguisorba Linn. Great Burnet.}

1. S. officinalis (L.); spikes ovate-oblong, stam. about as long as the calyx, leaflets cordate-oblong. $-E$. B. 1312.-L. pinnate glabrous; leaflets about 13, stalked, opposite, obtuse, coarsely serrate. Fr. oblong, winged chiefly in its upper half, transverse section round, 4 wings thin.- $\beta$. media; spikes elongated cylindrical.-Damp meadows. P. VI.-VIII.

\section{Poterium Linn. Lesser Burnet.}

1. P. Sanguisorba (L.); herbaceous, st. slightly angular, cal. of the fruit hardened quadrangular reticulate-rugose.-E.B.860. -L. pinnate with many small ovate coarsely serrate subsessile leaflets glabrous or slightly hairy beneath. Lower part of the stems and petioles often downy.-On a dry calcareous soil. P. VI.-VIII.

E. I.

2. P. muricatum (Spach); herbaceous, st. slightly angular, calyx of fruit hardened 4-winged pitted, pits with elevated and denticulate edges.-Closely resembling the preceding species but usually larger in all its parts. Leaflets usually oval.-Dry places. P. VI. VII.

E.

\section{Agrimonia Linn.}

1. A. Eupatoria (L.); cal.-tube of fr. obconic furrowed to the base, exterior spines spreading, l. interruptedly pinnate serrate shaggy beneath.-E. B.1335. St. 59.4.-St. erect, about 2 feet high. Spikes long with distant yellow flowers. Leaflets deeply serrated.-Fields and road-sides. P. VI. VII.

2. A. odorata (Mill.); cal.-tube of fr. bellshaped not furrowed, exterior spines declining, l. interruptedly pinnate hairy and with minute glands beneath.- Scented. Spikes long. Fl. yellow ; pet. obovate-lanceolate, wedgeshaped below, distant, spreading, flat, turning up at the end. Styles spreading. Leaflets deeply and sharply serrate throughout. Cal.-tube of the large fruits rarely with shallow furrows in its upper half. Taller than No. 1, usually more branched; 1 . and lts., fl. and fr. larger.-Waste places. P. VI. VII.

E. I. 


\section{Alchemilla Linn. Lady's Mantle.}

1. A. vulgaris (L.) ; $l$. reniform plaited 7-9-lobed, lobes rounded serrated throughout green beneath, fl. in terminal corymbs.-E. B. 597.- Slightly hairy. Fl. yellowish green. L. large on long stalks, st.-l. sessile with a pair of large notched connate stipules.- $\beta$. subsericea (Koch); st.-l. and petioles silky, old I. wavy with broad waves. A. montana Willd.-Dry hilly pastures. P. VI.-VIII. Common Lady's Mantle.

2. A. alpina (L.) ; radical l. digitate, divisions $5-7$ separated to their base oblong obtuse closely serrated at the end white and silky beneath, $\mathrm{fl}$. in interrupted spikes of small lateral and terminal corymbs, st. slightly branched simple below.-E. B. 244 . St. 51. 2.-St., cal. and under side of the l. heautifully silky. Leaflets rarely slightly combined, outer ones of the radical 1. usually nearly opposite to each other. Branches usually undivided, ascending.-Mountains. P. VI. VII. Alpine Lady's Mantle.

3. A. conjuncta (Bab.); radical l. peltate-palmate, divisions 5-7 combined through $\frac{1}{3}$ of their length oblong obtuse closely serrated at the end white and very silky beneath, $f$. in interrupted spikes of small lateral and terminal corymbs, st. with many branches. $-A$. argentea (Don) not Lam.-Closely allied to $A$. alpina but usually much larger; distinguished by the leaflets which are broader and so placed in the radical leaves that the 2 external ones almost if not quite tcuch each other so as to present the appearance of a peltate leaf; st. with long alternate spreading branches, which are often again subdivided; the $\mathrm{fl}$. in small nearly simple distant corymbs, upon longer stalks, and more silky. [Ferroe Isles. Sir W. C. Trevelyan.]-Clova Mountains. Mr. G. Don! and Mr. A. O. Black (1853). Glen Sannox, Arran. Dr. N. Tyache! P. VI. VII."

S.

4. A. arvensis (L.); l. palmate 3-fid wedgeshaped below hairy, lobes with 3-6 teeth at the end, fl. sessile axillary.-Aphanes (L.) E. B. 1011 . - St. prostrate or ascending, 4-5 in. long. Fl. very small, greenish, in small hairy inconspicuous tufts.-Dry fields on sand and gravel. A. V.-VIII. Parsley Piert.

\section{Tribe III. Dryadea.}

\section{Sibbaldia Linn.}

1. S. procumbens (L.); 1. ternate, leaflets wedgeshaped with 3 teeth at the end, fl. corymbose, pet. lanceolate.-E. B. 897. St. 17. 5.-L. pilose on both sides. St. woody, procumbent. Pet. very small. "Pistils and stam. very variable in number. 
"I am disposed to consider it as a Potentilla." W. Wilson.Dry summits of Scottish mountains. P. VII.

S.

\section{Potentilla Linn. Cinque-foil.}

* Hairs on the receptacle shorter than the glabrous carpels.

+ Leaves pinnate.

1. P. rupestris (L.); st. erect dichotomous, leaflets roundishovate unequally cut and serrate $5-7$ on the lower leaves, on the uppermost 3.-E. B. 2058. - Fl. white, large. Pet. much longer than the calyx. Base of 1 . wedgeshaped. St. 1-2 feet high.On Craig Breidden, Montgomeryshire. P. V. VI.

E.

2. P. anserina (L.); st. creeping, l. interruptedly pinnate, leaflets many oblong acutely serrate silky beneath, peduncles solitary.-E. B. 861. St. 4. 7.-Fl. yellow, large. L. green above, white and silky beneath; or white and densely silky on both sides.-Road-sides. P. VI. VII. Silver Weed.

\section{†† Leaves digitate.}

3. $P$. argentea (L.); st. decumbent or ascending, $l$. quinate, leaflets obovate-cuneate incise-serrate white and downy beneath their margins revolute.-E. B. 89. St. 17.7.-Fl. yellow, small, in terminal corymbs.-Dry gravelly places. P. VI. VII.

4. P. intermedia (Nesl.); st. ascending, l. of 7 hairy linearcuneate leaflets deeply serrated throughout green on both sides, st.-l. ternate, teeth 5 or more on each side of a leaflet. $-P$. opaca Sm. E. B. 2449.-Fl. on long simple solitary axillary or panicled stalks, yellow. Serratures large distant, extending to the base of the leaflet. I have not seen specimens.-Clova and Balquidder. P. VI.

S.

5. P. verna (L.); st. prostrate, lower l. of 5-7 obovate leaflets serrated towards the end bristly on the margin and ribs beneath, teeth $2-4$ on each side, lowest stipules narrowly linear.E. B. 37. St. 17.8.-St. woody, about 5 in. long. Fl. yellow, solitary or 2 or 3 together. The terminal tooth of the l. usually smallest and shortest.-Dry pastures. P. IV. V.

E. S.

6. P. alpestris (Hall.); st. ascending, lower l. quinate, leaflets obovate-cuneate somewhat hairy deeply cut in the upper half, teeth about 4 on each side, stip. all ovate.-E. B. 561. P. salisburgensis (Haenke) St. 17. 10.-Larger than the preceding. All the teeth of l. equal.-Mountains. P. VI. VII.

E. S.

7. P. reptans (L.); st. filiform procumbent rooting, $l$. quinate stalked, leaflets obovate bluntly serrated, peduncles solitary, pet. obcordate with a long claw, carpels granulate-scabrous.-E. $B$. 
862.-L. on long stalks, often with a bunch of small 1 . in their axils, sometimes solitary, usually in pairs. Leaflets blunt, rough or hairy on their ribs and margins. Fl. on long stalks, yellow.Sometimes the 1. and cal. are covered with long silky hairs on both sides.-Road-sides and banks. P. VI.-IX.

8. P. Tormentilla (Nesl.); st. procumbent or ascending, l. ternate sessile or shortly stalked, lower l. quinate on long stalks, leaflets lanceolate incise-serrate or obovate-cuneate, pet. obcordate their claw very short, carpels longitudinally wrinkled.-Tormentilla officinalis (L.) E. B. 863. St. 34. 12.-Leaflets acute, somewhat hairy. L. all nearly sessile except the lowest which often have long stalks. Stip. deeply cut. Fl. small, yellow, usually with 8 sep. and 4 pet.-P. mixta (Nolte); l. stalked, lts. obovate-oblong acutely serrate, stip. entire. A hybrid between No. 7 and 8.- 3 .P. procumbens (Sibth.); leaflets obovate-cuneate deeply cut, 1. 5-nate subpedate or 3-nate stalked, stip. entire or trifid. Fl. usually larger. T. reptans L., E. B. 864.-In dry places. $\beta$. Woods and hedge-banks. P. VI.-VIII.

** Hairs on the receptacle long, carpels hairy at the scar or all over.

9. P. fruticosa (L.); shrubby, l. pinnate, leaflets mostly 5 oblong acute entire hairy with revolute margins. - E. B. 88.-St. 3- 4 feet high. Fl. large, yellow, terminal, somewhat aggregated. -Teesdale. Wastdale. Galway. Clare. Sh. VI. VII. E. I.

[10. P. alba(L.); st.weak ascending, l. quinate, leaflets ellipticoblong narrowed below silky beneath tipped with converging serratures, filaments and carpels glabrous except at the scar of the latter.-E. B. 1384. St. 4. 2.-Fl. white. Stem-1. ternate.Said to have been found in Wales: Huds. P. VI.] E.?

11. P. tridentata (Sol.); st. woody creeping at the base, $l$. ternate, leaflets oblong-cuneate with 3 teeth at the end glabrous above hairy beneath, filaments glabrous, carpels downy.-E. $B$. 2389. - St. prostrate. Fl. white.- "Werron Hill, and East rocks Loch Brandy," Clova. Mr. G. Don. P. VI.

S.

12. P. fragariastrum (Ehrh.); st. procumbent, 1. ternate greyish green, leaflets roundish obovate serrate silky on both sides, pet. narrowly obcordate not contiguous, carp. glabrous except at the scar smooth or wrinkled transversely.-E. B. 1785.-Fl. small, white.-Woods, banks. P. IV. V. Barren Strawberry.

\section{Comarum Linn. Marsh Cinque-foil.}

1. C. palustre (L.).-E. B. 172.-St. ascending, 1 foot high, reddish. L. pinnate. Leaflets $5-7$, elliptic-oblong, acute, sharply serrate. Fl. several, dark purple; cal. purple within; 
pet. small. Differing from Potentilla by its enlarged spongy receptacle.-Marshes and peaty bogs. P. VII.

\section{Fragaria Linn. Strawberry.}

1. F. vesca (L.); cal. of the fruit spreading or reflexed, hairs on the peduncles spreading those of the pedicels adpressed upwards silky. -E. B. 1524. E. B. S. 2742.-Stoloniferous. L. bright green. Flowering stems short, erect, mostly simple, fewflowered. Lts. sessile. Hairs on pedicel of first fl. spreading, on the under side of 1 . adpressed. Carp. smooth, glabrous, on all parts of the receptacle. Pet. about as long as broad, white throughout, with 2 slight notches at the end, contiguous; claw indistinct.-Woods and thickets. P. V. VI. Wood Strawberry.

†2. F. elatior (Ehrh.); cal. of the fruit spreading or reflexed, hairs on the peduncles and pedicels spreading and somewhat deflexed. -E. B. 2197. F. moschata Lindl.-Fl. imperfectly diœcious. Pet. $\frac{1}{3}$ broader than long, white, entire; claw distinct, bright yellow. Larger and more hairy than F. vesca.-Woods in the south, rare. P. VI.-IX. Hautboy Strawberry.

\section{Rubus Linn. ${ }^{1}$ Bramble.}

A. Fruticosi.

* Stem suberect, shrubby, biennial.

i Idai. Ripe fruit separating from its receptacle. Stems having a glaucous bloom.

I. R. Idaus (L.) ; st. round, prickles setaceous straight, 1. 5pinnate or ternate white beneath, term. lt. long-stalked, interm. lts. sessile not imbricate, prickles of fl.-shoot and peduncles many deflexed from a dilated compressed base, fl. axillary and terminal corymbose.-E. B. 2442. R. G. 47.-With suckers. St. 4-6 ft. high; prickles small. L. usually pinnate, rarely ternate. Fr. red or amber-coloured.-Thickets. Sh. VI. Ráspberry.

2 ?. R. Leesii (Bab.) ; st. round, prickles setaceous straight, l. 3-nate white beneath, lts. all roundly ovate subsessile imbricate, prickles of fl.-shoot and ped. few setaceous from a bulbous base, fl. axillary and terminal racemose.-A. N. H. ser. 2. ix. 124.

1 In the descriptions by stem is meant the barren stem of the year; the prickles are called patent when they spread at right angles to the st., and subpatent when a little declining; the shape of the leaflets, unless otherwise stated, is taken from those of the barren stem. The term seta is used to express a hair or bristle tipped with a gland; aciculi are strong bristles.-By $R$. G. the plates in Weihe and Nees's Rubi Germanici are intended. 
With suckers. St. $2-3 \mathrm{ft}$. high ; prickles small. L. all ternate; lts. similar. Fr. unknown.-Ilford Bridges, Devon. Dunster, Som. Sh. VI.

E.

ii. Suberecti. Ripe fruit not separating from its receptacle. Stems glabrous, slightly pilose; prickles equal.-Sepals densely tomentose within, pilose externally with a narrow border of white tomentum.

3. $R$. suberectus (And.); st. roundish obtuse-angled at the end, prickles few small from a large compressed base confined to the angles of the st., 1.5-7-nate flexible thin, term. lt. cordate acuminate, basal lts. subsessile, lts. of fl.-shoot all narrowed below, pan. thyrsoid, fr.-cal. reflexed.-E. B. 2572. R. umbrosus Lees! -St. $3-4 \mathrm{ft}$. high. Prickles scarcely longer than the longitudinal extent of their base. L. green on both sides, rarely 3-nate, deeply and very acutely unequally serrate. Fr. dark red.-Boggy woods and heaths. Sh. VII. ViII.

4. R. fissus (Lindl.); st. reclining slightly angular, prickles from a small short oval base slightly deflexed not confined to the angles, 1. 5-7-nate coriaceous, lateral lts. of fl.-shoot often slightly gibbous below, pan. corymbose, fr.-cal. erect-patent.St. $1 \frac{1}{2}-2 \mathrm{ft}$. high. Prickles fully twice as long as the longitudinal extent of their base. L. green on both sides, unequally serrate; lower pair imbricate. Fr. dark red.-Bog in Almond Park, Salop. Llanberis, Caern. ? Sh. VII.-IX.

E.

5. R. plicatus (W. and N.); st. bluntly angular, prickles slender straight or deflexed from a rather long oval base confined to the angles, 1. 5-nate coriaceous mostly plicate, term. It. cordate acuminate, basal its. mostly subsessile, lateral lts. of fl.shoot dilated and gibbous below, pan. pyramidal, fr.-cal. reflexed. -E. B. 2714. R. G. 1. R. nitidus R. G. 4. R. fruticosus (L.) Arrh. R. G. 2.-St. 3-4 ft. long. Basal lts. sometimes stalked and prickles on st. stronger; usually those lts. are subsessile and imbricate.- $\beta$. carinatus; 1 . all lanceolate keeled.-Damp heaths. Sh. VII. VIII.

** Stem arched or prostrate, generally rooting at the end, shrubby.

iii. Nitidi. St. slightly pilose, but not stellately downy nor setose. Prickles chiefly on the angles of the stem, nearly equal, from a long low compressed base.

6. $R$. nitidus (Bell Salt.); st. angular shining smooth, prickles strong few declining compressed, 1. 5-nate plicate green and shining above paler and hairy beneath, term. lt. ovate or roundish acuminate, basal lts. stalked not imbricate, pan. compound leafy with spreading or divaricate short branches, rachis polished hairy 
above most prickly in the middle, fr.-cal. reflexed, prickles strong but slender straight declining. $-R$. Lindleianus Lees!-St. generally rooting, purplish when exposed. L. digitate, coarsely and doubly serrate. Ultimate pan.-branches tomentose. Primordial fr. small, globular; drupes small, black, glossy, globular, well-flavoured.-Sometimes the pan. is closer with ascending branches, and the lts. broader and less plicate.-The term. lt. is much narrowed below in true $R$. Lindleianus. $R$. nitidus (W. and N.) is R. plicatus.-Hedges and thickets. Sh. VII. VIII.

7. $R$. affinis (W. and N.); st. angular smooth, prickles slightly deflexed or declining conical from a long compressed base, 1. 5nate wavy towards the end dull green and rather pilose above paler and tomentose beneath, term. lt. cordate or cordate-ovate cuspidate, basal lts. stalked, pan. broad compound leafy with ascending cymose often elongated and leafy branches, rachis hairy tomentose above, prickles large deflexed with large compressed dilated base.-R. G. 3.-St. often seeming suberect. Basal lts. often slightly imbricate.-R. lentiginosus (Lees); st. a little fur. rowed, prickles declining, term. lt. oblong-obovate rather acuminate cordate below sometimes subglabrous beneath, pan. narrower: seems to be a state of $R$. affinis growing in exposed situations; the basal lts. are stalked, and its lts. plicate only from youth.-Heaths and open woods. Sh. VII. VIII. E. S.

8. R. latifolius (Bab.); st. decumbent or slightly arching angular furrowed, prickles moderate slightly declining compressed from a long base, 1. 5-nate pilose above more so beneath coarsely doubly dentate, term. lt. cordate acuminate, basal lts. sessile imbricate, pan. short leafy with ascending few-flowered corymbose branches pilose its top and pedicels tomentose and hairy, prickles short slender declining.-St. strong, green. L. very broad. Base of fl.-shoot slightly hairy. Pet. shortly ovate, clawed.Open woods. Cramond Bridge near Edinburgh. Acharn, Perthshire. Sh. VII. VIII.

S.

9. R. imbricatus (Hort); st. decurved much branched angular furrowed, prickles small strong declining from a long base, 1. 5nate thin convex opaque and subglabrous above paler and slightly pilose beneath dentate-serrate, lts. imbricate cuspidate convex, term. It. roundish-cordate, pan. narrow leafy below with distant long racemose ascending branches very hairy at the top not tomentose, prickles short slender from a large base deflexed, fr.-sep. abruptly cuspidate.-A. N. H. Ser. 2. vii.-St. much branched, purplish red. Prickles reddish. Base of fl.-shoot slightly hairy. Pet. elliptical, white. Styles greenish yellow below. Primordial fr. subglobose; torus subsessile.-Valley of the Wye below Monmouth, plentiful. Mr. Hort. Sh. VI. VII.

E. 
10. R. incurvatus (Bab.); st. angular, prickles strong patent or declining, 1. 5-nate coriaceous shining above very soft and grey beneath margins incurved and wavy, term. It. cordate-ovate acuminate, pan. narrow compact leafy below with short patent corymbose branches very hairy and tomentose at the top, prickles strong but slender deflexed, fr.-sep. ovate-attenuate.-St. purple, strong; prickles purple, tip yellow. L. coated with thick strong soft grey velvet beneath. Base of $\mathrm{f}$.-shoot hairy. Pet. elliptical, pink. Styles flesh-coloured below. Primordial fr. hemispherical; torus ovate.-Heaths and open woods. Llanberis, N. Wales. Milford, Pemb. Shrewsbury. Ambleside. Sh. VII. VIII. E.

11. R. rhamnifolius (W. and N.); st. angular furrowed, prickles patent or declining, $l$. 5-nate coriaceous thick flat opaque above grey tomentose beneath, term. lt. ovate or cordate-cuspidate, basal lts. stalked not imbricate, pan. pyramidal compaet above with distant axillary few-flowered racemose branches below tomentose, prickles strong deelining. $-E . B .2604$. R. G. 6 . R. cordifolius R. G. 5.-St. bright red. Prickles yellow or tipped with red. L. with hard shining grey or nearly green tomentum beneath, finely and equally serrate. Pet. roundish, white. Styles greenish. Primordial fr. oblong, very large; torus oblong; drupes many, black, dullish, rather flattened, insipid.-Hedges and thickets. Sh. VII. VIII.

iv. Villicaules. St. pilose (hairs often deciduous), often stellately downy (i. e. with very short stellate hairs, often adpressed), with scattered subsessile or slightly stalked glands or a very few setæ. Prickles chiefly on the angles of the stem, rarely a few scattered smaller ones. Basal leaflets stalked and not imbricate (i. e. not overlapping the intermediate pair).

12. R. Grabowskii (Weihe); st. arched angular nearly glabrous with a few hairs and subsessile glands on the young shoots, prickles many nearly equal (a few smaller) declining from a long base, 1. 5-nate opaque above ashy and downy beneath unequally dentate, term. lt. broadly cordate cuspidate on the fl.-shoot very broad below, pan. long compound prickly leafy below, branches ascending racemose-corymbose few lower axillary upper gradually shorter, rachis hairy, prickles very large hooked, sep. hairy and tomentose with sunken yellow setæ and aciculi.-St. ultimately purple, prickles on its end deflexed : I have not seen setæ upon it.-Caảeby, Leicestershire. Sh. VIII.

E.

13. R. thyrsoideus (Wimm.); st. angular furrowed subglabrous, prickles declining or hooked from a long base, $l$. 5-nate coriaceous grey hairy and tomentose beneath, pan. long lax many, lower branehes axillary many-flowered, upper gradually shorter, 
prickles strong hooked, cal. tomentose hairy, pet. obovate much narrowed below.-R. fruticosus $R$. G. 7.-St. roundish at the base, often nearly suberect, with scattered stellate down. I. usually softly tomentose beneath ; term. lt. usually ovate or oblong, gradually and shortly acuminate, rather coarsely and doubly serrate. $-\boldsymbol{R}$. argenteus (Lees !) is a form with more stellate down on the st., underside of $l$. and calyx. - I place var. macroacanthus (Bell Salt.) with $R$. discolor ; that of Bloxam here.-Hedges and thickets. Sh. VII. VIII.

14. R. discolor (W. and N.); st. arched angular furrowed stellately downy, prickles declining or deflexed from a long base, $l$. 5-nate coriaceous white closely tomentose beneath, pan. long narrow, few lower branches axillary many-flowered, upper short close together corymbose, prickles strong hooked, cal. closely tomentose, pet. roundish-obovate clawed.-R. G. 20 . R. fruticosus $S m$. E. B. 715.-St. nearly prostrate unless supported, often seeming glabrous. Prickles large, compressed. L. usually hairless beneath or slightly hairy on the ribs only, tomentum hard; term. lt. gradually obovate or oblong, abruptly acuminate; all often with decurved edges.-Hedges and thickets. Sh.VII.VIII.

15. R. leucostachys (Sm.); st. arched angular stellately downy and with clustered hairs, prickles slightly declining, 7.5 -nate grey or white shining soft tomentose and hairy beneath, term. lt. elliptic or round cuspidate, pan. long tomentose and hairy, branches all short few-flowered spreading, prickles slender straight, cal. tomentose hairy setose.-E.B. 2631. R. leucostachys and $R$. Leightonianus Bab., R. vestitus R. G. 33.-St. often nearly round, sometimes furrowed; stellate down abundant, often lax; hairs mostly clustered, with bulbous bases, sometimes 0 ; rarely a few subsessile glands or setæ. L. often pilose above; term. It. round in deep shade, more elliptical when exposed, often subcordate. Fl.-shoot hairy throughout; prickles yellow, from a large base.-Hedges and thickets. Sh. VII. VIII. E. I.

16. $R$. carpinifolius (W. and N.); st. arched angular patently hairy (hairs solitary and clustered) sometimes slightly stellately downy, prickles moderate conical compressed slender declining, 1. 5-nate pilose above pale green and hairy or grey and tomentose beneath, term. It. elliptic elliptic-obovate or roundish pointed, pan. narrow racemose leafy below very hairy setose, branches all short ascending few-flowered or lower elongated, prickles declining, cal. very hairy.-R. G. 13. R. vulgaris R. G. 12. $R$. carpinifolius $E$. B. S. 2664 is different. - St. sometimes nearly round; stellate down 0 , or very slight; subsessile glands rather many; setæ rare; prickles very regularly and gradually attenuated.- $a$. R. carpinifolius (W. and N.); st. often nearly suberect ultimately arched and rooting, term. It. elliptical acu- 
minate finely but unequally serrate grey hairy and finely tomentose beneath. Lts. rather coriaceous. - $\beta$. R. umbrosus (Arrh.); st. arched slightly angular, term. lt. elliptic-obovate subcuspidate irregularly dentate-serrate pale green softly hairy and mostly finely tomentose beneath. L. often 7-nate. Lts. large, flexible; term. lt. usually subcordate below. $R$. carpinifolius Blox.Hedges and thickets. Sh. VII. VIII.

17. R. villicaulis (W. and N.); st. arched angular patently hairy, prickles strong conical from a large base compressed straight subpatent, 1.5-nate thick pale green velvety shining with reddish veins beneath dentate-serrate, term. lt. cordate-ovate or ovate acuminate-cuspidate, pan. compound leafy lax hairy tomentose setose, branches corymbose, prickles slender declining or slightly deflexed, sep. long long-pointed hairy tomentose setose loosely reflexed-R. G. 17. R. sylvaticus Lees!, (Bab. in part). R. G. 15?-St. becoming nearly naked; stellate down rare ; hairs mostly solitary; glands subsessile; rarely a few setæe and aciculi. L. similarly clothed on both shoots. Fl.-shoot rather thinly hairy throughout. Pan. usually narrow.-Hedges and thickets. Sh. VII. VIII.

18. R. pampinosus (Lees); st. arched angular with few hairs, prickles slender conical declining from a long base, 1. 5-nate thin green on both sides thickly pilose only on the veins beneath unequally dentate, term. lt. cordate-ovate cuspidate, pan. long pyramidal leafy, lower branches racemose ascending, upper corymbose patent, prickles slender declining or deflexed, branches and top of rachis ashy with short hair and tomentum, sep. hairy tomentose and slightly prickly with a dilated or leaflike point.Bot. of Malv. ed. 2.55.-St. becoming naked and purple, polished, rarely a small seta. L. nearly glabrous and dull above, naked between the veins beneath. Very nearly allied to the large cordate-leafed form of $R$. villicaulis.-Woods near Malvern and Wire Forest. Sh. VII. VIII.

E.

19. R. mucronatus (Blox.); st. arched nearly round patently hairy, prickles few small slender conical from a large base straight subpatent, $l$. 5-nate rather thick green rough and pilose on both sides finely dentate-serrate, term. It. broadly obovate with a cordate base abruptly cuspidate, pan. narrow leafy very lax hairy tomentose setose, branches long $1-3$-flowered, prickles few slender declining, sep. long-pointed hairy tomentose setose loosely reflexed. $-R$. sylvaticus (Bab. in part).-St. becoming nearly naked; hairs scattered; glands subsessile; setæ and aciculi few. Fl.-shoot hairy throughout.-Hedges and thickets. Sh. VII. VIII. E. S.

20. R. Salteri (Bab.); st. arched angular furrowed subglabrous, prickles moderate compressed subpatent from a long base, 


\section{JULZRS INSTHUU,}

l. 5-nate thin green on both sides pilose beneath coarsely and doubly dentate-serrate, term. It. broadly obovate subcordate below cuspidate, pan. long lax leafy below hairy with short fewflowered patent subcorymbose branches, rachis wary, prickles slender declining, sep. long-pointed hairy tomentose.-K. calvatus Blox.-St. green, becoming quite glabrous; a few subsessile glands; setre and aciculi very few. L. very slightly pilose above, hard and rough beneath. Rachis of fl.-shoot wavy. The original $R$. Salteri has a very few sunken setæ on its panicle and calyx ; fl.-sboot with a nearly straight rachis ; branches of pan. more corymbose; fr.-sep. erect; prickles fewer on all parts than the typical $R$. calvatus. But they seem to be the extremes of one species.-Hedges. Sh. VI.-VIII.

E.

21. R. macrophyllus (W. and N.); st. arched or prostrate angular with scattered patent hairs, prickles short rather slender scarcely exceeding the longitudinal extent of their large base much declining, 1. 5-nate thin green and tomentose or pilose beneath, term. lt. elliptic-obovate, pan. compound rather elongate hairy tomentose with short sunken setæ, branches axillary racemose ascending, prickles slender much declining from a large base, cal. hairy tomentose.-R. G. 12. E. B. 2625? R. Schlechtendalii $B a b . \quad$ R. amplificatus Lees.-St. thick, very long, purplish green. Prickles usually singularly thick at their base but the upper part slender, sometimes rather small, yellow. Short aciculi and setæ not unfrequent. L. sometimes much rounder and cuspidate.-Hedges and thickets. Sh. VII. VIII. E. I.

22. R. Sprengelii (Weihe); st. prostrate round hairy, prickles many unequal from a large compressed base deflexed, 1. 3-5nate-pedate green on both sides distantly pilose beneath, term. lt. elliptical acuminate, pan. lax leafy below hairy tomentose setose, branches divaricate few-flowered the lower axillary ones often long and decompound, prickles slender few, sep. erect-patent hairy tomentose long-pointed.- $a$. R.Borreri (Bell Salt.); st. thick strong with many often very unequal prickles and some setæ and aciculi, 1. mostly 5 -nate, pan. often corymbose or when the branches are shorter subthyrsoid. - $\beta$. $R$. Sprengelii (Weihe); st. slender with small prickles and subsessile glands, 1 . mostly 3-nate, pan. lax few-flowered subcorymbose. R. G. 10.-These forms are quite connected by intermediate states; sometimes a few setæ occur on the st. of $\beta$, they are found on the panicle of both.-Woods and thickets. Sh. VI. VII.

E.

v. Glandulosi. St. with many hairs glands setæ and aciculi passing more or less gradually into scattered prickles.

A. L. 5-nate (rarely 3-nate); basal lts. stalked, not imbricate. Prickles on st. passing abruptly into aciculi and setce.

23. R. Bloxamii (Lees); st. prostrate angular or furrowed, 
prickles moderate subpatent compressed chiefly on the angles, aciculi and setæ small, hairs many all short, 1.5-3-nate green and pilose on both sides coarsely dentate, term. It. broadly obovate cuspidate, pan. long leafy, short branches and top corymbose, simple floral 1. very large subcordate below, prickles slender declining from long compressed bases, rachis angular not tomentose, sep. ovate-lanceolate leaf-pointed.-St. thick, rarely furrowed, green or purplish. L. subpedate. Upper floral l. simple; others 3-5-nate; term. It. cordate-ovate cuspidate.-Leicestershire. Warwickshire. Sh. VII. VIII.

E.

24. R. Hystrix (Weihe); st. arched angular slightly furrowed, prickles slender from a long compressed base slightly declining rather scattered, aciculi few setæ many hairs few all nearly equally short, 1. pedate green and pilose on both sides dentate-serrate, term. lt. obovate-oblong acuminate, pan. long leafy rather prickly with racemose ascending branches below upper half leafless with short patent or divaricate branches, prickles on fl.-shoot largebased declining on pan. very slender, rachis wavy, sep. lanceolate-attenuate (point flattened and dilated) erect-patent on fruit. -R. G. 41.- St. grcenish-purple. Prickles sometimes very small. I. paler and more hairy, but not white, beneath; term. lt. gradually narrowed into a long point in the typical plant, narrowed below on both shoots.-Hedges and thickets. Sh. VII. VIII.

25. R. Radula (Weihe); st. arched angular, prickles compressed from a long compressed base declining unequal and passing into aciculi, aciculi setæ and hairs many unequal, $l$. pedate whitishgreen and downy beneath unequally and finely serrate, term. It. ovate acuminate, pan. long leafy slightly prickly naked at the end with short corymbose ascending branches, prickles of fl.-shoot and base of pan. strong large-based deflexed, sep. ovate long not leaf-pointed loosely reflexed from the fruit.-R. G. 39.-The $\gamma$. pygmaus and $\delta$. foliosus of ed. 2 are R. pallidus; $R$. Lingua (Bab.) is this species with a less compound panicle.-Hedges and thickets. Sh. VII. VIII.

E.

26. R. rudis (Weihe); st. arched angular slightly furrowed, prickles long compressed nearly equal clearly separated from the aciculi, aciculi setæ and hairs equal, 1 . whitish green and downy beneath doubly and coarsely serrate, term. lt. obovate-elliptic acuminate, pan. long leafy naked at the end slightly prickly, branches ascending corymbose, prickles of the fl.-shoot and base of pan. strong large-based deflexed, sep. ovate leaf-pointed closely reflexed from the fruit.- $R$. G. 40.-The presence not absence of the leaf-point to the sep. is of value. Var. attenuatus (Bab.) is a wood form with thinner l. green beneath and term. lt. much lengthened at one or both ends. - $\beta$. $R$. Leightonii(Lees); term. 
lt. obovate cuspidate rounded below. $-\gamma$. denticulatus (Bab.); term. It. squarely obovate cuspidate cordate below obscurely but broadly dentate. $-\delta$. ? R. Reichenbachii (Weihe?); st. hairy with few aciculi and setæ, term. lt. nearly round ashy beneath, pan. oblong rather broad lower half leafy, branches racemose-corymbose, point of sep. long linear (not leaflike?). R. G. 37.Hedges and thickets. $\beta$. Shropshire. $\gamma$. Sheffield. $\delta$. Bangor. Sh. VII. VIII.

\section{B. L. 5-nate. Prickles passing very gradually into aciculi and setæ.}

a. Basal lts. stalked, not imbricate.

27. R. pallidus (Weihe); st. arched or decumbent roundishangular, prickles scattered unequal subpatent rather slender (in $\beta$. declining or deflexed strong) from a compressed base, aciculi and setæ scattered, hairs many, $l$. even green and soft beneath, term. lt. obovate-elliptical acuminate, pan. narrow leafy hairy, branches racemose erect-patent, prickles unequal slender declining a few strong, aciculi and setæ very unequal. $-R$. G. 29. $R$. Koehleri $\gamma . \delta . \epsilon$. of ed. 2. $R$. rosaceus Lees!-The amount of prickles varies much on all parts. Pan. sometimes simple, or lower branches long racemose, upper short $1-3$-flowered, sometimes subcorymbose.- $\beta$. infestus (Bab.); prickles many strong short much declining or deflexed, hairs aciculi and setæ few and short, pan. with short racemose branches and declining (or much deflexed strong) prickles.-Hedges and thickets. Sh. VII. VIIL.

28. $R$. Koehleri (Weihe); st. arched or decumbent roundish or angular, prickles many unequal from a compressed base, aciculi setæ and hairs many, l. even pale green and rough beneath, term. it. obovate, basal lts. stalked, pan. rather open and broad-topped leafy with short mostly corymbose and patent branches, prickles many long straight, hairs aciculi and setæ unequal many.- $R$. G. 25. E.B.S. 2605.-In the typical plant ( $a$. and $\beta$. ed. 2$)$ the term. 1t. varies from gradually acuminate to abruptly cuspidate, the prickles often nearly cover the st., the pan.-branches often have very many straight slender prickles. Prickles of pan. all straight and slender, or a few of the largest hooked and broad-based, rarely nearly all so.-Hedges and thickets. Sh. VII. VIII.

b. Basal lts. subsessile, usually imbricate.

29. R. fusco-ater (Weihe?); st. arched or decuubent angular slightly hairy, prickles many subpatent straight from a compressed base unequal, aciculi and setæ many, l. rugose above pale green beneath, term. lt . cordate-ovate acuminate, pan. long narrowish leafy naked above with short erect-patent subracemose 
branches, prickles strong longest about the middle of the fl.shoot, hairs aciculi and setæ mostly short and equal.-R. G. 26? -L. mostly soft beneath. I believe $R$. Schleicheri (Leight., not Weihe) is a form of this. The following plants are placed here doubtfully. $-\beta$. R. Colemanni (Blox.); prickles nearly equal often with deciduous glandular tips, hairs aciculi and seta very few deciduous, basal lts. not quite sessile, leafless top of pan. with short few-flowered divaricate branches, prickles many, aciculi and setæ rather few. $-\gamma$. aculeatus; prickles from a very large base declining, 1. grey and tomentose beneath, term. lt. obovate, basal lts. stalked not imbricate, leafless top of pan. with short few-flowered divaricate branches, prickles very many, hairs aciculi and setæ many unequal.-Hedges and thickets. $\beta$. Leicestershire and Warwickshire. $\gamma$. Coleford, Gloucestershire. Sh. VII. VIII.

C. L. 3-nate or 5-nate-pedate; basal lts. stalked, not imbricate. Prickles passing rather abruptly into aciculi and seta.

30. R. pyramidalis (Bab.); st. decumbent roundly angular, prickles many short strong with a very long compressed base much declining or deflexed, hairs few, aciculi and setre nearly equal short strong, 1. 3-nate rarely 5-nate-pedate green and pilose on both sides dentate-serrate, lts. of 3-nate 1. nearly equal with decurved edges, term. It. obovate cuspidate, pan. pyramidal leafy below its top and branches tomentose racemose, prickles slender straight, hairs and unequal setæ many, rachis straight and rigid.-St. quite procumbent, 1. paler and more pilose beneath. Pan. remarkably pyramidal; uppermost branches l-flowered. Sep. with long setaceous points, their base adpressed to the fruit. Pet. very narrow, often numerous.-Llanberis, N. Wales. Culbone, Somerset. "Sh. VII. VIII.

E.

31. R. Güntheri (Weihe); st. decumbent roundly angular, prickles weak unequal from a long compressed base declining, aciculi setæ and hairs nearly equal short, 1. 3-nate or 5-natepedate green and pilose on both sides unequally dentate-serrate, term. lt. broadly obovate acuminate, pan. thyrsoid leafy with ascending usually few-flowered racemose branches, prickles few small slender straight declining, aciculi setæ and hairs many unequal, rachis wavy. - R. G. 21.-Only slightly prickly. L. slightly pilose above, much beneath. Upper fl.-l. mostly simple. Sep. reflexed.-Thickets. Sh. VIII.

E.

32. R. hirtus (W. and N.); st. decumbent nearly round angular at the end, prickles small slender long-based declining unequal, hairs sete and slender aciculi many short unequal patent, 6. 5-nate-pedate or 3-nate green on bath sides pilose above paler 
and hairy beneath dentate, pan. with a racemose naked top and many short axillary distant branches very hairy and setose, prickles long slender declining lower ones long-based.-R. G. 43.-St. densely covered with hairs and very unequal setæ and aciculi. Term. It. with a cordate base, obovate-cuspidate, finely but doubly dentate. Axillary branches of pan. racemose-corymbose, sometimes 0 and then the pan. is usually simple. Fr.-cal. patent or reflexed, tomentose, setose, scarcely at all prickly.B. R. Menkii (Weihe); term. lt. obovate-lanceolate coarsely doubly dentate-serrate, cal. prickly. $R . G .22 ?-\gamma$. R. foliosus (Weihe); st. more angular with fewer hairs and setæ, term. lt. cordate acuminate, pan. leafy to the top, cal. slightly prickly. R. G. 28.-Thickets. $\beta$. Tonbridge Wells. $\gamma$. Warwickshire. Sh. VII. VIII. E. S.

33. R. glandulosus (Bell.); st. decumbent nearly round throughout, prickles small slender unequal large-based declining, aciculi setce and hairs rather many short nearly equal patent, $l$. 3-nate or 5-nate-pedate green on both sides pilose above hairy beneath dentate-serrate, pan. with a racemose or corymbose naked top and several short axillary corymbose branches very hairy and setose, prickles slender declining some large-based, fr.-cal. erect or patent.-L. scarcely paler beneath. Aciculi setæ and hairs on st. less numerous and far less conspicuous than in $R$. hirtus. Prickles on lower part of fl.-shoot often deflexed.- $a$. R. Bellardi (Weihe); st. round, prickles small, hairs and setæ rather many, term. lt. elliptic cuspidate finely dentate-serrate, pan. slightly divided, its top and few long distant branches corymbose. $R$. $G$. 44. E. B. S. 2883. A state of this is the R. dentatus Blox.B. R. fuscus (Bab.); st. roundish, prickles small, aciculi and setæ rather few, hairs dense, term. lt. elliptic-subcordate acute coarsely or doubly dentate, pan. rather long, branches subcorymbose. $R$. rotundifolius (Blox.) is a form of this.- The two following plants may constitute a distinct species from the two preceding. $-\gamma$. R. Lejeunii (Weihe); st. slightly angular sparingly hairy and setose, l. with long silky hairs on both sides, term. lt. ovate acuminate, pan. spreading densely hairy with many short sunken setæ, cal. very hairy. R. G.31.- $\delta$. R. rosaceus (Weihe); st. slightly angular, $l$. very slightly pilose above more so beneath, term. It. cordate or cordate-obovate-attenuate, pan. rather pyramidal branched below hairy with long unequal prominent setæ. $R$, G. 36.- $a$. Terrington Car, Yorkshire. Twycross, Leicestershire. Gt. Malvern. Tintern. $\beta$. Leicestershire. Worcestershire. Hertfordshire. $\gamma$. Channel Isles. Twycross. $\delta$. rather common. Sh. VII. VIII. E.

34. $R$. scaber (Weihe); st. rather angular, prickles strong short declining, aciculi setæ and hairs very short rather few 
with large bases, 1. 3-nate or 5-nate-pedate green and pilose on both sides paler and more hairy beneath doubly dentate, term. lt. obovate cuspidate or acuminate subcordate below, pan. subpyramidal tomentose leafy below, branches divaricate racemosecorymbose, prickles small declining or deflexed large-based, setæ nearly equal shorter than the hairs, sep. setose and prickly loosely reflexed. $-R$. G. 32.-R. Babingtonii Bell-Salt.!1 Rarely the st. is furrowed. Shape of lts. variable.-Woods. Widely distributed but not common. Sh. VII. VIII. E.

vi. Casii. St. round or bluntly angular with few, or no, hairs setæ or glands and usually a glaucous bloom. Prickles usually unequal ${ }^{2}$.

35. R. Balfourianus (Blox.); st. arched roundish or bluntly angular with scattered patent hairs and a few aciculi and setæ or subsessile glands, prickles rather unequal slender conical subpatent, $l .5$-nate green on both sides pilose above downy beneath dentate-serrate, term. It. cordate or ovate acute, basal lts. subsessile imbricate (?), pan. lax leafy hairy tomentose setose with long distant axillary spreading few-flowered racemose-corymbose branches, sep. ovate-attenuate with a long point, fr.-cal. erect patent, fr. depressed.-St. with few rarely many prickles. Pan. often very thinly tomentose setose and hairy. Sep. often leafpointed, prickly, setose. St. not floccose with few or no aciculi or setæ, pan. very broad lax and corymbose. Subglabrous $(R$. Balfourianus Blox.); or, st. with scattered short nearly equal aciculi and setæ, pan. closer and longer ( $R$. tenuiarmatus Lees). The extremes of these plants are very different, but there appear to be connecting forms.-Woods and hedges. Sh. VII. VIII. E.

36. R. corylifolius (Sm.); st. prostrate or arched nearly round throughout or bluntly angular upwards nearly or quite glabrous or with a few aciculi and setre or subsessile glands, prickles straight mostly equal, 1. 5-nate pale and soft beneath, term. lt. roundly ovate or cordate pointed, basal lts. subsessile imbricate, pan. and branches subcorymbose, sep. ovate reflexed, styles greenish, torus oblong stalked.- St. slightly glaucous. Pan. usually with 2 or 3 long axillary branches, closely tomentose, top with more or less prominent setæ.- - a. R. sublustris (Lees); st. round green, prickles slender from a small base patent, 1. whitish-tomentose beneath coarsely toothed, term.lt. usually lobed roundish-

1 The plants formerly included under the name of $R$. Babingtonii are now referred respectively to $R$. scaber, $R$. pyramidalis and $R$. fuscoater $\beta$. Colemanni.

2 The plants contained in the section are far from being determined satisfactorily. $R$. Wahlbergi (Bab. not Arrh.) is now placed partly under $R$. corylifolius and partly under $R$. nemorosus. 
cordate, fl.-shoot straightish, prickles on rachis few. $E . B .827$. Term. lt. sometimes divided into three.- $\beta$. conjungens; st. subangular green, prickles strong from a large base declining, 1. whitish tomentose beneath coarsely toothed, term. lt. usually not lobed cordate-ovate, fl.-shoot straightish, prickles on rachis few. - $\gamma$. purpureus; st. angular dark purple a little floccose, prickles patent or a little deflexed or declining from a large base, 1. whitish or greenish tomentose beneath rather finely toothed, term. lt. roundish ovate or subcordate, fl.-shoot wavy, prickles on rachis many. $R$. corylifolius $\gamma$. and $\delta$. Leight.-Hedges and thickets. Sh. VI.-VIII.

37. $R$. nemorosus (Hayne); st. prostrate bluntly angular with a few short hairs and setæ, prickles many very unequal patent conical, 1.5-nate or 3-nate nearly glabrous above paler and soft beneath, term. lt. roundly cordate pointed (on the fl.-shoot narrowed below), pan. nearly simple open, sep. ovate-acuminate conspicuously setose embracing the blue-black fr., "pet. narrowed below," base of styles flesh-coloured, torus conical. $-R$. dumetorum R. G. 45.-Prickles often slightly hairy especially on the petioles, a little curved on the midrib of leaves. Basal lts. stalked or subsessile. Fl.-1. simple.-a. glabratus; st. subglabrous, fl.-shoot tomentose, l. green and soft beneath.- $\beta$. pilosus; st. and fl.-shoot subtomentose, l. paler and soft beneath. $-\gamma$. R. bifrons (Vest.) ; st. subglabrous, l. whitish and tomentose beneath, fl.-shoot tomentose. $-\delta$. ferox (Leight.); prickles strong from a compressed cushionlike base, st. with a few hairs and setæ. A doubtful plant.-Hedges and thickets. . Sh. VI. VII.

38. R. casius (L.) ; st. prostrate round glaucous not hairy, prickles weak slender subulate very unequal straight or towards the end of the st. deflexed, l. 3-nate irregularly incise-serrate, term. lt. ovate or rhomboidal or 3-lobed, basal lts. usually sessile lobed below externally, pan. simple, sep. ovate long-pointed embracing the glaucous fr. of few drupes, pet. elliptical emarginate, styles green.-E. B. 826. R. G. 46.-St. long, slender. Prickles very variable in number and length. Term. lt. rarely dividerl into three and forming a 5-pinnate leaf. $R$. tenuis (Bell Salt.) is a state of this.-Heaths and hedges. Sh. VI.-IX.

\section{B. Herbacei. Stems nearly or quite herbaceous.}

39. R. saxatilis (L.); st. slender prostrate rooting unarmerl or with very few distant minute prickles, $l$. ternate, fl.-shoot erect with a terminal few-flowered corymb, pet. oval about equalling the calyx.-E. B. 2233. R. G. 9.-St. annual, very slender. Fl.shoots radical, about a span high. Fl. yellow Fr. of $1-4$ large red drupes.-Stony mountains. P. VIII. VIII. 
[40. $R$. arcticus (L.); st. erect unarmed herbaceous with about 1 terminal $\mathrm{fl}$., $l$. ternate, pet. obovate twice as long as the calyx, stam. connivent.-E. B. 1585. R. G. 48.-Fl. rose-coloured.-Isle of Mull and on Ben Ghlo?]

41. R. Chamamorus (L.); st. erect unarmed herbaceous l-flowered, l. simple lobed and plaited.-E. B. 1585. R. G. 49. -True st. subterranean, creeping, woody. Fl.-shoot (st.) 6-10 in. high. Fl. large, white, dicecious. Fr. large, red, afterwards orange-yellow.-Alpine turf-bogs. P. VI. Cloudberry.

\section{Index to the Rubi.}

R. aculeatus, 29. affinis, 7. amplificatus, 21. arcticus, 40. argenteus, 13. attenuatus, 26. Babingtonii, 24. Balfourianus, 35 . Bellardi, 33. bifrons, 37 . Bloxamii, 23. Borreri, 22. cæsius, 38 . calvatus, 20. carinatus, 5 . carpinifolius, 16. Chamæmorus, 41. Colemanni, 29. conjungens, 36 . cordifolius, 11. corylifolius, 36 . dentatus, 33. denticulatus, 26. discolor, 14. dumetorum, 37. ferox, 37 . fissus, 4. foliosus, 32 . foliosus, 25. fruticosus, 5, 14. fusco-ater, 29. fuscus, 33 .

glabratus, 37 . glandulosus, 33 . Grabowskii, 12. Güntheri, 31 . hirtus, 32 . Hystrix, 24. Idæus, 1 . imbricatus, 9 . incurvatus, 10. infestus, 27. Koehleri, 28. Koehleri, 27. latifolius, 8. Leesii, 2. Leightonianus, 15. Leightonii, 26. Lejeunii, 33. lentiginosus, 7 . leucostachys; 15. Lindleianus, 6. Lingua, 25. macroacanthus, 13. macrophyllus, 21 . Menkii, 32. mucronatus, 19. nemorosus, 37 . nitidus, 6 . nitidus, 5 . pallidus, 27. pampinosus, 18. pilosus, 37. plicatus, 5. purpureus, 36 . pygmaus, 25. pyramidalis, 30 . Radula, 25.

Reichenbachii, 26. rhamnifolius, 11 . rosaceus, 33 . rosaceus, 27. rotundifolius, 33 . rudis, 26.

Salteri, 20. saxatilis, 39 . scaber, 34 . Schlechtendalii, 21. Schleicheri, 29. Sprengelii, 22. suberectus, 3 . sublustris, 36 . sylvaticus, 17, 19. tenuiarmatus, 35 . tenuis, 38. thyrsoideus, 13. umbrosus, $3,16$. vestitus, 15. villicaulis, 17 . vulgaris, 16. Wahlbergii, 36. 


\section{Dryas Linn.}

1. D. octopetala (L.); 1. crenate-serrate obtuse, sep. 3 or 4 times as long as broad more or less pointed, base of the cal. hemispherical.-E.B. 451. St.20.3.-Fl. large, white. Pet. 8. L. simple, white with fine dense woolly pubescence beneath. St. prostrate, woody. Seeds obovate-oblong, apiculate.- $a$. Sep. acute, covered with red hairs. L. ovate-oblong, deeply cut into large rounded lobes; under side of the petiole and midrib green, bearing minute linear pellucid fringed scales mixed with long hairs, midrib and lateral ribs sparingly hairy and conspicuous.$\beta$. pilosa (Bab.). Sep. slightly pointed, covered with nearly black hairs. L. oblong or ovate-oblong, deeply cut into large slightly acute lobes; under side of the petioles and midrib dark red, hairy but without scales, midrib and lateral ribs covered with long white hairs and inconspicuous. Awn longer and more feathery.-Alpine situations, particularly on limestone. $\beta$. County of Clare, Ireland. P. VI. VII.

2. D. depressa (Bab.) ; 1. crenate-serrate obtuse, sep. twice as long as broad blunt and rounded at the end, base of the calyx truncate nearly flat.-A. N. H. x. 183. t.7. (calyx and leaf).Fl. large (white or yellowish?). Pet. 8. L. ovate, deeply cut into large rounded lobes, white with fine dense woolly pubescence beneath; under side of the petiole and midrib green, bearing minute pellucid fringed scales mixed with long hairs. Stems prostrate, woody. I have not seen recent petals.-Ben Bulben, Sligo. P. VI. VII.

\section{GEuM Linn. Avens.}

1. G. urbanum (L.); fl. erect, pet. obovate, cal. of the fruit reflexed, carpophore 0 , lower joint of the awn much longer than the glabrous upper joint, radical l. interruptedly pinnate and lyrate, stem-1. ternate, stip. large rounded lobed and cut.-E. B. 1400. St. 5.7.- St. 2 feet high. Fl. small, bright yellow, calyx green. Upper joint of the awn with a few minute hairs at its base.Hedges and thickets. P. VI.-VIII. Wood Avens.

2. G. intermedium (Ehrh.); fl. erect or nodding, pet. roundish with a wedgeshaped claw, cal. of the fruit patent, carpophore 0 , lower joint of the awn longer than the hairy upper joint, radical 1 . interruptedly pinnate and lyrate, stem-1. 3-lobed, stipules round toothed.-St. 1-2 feet high. Fl. larger than in No.1, less than in No. 3, yellow, calyx purplish. Upper joint of awn clothed with long hairs but with a rather long glabrous point. Perhaps a hybrid.-Damp woods. P. VI. VII. E. S.

3. G. rivale (L.); fl. nodding, pet. broadly obovate emarginate or olıcordate with a long wedgeshaped claw, cal. of the fruit 
erect, carpophore elongated, lower joint of the awn equalling the long hairy upper joint, radical l. interruptedly pinnate and lyrate, stem-1. ternate, stip. small ovate toothed.-E. B. 106. St. 3.St. about 1 foot high. Fl. large, purplish-brown with darker veins, calyx purplish. Head of fruit upon a stalk which is nearly as long as the calyx. Upper joint of the awn with a short glabrous point.-Damp woods. P. VI. VII. Water Avens.

\section{Tribe IV. Rosece.}

\section{Rosa Linn. (') Rose.}

* Shoots setigerous, prickles scarcely curved.

\section{$\dagger$ Bracts large.}

[1. R. Dicksoni (Lindl.); " shoots setigerous," prickles scattered slender subulate, leaflets oval with coarse double serratures hoary, sep. long simple equal, fruit ovate-urceolate.-E. B. S. 2707. - Smaller serratures of the 1 . irregular or wanting. Peduncles thickened upwards, setose.-Probably not a native. See Mack. Fl. Hibern. Sh. VI.]

[2. R. cinnamomea $(\mathrm{L}$.); shoots setigerous, prickles scattererl slender subulate, leaflets lanceolate-oblony simply serrate downy and glandulose beneath, sep. long simple, fr. ovate small. Borr.E. B. 2388.-Serratures of the leaves sometimes with an intermediate tooth. Peduncles not thickened upwards, without setæ. -Probably not a native. Sh. V.] E.? S. ?

\#t Bracts small or wanting.

3. R. rubella ( $\mathrm{Sm}$.$) ; st. anil branches densely setigerous$ throughout, prickles nearly equal few slender, leaflets simply serrate naked their disk without glands, fr. oblong or urceolate pendulous. $-E$. B. 2521 and (fruit) 2601.-Persistent sepals mostly spreading.-Fr. bright red.-South Shields? Abergeldy? Sh. V.

E.S.

4. R. spinosissima (L.); prickles many crowded very unequal mostly straight subulate intermixed with setæ, leaflets simply serrate their disk without glands, sep. half as long as the cor. acuminate entire, fr. nearly globular erect. $-E$. B. 187.-Fr. dark purple or black.- $\beta$. pilosa (Lindl.); "l. acute hairy on the under side."-Sandy and chalky heaths. $\beta$. Ireland. Sh. V.

5. $R$. hibernica $(\mathrm{Sm}$.$) ; prickles scattered unequal the larger$ slightly falcate, seta few, lts. simply serrate hairy beneath their

${ }^{1}$ In this genus I have availed myself of the observations of my valued friend Mr. Borrer in Hook.Br. Fl. ed. 3. -Seta. See note, p. 95. 
disk without glands, sep. shorter than the cor. pinnate slightly leaflike, fr. nearly globular.-E. B. 2196.-Fr. somewhat urceolate, blood-red. Fl. mostly solitary or 2 or 3 together. Lts. sometimes smooth.-Near Lorton, Cumb. Flotterton, Northumb. Near Belfast harbour. Sh. V.-VIII. E. I.

6. R. Wilsoni (Borr.); prickles many crowded very unequal straight, setæ few, leaflets simply serrate hairy on both sides their disk without glands, sep. shorter than the cor. slightly leaflike mostly simple, fr. ovate-urceolate.-E. B. S. 2723.-Fr. scarlet.-Banks of the Menai near Bangor. Sh. VI.

E.

T. R. involuta (Sm.); prickles crowded very unequal straight, setæ few, leaflets doubly serrate hairy and glandular beneath, sep. nearly as long as the cor. slightly leaflike mostly simple, fr. globose-urceolate setose.-E.B. 2068 and (fr.) 2601.-Fr. dark red. Dwarf.-Hebrides and western Highlands. Sh. VI.

8. R. Sabini (Woods); prickles scattered unequal straight or nearly so, setæ few, leaflets doubly serrate hairy glandular beneath, sep. nearly as long as the cor. somewhat pinnate slightly leaflike, fr. globose or slightly urceolate setose.-E.B.S.2594.Fr. dark red.- $\beta$. R. doniana (Woods); prickles more numerous, 1. very hairy, cal. almost simple. E. B.S.2601.- - . R. gracilis (Woods); larger prickles falcate, cal. almost simple. E.B.583 (fig. only).-Mostly in the north. Sh. VI.

** Shoots mostly without seta, leaves glandulose.

$\uparrow$ Prickles nearly uniform, setæ few or none.

9. R. villosa (L.); prickles uniform nearly straight, leaflets doubly serrate downy glandular, sep. slightly pinnate, rootshoots straight. - E. B. 2459.-Sep. persistent, usually connivent on the elliptical or nearly globose fruit.-Northern counties. Sh. VI. VII.

10. R. tomentosa (Sm.); prickles mostly uniform straight or curved, leaflets doubly serrate downy glandular, sep. copiously pinnate.-E. B. 990 and 1896.-Root-shoots straight or arched. Sep. persistent, usually spreading on the oblong or urceolate fruit. A very variable plant.-Hedges and thickets. Sh. VI. VII.

11. R. inodora (Fries); prickles uniform uncinate, leaflets doubly serrate hairy glandular beneath, sep. closely pinnate mostly deciduous, ramuli without setæ, fr. elliptical or nearly globular.-E. B. 2579.-L. sparingly glandular, sometimes with more numerous glands, and then the sep. are elongated and persistent. Sep. short with a short leaflike point and closely-set shortly-lanceolate often compound pinnæ.-Hedges and thickets. Sh. VI, VII. 
12. $R$. micrantha ( $\mathrm{Sm}$.$) ; prickles uniform uncinate, leaflets$ doubly serrate hairy glandular beneath, sep. and pinnce elongated deciduous, ramuli sparingiy setigerous, fr. small elliptical and ovate.-E. B. 2490.-Distinguished by the long leaflike point and narrow lanceolate simple pinnæ of its sepals combined with uniform prickles, small primordial fruit rounded at the base and deciduous sepals. Glands on under side of leaves many.Hedges and thickets in the south. Sh. VII. VIII. E. I.

†† Prickles various, intermixed with setæ.

13. $R$. rubiginosa (L.); prickles many the larger uncinate the smaller subulate, leaflets doubly serrate hairy glandulose beneath rounded at the base, sep. and pinna elongated persistent, primordial fruit pearshaped.-E. B. 991.-The various prickles, persistent calyx and pearshaped primordial fruit distinguish this from the preceding 2 with which it is very closely allied.-Bushy places. Sh. VI. VII. Sweet-Briar.

14. $R$. sepium (Thuil.); prickles many the larger curved the smaller subulate, leaflets doubly serrate hairy glandular beneath acute at the base, sep. and pinnæ elongated narrow, primordial fruit ovate rounded at the base.-E.B.S.2653.-Pinnæ of the calyx small, narrowly lanceolate, springing nearly at rightangles from the sepals which have a linear-lanceolate limb.Bridport, Warwickshire. Heyford, Oxfordshire. Sh. VI. E.

*** Shoots mostly without seta, leaves without glands.

† Styles distinct, included, or nearly so.

15. R. canina (L.); prickles uniform hooked, 1. naked or slightly hairy without glands the serratures simple or compound, sep. pinnate deciduous, styles distinct.-a. R. canina (Woods); leaflets naked keeled serratures simple. Leaflets narrowly elliptical, not rounded below, often with a twisted point, green or grey. E. B. 992.- $\beta$. R. sarmentacea (Woods); leaflets naked

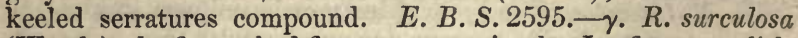
(Woods); leaflets naked flat serratures simple. Leaflets roundish or elliptical with irregular serratures. $-\delta$. $R$. dumetorum (Woods); leaflets hairy on both sides flat. Terminal leaflets often nearly cordate. E. B.S.2610.- $\epsilon$. R. Forsteri (Sm.); leaflets more or less hairy not flat. Leaflets concave or keeled, hairy on both sides or only beneath. E. B. S.2611.-See Borrer's detailed account of this species in Hook. Br. Fl.ed.3.-Hedges and thickets. Sh. VI. VII. Dog Rose.

16. $R$. bractescens (Woorls); "calyx-tube globose, prickles hooked, leaflets simply serrate downy beneath, bracteas overtopping the fruit." Woods.-Styles woolly. Fr.globose--Ulverston, Lancash.; Ambleside, Westm. Mr. Woods. Sh. E. 
17. R. casia (Sm.); prickles uniform uncinate, leaflets doubly serrate downy without glands, sep. distantly and sparingly pinnate, fr. elliptical smooth.-E. B. 2367.-Difficult to distinguish on paper from $R$. canina, but more resembling $R$. tomentosa in appearance.-In the north. Sh. VI.

†† Styles united in a column, mostly exserted.

18. R. systyla (Woods); prickles uniform uncinate, leaflets simply serrate without glands, sep. sparingly pinnate deciduous, central germens stalked, styles hairless surrounded by a convex disk, stigmas forming a conical head, shoots nearly erect.-E. B. 1895. - Serratures towards upper ends of the lts. usually converging. Germens in centre of calyx on stalks as long as themselves. Column of styles variable in length. L. nearly glabrous or hairy on both sides. The strongly arched shoots often rise to the height of 10-12 feet.-Hedges and thickets. Sh. VI. VII.

19. $R$. arvensis (Huds.); prickles uncinate those on the ramuli feeble, lts. simply serrate deciduous without glands, sep. sparingly pinnate deciduous, germens all sessile, styles hairless surrounded by a nearly flat disk, stigm. forming a round head, shoots trailing. - E. B. 188.-Hedges and thickets. Sh. VI. VII.

\section{Suborder III. Pomea.}

\section{Crategus Linn. Hawthorn.}

1. C. Oxyacantha (L.); spinose, l. obovate $3-4$-lobed cut and serrate cuneate at the base, fl. corymbose, cal. not glandular, styles 1-3.-E. B. (var. $\beta$. ?) 2504.-a. C. Oxyacantha (L., Jacq.); l. lobed bluntish, ped. and cal. usually glabrous, cal.lobes ovate-acuminate, styles $1-3$, fruit oval, nuts $1-3 .-\beta$. C. monogyna (Jacq.); l. deeply lobed usually acute, ped. and cal. villose, cal.-lobes lanceolate acuminate, style l. bent, fruit subglobose.-Hedges and thickets, $\beta$. the more common form. T. V. VI.

\section{Cotoneaster Lindl.}

1. C. vulgaris (Lindl.); l. roundish-ovate rounded at the base, flowerstalks and margins of the calyx downy. - E. B. S. 2713.Pet. rose-coloured. Fr. small, pendulous.-Cliffs at the Great Orme's Head, Caernarvonshire. Sh. V.

E.

\section{Mespilus Linn. Medlar.}

1. M. germanica (L.) ; l. lanceolate undivided downy beneath, fl. solitary.-E. B. 1523.-L. entire simply or doubly serrate. In the wild state it is spinous.-Hedges and thickets in Surrey, Sussex and Cheshire. T. V. VI. 


\section{Pyrus Linn.}

1. P. communis (L.) ; 1. simple ovate serrate, flowerstalks corymbose, fruit turbinate, styles distinct.-E.B.1784.-Germen woolly. Leaves sometimes obovate suddenly contracted into a long very acute point. Hedges and woods. T. IV. V. Wild Pear tree.

2. P. Malus (L.); l. ovate acute serrate, $f$. in a sessile umbel, fr. globose, styles combined below.-E. B. 179.-a. P. acerba (DC.) ; young branches calyx-tube and under side of the l. glabrous. - $\beta$. tomentosa (Koch); the same parts pubescent or woolly. -Woods and hedges. T. V. Crab tree.

[3. $P$. domestica (Sm.) ; 1. pinnate downy beneath serrate, fl. panicled, fr. obovate.-E. B. 350.-Fr. resembling a small pear.-One tree in Wyre Forest. T. V. Service tree.] E.

4. P. aucuparia (Gaert.); 1. pinnate downy beneath serrate, fl. corymbose, fr. (small red) globose.-E. B. 337.- Hilly woods and on mountains. T. V. VI. Rowan tree. Mountain Ash.

5. P. fennica (Bab.); $l$. oblong doubly serrate near the apex pinnatifid below, pinna lanceolate oblong serrate, under side white and downy, fl. corymbose.-E.B.2331? P. pinnatifida Sm., Sorbus fennica Kalm, Fries.-Fr. scarlet. Lower part of the l. often truly pinnate, the lobes becoming more and more combined as they approach the extremity of the leaf which is only deeply and doubly serrate.-Mountains in the northern part of the Isle of Arran. T. V.

6. P. Aria (Sm.); l. oval or oblong unequally and doubly serrate or slightly lobed towards the end nearly entire below, lateral veins about 12 on each side, under side white and downy, fl. corymbose.-E. B. 1858. - Fr. scarlet.-Hilly and mountain woods. T. V. White Beam tree.

7. P. scandica (Bab.); 1. broad lobed, lobes triangular-oval toothed deepest towards the middle of each side of the l., lateral veins about 7 on each side, under side white, $f$. corymbose.Sorbus scandica Fries. - "Fr. red." Basal $\frac{1}{4}$ of 1 . finely serrate, apical $\frac{1}{4}$ narrowly lobed. The continental distribution shows that neither this nor P. fennica can be bybrids.-Hilly woods. T. V.

8. P.torminalis $(\mathrm{Sm}$.$) ; l$. ovate or cordate lobed glabrous, lobes triangular acute serrate the lower ones larger and spreading, fl. corymbose.-E. B. 298.-Fr. oval, brown.-Woods and hedges chiefly in the south. T.IV. V. Wild Service tree. E. 


\section{Order XXVII. LYTHRACEÆ.}

Cal. tubular, lobed, lobes valvate or distant in æstivation, sometimes with intermediate teeth. Pet. between the lobes of the calyx, very deciduous. Stam. inserted in the tube of the cal. below the pet. and equalling them or 2,3 or 4 times as many. Ovary free, 2-4-celled. Caps. membranaceous, usually (by abortion) l-celled, with many seeds and a central placenta, covered by the calyx. Embryo straight.

1. Lythrum. Cal. tubular, cylindrical, with 8-12 teeth; 4-6 broader, erect; alternate teeth subulate. Pet. 4-6. Stam. as many as, or twice the number of the petals. Style filiform. Caps. 2-celled, many-seeded.

2. Peplis. Cal. campanulate with 12 teeth, of which 6 are broader and erect, 6 subulate. Pet. 6, minute, fugacious. Stam. 6. Style very short. Caps. 2-celled, many-seeded.

\section{Lythrum Linn. Loosestrife.}

1. L. Salicaria (L.) ; l. lanceolate from a cordate base opposite or whorled, fl. in whorled leafy spikes, bracts 0 , subulate calyxteeth twice as long as the others, stam. 12.-E. B. 1061.--Upper l. usually falling short of the flowers; or so large as totally to destroy the spiked appearance of the plant. St. $2-4$ feet high and 1. nearly glabrous, or downy with crisped hairs. Fl. large, purple or crimson.-Ditch-banks and damp places. P. VII. VIII. Purple Loosestrife.

2. L. Hyssopifolia (L.); l. alternate linear-lanceolate blunt, fl. axillary solitary, bracts 2 minute subulate, calyx-teeth all short, stam. 6.-E. B. 292.- - St. mostly procumbent, spreading, simple or branched. Fl. small, light purple. Glabrous.-Damp places where water has stagnated, rare. A. VI.-X. E. I.

\section{Peplis Linn. Water Purslane.}

1. P. Portula (L.); l. opposite obovate stalked, fl. axillary solitary sessile.-E. B. 1211. St. 1. 7.-Pet. often wanting. Cal.tube short, vase-shaped, shorter than the eapsule. St. 4-6 in. long, prostrate, creeping. Damp places. A. VII. VIII.

\section{Order XXVIII. TAMARISCACEÆ.}

Cal. 4-5-parted, persistent, æstivation imbricate. Pet. 4-5, withering, from the base of the calyx. Stam. equal to or twice as many as the pet., from the margin of a scutelliform disk. 
Caps. 1-celled, 3-valved, many-seeded, loculicidal. Placentas often only at the base. Seeds ascending, comose.

1. Tamarix. Styles 3, patent. Seeds affixed at the base of the capsule; coma or down of simple papilliform hairs at the apex.

\section{TAMarix Linn. Tamarisk.}

†1. T. anglica (Webb); l. glabrous rather narrowed at the base spurred, fl.-buds ovoid, hypogynous ring 5 -angled narrowed into the filaments of the cordate shortly apiculate anthers whose cells diverge below, caps. roundish-trigonous at the base abruptly narrowed towards the apex.-T. gallica Sm., E. B. 1318.-St. shrubby, with slender leafy branches. L. minute, with a loose spur at the base. Spikes lateral, rather panicled, slender. Fl. small, pink.-South-west coast of England. S. VII.

\section{Order XXIX. ONAGRACEA.}

Cal. tubular, adnate to the ovary wholly or in part, with $2-4$ lobes valvate in rstivation. Pet. as many as the calyx-lobes, twisted in æstivation, inserted at the top of the tube. Stam. 2, 4 or 8 , inserted with the petals. Ovary of several cells, with a central placenta. Style 1, filiform, stigma capitate or lobed. Fr. a berry or capsule with 4 cells. Albumen 0.-L. alternate or opposite, not dotted.

1. Epilobium. Cal. 4-cleft, deciduous. Pet. 4. Stam.8. Style filiform with a clavate or cruciform stigma. Caps. linear, 4-celled, 4-valved. Seeds many, bearded.

2. CEnothera. Cal.-limb tubular below. Seeds not bearded. In other respects like Epilobium.

3. Isnardia. Limb of the cal. 4-cleft, persistent. Pet. 4 or 0. Stam.4. Style filiform, deciduous, stigma capitate. Caps. obovate, 4-valved, 4-celled, many-seeded, with a loculicidal dehiscence.

4. Circasa. Limb of the cal. 2-cleft, deciduous, its tube closed by a cup-shaped disk. Pet. 2, obcordate. Stam.2, alternate with the petals. Style simple; stigma emarginate. Caps. 1- or 2-celled, cells 1-seeded, seeds erect.

1. Epilobium Linn. Willow Herbs.

A. Fl. irregular, cal. without a free tube, stam. and style ultimately declining, l. scattered.

1. E. angustifolium (L.); st. erect round, 1. lanceolate veined, 
pet. obovate shortly clawed, style exceeding the stamens.-Creeping extensively. St. 3-6 ft. high. Fl. crimson. - a. $E$. macrocarpum (Steph.) ; 1. lanceolate, fl.-buds obovate cuspidate, caps. long ( $2 \frac{1}{2}$ in.) erect. E. B. 1947.- $\beta$. E. brachycarpum (Leight.); l. lanceolate-attenuate (broadest near their base), fl.-buds narrowly obovate obliquely acute, caps. short (1 in.) spreading. $A$. N. H. viii. 246 and 401.-Damp shady places. P. VII. Rose-bay.

2. E. rosmarinifolium (Haenke); st. erect round, l. linear not veined, pet. elliptic-oblong not clawed, style equalling the stamens. -E. Dodonci, St. 72. 5.-Creeping moderately. St. dwarf, often prostrate. L. shortly attenuate at both ends. Fl. rosecoloured or white.-Stony places on mountains. Glen Tilt. P. VIII. S.

B. Fl. regular, cal. with a free tube, stam. and style erect, 1. opposite, upper l. lanceolate.

* Turionate; i. e. producing radical suckers.

3. E. hirsutum (L.); st. round woolly glandular, $l$. clasping slightly decurrent oblong-lanceolate denticulate-serrate, buds erect mucronate, sep. lanceolate, seeds tubercular oblong acute below.-E. B. 838.- Suckers thick, fleshy, with distant scales; others leafy and ending in rosettes. St. 4-5 ft. high, branched. L. most hairy upon the ribs. Fl. large.-Wet places by ditches and streams. P. VII. VIII. Great Willow Herb.

\section{** Stoles autumnal rosulate, st. erect.}

$\dagger$ Stem mostly round, stigmas 4-cleft.

4. E. parviflorum (Schreb.); st. round downy, l. sessile lanceolate from a rounded base denticulate, lowest 1 . shortly stalked, buds erect ovoid, sep. lanceolate, seeds tubercular obovate-oblong rounded below.-E. B. 795.-Autumnal rosettes on short stalks or sessile. St. $1-2 \mathrm{ft}$. high, nearly simple. L. uniformly hairy. Fl. small.-E. rivulare (Wahl.) is a subglabrous state.-Damp places. P. VII. VIII.

5. E. montanum (L.); st. round downy, 1. shortly stalked ovate-lanceolate from a rounded base denticulate, buds nodding ovoid, sep. lanceolate, seeds tubercular oblong blunt at both ends.-E. B. 1177. St. 72. 7.-Root truncate. Rosettes fleshy, oblong, sessile. St. 6-24 in. high. Margins and veins of l. pubescent. L. sometimes in threes.-Dry places. P. VI. VII.

6. E. lanceolatum (S. and M.); st. slightly angular downy, $l$. stalked lanceolate denticulate-serrate narrowed to an entire base, buds nodding ovoid, sep. linear-parabolic, "seeds tubercular 
obovate-oblong subacute below."-E. B. S. 2935.-Root not truncate. Rosettes loose, sessile. St. $1-2 \mathrm{ft}$. high, obscurely or very bluntly angled especially below. L. flaccid, mostly pendulous.-South of England, rare. P. VII.-IX.

H Stem with raised lines, stigma entire.

7. E. roseum (Schreb.); rosettes loose, l. stalked ovate narrowed and acute at both ends serrulate, buds nodding ovoid acuminate, sep. lanceolate acuminate, seeds obovate-oblong narrowed to a rounded base.-E. B. 693.-St. $1-2 \mathrm{ft}$. high, branching, with two sharp and two blunt angles. Petioles long. -Damp places. P. VII. VIII.

8. E. tetragonum (L.); rosettes dense subsessile, l. strapshaped much denticulate-serrate, limb of intern. 1. decurrent, buds erect, seeds oblong-obovate tubercular.-Curt. Lond. i. 66. -St. 1-2 ft. high, with 2-4 raised lines, usually much branched. -Damp places. P. VII. VIII.

*** Stoles astival long-jointed with small leaves, primary stem erect, stigma usually entire.

9. E. obscurum (Schreb.); l. tapering from a rounded base sessile remotely denticulate, lower 1 . oblong blunt, buds erect, seeds oblong-obovate.-E. virgatum Bab. See $A$. N. H. Ser. 2 . xvii. 236 for an account of this plant and its allies.-Resembling E. tetragonum but the caps.much shorter.-Wet places. P.VII. VIII.

**** Stoles astival long-jointed with very small leaves ending in autumnal bulbs which become.detached, base of stem cordlike.

10. E. palustre (L.); stoles long, st. rooting near the base, l. narrowly lanceolate from a wedgeshaped base sessile not decurrent, buds nodding, sep. lanceolate, seeds subfusiform attenuate and acute below and the testa prolonged above smooth. $-E$. B. 346 ? - Stoles very slender, st. round, often with two rows of down, 6-18 in. high. L. entire or denticulate.-Bogs. P. VII. VIII.

***** Stoles or barren stems astival leafy rosulate.

11. E. alpinum (L.); barren stems short their upper $l$. closely placed, fl.-st. erect from a short rooting base, l. oval or oblong blunt narrowed below not acuminate, upper 1. lanceolate, buds nodding, sep. linear-lanceolate acute, seeds lanceolate-obovate pointed below apiculate. $-E$. B. 2001.-St. filiform, simple, with two raised lines, $3-4$ in. long. L. pale green. Fl. pale.Higher mountains. P. VII. 
****** Stoles or barren stems astival leafy not rosulate.

12. E. anagallidifolium (Lam.); joints of barren stems all long with sinall obovate leaves, fl.-st. erect from a long rooting base, l. oblong blunt narrowed below not acuminate, upper 1 . lanceolate, buds nodding, sepals oblong blunt, seeds obovate pointed below apiculate.-See $A$. N. H. Ser. 2. xvii.-St. filiform, mostly simple, with two raised lines, $3-4$ in. long. L. pale green. Fl. pale reddish.-Higher mountains. P. VII. S.

******** Stoles astival scale-bearing not rosulate.

13. E. alsinifolium (Vill.); stoles (yellowish) with small roundish distant scales, st. erect from a long rooting base, $l$. ovateacuminate repand-dentate shortly stalked, buds nodding, sep. linear-oblong, seeds subfusiform.-Florig. Brit.f. 626.-St. mostly simple, rather thick, with 2 raised lines, $3-12$ in. long. L. shining, subpellucid. Fl. large, purplish. Caps. upright, long, long-stalked.-Higher mountains. P. VII.

E. S.

2. CEnothera Linn. Evening Primrose.

*1. E. biennis (L.) ; l. ovate-lanceolate flat toothed, st. rough rather hairy, pet. longer than the stamens.-E. B. 1534. St. 5.5. -Fl. large, many, bright yellow. Caps. short, hairy. St. $2-3$ feet high, leafy. - Sandy coast of Lancashire. Often an outcast from gardens. B. VII.-IX.

E. -

\section{Isnardia Linn.}

1. I. palustris (L.) ; st. procumbent rooting glabrous, 1. opposite ovate acute narrowed into a petiole, fl. axillary solitary sessile without petals.-E. B. S. 2593 . St. 22. 3.-St. 6-8 in. long, round, branching, often reddish. Fl. with 2 small bracts at the base. Caps. ovate, obtusely quadrangular, with the persistent calyx spreading horizontally.-Pools and marshes. Buxted, Suss. Petersfield and Brokenhurst, Hants. Jersey. A. VI. E.

\section{Circaea Linn.}

1. C. lutetiana (L.); $l$. ovate or slightly cordate below repanddenticulate opaque, petioles subterete, bracteoles 0 , pet. deeply emarginate, lobes broadly obovate, cal. hairy, ovary 2-celled, fr. broadly obovate.-E. B. 1056. St. 23. 1.-Pet. as long as the herbaceous sepals, broad below. Fr. persistent.-Woods and hedge-banks. P. VI.-VIII. Enchanter's Nightshade.

2. C. alpina (L.); l. cordate acuminate repand-dentate shining, petioles flat with membranous wings, bracteoles setaceous, pet. bifid, lobes oblong, cal. glabrous, ovary 1-celled.-E.B. 1057. 
St. 23: 2.-Usually glabrous. Pet. shorter than the membranous sepals, narrow below. Fr. soon falling. Bracteoles deciduous.-B. C. intermedia (Ehrh.); fl. larger, sep. less membranous equalling the petals. Whole plant much larger.-Woods and thickets in mountainous districts. P. VII. VIII.

\section{Order XXX. HALORAGACEÆ.}

Cal. adnate with the ovary, limb minute. Pet. minute, from the throat of the calyx. Stam. 1-8, inserted with the petals. Ovary of 1 or more cells. Styles equal in number to the cells. Fruit dry, not bursting, usually crowned with the rim of the calyx. Seed pendulous, with a small quantity of albumen.

1. Myriophyllum. Monœcious. Cal. 4-parted. Pet. 4, fugitive, longer than the calyx in the male, small and reflexed or 0 in the female. Stam. 8. Styles 4, villose. Fr. tetragonal, separable irito 4 hard nuts.-G. F. G. Monochl. 3.

2. Hippuris. Calyx-limb very minute, obsoletely 2-lobed. Pet. 0. Stam. 1. Style filiform Stigma simple, acute. Fruit a 1-celled nut.-G. F. G. Monochl. 2.

\section{Myriophyllum Linn. Water Milfoil.}

1. M. verticillatum (L.); fl. all axillary whorled, bracts pinnatifid.-E. B. 218.-L. whorled, pinnatifidly divided into setaceous segments. Bracts more or less longer than the flowers, pinnatifid or (M. pectinatum DC.) pectinate.-Ponds and ditches, rare. P. VII. VIII.

2. M. spicatum (L.); fl. whorled forming a leafless spike, bracts small entire, spike erect when in bud.-E. B. 83.-L. 4 in a whorl, submersed, lower bracts often pectinate.-Ponds and ditches. P. VI. VII.

3. M. alterniflorum (DC.); sterile fl. alternate about 6 forming a leafless spike, spike nodding when in bud afterwards erect, fertile $f$. about 3 together in axillary whorls at the base of the spike.-E. B. S. 2854.-L. 3 or 4 in a whorl, submersed.Ponds and ditches. P. V.-VIII.

\section{Hippuris Linn. Mare's Tail.}

1. H. vulgaris (L.); 1 linear $6-12$ in a whorl with a callous point. - E. B. 763. St. 44. 1.-St. simple, or sometimes branching at the base, erect. Fl. in the axil of each of the upper leaves, often without stamens. In deep water the submersed leaves are elongated flaccid pellucid and not callous at the end.-In stagnant water and slow streams. P. VI. VII. 


\section{Order XXXI. CUCURBITACEE.}

Cal. 5-toothed, tube adnate with the ovary. Cor. 5-cleft, often scarcely distinguishable from the calyx, reticulated with veins. Stam. 5, more or less cohering. Anth. sinuose. Ovary 3-5-celled or spuriously l-celled; placentas parietal. Style short. Stigmas lobed. Fr. more or less succulent. Seeds flat, in an arillus; embryo flat; albumen 0.-Plants succulent, climbing with extra-axillary tendrils. Often monœcious or diœcious.

1. Bryonia. Cal. 5-toothed. Cor. 5-cleft. Male: Stam. 5, in 3 bundles. Fem : Style 3-fid. Fruit a globose few-seeded berry. Seeds oval, compressed, more or less bordered.

\section{Bryonia Linn. Red Bryony.}

1. B. dioica (L.); 1. palmate 5-lobed dentate rough on both sides with callous points, fl. diœcious, cal. of the fertile $\mathrm{fl}$. half as long as the corolla.-E.B.439.- St. climbing. Tendrils simple. Fr. red. $-[B$. alba (L.) has the fertile cal. as long as the ecr. and black fruit. It is said to be monœcious.]-Hedges and thickets. P. V.-IX.

E.

\section{Order XXXII. PORTULACEÆ.}

Sep. 2 , rarely 3 or 5 , cohering at the base ; æstivation imbricate. Pet. usually 5 , from the base of the calyx. Stam. indefinite, inserted with the petals, often opposite to the petals ; filaments distinct. Ovary l-celled. Style 0. Stigmas several. Caps. opening transversely or by 3 valves; placenta central. Embryo curved round the albumen.

1. Montia. Cal. of 2 sepals, persistent. Cor. 5-parted, with 3 segments smaller than the others, tube split to the base in front. Stam. 3, inserted in the throat and opposite to the smaller segments of the corolla. Ovary turbinate. Style very short. Stigmas 3. Caps. 3-valved, 3-seeded.

\section{Montia Linn.}

1. M. fontana (L.).-E. B. 1206. St. 11.1.-L. opposite, spathulate, entire. Valves of the caps. rolled longitudinally inwards after the seeds have fallen.- - . M. minor $(\mathrm{Gm}$.); st. short ascending rigid, ped. axillary and terminal, seeds reticulate-scabrous.B. M. rivularis $(\mathrm{Gm}$.) ; st. flaccid ascending, ped. axillary, seeds reticulate.-Watery places. $\beta$. in water. A. IV.-VIII. 


\section{Order XXXIII. PARONYCHIACEAE.}

Cal. 5 -parted, rarely 4 or 3 , æstivation imbricate. Pet. minute and resembling abortive stam. or 0 . Stam. indefinite, opposite the sep. (when the same number), somewhat hypogynous. Ovary free. Styles 2 or 3. Fr. dry, 3-valved or indehiscent; placenta central. Embryo more or less curved. Albumen farinaceous.-Perhaps the whole Order should be joined to Caryophyllacea.

* With stipules, sep. slightly connected.

Tribe I. PARONYCHIEAE. Caps. 1-seeded. Pet. 0, or small and subulate.

1. Corrigiola. Sep. 5. Pet.5, oblong, equalling the sepals. Stam. 5. Stigmas 3, sessile. Fr. 1-seeded, indehiscent. Seed suspended by its seed-stalk which arises from the base of the capsule.-L. alternate.

2. Herniaria. Sep. 5. Pet. 5, filiform, inserted with the 5 stam. on a perigynous ring. Stigmas 2, nearly sessile. Fr. 1-seeded, indehiscent, membranous.-L. opposite.

3. Illecebrum. Sep. 5, thickened, horned at the back. Pet. 0 or 5 , subulate, inserted with the 5 stain. on a perigynous ring. Stigmas 2. Fr. 1-seeded, furrowed, bursting along the 5 furrows.

Tribe II. SPERGULEAE. Caps. 1-celled, 3-5-valved, manyseeded.

4. Polycarpon. Sep. keeled on the back, hooded at the end. Pet. 5, emarginate. Stam. 3-5. Styles 3, short. Fr. 1-celled, 3-valved, many-seeded.

5. Lepigonum. Sep. 5, flattish. Pet. 5, entire, as long as the calyx. Stam. 5-10. Styles 3 or 5. Fr. 3-5-valved, many-seeded; valves fewer than or alternate with the sepals.

6. Spergula. Sep. 5. Pet. 5, entire, as long as the calyx. Stam. 5-10. Styles 5. Fr. 5-valved, many-seeded; valves opposite the sepals.

** Without stipules, sep. tubular below.

Tribe III. SCLERANTHEAE. Caps. 1-seeded, inclosed in the hardened cal.-tube.

7. Sclerantuus. Tube of the cal. urceolate, contracted at the mouth by a glandular ring; limb 5-fid. Pet. 0. Stam. 10 rarely 5 , inserted in the throat of the calyx. Styles 2. Fr. membranous.-G. F. G. Monochl. 77. 


\section{Tribe I. Paronychiea.}

\section{Corrigtola Linn.}

1. C. littoralis (L.); st. leafy amongst the flowers. $-E$. B. 668. - Fl. stalked, white, small, in small clusters. Stem-l. oblong, narrow below. St. many from the crown of the root, prostrate, slender.-Sandy shores. Slapton Sands and near the Start Point, Devon. Helston, Cornwall. A. VII. VIII. E.

\section{Herniaria Linn.}

1. H. glabra (L.); st. herbaceous prostrate clothed with minute decurved hairs, 1 . oval-oblong, clusters of sessile fl. axillary coalescing on the lateral branches into a slightly leafy spike.E. B. 206.-Pale yellowish-green. St. procumbent or subterranean, rooting extensively; autumnal shoots ascending, irregularly branched with spreading not imbricate leaves. Lateral branches resembling leafy spikes from the dense aggregation of the clusters. Cal. glabrous or with a very few hairs. L. glabrous. - $\beta$. subciliata (Bab.); 1. more or less ciliated.-Rare. Suffolk. Ruan Minor, Cornwall. Wilsford, Lincoln. Six-mile Bottom, Camb. Finchley Common. West of Kerry. P. VII. E. I.

2. H. ciliata (Bab.); st. herbaceous prostrate clothed with minute decurved hairs, 1. orbicular-ovate ciliated, clusters of sessile fl. axillary upon the lateral branches and distinct. -E.B.S. 2857. -Dark green. Root strong, woody. St. spreading extensively from the crown of the root but scarcely rooting until the autumn when they are prostrate and regularly alternately branched and the leaves are imbricated in two rows. Clusters $1-3$ together in small distinct bunches. Sep. tipped with a strong bristle. Very different in habit from H. glabra.-Very rare. Lizard Point, Cornwall. Guernsey. P. VII. VIII. E.

[3. H. hirsuta (L.); st. herbaceous prostrate clothed with straight spreading hairs, l. oval-oblong, clusters of sessile fl. axillary distinct.-E. B. 1379. - Cal. hairy, resembling a minute bur. -A very doubtful native. The Finchley Common plant was H. glabra. P. VII.]

\section{Illecebrum Linn.}

1. I. verticillatum (L.).-E. B. 895.-St. procumbent, filiform, glabrous. Fl. whorled, axillary, minute, white. L. roundish, variable in size, shorter or longer than the flowers.-Boggy ground in Devon and Cornwall. P. VII. 


\section{Tribe II. Spergulea.}

\section{Polycarpon Linn.}

1. P. tetraphyllum (L.); triandrous, pet. emarginate, stem-l. in fours, l. on the branches opposite.-E. B. 1031.-In young plants the 1. are often all opposite.-Coasts of the south-west of England. A. VI. VII.

L.

\section{Lepigonum $W a h l b$.}

1. L. rubrum (Wahlb.); st. round, l. flat linear pointed, caps. about equalling cal.rather shorter than slightly declining $f r$.-stalks, seeds triangular obovate with a thickened rough border.-St. procumbent. Short ped. and cal. glandular hairy. L. bristle-pointed. Sep. obtuse, obscurely 3-veined.-a. Aren. rubra (L.); seeds all wingless, l. flat on both sides. Arenaria Sm. E. B. 852.- $\beta$. A. media (L. ?); seeds mostly wingless a few winged, l. Heshy flat above.-Sandy fields. $\beta$. Near the sea. A. VI.-IX.

2. L. marinum (Wahlb.); st. compressed, l. fleshy blunt apiculate, caps. exceeding cal. much shorter than declining fr.-stalks, seeds roundish usually surrounded by membranous striated wing. - Root almost woody. St. glabrous or glandular hairy. L. sometimes pointed. Sep. obtuse, obscurely 3-veined.-a. Aren. marina (Sm.); seeds nearly all winged, caps. large exceeding cal. by $\frac{1}{3}$. E. B. 958.- $\beta$. salinum; seeds nearly all wingless, caps. small slightly exceeding calyx.-Sea-coast. P. VI.-VIII.

\section{Spergula Linn. Spurrey.}

1. S. arvensis (L.); l. linear convex above furrowed beneath, $\mathrm{fl}$. in forked panicles, fr.-stalks deflexed, seeds slightly compressed with a narrow margin tubercled or papillose.-St. 6-12 in. high. L. long, slender. Seeds black.-a. S. arvensis (R.); seeds covered with minute elevated points. E.B. 1535.- $\beta$. S. vulgaris (Boeningh.); seeds covered with white or brown club-shaped papillæ.-Cultivated land. A. VI.-VIII.

[2. S. pentandra (L.); 1. linear subterete convex beneath, $\mathrm{fl}$. panicled, seeds smooth with a broad membranous margin.E. B. 1536?-I have seen no specimens.-Ireland. Sherard. A. VIII. ?]

\section{Tribe III. Scleranthea.}

\section{Sclerantuus Linn.}

I. S. annuus (L.); subdecandrous, segments of the calyx of the fr. patent acute with a very narrow membranous margin, as 
long as their tube.-E. B. 351.-Styles longer than the stamens. St. repeatedly dichotomous, green. Fl. green, often solitary in the forks of the stem, or densely corymbose.-Sandy fields. A. VI.-VIII.

2. S. perennis (L.); decandrous, segments of the calyx of the fr. connivent obtuse rounded with a broad membranous margin. -E. B. 352. - Styles usually shorter than the stamens. St. nearly simple or irregularly branched, procumbent, glaucous, at length reddish. Fl. variegated with green and white. L. erect, directed to one side.-Sardy fields in Norfolk and Suffolk. Stanner rocks, Radnorshire. P. VI.-VIII.

E.

\section{Order XXXIV. CRASSULACEA.}

Sep. 3-20, more or less united at the base. Pet. the same number, regular, free or slightly connected, inserted at the base of the calyx. Stam. inserted with the pet. and the same or twice their number. Hypogynous scale $\mathbf{l}$ at the base of each carpel or obsolete. Carpels the same number as and opposite to the pet., free or slightly connected, l-celled. Fr. of several follicles opening on their face, with slightly albuminous seeds on the inner suture.

1. TilleaA. Sep., pet., and stam. 3-4. Carp. 3-4, constricted in the middle and 2-seeded. Hypogynous scales 0.

2. Sedum. Sep. and pet. 5, rarely 4 or 6 . Stam. 10 or 12 . Hypogynous scales entire. Carp. 5 or 6 , many-seeded.$S$. Rhodiola has 4 sep., 4 pet., 8 stam., 4 carp., and is subdiœcious.

[3. Sempervivum. Sep. 6-10. Pet. the same. Stam. twice as many as the pet. Hypogynous scales laciniated. Carp. as many as the petals.]

4. Cotyledon. Sep. 5. Pet. cohering into a tubular 5-cleft corolla. Stam. 10, inserted on the corolla. Hypogynous scales 3. Carp. 5.

\section{Tillea Linn.}

1. T. muscosa (L.); st. branched and decumbent at the base, fl. axillary sessile trifid.-E. B. $116 . \quad R . I$. t. 191.-Very minute, about $l$ in. long, reddish. L. opposite, oblong, obtuse, concave above, connate. Sep. ovate or lanceolate, acute, bristlepointed. Pet. nearly subulate, white tipped with red.-On barren sandy heaths. A. VI. VII.

E. 


\section{Sedum Linn. Stonecrop.}

* Root thick, many-headed. Leaves flat.

† Flowers yellow, subdiœcious, 4-parted. RHodiola Linn.

1. S. Rhodiola (DC.); root fleshy, l. oblong smooth.-E. B. 508. Rhodiola rosea Sm.-Fl. in a compact terminal cyme. Stam. 8. L. acuminate, usually dentate in their upper half. Root (rhizome) large, having a remarkable smell. St. 6-8 in. high, simple.-Wet alpine rocks. P. VI. VII. Rose-root.

+† Flowers white or purple, perfect, 5 -parted.

2. S.Telephium(L.); uppermost l.oval-oblong dentate rounded at the base and sessile, lower $l$. obovate or oblong narrowed below, corymb dense, ovaries flattened and slightly furrowed on the brck. -E. B. 1319. R. I. 968. S. purpurascens Koch. -St. 1-2 feet high. L. large and broad. Pet. recurved from the middle, faintly channeled at the end. Stam.10. [In S. maximum Sut., R. I. 969. St. 83. 7, the lower 1 are broad, the uppermost cordate at the base, the back of the ovaries convex.] -Hedge-banks and thickets. P. VII. VIII. Orpine. Live-long.

3. S. purpureum (Tausch); 1. dentate oblong-lanceolate or lanceolate all attenuated below, corymb dense, ovaries not furrowed-S. Fabaria Koch, St. 83.9.-Resembling S. Telephium. Pet. spreading. Stam. 10.-Hedges and thickets. P. VIII. Orpine. Live-long.

** Root small, weak, without any rootiny shoots. L. subterete.

4. S. villosum (L.); st. erect, 1. linear hlunt flat above not produced at the base, pet. ovate acute, 1 . st. and panicle glandular-pubescent.-E. B.394. St. 6. 12.-Pet. rose-coloured with a purple streak. St. 3-4 in. high producing short barren shoots below.-Wet mountain pastures. B. VI. VII. $\quad$ E. S.

*** Root small, producing rooting shoots. Leaves subterete.

$\dagger$ Flowers white.

5. S. album (L.); flowering st. erect, barren st. procumbent rooting, l. oblong subcylindrical flattened above blunt spreading, pet. lanceolate, panicle much branched glabrous. - E. B. 1578.Pet. white. St. $4-5$ in. high, purplish, leafy - [ $\beta$. S. micranthum (DC.); l. oblong-obovate flattened on hoth sides obtuse.] - Rocks and walls, not common. [ $\beta$. In and near Arundel.] P. VII. VIII.

6. S. dasyphyllum (L.); flowering and barren st. procumbent, l. ovoid blunt fleshy gibbous, pet. and sep. ovate obtuse, panicle 
small glandular-pubescent.-E. B. 656.-Pet. white. Sep., pet., and carp. often in sixes. L. very short and thick, glaucous, often tinged with red, opposite on the barren shoots. Flowering st. 3-4 in. long.-Rocks and walls, rare. P. VI. VII.

7. S. anglicum (Huds.); st. procumbent at the base ascending, l. ovoid fleshy gibbous spurred at the base, pet. lanceolate acute, sep. ovate bluntish, cyme bifid smooth.-E. B. 171.-Pet. white spotted with red. L. mostly alternate. Flowering st. 3-6 in. long.-Sandy and rocky places. A. VII. VIII.

\section{i† Flowers yellow.}

8. S. acre (L.); l. ovoid thick tumid spurred at the base, pet. lanceolate acute, sep. ovate obtuse gibbous at the base, cyme trifid smooth.-E. B. 839.-L. closely imbricated on the barren shoots, very acrid.-Walls and dry places. P. VI. VII. Wall Pepper.

[9. S. sexangulare (L.); l. linear obtuse terete spurred at the base, pet. lanceolate acute, sep. lanceolate acute not gibbous, cyme trifid smooth. - E. B. 1946.-I have seen no British specimens.-Old walls : a doubtful native. P. VII.]

E.

10. S. reflexum (L.); $l$. subulate scattered spurred at the base convex on both sides the lowermost recurved, $\mathrm{fl}$. cymose, sep. ovate rather acute, pet. lanceolate obtuse.-E. B. 695.-Barren st.long. L. many, patent or reflexed. Cyme nearly level-topped, its outer branches spreading or recurved.- $\beta$. S. glaucum (Sm.) ; l. more slender glaucous not recurved. E. B. 2477.-Walls and rocks, common. $\beta$. Dry hills, rare. P. VII. VIII.

11. S. rupestre (L. ?); l. linear-lanceolate spurred at the base flattened, fl. imperfectly cymose, sep. elliptical, pet. lanceolate.E. B. 170. S. elegans Lej., Koch.-Barren st. short with densely imbricated adpressed glaucous leaves. $\mathrm{Fl}$. corymbose rather than cymose.-On limestone rocks. Bristol. Cheddar. Orme's Head, \&c. P. VI. VII.

12. S. Forsterianum (Sm.); 1. lanceolate spurred at the base flattened, cyme round-topped compact, sep. elliptical, pet. lanceolate.- $\dot{E}$. B. 1802.-Barren st. short, erect, densely leafy. L. forming small roselike tufts, bright green. Fl. truly cymose. Very different from the last in appearance.-Rocks in Wales, Shropshire and West Somerset. P. VI. VII.

\section{Sempervivum Linn. Houseleek.}

[1. S. tectorum (L.) ; 1. glabrous ciliated, pet. 12 or more entire at the margins, hypogynous scales short convex resembling glands.-E. B. 1320.-L. succulent, forming large roselike tufts. -Walls and roofs (planted). P. VII.] 


\section{Cotyledon Linn. Navelwort.}

1. C. Umbilicus (L.) ; lower 1. peltate concave, bracts entire, fl. pendulous. - E. B. 325.-Raceme usually simple. St. $6-12$ in. high, leaves mostly collected at its base. Fl. greenish-yellow.Rocks and walls in the west. P. VI.-VIII.

[C. lutea (Huds.); bracts toothed, fl. erect.-E. B. 1522.-F]. bright yellow.-Not a native. P. VII.]

\section{Order XXXV、 GROSSULARIACEÆ.}

Cal. superior, 4-5-cleft, regular. Pet. 4-5, small, inserted at the mouth of the tube and alternating with the stamens. Ovary 1-celled, with 2 opposite parietal placentas. Style 2-4-cleft. Berry many-seeded; cell filled with pulp. Albumen horny.

1. Ribes. Cal. 5-cleft. Berry many-seeded, crowned with the persistent calyx.

\section{RiвES Linn.}

* Peduncles 1-3-flowered. Stems spinous. Gooseberry.

†1. R. Grossularia (L.); ped. with 2 minute bracts, cal. bellshaped, sep. reflexed oblong, pet. ovate. $-E$. B. 1292 and 2057. - Thorns $1-3$ at the base of the young branches. Germen and fruit smooth or pubescent or glandular. L. rounded 3-5-lobed and cut, glabrous or hairy.-Hedges and thickets, doubtfully native. Sh. IV. V.

\section{** Flowers racemose. Spines none. Currants.}

2. R. alpinum (L.) ; diøcious, racemes upright both in flower and fruit glandular-pilose, bracts longer than the pedicels lanceolate, cal. glabrous, 1. shining beneath.-E. B. 704. St. 51.6.Male raceme dense, of many flowers; fem. of $2-5 \mathrm{fl}$. Limb of the calyx nearly flat. Berries scarlet. L. with 3 acute deeply serrate lobes.-Woods. North of E., rare. Sh.IV. V. E.S.

3. $R$. nigrum (L.); racemes pendulous downy with a separate simple pedicel at the base of each, bracts subulate shorter than the pedicels, cal. pubescent, l. glandular punctate beneath.E. B. 1291.-Racemes lax. Calyx-limb bell-shaped. Berries large, black. L. with $3-5$ acute serrated lobes.-In damp and swampy places. Sh. IV. V. Black Currant.

4. R. rubrum (L.); racemes mostly glabrous and pendulous, bracts shorter than the pedicels ovate, cal. nearly flat glabrous, 1. bluntly 5-lobed.-E. B. 1289.-The wild and cultivated plants differ slightly in their flowers (Phytol. ii. 517).- $\beta$. R. petraum 
(Sm. not Wulf.); racemes slightly downy, in flower upright, in fruit pendulous. E. B. 705.- - R. Rpicatum (Robs.); racemes erect both in flower and fruit, "fl. neariy sessile." E. B. 1290. -Woods. $\beta$. North of E., S. $\gamma$. Richmond, Yorkshire. Sh. IV. V. Red Currant.

\section{Order XXXVI. SAXIFRAGACEE.}

Cal. 4-5-cleft, superior or inferior. Pet. 4-5, rarely 0 . Stam. 5-10, free, perigynous or hypogynous. Glandular disk present or wanting. Ovary of 2 carpels cohering by the inflexed sides or margins. Styles 2, persistent, usually diverging. Seeds many. Albumen fleshy.

1. Saxifraga. Cal. 5-fid or 5-parted, more or less adnate to the ovary or free. Cor. of 5 petals. Stam. 10, rarely 5 . Styles 2, persistent. Caps. 2-celled, with 2 beaks, opening by a pore between the beaks.

2. Chrysosplenium. Cal. 4-fid, half superior. Cor. 0. Stam. 8, rarely 10. Styles 2. Caps. 1-celled, with 2 beaks, opening into the form of a cup.

\section{Saxifraga Linn. Saxifrage.}

Sec. 1. With decumbent barren shoots at the base.

* Cal. reflexed inferior, fl. panicled, flowering stems leafless.

† Filaments enlarged upwards. Roвertsonia Haw.

1. S. umbrosa $\left(\mathrm{L}_{0}\right) ;$ l. obovate with cartilaginous crenatures or sharp notches tapering at the base into dilated flat footstalks, panicle racemose. - L. crenate or dentate, spreading.-E. B. 663 . - . S. S. punctata (Haw.); l. nearly round acutely serrate erect. R. I. t. 622, 623.- . S. serratifolia (Mack.); l. oblong acutely serrate erect. E. B. S. 2891.-West of Ireland (all the forms). Yorkshire, a doubtful native. P.VI. London Pride. St.Patrick's Cabbage.

E. I.

2. S. elegans (Mack.); l. round smooth shining acutely serrate, footstalks broad flat convex beneath, panicle racemose.-E.B.S. 2892. - L. not tapering into the footstalks. - Very rare. Top of Turk Mountain, Killarney. Connor Hill, Kerry. P. VI. I.

3. S. hirsuta (L.) ; l. oval sharply serrate, footstalks linear semicylindrical channeled hairy, panicles racemose.-E. B. 2322. - Footstalks slightly tapering upwards. I.. longer than broad. - Very rare. Gap of Dunloe and Connor Hill, Kerry. Hungry Hill, Co. Cork. P. VI. 
4. S. Geum (L.); l. transversely oval or reniform crenate or dentate, footstalks semicylindrical channeled hairy, panicle racemose.-E. B. 1561. E. B. S. 2893.-L. always broader than long, usually hairy, sometimes glabrous, often beautifully reticulated with purple beneath. - West of Ireland. P. VI.

†† Filaments subulate. Spatularia Haw.

5. S. stellaris (L.); l. oblong wedgeshaped dentate-serrate narrowed below scarcely stalked, panicle corymbose of few flowers. - E. B. 167. St.35.3.-Stems tufted. Fl.-stalks 1-5 in. high, naked. Pet. ovate, clawed, white with 2 transverse yellow spots on their lower half.- $\beta$. integrifolia (Hook.); l. quite entire.Damp rocks on mountains. $\beta$. Ben Nevis. P. VII.

** Cal. at length reflexed inferior, st. leafy, l. undivided.

6. S. Hirculus (L.); st. erect, barren shoots prostrate filiform, 1. alternate lanceolate flat entire, root-l. narrowed into a footstalk, sep. obtuse fringed at the margin, pet. obtuse with 2 callous points near the base.-E. B. 1009. St. 35. 8.-Fl. few or solitary, terminal. Pet. obovate, spreading, yellow dotted with red. St. $4-8$ in. high, downy in the upper part. - Wet moors, rare. P. VIII.

*** Cal. erect or spreading half inferior, st. leafy, l. simple toothed or with rigid jointless cilia.

7. S. aizoides (L.); st. decumbent below, l. alternate linearoblong mucronate ciliated entire flat above convex beneath, sep. blunt.-E. B. 39. St. 35. 9.-Fl. in a leafy panicle, with glutinous downy stalks. Pet. bright.yellow often spotted with scarlet. St. 3-6 in. long. L. rigidly ciliated. - $\beta$. dentata ; l. with several strong teeth.-Wet places on mountains. P. VII.-IX.

**** Cal. erect or spreading superior or half inferior, st. more or less leafy, $l$. lobed, cilia all jointed.

[8. S. muscoides (Wulf.); " root-1. crowded linear obtuse entire or trifid, st. nearly naked few-flowered, pet. oblong obtuse a little longer than the superior calyx." Hooker. - $\beta$. pygmaa; "pet. obovate, cal. glandular." Sm. E. B.2314.-Said to have been found in Westmoreland. $\beta$. Highlands of Scotland. P. V.]

9. S. caspitosa (L.); root-l. crowded 3-5-cleft obtuse veined fringed, fl. I-5, pet. rounded 3-veined, cal. half inferior, sep. obtuse.-E. B.794.-Germen broad and rounded below. Common base of the l. not furrowed. Anth. long, cordate, with an open notch. Horns of caps. spreading.- $\beta$. S. decipiens (Sm.); larger and with more numerous flowers. E. B. 4E5.- $\gamma$. S. in- 
curvifolia (D. Don); stem-l. more numerous with incurved lobes. E. B. S. 2909.-Caernarvonshire. Aberdeenshire. Kerry. P. V. VI.

10. S. hirta (Sm.); $l$. crowded 3-5-cleft, lobes lanceolate pointed fringed, fl. few (usually 3 ) loosely panicled, pet. obovate 3-veined, cal. half inferior, sep. ovate acute.-E. B. 2291 (good). -L. on the barren shoots as well as the radical l. 3-cleft, the lateral lobes often divided half way down, lobes diverging. St. 3-6 or 8 in. long, weak, ascending, hairy, glandular, bearing 2 or 3 deeply 3 -lobed leaves and a few simple linear bracts. Lateral peduncles ultimately much overtopping the intermediate one. Anth. large, round, with a deep parallel-sided notch. Horns of caps. slightly spreading.-On the summit of Brandon Mountain, and Hag's Glen, Kerry ; and Galty More, Tipperary. West of Scotland. Mr. G. Don. P. VII.

S. I.

11. S. affinis (Don); l. of the trailing shoots $3-5$-lobed with a very broad base fringed, lobes linear acute, fl. few (2-4), pet. oblong 3-veined inflexed at the sides, cal. half inferior deeply divided into subulate acute sepals.-E. B.S.2903.-The 5-cleft 1. few ; lobes of the others nearly parallel or slightly spreading. St. l-3 in. high, erect, with a few linear simple leaves, glandular. Anth. $\frac{1}{2}$ as large as in Nos. 9 and 10, cordate-ovate. Horns of caps. spreading.-I have examined this plant and $S$. hirta upon Brandon Mountain and consider them as distinct from S. hypnoides.-Summit of Brandon Mountain, Kerry. P. VII.

12. S. hypnoides (L.); root-1. 3-5-cleft, those of the trailing shoots undivided or 3-cleft, lobes all acute bristle-pointed and fringed, calyx half inferior, sep. ovate acute.-E. B. 454. S. platypetala (E. B. 2276), hypnoides, elongella (E. B. 2277), leptophylla, and denudata of Smith. Anth. very small, oblong-ovate. Horns of caps. divaricate. $-a$. l. of the trailing shoots undivided. $-\beta$. l. of the trailing shoots 3-cleft, lobes broad.- $\gamma$. as $\beta$. with linear-lanceolate widely spreading lobes.-These varieties are scarcely worth notice. In all of them the lobes of the $l$. are gradually narrowed from just above the middle to an acute point. "Petiole inflated semiterete beneath."-Mountains. P. V.-VII.

13. S. lcetevirens (D. Don); trailing shoots procumbent elongated, 1. 5- or 3-parted, lobes linear acute, calyx-segments lanceolate mucronate, pet. spathulate emarginate. Don.- "The recurved points of the segments of the 1 . may possibly distinguish this as a species." $W$.Wilson. Unknown to me.-Mountains. Angus, Aberdeen, and north of Loch Lomond. P. VI. S.

14. S. pedatifida (Sm.); root-l. and those of the short sterile shoots upon very long stalks divided into 3 deep linear-lanceolate 
acute lobes, lateral lobes deeply bifid, calyx almost superior, sep. linear-lanceolate as long as the capsule shorter than the germen. $-E$. B. 2278.-Fl. in a cymose panicle, many, white. St. a foot high, solitary. "Petioles many-nerved. L. oval." Peduncles, germens and cal. downy and viscid. Caps. not tubercular. Hooker and Arnott refer this to S. geranioides (L.): not having seen Smith's plant, which is said to be also found on the Cevennes, I retain his name.-Clova Mountains. G. Don. Isle of Achill, I. Mr. Wynne. P. V.

S. I.

Sec. 2. Without barren shoots at the base.

* Stem leafy.

15. S. tridactylites (L.); st. panicled erect leafy, 1. wedgeshaped 3-5-fid with a flat petiole, lowermost often simple and spathulate, peduncles l-flowered much longer than the fruit with 2 bracts at the base, cal. superior.-E. B. 501. St. 33. 15.Whole plant viscid, $2-4$ in. high. Fl. scattered, many, small, white.-Walls and dry banks. A. IV.-VII.

16. S. granulata (L.); st. erect slightly leafy, radical $l$. reniform crenately lobed with channeled petioles, stem-l. nearly sessile 3 -5-fid, fl. in a cymose panicle, cal. half inferior, pet. obovateoblong 2 or 3 times as long as the sepals, roots granulated.E. B. 500.-Root bearing many small round downy bulbs. St. 6-12 in. bigh. Fl. large, white.-Gravelly banks. P. V.

17. S. cernua (L.); st. erect simple 1-flowered leafy, radical 1. reniform palmately lobed stalked, upper l. nearly sessile subtrifid, uppermost entire, axils bearing bulbs, cal. quite inferior.-E. B. 664.-Rarely flowering; fl. replaced by reddish bulbs. St. 3-6 in. high.-Rocks on the top of Ben Lawers, very rare. P. VI.VIII.

S.

18. S. rivularis (L.); st. ascending branched few-flowered leafy, radical 1 . subreniform stalked with $3-5$ rounded lobes, uppermost 1. lanceolate entire, cal. half inferior.-E. B. 2275.-St. $1-2$ in. long. Fl. few, stalked, white.-Wet places on the highest summits of mountains. P. VIII.

\section{** Stem leafless.}

19. S. nivalis (L.); st. erect leafless, $l$. all radical roundishobovate dentate-serrate narrowed into a footstalk, $f$. capitate, cal. half inferior, pet. longer than the calyx. - E.B. 440. St. 35.4. -St. 3-6 in. high, usually simple, sometimes with 1 branch. Fl. in a dense cluster, white--Alpine rocks. P. VII.

[S. Andrewsii (Harv.); 1. linear-spathulate dentate-serrate with a membranous margin tapering below into a dilated plane- 
convex footstalk, panicle racemose.-Lond.Journ. Bot. vii. t. 19. -Sep. patent, oblong, obtuse. Pet. thrice as long as cal., broadly elliptical, punctate.-Head of Glen Caragh, Kerry. Mr. Andrews. Some error. A garden hybrid? P. VI.]

Sec. 3. Stems procumbent with opposite 1. and terminal flowers.

20. S. oppositifolia (L.); st. procumbent, l. opposite oblong obtuse fringed, sep. ciliated without glands, pet. ovate.-E. B. 9 . - Very different from our other species. Fl. large, purple.Damp alpine rocks. P. IV. V.

\section{Chrysosplenium Linn. Golden Saxifrage.}

1. C. alternifolium (L.); l. alternate, lower 1. subreniform hairy crenate upon long stalks.-E. B. 54. St. 12.-Crenatures of the lower l. emarginate, npper 1 . glabrous with the crenatures often rather acute. St. erect, $4-5$ in. high, branching only near the top. Fl. umbellate, nearly sessile, deep yellow. Stam. usually 8.-Boggy places. P. IV.

2. C.oppositifolium (L.); l. opposite, lower l. roundish-cordate shortly stalked wavy.-E. B. 490. St. 4.6.-St. branching from the base, 4-6 in. long, decumbent, straggling. Fl. paler and more scattered than in the last. L. usually glabrous, sometimes slightly hairy. Stam. usually 8.-Damp shady places. P. IV.V.

\section{Order XXXVII. UMBELIIFER}

Cal. 5-toothed or entire, adherent to the ovary, limb often obsolete. Pet. 5, usually inflexed at the point. Stam. 5, inserted with the pet. on the mouth of the calyx. Ovary 2-celled, crowned with a double fleshy disk (stylopode). Styles 2 . Fr. consisting of 2 carpels (mericarps) adhering by their face (commissure) to a common axis from which they ultimately separate and become pendulous. Seed solitary, pendulous. Albumen horny.Inflorescence umbellate.-Each carpel has 5 primary ridges and often 4 intermediate secondary ones with channels between, and in the substance of the pericarp are usually linear receptacles of oil (vittæ) under the channels or rarely the ridges. These parts are sometimes either wanting or only slightly apparent.

\section{Suborder I. ORTHOSPERM E.}

Seed or albumen not furrowed in front. Umbels varions.

* Umbels imperfect or simple.

Tribe I. HYDROCOTYLEAE. Fr. laterally compressed, its back even or acute. 
1. Hydrocotyle. Cal.' obsolete. Pet. ovate, entire, acute. Fr. of 2 flat nearly circular naked carpels, each with 5 filiform ridges, of which the dorsal and 2 lateral are often obsolete, the 2 others arched. Vittæ 0 . Commissure linear.

Tr. II. SANICULEAE. Fr. ovate; transverse section nearly round.

2. Sanicula. Cal. of 5 leaflike teeth. Pet. erect, obovate, with a long inflexed connicent point. Fr. subglobose, covered with hooked spines; ridges 0 ; vittæ many.

3. Astrantia. Cal. of 5 leaflike teeth. Pet. erect, with a long inflexed point. Fr. subglobose with 5 plicate-dentate ridges; vittæ 0 .

Tr. III. ERYNGIEAE. Fr. ovoid; transverse section nearly round. Fl. in a head.

4. Eryngium. Cal. of 5 leafiike teeth. Pet. erect, oblong, with a long inflexed point. Fr. ovoid, covered with chaffy scales without ridges or vittæ.

[33. Torilis.]

** With perfect or compound umbels.

+ With primary ridges only.

Tr. IV. AMMINEAE. Fr. laterally compressed or didymous.

\section{A. Leaves compound.}

5. Cicuta. Cal. of 5 leaflike teeth. Pet. obcordate with an inflexed point. Fr. subdidymous. Carp. with 5 equal broad flattened ridges, the lateral marginal ; vittæ solitary.

6. Apium. Cal. obsolete. Pet. roundish entire with a small involute point. Fr. roundish ovoid, didymous. Carp. with 5 filiform equal ridges and solitary vittæ.-Inv. 0 .

7. Petroselinum. Cal. minute or obsolete. Pet. roundish entire with a narrow incurved point. Fr. ovoid. Carp. with 5 filiform equal ridges and solitary vittæ. Carpophore bipartite.-Involucre, partial of many, general of few leaves.

8. Trinia. Diocious. Cal. obsolete. Pet. of the barren $\mathrm{fl}$. lanceolate with the point inflexed, of the fertile fl. ovate with a short inflexed point. Fr. ovoid. Carp. with 5 filiform prominent equal ridges with a single ritta beneath each of them. Interstices without vitta.

1 By calyx, throughout this Order, the free margin is intended. 
9. Helosciadium. Cal. of 5 small teeth or obsolete. Pet. ovate entire with a straight or incurved point. Fr. ovoid or oblong. Carp. with 5 filiform prominent equal ridges. Interstices with solitary vitta. Carpophore entire.

10. Sison. Cal. obsolete. Pet. broadly obcordate, deeply notched with an inflexed point. Fr. ovoid. Carp. with 5 filiform equal ridges. Vitta solitary, clavate.

11. Egoponium. Cal. obsolete. Pet. obovate, notched with an inflexed point. Fr. oblong. Carp. with 5 filiform ridges. Interstices without vittce. Stylopode conical.

12. CArum. Cal. obsolete. Pet. obcordate with a narrow acute inflexed point. Fr. oblong. Carpels with 5 filiform ridges. Vittæ solitary. Stylopode depressed.

13. Bunium. Cal. obsolete. Pet. obcordate with a broad obtuse inflexed point. Fr. oblong. Carp. with 5 filiform equal ridges. Vittæ $1-3$ together. Stylopode conical.

14. Pimpinella. Cal. obsolete. Pet. obcordate with an inflexed point. Fr. ovoid, Carp. with 5 filiform equal ridges. Vitta 3 or more together. Stylopode tumid. Styles of the fr. divaricated or recurved.-Inv. 0 (rarely of 1 leaf).

15. Sium. Cal. of 5 small teeth. Pet. obcordate with an inflexed point. Fr. ovoid or subdidymous. Carp. with 5 filiform equal obtuse ridges. Vittæ 3 or more together. Stylopode depressed or shortly conical. Styles of the fr. divaricated or recurved.-Inv. universal and partial.

\section{B. Leaves simple.}

16. Bupleurum. Cal. obsolete. Pet. roundish entire with a closely involute broad retuse point. Fr. subdidymous. Carp. with equal, winged, or filiform and sharp, or obsolete ridges. Stylopode depressed.

Tr. V. SESELINEAE. Section of the fr. rounded or roundish.

A. Vitte solitary, between the ribs.

17. CEnantue. Cal. of 5 lanceolate teeth. Pet. obcordate with an inflexed point. Fr. ovoid-cylindrical or subturbinate, crowned with the long erect styles. Carpels more or less corky, with 5 blunt convex ridges.

18. Etruusa. Cal. obsolete. Pet. obcordate with an acute inflexed point. Fr. shortly ovoid, crowned with the reflexed styles. Carp. with 5 thick acutely-keeled ridges.

19. Foniculum. Cal. obsolete. Pet. roundish, entive with 
a broad obtuse inflexed lobe. Fr. oblong. Carp. with 5 prominent obtusely-keeled ridges. Stylopode conical.

20. Seseli. Cal. with acute teeth. Pet. obcordate with a broad inflexed lobe. Fr. ovoid or oblong, slightly dorsally compressed. Carp. with 5 thick blunt ridges. Stylopode conical.

B. Vitta 2 or more together, between the ribs.

21. Haloscias. Cal. of 5 small persistent teeth. Pet. ovate with an inflexed lobe and short claw. Fr. elliptical terete or slightly dorsally compressed. Carp. with 5 sharp somewhat winged ridges. Interstices and commissure with many vittæ. Seed not cohering to the carpel, without vittæ.

22. Sila us. Cal. obsolete. Pet.ovate-oblong entire or slightly emarginate with an inflexed lobe, sessile truncate or appendaged at the base. Fr. elliptical, terete or slightly dorsally compressed. Carp. with 5 sharp somewhat winged ridges. Vittæ many.

23. Meum. Cal. obsolete. Pet. entire, elliptical, acute at both ends, with an incurved point. Fr. as in Silaus.

24. Crithmum. Cal. obsolete. Pet.elliptical, entire, involute. Fr. elliptical, terete. Carp. with 5 elevated sharp slightly winged ridges. Seed free, with many vitta.

Tr. VI. ANGELICE AE. Fr. much and dorsally compressed, with a double wing on each side.

25. Angelica. Cal. obsolete. Pet. lanceolate, entire, acuminate, incurved. Fr. solid. Carp. with 3 dorsal elevated filiform ridges and 2 marginal ridges dilated into broad wings. Interstices with solitary vitta.

[26. Archangelica. Cal. minutely 5-toothed. Pet. ovate, entire, acuminate, incurved. Fr. nucleated. Carp. with 3 dorsal elevated thick ridges, and 2 marginal ridges dilated into broad wings. Vittæ 0 . Seed free, with many vitta.]

Tr. VII. PEUCEDANEAE. Fr. much and dorsally compressed, with a single wing on each side which is flat or thickened towards the edge.

27. Peucedanum. Cal. of 5 teeth or obsolete. Pet. obovate or obcordate with an inflexed point. Fr. with a dilated thin flat margin. Carp. with equidistant ridges, 3 dorsal filiform, 2 lateral close to the base of the dilated margin obsolete. Vittæ solitary. 
28. Pastinaca. Cal. of 5 very small or nearly obsolete teeth. Pet.roundish, entire, involute with an acute point. Fr. with a dilated flat margin. Carp. with slender ridges, 3 dorsal equidistant, 2 lateral distant near the outer edge of the dilated margin. Vitta linear, solitary.

29. Heracleum. Cal. of 5 minute teeth. Pet. obcordate with an inflexed point, outer ones radiant. Fr. as in Pastinaca. Vitta short clubshaped.

30. Tordylium. Cal. of 5 awlshaped teeth. Pet. obcordate with an inflexed lobe, outer ones radiant. Fr. with a thickened wrinkled margin. Carp. with slender ridges, 3 dorsal equidistaut, 2 lateral distant close to the thickened margin. Vittæ $1-3$ together.

†† With primary and secondary ridges. Fruit prickly.

Tr. VIII. DAUCINEAE. Fr. somewhat dorsally compressed. Carp. with 5 primary ridges, the lateral ones on the inner face; and 4 secondary forming rows of prickles.

31. Daucus. Cal. of 5 teeth. Pet. obcordate with an inflexed lobe, exterior usually radiant and bifid. Fr. dorsally compressed. Carp. with bristly primary ridges; secondary ridges equal winged with 1 row of spines.

\section{Suborder II. CAMPYLOSPERMAE.}

Seed inflexed at the margin or deeply furrowed in front. Umbels compound or perfect.

Tr. IX. CAUCALINEAE. Fr. contracted or rounded. Carp. with the lateral primary ridges on the inner face; 4 secondary more prominent, prickly. Vittæ solitary.

32. Caucalis. Cal. of 5 teeth. Pet. obcordate with an inflexed point, outer ones radiant and bifid. Fr. slightly laterally compressed. Carp. with filiform bristly primary, and more or less prominent secondary ridges, all bearing $1-3$ rows of prickles.

33. Torilis. Cal. of 5 teeth. Pet. obcordate with an inflexed point, outer ones radiant and bifid. Fr. slightly laterally compressed. Carp. with bristly primary ridges; the secondary hidden by the many prickles which occupy the interstices.

Tr. X. SCANDICINEAE. Fr. compressed or contracted on the sides, often beaked. Carpels with primary ridges only. Fruit not prickly. 
34. Scandix. Cal. obsolete. Pet.obovate with an inflexed point. Fr. with a very long beak. Carp. with 5 obtuse ridges. Vittæ none.

35. Anthriscus. Cal. obsolete. Pet. obcordate with an inflexed short point. Fr. narrowed below the short beak. Carp. without ridges; beak with 5 ridges. Vittæ none.

36. Charophyllum. Cal. obsolete. Pet. obcordate with an inflexed point. Fr. not beaked. Carp. with 5 equal obtuse ridges. Vittce solitary.

37. Myrrhis. Cal. obsolete. Pet. obcordate with an inflexed point. Fr. not beaked. Carp. with a double membrane; the outer with elevated keeled ridges hollow within, the inner close to the seed. Vittæ 0.

Tr. XI. SMYRNIEAE. Fr. turgid compressed or contracted at the sides. Carp. with primary ridges only.

38. Echinophora. Cal. of 5 teeth. Pet. obcordate with an inflexed point, the exterior larger and bifid. Fl. of the ray sterile on long stalks, fertile central and solitary. Fr. ovoid, terete, imbedded in the enlarged prickly receptacle. Carp. with 5 depressed equal striated wavy ridges. Interstices with single vittæ and covered by a cobweblike membrane.

39. Conium. Cal. obsolete. Pet. obcordate with a short inflexed point. Fr. ovoid, laterally compressed. Carp. with 5 prominent wavy or crenate ridges, the lateral marginal. Interstices striated. Vittæ 0.

40. Physospermum. Cal. of 5 teeth. Pet. obcordate with an inflexed point. Fr. laterally compressed, didymous. Carp. reniform-globose, with 5 filiform slender equal ridges, the lateral within the margin. Vitta solitary.

41. Smyrnium. Cal. obsolete. Pet. lanceolate or elliptical, entire, with an inflexed point. Fr. laterally compressed, didymous. Carp. reniform-oblong with 3 dorsal prominent sharp ridges, the 2 lateral marginal and nearly obsolete. Vitte many.

\section{Suborder III. CCELOSPERME.}

Seed with the base and apex curved inwards in front.

Tr. XII. CORIANDREAE. Fr. globose or didymous. Primary ridges of the carp. often obsolete, secondary more prominent, all apterous. 
42. Coriandrum. Cal. of 5 teeth. Pet. obcordate with an inflexed point, outer ones radiant and bifid. Fr. globose. Carp. scarcely separating, the primary ridges obsolete, the 4 secondary conspicuous prominent keeled. Interstices without vittæ. Commissure with 2 vittæ.

\section{Suborder I. Orthosperma. Tribe I. Hydrocotylea.}

\section{Hydrocotyle Linn. Penny-wort.}

1. H. vulgaris (L.) ; l. peltate nearly circular doubly crenate, heads of 5 fl., fr. emarginate below.--E. B. 751.-Fl. and fr. almost sessile. Umbels or rather heads often proliferous in the centre and bearing a second head. St. creeping extensively. L. upon stalks which are considerably longer than the peduncles.Bogs and marshy places. P. V.-VIII.

\section{Tribe II. Saniculea.}

\section{SANicula Linn. Sanicle.}

1. S. europaa (L.); lower l. palmate 3-5-lobed, lobes trifid unequally serrate, fertile fl. sessile, barren fl. slightly stalked.E. B. 98.-Umbels many, capitate, in an irregular slightly umbellate panicle. Styles persistent, reflexed. St. ascending, about a foot high.-Woods and thickets. P. VI. VII.

\section{Astrantia Linn.}

†1. A. major (L.); lower l. palmately 5-7-fid, lobes oblong acute unequally incise-serrate, inv.-l. entire, cal.-teeth ovate-lanceolate narrowed to an acute point.-St. 29. 8.- Inv. equalling the umbel, usually straw-coloured.-Woods in hilly districts. Between Whitbourne and Malvern. Above Stokesay Castle, near Ludlow. In the latter place Mr. Borrer considers it to have been introduced "ages ago." P. VI.-VIII. E.

\section{Tribe III. Eryngiea.}

\section{Eryngium Linn. Eryngo.}

1. E. maritimum (L.) ; radical $l$. roundish plaited spinous stalked, upper l. amplexicaul palmately lobed, inv.-l. 3-lobed spinous exceeding the heads, scales of the receptacle 3-lobed.E. B. 718. - St. I foot or more in height, branched, leafy, rigid, 
glaucous. Fl. in heads rather than umbels, blue.-Sandy seashores. P. VII. VIII. Sea Holly.

2. E. campestre (L.); radical $l .2$ or 3 times pinnatifid spinous stalked, st.-l. amplexicaul bipinnatifid, inv.-l. lanceolate spinous longer than the heads, scales of the receptacle undivided.-E. B. 57.-More bushy and slender than the last. Pet. purplish or white. Petioles thick, semiterete, channeled.-On waste ground, very rare. P. VII. VIII.

\section{Tribe IV. Amminea.}

\section{Crcuta Linn. Water Hemlock.}

1. C. virosa (L.); fibres of the root filiform, 1. tripartite, leaflets linear-lanceolate acute serrate decurrent.-E.B. 479.St. 3-4 feet high, very thick round and hullow below. Lower l. on long stalks; leaflets $1-2$ in. long. Umbels large; general inv. 0 , or of 1 or 2 slender leaflets; partial of many subulate leaflets. Fl. white. Herb poisonous.-Ponds and ditches, not common. P. VII. VIII. Cowbane.

\section{Apium Linn. Celery.}

1. A. graveolens $($ L.); glabrous, l. pinnate or ternate, leaflets of the upper 1 . wedgeshaped and notched at the end. $-E$. B. 1210. - St. 1-2 feet high, branched, furrowed, leafy. Umbels terminal or lateral, frequently almost sessile, accompanied by 1 or 2 ternate leaves. Fl. small, white.-Marshes and ditches, especially near the sea. P. VI.-VIII.

\section{Petroselinum Hoffm.}

†1. P. sativum (Hoffm.); l. tripinnate shining, leaflets of the lower 1. ovate-cuneate trifid and toothed, of the upper l. ternate lanceolate entire--E. B. S. 2793.-Partial involucres filiform. L. greenish.-Rocks and old walls. B. VI.-VIII. Parsley.

2. P. segetum (Koch); lower $l$. pinnate, leaflets nearly sessile ovate lobed and serrate, upper 1. entire or trifid.-Sison Sm., E. B. 228.-Umbels very irregular. General inv. of $1-2$ leaves. Fl. whitish. St. erect, roundish, nearly leafless above, $1-1 \frac{1}{2}$ foot high, wiry. - Damp calcareous fields and near the sea. B.VIII. IX.

\section{Trinia Hoffm.}

1. T. vulgaris (DC.); glabrous, inv. 0 or of 1 leaf, ridges of the fr. obtuse.-Pimpinella dioica Sm., E. B. 1209.-L. tripinnate, 
glaucous-green; lts. linear or filiform. Root crowned with the remnants of former leaves. St. branched, erect, $6-8$ in. high. Diocious.-Dry limestone hills, rare. P. V. VI. E. I.

\section{Helosciadium Koch.}

1. H. nodiflorum (Koch); st. procumbent at the base and rooting, l. pinnate, leaflets ovate or ovate-lanceolate unequally obtusely serrate, umbels opposite to the l. longer than their peduncles or nearly sessile.-Sium Sm., E. B. 639.-St. 1-2 feet long. - $\beta$. H. repens (Koch); st. prostrate, lts. roundish-ovate unequally and acutely incise-serrate, umbels shorter than the peduncles. E. B. 1431.-Banks of ditches and brooks. P. VII. VIII.

2. H. inundatum (Koch); st. creeping, l. pinnate, lts. of lower l. in capillary segments, of upper l. wedgeshaped and trifid, umbels generally with 2 rays.-Sium Sm., E.B. 227.-Usually submersed, a few of the upper l. and the fl. rising above the water. Partial umbels very small.-Ponds. P. VI. VII.

\section{Sison Linn. Honewort.}

1. S. Amomum (L.).-E. B. 954.-St. erect, panicled, 2-3 feet high. Lower l. pinnate; lts. oblong lobed cut and serrate ; upper l. divided into narrow segments. Partial umbels and $\mathrm{f}$. small.-Dampish places on a calcareous soil. B. VIII. E S.

\section{Egopodium Linn. Gout Weed.}

1. A. Podagraria (L.).-E. B.940,-St. 1-2 feet high, erect, furrowed. L. 2 or 3 times ternate; leaflets ovate-acuminate, unequal at the base, acutely serrate. Root creeping.-Damp places. P. VI. VII.

\section{Carum Linn.}

†1. C. Carui (L.); partial involucre 0 , general 0 or of 1 leaf, 1. bipinnate, leaflets cut into linear segments.-E. B. 1503.-St. 1-2 feet high, branched. Root fusiform. Carp. aromatic.Meadows and pastures. B. VI. Caraway.

2. C. verticillatum (Koch); general and partial involucres of many leaves small, l. pinnate, leaflets divided to the base into

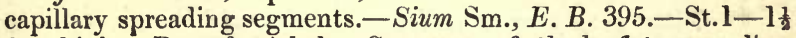
foot high. Root fascicled. Segments of the leaflets spreading so as to appear whorled and quite surrounding the petiole. L. mostly long-stalked, radical.-Damp and hilly pastures, rare. P. VIII. 


\section{Bunium Linn. Pig-nut.}

1. B. flexuosum (With.); general involucre of $1-3$ leaves, partial more numerous, $f r$. oval narrowing upwards crowned with the elongated stylopode and erect styles, interstices with 3 vittæ. - E.B.988. B.denudatum DC.-Involucres sometimes altogether wanting. Root a solitary tuber. St. a foot or more high, very slender below, bearing a few 1 . with linear segments. Radical 1 . triternate with long footstalks tapering downwards.-Sandy and gravelly pastures. $\mathbf{P}$. V. VI.

2. B. Bulbocastanum (L.); general and partial involucres of many leaves, fr. oblong crowned with the short stylopode and reflexed styles, interstices with single vittæ.-E. B. S. 2862. Carum Koch, DC. - Involucres always present. Lower 1. bipinnate, with a triangular outline, rather numerous near the base of the stem, rarely 1 or 2 radical upon long footstalks tapering downwards.-Chalky fields in Camb. and Herts. P. VI. VII. E.

\section{Pimpinelda Linn. Burnet-Saxifrage.}

1. P. magna (L.); l. pinnate, leaflets all ovate serrate somewhat eut the terminal one 3-lobed, st. angularly striate.-E. B. 408. - St. $1-2$ feet high, leafy. Lateral leaflets sometimes 3-lobed. Styles longer than the ovary, as long or longer than the oval fruit.-Shady hills. P. VII. VIII.

2. P. Saxifraga (L.) ; l. pinnate, leaflets of the lower 1 . roundish-ovate serrated somewhat cut, those of the stem-l. bipinnatifid with linear segments, st.terete, ped. glabrous.-E. B. 407 . - St. 1-2 feet high, naked above. Styles shorter than the ovary. L. sometimes all pinnatifid.- $[P$. nigra (Willd.) has densely pubescent peduncles.]-Dry pastures. P. VII.-IX.

\section{SiUm Linn.}

* Vitta superficial. Lateral ridges marginal. Stylopode depressed. Sium Koch.

1. S. latifolium (L.); 1. pinnate, lts. oblong-lanceolate equally serrate pointed, inv.-1. many lanceolate.-E. B. 204.-St. 3-5 feet high, angular, furrowed, erect. L. of 9-13 very large distant lts. Umbels terminal.-Ditches and rivers, rare. P. VII. VIII.

** Vittce deeply seated. Lateral ridges not marginal. Stylopode shortly conical. BerUla Koch.

2. S. angustifolium (L.); 1. pinnate, leaflets unequally lobed and cut ovate, of the stem-1. lanceolate, inv. of many lanceolate 
entire or cut leaves.-E. B. 139.-St. $1-3$ feet high, round, striated, erect. Lts. often very deeply cut and lobed. Umbels lateral.-Ditches. P. VIII.

\section{Bupleurum Linn.}

* Fruit granulated.

1. B. tenuissimum (L.); st. branched, l. linear acute, umbels lateral and terminal minute, partial umbels of 3-5 flowers usually overtopped by their involucres, carp. granulated between the 5 ridges.-E. B. 478. - St. very slender, wiry, 6-12 in. long.Muddy salt marshes. A. VIII. IX.

E.

\section{** Fruit not granulated.}

2. B. aristatum (Bartl.); st. branched, l. linear-lanceolate acuminate 3-veined, 1 . of the partial involucres elliptic-lanceolate cuspidate somewhat awned with branching veins, pedicels short equal.-B. Odontites Sm., E. B. 2468 (not Linn.). - St. 1-6 in. high.-Torquay, Devon. Channel Islands. A. VII. E.

3. B. falcatum (L.); st. branched, 1. 5-7-veined, lower $l$. elliptical-oblong on long stalks, upper l. linear-lanceolate acute sessile, partial involucre of 5 lanceolate pointed $\mathrm{l}$. as long as the flowers.-E. B. S. 2763.-Pedicels as long as the fruit. St. 1-4 feet high.-Near Ongar, Essex. P. VIII.

4. B. rotundifolium (L.); st. branched above, l. oval perfoliate, fr. with striate interstices.-E. B.99.-General involucre 0 . Partial involucre connivent.-Corn-fields on a calcareous soil. A. VII. Thorow-wax. Hare's ear.

E.

\section{Tribe V. Seselinea.}

\section{Enanthe Linn. Water-Dropwort.}

* Root fasciculated, fibres more or less thickened or tuberous.

1. EE. fistulosa (L.); root stoloniferous, st. and petioles fistulose, root-l. 2-3-pinnate with 3-fid leaflets, stem-l. simply pinnate shorter than their petioles, leaflets linear, fr. angular turbinate.-E. B. 363.-St. 1-3 feet high, remarkably fistulose. Stem-l. distant, with very long stalks. Stoles with simply pinnate leaves. Umbels small, globose in fruit; general involucre 0 . Fruit tipped with the long slightly diverging rigid styles.-By ponds and ditches. P. VII.-IX.

E. I.

2. E. pimpinelloides (L.); root of long fibres bearing round or oval knobs beyond their middle, root-l. bipinnate, lts. aculely 
cut or trifid, st.-l. pinnate uppermost simple, lts. linear acute, radiant pet. obcordate divided to the middle, $f r$. subcylindrical - with an enlarged corky base.-Jacq. Aust. t. 394.-St. $\frac{1}{2}-3 \mathrm{ft}$. bigh, alternately branched. General inv. 0-6-leaved; partial of many l., about as long as the barren fl. Partial umbels close together forming one compact flat-topped umbel. Fr. nearly cylindrical ; cal. erect-patent.-Southern counties. P. VI. VII. E.

3. E. Lachenalii (Gmel.); root of elongate-subclavate fleshy fibres tapering at both ends, root-l. bipinnate, lts. oblong entire or wedgeshaped and bluntly 2-3-lobed, lower st.-1. 2-3-pinnate upper simply pinnate, lts. linear acute, radiant pet. divided to the middle, fr. oblong narrowed below.-E. pimpinelioides Sm., E. B. 347.- St. 1-3 feet high, slightly branched. General inv. of many leaves, sometimes wanting; partial of many leaves, shorter than the barren flowers. Outer fl. on long stalks, mostly barren ; inner $\mathrm{fl}$. fertile, nearly sessile. Radiant pet. roundishobcordate with a short narrow claw. Partial umbels distinct, spherical. Fr. crowned with the inflexed calyx. Root-leaves very evanescent - Marshes. P. VII.-IX.

4. EE. silaifolia (Bieb.?); root of elliptical-oblong knobs, radical 1. bipinnate, st.-1. pinnate, lts. all linear acute, external fr. nearly cylindrical with a corky base.-E. B. 348.-St. $2-3$ feet high, branched. Outer fl. stalked, mostly barren; cal. very unequal ; radiant pet. small, obcordate with an attenuated base ; notch $\frac{1}{3}$ their length. Fr. usually slightly narrowed downwards, in the middle of the umbel much narrowed and appearing to want the corky base; cal. erect or inflexed. General involucre 0 , partial of many leaves shorter than the flowers. Distinguished from the preceding by its pet., uniform leaflets, want of a general involucre, and fruit. - Scarcely $E$. silaifolia (Bieb.), not $E$. peucedanifolia (Poll.).-In freshwater marshes. P. VI.

E.

5. E. crocata (L.); root of large fusiform tubers, radical l. 2-3-pinnate, stem-l. pinnatifid, leaflets stalked roundish or oblong-wedgeshaped variously cut those of the upper I. narrower, fr. cylindrical oblong striated longer than its pedicel.- $E . B$. 2313.-St. 3-5 feet high, much branched. L. large, lts. broad. Inv.-I. various in number and shape.-Wet places. P. VII.

** Root of whorls of slender fibres.

6. E. Phellandrium (Lam.) ; st. erect fusiform below, 1. tri pinnate, lts. ovate pinnatifid cut spreading, of the submersed $l$. multifid with capillary diverging segments, umbels lateral opposite to the leaves, fr. ovate.-E. B. 684.-St. $2-3$ feet high, very thick below, stoloniferous. Segments of the I. many, fine, acute, pale green; submersed 1. dark green. The flowering root 
dies each year, but the plant is continued by the offsets.-In the water of ditches and ponds. B. ? VII.-IX.

7. E. fluviatilis (Colem.); st. floating, l. bipinnate, lts. simple or pinnatifid, of the submersed $l$. cuneate cut pellucid with many parallel veins, umbels lateral opposite to the l., fr. broadly elliptical.-A. N. H. xi. 188. E. B. S. 2944.-A decumbent floating plant well marked by the submersed lts. being divided into fingerlike acute broadly linear parallel segments deeply incised at the end. Lts. of the upper 1. broader than those of $Q E$. Phellandrium.Streams. B. or P. VII.-IX.

E.

\section{Ethusa Linn. Fools' Parsley.}

1. AE. Cynapium (L.); partial involucre of 3 leaves longer than their umbel, 1. all doubly pinnate, leaflets lanceolate decurrent pinnatifid.-E. B.1192.-St. 4-12 in. high. L. dark green, lurid, stinking. General involucre 0 ; partial one long, narrow, pendulous. Herb poisonous.-Cultivated land. A. VII. VIII.

\section{Foniculum Hoffm. Fennel.}

1. F. officinale (All.); st. terete below, 1. decomposite, segments all capillary elongate in the upper $l$. flaccid, umbels of many rays concave.-Meum Sm., E. B. 1208.- Involucres 0. St. 3 - 4 feet high, usually filled with pith, branching. Umbels large. Fl. yellow. Whole herb aromatic. Segments of 1. channeled, usually capillary in the wild plant, but the cultivated plant with awlshaped segments is probably the same species.-Rocks and walls, particularly near the sea. P. VII. VIII. E. I.

\section{Seselr Linn. Mountain Spignel.}

1. S. Libanotis (Koch); l. doubly pinnate cut, segments lanceolate mucronate, the lowermost leaflets crossing, general involucre of many leaves, fr. hairy.-Athamanta Sm., E. B. 138.St. $1-3$ feet high, covered at the base with the fibrous remains of decayed petioles. Umbels terminal, convex, with many downy rays.-Chalk hills of Cambridgeshire and Sussex. P. VII. VIII.

E.

\section{Haloscias Fries. Scottish Lovage.}

1. H. scoticum (Fr.); 1. twice ternate, leaflets ovate somewhat rhomboidal dentate-serrate opaque, involucre of $5-7$ linearlanceolate leaves, cal. 5-toothed.-Ligusticum L., E. B. 1207.St. herbaceous, nearly simple, striated, tinged with red, $1-1 \frac{1}{2}$ foot high. Lts. large, lobed and cut. Interstices with 3, com- 
missure with 6 vittæ. Seed free.-Rocks on the sea-coast of Scotland and Northumberland. P. VII.

E. S.

\section{Silaus Besser.}

1. S. pratensis (Bess.) ; st. angular, radical 1. 3-4 times pinnate, leaflets lanceolate entire or bifid, terminal tripartite, involucre of $1-2$ leaves, involucels of many leaves.-Cnidium Silaus Sm., E. B. 2142.-St. $1-2$ feet high. L. mostly radical, stem-1. decreasing upwards. Fl. pale yellow.-Damp meadows and pastures. P. VI.-IX.

\section{Meum Tourn. Bald-money.}

1. M. athamanticum (Jacq.) ; 1. bipinnate, leaflets multipartite, segments threadshaped acute.-E. B. 2249.-St. 1-2 feet high, round, clothed at the base with the fibrous remains of the decayed petioles. Fl. many, whitish-yellow. General involucre of 2 or 3 leaves, partial more numerous. Highly aromatic.-Dry mountainous pastures. P. VI. VII.

E. $\mathrm{S}$.

\section{4. Сrithmum Linn. Samphire.}

1. C. maritimum (L.).-E. B. 819.-St. 6-12 in. long. L. fleshy, 2-3-pinnate; leaflets lanceolate, narrowed at both ends, few. Involucre of many lanceolate acute leaves. Fl. whitish. -On rocky sea-coasts. P. VIII.

\section{Tribe VI. Angelicea.}

\section{Angelica Linn.}

1. A. sylvestris (L.); leaflets equal ovate-lanceolate or ovate incise-serrate not decurrent, lateral ones rather unequal at the base. $-E$. B. 1128.-St. $2-3$ feet high, slightly downy above, purplish. Fl. pinkish-white. Inv. about 3-leaved, deciduous. Lts. often subcordate at the base.-Wet places. P. VII. VIII.

\section{Archangelica Hoffm.}

[1. A. officinalis (Hoffm.); leaflets ovate lanceolate all sessile partly decurrent, terminal one trifid.-E. B. 2561.-St. 3-5 feet high. Foliage, stalks and even fl. bright green. L. 2-3 feet wide. Petioles much dilated at the base. - A very doubtful native. Watery places. P. VII.-IX.] E S. 


\section{Tribe VII. Peucedanea.}

\section{Peucedanum Linn.}

1. $P$. officinale (L.); $l .5$ times tripartite, leaflets linear acute flaccid, general involucre 3-leaved deciduous, pedicels much longer than the fruit.-E. B. 1767.- Leaflets very long, narrow. Fl. yellow. St. terete, striated. Vittæ of the commissure supcrficial.-Salt marshes. Kent. Essex. P. VII.-IX. E.

2. P. palustre (Moench); l. 3-pinnate, leaflets pinnatifid with linear-lanceolate acuminate segments, general involucre of many persistent lanceolate deflexed leaves, st. furrowed.-Selinum Sm., E. B. 229.-St. erect, 3-5 feet high. Fl. white. Vittæ of the commissure deeply seated.-Marshy and fenny places, rare. P. VII. VIII.

†3. P. Ostruthium (Koch); l. biternate, leaflets broadly ovate lobed cut and serrated, sheaths very large, general involucre 0 , cal.-segments obsolete.-E. B. 1380.-St. 1-2 feet high. Fl. white.-Moist meadows in Scotland. P. VI. Masterwort.-S.

\section{Pastinaca Linn. Parsnep.}

1. P. sativa (L.); st. angular furrowed, 1. pinnate downy beneath, leaflets ovate-oblong crenate-serrate often with a lateral lobe at the base, inv. 0 , fr. oval. $-E$. B. 556. - St. $2-3$ feet high. Fl. yellow. L. generally shining above, downy beneath.-Hedgebanks on a calcareous soil. P. VII.

\section{Heracleum Linn. Cow Parsnep.}

1. H. Sphondylium (L.) ; l. pinnate, leaflets lobed or pinnatifid cut and serrate, fr. at length glabrous.-E. B. 939.-St. 4 feet high. Lower l. very large. Umbels large, flattish. Fl. white or reddish, outer fl. radiant.- $\beta$. angustifolium; leaflets deeply pinnatifid, lobes lanceolate, lower ones elongated and spreading. -Hedge-banks. P. VII. Hog-weed.

\section{Tordyuium Linn.}

1. T. maximum (L.); outermost pet. radiant with 2 equal lobes, partial involucres linear shorter than the umbel, fr. hispid the thickened margin slightly crenate.-E. B. 1173. -St. 2-4 feet high. Fl. reddish.-Waste ground, very rare. A. VII. E.

[2. T. officinale (L.); two outermost pet. radiant each with 2 very unequal lobes, partial involucres lanceolate about as long as the umbel, fr. rough with the thickened margin beautifully crenate.-E. B. 2440.-Near London. A. VII.] 


\section{Tribe VIII. Daucinea.}

\section{Daucus Linn. Carrot.}

1. D. Carota (L.); radical l. with an oblong narrow outline bipinnate, lts. incise-dentate, segments acute, upper 1. broader below with lanceolate segments, prickles of fr. slender mostly distinct about equalling its breadth spreading tipped with $1-3$ recurved minute bristles. - E. B. 1174.-St. 2-3 ft. high, hairy. Umbel of fr. usually concave.-Pastures. B. VI.-VIII.

2?. D. gummifer (Lam.); radical l. triangular broad 2-3-pinnate, lts. ovate cut or pinnatifid, segm. blunt mucronate, upper 1. narrower below, prickles of fr. usually flattened and often united below and shorter than its breadth incurved tipped with one bristle.-D. maritimus With. (not Lam.), E.B.2560.-St. short, very hispid below. L. shining above, rather fleshy. Umbel of fr. usually convex. Prof. E. Forbes found a form of this with ciliated petals. Perhaps not distinct from D. Carota.-Seacoasts, chiefly in the south. B. VII. VIII.

\section{Suborder II. Campylosperma. Tribe IX. Caucalinea. 32. Caucalrs Hoffin. Hen's-foot.}

1. C. daucoides (L.); 1. bipinnate, leaflets pinnatifid with linearacute segments, general involucre 0 , partial umbels of few $\mathrm{fl}$. with involucres of $3-5$ leaves, secondary ridges of the fr. each with one row of glabrous hooked prickles.-E. B. 197.-St. $6-12$ in. high, furrowed, hairy at the joints. General umbels 3-cleft ; partial bearing about 3 large oblong very prickly fruits. Fl. small, reddish.-Corn-fields on a chalky soil. A. VI.

†2. C. latifolia (L.); l. pinnate, leaflets lanceolate decurrent coarsely serrate, involucres oblong membranous, secondary ridges of the fr. with retrorsely scabrous prickles.-E. B. 197. Turgenia Koch.-St. 1-2 feet high, scabrous. General umbels about 3-cleft; partial bearing about 5 large oblong very prickly fruits. Fl. large, pink.-Corn-fields, mostly on a chalky soil, very rare. Formerly "abundant in Caunbridgeshire." A. VII. E.

\section{Torilis Adans. Hedge Parsley.}

1. T. Anthriscus (Gaert.); 1. bipinnate, leaflets ovate-oblong incise-serrate, umbels stalked terminal, general involucre of many leaves, fr. with subulate incurved not hooked scabrous prickles. - E. B.987. - St. erect, $1-3$ feet high. Umbels on long stalks. Fr. densely prickly. Fl. small, white or reddish.-Hedges and banks. A. VII. VIII. 
2. T. infesta (Spr.) ; l. bipinnate, leaflets ovate-lanceolate incise-serrate, umbels stalked terminal, general involucre of one leaf or $0, f r$. with spreading hooked retrorsely scabrous prickles.E. B. 1314.-St. erect, usually much and densely branched, 6-18 in. high. Umbels on long stalks. Fr. densely prickly, primary ridges with adpressed prickles. Fl. small, white or reddish. Styles scarcely twice as long as the stylopode.-Fields. A. VII. VIIII.

3. T. nodosa (Gaert.); lower l. bipinnate, upper pinnate, leaflets deeply narrowly and uniformly pinnate, umbels nearly sessile dense lateral, outer carpels with hooked bristles inner often warted.-E. B. 199.- St. diffuse. Unbels very small, nearly globular.-Banks and dry places. A. V.-VII.

\section{Tribe X. Scandicinea.}

\section{Scandix Linn. Shepherd's Needle.}

1. S. Pecten-veneris (L.); beak 3 times as long as the roughish fr. dorsally compressed glabrous with bristly edges, lts. of partial inv. entire or bifid longer than the pedicels.-E. B. 1397.-St. often a foot high. L. light green, triply pinnate; segments short, linear. Umbels $1-2$ together, small. Fl. often slightly radiant. Styles always straight. Stylopode purple. Partial involucres sometimes much divided.-Fields. A. VI.-IX.

\section{Anthriscus Hoffm. Chervil.}

1. A. sylvestris (Hoffm.); st. hairy below glabrous above slightly swollen below the joinings, umbels terminal stalked, l. bipinnate, leaflets pinnatifid, fr. linear glabrous with a short beak. - Chærophyllum Sm., E.B.752.-St. 3 feet high, erect, leafy, furrowed, branched. Partial involucre of several ovate-lanceolate ciliated leaflets. Umbels at first drooping.-Hedges and banks. P.IV.-VI. Wild Chervil.

†2. A. Cerefolium (Hoffm.); st. hairy above the joinings only, umbels lateral sessile, l. tripinnate, leaflets ovate pinnatifid, $f r$. linear smooth about twice as long as its beak.-Charophyllum sativum Sm., E. B. 1268.-St. 1-3 feet high, slender, striated, much branched. Partial involucre of 3 unilateral linear-lanceolate leaflets. Peduncles downy.-Waste ground. Probably an escape from cultivation. A. V. VI. Garden Chervil.

3. A. vulgaris (Pers.); st. glabrous, umbels lateral stalked, 1. tripinnate, leaflets pinnatifid, fr. ovate hispid about twice as long as its glabrous beak.-E. B. 818.--St. erect, 2 feet high, 
branched. L. slightly hairy. Umbels on rather short stalks. Partial involucres of few ciliated leaflets.-Waste places. A.V.VI.

\section{Charophyllum Linn.}

1. C. temulum (L.); st. swelling beneath the joinings rough, 1. bipinnate, leaflets ovate-oblong pinnatifid with obtuse mucronate segments, pet. glabrous, styles equalling the stylopode.-Myrrhis temulenta Sm., E. B. 1521.-St. 3-4 feet high, round, spotted, scabrous below, hairy near the summit. Umbels at first nodding. -Hedge-banks. P. VI. VII. Rough Chervil.

[2. C. aureum (L.) ; st. somewhat thickened below the joinings, 1. tripinnate, leaflets attenuated very acute incise-pinnatifid, pet. glabrous, styles longer than the stylopode.-Myrrhis Sm., E. B. 2103. - St. 3 feet high, angular, striated. Partial involucres with ovate-lanceolate much attenuated leaflets.-Between Arbroath and Montrose and at Costorphine. Mr. G. Don. P. VI.]

[3. C. aromaticum (L.); st. slightly thickened below the joinings, 1. subternately bipinnate, leaflets undivided broad oblong acuminate sharply serrate hairy beneath, styles longer than the stylopode.-Myrrhis Sm., E. B. S. 2636.-St. 2-3 feet high, furrowed, angular, bristly and spotted bclow.-By the river Lunan near Guthrie, Forfarshire. Mr. G. Don. P. VI.]

\section{Myrrhis Scop. Sweet Cicely.}

1. M. odorata (Scop.); 1. downy beneath, leaflets of the partial involucres lanceolate-acuminate.-E.B.697.-St. $2-3$ feet high, round, leafy, hollow. L. very large, tripinnate. Leaflets ovatelanceolate, pinnatifid. Umbels terminal. Fl. many, white. Fr. large, nearly an inch long, dark brown. Whole plant highly aromatic.-Pastures in hilly districts. P. V. VI.

\section{Tribe XI. Smyrniea.}

\section{Echinophora Linn.}

1. E. $\operatorname{spinosa}($ L.) ; l. pinnate, leaflets pinnatifid with spinous awlshaped entire segments.-E. B. 2413.-Sandy sea-shores, probably now lost. Lancashire and Kent. P. VIII. E.

\section{Conium Linn. Hemlock.}

1. C. maculatum (L.); leaflets of the partial involucres unilateral ovate-lanceolate with an attenuated point shorter than the umbels. - E. B. 1191. - St. 3-5 feet high, erect, round, hollow, glaucous, spotted with purple, branched. L. tripinnate; leaflets 
lanceolate, pinnatifid with acute cut segments. Readily distinguished by its fotid smell, spotted stem, unilateral partial involucres and wavy crenate ridges of the fruit. Highly poisonous. -Hedge-banks and waste places. B. VI. VII.

\section{Physospermum Cusson.}

1. P. cornubiense (DC.) ; radical 1. tritemate, leaflets wedgeshaped cut or deeply 3-lobed with acute segments, stem-l. ternate lanceolate entire.-E. B. 683.-St. $1-3$ feet high, erect, round, striated, minutely scabrous, bearing a few small ternate leaves with linear lanceolate segments, the uppermost represented by a barren lanceolate acute sheath. Umbels terminal. Carp. Iunger than broad; the coat loose. Seed free.-Hooker and Arnott refer P. aquilegifolium (Koch) to this ; Bertoloni with Hooker's observations before him, states that they are quite different.Devon and Cornwall, rare. P. VII. VIII.

E.

\section{Smyrnium Linn. Alexanders.}

1. S. Olusatrum (L.) ; st. terete, stem-l. ternate stalked serrate.-E. B. 230 .- St. 3-4 feet high, stout, branched, leafy, furrowed. Radical l.verylarge, all with large membranous sheaths and large ovate shining cut and serrated leaflets. Fl. greenishyellow in dense rounded umbels. Fr. nearly black, aromatic.Waste ground and near ruins. B.? V. VI.

\section{Suborder III. Colosperma. Tribe XII. Coriandrea.}

\section{Cortandrum Linn. Coriander.}

*1. C. sativum (L.).-E. B. 67.-St. 12-18 in. high, leafy, round, striated. L. bipinnate, cut; upper ones more divided into linear segments. Fl. white.-Fields and waste places, an escape from cultivation. A. VI.

\section{Order XXXVIII. ARALIACEA.}

Cal. 4-5-toothed, adnate to the ovary. Pet. 5-16, rarely wanting; æstivation valvate. Stam. as many as the pet. and alternate with them or twice as many, inserted below the margin of an epigynous disk. Ovary with 2 or more cells. Styles as many as the cells. Fr. succulent or dry, of several cells each with 1 pendulous seed. Albumen fleshy. Embryo minute (not so in our Hedera).-L. alternate without stipules.

1. Adoxa. Cal. half inferior, limb trifid. Cor. superior, $4-5$-cleft, rotate with a short tube contracted at the throat. 
Stam. 8-10, in pairs alternate with the petals, anthers 1celled. Berry 4-5-celled; cells 1-seeded.

2. Hedera. Cal. superior, limb of 5 teeth. Pet. $5-10$, not adhering at the apex. Stam. 5-10. Styles 5-10, connivent, or combined into one. Berry 5-celled and 5-seeded, crowned with the calyx.

\section{Adoxa Linn. Moschatel.}

1. A. Moschatellina (L.).-E. B.453.-Rhizome white, fleshy, toothed, stoloniferous. St. solitary, erect, simple, 3-4 in. high, with 2 opposite leaves, and a head of 4 whorled and 1 terminal flowers. Stam. often more or less combined, showing their number to be normally 4 . Fl. with a musky smell. Terminal fl. usually divided in fours, the others in fives, but the numbers vary.-Woods and shady hedge-banks. P. IV. V.

\section{Hedera Linn. Ivy.}

1. H. Helix (L.); l. coriaceous ovate or cordate and 5-lobed, lobes angular, umbels simple downy erect.-E. B. 1267.-Climbing by means of rootlike fibres. L. of the flowering branches ovate-oblong, acute, entire. Berries black. Embryo like that of Cornacea.-Rocks, old walls, hedges. Sh. X.XI.

\section{Order XXXIX. CORNACEÆ.}

Cal. 4-lobed. Pet. 4, oblong, broad at the base, inserted at the top of the calyx-tube; æstivation valvate. Stam. 4. Ovary 2-celled. Style filiform. Fruit a drupe, crowned with the remains of the calyx. Seed pendulous, solitary. Embryo in the axis of fleshy albumen and as long as it.-Leaves opposite.

1. Connus. Calyx-limb superior, of 4 teeth. Pet. 4. Stam. 4. Style 1. Drupe with a 2-celled and 2-seeded nut.

\section{Cornus Linn.}

1. C. sanguinea (L.); arborescent, branches straight, 1. ovate cuspidate green on both sides, cymes flat without an involucre. - E. B. 249. St. 52. 3. - Shrub 5-6 feet high. Old bark reddish. Fl. many, white, in terminal cymes. Fr. dark purple. L. mostly opposite, strongly veined, acutely cuspidate, rounded below.-Hedges and thickets. Sh. VI. Dog-wood.

2. C. suecica (L.); herbaceous, 1. all opposite sessile ovate, fl. umbellate shorter than the 4-leaved petaloid involucre.-E.B. 310. St. 52. 1.-Flowering shoots about 6 in. high, annual, springing from the procumbent or subterranean creeping woody 
leafless stems. Fl. dark purple with yellow stamens, in a small solitary terminal umbel with an inv. of 4 ovate yellow l. tipped with purple. Fr. red.-Moist alpine pastures. P. VII. E. S.

\section{Subdivision III. COROLLIFLORÆ.}

Pet. united bearing the stamens.

\section{Order XL. LORANTHACEA.}

Cal. adnate to the ovary, with 2 bracts at its base ; limb entire or lobed. Cor. of $4-8$ more or less united petals. Stam. as many as and opposite to the petals with which the filaments more or less combine; anth. sometimes adnate to the petals. Ovary 1, 1-celled with 1 erect ovule. Style filiform or 0. Stigma capitate. Fr. succulent. Albumen fleshy.-Parasitical plants with entire, mostly opposite leaves.

1. Viscum. Diøcious. Male: Cal.0. Pet. 4, ovate, fleshy, united at the base. Anth. adnate to the petals, many-celled. Fem. : Cal. an obscure entire superior margin. Pet. 4, erect, somewhat triangular, minute. Stigma sessile, obtuse. Berry 1-seeded, crowned with the calyx.

\section{Viscum Linn. Mistletoe.}

1. V. album (L.); st. repeatedly dichotomously branched, branches terete, $\mathrm{l}$. ovate-lanceolate obtuse, fl. in the forks of the stem sessile clustered.-E. B. 1470. St. 8.-Evergreen, parasitical, yellow, succulent. Male fl. about 3 together, female about 5, yellowish. Berries white, pellucid, globular, viscid.-Parasitical on various trees. P. III. IV.

\section{Order XLI. CAPRIFOLIACEZ.}

Cal. adnate with the ovary, usually with bracts at the base; limb 4-5-lobed. Cor. regular or irregular, 4-5-cleft. Stam. free, on the corolla, $4-5$, alternate with the lobes. Ovary 3-5celled. Stigmas 1-3. Fruit indehiscent, 1- or many-celled, usually fleshy. Albumen fleshy.-L. opposite.

1. Sambucus. Cal.-limb 5-cleft. Cor. rotate, 5-lobed. Stam. 5. Stigmas 3, sessile. Fr. 3-4-seeded.

2. Viburnum. Cal.-limb 5-cleft. Cor. bell-or funnel-shaped, 5-lobed. Stam. 5. Stigmas 3, sessile. Fruit 1-seeded.

3. Lonicera. Cal.-limb small, 5-cleft. Cor. tubular or funnelshaped, usually saccate at the base, limb 5-fid or irre- 
gular. Stam. 5. Style filiform. Stigma capitate. Fruit 1-3-celled, few-seeded.

4. Linnea. Cal.-limb 5-cleft, with lanceolate subulate equal deciduous segments. Cor. turbinate-bellshaped, 5-lobed. Stam. 4, rarely 5, 2 longer. Style filiform; stigma capitate. Fr. dry, 3-celled; 2 cells barren, 1 single-seeded.-Two large and 2 minute bracts at the base of the fruit.

\section{SAmbucus Linn. Elder.}

1. S. Ebulus (L.); herbaceous, st. furrowed, stip. leaflike ovate serrate, 1 . pinnate, leaflets lanceolate serrate, cyme with 3 principal branches. - E. B. 475.-St. 2-4 feet high. Cymes terminal. Fl. white, reddish externally; anth. purple. Fr. reddishblack.-Hedge-banks. P. VIII. Dwarf Elder. Danewort.

2. S. nigra (L.) ; arborescent, stip. obsolete, l. pinnate, leaflets ovate cuspidate serrate, cymes with 5 principal branches.-E. $B$. 476.-A small tree. Cymes large, terminal. Fl. cream-coloured. Fr. black, rarely green or white.- $\beta$. laciniata ; $1.2-3-$ pinnate, lts. laciniate. $-\gamma$. rotundifolia (DC.); lts. usually 3 quite round.-Woods and hedges. $\beta$. near Ayr. Hooker. Enderby, Leicestershire. $\gamma$. Isle of Wight. T. VI. Elder.

\section{Viburnum Linn. Guelder-rose.}

1. V. Lantana (L.); $l$. elliptical with a cordate base finely denticulate-serrate downy beneath, pubescence stellate.-E. $B$. 331. - A small tree with round mealy branches. Young shoots, petioles, and under sides of the 1. densely, upper side more sparingly, covered with stellate down. Cymes terminal. Fl. white, not radiant. Fr. black.-Hedges and thickets on a calcareous soil. T. V. Mealy Guelder-rose. Wayfaring tree. E. S.

2. V. Opulus (L.); l. 3-5-lobed, lobes acuminate and dentate, petioles with glands.-E. B.332. St. 27.6.-Branches glabrous, tetragonal when young. L. slightly downy beneath. Cymes large, with linear bracts; $\mathrm{fl}$. white, inner ones fertile, outer barren and radiant. Fr. red. Hedges and thickets. T. VI. VII. Common Guelder-rose.

\section{Lonicera Linn. Honeysuckle.}

†1. L. Caprifolium (L.) ; fl. ringent whorled terminal sessile, 1. deciduous glabrous on both sides obtuse, upper l. connate-perfoliate, style glabrous.-E. B. 799.-St. twining. Fl. white or purplish. Fr. orange. Upper pairs of leaves connate, the rest distinct.-Thickets. Sh. V. VI.

2. L. Periclymenum (L.); fl. ringent capitate terminal, heads 
stalked, l. all distinct deciduous oval, st. twining. - E. B. 800.Fl. pale yellow, externally red. Fr. red. L. sometimes downy beneath, rarely lobed.-Woods and hedges. Sh. VI.-IX. Honeysuckle. Woodbine.

3. L. Xylosteum (L.) ; peduncles 2-flowered downy as long as the flowers, calyx-limb deciduous, berries slightly connected at the base, l. oval downy, st. erect.-E. B. 916.-Fl. pale yellow. L., bracts, cal., cor. externally, filaments, and style downy. Fr. scarlet.-Thickets. Native in Sussex. Sh. V.

\section{IINN}

1. L. borealis (Gron.).-E. B. 433.-St. trailing and creeping. L. opposite, broadly ovate, stalked, dark green above, paler beneath. Peduncles long, erect, 2-flowered, from short lateral branches with 2-4 leaves. Fl. flesh-coloured, purple within.Woods, chiefly of fir, in the north. P. VII. E. S.

\section{Order XLII. RUBIACE $\nexists$.}

Cal. superior, entire or lobed. Cor. regular, 4-6-lobed. Stam. 4-5, alternate with the lobes of the corolla. Ovary 1, 2-celled, with solitary erect ovules. Style 1, often bifid. Stigmas 2. Fr. a didymous indehiscent pericarp. Embryo straight in horny albumen.

1. Sherakdia. Cor. funnelshaped. Fr. crowned with the 6-toothed calyx, dry.

2. Asperula. Cor. funnelshaped. Fr. dry, not crowned with the limb of the calyx.

3. Galium. Cor. rotate. Fr. dry, not crowned with the calyx.

4. Rubia. Cor. rotate. Fr. succulent, 2-lobed.

\section{Sherardia Linn.}

1. S. arvensis (L.).-E. B. 891.-St. mostly decumbent, branched, square, leafy. L. 6 in a whorl, obovate-lanceolate, acute. Fl. lilac, in a small sessile terminal umbel. Cal. of 4 segments, 2 of them bifid.-Fields. A. V.-VII.

\section{Asperula Linn.}

1. A. cynanchica (L.) ; l. 4 in a whorl linear, uppermost 1. very unequal, $\mathrm{fl}$. corymbose, bracts lanceolate mucronate, cor. scabrous, "fr. granular-scabrous."-E. B. 33.-Root fusiform. Stems many diffuse or ascending branched. Fl. generally lilac. -Dry banks in limestone districts. P. VI. VII. 
2. A. odorata (I.); $l$. $6-8$ in a whorl lanceolate, margins scabrous, fl. in stalked terminal corymbs, fr. hispid.-E. B. 755. -St. erect, about 6 in. high. Fl. white. L. broad. Whole plant fragrant.-Woods. P. V. VI. Woodruff.

[A. arvensis (L.); $l$. 6-10 in a whorl linear-lanceolate obtuse, fl. aggregate terminal surrounded by long ciliated bracts, fr. glabrous.-E. B. S. 2792.-Like Sherardia arvensis. Fl. bright blue.-Introduced. Devonport. A. VI.]

[*A. taurina $($ L. $) ; 1.4$ in a whorl elliptical acuminate 3 -veined, fl. corymbose, cor.-tube very long, fr. punctulate scabrous.Cadeby, Leicestershire. Casterton Woods, Westmoreland.]

\section{Galium Linn. Bed-straw.}

A. Leaves 3-veined.

* Inflorescence panicled, terminal ; fl: perfect ; fr.-stalks erect.

1. G. boreale (L.); l. 4 in a whorl lanceolate, st. erect panicled, fruitstalks patent, fr. covered with hooked bristles.-E. B. 105.St. about 18 in. high; branches many, leafy. Fl. white in compact terminal panicles.-Moist rocky places. P. VII. VIII.

** Inflorescence axillary; lateral fl. imperfect ; fr.-stalks deflexed.

2. G. cruciatum (Witb.); $l .4$ in a whorl elliptic-oblong hairy, flowers corymbose bracteated, terminal fl. fertile, lateral mostly male, fr. smooth. - E. B. 143.-St. simple above, l-2 feet high, hairy. Fl. small, about 8 together in small corymbs, yellow." $\beta$. peduncles and pedicels glabrous."-Hedges and thickets. P. V. VI. Crosswort.

B. Leaves l-veined. Root annual.

* Inflorescence axillary : lateral fl. imperfect.

[3. G. saccharatum (All.); l. about 6 in a whorl linear-lanceolate with marginal forward prickles, st. rough with decurved prickles, peduncles 3-flowered, fr. warted reflexed.-E. B. 2173. -St. procumbent, spreading. Fl. small, pale yellow. Fr. large, a double globe, with large pyramidal tubercles.-Carse of Gowrie and Forfar. Malton, Yorkshire. A. VI.-VIII.] E. S.

** Inflorescence axillary, panicled; $f$. all perfect.

4. G. tricorne (With.); l. 6-8 in a whorl linear-lanceolate with marginal backward prickles, st. rough with deflexed prickles, 
peduncles 3-flowered, fr. granulated reflexed.-E. B. 1641.-St. procumbent, spreading. Fl. small, all 3 appearing perfect, the middle one usually alone fertile. Fr. large, a double globe, covered with small granulations.-Dry calcareous fields. A. VI. - IX.

5. G. Aparine (L.); 1. 6-8 in a whorl linear-lanceolate with marginal backward prickles, st. rough with deflexed prickles, peduncles few- (about 3 ) flowered, fruitstalks divaricated straight, fruit covered with short hooked bristles.-E. B. 816.-St. straggling amongst bushes, $3-4$ feet long. The marginal prickles near the extremity of the 1. point forwards, the rest backwards. Fl. small. Peduncles or rather flowering branches with several leaves at the primary divisions. Fr. large.-Common. A. VI. -VIII. Goose-grass. Cleavers.

6. G. spurium (L.) ; 1. 6-8 in a whorl linear-lanceolate with marginal backward prickles, st. rough with deflexed prickles, peduncles with 3-9 flowers, fruitstalks divaricated straight. $-E . B$. 1871.-Closely resembling the preceding; distinguished by its more numerous green flowers, floral leaves solitary ("or in pairs"), fruit of about half the size and smooth.- $\beta$. G. Vaillantii (DC.); fr. hispid. E. B. S. 2943.-Fields. a. Forfar; $\beta$. Saffron Walden and Chesterford, Essex. A. VII.

E. S.

7. G. parisiense (L.); l. about 6 in a whorl linear-lanceolate bristle-pointed with marginal forward prickles, st. rough with decarved prickles, panicles small dichotomous, branches divaricated bifid.-G. anglicum Huds., E. B. 384.-St. 6-8 in. high, spreading, slender, brittle. L. usually 6 in a whorl, the lowermost sometimes in fours. Branches of the small panicles often spreading nearly at right angles with their stalk. Fr. granulated, nearly black. The typical G. parisiense has hooked prickles on the fruit.-Old walls and dry sandy places. A. VI. VII.

C. Leaves 1-veined. Root perennial. Fl. in terminal panicles.

\section{* Fruit not granulated. No downward prickles on the stem.}

8. G. erectum (Huds.) ; l. about 8 in a whorl lanceolate mucronate the margins rough with forward prickles, midrib slender, branches of the panicle all ascending, fruitstalks divaricated, fr. oval smooth, pet. taper-pointed.-E. B. 2067.-St. weak, glabrous or hairy, ascending. L. lanceolate, scarcely at all obovate; margins with 2 rows of prickles pointing forwards; midrib beneath rather slender, smooth.- $\beta$. cinereum; $1.6-8$ in a whorl linear. -G. cinereum Sm., E. B. S. 2783, seems to be only a narrowleaved variety.-G, aristatum (Sm.), E.B. 2784 , has l. in sixes but is probably a state of this.-Hedges and pastures. P. V1. VII. 
9. G. Mollugo (L.); l. about 8 in a whorl lanceolate-obovate or obovate-oblong cuspidate the margins rough with forward prickles, midrib slender, branches of the panicle many-flowered lower ones spreading horizontally or deflexed, fruitstalks divaricated, fr. glabrous, pet. cuspidate.-E. B. 1673.-St. ascending, square, thickened at the joinings, glabrous, or in $\beta$. scabrum (Sm.) as well as the l. hairy. Panicle large. Fl. small. $-\gamma$. G. insubricum (Gaud.); 1. about 6 in a whorl obovate abruptly cuspidate, branches of the panicle few-flowered terminating in trichotomous umbels, floral l. large, bracts large usually solitary.-Hedges and thickets. $\gamma$. Winander Mere. P. VII. VIII.

10. G. verum (L.); l. about 8 in a whorl linear-setaceous with revolute margins channeled above downy beneath, panicles many small densely flowered subterminal, fruitstalks patent, fruit smooth, pet. obtuse and apiculate.-E.B. 660.-St. erect, slightly branched, somewhat woody, with many whorls of narrow deflexed leaves. $F l$. golden yellow, rarely green or straw-coloured, usually in many small dense panicles collected into a kind of terminal spike. St. and upper surface of the 1. sometimes downy or scabrous. On loose sands the st. are much more branched and the fl. sometimes solitary but agreeing in all other respects with this species.-Dry and sandy places. P. VII. VIII.

** Fruit granulated, not hairy. St. without downward prickles.

11. G. saxatile (L.); l. about 6 in a whorl obovate pointed, midrib slender, panicles corymbose small, fl.- and fr.-stalks erectpatent, fr. granulated, pet. acute.-E. B. 815.-St. many, procumbent, much branched. L. suddenly narrowed to a point, smooth, with a few marginal forward prickles; lower 1. roundly obovate. Turns black in drying.-Heaths. P. VII. VIII.

12. G. montanum (Vill.); $1.6-7$ in a whorl, lower $l$. obovatelanceolate, upper $l$. narrower, midrib "rather thick and prominent below," pan. loose few-flowered, fl.- and fr.-st. erect-patent, fr. slightly rough, pet. " apiculate."-St. many, slightly ascending, much branched. L. glabrous or with minute mostly backward prickles. Green when dry.-Settle "and elsewhere." Mr. J. G. Baker. P. VII. VIII.

E.

13. G. commutatum (Jord.); 1. 7-8 in a whorl linear thick mucronate, "midrib broad not prominent," pan. with many branches, fl.- and fr.-st. erect-patent, fr. faintly granulated, pet. mucronate.-St. many, nearly prostrate, glabrous. L. mostly glabrous.-White Force, Teesdale. Mr. Baker. P. VIII. E.

14. G. sylvestre (Poll.); l. about 8 in a whorl linear-lanceolate mucronate, midrib slender prominent, panicles few-flowered, fl.- and fr.-st. erect-patent, fr. faintly granulated, pet. acute.- 
G. pusillum E. B. 74, not Linn.-St. many, slender, square, diffuse, ascending. L. often nearly glabrous or with marginal hairs (not prickles) spreading or backward. Lower part of stem and leaves sometimes densely covered with patent hairs. Panicle very variable in size. Fr. very minutely granulated.-Limestone hills, rare. P. VI. VII.

*** Stem rough with downward prickles.

15. G. uliginosum (L.); l. 6-8 in a whorl linear-lanceolate bristle-pointed with margins rough like the angles of the stem with backward prickles, panicles small axillary few-flowered trichotomous the branches patent 3-fid, fruitstalks divaricate straight, fruit granulated.-E. B. 1972.-Stems slender, brittle, about a foot high, weak. L. usually 6 in a whorl, discoloured at the tip and shortly acuminate. Branches of the small panicles divaricate. Fr. dark brown.-Wet places. P. VII. VIII.

16. G. palustre (L.); $l .4$ in a whorl broadly linear broader upwards blunt, midrib slender, panicle diffuse, fr.-st. straight spreading at right angles, fr. small ( $1 \frac{x}{4}$ lin. nearly) smooth.-St. 1-2 feet high, slender usually branched. Fl. small, white. St. and branches nearly smooth. L. very narrow, lowest usually in sixes, upper in fours of which 2 are smaller.-G. Witheringii (Sm.) differs only by having rough edges to the leaves.-Wet places by ditches and rivers. P. VII. VIII.

17. G. elongatum (Presl); $l .4$ in a whorl linear-oblong blunt narrowed below, midrib prominent, panicle diffuse, fr.-st. spreading at right angles, fr. large slightly rough.-G. palustre, $E$. $B$. 1857. - Differs from G. palustre by its thick weak stem $2-4 \mathrm{ft}$. high, less branched and entangled; 1 . broad and long (sometimes $1 \frac{1}{2}$ in. long and $\frac{1}{4}$ broad, but usually smaller); fl. and fr. of twice the size. Known at sight by the much superior size of all its parts.-Wet places. P. VII. VIII.

\section{Rubia Linn. Wild Madder.}

1. R. peregrina (L.) ; 1. 4-6 in a whorl elliptic or lanceolate shining smooth above without veins the margin and keel rough with reflexed bristles.-E.B.851.-Old st. terete; shoots spreading, square. L. rigid, persistent. Cor. rotate, 5-cleft; lobes oval suddenly narrowed into a slender point.-Stony and sandy thickets in the south. P. VI.-VIII.

\section{Order XLIII. VALERIANACEÆE.}

Cal. superior; limb various, toothed, obsolete or involute and ultimately resembling a pappus. Cor. tubular, 3-5-lobed, un- 
equal or irregular often spurred or gibbous at the base. Stam. $1-5$, inserted in the tube, free. Ovary with 1 perfect cell and often 2 abortive cells ; ovule solitary, pendulous. Fr. dry.

1. Centranthus. Cor, regular, 5-lobed, with a spur. Stam. 1. Fr. 1-celled, indehiscent, crowned with the limb of the calyx expanded into a feathery pappus.

2. Valeriana. Cor. regular, 5-lobed, gibbous but without a spur. Stam. 3. Fr. 1-celled, indehiscent, crowned with the limb of the calyx expanded into a feathery pappus.

3. Valerianella. Cor. regular, 5-lobed, without a spur. Stam. 3. Fr. 3-celled, indehiscent, crowned with the erect unequally toothed limb of the calyx, 2 of the cells usually empty inflated or filiform.

\section{Centranthus Cand.}

†1. C. ruber (DC.); 1. ovate-lanceolate, spur much shorter than the tube of the corolla and twice as long as the germen.Valeriana Sm., E. B. 1531.-St. 1-2 feet high. Fl. purple or white.-Chalk-pits and old walls. P. VI.-IX. Red Valerian.

[C. Calcitrapa (Dufr.); radical l. ovate entire, stem-1. pinnatifid, spur very short, is naturalized at Eltham in Kent.]

\section{Valeriana Linn. Valerian.}

1. V. officinalis (L.); $l$. all pinnate, $l t s .15-21$ lanceolate dentate-serrate terminal one not larger than the others, st. sulcate solitary, fr. glabrous ovate-oblong. $-R$. xii. 727. St. 9.Root with short subterranean stoles. St. $2-4$ feet high. Anterior edge of lts. nearly entire, posterior strongly toothed. Fl. flesh-coloured. Radical l. on long stalks. Fr. narrowed usually from about its middle.- $V$. angustifolia (R.); lts. more numerous nearly entire. $R$. xii. 728.-Ditches and damp chalky places. P. VI. VII.

2. V.sambucifolia (“Mikan."); 1 . all pinnate, lts. 9-11 dentate-serrate, of the radical 1. ovate acute, of the stem-l. oblonglanceolate, terminal lt. not larger than the others, st. sulcate solitary, fr. glabrous ovate-attenuate. $-R$. xii. 726. $V$. officinalis Sm., E. B. 698.-Root with long stoles usually not buried. St. $2-4$ feet high. Lts. toothed on both edges ; term. lt. of rt.-l. sometimes slightly larger than the others. Fr. narrowing from below its middle.-Damp places. P. VI. VII.

*3. V. pyrenaica (L.); l. heartshaped serrate stalked, upper 1. with $1-2$ pairs of small lanceolate leaflets. $-E$. B. 1591.-St. 
2-3 feet high, furrowed. Fl. light rose-coloured.-Woods in Scotland. P. VI. VII.

E. S.

4. V. dioica (L.); fl. imperfectly diœcious, root-l. ovate stalked, stem-l. pinnatifid with a large terminal lobe, fr. glabrous.-E. $B$. 628. St. 9.-St. 6-12 in. high, simple. Fl. flesh-coloured; rather large with protruded stam., barren; or small with included stamens and forming a closer corymb, fertile. Root creeping.-Boggy places. P. V. VI.

E. S.

\section{Valerianella Moench.}

* Fruit with 2 barren cells, fertile cell corky on the back.

l. V. olitoria (Moench); fr. compressed oblique, barren cells without furrows, dissepiment incomplete, bracts ciliated.-E. $B$. 811. St. 2. 3. R. xii. 708. Fedia Sm.-L. ovate-spathulate, upper ones narrower. Fl. in terminal dense cymes with oblong linear opposite bracts. Fr. 3-celled; 1 fertile with its back formed of a thick gibbous mass of spongy cellular tissue which is usually traversed by a single furrow, a groove on each side separates it from the 2 barren slightly confluent cells each of which has a slender rib on its side and their junction marked by a slight furrow.-Corn-fields and banks. A. V. VI. Corn Salad.

** Fruit with 2 barren conspicuous cells, fertile cell not corky.

2. V. carinata (Loisel.); fr. oblong boatshaped crowned with I straight tooth, cells nearly equal each with a single rib on the back, barren cells contiguous in their whole length and with a deep furrow between them, $\mathrm{fl}$. in dense cymes.-Fedia $E$. B. S. 2810. R. xii. 708.-Fl. pale blue. Root-l. spathulate, st.-1. oblong. Bracts ciliated. Section of the fr. crescent-shaped.Hedge-banks, rare. A. IV.-VI. Lambs' Lettuce. E. S.

3. V. Auricula (DC.); fr. subglobose crowned with 1 erect membranous leaf, barren cells larger than the fertile one inflated contiguous having a narrow furrow between them, $\mathrm{fl}$. scattered. -Fedia E. B. S. 2809. V. dentata DC., R. xii. 709.-Fl. distant, in the forks of a repeatedly dichotomous cyme. Lower 1. obovate attenuate downwards, upper l oblong. Bracts ciliated. Section of the fruit nearly round. Crown of one oblong obtuse obliquely truncate tooth, sometimes with a minute tooth on each side; or of 3 acute teeth, of which one is much the longest and often 3-pointed.-Cultivated land. A. VII. VIII.

\section{*** Barren cells 0 , or reduced to a rib.}

4. V. dentata (Deitr.); fr. oval crowned with the small oblique unequally 4-toothed calyx flat in front with an oblong space 
inclosed between 2 elevated curved ribs (barren cells) convex behind, cyme lax spreading, its branches long divaricated.-Fedia Sm., E. B. 1370. R. xii. 710. V. Morisonii DC.-Teeth of the crown spreading or all incurved except the largest. Fr. smooth or hairy. Fl. corymbose.-Corn-fields and banks. A. VI. VII.

5. V. eriocarpa (Desv.); fr. oval crowned with the large oblique open unequally 5-7-toothed calyx flat in front with an oval space inclosed between 2 elevated curved ribs (barren cells) convex behind, cyme condensed.-Very different in habit from the preceding but scarcely affording any specific character. A variety?-Great Orme's Head, N. Wales. A. VI. E.

\section{Order XLIV. DIPSACACEE.}

Fl. capitate. Cal. superior, surrounded by an involucel which closely invests the ripe fruit. Cor. 4-5-fid with unequal lobes. Stam. 4, inserted in the tube, free; filaments not jointed. Style 1. Stigma simple. Ovary 1-celled with a pendulous ovule. Fr. crowned with the pappus-like calyx. Embryo in fleshy albumen.

1. Dipsacus. Calyx cupshaped. Involucel forming a thickened margin to the ovary. Cor. 4-fid. Receptacle with spinous scales shorter than the involucre. Fr. with 4 sides and 8 little depressions.

2. Knautia. Calyx cupshaped with radiant teeth. Involucel terminating in 4 small teeth. Receptacle hairy; scales 0 . Fr. with 4 sides and 4 little depressions.

3. Scabiosa. Calyx of 4 or 5 bristles. Involucel membranous and plaited. Receptacle scaly. Fr. nearly cylindrical with 8 excavations.

\section{Dipsacus Linn. Teasel.}

1. D. sylvestris (L.); 1. opposite undivided sessile, stem-l. connate, scales of the receptacle straight at the end exceeding the flowers, involucres curved upwards.-E. B. 1032.-St. 5-6 feet high, prickly, leafy, branched. Heads of $t$. large, conical, overtopped by the slender ascending involucre.-Hedges and roadsides. B. VIII. IX. Wild Teasel.

[2. D. Fullonum (L.); 1. opposite undivided sessile, stem-1. connate, scales of the receptacle hooked at the end equalling the flowers, involucres reflexed.-E. B. 2080.-St. 5-6 feet high, prickly, leafy, branched. Heads of $f$. obtuse, conical, about equalling the spinous spreading involucre.-West of England, scarcely wild. B. VIII. IX. Teasel.] 
3. D. pilosus (L.); l. stalked with a lt. at the base on each side, scales of the receptacle obovate-cuspidate straight, involucres deflexed.-E.B. 877.- St.3-4 feet high, branclied, rough, leafy. Heads of fl. small, globose, exceeding the involucres.-Moist shady places. B. VIII.

E.

\section{Knautia Coult.}

1. K. arvensis (Coult.); lower l. simple, stem-l. pinnatifid, st. bristly, calyx with about 8 awned teeth.-E. B. 659 .-St. $2-3$ feet high, slightly branched, with few leaves. Radical l. many, sometimes pinnately lobed. Fl. purple, in large convex longstalked heads, outer ones usually unequal and radiant. Involucres bluntish. $-\beta$. integrifolia (Coult.); 1 . all simple narrowly lanceolate entire or superficially crenate.-Fields. P. VII.-IX. Field Scabious.

\section{Scabiosa Linn. Scabious.}

1. S. succisa (L.); root abrupt, heads of fl. and fr. nearly globose, involucel hairy 4-fid herbaceous, cor. 4-cleft regular, 1. oblong entire, upper 1. narrower mostly entire.-E. B. 878 . -St. 1-3 feet high. Radical l. many, stem-l. usually few. Fl. purplish-blue, rarely white. St. and both sides of the l. hairy or glabrous.-Meadows and pastures. P.VII.-X. Devil's bit.

2. S. Columbaria (L.); heads of fr. globose, involucel membranous plaited notched, cor. 5-cleft radiant, radical l. oblong stalked crenate entire or lyrate, uppermost l. pinnatifid with linear segments.-E. B. 1311.-St. 12-18 in. high. Radical 1. obtuse, or, rarely, lanceolate and acute, on long stalks ; upper l. rarely entire, linear. Fl. purplish._-“ $\beta$. glabra (Ball); calycine bristles more flattened with traces of a medial nerve."-On a calcareous soil. $\beta$. Pennard Castle, Glam. Mr. J. Ball. P. VII. VIII.

E. S.

\section{Order XLV. COMPOSITÆ⿸尹}

Fl. capitate, surrounded by an involucre formed of scales (phyllaries). Cal. superior; limb obsolete or forming a toothed bristly or feathery pappus. Cor. tubular or ligulate. Stam. 5, inserted in the tube; anthers united, syngenesious. Fr. an indehiscent dry pericarp with an erect seed without albumen.

The following arrangement of the genera is nearly that of Jussieu. It is more simple than that of DeCandolle, which is followed in the arrangement of the species. 


\section{Suborder I. CORYMBIFERA.}

Florets of the disk tubular; marginal florets often ligulate. Style not swollen below its branches.

\section{A. Pappus more or less hairy.}

* Anthers without bristles at their base.

(1.) 1. Eupatorium. Heads few-flowered. Phyll. imbricate oblong. Receptacle naked. Florets tubular-funnelshaped, hermaphrodite. Anth. included. Branches of the style exserted, cylindrical obtuse.

(2.) 2. Petasites. Heads many-flowered, subdicecious. Fem. florets filiform, obliquely truncate or shortly ligulate, in many rows in the fem. heads, none or in 1 row in the male heads. Male florets tubular, few and central in the fem. heads, occupying the whole disk in the male heads. Receptacle naked. Phyll. in one row.-Plants subdiœcious.

(3.) 3. Tussilago. Heads many-flowered, heterogamous. Fem. florets marginal, in many rows, narrowly ligulate. Male florets discoidal, tubular, 5-cleft. Receptacle naked. Phyll. in 1 row, with membranous margins.

(4.) 23. Senecio. Florets of the ray ligulate, fem., rarely 0 ; of the disk perfect, tubular. Involucre cylindrical or conical of 1 row of equal phyll. not membranous at the margin, with or without smaller scales at its base. Pappus pilose.

(5.) 22. Doronicum. Florets of the ray ligulate, fem.; of the disk perfect, tubular. Involucre hemispherical of 2 or 3 rows of equal phyll. Pappus pilose, wanting in the ray.

(6.) 8. Linosyris. Heads not radiant. Florets all perfect, tubular. Receptacle naked, pitted, pits with elevated dentate margins in our plant. Phyll. imbricated. Pappus pilose. Fr. compressed, silky, without a beak.

(7.) 4. Aster. Heads radiant. Florets of the ray fem., ligulate, in 1 row; of the disk perfect, tubular. Receptacle naked, pitted. Phyll. imbricated and a few scales on the peduncle. Pappus pilose, in many rows. Fr. compressed, without a beak.

(8.) 5. Erigeron. Heads radiant. Florets of the ray fem., ligulate, in many rows; of the disk mostly perfect, tubular. Receptacle naked. Phyll. imbricated. Pappus pilose, in many rows. Fr. compressed, without a beak.

(9.) 7. Solidago. Pappus pilose, in 1 row. Fr. terete. Otherwise like Aster. 
** Anthers with 2 bristles at their base.

$\dagger$ Receptacle without scales. Fr. cylindrical or tetragonal.

(10.) 9. Inula. Heads radiant. Florets of the ray fem., ligulate, rarely subtubular; of the disk perfect, tubular. Anth. with 2 bristles at the base. Receptacle naked. Phyll. imbricated in many rows. Pappus pilose, uniform, in 1 row.

(11.) 10. Pulicaria. Phyll. laxly imbricated in few rows. Pappus in 2 rows, outer short cuplike membranous toothed, inner pilose. Otherwise like Inula.

†† Receptacle without scales or scaly only at the margin. Fr. cylindrical or compressed.

(12.) 20. Gnaphalium. Outer florets fem., central perfect, all tubular. Pappus capillary. Receptacle flat, naked. Involucre hemispherical, imbricated; phyll. equalling the florets but not intermixed with them.-Cor. of the fem. florets often obsolete.

(13.) 19. Filago. Outer florets fem., filiform, in several rows, outermost ones intermixed with the inner phyllaries or paleæ; central florets few, perfect, tubular. Pappus capillary. Receptacle conical, scaly at the margin. Involucre subconical, imbricated; phyll. lanceolate, longer than the florets.

(14.) 21. Antennaria. Heads subdiœcious. Male florets tubular, style almost simple, pappus clavate. Fem. florets filiform, pappus capillary. Receptacle convex. Involucre hemispherical, imbricated; phyll. coloured at the end.

\section{B. Pappus 0 , or membranous.}

† Receptacle without scales. Heads heterogamous, radiant. Fl. of the ray fem., ligulate, in 1 row ; of the disk herm., tubular

(15.) 6. Bellis. Phyll. in 2 rows equal obtuse. Receptacle conical. Fr. compressed. Pappus 0.

(16.) 15. Chrysanthemum. Involucre hemispherical. Fr. terete, without wings, or slightly angular and somewhat winged. Pappus 0 or of 3 minute teeth.

(17.) 16. MATRICARIA. Involucre conical, hemispherical or nearly flat. Fr. angular, not winged. Pappus 0, or a slight membranous border. 
† Receptacle without scales. Heads discoidal.

(18.) 17. Artemisia. Florets of the disk perfect, of the ray fem. slender in 1 row; or all herm. and tubular. Involucre roundish. Phyll. imbricated. Receptacle naked or hairy. Fr. obovate, with a small epigynous disk, without pappus.

(19.) 18. Tanacetum. Florets as in Artemisia. Involucre hemispherical. Phyll. imbricated. Receptacle naked. Fr. oblong, angular, with a large epigynous disk (as broad as the fruit), crowned with a slight membranous border.

†† Receptacle scaly. Pappus 0 .

(20.) 12. Antuemis. Heads heterogamous, radiant. Florets of the ray fem., or neuter, ligulate, in l row; of the disk herm., tubular. Receptacle convex or conical. Phyll. imbricated, of few rows. Fr. terete, or obtusely tetragonal, without pappus, but with a more or less prominent margin.

[Anacycuus. Fr. compressed, winged at the edges. Otherwise like Anthemis.]

(21.) 13. Achillea. Heads heterogamous, radiant. Florets of the ray fem., ligulate, short ; of the disk herm., tubular; tube plane-compressed, 2-winged. Receptacle narrow, slightly elevated. Involucre ovate or oblong. Phyll. imbricated. Fr. compressed, without pappus.

(22.) 14. Diotis. Heads homogamous, discoidal. Florets herm., tubular; tube compressed, with 2 auricles at the base. Receptacle convex with concave downy-topped scales. Inv. bellshaped. Phyll. imbricated. Fr. compressed, crowned with the persistent auricled tube of the cor.; pappus 0 .

C. Pappus of 2-5 stiff bristles. Receptacle scaly.

(23.) 11. Bidens. Heads homogamous, discoidal, sometimes radiant. Florets (of the ray neuter, ligulate;) of the disk herm., tubular. Receptacle flat. Phyll. in 2 rows, outer row spreading. Branches of the style surmounted by short cones. Fr. compressed, angular, rough at the edges; the angles terminating in $2-5$ stiff retrorsely hispid bristles.

\section{Suborder II. CYNAROCEPHALEA.}

Florets all tubular. Style swollen below its branches.

a. Anthers with 2 bristles at their base.

24. Sa ussurea. Florets all herm., tubular. Phyll. imbri- 
cated, unarmed. Receptacle scaly. Pappus in 2 rows, outer of short rough bristles, inner feathery.

25. Carlina. Florets all herm., tubular. Phyll. imbricated, outer lax leaflike spinose, inner linear membranous coloured and resembling a ray. Receptacle with cleft scales. Pappus in 1 row, branched and feathery, connected into a ring below.

26. Arctium. Involucre globose. Phyll. imbricated, terminating in hooked points. Receptacle flat, with rigid subulate scales. Fr. compressed, oblong. Pappus short, pilose, distinct.

b. Anthers without bristles.

* Pappus in many rows of different lengths: inner row longest, longer than the fruit.

27. Serratula. Heads diœcious by abortion. Phyll. imbricated, sharp, unarmed. Scales of the receptacle split longitudinally into linear bristles. Fr. compressed, not beaked, basal areola oblique. Pappus persistent.

** Pappus in many rows unequal; second row longest, equal to or shorter than the fruit, rarely none.

- 28. Centaurea. Anthers with papillose filaments, involucre imbricated. Receptacle chaffy. Fr. attached laterally above

- the base to the receptacle. Pappus pilose, rarely 0.

*** Pappus in many rows, equal, long.

29. Onopordum. Receptacle honey-combed. Fr. 4-ribbed. Pappus rough. Otherwise like Carduus.

30. Carduus. Involucre imbricated with simple spinous pointed scales. Receptacle with fimbriated scales. Fr. compressed, oblong, with a somewhat fleshy terminal areola. Pappus long, pilose or plumose, united into a ring at the base and deciduous. - Includes Cnicus Linn. and Cirsium DC.

**** Pappus in many rows. Filaments monadelphous.

31. Sily вим. Involucre imbricated; scales leaflike at the base, narrowed into a long spreading spinous point. Receptacle scaly. Fr. compressed, its terminal areola surrounded by a papillose ring. Pappus pilose, united into a ring at the base, deciduous.

Suborder III. CICHORIACEA.

Florets all ligulate and perfect. 
* Pappus 0. Receptacle without scales.

32. Lapsana. Heads 8-12-flowered. Phyll. in 1 row, erect, with 4-5 short bracts at their base. Fr. compressed, striated, deciduous, not enveloped in the phyllaries.

** Pappus like a crown or of many entire broad scales. Receptacle without scales.

33. Arnoseris. Heads many-flowered. Phyll. in 1 row, about 12 , keeled, linear-lanceolate, at length converging, a few small bracts at their base. Fr. angular crowned with a short elevated entire margin.

34. Cichorium. Heads many-flowered. Phyll. in 2 rows; outer of about 5 , lax, shortish ; inner of 8-10, longer, converging, at length reflexed. Receptacle sometimes slightly pilose. Fr. obovate compressed striated. Pappus of 2 rows of minute erect chaffy scales.

*** Pappus feathery. Receptacle scaly.

35. Hyроснєris. Heads many-flowered. Phyll. oblong, imbricated. Fr. glabrous, muricated, often beaked. Pappus in 2 rows, outer short and setaceous, inner long and feathery; or in 1 row and feathery.

**** Pappus feathery, or on the exterior fruits scaly. Receptacle without scales.

36. Thrincia. Involucre oblong. Phyll, in 1 row, with a few additional at the base. Receptacle punctured. Fr. beaked. Pappus in 2 rows; outer setaceous, deciduous; inner longer, feathery, dilated at the base. Marginal row of fruits enveloped in the phyllaries, scarcely beaked and with a short crownlike fimbriated pappus.

37. APA RGIA. Involucre subinbricated, exterior phyll. much smaller in $1-3$ rows. Receptacle punctured. Fr. uniform, slightly beaked. Pappus of all the fr. in 2 rows; outer setaceous, persistent; inner longer, feathery, dilated at the base; or in 1 row feathery.

38. Tragopogon. Involucre simple, of $8-10$ phyll. connected at the base. Receptacle punctured. Fr. longitudinally striated, with a long beak; areola lateral. Pappus in many rows, feathery, interwoven in the ray.

39. PIcris. Phyll. in 1 row, equal, with unequal linear often spreading ones at the base. Receptacle dotted. Fr.terete, 
transversely striated, constricted or slightly beaked above; areola terminal. Pappus in 2 rows, feathery; external row subpilose.

40. Helminthia. Phyll. in 1 row, equal, with equal subulate adpressed ones at the base, and surrounded by $3-5$

- leaflike loose bracts. Receptacle dotted. Fr. compressed, transversely rugose, rounded at the end and with a slender beak longer than itself. Pappus in several rows, feathery.

***** Pappus filiform, deciduous, never feathery nor dilated at the base. Receptacle generally without scales. Fruit compressed.

41. Lactuca. Heads few-flowered. Phyll, with a membranous margin, imbricated in $2-4$ rows; outer row shorter. Fr. plane-compressed, contracted and produced into a filiform beak which is not crowned nor muricated at the base.

42. LeONTOdon. Heads many-flowered. Involucre double; inner of 1 row, erect; outer of few short lax or adpressed imbricated phyllaries. Fr. subcompressed, muricated and suddenly contracted above, produced into a filiform beak.

43. Sonchus. Heads many-flowered. Phyll. imbricated in 2 or 3 rows of unequal scales. Fr. plane-compressed, truncate above, not beaked.

44. Mulgedium. Heads many-flowered. Involucre double; inner of 1 row, outer of short lax imbricated phyllaries. Fr. compressed, constricted above, and terminating in a ciliated disk. Outer rows of the pappus rigid and brittle.

****** Fruit terete, ribbed. Otherwise like the preceding section.

45. Crepis. Heads many-flowered. Involucre double; inner of 1 row, outer of short lax phyllaries. Fr. terete, narrowed upwards or beaked.

46. Hieracium. Heads many-flowered. Phyll.imbricated, many, oblong. Fr. truncate above, not beaked, with a very short crenulated margin.

\section{[Anomalous Genus. Order Ambrostacee Link.}

47. Хanthium. Heads monœcious. Male : involucre of 1 row of free phyllaries, many-flowered. Receptacle scaly. Cor. funnelshaped, 5-cleft. Anth. free. Stigma obtuse, entire.-Fem. fl. 2, inclosed within the involucre which is terminated by $1-2$ beaks and covered with hooked spines and at length hardened over the fruit. Cor. filiform. 
Stam. 0. Stigmas 2, diverging, linear. Fr. compressed, each occupying a cell in the involucre.]

Suborder I. TUBULIFLORA. Perfect florets tubular, regular, teeth 4 or 5 .

Tribe I. Eupatoriece.

Style of the perfect florets cylindrical with elongated slightly clavate branches which are downy above; stigmatic lines but little promincnt, often not extending as far as the middle of the branches.

Section 1. ADENOSTYLEAE. Heads homogamous (florets all perfect).-Pappus pilose and rough.

\section{Eupatorium Linn. Hemp-Agrimony.}

1. E. cannabinum (L.); 1. in 3 or 5 deep lanceolate serrated segments the middle one longest. - E. B. 428.-St. herbaceous, erect, striated, scabrous, $2-3$ feet high. Heads in a fastigiate corymb, 5-6-flowered. Phyll. about 10; 5 exterior short obtuse. Florets reddish-purple. L. downy. Herb slightly aromatic.Banks of streams. P. VIII. IX.

Section 2. TUSSILAGINEAE. Heads heterogamous or subdiœcious.

\section{Petastes Gaert. Butterbur.}

1. P. vulgaris (Desf.); 1. roumlish-cordate unequally toothed downy beneath with approximate basal lobes, stigmas of the submale florets short ovate, female fl.truncate obliquely. $-R$.xvi.901. Tussilago Petasites Sm., E. B. 431 and 430.-Thyrsus long and lax in the female plant, ovate and dense in the male. Root thick, creeping extensively. Fl. appearing bcfore the l., on stout erect stalks which are clothed with concave tumid petioles either leafless or with a small limb. L. very large, radical, ultimately often 3 feet broad, glabrous above.-Swamps. P. IV.

[P. fragrans (Presl) which has shortly ligulate female $\mathrm{fl}$. is quite naturalized in some places in the South.]

\section{Tussilago Linn. Coltsfoot.}

1. T. Farfara (L.).-E.B.429. R. xvi.904.-Root creeping extensively. Fl. appearing before the 1., in bright yellow solitary beads, erect in blossom and seed, drooping before and after flowering, their stalks clothed with scalelike smooth bracts. L. 
roundish-cordate, angular, toothed, downy beneath. - Moist chalky and clay soils. P. III. IV.

\section{Tribe II. Asteroidece.}

Style of the hermaphrodite florets cylindrical with linear branches which are flat and equally and minutely downy on the outer surface and have narrow prominent stigmatic lines throughout.

Section 1. ERIGERINEAE. Heads never diœcious, mostly radiant. Anth. without appendages. L. alternate.

\section{4. (7.) Aster Linn. Starwort.}

1. A. Tripolium (L.); st. glabrous corymbose, l. linear-lanceolate fleshy smooth, involucre imbricate, phyll. obtuse membranous the inner ones longer.-E. B. 87.R. xvi. 907. Tripolium vulgare DC.-St. I 2 feet high, erect, hollow, leafy, manyflowered. Heads large with a yellow disk and bright blue rays; rays often wanting.-Muddy salt marshes. P. VIII. IX.

\section{5. (8.) Erigeron Linn.}

*1. E. canadensis (L.); st. much branched hairy panicled many-flowered, 1. linear-lanceolate ciliated.-E. B. 2019.-St. erect, $1-2$ feet high. Heads many, small, yellowish. Involucres cylindrical, scarcely shorter than the florets of the ray, finally spreading.-Waste ground, rare. A. VIII. IX. E.

2. E. acris (L.); st. corymbose, branches alternate 1-headed, 1. linear-lanceolate entire spreading, lower l. narrowed below, ray erect scarcely longer than the disk, inner female florets filiform many. $-E$. B. 1158. $R$. xvi. 917 . - St. erect, $6-18$ in. high, simple below, corymbosely-branched above, often several from one root. Fl. yellow, the ray pale blue.-Dry gravelly places and walls. B. VII. VIII. Fleabane.

3. E. alpinus (L.); st. mostly with a single head, l. lanceolate, lower 1 . narrowed below, ray spreading twice as long as the disk, "inner female florets tubular-filiform numerous."-E. B. 464. R. xvi. 914.-St. 4-8 in. high, usually terminating in a solitary head with a yellow disk and light purple ray. Involucre hairy. $-\beta$. E. unifforus ( $\mathrm{Sm}$. not $\mathrm{L}$.) has a shorter and more erect ray and a rather more hairy involucre. E. B. 2416.-Highland mountains. P. VII. VIII. 


\section{6. (15.) BeLxis Linn. Daisy.}

1. B. perennis (L.) ; l. obovate-spathulate single-ribbed crenate-dentate.-E. B. 424. - St. a short procumbent rhizome producing l. only at its extremity. Flowerstalks simple, each bearing a single head. Sometimes all the florets are ligulate, rarely all are tubular.-Banks and pastures. P. III.-X.

\section{7. (9.) Solidago Linn. Golden Rod.}

1. S. Virgaurea (L.); st. erect slightly angular, l. lanceolate narrowed at both ends, lower l. elliptical stalked serrated, raceme erect simple or compound, phyll. lanceolate acute, fr. downy.E. B. 30l. R. xvi. 911.-St. usually $1-3$ feet high, leafy, nearly simple, terminating in a long cluster of yellow heads. - $\beta$. angustifolia (Koch); l. all lanceolate. $-\gamma$. S. cambrica(Huds.); st. $2-6$ iu. high, l. ovate-lanceolate, heads larger.-Woods and thickets. $\beta$. on mountains. P. VII.-IX.

\section{8. (6.) Linosyris Cand.}

1. L. vulgaris (Cass.); herbaceous, 1. linear glabrous, heads corymbose, inv. lax.-Chrysocoma Linosyris Sm., E. B. 2505.St. $12-18$ in. high, simple, leafy. L. single-ribbed, smooth or scabrous, very many, more or less dotted. Fl. yellow.Limestone cliffs, rare. P. VIII. IX.

E.

Section 2. INULE EE. Heads never diocious, rarely homogamous or discoid, generally heterogamous and radiant. Female florets ligulate. Anth. with appendages. Receptacles without scales. L. alternate.

\section{9. (10.) InUla Linn.}

1. I. Helenium (L.); outer phyll. ovate, inner obovate, l. unequally dentate downy beneath cordate-ovate acute clasping, root1. stalked elliptic oblong, fr. quadrangular glabrous. $-E$. B.1546. Corvisartia Helenium R. xvi. 921.-St. 3-4 feet high, round, furrowed, solid, leafy, branched above. Heads few together or solitary, terminal, very large ; florets bright yellow. Phyll. reflexed.-Moist pastures. P. VII. VIII. Elecampane. E. I.

2. I. Conyza (DC.); phyll. all linear, 1. ovate-lanceolate downy denticulate, lower 1 . narrowed into a footstalk, florets of the ray subligulate, fr. terete.-R. xvi.923. Conyza squarrosa Sm., E.B. 1195. - St. $1-2$ feet high, leafy. Heads corymbose. Phyll. reflexed, leaflike. Fl. yellow, those of the circumference between tubular and ligulate, deeply divided on the inner side.-Calcareous soils. P.VII.-IX. Plowman's Spikenard. 
3. I. crithmoides (L.); phyll. linear taper-pointed, l. fleshy linear obtuse or with 3 points, fr. terete.-E. B. 68.-St. about a foot high, slightly branched near the top, each branch terminating in a solitary head with an orange-coloured disk and yellow rays. - On rocks and in muddy salt marshes by the sea. P. VII. VIII. Golden Samphire.

\section{0. (11.) Pulicaria Gaert.}

1. P. vulgaris (Gaert.); l. lanceolate wavy narrow at the base and somewhat clasping, st. much branched downy, heads lateral and terminal hemispherical with very short rays.-Inula Pulicaria Sm., E. B. 1196.-St. 6-12 in. high, leafy. Heads small; florets yellow. Fr.terete. Outer pappus setulose-laciniate.-Moist sandy heaths. A. VIII. IX.

2. P. dysenterica (Gaert.) ; $l$. oblong cordate at the base clasping obsoletely toothed downy beneath, st. panicled woolly, heads axillary and terminal corymbose, rays much exceeding the disk. - Inula E. B. 1115.-Floccose. St. 12-18 in. high, leafy. Heads larger than in No. 1, bright yellow; fr. angular. Outer pappus cuplike, crenulate.-Damp places. P. VIII. IX. Fleabane.

\section{Tribe III. Senecionea.}

Style of the hermaphrodite florets cylindrical with long linear branches terminated by a bunch of hairs or sometimes extending beyond the hairs into a short cone or elongated appendage. Stigmatic lines broad and prominent and extending as far as the hairs.

Section 1. HELIANTHEAE. Heads usually heterogamous and radiant, or homogamous and discoid. Anth. without appendages. Receptacle paleaceous throughout or only near the margin. Cor. of the hermaphrodite florets with thickened lobes. Pappus aristate in our plants.

\section{1. (23.) Bidens Linn.}

1. B. tripartita (L.); l. stalked 3-partite, segments lanceolate serrate, fr. obovate-cuneate usually with 2 bristles. $-E . B .1113$. R. xvi. 941.-St. 1-3 feet high, with opposite branches. L narrowed into winged footstalks, sometimes undivided, sometimes pinnate-5-fid. Heads terminal, solitary, slightly drooping. Florets brownish-yellow.- $\beta$. radiata; with radiant 3 -toothed marginal florets.-Marshy places. A. VIII. IX. 
2. B. cernua (L.); $l$. sessile connate lanceolate undivided serrate, fr. cuneate usually with $3-4$ bristles. $-E$. B. 1114. $R$. xvi. 94l.-St. 1-3 feet high, with opposite branches. L. simple, narrowed below but not stalked. Heads terminal, solitary, drooping. Florets brownish-yellow.- $\beta$. radiata; with radiant marginal florets. Coreopsis Bidens (L.) St. 1. 16.-Watery places. A. VIII. IX.

Section 2. ANTHEMIDE $A$. Heads usually heterogamous; ray female or neuter. Anth. without appendages. Branches of the style truncate, bearded, very rarely terminated by a cone. Pappus often wanting or crownlike, rarely formed of scales or capillary hairs.

\section{2. (20.) Anтhemis Linn. Chamomile.}

* Scales of the receptacle lanceolate or oblong terminating in an acute rigid point.

1. A. arvensis (L:); receptacle conical, fr. tetragonal, l. bipinnatifid hairy, segments linear-lanceolate. $-E . B$. 602 . $R$. xvi. 1004.-St. 1-2 feet high, striated, downy, much branched. Segments of the 1. parallel and at length converging. Heads on long stalks, solitary, terminal; disk convex, bright yellow ; ray white, always having styles. Scales just appearing above the florets of the disk, lanceolate. Outer fr. crowned with a tumid plicate-rugose ring, inner with an acute margin.-Borders of cultivated fields, rare. A. VI. VII. Corn Chamomile.

[2. A. tinctoria (L.); receptacle hemispherical, fr. tetragonal crowned with a membranous undivided border, 1. bipinnatifid downy beneath, segments parallel decurrent serrated, ray shorter than the breadth of the disk. $-E$. B. 1472. - St. $1-2$ feet high, much branched, cottony. L. green, rough or hairy above, cottony and white beneath. Heads on long stalks, solitary, terminal; disk and rays bright yellow. Scales not protruding.-Fields and stony places, rare. B.? VII. VIII.] E. S.

[3. A. anglica (Spr.); receptacle flat, fr. crowned with a very narrow entire border, 1 . pinnatifid somewhat hairy, lobes inciseserrate acute bristle-pointed rather fleshy. $-A$. maritima Sm., E. B. 2370.-St. prostrate, branched, downy. Involucre downy. Disk yellow ; ray white. Scales of the receptacle shorter than the opened flowers, subulate. (See DC. Prod.vi. 10.)-Sea-shore. Sunderland. Mr. Robson. Mr.Backhouse. 1844! A. V1I.] E.

** Scales of the receptacle linear-setaceous acute. MARUTA Cass.

4. A. Cotula (L.); receptacle elongate-conical, fr.terete tubercular-striated crowned with a crenulated margin surrounding a 
slightly convex disk, l. bipinnatifid nearly glabrous, lobes linear acute mostly entire.-E. B. 1772. R. xvi. 1000.-St. 1-2 feet high, branched, angular, furrowed. Heads solitary on long terminal stalks; scales confined to the central part of the receptacle; disk yellow; ray white, without styles. Tube of cor. 2 -winged. Phyll. obtuse,with white membranous margins. Whole plant fetid and acrid.-Fields and waste places. A. VII.-IX.

\section{*** Scales of the receptacle thin membranous obtuse.}

5. A.nobilis (L.); receptacle conical,fr. " subtrigonous smooth crowned with an obsolete margin," l. bipinnate, leaflets linearsubulate slightly downy rather fleshy acute. $-E$. B. 980. St. 27 . 15.-St. procumbent, 1 foot long, much branched. Heads solitary, terminal ; disk yellow ; ray white. Pleasantly aromatic.Gravelly and sandy places. P. VII. VIII. Chamomile. E.I.

[Anacyclus radiatus (Lois.); 1. bipinnatifid rather woolly, lobes linear-subulate, outer phyll. hairy on the back, inner obtuse dilated diaphanous above.-Head solitary; ray yellow.-Dunboy Quay, Bearhaven, Cork. Mr.W. Wilson. A. VII.]

\section{3. (21.) Achillea Linn. Yarrow.}

1. A. Ptarmica (L.); l. shining linear-lanceolate attenuated acute glabrous smooth uniformly and finely serrate, serratures adpressed mucronate minutely scabrous at the margin, ray 8-12flowered equalling the involucre, corymb compound.-E. B. 757 . $R$. xvi. 1024.-St. about 2 feet high, slightly branched above, erect, leafy, angular, smooth. Phyll. with a dark brown membranous inargin. Limb of the radiant florets longer than broad, white. Disk broad, white. L. sometimes very narrow; serratures closely adpressed, lower not deeper than the others.Moist meadows and thickets. P. VII. VIII. Sneezewort.

[2. A. decolorans (Schrad.); l. opaque linear-lanceolate bluntish downy thickly punctured coarsely and doubly serrate with spreading serratures laciniate and radiating at the base, ray 5- or 6flowered about equalling the involucre, corymb compound.- $A$. serrata Sm., E. B. 2531 (not Retz.).-St. simple, erect, leafy, with axillary leafy tufts, downy. Phyll. with a reddish-yellow membranous margin. Limb of the radiant florets pale yellow, broader than long. Disk darker yellow. L. not at all attenuated and very different in shape, consistency and sculpture from those of the preceding. - Near Matlock. P. IX.]

*3. A.tomentosa $(\mathrm{L}$. $)$; l. with a linear-lanceolate outline pinnatifid woolly, lobes crowded linear acute, trifid in the lowermost leaves, $2-3$-fid in the intermediate, uppermost simple, corymb repeatedly compound, ray equalling about half the involucre.- 
E. B. 2532.-St. 10-12 in. high, decumbent at the base, woolly, simple. Phyll. woolly, edged with brown. Disk and rays golden-yellow.-Naturalized. P. VII. VIII. S. I.

4. A. Millefolium (L.); l. with a lanceolate outline bipinnatifid woolly or nearly glabrous, lobes cut with linear segments, rachis entire or subdentate with entire teeth, corymb dense, rays equalling about half the involucre $-E . B$. 758. R. xvi. 1024.-St. erect, $6-18$ in. high, nearly glabrous or woolly. Phyll. nearly glabrous with a brown margin. Heads small. Florets white, occasionally reddish or purple.-Pastures and waste ground. P. VI.-VIII. Yarrow. Millefoil.

5. A. tanacetifolia (All.); stem-l. with an oblong outline bipinnatifid woolly or nearly glabrous, rachis winged serrate, pinna pinnules and teeth of the rachis incise-serrate, corymb dense, rays equalling about half the involucre. $-R$. xvi. 1027.-St. $3-4$ feet high, erect, woolly. Root-l. stalked, with a lanceolate outline; rachis with large incise-serrate teeth especially just under the pinnæ. Pinnæ and pinnules broad. Rachis of the st.-1. and the upper part of the radical 1. broadly winged. Fl. yellowish. St.-l. sometimes pinnatifid only.-Ringing Low near Sheffield; Cromford Moor, Derbyshire. Mr. John Hardy. P. VII.

E.

\section{4. (22.) Diotis Desf. Cotton-weed.}

1. D. maritima (Cass.).-E. B. 141.-Densely cottony and white. St. about a foot high, recumbent below, densely leafy, corymbose above. L. sessile, oblong, obtuse, flat, crenate, persistent. Heads in terminal corymbose tufts. Inv. cottony. Florets yellow.-Sandy sea-shores, rare. P. VIII. IX. E.

\section{5. (16.) Chrysanthemum Linn.}

1. C. Leucanthemum (L.); lower 1. obovate stalked, stem-1. oblong obtuse cut sessile pinnatifid at the base, phyll. lanceolate obtuse with a narrow membranous margin, florets of the ray white, fr. without a border.-E. B.601. St.2.11.-St.erect, $1-2$ feet high, simple, striated. Lower 1 . narrowing into a winged and auricled stalk. Heads solitary, terminal, large; disk yellow.Fields. P. VI.-VIII. Ox-eye.

2. C. segetum (L.); 1. glabrous toothed dilated outwards and lobed, upper l. clasping, phyll. ovate obtuse with a broad membranous margin, florets of the ray yellow. - E. B. 540.-St. a foot high, alternately branched, angular. L. incise-serrate or lobed in the upper part, simply toothed below. Heads solitary, terminal.-Corn-fields. A. VI.-VIII. Corn Marigold. 


\section{6. (17.) Matricaria Linn. Feverfew.}

1. M. Parthenium (L.); l. stalked pinnate, segments ovate or oblong pinnatifid, lobes cut, st. branched, heads corymbose, phyll. linear obtuse, receptacle convex, fr. crowned with a short jagged membrane.-E. B. 1231.-St. erect, 2 feet high, branched, furrowed, panicled. Heads in small corymbs terminating the stem and branches; disk yellow ; ray white.-Waste places, not very common. P. VII. VIII. Feverfew.

2. M. inodora (L.); $l$. sessile pinnatifid with many capillary pointed segments, st. branched, heads solitary, phyll. lanceolate obtuse, receptacle ovate, $f r$. rugose and with 2 round glandular dots on the external face just below the elevated entire border.E. B. 676.-St. erect, $12-18$ in. high, smooth, angular. L. in very narrow elongated mostly alternate segments "furrowed beneath." Heads solitary, terminating the branches ; margin of phyll. cut and fuscous ; ray white ; disk yellow. Fr. with 3 prominent smooth ribs; intermediate spaces rugose, 2 narrow and internal, 1 broad and external.- $\beta$. $M$. maritima $\left(\mathrm{L}_{\text {. }) \text {; segments }}\right.$ fleshy linear bluntish convex above, principal ribs keeled beneath, fr. with 2 elongated glandular spots on the external face just below the lobed elevated border. E. B.979. L. with short crowded mostly opposite segments. "Margin of phyll. pale and entire." Fr. with 3 prominent smooth ribs; a narrow intermediate rugose space externally, 2 internal spaces reduced to simple lines.-Fields and waste places. $\beta$. Sea-shore. A.VII. VIII.

3. M. Chamomilla (L.); l. bipinnate smooth, segments capillary simple or divided, heads solitary, receptacle hollow conical, phyll.linear obtuse.-E.B.1232.-St. erect, 1 foot high, branched. Heads on long naked stalks; disk yellow; ray white.-Cultivated and waste ground. A.VI. VII. Wild Chamomile.

\section{7. (18.) Artemisia Linn. Wormwood.}

* Receptacle hairy.

1. A. Absinthium (L.); heads drooping hemispherical hetero-. gamous, 1. silky in many deep lanceolate obtuse segments, outer phyll. linear silky, inner roundish scarious.-E. B. 1230.-St. bushy, $1-2$ feet high. Heads in erect aggregate leafy panicles. Floral 1. simple. Florets dull yellow, the outer row female.Waste ground. P. VII. VIII. Wormwood.

** Receptacle naked.

2. A. campestris (L.); heads drooping ovate glabrous heterogamous, $l$. silky with many linear-lanceolate mucronate segments, stem-1. once or twice pinnate with linear segments, st. wandlike 
procumbent before flowering, phyll. ovate glabrous with a scarious margin.-E. B. 338.-Barren st. cæspitose. Flowering st. slender, $1-2$ feet long, ascending when the flowers appear, leafy, smooth. Florets yellow, those of disk sterile; involucre purplish. - Sandy heaths in Norf. and Suff., rare. †Belfast. P. VIII. IX.

E. I.

3. A. vulgaris (L.); heads ovate heterogamous, $l$. woolly and white beneath pinnatifid with lanceolate acuminate cut and serrated segments, phyll. woolly.-E. B. 978.-St. $2-3$ feet high, erect, leafy. Clusters leafy, nearly simple, erect. Fl. few, reddish or brownish yellow.-Waste ground. P. VII.-IX. Mugwort.

4. A. maritima (L.); heads oblong, florets few all perfect, 7 . downy pinnatifid with linear obtuse segments, phyll. oblong outer woolly inner scarious.-E. B. 1706.-St. recumbent or ascending, woolly, much branched. Florets reddish-yellow. Racemes drooping.- $\beta$. A. gallica (Willd.); racemes more dense, heads erect. E. B. 1001. - . A. salina (Willd.); racemes unilateral, heads drooping.--Salt marshes. P. VIII. IX.

[A. carulescens (L.); heads oblong, flts. few all perfect, $l$. hoary lanceolate undivided pinnatifid on the barren shoots. E. B. 2426.-Boston. Isle of Wight. Not a native. P. VIII. IX.]

\section{8. (19.) Tanacetum Linn. Tansy.}

1. T. vulgare (L.); l. bipinnatifid, lts. serrated.-E. B. 1229. -Heads in a terminal corymb. Fl. golden-yellow. Fr. with an entire crown. St. $2-3$ feet high.-Way-sides. P. VIII.

Section 3. GNAPHALIEAE. Heads homogamous or heterogamous, discoid. Anthers with appendages. Branches of the styles of the hermaphrodite florets truncate. Pappus pilose or setaceous, rarely 0 .

\section{9. (13.) Filago Linn. Cudweed.}

1. F. germanica (L.); cottony, st. proliferous at the summit, 1. lanceolate wavy acute, heads obscurely 5 -angled half sunk in tomentum forming axillary and terminal clusters not surrounded and overtopped by l., phyll. longitudinally folded linear cuspidate with glabrous points.-Gnaphalium Sm., E. B.946.-Grey. St. erect or ascending, 4-12 in. long, usually simple below, bearing a solitary terminal cluster of heads, afterwards producing from just below it 2 erect branches which are again proliferous. Heads $20-40$ in each cluster; re-entering angles obsolete; 1. nearest to the cluster much narrowed upwards and acute. Tips of phyll. yellow, rarely reddish.-Dry fields. A. VII. VIII. 
2. F. apiculata (G. E. Sm.); cottony, st. proliferous at the summit, $l$. all oblong blunt apiculate, heads prominently 5-angled half sunk in tomentum forming lateral axillary and terminal clusters surrounded and overtopped by $1-2$ blunt $l$., phyll. boatshaped cuspidate with glabrous points.-G. E. Sm.! in Phytol. ii. 575. F. lutescens Jord.! Pl. nov. Fr. iii. t. 7.-Greenish. Smelling like Tansy. St. mostly ereet, with short branches below. Heads larger than in F. germ., 10-20 in a cluster; reentering angles deep; cluster often seeming lateral from only 1 branch being produced just below it; 1 . nearest to the cluster scarcely narrowed upwards, blunt, apiculate. Tips of phyll. purple.-Sandy places. A. VII. VIII.

3. F. spathulata (Presl); silky, st. 2-3-chotomous, l. oblongobovate, heads prominently 5-angled not deeply sunk in tomentum forming axillary and terminal clusters overtopped by $2-3$ acute $l$., phyll. cuspidate boatshaped with glabrous points.-F. Jussiæi Atl. Fl. Par. t. 26.-Whitish. St. usually branched from near its base. Heads larger than those of F. germ., 8-15 in each cluster; re-entering angles very deep. Tips of phyll. yellow.Dry fields. A. VII. VIII.

4. F. minima (Fr.); st. dichotomously branched, l. linear-lanceolate acute flat adpressed, heads pyramidal in lateral and terminal clusters longer than the leaves, phyll. bluntish cottony with glabrous points.-E.B. 1157 . Gnaphalium Sm.-St. slender, erect, 2-6 in. high, branched, the branches dichotomous, or prostrate and spreading. Fl. yellowish in very small heads. Whole plant cottony, grayish.-Dry sandy and gravelly places. A. VI.-IX.

5. F. gallica (L.); st. dichotomously branched, l. linear acute, heads conical in axillary terminal clusters shorter than the leaves, outer phyll. cottony with bluntish glabrous points gibbous at the base and inclosing the marginal fr.-E. B. 2369. Gnaphalium Sm.-St. 6-8 in. high, slender. L. narrowing upwards from the base, upright, afterwards revolute.-Dry gravelly places, very rare. Bere Church, Essex, 1842. A. VII.-IX.

\section{0. (12.) Gnaphalium Linn.}

1. G. luteo-album (L.); st. simple branched at the base slightly corymbose above, heads densely clustered leafless, 1 linear-oblong wavy woolly on both sides half clasping, lower l. broader at the end and obtuse, upper l. narrowing and acute.-E. B. 1002.Woolly. St. 3-12 in. high, decumbent below, then erect or ascending. Heads aggregated at the extremities of the stem; involucre straw-coloured; florets tinged with red.-Sandy fields, very rare. † Belfast. Mr. W. Thompson. A. VII. VIII. E. I. 
2. G. uliginosum (L.); st. diffuse much branched, heads in terminal dense clusters shorter than the leaves, 1. linear-lanceolate cottony on both sides.-E. B. 1194.-St. 3-5 in. high, much branched, decumbent or ascending. Heads aggregated at the extremity of the st. and branches; involucre yellowish-brown.Wet sandy places. A. VII. VIII.

3. G. sylvaticum (L.); st. simple nearly erect, heads in axillary clusters forming an interrupted leafy spike, 1. acute linear-lanceolate, st.-1. narrower.-R. xvi. 58. G. rectum Sm., E. B. 124.St. 3-24 in. high, upper half constituting the spike. Upper 1. very narrow.-Woods and heaths. P. VII.-IX.

4. G. norvegicum (Gunn.); st. simple nearly erect, heads in a close terminal leafy spike, 1. silky or cottony on both sides lanceolate, st.-l. acuminate-mucronate broad.-R. xvi. 58. G. sylvaticum Sm., E. B. 913.-St. 6-12 in. high, spike distinctly terminal. St.-l. broad. Fl. longer in proportion to the inv. Quite distinct froun G. sylvaticum.-Highland mountains. P. VIII. S.

5. G. supinum (L.); caspitose, st. decumbent, flowering st. erect, heads $1-5$ distant, 1 . linear downy on both sides mostly radical.-Height 2-3 in. Cæspitose, very leafy at the root. Flowering st. with few leaves which are downy on both sides. a. G. supinum (Willd.); heads sessile forming a sort of capitate spike.- $\beta$. G. fuscum (Willd.); heads stalked subracemose. E.B. 1193. $-\gamma$. G. pusillum (Willd.); heads solitary.-Highland mountains. P. VII.

\section{1. (14.) Antennaria $R . B r$.}

1. A. dioica (Gaert.); shoots procumbent, flowering st. simple erect, corymb dense terminal, phyll. oblong dilated upwards obtuse coloured, root-l. obovate-spathulate glabrous above cottony beneath, stem-1. nearly equal lincar-lanceolate adpressed.-E. B. 267. Gnaphalium Sm.-Root of long simple fibres. St. prostrate, woody, terminating in a tuft of many 1 . and producing prostrate leafy stoles. Flowering st. $4-8$ in. high, quite simple, cottony. Heads $4-5$, erect, slightly stalked. Phyll. white or rose-colour.- $\beta$. A. hyperborea (D. Don); 1. cottony on both sides. E. B. S. 2640.-Mountain heaths. P. VI. VII.

†2. A. margaritacea (R. Br.); st. erect branched above corymbose leafy, $l$. linear-lanceolate acute cottony below, heads in level-topped corymbs.-E. B. 2018.-St. 2-3 feet high, cottony. L. alternate, slightly cottony above, densely beneath. Inv. white. Fl. yellowish.-Moist meadows, rare. P. VIII. 
Section 4. SENECIONEAE. Heads homogamous or heterogamous, discoid or radiant. Anth. without appendages. Pappus pilose or setaceous, rarely 0 .

\section{2. (5.) Doronicum Linn. Leopard's-bane.}

†l. D. Pardalianches (L.); l. cordate denticulate, lowermost l. on long stalks, intermediate with clasping auricles at the base of the stalk, uppermost sessile clasping, root creeping tuberous. E. B. S. 2654.-St. $2-3$ feet high, erect, solitary, hollow, hairy. L. hairy, minutely toothed, soft, blunt, the uppermost acute. Lowest petioles not auricled. Heads several, phyll. lanceolatesubulate. Florets yellow. The earlier heads overtopped by the latter ones. Fr. oblong, furrowed, of disk hairy, of ray glabrous. -Damp and hilly woods and pastures, rare. P. V.-VII.

†2. D. plantagineum (L.?); l. ovate denticulate, radical on long stalks rounded or subcordate produced at the base, stem-l. sessile clasping the lowermost with a winged and auricled stalk. - E. B. 630. (excl. leaf.)-Crown of the root woolly. St. 2-3 feet high. Stem-l. narrowed in their lower half but sessile, uppermost with a long taper point. Heads usually solitary, or, if more, the lateral ones not overtopping the terminal one. Phyll. subulate. Fr. of ray glabrous. Florets yellow.-Damp places, rare. P. VI. VII.

E. S.

\section{3. (4.) Senecio Linn. Ragwort.}

A. Involucre with small scales at its base.

* Florets all tubular, or the marginal ones ligulate but revolute.

1. S. vulgaris (L.); 1. half-clasping pinnatifid, segments distant oblong obtuse and together with the rachis and auricles acutely and unequally toothed, lower 1 . narrowed into a stalk, heads in clustered racemes, outer phyll. very short adpressed with black points, ray $0 .-E$. B. 747. - Smooth or woolly. St. $6-12$ in. high, branching. Heads small ; involucre oblong-conical, glabrous; florets yellow; fr. silky. - $\beta$. radiatus (Koch); with a single row of ligulate minute revolute marginal florets.-Commoin. A.I.-XII. Groundsel.

2. S. viscosus (L.); l. deeply pinnatifid viscid glandular-hairy, segments oblong unequally toothed and lobed, heads in an irregular corymb, involucre viscid, outer phyll. half the length of the inner hairy, ray small revolute, fr. glabrous.-E.B.32.-St. $1-2$ feet high, much branched, spreading. Heads on long stalks; inv. cylindrical ; fl. yellow.-Waste ground, rare. A. VII.-IX.

3. S. sylvaticus (L.); l. deeply pinnatifid downy, segments ob- : long unequally toothed, heads corymbose, involucre downy, outer 
phyll. very short glabrous, ray small revolute, fr. silky.-E. B. 748. - St. $1-2$ feet high, erect, more or less branched, hairy. L. narrower than in the last. Involucres conical ; florets yellow. $-\beta$. S. lividus ( $\mathrm{Sm}$.); upper 1. distinctly auricled and clasping. E. B. 2515.-Dry and gravelly places. A. VII.-IX.

\section{** Heads with spreading rays. Leaves pinnatifid.}

*4. S. squalidus (L.); l. pinnatifid glabrous, segments linear or oblong distant toothed irregular, heads loosely corymbose, involucre glabrous, outer phyll. few small, fr. silky.-E. B. 600 . S. chrysanthemifolius DC.-St. much branched, leafy, smooth. L. sessile, often auricled, deeply and irregularly lobed. Heads few, broad. Outer phyll. very small, sometimes very few. Many awlshaped scattered bracts below the heads. Florets yellow.Walls. Oxford. Bideford, Devon. A. VI.-X. E.

5. S. erucifolius (L.); l. pinnatifid margins somewhat revolute downy beneath, lower l. stalked, segments linear the lowermost smallest entire and clasping the stem, outer phyll. half as long as the inner, fr. all silky.-E. B. 574. S. tenuifolius Sm.-Root creeping. St. erect, 2 feet high, angular, furrowed, somewhat cottony, simple. Lower 1. oblong-ovate deeply pinnatifid, the segments often linear, downy on both surfaces but particularly beneath. Fr. all having persistent pappus. Florets yellow. When the 1 . are divided into very narrow segments it is S. tenuifolius Jacq.-Calcareous soils. P. VII. VIII.

6. S. Jacobaa (L.); lower l. oblong-ovate attenuated below lyrate-pinnatifid stalked, stem-1. sessile bipinnatifid, segments spreading oblong deeply and irregularly toothed and cut lowermost much divided clasping, outer phyll. scattered few, fr. hairy those of the ray glabrous. - E. B. 1130 .- Root fleshy. St. 2-3 feet high, smooth, striated, branched, leafy. Corymb with erect branches. L. glabrous. Fr. of the ray with deciduous pappus. Florets yellow. Ray sometimes wanting.-Waste ground. P. VII.-IX. Ragwort.

7. S. aquaticus (Huds.); lower $l$. stalked crenate or dentaie obovate or oblong slightly produced at the base undivided or sublyrate obtuse, upper 1 . lyrate or pinnately cut, segments oblong or linear, st. round corymbosely branched, fr. all glabrous submuricate. $-E$. B. 1131. - St. erect, $1-4$ feet high, simple or branched in the upper half, branches ascending. Terminal lobe of the lower l. rounded below and narrowed into its stalk.B. major; 1. lyrate, terminal lobe truncate or subcordate below, segments subspathulate. St. with many branches.-In marshy places. P. VII. VIII. 
*** Heads with spreading rays. Leaves undivided.

8. S. paludosus (L.); $l$. sessile elongate-lanceolate tapering sharply serrate cottony beneath, st. straight hollow, corymbs terminal. - E. B. 650. - St. 4-6 feet high, somewhat woolly. Florets yellow, of the ray narrow $13-16$. - Fen ditches, very rare. P. V.-VII.

E.

9. S. saracenicus (L.); $l$. sessile lanceolate acute glabrous irregularly serrate the teeth small incurved, st. straight solid, corymbs terminal, ray of $6-7$ florets. $-E$. B. 2211. - St. 3-5 feet high, smooth. L. broad. Corymb many-headed. Florets yellow.Watery places, local. P. VIII.

B. Involucre without scales at its base. Heads with a spreading ray. Leaves nearly entire.

10. S. palustris (DC.); shaggy, st. much branched and corymbose above, $l$. broadly lanceolate half-clasping, lower 1 . sinuatedentate.-Cineraria Sm., E. B. 151.-St. 3 feet high, thick, hollow, leafy. Heads erect. Florets bright yellow.-Fen ditches, now become very scarce. P. VI. VII.

E.

11. S. campestris (DC.); shaggy, st. simple, root oblong nearly entire narrowed below, stem-l. lanceolate, heads corymbose, involucre woolly below nearly glabrous in the upper half, fr. hispid.-C. integrifolia Sm., E. B. 152.-St. 6-8 in. high, with small st.-leaves. Heads erect, $\mathrm{l}-6$, in a simple corymb. Involucre often almost glabrous, pale. Florets yellow.-In very wet seasons and near the sea this plant is often thrice as large with many larger heads and dentate lower leaves, when it is the $\beta$. maritima of authors. - Chalk downs, and on maritime rocks near Holyhead. P.? VI.

E.

\section{Tribe IV. Cynarea.}

Style of the hermaphrodite florets nodosely thickened above and often with a bunch of hairs at the knot; its branches united or free, downy externally. Stigmatic lines reaching to the apex of the branches and there confluent.

Section 1. CARLINEAE. Heads many-flowered, never diœcious. Phyllaries in many rows, distinct, often spinous. Filaments distirct, naked. Fr. mostly villose. Pappus in $1-2$ rows, not surrounded by an elevated margin.

\section{Saussurea Cand.}

1. S. alpina (DC.); l. nearly glabrous above cottony beneath, lower ones ovate lanceolate, upper sessile lanceolate, all distantly 
toothed, heads few in a dense corymb, involucre subcylindrical, phyll. adpressed hairy.-Serratula Sm., E. B. 599.-St. 3-12 in. high, erect, downy, simple, terminating in a small corymb of heads with pinkish florets and purple anthers. Fl. scented like Heliotrope. Fr. glabrous.-In alpine situations. P. VIII.

\section{Carlina Linn.}

1. C. vulgaris (L.) ; st. corymbose one- or many-headed, l. oblong-lanceolate sinuate spinous, outer phyll. bipinnatifid spinous, inner linear-lanceolate attenuated acute ciliated in the lower half, bracts shorter than the heads.-E. B. 1144.-St. 6-12 in. high, usually cottony, leafy. Spines many, short. Root-l. lanceolate or linear-lanceolate. Under side of the 1. and phyll. often cottony. Heads large; inner phyll. cream-coloured; florets red; anth. yellow.-Dry sandy heaths. B. VII.-X.

[C. racemosa (L.); heads in the axils of dichotomous st. or terminal, inner phyll. radiant yellow, bracts exceeding heads. A single specimen found in the Isle of Arran. I.]

\section{Arctium Linn. Burdock.}

1. A. tomentosum (Pers.); heads subcorymbose long-stalked spherical and closed in fr. much webbed (purplish), phyll. falling short of the flts. subulate inner row longest and broad, inflated upper part of fts. a little shorter than the lower part. $-E$. B. 2478. R. xv. 811.-St. $3-5 \mathrm{ft}$. high ; centre and often most of the branches ending in corymbs. Stalks of lower heards sometimes shorter. Heads rarely almost webless. Fr. dark brown with black blotches, nearly smooth. - East of England. B. VIII.

2. A. majus (Schk.); heads subcorymbose long-stalked hemispherical and open in fr. glabrous (green), phyll. equalling or exceeding flts. subulate inner row shorter than the others, $s u b$ cylindrical upper part of fts. more than $\frac{1}{2}$ as long as the lower part. $-R$. xv. 812.- St. 3-4 ft. high, centre and usually most of the branches ending in corymbs. Heads very large, a few of the lower sometimes with short stalks. Fr. yellowish, irregularly rugose.-Waste places. B. VIII.

3. A. intermedium (Lange); heads racemose subsessile ovate and closed in fr. slightly webbed (purplish), phyll. equalling or exceeding the flts. subulate inuer row lanceolate shorter than the others, subcylindrical upper part of flts. as long as the lower part. $-R$. xv. 812.-St. 2-4 feet high. Heals less than in No. 2 , three usually placed close together at the end of each branch. Most of the phyll. ascending.-Local? Berwickshire. Warwickshire. B. VIII. E. S. 
4. A. minus (Schk.); heads racemose shortly stalked globular slightly contracted at the mouth in fr. slightly webbed (greenish), phyll. falling short of the fts. subulate inner row equalling the others and gradually subulate, subcylindrical upper part of fits. about as long as the lower part.-E. B. 1228. R. xv. 811.Smaller than either of the preceding. Central st. mostly nodding and as well as the branches having scattered small heads. Term. head solitary. Fr. fuscous with black blotches.-Waste places. B. VIII.

5. A. pubens (Bab.); heads subracemose stalked hemispherical and open in fr. much webbed (greenish), phyll. equalling the flts. subulate inner row equalling the others and gradually subulate, subcylindrical upper part of fits. as long as the lower part. - See $A$. N. H. ser. 2. xvii. for an account of this plant and its allies.-St. about $3 \mathrm{ft}$. high. Stalks of the heads rather long, those of the lower heads longest. Heads usually with much wool, twice as large as those of $A$. minus. Fr. dark brown with a few paler spots towards the top.-Camb., Warw., Sheffield, Llanberis. B. VIII.

Section 2. SERRATULEAE. Heads many-flowered; florets all tubular, hermaphrodite or diœcious, the external row sometimes female. Involucre of many rows of distinct phyllaries. Filamerts distinct. Pappus in many rows of different lengths, inner row longest, pilose or plumose, surrounded by a margin.

\section{Serratula Linn. Saw-wort.}

1. S. tinctoria (L.); l. with bristly serratures pinnatifid somewhat lyrate, heads oblong corymbose, phyll. ovate adpressed, inner ones linear coloured.-E. B. 38. St. 3. 16.-St. $2-3$ feet high, straight, erect, angular, branched above. L. pinnatifid or lyrate, rarely entire. Flts. purple.-Groves and thickets. P. VIII. E.

Section 3. CENTAUREA. Heads many-flowered, discoidal, outer row of florets usually barren enlarged and irregular. Phyllaries in many rows. Filaments distinct. Pappus in many rows of different lengths, second row longest, setaceo-pilose, placed within the margin which surrounds the epigynous disk, rarely 0.

\section{Centaurea Linn. Knapweed.}

* Phyll. with a scarious pectinated not decurrent appendage.

[1. C. Jacea (L.) ; phyll.-appendages erect rounded, pappus 0, 1. linear-lanceolate lower ones broader and toothed.-E. B. 1678 . - Lower l. ovate-lanceolate, stalked, toothed. Involucre pale brown; few outermost phyll. with appendages deeply jagged in a pinnatifid manner, few innermost entire, the rest irregularly 
jagged. Heads radiant. I have seen no native specimens.Very rare. Sussex. Angusshire. Belfast. P. VIII. IX.]

2. C. nigra (L.); phyll.-appendages patent or erect ovatelanceolate pectinate, teeth subulate long, pappus short deciduous, 1. lanceolate acute.-E. B. 278 (inv, not good). $R$. xv. 761. - St. 1-2 ft. high; branches long, mostly simple, 1-headed. L. green; lower narrowed into long stalks, entire or sinuateserrate ; upper sessile. Heads large, globose. Phyll. pale, brown or black appendages usually quite covering them; length of sheath about twice as long as the breadth of appendage; innermost appendages torn. Fr. oblong, downy; basal scar obovate. Outer row of flts. usually radiant. Sometimes 1. very narrow.-A plant from Berkshire has patent or recurved lanceolate-attenuate appendages, no pappus, slender 1., and differs otherwise. C. microptilon, Godr.?-Meadows and pastures. P. VIII. IX. Black Knapweed.

3. C. nigrescens (Godr.); phyll.-appendages erect lanceolate or ovate-lanceolate pectinate, teeth subulate short, pappus 0,1 . lanceolate or ovate-lanceolate acute.-Like C. nigra. St. $\frac{1}{2}-1 \frac{1}{2}$ ft. high, nearly always simple, l-headed. L. green, broader than in No. 2 ; lower narrowed into stalks sinuate-dentate or lyratesinuate or entire; upper sessile. Heads smaller than in No. 2, globose. Phyll. pale, brown appendages usually not wholly covering them; length of teeth often scarcely longer than the breadth of the brown appendage; three innermost rows usually protruding and with roundish irregularly torn appendages. Fr. obovate, downy; basal scar ovate. Outer row of fits. usually radiant.-S.W. of England. P. VI.-IX.

E.

** Phyllaries lanceolate, their upper half with a somewhat scarious deeply toothed or fringed decurrent margin.

4. C. Cyanus (L.); phyll. erect adpressed deeply toothed, pappus as long as the fruit, $l$. linear-lanceolate, the lowermost toothed or pinnatifid.-E. B. 277.- St. 1-3 feet ligh, loosely cottony, leafy. L. slightly cottony above, densely beneath. Involucre greenish-yellow; phyll. often tinged with purple in their upper half, margins brown decurrent with whitish teeth. Heads with large radiant blue flowers, disk purple.-Corn-fields. A. VI. -VIII. Corn Bluebottle.

5. C. Scabiosa (L.); phyll. erect adpressed, the triangularovate black pectinated appendages not covering the inv., teeth ascending setaceous short, pappus as long as the fruit, $l$. pinnatifid roughish, segments lobed with callous points.-E.B. 56.St. 2-3 feet high, rough, furrowed. L. hispid, lobes of the upper ones entire. Heads on long naked stallss, solitary. Invo- 
lucres usually rather woolly; scales pale, with dark acute membranous pectinated decurrent appendages; teeth paler, short, not longer than $\frac{1}{2}$ the width of the scale. Florets purple, outer row radiant or 0.-In a plant from "Carnouctie, Fife," the inv. is quite covered by the appendages, not showing any of the pale portion. It may be C.kotschyana Koch.-Fields and hedges. P. VII. -IX. Great Knapweed.

\section{*** Phyll. horny at the end, spines palmate or pinnate.}

*6. C. solstitialis (L.); phyll. woolly palmately spinous, central spine of the intermediate ones very long needle-shaped, inner ones with a roundish scarious appendage, heads terminal solitary, st. winged with the decurrent bases of the linear-lanceolate entire hoary leaves, root-l. lyrate.-E. B. 243.-St. $1-2$ feet high, branched, spreading. Involucres sometimes glabrous. Florets yellow.-Cultivated land, probably introduced. A. VII.-IX. Yellow Star-thistle.

E.

7. C. Calcitrapa (L.); phyll. glabrous palmately spinous, central spine strong channeled, innermost phyll. with a scarious obtuse appendage, heads lateral sessile solitary, pappus obsolete, l. deeply pinnatifid, lobes of the root-l. lauceolate toothed, of the stem-l.linear.-E.B. 125.-St. furrowed, slightly hairy, branched, spreading, about a foot high. Fl. purplish.-Gravelly and sandy places. A. VII. VIII. Common Star-thistle.

E.

[8. C. Isnardi (L.); phyll. palmately spinous, spines nearly equal 3-5, innermost phyll. with a scarious obtuse lanceolate or slightly spathulate appendage, heads terminal solitary, pappus of all the fr. in several rows, l. linear coarsely toothed narrowed below sessile rough, lower ones (and those of the primary stem?) broader incise-dentate with clasping auricles - E. B. 2256.-St. procumbent, with long slender simple leafy branches each terminated by a solitary head. L. mostly linear, slightly toothed or entire.-Fl. purple.-Distinguished from C. aspera only by its simple upper leaves.-Guernsey. P. VII. VIII.]

Section 4. CARDUINEAE. Heads many-flowered; florets all tubular. Involucre in many rows of distinct spinous phyllaries. Filaments distinct. Pappus in many rows, not surrounded by a prominent margin.

\section{Onopordum Linn. Cotton Thistle.}

1. O. Acanthium (L.) ; st. erect many-headed, l. elliptic-oblong woolly on both sides sinuate spinous decurrent, outer phyll. lanceolate-subulate recurved and spreading.-E. B. 977.- St. 4 -5 feet high, woolly, with broad spinous wings, branched. Inv. 
nearly globose, large, somewhat cottony; phyll. fringed with minute spinous teeth. Flts. purple.-Waste ground. B. VIII.

\section{Carduus Linn. Thistle.}

[Many hybrids occur in this genus.]

\section{* Pappus rough. Carduus Sm., DC., Koch.}

1. C. nutans (L.); I. decurrent spinous lanceolate sinuated, heads solitary drooping hemispherical, phyll. lanceolate cottony outer ones reflexed.-E. B.1112.-St. 2 feet high, erect, angular, furrowed, cottony, winged. L. hairy on both sides, with woolly veins beneath, pinnatifid with 3 -lobed wavy spinose-ciliated segments ending in strong spines. Heads large; fl. crimson; unopened anth. purple. Inv. hemispherical,internal phyll.contracted above the base and then lanceolate.-Waste ground. B. V.VIII.

2. C. crispus (L.); 1. decurrent spinose-ciliated lanceolate glabrous or cottony beneath deeply pinnatifid, lobes trifid and dentate, heads aggregated roundish, phyll. linear-subulate erect or ascending.-E. B. 973.-St. about 3 feet high. L. lanceolate, downy or woolly beneath. Heads small, usually clustered. Phyll. ending in a weak spine, ascending. Epigynous disk of fr. with a conical not angular tubercle. $-\beta$. C. acanthoides (L.); 1. broadly lanceolate, usually not downy beneath, head twice as large solitary or rarely 2 or 3 together, phyll. strongly spinous erect, central tubercle of fr. 5 -angled.-Dry banks and waste places. $\beta$. is the less common plant. B.? VI.-VIII.

3. C. tenuiflorus (Curt.); l. decurrent sinuate spinous broadly lanceolate cottony beneath, segments ovate lobed, heads many aggregate sessile subcylindrical, phyll. ovate-lanceolate attenuated.-E.B. 412.-St. about 3 feet high, slightly branched, with broad deeply lobed spinous wings. L. deeply sinuate or pinnatifid. Involucres nearly glabrous. Florets pink.-Sandy places near the sea. B.? VI.-VIII.

** Pappus feathery. CNicus Linn., Sm. Cirsium Koch, DC.

+ Leaves spinous-hairy above, fl. purple.

4. C. lanceolatus (L.); l. decurrent white and cottony beneath pinnatifid, lobes bifid with lanceolate entire segments each terminated by a strong spine, involucres ovate shaggy, phyll. lanceolate spinous spreading. - E. B. 107.-St. $3-4$ feet high, erect, furrowed, hairy, with strong spinous wings. Heads terminal, solitary or 2 or 3 together, large ; florets purple.-Waste ground. B. VII. VIII. Spear Thistle. 
5. C. eriophorus (L.); l. half-clasping not decurrent white and cottony beneath deeply pinnatifid, lobes bifid the segments lanceolate entire alternately pointing upwards and downwards and each terminated by a strong spine, involucres globose shaggy lanceolate with a long linear spinous-tipped reflexed point.-E. B. 386. - St. 3-4 feet high, much branched, furrowed, hairy. Root-1. 1-2 feet long, linear with long divergent lobes which form double rows in a very regular manner. Stem-l. similar but smaller. Heads very large; involucre covered with a dense white web; florets purple. A remarkably conspicuous plant.-Waste ground on a limestone soil. B. VIII. Woolly-headed Thistle.

\section{i† Leaves not spinous-hairy above.}

\section{a. Limb of the cor. 5-parted to its base. BREEA Less.}

6. C. arvensis (Curt.); heads subdiœcious, $l$. subsessile oblonglanceolate pinnatifid spinous wavy, involucres ovate subglabrous, phyll. broadly lanceolate adpressed terminating in a short spreading spine, root creeping.- - E. B. 975.-St. erect, 3-4 feet high, leafy, angular, corymbose above. $L$. very spinous, sessile or very slightly decurrent, varying greatly in width.- $+\beta$. setosus; 1 . lanceolate flat entire or slightly lobed. Cir. setosum M. B.Fields and roads. $\beta$. Culross and Kirkwall, S. P. VII. $\beta$. IX. Creeping Thistle.

\section{b. Limb of the cor. 5-parted to its middle.}

7. C. palustris (L.) ; l. decurrent lanceolate deeply pinnatifid spinose, involucres ovate clustered, phyll. ovate-lanceolate adpressed mucronate.-E. B. 974.-St. solitary, erect, 3-5 feet high, wandlike, with wavy spinose wings throughout, slightly branched. Heads in a terminal cluster. Florets purple or white. Under side of the l. usually cottony. Involucre with a slight web.-Wet meadows. A. VII. VIII.

8. C. pratensis (Huds.); l. mostly radical lanceolate wavy or lobed pilose above cottony beneath fringed with minute prickles, stem- $l$. not decurrent few clasping, involucres globose solitary terminal slightly cottony, phyll. lanceolate-attenuate adpressed mucronate, root stoloniferous.-E. B. 177. Cir. anglicum Lam. -St. 1-2 feet high, cottony, usually quite simple and singleheaded, leafless in the upper half with a few scaly bracts, springing singly from the suckers. L. broad, soft, sinuate-dentate, rarely with small 2-3-fid lobes, not pinnatifid, fringed with small but unequal prickles, lower l. stalked. Occasionally there are 2 or 3 fl. on a stem.-C. Fosteri (Sm.) is a hybrid between this and C. palustris having l. slightly decurrent lanceolate all pinnatifid spinous cottony beneath, st. panicled, inv. ovate slightly cottony, 
root cæspitose producing several stems.-Boggy meadows. P. VI.-VIII.

9. C. tuberosus (L.); l. lanceolate deeply pinnatifid pilose above hairy or slightly cottony beneath fringed with minute prickles, stem-l. sessile not decurrent, lobes $2-3$-fid, involucres ovate terminal $1-3$ together slightly cottony, phyll. lanceolate mucronate adpressed, root of elliptical tapering fieshy fibres.E. B. 2562. Cir. bulbosum DC., Koch.-St. 2 feet high, erect, round, hairy, leafless above the middle with a few minute bracts. Lower l. stalked, stem-l.nearly or quite sessile.-Great-ridge Wood near Boyton, Wilts. (See Cyb.Brit.iii. 455.) P. VIII. IX. E.

10. C. acaulis (L.) ; l. glabrous radical lanceolate pinnatifid, lobes subtrifid spinose, involucre ovate glabrous nearly sessile mostly solitary, outer phyll. ovate inner ones gradually longer adpressed, root with filiform fibres.-E. B. 161. St.24. 16.-St. generally wanting; sometimes $3-12 \mathrm{in}$.long, leafy, woolly. L. all stalked, glabrous except a few hairs upon the ribs beneath. Heads very large, fl. crimson.- $\beta$. C. dubius (Willd.); st. much branched woolly a foot or more in height. Willd. Fl. Berol. f. 11. Perhaps a hybrid between this and C. arvensis.-Dry calcareous pastures. $\beta$. Saffron Walden, Essex. Mr. G. S. Gibson. P. VII.-IX.

11. C. heterophyllus (L.); 1. clasping not decurrent glabrous above white and downy beneath lanceolate serrate fringed with minute prickles, root-l. with long stalks clasping at the base, involucres ovate slightly downy, phyll. ovate or lanceolate acuminate arlpressed.-E.B. 675.-Root creeping. St. 3-4 feet high, furrowed, cottony, slightly branched above. Heads large and handsome. L. very large, undivided.-Moist mountain pastures. P. VII. VIII.

E. S.

Section 5. SILYBEAE. Filaments monadelphous. Pappus in many rows.

\section{Silybum Gaert. Milk Thistle.}

1. S. marianum (Gaert.).-Carduus Sm., E. B. 976.-St. 3-4 feet high, ribbed and furrowed. L. very large, oblong-lanceolate, wavy, clasping; radical l. pinnatifid, usually variegated with green and milk-white. Heads large, globose. Phyll. closely adpressed below, leaflike, with a long terminal recurved spine. Florets purple, their tube very long.-Waste places.

B. VI. VII. 
Suborder II. LIGULIFLORAE. Fl. all perfect, ligulate.

\section{Tribe V. Cichoriea.}

Style cylindrical above and, with its long obtuse branches, equally pubescent. Stigmatic lines prominent, narrow, terminating below the middle of the branches.

\section{Section 1. LAPSANEAE. Receptacle naked. Pappus 0.}

\section{Lapsana Linn. Nipplewort.}

1. L. communis (L.); 1. dentate or lobed stalked, lower l. lyrate, involucres glabrous angular, st. panicled.-E. B. 844.-St. and 1. hispid or nearly glabrous. St. $1-3$ feet high, branched above. Heads small, with yellow florets, in terminal panicles with small subulate bracts at the subdivisions. Involucre of the fruit erect. -Waste and cultivated land. A. VII. VIII.

Section 2. HYOSERIDEAE. Receptacle naked. Pappus like a crown, of many entire broad scales.

\section{Arnoseris Gaert.}

1. A. pusilla (Gaert.).-Lapsana Sm., E. B. 95.-St. 3-8 in. high, swelling and hollow upwards, leafless, with a minute bract at the base of each branch. Each branch overtopping its predecessor and gradually thickening up to the solitary small terminal head of yellow florets. Inv. connivent over the fr. when its phyll. become remarkably keeled. Receptacle alveolate towards the margins. Fr. small obovate, attenuated below, 5-angled. L. radical, oblong, toothed.-Gravelly and sandy fields, rare. A. VI.-VIII.

E. S.

\section{Cichorium Linn. Succory. Chicory.}

1. C. Intybus (L.); lower l. runcinate hispid on the keel, upper 1. oblong or lanceolate clasping entire, heads axillary in pairs nearly sessile.-E. B. 539. St. 6.15 .-St. $2-3$ feet high, bristly, alternately branched. Heads many, fl. bright blue handsome. Floral 1. lanceolate from a broad clasping base.-Waste places on a gravelly or chalky soil. P. VII. VIII.

Section 3. HYPOCHERIDEAE. Receptacle scaly. Pappus feathery.

\section{Hyроснєеris $\operatorname{Linn}$.}

* Pappus with an outer row of bristles.

1. H. glabra (L.); st. branched leafless glabrous, $l$. oblong 
dentate-sinuate, involucre glabrous equalling the florets. $-E$. $B$. 575.- St. 3-10 in. high, branched, scaly, each branch terminating in a small solitary head. L. spreading in a circle on the ground, glabrous, except a few scattered hairs. Outer row of fruits destitute of a beak, the rest with a long beak.- $\beta$. H. Balbisii (Lois.); all the fruits with long beaks.-Sandy and gravelly places. $\beta$. In Kent and Salop. A. VII. VIII.

E. S.

2. $H$. radicata (L.); st. branched leafless glabrous, $l$. runcinate obtuse, involucrefalling short of the florets. -E.B.831.-St.about a foot high, branched, scaly, each branch terminating in a rather large solitary head. L. spreading upon the ground, scabrous. Stalks slightly thickened beneath the heads. Fr. all beaked. Pappus with an outer row of hairs.-Waste ground. P.? VII.

** Pappus in one row. Achy Rophorus Scop.

3. H. maculata (L.) ; st. simple or slightly branched almost leafless, 1. ovate-oblong undivided toothed pilose, phyll. bristly on the back.-E. B. 225.-St. about a foot high, stout, slightly hairy. L. often all radical. Heads large, florets deep yellow. -Chalky and limestone hills. P. VII. VIII. E.

Section 4. SCORZONEREA. Receptacle without scales. Pappus feathery or on the exterior fruits scaly.

\section{Thrincia Roth.}

1. T. hirta (DC.); l. lanceolate sinuate-dentate or entire hispid or hairy with forked or simple hairs, stalks simple pilose below. - E. B. 555.-L. all radical, sometimes nearly or quite entire, occasionally runcinate. Stalks purplish, quite simple, longer than the leaves, somewhat hairy in their lower half. Phyll. downy on the margins at the apex or hairy. Root premorse.Gravelly places and fields. P. VII.-IX.

\section{Apargia Schreb. Hawkbit.}

* Pappus with an outer row of bristles.

1. A. hispida (Willd.); 1. radical oblong-lanceolate runcinate hispid with forked hairs, stalks simple naked or with 1 or 2 minute scales thickened upwards hispid, inv. hairy. $-E . B .554$. Leontodon L.-L. with regular spreading or reflexed narrow teeth. Stalks green, erect, longer than the leaves. Head drooping in bud afterwards erect. Florets glandular at the end. Fr. muricated.-Meadows and pastures. P. VI.-IX.

** Pappus in one row. Oporinia Don.

2. A. autumnalis (Willd.); 1. radical linear-lanceolate toothed 
or pinnatifid nearly glabrous, stalk branched scaly and thickened upwards, inv. glabrous or hairy. $-E$. B. 830. Leontodon Koch. -L. all radical, tapering at the base, often with long linear spreading segments, usually somewhat hairy particularly on the midrib beneath. Inv. nearly always hairy. Pappus brownish.$\beta$. A. Taraxaci (Sm. not Willd.); l. glabrous, stalk mostly simple, inv. shaggy with greenish-black hairs. E. B. 1109.- - . sordida; 1. hairy, st. branched, inv. as in $\beta$, plant very large.-Meadows and pastures. $\beta$. mountains. $\gamma$. Highland glens. P. VIII.

\section{Tragopogon Linn. Goat's-beard.}

1. T. minor (Fries); inv. about twice as long as the florets, ped. slightly thickened at the very summit, l. tapering into a long slender point from a dilated base.-T. major Hook. (not Jacq.) -St. 2 feet high, branched, erect. L. clasping the stem, gradually tapering into a very long acute point. Phyll. 8 , in 2 rows. Fl. yellow, truncate, 5-toothed. Anth. dark brown. Marginal fr. angular, striated; angles squamosely toothed; interstices tubercular.-Meadows and pastures. B.? VI. VII. E. S.

2. T. pratensis (L.); inv. equalling or shorter than the florets, ped. slightly thickened at the very summit, l. linear keeled dilated at the base.-E. B. 434 .-St. $1 \frac{1}{2}-2$ feet bigh, branched, erect. L. clasping the stem, narrowing upwards and terminating in a very long linear-acute point. Phyll. 8 , in 2 rows. Fl. yellow, truncate, 5-toothed. Anth. yellow. There are 2 forms of this plant : (a) inv. equalling the fl., marginal fr. obsoletely striated and squamosely-scabrous throughout; $(b)$ inv. rather shorter than the fl, marginal fr. (in my specimen) yellow slightly furrowed and quite smooth.-Meadows and pastures, less frequent than the preceding. B.? VI.

†3. T. porrifolius (L.); inv. longer than the florets, ped. much thickened upwards, l, tapering slightly dilated just above the base. -E. B. 638.-St. 3-4 feet high, erect, branched. L. slightly broader just above the base then gradually narrowing to an acute point. Heads twice as large as in the two preceding. Inv. usually $\frac{1}{3}$ longer than the fl., sometimes only equalling them. Fl. purple. Marginal fr. squamosely-tubercular throughout but particularly on the ribs.-T. major is probably only a yellow-flowered variety of this ; it has not been found in Britain.-Moist meadows. B. VI. Salsify.

\section{Picris Linn.}

1. P. hieracioides (L.); rough with forked and hooked bristles, 1. linear or lariceolate dentate or sinuated, upper 1 . somewhat clasping, heads solitary terminating the stem and branches, outer 
phyll. lax oblong bristly on the keel glabrous on the margin, fr. constricted just below the pappus.-E. B. 196.-St. 1-3 feet high, branched above, rather corymbose, very rough. Florets yellow.-Dry banks. B. VII.-IX.

E. I.

\section{Helminthia Juss. Ox-tongue.}

1. H. echioides (Gaert.) ; hispid with rigid 3-fid and hooked hairs from tubercular bases, st. erect, phyll. 5 ovate-cordate.E. B. 972.-St. $2-3$ feet high, branched, covered, as well as the leaves and involucre, with strong prickles springing from white tubercles and with 3 minute hooks at the apex (glochidate). L. clasping.-Dry banks. A. VII.-IX.

Section 5. LACTUCE E. Receptacle generally without scales. Pappus filiform, deciduous, never feathery nor dilated at the base. Fruit compressed.

\section{Lactuca Linn. Lettuce.}

* Beak elongated, white. Leaves with a bristly keel.

1. L. saligna (L.); upper $l$. linear entire acuminate with a sagittate base, lower l. pinnatifid, beak twice as long as the fruit. -E.B. 707.-St. 2 feet high, slender, wavy, slightly branched. Heads in small alternate tufts forming long clusters. Florets yellow.-Chalky places and near the sea. B. VII. VIII. E.

2. L. virosa (L.); l. horizontal oblong auricled and clasping mucronate-dentate or sinuated, beak equalling the black fruit.E. B. 1957.-St. 2-4 feet high, leafy, branched above, panicled. Heads scattered, with many heartshaped acute bracts. Plant full of acrid milky juice.-Dry banks. B. VII. VIII. Acrid Lettuce.

E. S.

3. L. Scariola (L.); l. upright arrowshaped at the base and clasping sinuate, beak equalling the pale fruit.-E.B. 268.-St. 2-5 feet high, leafy, panicled. Heads scattered with many heartshaped bracts. Juice rather less acrid than in the preceding. -Waste places, rare. B. VII. VIII. Prickly Lettuce. E.

** Beak short. Leaves with a smooth keel.

4. L. muralis (DC.); florets 5, 1. lyrate-runcinate angled and toothed clasping, terminal lobe largest angled, beak much shorter than the fruit, heads panicled.-Prenanthes Sm., E. B. 457.St. erect, a foot high, smooth, round, hollow. Florets bright yellow. Fruit black.-Banks and old walls. A.? VII. E. I. 


\section{Leontodon Linn. Dandelion.}

1. L. Taraxacum (L.) ; l. runcinate toothed, fr. linear-obovate blunt and squamosely muricated at the summit longitudinally striated with a long beak.-Stalks single-headed, radical. Florets yellow. L. all radical, very variable, glabrous or slightly hispid. -I. Outer involucral scales reflexed or patent.-a. L. Taraxacum (Sm.); outer scales linear deflexed, fr. yellow its upper half muricated, glabrous or woolly at the crown of the root, l. runcinate broad. E. B. 517.- $\beta$. Taraxacum lavigatum (DC.); outer scales erect-patent ovate, fr. reddish-yellow muricated at the summit, beak with a thickened and coloured base, 1. runcinatepinnatifid with unequal teeth. $-\gamma$. T. erythrospermum (DC.); outer scales lanceolate adpressed or patent, fr. bright red muricated at the summit, beak with a thickened and coloured base, 1. runcinate-pinnatifid with unequal teeth and intermediate smaller ones. Lowermost 1 . sometimes obovate and dentate, not runcinate when it becomes T. obovatum DC.-II. Outer scales adpressed.- $\delta$. L. palustre (Sm.); outer scales ovateacuminate, fr. pale yellow or brown muricated at the summit, l. oblong and entire sinuate-dentate or runcinate; or outer scales ovate-lanceolate or (L. leptocephalum R.) lanceolate. E. B.553. - Very common, $\gamma$. in dry places, $\delta$. in bogs or damp places. P. III. -X.

\section{Sonchus Linn. Sowthistle.}

1. S. oleraceus (L.) ; 1. undivided or pinnatifid toothed clasping, auricles spreading arrowshaped, fr. transversely rugose and longitudinally ribbed, st. branched, heads subumbellate, involucres glabrous.-E. B. 843. - St. $2-3$ feet high. L. flattish, lower stalked. Florets yellow.- $\beta$.glandulosus(Gaud.); top of st., ped., and inv. bearing gland-tipped hairs.-Common. A. VI.-VIII. Sowthistle.

2. S. asper (Hoffm.); l. undivided or pinnatifid sharply toothed clasping, auricles rounded, fr. longitudinally ribbed smooth, st. branched, heads subumbellate, involucres glabrous.-E. B.S. 2765, 2766.-St. 2-3 feet high. L. crisped, lower stalked. Florets yellow.-Common. A. VI.-VIII. Sowthistle.

3. S. arvensis $($ L.) ; l. lanceolate runcinate finely toothed cordate at the base, uppermost l. entire, st. simple, heads corymbose, involucre and peduncles glandular-hairy, fr. with transversely rugose ribs, root creeping.-E. B. 674 . - St. $3-4$ feet high, leafy. L. long, acute. Heads large, florets yellow.-Fields and waste ground. P. VIII. IX. Corn Sowthistle.

4. S. palustris (L.); l. linear-lanceolate "lower runcinate," upper l. simple, all arrowshaped spinosely-ciliated, auricles acute, 
st. simple, heads corymbose, involucre and peduncles glandularhairy, fr. with finely-rugose ribs, root without stoles.-E. B. 935. -St. 4-6 feet high, leafy. Florets lemon-coloured.-Marshes, very rare. $P$. VII. VIII.

E. S.

\section{Mulgedium Cass.}

1. M. alpinum (Less.); 1. glabrous lyrate arrowshaped at the base, terminal lobe large triangular-hastate acute, st. simple, heads racemose, bracts peduncles and involucres glandular-hairy, fr. oblong not attenuated with many ribs.-Sonchus caruleus Sm., E. B. 2425.-St. 3 feet high, glabrous below, leafy. L. gradually smaller upwards, cordate on the barren shoots. Heads small, many. Florets blue.-Clova Mountains. P. VIII. S.

Section 6. HIERACIEAE. Receptacle generally without scales. Pappus filiform, never feathery nor dilated at the base. Fruit terete, ribbed.

\section{Crepis Linn. Hawk's-beard.}

* Fruit with a long subulate beak. Barkhausia Moench.

1. C. taraxacifolia (Thuil.); 1. rough runcinate-pinnatifid, heads erect, involucre bristly and downy covering half the pappus, outer phyll. ovate-lanceolate with a membranous margin, bracts herbaceous, fr. all equally beaked.-E. B. S. 2929.- Root fusiform. St. 1-2 feet high, hispid, angular, furrowed, purple below, at length branched, corymbose. L. mostly radical lyrateruncinate with retrorse teeth, or deeply pinnatifid with the terminal lobe large. Stem-l. few, sessile, clasping, deeply pinnatifid and toothed. Florets yellow, purple beneath. Fr. narrowing very gradually into a setaceous beak of about its own length, ribs rough.-Limestone districts. B. VI. VII. E. I.

[C. setosa (Hall.); 1. runcinate-dentate or lyrate-runcinate, st.-1. sagittate entire or incise-dentate below, heads erect, inv. about covering the pappus, margin of the outer lanceolate acute phyll. and the bracts the back of the inner phyll. and the ped. hispid with rigid simple bristles. $-E$. B. S. 2945.-Plant $1-2$ feet high. Stem-1. large, rather strapshaped, clasping.-Fields. Introduced with seed. A. VII. VIII.]

2. C. fotida (L.) ; 1. hairy runcinate-pinnatifid, unopened heads nodding, involucre hairy and downy as long as the greatly protruded pappus, outer phyll. lanceolate acute downy, marginal fr. slightly beaked shorter than the involucre, central ones with long beaks equalling it.-E. B. 406.- Root slender, fusiform. St. 6-12 in. high, hairy, round, branched. L. mostly radical, 
stem-1. few small lanceolate deeply toothed at the base sessile. Heads solitary, terminal, on long simple stalks. Midrib of the phyll. at length much thickened and hardened. Ribs of the fr. rough.-Chalky places, rare. B. VI. VII.

** Fruit narrowed upwards or obscurely beaked.

[3. C.pulchra (L.); outer phyll.ovate short adpressed, 1. downy toothed, stem-l. arrowshaped clasping, panicle corymbose, $f r$. about as long as the pappus obsoletely striated slightly attenuated upwards.-E. B. 2325.-St. erect, downy. Lower l. obovate runcinately toothed, stem-l. small. Heads small, florets yellow, involucre at length thickened. Outer row of fruits often apparently without pappus.- "Hill of Turin near Forfar." Mr. G. Don. A. VI.-IX.]

4. C. virens (L.); outer phyll. adpressed linear inner ones glabrous within, l. lanceolate remotely dentate runcinate or pinnatifid, uppermost $l$. linear-arrowshaped clasping with flat margins, st. subcorymbose, fr. shorter than the pappus oblong slightly attenuated upwards with smooth ribs.-C.tectorum Sm.(not Linn.). E. B. 1111.-St. 1-3 feet high. L. very variable. Florets yellow. [C. tectorum (L.) has revolute margined upper l., phyll. downy within, fr. somewhat beaked with scabrous ribs.]-Common. A. VI.-IX.

5. C. biennis (L.) ; outer phyll. oblong-linear lax inner downy within, l. runcinate-pinnatifid hispid, uppermost 1. lanceolate clasping dentate-pinnatifid, st. subcorymbose, fr. oblong slightly attenuated upwards with smooth ribs and about as long as the pappus. - E. B. 149 ? (excluding the fruit.) -St. $1-3$ feet high, hispid, nearly leafless above, branched in a corymbose manner. Heads large, florets yellow. Angles of fr. often rough. L. radical and extending half-way up the stem.-Chalky places, rare? B. VI. VII.

E.

6. C. succisafolia (Tausch); phyll. lanceolate-attenuated outer ones very short adpressed, $l$. entire nearly glabrous oblong obtuse lower ones narrowed into a footstalk, upper $l$. sessile and somewhat clasping, st. corymbose, peduncles and involucres glandularhairy, fr. much striated slightly narrowed upwards as long as the pappus which is shorter than the involucre.-Hieracium molle Sm., E. B. 2210.-St. erect, with few leaves, simple below. Heads few, florets yellow.-Woods in the north. P. VII. VIII.

E. S.

7. C. paludosa (Moench); phyll. lanceolate much attenuated glandular-pilose outer ones short, $l$. ovate-oblong taper-pointed runcinate-dentate narrowed into a footstalk glabrous, upper $l$. ovate-lanceolate cordate and clasping acute entire or dentate, st. 
subcorymbose, fr.striated scarcelynarrowed upwards.-Hieracium Sm., E. B. 1094. Aracium Neck., Soyera Monn.-St. 2 feet high, leafy, simple, angular. L. large. Florets yellow. Pappus in one row, rigid, brittle.-Damp woods and shady places. $P$. VII.-IX.

\section{Hieracium Linn. ${ }^{1}$ Hawkweed.}

i. PILOSELLOIDEA. Stoloniferous. St. scapelike. Fr. minute, crenulate at top, striate. Hairs of pappus equal, slender.

1. H. Pilosella (L.); stoles slender leafy rooting, scape 1headed leafless, 1. oblong or lanceolate hairy on both sides whitish and densely floccose beneath, inv. ovate below ultimately conical, inner phyll. acute, flts. glabrous, styles yellow.-E. B. 1093.Stoles slender, aërial, many, sometimes flowering. Flts. pale yellow; outer striped with red or purple externally.- $\beta$. H. Peleterianum (Mer.); stoles short thick, l. st. and inv. with long silky hairs, heads large, phyll. all lanceolate.-Dry banks. P. V.-VIII.

*2. H. aurantiacum (L.); stoles often wanting, st. slightly hairy above densely corymbose at top hairy setose above, $l$. obovate-lanceolate green and hairy on both sides not floccose beneath, phyll. blunt, fits. glabrous, styles brown.-E. B. 1469.St. 15-20 in. high. Corymb 2-10-headed, floccose. Phyll. dark. Flts. orange.-Woods and wastes in the north, naturalized. P. VI.-VIII.

ii. PULMONAREA. Radical rosettes in autumu. Root-l. persistent. Phyll. interruptedly or irregularly imbricate. Fr. short, truncate not crenulate, striate. Hairs of pappus unequal, rigid.

* Alpiniformes. Inv. shaggy or silky. Outer phyll. lax; inner acuminate or acute. Flts. hairy externally, more or less pilose at the tips. St.-l. 1 or few, or leaflike bracts.

3. H. alpinum (L.); deep green, st. 1-headed hairy floccose, $r t .-l$. lanceolate or ovate-spathulate narrowed into petioles, st.-l. 1 or few sessile, buds slightly nodding, inv. hemispherical shaggy with long soft black-based hairs setose, phyll. few broad acuminate lax, styles yellow. $-4-8$ in. high. Usually 1 st.-leaf. Head large, always solitary; flts. bright yellow, with short hairs at the top.-a. rt.-l. ovate-spathulate.- $\beta$. insigne; rt.-l. lanceo-

I A seta is a gland-tipped hair.-In this genus I have availed myself largely of the 'British Hieracia,' lately published by my friend Mr. James Backhouse, Jun. 
late with a few large teeth, heads very large.-Lofty mountains of Scotland. P. VII. VIII.

4. H. holosericeum (Backh.); green, st. 1-headed shaggy silky floccose, rt.-l. lanceolate-spathulate or linear-lanceolate blunt hairy on both sides narrowed into winged petioles, st.-l. few small sessile, buds nodding, inv. turbinate shaggy with long silky white black-based hairs, outer phyll. very lax leaflike blunt, inner phyll. adpressed linear acute, styles yellow.-H. alpinum Sm. E. B. 1110.-3-9 in. high. Usually $1-2$ st.-leaves. Head solitary; outer phyll. very broad, often scattered below the head. L. entire or sometimes slightly denticulate. Flts. densely hairy at the tips, bright yellow.-Lofty mountains. Cumberland. Grampian and Breadalbane Mountains. P. VII. VIII. E. S.

5. H. eximium (Backh.); green, st. usually 1-headed hairy floccose, rt.-l. lanceolate acute sharply toothed hairy on both sides narrowed into broadly winged petioles, st.-l. small slender, buds nodding, inv. truncate below shaggy with rather silky blackbased hairs, phyll. many linear-attenuate, outer phyll. small lax. $-H$. melanocephalum H. and A. $-6-15$ in. high. St.-l. few. Rarely more than 1 large head. L. sometimes entire, usually with large teeth. Flowers twice in cultivation, (l) with one head, (2) with many nearly parallel branches and many heads. $a$. st. elongate, rt.-l. lanceolate dentate, styles livid.- $\beta$. tenellum; st. short slender, rt.-1. lanceolate or linear-lanceolate, styles yellow. Considered a distinct species by Dr. Grenier. - Lofty mountains. Clova. Braemar. P. VIII. VIII.

S.

6. H. calenduliflorum (Backh.); deep green, st. usually 1headed hairy floccose, rt.-l. broadly ovate-spathulate blunt apiculate sharply toothed hairy on both sides narrowing into broadly winged petioles, st.-l. very small slender, buds nodding, inv. truncate below shaggy with rather silky black-based hairs, phyll. many linear-attenuate, outer phyll. lax, styles livid.-6-14 in. high. St.-l. few. Head most usually solitary, very large. Youngest 1 . sometimes rather acute. Original l. nearly circular. Nearly allied to $H$. eximium.-Lofty mountains. Lochnagar. Clova. P. VII. VIII.

S.

** Nigricantes. Inv. villose or hairy. Phyll. adpressed, or few outermost lax. Flts. nearly hairless externally, minutely pilose or subglabrous at the tips.

$\dagger$ St. short with 1 or few heads.

7. H. gracilentum (Backh.); green, st. usually 1-headed hairy floccose, $r$. $-l$. lanceolate or oblong-lanceolate narrowed into petioles, st.-l. few large narrow-lanceolate attenuate below, inv. 
ventricose rounded below shaggy with black soft hairs setose, phyll. few broad acuminate adpressed with floccose tips outermost lax, styles livid.-H. alpinum var. melanocephalum Fries, not Bab., nor H. melanocephalum Tausch, nor H. and A.-6-10 in. high. St. hairy and floccose, with straight simple diverging branches and many heads when under cultivation; st.-l. usually 2 or more. L. broad, narrowed gradually below; original 1. roundish. Petioles sometimes slightly winged. Heads usually solitary, rather large; flts. bright yellow, nearly or quite glabrous on the back. - Lofty mountains. P. VII. VIII. S.

8. H. globosum (Backh.); glaucous or green, st. few-headed floccose, $r t$. $-l$. ovate or ovate-lanceolate subacute glabrous above entire or dentate narrowed into petioles, inv. rounded below ultimately globose greenish-black with short black-based hairs, phyll. many attenuate acute adpressed, styles yellow.-6-12 in. high. St. usually l-headed, branching rarely even from near the base, leafless or with few narrow bractlike leaves. Original 1. blunt. Innermost l. sometimes acute. Petioles short, sometimes slightly winged. Buds globose. Flts. bright yellow.-Cairngorm mountains. P. VII. VIII.

S.

+ St. frequently lengthened and branched with several heads.

9. $H$. nigrescens (Willd.); green, rt.-l. ovate or lanceolate coarsely and irregularly dentate in their lower half hairy with slender petioles, st. simple or branched with few heads and few lanceolate or oblong shortly stalked 1., inv. ovate below dark green with soft black-based hairs setose, ped. densely floccose, phyll. acuminate outer ones blunt, styles brownish.-H. pulmonarium E. B. 2307 ? - Variable in height. Flts. deep brilliant yellow, pilose at the tips. Phyll. overtopping the buds. L. rarely nearly glabrous above. Rt.-l. suddenly narrowed below; original 1. roundish. St.-1. usually 1, narrowed at both ends. St. floccose, branching much in cultivation.-Highland mountains. P. VII. VIII.

10. H. lingulatum (Backh.); green, $r t .-l$. lanceolate or oblong apiculate denticulate or dentate hairy with short petioles, st. simple or branched with few heads and few lanceolate or lanceolate-attenuate acute sessile 1., inv. broad becoming truncate below very dark with soft black-based hairs slightly floccose, phyll. attenuate acute incumbent, styles livid.- $H$. saxifragum Bab.15-24 in. high. Fl. bright yellow. Phyll. greenish black, overtopping the buds. L. coarsely hairy above, entire towards the end. Original 1. broad and rounded. St. with scattered blackbased hairs throughout, a little floccose. St. and inv. nearly without setæ. - Mountain glens. Clova. Braemar. Ben Lawers. P. VII. VIII. 


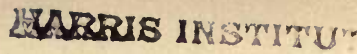 \\ HIERACIUM. \\ PRESTO261}

11. H. senescens (Backh.); green, rt.-1. elliptic-lanceolate denticulate or remotely dentate hairy with slender petioles, st. simple with few heads and 1 or 2 linear-lanceolate $l$. with slender stalks, inv. ovate or turbinate below with short black-based hairs and many setæ slightly floccose, phyll. acute adpressed (?), styles yellow.-15-18 in. high. Fl. golden. Phyll. of the buds with a tuft of white down at the tips. L. with scattered hairs on both sides, entire at both ends. Original l. broader. Lowest ped. above the middle of the stem.-Grassy slopes and edges of streams in mountain districts. Clova. Braemar. Ben Voirlich, Dumbartonshire. P. VII. VIII.

S.

12. H. chrysanthum (Backh.); green, rt.-l. ovate acute at both ends sharply irregularly and deeply toothed hairy with long slender petioles, st. simple or branched with few heads and linear-lanceolate or subulate stalked st.-l., inv. rounded below floccose and with short black-based hairs and setæ, phyll. many linear-attenuate outermost small and lax, styles dull yellow.$H$. rupestre Bab. $-9-15$ in. high. Fl. golden. Phyll. greenishblack, overtopping the drooping buds, incumbent. L. with scattered hairs on both sides, entire towards the end. Original l. blunt, roundish. St. often with only 1 head, with subplumose hairs below, floccose setose and with black-based hairs above, sometimes branching throughout. Hairs on st. and inv. with dull reddish tips. Buds sometimes pilose at the tip.- $\beta$. microcephalum; st. simple with 1 or few nearly erect heads, l. dentate or nearly entire, inv. urceolate, styles rather livid. $H$. atratum Bab.-Lofty mountains in Scotland. $\beta$. Cumberland and Lochnagar. P. VII. VIII.

E. S.

\section{†† St. usually lengthened.}

13. H. cerinthoides $(\mathrm{L}$.); glaucous green, rt.-1. ovate-lanceolate apiculate or acuminate denticulate with long shaggy winged petioles, st. with few 1 . and few heads, st.-l. clasping ovate acuminate, inv. ventricose hairy setose, phyll. acuminate, styles livid. - $a$. and $\gamma$. H. vogesiacum Gren. !-12-18 in. high. St. branching in cultivation. Original rt.-l. roundish. Rhizome short. Fl. pale yellow.-a. H. cerinthoides (Fr.); st. scarcely branched with I or few terminal heads, st.-l. few clasping, outer phyll. lax. E. B. 2378?-3. H. anglicum (Fr.); st. with long arcuate ascending lateral ped., st.-l. usually solitary sessile scarcely clasping, phyll. all adpressed. H. Lawsoni Bab.- $\gamma$. acutifolium (Backh.); very glaucous, st. much branched, 1 . very acute or acuminate sharply and coarsely toothed nearly glabrous, phyll. adpressed. -Mountains. a. Grampians. $\beta$. Teesdale. Ćraven. Lake district. Scottish Highlands. $\gamma$. Cairntoul and by rivers Clunie and Dee in Scotland. Aberdeen Links. P. VII. VIII. 
14. H. iricum (Fr.); glaucous green, st.-l. ovate or oblonglanceolate acute with short shaggy winged petioles, st. leafy corymbose at top, st.-l. clasping broadly ovate taper-pointed denticulate or dentate lower ones narrowed below, ped. and inv. hairy setose floccose, inv. truncate below, phyll. blunt, styles livid.-H. Lapeyrousii Bab., E. B. S. 2906. - I-3 ft. high, very leafy, rigid, not branching, l-headed on barren soil. Ped. rigid, diverging. Original rt.-l. blunt. L. often purplish at the end. St.-l. decreasing successively, upper l. broad and rounded below. Phyll. broad, narrowed upwards.-Chiefly in mountain districts. Braemar. Teesdale. Cunnamara; Garron Head; Bantry Bay; Castle Taylor, Galway. P. VII. VIII.

*** Pallidiformes. Inv. more or less hairy. Phyll. adpressed. Flts. hairless externally, nearly or quite glabrous at the tips.

† Styles yellow, rarely with minute fuscous hairs.

15. H. pallidum (Fr.); glaucous, rt.-l. ovate-lanceolate acute apiculate-dentate or dentate below with slender petioles, st. fewheaded with about 1 sessile or stalked l., inv. ovate below ventricose constricted above floccose slightly hairy and setose, phyll. acute or cuspidate, styles yellow.-H. Halleri Hook. -6-18 in. high. Rhizome elongate, prostrate. L. fringed with long hairs which sometimes spread over the surfaces, obscurely floccose beneath. St.-l. nearly or quite sessile, if more than 1 then the lower is stalked. Original rt.-1. rounded at both ends. Flts. very slightly pilose at the tips, bright yellow.-Mountains. P. VI. VII. and IX. $\quad$ E. S.

16. H. lasiophyllum (Koch); ash-coloured or glaucous, rt.-l. oval or ovate-lanceolate rounded at both ends entire or denticulate, petioles shaggy, st.-l. 0 or 1 , st. few-headed with straightbased ped., inv. rounded below floccose setose slightly hairy, phyll. acuminate or cuspidate, styles yellow.- $H$. cinerascens Jord., Gren.! H. pallidum var. crinigerum Fr.! $-8-20$ in. high. Very hairy. Branches slender, long. Young heads roundish. Outer phyll. sometimes bluntish. Flts. bright yellow. L. rosulate, persistent, broad, apiculate, usually with many scattered bulbous hairs on each side. Original l. roundish. St.-l. rare, lanceolate, acute at both ends.-Mountains. Grampians. Snowdonia. Craig Breidden. P. VII. VIII.

17. H. Gibsoni (Backh.); glaucous green, rt.-l. ovate blunt apiculate rather truncate or cordate below denticulate, petioles slender, st. leafless rigid simple or forked with straight-based ped., inv. truncate below floccose hairy setose, phyll. broad and blunt 
incumbent, styles yellow.-H. hypochœroides S. Gibs. H. hypochœridis H. \& A. -6-18 in. high. Flts. bright yellow. Phyll. not cuspidate. L. rosulate, persistent, very broad, blotehed with purple above. - On limestone rocks near Settle, Yorkshire. P. VII. VIII.

E.

18. H. argenteum (Fr.); very glaucous, rt.-l. lanceolate acute denticulate towards the middle or entire glabrous above with short petioles, st. simple or branched with few sessile or stalked 1., branches long straight, inv. broadly ventricose becoming subtruncate below slightly setose and hairy and floccose, phyll. blunt adpressed, styles yellow.- $\dot{H}$. pallidum $\boldsymbol{\beta}$. persicifolium Bab.$1-2 \mathrm{ft}$. high. Buds cylindrical. Inner phyll. subacute, paleedged. Flts. bright yellow. L. with scattered hairs beneath and at the edges. Petioles usually short. Original l. bluntish. Upper st.-l. small, narrow.- Mountain districts of England, Scotland and Wales. P. VII. VIII.

E. S.

19. H. nitidum (Backh.); dark green, rt.-l. lanceolate acute coarsely and sharply toothed glabrous above with short petioles, st.-l. 1 or 0 , st. few-headed, ped. scaly, inv. ventricose setose and hairy slightly floccose, phyll. acuminate or bluntish, styles yellow. $-15-24$ in. high. St. nearly hairless. Heads large; flts. bright yellow. L. slightly hairy beneath; teeth very large, not directed downwards. Petioles usually short. Original l. roundish. -By mountain streams in Aberdeenshire. P. VII. VIII. S.

20. H. aggregatum (Backh.); deep green, rt.-l. ovate blunt coarsely dentate below floccose beneath when young, st.-1. 1 lanceolate narrowed at both ends, st. corymbose and floccose at the top, ped. aggregate, inv. subtruncate below loosely floccose setose nearly hairless, phyll. blunt.-H. bifidum Koch ?-12-20 in. high. St. usually simple. Ped. forming a close corymb as in H. umbellatum. Heads many. Buds cylindrical. Flts. bright yellow or orange. Styles yellow. L. rosulate, persistent ; original 1. nearly round; innermost acutish. Petioles rather winged, slightly hairy. St.-l. subsessile. Phyll. adpressed.-By mountain streams in the Grampian Mountains. P. VII. VIII. S.

\section{†† Styles more or less livid.}

21. H. murorum (L.) ; green, rt.-l. ovate often cordate and with large patent or descending teeth below, petioles shaggy, st.-1. 0 or 1 stalked and placed high, heads subcorymbose, ped. arcuate ascending, inv. thinly clothed floccose setose with few hairs, phyll. acuminate erect overtopping the glabrous-tipped buds, styles livid. $-12-18$ in. high. Young heads cylindrical. L. usually thin. St.-l. ovate-acuminate, often rounded or cordate below. Styles rarely yellowish.- " $\beta$. rotundatum (Backh.); st. elongate, often leafless, rt.-l. broadly ovate rounded at both 
ends or cordate below denticulate or entire."-Woods and rocks. $\beta$. Canlochen, Forfarshire. P. VI. VII.

22. H. cœsium (Fr.); cæsious or dull green, rt.-l, ovate or lanceolate rounded or narrowed below irregularly dentate-serrate with patent or ascending teeth, petioles slender, st.-1. 0 or 1 placed low, st. few-headed with straight-based ped., inv. rounded below floccose hairy slightly setose, phyll. bluntish inner ones acute incumbent, styles slightly livid.-H. murorum Sm., $E$. B. 2082. - 12-18 in. high. Young heads roundish. Flts. bright yellow. Phyll. not cuspidate ; inner very slender, pointed. Rootstock long. L. nearly glabrous above, coriaceous, not fringed with coarse hairs; innermost acute. St.-l. not stalked, narrowed below.-H. obtusifolium (Backh.); yellowish-green, original rt.-1. ovate rounded at both ends entire, petioles densely villose, st.-l. 1 stalked ovate-lanceolate, inv. ventricose becoming truncate below, phyll. acuminate, buds pilose at the tip; is probably a variety, and is found at Clova.-Mountains. P. VII. VIII.

23. H. stelligerum (Froel.); ashy-green, rt.-l. ovate or oval blunt or acutish with small teeth below floccose on both sides narrowed into long petioles, st.-l. few large $\frac{1}{2}$-clasping, st. subcorymbose floccose throughout, ped. straight-based, inv. ovate below floccose setose hairy, phyll. acuminate incumbent, styles rather livid. $-1 \frac{1}{2}-2 \mathrm{ft}$. high. Flts. bright yellow. L. rosulate, persistent; original spathulate; innermost acutish. Petioles rather sleuder and woolly. St.-l. stalked; uppermost sessile.Alpine streams on Grampian Mountains. P. VII. VIII. S.

24. H. vulgatum (Fr.); green or glaucous, l. oblong or lanceolate often with patent or forward teeth on lower half, rt.-l. narrowed into petiole, st.-l. often many all or uppermost sessile, heads panicled or subcorymbose, inv. and straight ascending ped. floccose setose with few hairs, phyll. equally attenuate acutish incumbent, styles livid.-H. sylvaticum Sm., E. B. 2031.-Very variable. $1-3 \mathrm{ft}$. high. Rt.-l. persistent, st.-l. few ; or rt.-1. few and evanescent, st.-l. many. The typical plant has panicled heads cylindrical when young, glaucescent 1. purplish beneath, persistent rt.-l., few st.-l., greenish inv.- $-H$. maculatum (Sm.) E. B. 2121. is a form with evanescent rt.-l., many and broad st.1., and imperfectly corymbose heads. Many other forms are named, but they defy definition.-Woods, banks, walls. P. VII.-IX.

**** Pseudo-accipitrince. Inv. subglabrous. Rt.-l. often forming a winter rosette but rarely present with the flowers.

25. H. gothicum (Fr.) ; l. ovate-lanceolate denticulate or dentate at the middle, rt.-l. shortly stalked usually evanescent, lower 
st.-1. often stalked and aggregate, upper st.-1. sessile, heads few subcorymbose, ped. rigid erect slightly floccose, inv. roundly ventricose subglabrous or slightly hairy, phyll. dark green broad blunt incumbent, style yellow with fuscous hairs. - Very variable, 1-4 ft. high. St. rigid, rarely much branched. Rt.-l. very rarely persistent. L. all similar, firm, narrowed at both ends, sometimes very narrow. Young heads cylindrical. Inv. with few brownish hairs and very slightly floccose or subglabrous.$\beta$. latifolium (Backh.); st. branched, l. broadly lanceolate, style nearly wholly yellow. H. norvegicum (Fr,?).-Heathy or grassy subalpine places. P. VII.-IX.

iii. ACCIPITRINA. No true rt.-leaves. Forming closed buds at the base of the st. in autumn. St. leafy. Pliyll. in many rows. Hairs of pappus rigid, unequal.

* Pseudo-pulmonarece. Rarely forming small basal rosettes which do not outlive the winter.

26. H. tridentatum (Fr.) ; st. leafy, l. lanceolate few-toothed at the middle falsely 3 -veined, rt.-l. narrowed into winged petioles, st.-l. sessile, heads corymbose, round-based inv. and long floccose slender ped. with short hairs, inv. of fr. truncate below constricted in the middle, phyll. pale-edged subglabrous rather blunt, styles livid.-Rt.-l. rarely persistent. $2-5 \mathrm{ft}$. high. St. often much branched above, with leaves decreasing successively to small bracts, hairy below. Petioles and base of sessile l. villose. Teeth of 1 . usually large. Inv. of fr. often an acute cone, sometimes floccose. Pappus reddish.-Banks. P. VIII. IX.

** Aphyllopoda. Never forming rosettes. Rt.-l. fading early.

+ Florets minutely pilose or subglabrous at the tips.

27. H. prenanthoides (Vill.); st. leafy, l. all clasping netveined and glaucous beneath hairy on both sides, lowest narrowed into winged auricled petioles, interm. pinched above their base, uppermost l. cordate-lanceolate, heads in a corymbose panicle, ped. short lax very floccose and setose, inv. cylindrical rather floccose very setose, outer phyll. few much the shortest, inner all about equal and blunt, styles with dark hairs, fr. pale.-E. $B$. $2235 .-1-3 \mathrm{ft}$. high. St. rather rigid, usually hairy. Pan. leafy below. Heads small. Pappus whitish.--River sides in the north. P. VII. VIII.

28. H. strictum (Fr.); st. leafy, l. sessile oblong-lanceolate denticulate glaucous beneath, lowest lanceolate much narrowed below, uppermost $l$. rounded below scarcely clasping, heads 
irregularly corymbose, ped. straight floccose scarcely setose, inv. elliptical thinly floccose setose and hairy, phyll. irregularly imbricate blunt, outermost rather acute, styles with dark hairs, fr. fuscous. - H. denticulatum E. B. 2122.-1-3 ft. high. St. slightly hairy. L. broad, not auricled, mostly with bulbous hairs beneath. Heads thicker and paler than those of $H$. prenanthoides. Phyll. pale-edged, not in two distinct ranks. Pappus reddish.Mountain glens. P. VII. VIII.

\section{†† Florets glabrous at the tips.}

29. H. umbellatum (L.); st. leafy, $l$. all linear or oblong-lanceolate narrowed below sessile net-veined, heads in an umbellate corymb, top of ped. floccose, turbinate-based inv. uniformly dark green glabrous, phyll. blunt with recurved points, styles yellow.E. B. 1771.-1-4 ft. high. St. rigid, hairy below. L. usually all alike or upper rather broad and rounded at the base. Outer phyll. often very small, slender, acute. Inv. very rarely strawcoloured, rarely with a few white hairs. Pappus whitish.Sandy and stony places. P. VII.-IX.

30. H. crocatum (Fr.); st. leafy, 1. oblong or narrowly lanceolate sessile with a broad base falsely 3-veined, lower 1. narrowed downwards, heads subcorymbose, branches nearly simple, ped. floccose, inv. very broad and blunt below subglabrous, phyll. blackish blunt adpressed, styles yellowish with fuscous hairs.H. inuloides Tausch.-Very variable. $1 \frac{1}{2}-4 \mathrm{ft}$. high. St. rigid. L. toothed or nearly entire; lower often narrowed very gradually but again slightly enlarged at their base. Inv. rarely pilose. Inner phyll. sometimes pale-edged.-Mountain districts. P. VII. VIII.

31. H. rigidum (Fr.) ; st. leafy, l. ovate-lanceolate or lanceolate denticulate or subdentate at their middle rounded below falsely 3-veined, lower 1 . narrowed into short winged petioles, heads in a rather leafy branched corymbose panicle, round-based inv. and floccose ped. with scattered hairs, inv. of fr. not constricted conical, phyll. uniformly blackish green blunt adpressed, styles yellowish with fuscous hairs. $-H$. rigidum and $H$. corymbosum Bab. $-3-4 \mathrm{ft}$. high. St. rigid, mostly glabrous. Uppermost l. broad-based. Inv. of fr. often subglabrous, blunt, rarely floccose. Inner phyll. sometimes pale-edged. Pappus reddish. -Mountain districts. P. VIII. IX.

32. $H$. corymbosum (Fr.); st. very leafy, $l$. ovate-lanceolate dentate below clasping net-veined glaucous beneath, heads in a spreading branched corymbose panicle, inv. ovate or subtruncate below and ped. slightly hairy setose and floccose, phyll. blunt, inner pale-edged, outer phyll. acutish, styles yellow. $-3-4 \mathrm{ft}$. 
high. St. rather rigid, floccose, rather woolly, reddish. L. hairy on both sides, floccose beneath, strongly and sharply toothed; lower sometimes narrowed below; uppermost narrowing from a broad base. Pappus whitish tawny.-Banks of river Clunie, Braemar. P. VII. VIII.

S.

33. $H$. boreale (Fr.); st. leafy, l. ovate or lanceolate dentate below falsely 3-veined, upper broad sessile scarcely clasping, lowest 1 . much narrowed below but scarcely stalked, heads in a rather leafy corymb or panicle, top of ped. floccose, ovate-based inv. uniformly blackish-green nearly glabrous or pilose, phyll. blunt adpressed, styles livid blackish. $-H$. sabaudum Sm., E. B. $349 .-2-4 \mathrm{ft}$. high. St. rigid, usually hairy and often very leafy below. Base of corymb or panicle leafy; branches nearly erect. Interm. 1. narrowed to a rounded base; upper with a broad rounded or subcordate base. Phyll. turning black, scarcely at all setose or floccose, rarely with spreading tips. Pappus whitish.-Banks. P. VIII. IX.

\section{Index to the Hieracia.}

H. acutifolium, 13. aggregatum, 20. alpinum, 3 . anglicum, 13. argenteum, 18. atratum, 12. aurantiacum, 2. bifidum, 20. boreale, 33 . cæsium, 22. calenduliflorum, 6 . cernithoides, 13. chrysanthum, 12. cinerascens, 16. corymbosum, 32. corymbosum, 31 . crocatum, 30 . denticulatum, 28. eximium, 5. Gibsoni, 17. globosum, 8. gothicum, 25. gracilentum, 7. Halleri, 15. holosericeum, 4. hypochoridis, 17. hypochœroides, 17. insigne, 3. inuloides, 30 . iricum, 14. Lapeyrousii, 14. lasiophyllum, 16. latifolium, 25. Lawsoni, 13. lingulatum, 10. maculatum, 24. melanocephalum, 5,7 . sylvaticum, 24 . microcephalum, 12. murorum, 21. murorum, 22. nigrescens, 9 . nitidum, 19 . obtusifolium, 22. pallidum, 15 . pallidum, 16, 18. Peleterianum, 1. persicifolium, 18. Pilosella, 1. prenanthoides, 27. rigidum, 31 . rotundatum, 21. rupestre, 12. sabaudum, 33. saxifragum, 10. senescens, 11. stelligerum, 23. strictum, 28. tenellum, 5 . tridentatum, 26. umbellatum, 29. vogesiacum, 13. vulgatum, 24.

[H. auricula, H. dovrense, H. dubium, H. oreades and $\boldsymbol{H}$. villosum are omitted, having probably never been found in Britain. $H$. amplexicaule is not even naturalized. $\boldsymbol{H}$. pulmonarium is perhaps not determinable, but may be $H$. nigrescens.] 


\section{Anomalous Genus. Order AMBROSIACEæ Link.}

\section{Xanthium Linn.}

[1. X. strumarium (L.); st. without spines, lower l. heartshaped 3-lobed at the base coarsely dentate, beaks of the fr. 2 straight.-E. B. 2544.-Involucre of the fr. oval, downy.-Rich waste land, scarcely naturalized. A. VIII. IX.]

\section{Order XLVI. CAMPANULACEA.}

Cal. superior, 5 -fid or entire. Cor. monopetalous, inserted on the calyx, 5-lobed, regular or irregular. Stam. inserted with the cor. and alternate with its lobes; anth. distinct or cohering, 2-celled, opening longitudinally. Fr. dry, capsular, opening by lateral fissures or valves at the apex, many-seeded. Embryo straight in the axis of fleshy albumen.

Tribe I. LOBELIEAE. Odd segment of the calyx anterior. Cor. irregular. Anth. cohering. Style glabrous with a fringe of hairs below the stigma.

1. Lobelia. Cal. 5-fid, Cor. irregular; tube split to the base on the upper side; limb 2-lipped, 5-parted. Anth. 5, cohering. Stigma blunt, surrounded by a cupshaped fringe. Caps. 2 -3-celled, opening at the end by $2-3$ valves.

Tr. II. CAMPANULEAE. Odd segment of the calyx posterior. Cor. regular. Anth. usually free. Style pubescent.

2. JAsione. Cal. 5-fid. Cor. rotate with 5 long linear segments. Anth. cohering at their base. Style hairy, bifid. Caps. 2-celled, opening at the end by minute teeth.

3. Phyteuma. Cal. 5-parted. Cor. rotate with 5 long linear segments. Anth. free; filaments dilated at the base. Style hairy, 2-3-fid. Caps. 2-3-celled, bursting at the sides.

4. Campanula. Cal. 5-parted. Cor. mostly bell-shaped with 5 broad and shallow segments. Anth. free; filaments dilated at the base. Stigma 3-5-fid. Caps. not elongated, 3-5-celled, opening by lateral pores outside the segments of the calyx.

5. Specularia. Cor. rotate. Caps. linear-oblong, prismatical, opening by lateral pores between the segments of the calyx. Otherwise like Campanula.

6. Wahlendergia. Caps. half superior, 3-celled, opening by $3-5$ valves within the segments of the calyx. Otherwise like Campanula. 


\section{Tribe I. Lobeliea.}

\section{Lobelta Linn.}

1. L. Dortmanna (L.) ; 1. linear entire of 2 parallel tubes, st. simple nearly naked.-E. B. 140.-Root-stock fleshy with filiform runners. L. blunt, $1-2$ in. long, mostly radical. St. $12-$ 18 in. high. Fl. light blue, distant, in a simple raceme, slightly raised above the water, the rest of the plant submersed.-Lakes with a gravelly bottom. P. VII.

2. L. urens (L.); st. nearly upright, lower l. obovate or oblong slightly toothed, upper lanceolate serrate, fl. in long terminal racemes. - E. B. 953.-St. 12-18 in. high, leafy, branched, angular, roughish. Racemes erect, simple, lax. Fl. light blue.Heaths near Axminster, Devon. P. VIII. IX.

E.

\section{Tribe II. Campanulea.}

\section{JASIONe Linn. Sheep's Scabious.}

1. J. montana (L.); root simple, l. bluntish oblong wavy, fl. stalked.-E. B. 882.-St. several from the crown of the root, 6 in. to 2 feet long, simple or branched, pilose, leafy below, bare and usually glabrous above. Fl. small, in terminal bracteated heads. Bracts glabrous or hairy. Calyx-segments linear-setaceous, glabrous. Cor. light blue.-Dry places. B. VII.

\section{Phyteuma Linn. Rampions.}

1. P. orbiculare (L.); heads of fl. globose of fr. oblong, l. crenate-serrate, lowermost cordate-ovate stalked, upper ones linearlanceolate sessile, outer bracts ovate-lanceolate attenuate, stigmas 3. - E. B. 142.-St. 12-18 in. high, each with 1 terminal head of blue flowers.-Chalky downs. P. VII.

E.

2. P. spicatum (L.); heads of fl. oblong of fr. elongated cylindrical, lower l. cordate-ovate somewhat doubly serrate stalked, upper l. linear-lanceolate sessile, bracts linear, stigmas 2.-E.B.S. 2598. - St. 1-2 feet high, each with a solitary terminal head of cream-coloured flowers. Spike of fruit often $2-3$ in. long.- Woods and thickets about Waldron, Sussex. P. VII.

E.

\section{Campanula Linn. Bell-flower.}

* Caps. sessile, erect; pores at the base.

1. C. glomerata (L.); 1. minutely crenate-serrate lowermost stalked ovate-lanceolate generally cordate at the base, upper 1 . 
half-clasping sessile ovate acute, $f$. sessile in terminal and axillary clusters. - E. B. 90.-St. $6-18$ in. high. Bracts ovate-acuminate, shorter than the large erect flowers. Cal. hoary with lanceolate segments. Cor. funnelshaped, large, deep blue, downy. L. often hoary beneath.-Dry calcareous pastures. P. VII. VIII. Clustered Bell-flower.

E. $\mathrm{S}$.

** Caps. stalked, nodding; pores at the base.

2. C. latifolia (L.); l. ovate-lanceolate acuminate doubly serrate hairy lower ones stalked, upper l. nearly sessile, fl. racemose, peduncles l-flowered, cal.-segments lanceolate acuminate glabrous finely serrate, st. erect slightly angular.-E. B. 302. St. 72. 3.-St. 3-4 feet high, simple, leafy. Cor. very large, deep blue, glabrous, hairy within.-Woods and thickets, chiefly in the north. P. VII. VIII. Giant Bell-flower.

3. C. Trachelium (L.); l. coarsely double serrate hispid lower ones cordate with long stalks, upper 1. nearly sessile ovate or lanceolate-acuminate, fl. racemose, peduncles 2 -3-flowered, cal.-segments triangular-lanceolate entire erect, st. erect angular. - E. B. 12.-St. $2-3$ feet high, mostly simple, leafy. Cor. truly bellshaped, large, deep blue.-Hedges and thickets chiefly in the south. P. VII. VIII. Nettle-leaved Bell-flower.

4. C. rapunculoides (L.); $l$. unequally crenate-serrate scabrous lower ones cordate with long stalks, upper l. sessile lanceolate, $f$. racemose unilateral, peduncles l-flowered, cal.-segments linearlanceolate entire at length reflexed, st. erect slightly angular, root creeping.-E. B. 1369.-St. 2 feet high, simple, leafy. Cor. pale blue.-Woods and hedges, very rare. P. VII. VIII. E. S.

5. C. rotundifolia (L.); radical l. cordate or reniform shorter than their stalks, stem-l. linear the lower ones lanceolate, $f .1$ or more racemose, cor. turbinate-campanulate.-E. B. 866 . St. 6-12 in. high. Radical 1. soon vanishing. Cor. blue. Cal.segments linear-subulate.- $\beta$. lancifolia (Koch); lower st.-l. rather broadly lanceolate, upper 1 . gradually smaller, $\mathrm{fl}$. often solitary.-Dry and hilly places. $\beta$. on mountains. P. VII, VIII. Hairbell.

*** Caps. stalked, erect ; pores just below cal.-segments.

*6. C. persicifolia (L.); 1. smooth slightly serrate, root-l. obovate narrowed into a petiole, stem-l. linear-lanceolate sessile, raceme few-flowered, cal.-segments lanceolate.-E. B. S. 2773.St. $1-2$ feet high. L. long, narrow, with very narrow serratures. Fl. very large, often solitary. Cal.-segments entire.- "Woods near Cullen." A very doubtful native. P. VII. S.? 
7. C. Rapunculus (L.); 1. crenate, root-1. elliptic-lanceolate narrowed into a petiole, stem-l. linear-lanceolate, panicle erect racemose, cal.-segments subulate. - E. B. 283.-St. 3 feet high, angular, rough. Fl. small, pale blue. Cal.-segments entireSandy soil in the south. P. VII. VIII. Rampions.

E.

8. C. patula (L.); 1. crenate, root-1. oblong-elliptical narrowed into a petiole, stem-l. linear-lanceolate, panicles lax, fl. on long stalks erect, cal.-segments toothed at the base subulate.-E. B. 42 . -St. 2 feet high, terminating in a very loose spreading panicle. Fl. purplish-blue, funnelshaped, open.-Hedges and thickets. B. VII. VIII.

E.

\section{Specularia Heist.}

1. S. hybrida (A. DC.); st. simple or branched, 1. slightly crenate wavy oblong sessile, lower l. spathulate, cal. scabrous, segments lanceolate longer than the cor. shorter than the ovary.Campanula Sm., E. B. 375.-St. 6-12 in. high, rough with rigid minute hairs. Fl. few, terminal, solitary, small.-Cornfields. A. VI.-IX.

E. S.

\section{Wahlenbergia Schrad.}

1. W. hederacea (Reich.); 1.roundish-cordate angularly 5-lobed stalked alternate, st. filiform prostrate, peduncles solitary, "seeds punctate."-Campanula Sm., E. B. 73.-St. branched and creeping to a great extent. Peduncles longer than the leaves. Fl. pale blue, at first nodding, afterwards erect. Cal.-segments subulate. Caps. nearly globose.-Damp peaty places in the south and west. P. VII. VIIII. Ivy-leaved Bell-flower.

\section{Order XLVII. ERICACEAE.}

Cal. 4-5-parted, persistent. Cor. monopetalous, 4-5-parted, usually regular and marcescent. Stam. 8-10. Anth. 2-celled, opening by pores and often appendaged. Ovary surrounded by a disk or scales, free or adhering to the corolla. Fr. capsular or baccate with several cells, many-seeded.

Tribe I. ARBUTE $A$. Fr. baccate, fleshy. Anth. 2-celled. Disk hypogynous.

1. Arbutus. Cal. 5-parted. Cor. globose or ovate-campanulate with a small contracted 5-cleft reflexed border, deciduous. Stam. 10, with flattened filaments. Anth. compressed, with 2 pores at the apex, fixed at the back beneath the apex and there furnished with 2 reflexed awns. Berry globose, granular; cells 5, many-seeded. 
2. Arctostaphy los. Fr. with 5 l-seeded cells, not granular externally. Otherwise like Arbutus.

Tr. II. ERICEAE. Fr. capsular, dry. Anth. 2-celled. Diŝ hypogynous. Testa close.

3. Andromeda. Caps. dry, of 5 cells and 5 valves. Otherwise like Arbutus.

4. Calluna. Cal. 4-parted, membranous, coloured, longer than the 4-cleft campanulate corolla, surrounded by 4 green bracts. Cor. persistent, fading. Stam. 8, with dilated filaments. Caps. 4-celled; dissepiments adhering to the axis; valves opening at the dissepiments and separate from them.

5. Erica. Cal. 4-parted. Cor. campanulate or ovate often ventricose, 4-toothed, persistent, fading. Stam. 8. Caps. 4-celled; valves opening between the dissepiments and carrying a part with them.

6. Phyllodoce. Cal. 5-parted. Cor. ovate, deciduous; mouth contracted, 5 -toothed. Stam. 10, included; filaments slender, longer than the anthers; cells short, truncate, opening by pores at the apex. Stigma peltate with 5 tubercles. Caps. 5-celled with 5 valves opening at the dissepiments.

7. Da Beocia. Cal. 4-cleft. Cor. ovate, ventricose, limb 4toothed. Stam.8, included; filaments flattened shorter than the linear anthers which are sagittate below; cells loosened and opening by oblique pores at the apex. Stigma simple, truncate. Caps. 4-celled with 4 valves opening at the dissepiments.

8. Azalea. Cal. 5-parted. Cor. campanulate, 5-cleft. Stam. 5 , equal, shorter than the corolla; anth. roundish; cells opening by a longitudinal fissure. Stigma capitate. Caps. 2-3-celled with 2 or 3 bifid valves whose inflexed edges form the double partitions.

Tr. III. VACCINIEAE. Fr. baccate, fleshy. Anth. 2-celled. Disk epigynous.

9. VACcinium. Cal. entire or 4-5-toothed or lobed. Cor. 4-5-cleft or toothed. Stam. 8-10; anth. oblong, bifid at the summit. Berry globose, crowned by the persistent limb of the calyx, 4-5-celled, many-seeded.

Tr. IV. PYROLEA ${ }^{1}$. Fr. capsular, dry. Seeds with a loose testa. Disk 0. Anth. opening by pores.

1 Combined with Droseracea by Coss. and Germ. (Fl. Par. 66) under the name of Roridulea. 
10. Pyrola. Cal. 5-parted. Cor. of 5 petals. Stam. 10 ; anth. inverted, with 2 cells each opening by a round pore at the base. Style 5-lobed. Caps. 5-celled, 5-valved, opening near the base, margins of the valves connected by a web.

11. Moneses. Cal. 5-parted. Cor. of 5 petals connected below. Stam, 10 ; anth. inverted, with 2 cells each furnished with a tubular horn opening at the end. Stigma 5-parted, radiant. Caps. 2-celled, 5-valved, "opening from the summit" with connected margins.

Tr. V. MONOTROPEAE. Fr. capsular, dry. Seeds with a loose testa. Disk 0. Anth. opening by a transverse fissure.

12. Monotropa. Cal. 4-5-parted. Cor. of 4-5 petals each with a hooded nectariferous base. Stam. 8-10. Anth. kidney-shaped, l-celled, 2-valved. Stigma peltate. Caps. 5-celled, 5-valved, many-seeded.

\section{Tribe I. Arbutea.}

\section{Arbutus Linn. Strawberry-Tree.}

1. A. Uncdo (L.); bark rough, 1. elliptic-lanceolate serrate coriaceous glabrous, panicle terminal nodding, pedicels glabrous. -E. B. 2377. - An evergreen tree. Fl. whitish, pendulous. Fr. red.-Killarney, where it is truly wild. T. IX. X.

\section{Arctosta phylos Adans.}

1. A. alpina (Spr.); procumbent, $l$. wrinkled serrate fading but persistent, clusters terminal.-Arbutus Sm., E. B. 2030. St. 6. 8.-St. woody, trailing, long. L. obovate, reticulated. Fl. white, hairy about the mouth. Berry smooth, black.-Dry barren spots on the Highland mountains. Sh. V.

S.

2. A. Uva-ursi (Spr.); procumbent, l. obovate entire shining evergreen, clusters terminal.-Arbutus Sm., E. B. 714. St. 6.8. -St. woody, trailing, long. L. obtuse, quite entire. Fl. rosecoloured, smooth. Berry globose, scarlet.-Dry stony mountain heaths. Sh. VI.

\section{Tribe II. Ericea.}

\section{ANDRomeda Linn.}

1. A. polifolia (L.); 1. alternate lanceolate with revolute margins glaucous beneath, fl. subumbellate terminal. $-E$. B. 713 . -St. slender, woody, prostrate below. Fl. drooping, ovate, 
pink, occasionally 4-fid and 8-androus. L. evergreen, acute. Peduncles 2 or 3 times as long as the flowers, not as in E. B.Peat bogs. Sh. V.-IX.

\section{Calluna Salisb. Ling.}

I. C. vulgaris (Salisb.).-E. B. 1013.-A low tufted shrub. L. small, sessile, closely imbricated, keeled, in 4 rows, each with 2 small spurs at the base, nearly or quite smooth. Fl. small, shortly stalked, drooping, lilac-rose-coloured or white.- $\beta$.tomentosa; 1. hoary.-Dry heaths. Sh. VI.-VIII.

\section{Erica Linn. Heath.}

* Cor. globose or urceolate, stam. included, filaments capillary, stigma peltate. ERICA D. Don.

1. E. Tetralix (L.); $l .4$ in a whorl lanceolate or linear ciliate downy above and on the midrib beneath, margins revolute, fl. capitate, sep. linear downy ciliate, anth. awned, ovary downy.E. B. 1014.-St. branched below, often in a determinate manner about the middle, simple in the upper part, densely leafy below, the whorls more distant towards the top and usually leaving a leafless space next to the flowers. Tips of young shoots green. Young 1. always downy above, old 1 . sometimes glabrous. Sep. downy and mealy. Fl. rose-coloured. Style usually included. - $\boldsymbol{\beta}$. Watsoni ; cor. ventricose, fl. more or less racemose. It may be a hybrid.-Boggy heaths. $\beta$. Truro, Cornwall. Sh. VII. VIII.

2. E. Mackaiana (Bab.); $l .4$ in a whorl ovate ciliate the midrib beneath and upper surface glabrous, margins revolute, $\mathrm{fl}$. capitate, sep. ovate-lanceolate glabrous, anth. awned, ovary glabrous.-E. B. S. 2900 . - St. irregularly branched throughout, particularly above, densely and equally leafy quite up to the flowers. Tips of young shoots pink. L. and sepals quite without down; 1 . mealy beneath but the midrib bare; sep. with a small portion of meal near the apex beneath, otherwise quite bare. Fl. purplish. Style protruded.-Between Roundstone and Clifden, Cunnamara. Sh. VIII. IX. Mackay's Heath.

3. E. cinerea (L.); $l$. 3 in a whorl linear-lanceolate acute keeled beneath with a central furrow glabrous, $f$. in dense whorled racemes, sep. linear-lanceolate smooth acute keeled, anth. awned, ovary glabrous.-E. B. 1015.-St. with many upright branches. L. flat above, minutely serrulate. Fl. reddish-purple.-Dry heaths. Sh. VII. VIII. Fine-leaved Heath.

4. E. ciliaris (L.); $l .4$ in a whorl ovate ciliate the margins revolute, $f$. in terminal unilateral racemes, anth. without awns, 
mouth of the cor. oblique.-E.B. S. 2618.-St. long, straggling, each terminating in a long raceme of large oblong purple flowers and producing many short barren branches. Style protruded. Ovary glabrous.-Heaths. Wareham, Dorset. Carclew, Cornwall: "Near Clifden, Galway, I." Sh. VII. VIII. E. I.

** Cor. campanulate or shortly tubular, stam. exserted, filaments flattened, style capitate. Gypsocallis D. Don.

5. E. mediterranea (L. ?); $l .4$ in a whorl linear glabrous flat above convex with a central furrow beneath, decurrent line from the l. reaching but not extending beyond the next whorl, $\mathrm{fl}$. axillary drooping racemose, cor. cylindrical-urceolate twice as long as the coloured calyx, anth. without awns opening throughout nearly their whole length.-E. B. S. 2774.-St. $2-5$ feet high, with many, upright rigid branches terminating in leafy racemes of flesh-coloured flowers but afterwards prolonged. L. many erect-patent. Bracts above the middle of the pedicels. Stam. and style slightly exserted, style afterwards elongated. Ovary glabrous.-Our plant differs from $E$. carnea by its 1 . having a longitudinal furrow, not a keel on the back, the decurrent ridge from their base not extending beyond the next whorl (in $E$. carnea it reaches the second); the anthers much shorter and their pores much longer in proportion; and the cor. of a different shape.-Mountain bogs. West of Mayo and Galway. Sh. IV.

6. E. vagans (L.) ; 1.4-5 in a whorl linear glabrous, fl. axillary crowded, cor. short campanulate, sep. small ovate obtuse, anth. ovate of 2 distinct cells gibbous at the base.-E. B. 3.St. 1-2 feet high, copiously branched. Fl. usually collected in large numbers considerably below the top of the branches, cor. red or white. Anth. dark purple. Ovary glabrous.-Western parts of Cornwall. Coast of Waterford. Sh. VII. VIII. Cornish Heath.

E I.

\section{Phyllodoce Salisb.}

1. P. carulea; 1. linear denticulate, pet. glandular-hairy, calycine segments lanceolate acute, anth. 3 times shorter than the glabrous filaments.-Menziesia Sm., E. B. 2469.-St. 4-5 in. high, determinately branched, naked below, densely hairy above. Ped. terminal, aggregate, simple. Fl. large, pale, bluishred.-Sow of Athol, Perthshire. Sh. VI. VII.

\section{Dabeocia D. Don.}

1. D. polifolia (D.Don).-Menziesia Sm., E.B.35.-St. bushy, 1-2 feet long, ultimately decumbent. L. ovate or elliptical, flat, 
with revolute margins, white and cottony beneath. Fl. large, purple, sometimes white, drooping, on short stalks, in terninal simple unilateral clusters. Anth. very large.-Cunnamara. Sh. VIII. Cunnamara or St. Dabeoc's Heath.

\section{Azalea Linn.}

1. A. procumbens (L.).-E. B. 865 . The original and only Azalea.-St. woody, spreading, procumbent. L. small, opposite, revolute. Fl. small, on simple stalks, terminal, aggregated.Summits of the Highland mountains. Sh. V. VI.

S.

\section{Tribe III. Vacciniea.}

\section{VACCINIU M Linn.}

* Anthers with 2 dorsal horns.

1. V. Myrtillus (L.); $l$. ovate serrate glabrous deciduous, ff. solitary, st. acutely angular.-E.B. 456 .-St. woody, about a foot high, branching. Fl. greenish, tinged with red, nodding. Berries black.-Stony woods and heaths. Sh. V. Bilberry.

2. V. uliginosum (L.); l. obovate entire glaucous and veined beneath deciduous, fl. aggregate, st. rounded.-E. B. 581. St. 12. -St. woody. Fl. flesh-coloured, nodding. Berries black.Mountain bogs. Sh. V. Bog Whortleberry. E. S.

$$
\text { ** Anthers without horns on the back. }
$$

3. V.Vitis-idaa (L.); l. obovate dotted beneath persistent, margins revolute and somewhat crenate, fl. racemose terminal, cor. campanulate.-E. B. 598.-St. woody, 6-8 in. high, straggling. L. like those of Box, dark green above. Fl. pink, 4-cleft. Berries red.-Mountain heaths. Sh. VI. VII. Red Whortleberry. Cowberry.

4. V. Oxycoccos (L.); l. ovate entire persistent with revolute margins glaucous beneath, fl. terminal on long simple peduncles, cor. rotate with reflexed segments.-E. B. 319. Oxycoccus palustris DC.-St. procumbent, filiform, rooting. L. small. Fl. bright rose-colour. Cor. deeply divided, remarkably reflexed. Berries crimson.-Wet bogs. Sh. VI. VII. Cranberry.

[V.macrocarpum (Ait.) ; l. oblong with flat margins, fl. lateral on long simple peduncles. Loughton Bog, Mould, Flintshire. It has probably been sown there.] 


\section{Tribe IV. Pyrolea.}

\section{Pyrola Linn. Winter-green.}

1. P. rotundifolia (L.); l. nearly round entire or slightly crenate, fl. racemose, cal.-segments lanceolate acute, style bent down and curved upwards at the end longer than the ascending stam., stigma annular with 5 erect blunt points. - E. B. 213.-Fl. white, rather many, expanded. Style longer than the petals. Stam. all turned upwards. L. many. $-\beta$. bracteata (H. and A.); 1 . smaller, st. with bracts throughout, cal.-segments shorter and broader.-Damp bushy places and reedy marshes. $\beta$. Sand-hills near Lytham, Lancashire. P. VIII.

E. S.

2. P. media (Sw.); 1. nearly round or roundish-oval slightly crenate, fl. racemose, cal.-segments ovate acute, stam. regularly inflexed shorter than the nearly straight declining style, stigma annular with 5 erect points. - E.B. 1945.-Fl. milk-white, tinged with pink, rather many, less expanded than in the preeeding. Style projecting a little beyond the corolla, always nearly straight. Stam. all regularly incurved round the germen. L. many.Woods in the north. P. VII. VIII.

3. P. minor (L.); l. roundish-oval crenate, fl. racemose, cal.segments ovate-triangular acute, stam. regularly inflexed equalling the straight style, stigma without a ring 5-lobed pointless. -E. B. 2543 and 158 (bad). St. 13. 12.-Fl. pale pink, many, on very short pedicels, nearly closed. Style very short, inciuded. Stam. all equally inflexed. L. many.-Mossy woods and thickets. P. VII.

4. P. secunda (L.); l. ovate acute serrate, fl. in a secund raceme, cal.-segments triangular rounded notched, stam. regularly incurved equalling the long straight style, stigma 5-labed without a ring or points.-E. B. 517. St. 13. 13.-Fl. white, drooping, oval-oblong, nearly closed. Style very long, exserted. L. many. -Mossy alpine woods. P. VII.

\section{Moneses Salisb.}

1. M. grandiflora (Salisb.).-Pyrola uniflora Sm., E. B. 146. -L. few, roundish, serrate. Fl. solitary, terminal, large, drooping, white, open, nearly an inch broad. Stam. shorter than the pet. and closely adpressed to them. Stigmas very large.-Woods in Scotland, rare. P. VI. VII.

S. 


\section{Tribe V. Monotropea.}

\section{Monotropa Linn.}

1. M. Hypopitys (L.); fl. in a drooping eluster, lateral ones with 8 terminal with 10 stamens, fr. erect, bracts and fl. glabrous externally.-E. B. 69.-Inner side of the pet., filaments, germen and style glabrous (Hypopitys glabra Bernh., DC.); or hairy (H. multiflora Scop., DC.).-- Plant 6-8 in. high, succulent, simple, clothed with ovate scales, terminating in a short cluster, dingy yellow, at length turning nearly black. Fl. with large scaly bracts. Not parasitical. (Phytol. j. 341.) Clusters sometimes erect.-Woods. P. VII. VIIII. Yellow Bird's-nest.

\section{Order XLVIII. AQUIFOLIACEZE.}

Sep. inferior, 4-6, imbricate. Cor. regular, 4-6-parted, imbricate. Stam. inserted into the base of the corolla and alternate with its lobes. Disk 0. Ovary 2-6-celled; ovules solitary, pendulous, with a cupshaped seed-stalk. Fr. fleshy, not bursting; seeds stony, $2-6$.

1. ILex. Cal. 4-5-fid, persistent. Cor. rotate, 4-5-fid. Stam. 4-5, inserted upon the corolla. Stigmas $4-5$, nearly sessile. Fr. Aleshy, containing 4-5 l-seeded nuts.

\section{ILEx Linn. Holly.}

1. I. Aquifolium (L.); 1. ovate acute spinous wavy shining, peduncles axillary short many-flowered, fl. somewhat umbellate. -E. B. 496. St.7.4.-A small tree. L. evergreen, often quite entire on the upper branches, edged with strong spinous teeth and terminated by a spine on the lower ones. Fl. white. Berries scarlet.-Woods and hedges. T. VI.-VIII.

\section{Order XLIX. OLEACE压.}

Cal. monosepalous, divided, persistent. Cor. with 4-8 divisions, rarely 0 , valvate. Stam. 2. Ovary free, 2-celled; ovules in pairs, pendulous. Stigma entire or bifid. Fr. a berry, drupe or capsule, often l-seeded. Albumen dense or none.

1. Ligustrum. Fr. fleshy, a berry containing 2 membranous l-seeded nuts. Cal. cupshaped with 4 minute teeth. Cor. funnelshaped; limb 4-cleft, spreading. Stam. 2. 
2. Fraxinus. Fr. dry, a pendulous samara of 1 or 2 singleseeded cells. Cal. 0 or 4-cleft. Cor. 0.-Fl. sometimes without stamens.

\section{Ligustrum Linn. Privet.}

1. L. vulgare (L.) ; l. elliptic-lanceolate entire glabrous, panicles terminal compound dense.-E. B. 764. St. 14. 1.-A bushy shrub, $6-8$ feet high, with straight smooth branches and opposite leaves. Fl. white. Berries globose, black, rarely yellow. -Thickets in the south of England. Sh. VI. VII. E.

\section{Fraxinus Linn. Ash.}

1. F. excelsior (L.) ; 1. pinnate with 4-8 pairs of nearly sessile ovate-lanceolate acuminate serrate leaflets, cal. wanting. -E. B. 1692. St. 44. 7.-A handsome tree. Fl. appearing before the 1., in axillary clusters.- $\beta$. F. heterophyllus (Vahl), l. simple and pinnate.-E. B. 2476.-Woods and hedges. T. IV.V.

\section{Order L. APOCYNACE E.}

Cal. in 4 or 5 persistent divisions. Cor. regular, $4-5$-lobed, deciduous, contorted. Stam. 5, filaments distinct. Anth. 2celled, pollen granular. Ovaries 2, 1-celled; or 1 of 2 cells. Stigma 1. Seed with fleshy albumen.

1. Vinca. Cor. salvershaped; tube long with 5 angles at the mouth, closed with spreading hairs and the connivent stamens ; limb flat, 5-lobed. Stigma capitate with a ring at its base. Fr. of 2 erect elongated follicles.

\section{Vinca Linn. Periwinkle.}

1. V. minor (L.); st. procumbent, l. lanceolate-elliptical, their margins as well as those of the small lanceolate calyx-segments glabrous.-E.B. 917.- St. prostrate, rooting, flowering branches erect. Fl. smaller than those of the next, blue, rarely white.-Woods and thickets. P. V. VI. Lesser Periwinkle. E. S.? I.?

*2. V. major (L.); st. somewhat ascending, l. ovate acute or subcordate, their margins as well as those of the elongate-subulate calyx-segments ciliate.-E.B.514.-St. at first ascending, afterwards prostrate and rooting, flowering shoots erect. Fl. large, purplish-blue.-Hedges and thickets, naturalized. P.IV. V. Greater Periwinkle. 


\section{Order LI. GENTIANACEE.}

Cal. inferior, persistent. Cor. regular, 4-8-fid, hypogvnous, marcescent ; æstivation imbricate-twisted. Stam. inserted on the cor., as many as the segments. Ovary of 2 carpels with the edges slightly inflexed or meeting. Caps. or berry many-seeded, generally 2 -valved.

Subord. I. GENTIANEAE. Corolla twisted in æstivation. L. opposite.

* Style deciduous.

Tribe I. CHLOREAE. Corolla rotate.

1. Chlora. Cal. 8-parted. Cor. nearly rotate, 8-parted. Stam. 8. Style 1. Stigma 2-4-cleft. Caps. 1-celled; placentas on the inflexed margins of the valves.

Tr. II. ERYTHRAEEA. Corolla funnelshaped.

2. Erythraea. Cal. 5-fid. Cor. funnelshaped, limb short 5-fid. Stam. 5. Anth. erect, at length spirally twisted. Style simple, stigmas 2. Caps. imperfectly 2-celled from the inflexed margins of the valves.

3. Cicendia. Cal. 4-partite or lobed. Cor. funnelshaped, limb short 4-fid. Stam. 4. Anth. erect, not twisted. Stigma capitate, undivided. Caps. 1- or imperfectly 2-celled.

** Style persistent or stigma sessile.

Tr. III. SWERTIE $A$. Style often wanting, stigma persistent.

4. Gentiana. Cal.4-5-cleft. Cor. funnel-or salver-shaped, limb 4-5-cleft. Stam.4-5. Stigmas 2. Caps.1-celled, seeds on the inflexed margins of the valves.

Subord. II. MENYANTHIDE无. Corolla induplicate in æstivation. L. alternate.

5. Villuarsia. Cal. 5-parted. Cor. rotate, thin; limb 5parted, smooth on the disk, bearded or scaly at the base. Stam. 5. Stigma with 2 toothed lobes. Caps. 1-celled with sutural placentas, 2 -valved (in our plant), not bursting.

6. Menyanthes. Cal.5-parted. Cor. funnelshaped, fleshy; limb 5-parted, bearded internally, Stam.5. Stigma capitate. Caps. 1-celled, 2-valved; valves bearing the seeds along their middle. 


\section{Suborder I. Gentianea. Tribe I. Chlorea.}

\section{Chlora Linn. Yellow-wort.}

1. C. perfoliata (L.); lowermost l. elliptic-oblong narrowed below, stem-l. broadly connate, st. perfoliate.-E. B. 60 . R. xvii. 1060.-St. 12-18 in. high, simple. Stem-l. triangular-ovate, connected by their whole breadth in rather distant pairs, glaucous. Panicle forked, many-tlowered. Cal. divided to its base into linear-subulate segments. Cor. bright yellow. Stigmas yellow.-Dry calcareous hills. A. VII.-IX. E. I.

\section{Tribe II. Erythraea.}

\section{Erythras Renealm. Centaury.}

1. E. pulchella (Fries); st. erect much branched acutely quadrangular, 1 . ovate the uppermost oblong-lanceolate, fl. all stalked axillary and terminal, cal. rather shorter than the tube of the opening corolla, lobes of the cor. elliptic-oblong obtuse.E. B. 458. - St. quite simple, 1 in. high and single-flowered; or very much branched, even from the base, $6-8$ in. high, with very many flowers. Radical l. very few. Inflorescence forked, the lateral fl. distant from the floral leaves. The length of the tube must be observed exactly at the time when the flower is about to expand.-Sandy ground. A. VII.-IX.

2. E. Centaurium (Pers.) ; st. erect branched above quadrangular, 1. elliptic-oblong the upper ones acute, $f$. nearly sessile corymbosely panicled, cal. not half as long as the tube of the opening corolla, lobes of the cor. oval.-E. B. 417.-St. 6-18 in. high, usually simple below. Panicles of Al. lax. Lateral fl. apparently stalked but sessile between the small floral leaves. Radical l. many.-Dry pastures. A. VII. VIII.

3. E. latifolia $(\mathrm{Sm}$.$) ; st. short branched from the base qua-$ drangular, 1. broadly elliptical obtuse, $f$. in dense forked tufts sessile, cal. rather shorter than the tube of the opening corolla, lobes of the cor. lanceolate.-E. B. S. 2719.-St. thick, 2-3 in. high, sometimes taller and brancbed, usually dividing into 3 main branches. Fl. densely aggregated. Radical 1 . very large, with 5-7 ribs, many. "Cor.-lobes sometimes oval." Mr. Watson. - Near the sea-shore. A. VI.-VIII.

4. E. littoralis (Fries); st. simple solitary or several from the crown of the root, l. oblong-linear obtuse narrowed below, radical 1. crowded spathulate, fi. sessile between the floral 1. densely. corymbose, calyx as long as the tube of the opening corolla, lobes 
of the cor. oval obtuse.-E. B. 2305. E. chloodes Gren., not E. linariifolia. See Fr. Sum. 554.-St. 2-6 in. high. Inflorescence usually trichotomous, dense; branches sometimes elongated. Radical 1. narrow, many.-Sandy sea-shores. A. VII. VIII.

\section{Cicendia Adans.}

1. C. filiformis (Reich.); cal. bell-shaped with 4 ovate acute lobes, st. thread-shaped forked.-Exacum Sm., E. B. 235. Microcala Griseb.-St. 1-4 in. high. Radical 1. linear-lanceolate, stem-l. subulate, all sessile. Fl. yellow, solitary, on long stalks. -Damp sandy places. A. VII. VIII. E. I.

[2. C. Candollii (Griseb.); cal. 4-parted with linear adpressed segments, st. slender branching from its base.-DC. Icon. Gall. t. 16. - St. much branched throughout, $1-4$ in. high. L. all narrowly linear-lanceolate. Fl. pink.-On spots sometimes flooded. Paradis, Guernsey. Capt. Gosselin. A. VI. VII.]

\section{Tribe III. Swertiea.}

\section{Gentiana Linn. Gentian.}

1. G. Amarella (L.); cor. salvershaped 4-5-cleft bearded in the throat, cal.-lobes 5 nearly equal lanceolate, 1. sessile ovate-lanceolate, radical l. obovate.-E.B.236.-Very variable in size and in the number of the flowers, 3-12 in. high, erect. St. square, much branched. Fl. pale purple. Caps. stalked or sessile. Cor.tube obconical or subcylindrical.- There are two forms, the $G$. Amarella and G. germanica of authors. The latter has usually stalked caps. and larger and obconical flowers.-Dry calcareous fields. A. VIII. IX.

2. G. campestris (L.); cor. salvershaped 4-cleft bearded in the throat, cal.-lobes 4, 2 outer ones very large ovate, l. elliptic-oblong.-E. B. 237.-St. 3-10 in. high. Fl. blue, tube of the corolla slightly thicker upwards. Caps. nearly sessile. Upper 1. and sepals pointed.-Dry limestone hills. A. VIII. IX.

3. G. nivalis (L.); cor. salvershaped 5-cleft with minute intermediate bifid lobes, throat naked, cal. cylindrical with 5 keeled angles, 1. ovate lowermost broadly elliptical.-E. B. 896.-St. erect, slightly branched, $2-6$ in. high. Fl. bright blue.-Summits of Highland mountains, very rare. A. VIII.

4. G. verna (L.); cor. salvershaped 5-cleft with small intermediate bifid segments, throat naked, cal. with prominent angles and sharp teeth, l. ovate lower ones crowded, st. crespitose singleflowered with 1 or 2 pairs of leaves. $-E$. B. 493 . St. 40, 12.- 
St. prostrate, rooting, each terminating in a roselike tuft of 1 . and producing a single short flowering shoot. Fl. rather large, vivid blue.-Barren limestone districts. Teesdale, Durham. Burrin, Clare; and between Gort and Galway. P. IV.-VI.

E. I.

5. G. Pneumonanthe (L.); cor. bellshaped 5-cleft, throat naked, cal. entire with linear obtuse segments, fl. mostly solitary slightly stalked, l. linear obtuse.-E. B. 20.-St. 4-10 in. high, leafy, simple, erect or ascending. Fl. very large, deep blue within and with a broad greenish band down the middle of each segment.Moist turfy heaths. A. VIII. IX.

[G. acaulis (L.) E. B. 1594. is not a native.]

[SWERTIA perennis (L.), which has 2 curious fringed glands at the base of each segment of the cor. $(E, B .1441$.$) , is said to$ have been formerly found in Wales.]

\section{Suborder II. Menyanthidea.}

\section{Villaarsia Vent.}

1.V. nymphaooides (Vent.); 1. opposite roundly heartshaped floating wavy at the edges, peduncles aggregate 1 -flowered, cor. ciliate.-E. B. 217. Limnanthemum Griseb., Koch. $R$. xvii. 1042. - Floating. St. long, round, branched. L. resembling those of Nymphaa alba, but much smaller. Fl. yellow. Caps. sometimes 3-valved.-Still places in rivers, rare. P. VII. VIII.

E. I.

\section{Menyanthes Linn. Buckbean.}

1. M. trifoliata (L.).- E.B. 495.-St. ascending, round, leafy. L. ternate. Leaflets equal, obovate, wavy. Clusters stalked, each opposite to a leaf, many-flowered. Cor. flesh-coloured, densely bearded.-Boggy places. P. V.-VII.

\section{Order LII. POLEMONIACEÆ.}

Cal. inferior, 5-parted, persistent. Cor. hypogynous, regular, 5-lobed. Stam. 5, unequal, on the tuke of the corolla. Ovary 3 -celled. Stigmas 3-fid. Caps. 3-celled, 3-valved; valves separating at the axis.

1. Polemonium. Cal. 5-fid. Cor. rotate, with a short tube and 5-lobed limb; throat nearly closed by the dilated basses of the filaments.-G. F. G. Gam. i. 62. 


\section{Polemonium Linn. Jacob's Ladder.}

1. P. caruleum (L.); st. angular, l. glabrous pinnate, leaflets ovate-lanceolate pointed, panicle downy glandular.-E.B. 14 . -St. 1-2 feet high, simple, hollow. L. alternate, leaflets many. Fl. many, somewhat drooping, bright blue or white.Bushy hilly places, rare. P. VII.

\section{Order LIII. CONVOLVULACEE.}

Cal. inferior, 5-parted, persistent, imbricated, often unequal. Cor. hypogynous, regular, plaited, deciduous. Stam. 5, from near the base of the corolla. Ovary of $2-4$ cells, few-seeded, surrounded by an annular hypogynous disk. Style 1, rarely 2. Caps. with the valves separating from the edges of the dissepiments or bursting transversely.

* With leaves and cotyledons.

1. Convolvulus. Cor. bellshaped, with 5 prominent plaits and 5 sballow lobes. Style simple; stigmas 2. Caps. 2-4celled; cells 2-seeded.-G. F. G. Gam. i. 63, 64.

** Without leaves or cotyledons.

2. Cuscura. Cal. 4-5-cleft. Cor. roundish-urceolate or bellshaped, 4-5-parted, with as many scales alternating with the segments at the base within. Stam.4-5. Styles 2, rarely 1. Caps. bursting transversely, 2-celled, 4-seeded. -G. F. G Gam. i. 65.

\section{Convolvulus Linn. Bindweed.}

1. C. arvensis (L.); l. arrowshaped with acute lobes, peduncles mostly 1 -flowered, bracts minute distant from the flower. $-E$. B. 312.- St. many, angular, twining or prostrate, leafy, branched. Peduncles sometimes 2 -flowered. Cor. beautifully variegated with pink and white. Caps. 2-celled. Roots descending remarkably deep. Plant glabrous, or st. and l. downy.-Fields and hedges. P. VI.-VIII.

2. C. sepium (L.) ; 1. arrowshaped with truncate lobes, peduncles I-flowered square, bracts large cordate close to the flower. -E. B. 313. Calystegia R. Br.-St. twining, many feet long, with large rather distant leaves. Fl. solitary, axillary, large, white, rarely pink. Bracts quite inclosing the calyx. Fr. imperfectly 2-celled through the shortness of the dissepiment.Hedges and thickets. P. VII. VIII. 
3. C. Soldanella (L.); 1. reniform slightly angular fleshy, peduncles l-flowered with 4 membranous angles, bracts ovate close to the flower.-E. B. 314. Calystegia R. Br.-St. short, procumbent. Fl. large, solitary, axillary, very handsome, pink with yellow bands. Bracts rather shorter than the calyx. - Sandy seashores. P. VI.-VIII. Sea-side Bindweed.

\section{Cuscuta Linn. Dodder.}

1. C. europaa (L.); clusters of fl. bracteated sessile, cor.-tube cylindrical afterwards ventricose, scales adpressed to inside of tube bifid distant below with rounded spaces, cal. much shorter than corolla.-E. B. 378. - St. threadshaped, branching, reddish. Fl. in rather large clusters, yellowish.-Parasitical upon herbaceous plants. A. VIII. IX. Greater Dodder.

E.

+2. C. Epilinum (Weihe); clusters of fl. bracteated sessile, cor.-tube ventricose, scales adpressed fimbriated distant below with rounded spaces, cal. with fleshy segments deltoid below nearly as long as the tube of the corolla.-E. B. S.2850. C. densiflora Soy.-Willm.--St. slender, nearly simple, pale green. Fl. in rather small distant clusters, whitish. Scales bifid with $4-8$ fimbriæ on each lobe. Ventricose cor.-tube with 5 longitudinal protuberances; segments ventricose. Styles at first erect, soon bowing outwards; stigmas converging.-Parasitical upon Flax and very injurious to the crop. A. VIII. Flax Dodder.

3. C. Epithymum (Murr.); clusters of fl. bracteated sessile, cor.-tube cylindrical, scales converging equalling the tube of the cor. fimbriated and rounded at the end approximate below with narrow acute spaces, cal. bellshaped shorter than the tube of the corolla.-E. B. 55.-St. slender, red, twining irregularly. Fl. small, with a reddish thin cal., and white cor. with spreading ovate-acute segments. Sep. broad, ovate-apiculate, longer than their tube, with patent tips. Anth. blunt or notched at the end. Scales broad; the connecting membrane adpressed throughout. -Parasitical upon small shrubby plants. A. VII.-IX. Lesser Dodder.

E. S.

†4. C. Trifolii (Bab.); clusters of fl. bracteated sessile, tube of the cor. cylindrical, scales converging equalling half the tube of the cor. fimbriated and rounded at the end distant below with rounded spaces, cal. narrowed below about as long as the tube of the cor.-E. B. S. 2898. - St. slender, branching, reddish-yellow, clasping like a ring. Fl. small, white. Cal. fleshy, usually tipped with red; sep. lanceolate, about as long as their tube, adpressed. Anth. apiculate. Scales narrow; the connecting membrane not adpressed, but forming cuplike spaces between itself and the corolla.-Parasitical upon clover chiefly. A. VII.-IX. Clover Dodder. 
[C. hassiaca (Pfeiff.); fl. stalked, cor.-tube bellshaped closed with converging scales, stig. capitate; Heliotrope-scented.-On Lucerne in Essex. Introduced. A. VIII. IX.]

\section{Order LIV. BORAGINACEÆ.}

Cal. inferior, 4-5-parted, persistent. Cor. hypogynous, regular. Stam. 5, inserted on the corolla. Ovary 4-parted, 4seeded; ovules pendulous. Style simple. Fr. separating in 4 nutlike or 2 bilocular portions. Seeds without albumen.-Figures of all the genera are in G.F. G. Gam. ii.

Tribe I. CYNOGLOSSEAE. Nuts 4, on the persistent base of the style.-Stam. included.

1. Asperugo. Cal. 5-cleft with alternate smaller teeth, enlarged and compressed in fruit. Cor. funnelshaped with rounded scales in the throat. Filaments of stam. short. Nuts verrucose, compressed, attached by their narrow side, covered by the compressed calyx.

[2. Echinos permum. Cal. in 5 deep segments. Cor. salvershaped with rounded scales in the throat. Stam. subsessile. Nuts triquetrous with muricated margins, attached by their inner edge.]

3. Cynoglossum. Cal. 5-cleft. Cor. funnelshaped, the mouth closed with prominent blunt scales. Filaments very short. Nuts roundish-orate; depressed, muricated, attached by their inner edge.

Tr. II. ANCHUSEAE. Nuts 4, on an hypogynous disk, with an excavated space surrounded by a tumid ring at their base.

4. Borago. Cal.in 5 deep segments. Cor. rotate; tube very short; throat with short erect emarginate scales. Stam. exserted; filaments bifid, the inner fork bearing the anther; anthers linear-lanceolate, connivent in the form of a cone.

5. Anchusa. Cal.5-fid. Cor. funnelshaped with a straight tube ; throat closed by prominent obtuse scales. Stam. included, subsessile. Nuts depressed.

6. Lycopsis. Cal. in 5 deep segments. Tube of the cor. curved; limb oblique. Otherwise like Anchusa.

7. Sумрнутuм. Cal.5-cleft or 5-parted. Cor. cylindricalbellshaped, throat closed by a prominent cone of connivent lanceolate-subulate scales. Stam. exserted from the tube but covered by the scales; filaments short. Nuts ovate. 
Tr. 1II. LITHOSPERMEAE. Nuts 4, affixed to an hypogynous disk, their base not excavated but attached by a flat or rather convex surface.

8. Echium. Cal. in 5 deep segments. Cor. subbellshaped; throat dilated, naked; limb irregular. Stam. exserted; filaments very long, unequal. Style bifid. Nuts wrinkled, attached by a flat triangular base.

9. Pulmonaria. Cal. tubular, 5-fid. Cor. funnelshaped, its throat naked. Stam. included in the tube; filaments very short. Styles simple. Nuts smooth, attached by their truncate base which has a central tubercle.

10. Mertensia. Cal. in 5 deep segments. Cor. bellshaped, with a short thick cylindrical tube with 5 minute protuberances in its throat. Stam. protruded beyond the throat; filaments elongate. Style simple. Nuts smooth, inflated, rather drupaceous, attached laterally near their base by a flat surface; seeds free.

11. Lithospermum. Cal. in 5 deep segments. Cor. funnelshaped, throat naked or with 5 minute scales. Stam. included in tube; filaments very short. Style simple. Nuts smooth or tubercular, stony, attached by a truncate flat base.

12. Myosotis. Cal. 5-parted. Cor. contorted in astivation, salvershaped; throat closed with scales; limb 5-fid, obtuse. Stam. included; filaments very short. Style simple. Nuts smooth, convex externally, keeled within, attached by a minute lateral spot near their base.-Distinguished from all the other genera by the contorted æstivation of its corolla.

\section{Tribe I. Cynoglossea.}

\section{Asperugo Linn. Madwort.}

1. A. procumbens (L.).-E. B. 661.-St. procumbent, angular, rough with short decurved bristles. L. oblong, rough, hispid, lower ones stalked, upper sessile. Fl. small, axillary, solitary, blue, upon short peduncles. Cal. of the fr. much enlarged.Rich waste ground, rare. A. VI. VII.

E. S.

\section{Echinospermum $S w$.}

[1. E. Lappula (Lehm.); st. branched above, l. lanceolate adpressed-hairy, cor. exceeding the calyx, fr.-st. erect, nuts with a double series of barbed spines on the margins the disk and sides tubercled.-St. 43. 16.-St. and l. covered with adpressed hairs giving them a silky appearance. Closely resembling a Myo- 
sotis.-Upon shingle, Southwold, Suff., in very small quartity; probably introduced.-A. VI.]

\section{Cynoglossum Linn. Hound's-tongue.}

1. C. officinale (L.); 1. downy acute, lower 1. elliptical contracting into a petiole, upper $l$. lanceolate narrowed below subcordate half clasping.-E. B. 921.-Cor. dull crimson, veiny; veins disappearing in drying. Nuts flat in front, and there surrounded by a thickened prominent margin. Fetid, rarely subglabrous and nearly scentless. - Waste ground. B. VI. VIII.

2. C. montanum (Lam.); l. slightly hairy acute nearly glabrous and shining above scabrous beneath, inferior oblong narrowed into a long petiole, upper $l$. lanceolate slightly narrowed below clasping.-C. sylvaticum Sm., E.B. 1642.-Cor. reddish, changing to blue. L. sometimes very scabrous. Seeds without a prominent margin.-Shady situations. B. VI. VII.

\section{Tribe II. Anchusea.}

\section{Borago Linn. Borage.}

†1. B. officinalis (L.); lower 1 . obovate obtuse attenuated below, segments of the cor. ovate acute flat spreading.-E. B. 36 . -Fl. blue. Stem-l. much narrowed below so as to appear stalked, eared at the base. Whole plant hispid with bulbous hairs. St. spreading.-On rubbish and waste ground, scarcely a native. B. VI. VII.

\section{Anchusa Linn. Alkanet.}

†1. A. officinalis (L.); l. lanceolate hispid, spikes crowded unilateral, bracts ovate-lanceolate, cal.-segm. bluntish bairy on both sides, scales of cor. hairy.-E. B. 662. - Fl deep purple. Cal.-segm. narrow, longer than tube. St. $1-2$ feet high, rough with deflexed hairs.-Waste ground, rare. P. VI. VII. E.

†2. A. sempervirens (L.); l. ovate, lower $\mathrm{l}$. on long stalks, peduncles axillary each bearing 2 dense spikes with an intermediate flower, cal.-segments hairy on the outside only, bracts minute lanceolate, scales of the cor. downy.-E. B. 45.-Fl. blue, rather salver- than funnel-shaped. Cal.-segments narrow. St. $1 \frac{1}{2}-2$ feet high, rough with spreading somewhat deflexed hairs. -Waste ground near ruins, rare. P. V.-VIII.

\section{Lycopsis Linn. Bugloss.}

1. L. arvensis (L.); l. lanceolate erose-dentate very hispid, 
cal. of fr. bellshaped erect.-E. B. 938.-Fl. small, blue. Whole plant very hispid with strong hairs each rising from a scaly tubercle.-Fields and hedges. A. VI. VII.

\section{Sум рнyтum Linn. Comfrey.}

1. S. officinale (L.) ; l. ovate-lanceolate attenuated below, stem-l. very decurrent lanceolate, st. winged in the upper part.E. B. 817.-Height $1-2$ feet. Racemes in pairs, drooping. Fl. yellowish-white or purple. Cal.-segments somewhat spreading and pubescence rougher in the purple-flowered variety, S. patens Sibth.-Common in damp places. P. V. VI.

2. S. tuberosum (L.); l. ovate-oblong attenuated below, stem-l. lanceolate, uppermost slightly decurrent, st. scarcely winged nearly simple.-E. B. 1502. - Fl. yellowish-white, whole plant smaller and slenderer than the preceding. Anth. twice as long as their filaments.-Damp woods and river banks, rare. P. VI. VII.

[S. asperrimum, S. tauricum, and S. orientale havı been noticed in England, but are not natives.]

\section{Tribe III. Lithospermea.}

\section{Eснгим Linn. Viper's Bugloss.}

1. E. vulgare (L.) ; tubercular-hispid, st. erect simple, 1. lanceolate 1-ribbed, stem-l. narrowed below sessile, $f$. in short lateral spikes, stam. exceeding the corolla.-E. B. 181.-Lower l. attenuated into a footstalk. Fl. at first reddish, afterwards bright blue.-Dry places. B. VI. VII.

[2. E. violaceum (L.); pilose-hispid, st. erect branched diffuse, lower branches prostrate, radical l. oblong-ovate stalked, stem-l. oblong narrowed from a cordate half-clasping base with lateral ribs, spikes panicled elongate simple, stam. scarcely exceeding the corolla. - E. B. S. 2798 . - Stam. very unequal, 1 short, 2 intermediate, and 2 longer. Fl. violet-blue. Hairs from minute tubercles. Root reddish.-Jersey. B. VI.-IX.]

\section{Pulmonaria Linn. Lungwort.}

1. P. officinalis (L.); l. ovate roundish or cordate stalked, upper 1. oblong sessile.-E. B. 118.-Whole plant more or less hispid. Fl. purple. L. often spotted.-Woods and thickets, rare. P. V.

E. S.?

2. P. angustifolia (L.) ; 1. all lanceolate.-E. B. 1628.--More pubescent than the last, l. rarely spotted; scarcely distinguishable as a species.-Woods in Hampshire. P. IV. V. E. 


\section{Mertensia Roth.}

1. M. maritima (Don); st. procumbent branched, 1. ovate acute rough with callous dots glabrous fleshy glaucous, nuts smooth.-Lithospermum Sm., E. B. 361. Stenhammaria Fr.Fl. in racemes, purplish-blue. Protuberances in throat of cor. yellow. I. tasting like Oysters. Nuts free, forming a pyramid, exceeding the calyx. Pericarp membranous; seed smaller than the cavity.--Northern sea-shores. P. V.-VIIII.

\section{Lithospermum Linn. Gromwell.}

1. L. officinale (L.); st. erect much branched, 1. lanceolate acute veined hispid with bulbous adpressed bristles above hairy beneath, throat of the cor. with a crown of scales, nuts smooth. -E.B. 134.-Fl. greenish-yellow. Nuts gray, highly polished, stony, 2 or 3 ripening in each calyx. Root whitish.-Dry and stony places, especially on limestone. P. VI.-VIII. Gromwell.

2. L. purpureo-caruleum (L:); barren st. prostrate creeping, the others erect $2-3$-fid above, l. lanceolate acute hispid, hairs on the upper side adpressed bulbous, cor. much exceeding the calyx, nuts smooth.-E. B. 117.-Fl. large, bright blue. Nuts " silvery-white, highly polished, slightly rugged," rarely produced. This species and the following have no scales in the throat of the cor., but merely 5 longitudinal downy folds, and belong to the genus Rhytispermum Link, Spenn.-Thickets on a limestone soil, rare. P. V.-VII.

E.

3. L. arvense (L.); st. erect branched, 1. lanceolate rather acute hispid with adpressed bulbous hairs on both sides, cor. rather exceeding the calyx, nuts tubercular.-E. B. 123.-Fl. small, white. Nuts pale brown, polished, wrinkled, pitted, 3 or 4 perfected in each calyx. Root bright red, colouring paper.Corn-fields. A. V.-VII. Corn Gromwell.

\section{Myosotis Linn. Scorpion-grass.}

i. Persistentes Cal. of fruit shorter than its stalk.

1. M. palustris (With.); fr.-cal. open with straight adpressed bristles, teeth short triangular, cor.-limb flat longer than the tube, lobes slightly emarginate, style about equalling cal., pubescence of st. spreading.-E. B. 1973. St. 42.2.-L. bluntish, apiculate. St. angular owing to the prominent decurrent lines from the margins of the leaves. Clusters quite leafless. Cor. large, bright blue with a yellow eye. Cal. divided about $\frac{2}{3}$ down.$\beta$. M. strigulosa (R.); slenderer, more erect, pubescence of st. adpressed, 1. less blunt, cal.-teeth rather longer. St. 42.3. Base 
of st. sometimes patently hairy. - Ditches and watery places. P. VI.-VIII. $\beta$. VI. Forget-me-not.

2. M. repens (Don); fr.-cal. open with straight adpressed bristles, teeth narrow lanceolate acute, style falling short of cal., cor.-limb flat longer than the tube, lobes slightly emarginate, pubescence of the st. spreading.-E. B. S. 2703. St. 42. 4.-L. rather acute. St. slightly angular. Clusters usually slightly leafy ( $1-4$ leaves) below. Cor. pale blue. Cal. divided fully half-way down.-Boggy places. P. VI.-VIII.

3. M. caspitosa (Schultz!); fr.-cal. open with straight adpressed bristles, teeth narrow lanceolate bluntish, cor.-limb equalling the tube,'lobes entire, style very short, nut not keeled, pubescence of the st. adpressed.-E.B.S.2661. St.42.7.-L. usually obtuse or even emarginate. St. round, with a decurrent line from the margin of the leaves. Clusters usually slightly leafy below. Cor. smaller than in the preceding, bright blue, segments narrower and rounded at the end. Style about equalling the cal.-tube.-Watery places. P. VI.-VIII.

4. M. alpestris (Schm.); cal. attenuated below deeply 5-cleft open with fruit with straight and a few curved adpressed bristles, pedicels ascending, cor.-limb exceeding the tube flat, style equalling $\frac{1}{2} \mathrm{cal}$., nut not keeled rounded at the end, root-l. on long stalks pointed.-St. 42. 8. not DC. M. rupincola Sm., E. B. 2559. M. suaveolens Bab.-L. oblong-lanceolate, stalks of the lower ones slender. Fl. large, handsome, blue, sweetscented in the evening.- Summits of the Breadalbane mountains. Micklefell, Teesdale. P. VII. VIII.

5. M. sylvatica (Ehrh.); cal. rounded below deeply 5-cleft closed with fruit, tube with spreading hooked bristles, pedicels divergent, cor.-limb longer than tube flat, cor.-lobes emarginate, style nearly equalling cal., nut keeled on one side upwards bluntish, root-l. on short dilated stalks bluntish.-E. B. S. 2630. St.42. 6.-L. oblong-lanceolate; stalks of the oblong-ovate lower 1. dilated. Fl. large, handsome, blue. Cal. divided more than half-way down.-Shady places, rare. P. V. VI.

6. M. arvensis (Hoffm.); cal. half 5-cleft closed with fruit, tube with spreading hooked bristles, pedicels divergent, cor.limb equalling tube concave, cor.-lobes entire, style very short, clusters stalked.-E. B. S. 2629. St. 42. 13. M. intermedia Link, Reich., Koch.-L. oblong, acute ; lower l. oblong-obovate, obtuse. Fl. usually small.-A large-flowered ( $\beta$. umbrosa) plant found in shade is often taken for M. sylvatica.-Cultivated land and thickets. A. VI.-VIII. 
ii. Fugaces. Cal. of fruit not shorter than its stalk.

7. M. collina (Hoffm.); fr.-cal. open and ventricose as Iong as the diverging pedicels, tube with spreading hooked bristles, cor.-limb shorter than tube concave, style about equalling $\frac{1}{2}$ cal., clusters stalked usually with 1 distant flower, hairs on the 1 . straight.-E. B. 2558. St. 42.11. M. hispida Koch.-Usually slender, erect; or cæspitose with prostrate branches. L. oblong, obtuse, lower obovate, with straight silky hairs on both sides. Fl. small, blue.- $[M$. stricta Link, $M$. arvensis (R.) St. 42.14. has its fr.-cal. closed, very short pedicels, sessile clusters leafy below. Probably a native of Britain.]-Dry banks. A. IV. V.

8. M. versicolor (Ehrh.); fr.-cal. closed and oblong longer than the ascending pedicels, tube with spreading hooked bristles, cor.-limb shorter than tube concave, style equalling cal., clusters stalked.-E. B. 480. (left fig.) St. 42. 12.-L. narrow, oblong, acutish; upper ones frequently opposite. Fl. small, at first pale yellow, afterwards blue.-On plants inhabiting damp places the fl. are at first white and the cal. is "less deeply divided."-Meadows and banks. A. V. VI.

\section{Order LV. SOLANACEA.}

Cal. inferior, 5- rarely 4-parted, persistent. Cor. hypogynous, regular or slightly irregular, 5-cleft, deciduous, plicate in æstivation; æstivation of lobes imbricate or imbricate-plicate (in Solanum valvate). Stam. 4-5, inserted on the cor., alternate with the lobes. Ovary 1-2- or 4-celled. Stigma simple, rarely lobed. Pericarp 1-2- or 4-celled. Seeds many. Embryo usually curved, in fleshy albumen, often not in the axis.-Figures of the genera are in G.F.G. Gam. i.

Tribe I. SOLANEAE. Cor. rotate, lobes nearly regular and equal with a valvate æstivation. Anth. opening by pores.

1. Solanum. Cor.-limb 5-cleft, reflexed. Anth. erect, connivent. Berry roundish with 2 or more cells.

Tr. II. ATROPEAE. Cor. tubular; tube plicate in bud; lobes slightly unequal with an imbricate æstivation. Anth. opening longitudinally at the margin.

2. Atropa. Cor. bellshaped with 5 equal lobes. Stam. distant above. Berry globose, 2-celled.

3. Hyoscyamus. Cor. funnelshaped with a short tube and 5 unequal obtuse lobes. Stigma capitate. Caps. 2-celled, ventricose below, furrowed, opening transversely by a convex lid. 
4. Datura. Cor. funnelshaped, angular, 5-lobed. Cal. deciduous. Stigma 2-lobed. Caps. 4-valved, with 2 partially bipartite cells.

\section{Tribe I. Solanea.}

\section{Solanum Linn. Nightshade.}

1. S. nigrum (L.); st. herbaceous with tubercled angles, 1. ovate bluntly dentate or wavy, fl. drooping, hairs incurved upwards.E. B. 556. St. 1. 4.-Umbel from the intermediate spaces between the leaves. L. attenuated below. Fr.-stalks thickened upwards. Berries globular, black, or rarely green, when ripe. St. a foot or more high.- $[\beta$. S. miniatum (Bernh.); angles of the st. with prominent tubercles, l. sinuate-dentate. Closely allied to this species, but differs by its more deeply toothed 1 . which are less attenuated below, its patent pubescence and red berries, and is probably distinct.]-Waste ground. [ $\beta$. Jersey.] A. VII.-X. Black Nightshade.

2. S. Dulcamara (L.); st. shrubby zigzag, l. cordate-ovate, upper l. auriculate-hastate, fl. drooping.-E.B. 565. St. 18.3.Corymb opposite to leaves. Fl. purple with 2 green spots at the base of each segment. Berries ovate, red. St. climbing to the height of 12-14 feet, nearly round, almost glabrous throughout. - $\beta$. tomentosum (Koch); st. and l. downy with patent hairs.$\gamma$. marinum; branches of the present year and l. fleshy and usually clothed with hairs incurved upwards, st. angular prostrate diffuse much branched, l. all (?) cordate not hastate. S. lignosum seu Dulcamara marina Ray 265.- $a$. and $\beta$. Woods and hedges, common. $\gamma$. Pebbly sea-beach. Sh. VI. VII. Bitter-sweet.

\section{Tribe II. Atropea.}

\section{Atropa Linn. Deadly Nightshade. Dwale.}

1. A. Belladonna (L.); st. herbaceous, l. broadly ovate entire, fl. solitary axillary on short stalks.-E. B. 592. St. 3. 5. - St. 3 ft. high. Fl. lurid, purple, drooping. Berry violet-black, highly poisonous.-Waste places, rare. P. VI.-VIII.

\section{Hyoscyamus Linn. Henbane.}

1. H. niger (L.) ; l. oblong pinnatifid or sinuate sessile and subamplexicaul, lower l. stalked, fl. nearly sessile axillary unilateral.-E. B. 591. St. 3. 4.-Fl. lurid yellow, with dark veins, drooping. Fr. erect. Whole herbage downy, glandular, viscid, 
fetid.-ß. pallidus (Koch); fl. without dark veins.-Waste places, preferring a calcareous soil. $\beta$. Esher, Surrey. $M r . H . C$. Watson. A. or B. V.-VII.

\section{Datura Linn. Thorn-apple.}

†1. D. Stramonium (L.); l. ovate unequally sinuate-dentate glabrous, caps. erect spinose.-E.B.549.-Fl.white, large, erect. Fr. densely spinose. Caps. with 4 dissepiments below, but only 2 at the top.-Waste ground, rare. A. VI. VII.

E.

\section{Order LVI. OROBANCHACEA.}

Cal. variously divided, persistent. Cor. irregular, usually 2lipped, persistent, imbricate in æstivation. Stam. on the cor., 4, didynamous. Anth. 2-celled; cells distinct, parallel. Ovary in a fleshy disk, 1-celled, with 2 or more parietal placentas. Stigma 2-lobed. Fr. capsular, 2-valved, many-seeded.

1. Orobanche. Cal. 4-cleft or of 2 usually bifid sepals. Cor. ringent, $4-5$-cleft, deciduous, its base persistent. Bracts 1-3.-G. F. G. Gam. i. 49, 50.

2. Lathraea. Cor. 2-lipped, the upper lip galeate, deciduous, entire. Otherwise like Orobanche.-G. F. G. Gam. i. 51.

1. Orobanche Linn. Broom-rape.

* Sepals 2, entire or bifid, separate or connected below in front. Bract 1. Valves of caps. adhering at both ends.

1. O. Rapum (Thuill.); sep. 2-veined equally bifid nearly equalling the cor.-tube, cor. bellshaped ventricose at the base in front arcuate, lips wavy obsoletely denticulated (not fringed), upper lip helmetshaped scarcely emarginate, sides patent, middle lobe of lower lip much longer than lateral lobes, stam. inserted at the base of the cor. glabrous below, their upper part and the style glandular-pubescent. - E. B. 421. R. I. f. 900 and 923. $O$. major (L.) Sm., but Fries states that that syn. belongs to $O$. elatior.-Stigma distantly bilobed, yellow. Anth. white when dry. For a full description from fresh specimens see Leight. Fl. Shrop. 302. - Parasitical upon Broom, Furze and other shrubby leguminous plants. P. V.-VII.

2. O. rubra (Sm.); sep. 1-veined lanceolate subulate-attenuated exceeding the cor.-tube undivided, cor. bellshaped arcuate glandular-pubescent externally and the upper lip internally, lips acutely denticulate and crisped, upper lip emarginate, sides patent, lobes of lower lip nearly equal intermediate lobe rather 
longer, stam. inserted near to the base of the corolla slightly pilose within below, their apex and the upper part of the style slightly glandular-pilose.-E. B. 1786 (bad). R. I. f. 885. Probably O. epithymum DC., Koch, Fries (Mant. iii. 59), but there are some discrepancies in the descriptions.-Stigma approximately 2-lobed, pale red. Anth. fuscous when dry. Sep. with a second faint vein near their anterior margin and, in the dry plant, there is the appearance of several more. L. few. Sweetscented.-Description drawn from fresh Cornish specimens.Parasitical upon Thymus Serpyllum. P. VI.-VIII.

3. O. caryophyllacea ( $\mathrm{Sm}$.$) ; sep. many-veined lanceolate$ equally bifid falling short of the cor.-tube distinct or combined in front, cor. tubular-bellshaped curved on the back, lips spreading, upper one 2-lobed, lobes porrect, lobes of lower lip nearly equal rounded wavy, stam. inserted above the base of the cor. hairy within below, above together with the style glandularpilose--E. B. S. 2639. O. Galii Duby, Koch.-Stigma purplish-black, approximately lobed. Anth. fuscous, yellow when dry. Sep. with crisped glandular hairs externally, each lobe with 1 strong vein and several slender ones. Cor. similarly hairy on both sides.-Described from fresh Kentish specimens.-On Galium Mollugo in Kent. P. VI. VII.

E.

4. O. elatior (Sutt.); sep. many-veined equally bifid equalling the cor.-tube connected in front, cor. curved tubular slightly compressed above, upper lip 2-lobed toothed, lobes inflexed, lobes of lower lip 3 nearly equal acute toothed, stam. inserted above the base of the cor. glandular-hairy in the lower half within.E. B. 568. O. major (L.) Fries.-Stigma bilobed, yellow. Upper lip of the cor. usually with an elevated point between the lobes. Cor. glandular externally. Stam. sometimes slightly hairy above. Anth. whitish when dry. Stem $2-3$ feet high.-Parasitical upon Centaurea Scabiosa, rare. P.? VI. VII.

5. O. Picridis (F. W. Schultz); sep. 1-3-veined entire or toothed in front below gradually narrowed into 1 or 2 subulate points, cor. tubular-bellshaped its back nearly straight and compressed slightly curved at each end, lips denticulate wavy upper not notched its sides porrect, stam. inserted below the middle of the cor.-tube hairy in their lower half within, style glandular below in front and above throughout, stigma bilobed.-E. B.S. 2956.-Lobes of the stigma just touching, purple. Anth. fuscous, pale purple or yellowish.-Parasitical upon Picris. Comberton, Camb. Tenby, Pemb. Isle of Wight. P.? VII. E.

6. O. Hederce (Duby); sep. l-veined ovate below suddenly narrowed into 1 or 2 subulate points about equalling the cor.tube, cor. tubular arcuate, lips denticulate wavy, upper one 
bilobed porrect (straight when dry), lobes of lower lip nearly equal the middle one longest, stam. inserted below the middle of the cor.-tube glabrous with a few scattered hairs on their lower part posterior pair distant below, style glabrous with a few hairs on the upper part, stigma scarcely bilobed.-0. barbata $R$., Bab., E. B. S. 2859, not Poir.-Iobes of the stigma attached together by at least $\frac{1}{3}$ of their circumference, yellow. Anth. fuscous, rather paler when dry. St. purplish.-Parasitical upon Ivy. P. VI. VII.

E. I.

7. O. minor (Sutt.); sep. many-veined ovate below suddenly narrowed into 1 or 2 subulate points equalling or exceeding the cor.-tube, cor. tubular arcuate, lips obtusely denticulate wavy, upper lip bilobed porrect (inflexed when dry), lobes of lower lip nearly equal, stam. inserted below the middle of the cor.-tube glabrous with a few scattered hairs below posterior pair near together and parallel, style glabrous with a line of distant hairs on its anterior side, stigma bilobed.-E.B.422.-Stigma approximately lobed, lobes only just touching at one point, purple. Anth. yellow when dry.-Parasitical chiefly upon Trifolium pratense. A.? VI. VII.

8. O. amethystea (Thuill.); sep. many-veined ovate below suddenly narrowed into 1 or 2 subulate points, cor. tubular its back curved immediately from the base otherwise straight, lips unequally acutely denticulate wavy, upper lip hooded porrect notched, lobes of lower lip unequal middle one larger, stam. inserted in the curvature of the cor. glabrous with many hairs at the base within, stigma bilobed.-Atl.Fl.Par.t. 19. E. O.Eryngii Duby.-Lobes of stig. " divaricate, purple." (Phytol.ii. 239.) - "Parasitical upon Daucus maritimus." Whitsand Bay, Cornwall. A.? VI. VII.

E.

** Sepals 4 or 5, connected below. Bracts 3. Valves of capsule separating at the top. Phelipas Desf.

[9. O. arenaria (Bork.); cal. of 5 sep. tubular with triangular-subulate teeth falling short of the cor--tube, cor. tubular slightly curved in front, middle of the tube compressed on the back, throat slightly inflated externally glandular, lobes of lips blunt with reflexed edges, lower lip hairy within, suture of anth. hairy.-Atl. Fl. Par. t. 19. L.- Stigma scarcely 2-lobed; style pale yellow (?), glandular. Filaments glabrous with a few hairs at their base. Lateral bracts linear-subulate, intermediate lanceolate attenuated above. St., scales, and cal. glandular-pubescent.-Parasitical upon Achillea Millefolium? Channel Islands. P. VII. VIII.]

10. O. carulea (Vill.); cal. of 5 sep. tubular with lanceolate 
acute teeth falling short of the cor.-tube, cor. tubular curved in front, middle of tube compressed, lobes of lips acute with reflexed edges, lower lip hairy within, anth. glabrous.-E. B. 423. Atl. Fl. Par. t. 19. K.-Stig. scarcely 2-lobed, white. St., scales, bracts, cal., and cor. glandular-pubescent.-Grassy pastures. Herts. Norf. Isle of Wight. Chepstow. P. VI. VII. E.

[O. ramosa (L.); cal. of 4 sep. tubular with triangular ovate acuminate teeth, anth. glabrous, st. usually branched.-E. B. 184.-I have not seen living specimens.-Parasitical upon Hemp. Very rare. A. VIII. IX.]

\section{Lathrea Linn. Toothwort.}

1. L. squamaria (L.); st. simple, fl. pendulous secund, lower lip of the cor. 3-cleft.-E. B. 50. G. E. Smith S. Kent, t. 3.Bracts ovate or lanceolate. Style straight or curved. Upper lip nearly entire, or bifid.-Woods and thickets, parasitical upon Hazels, \&c. P. IV. V.

\section{Order LVII. SCROPHULARIACEÆ.}

Cal. 4-5-cleft, persistent. Cor. irregular or 2-lipped or personate, deciduous, imbricate in æstivation. Stam. on the cor., usually 4 , didynamous or 2 or 5 . Ovary free, 2-celled. Style simple; stigma 2-lobed. Fr. capsular, 2-celled; placentas attached to the dissepiment or ultimately central. Embryo straight, in axis of fleshy albumen.-Fig. of all the genera except Mimulus and 11 and 13 are in G. F. G. Gam. i.

\section{* Stamens 5 .}

1. Verbascum. Cal. of 5 sepals. Cor. rotate; segments unequal, spreading. Stam. unequal, 2 or more hairy at the base.

** Stamens 4, didynamous.

2. Digrtalis. Cal. in 5 deep segments. Cor. bellshaped, oblique, 4-5-fid.

3. Antirrhinum. Cal. 5-parted. Cor.personate, gibbous at the base (no distinct spur); lower lip 3-fid with a prominent palate closing the mouth. Caps. opening by 2 or 3 pores at the top, 2-celled.

4. Liñaria. Cal. 5-parted. Cor. personate, spurred; lower lip 3-fid, with a prominent palate closing the mouth. Caps. with valves or teeth at the top, 2 -celled.

5. Scrophularia. Cal. 5-lobed (in S.vernalis 5-cleft). Cor. 
globose; limb minute, of 2 short lips, upper 2-lobed, lower 3-lobed. Often the rudiment of a fifth stamen. Caps. opening by 2 valves with their margins inflexed, 2 -celled.

6. Limosella. Cal. 5-cleft. Cor. 5-fid, bellshaped, equal. Caps. globose, 2-valved, 1-celled ; placenta central, free or connected with a short dissepiment below.

7. Melampyrum. Cal. tubular, 4-toothed. Cor. ringent; upper lip compressed laterally with reflexed margins; lower furrowed, 3-fid. Caps. oblong, obliquely acuminate, compressed. Seeds 1-2 in each cell, smooth.

[Mrmulus. Cal. prismatical, 5-toothed. Cor. ringent; upper lip folded back at the sides. Seeds many.]

8. Pedicularis. Cal. inflated, 5-toothed. Cor. ringent; upper lip compressed laterally; lower plane, 3-lobed. Caps. compressed, acute. Seeds many, angular.

9. Rhinanthus. Cal. inflated, 4-toothed. Cor. ringent; upper lip compressed laterally; lower plane, 3-lobed. Caps. compressed, obtuse. Seeds many, compressed, with an orbicular margin. - Alecterolophus (Hall.).

10. Bartsia. Cal.bellshaped,4-fid. Cor. tubular, ringent. Caps. pointed; cells many-seeded. Seeds compressed at the hilum and with winged ribs at the back (large).

11. Eufragia. Cal. tubular, 4-cleft. Cor. tubular, 2-lipped. Caps. pointed; cells many-seeded. Seeds slightly angular, very minute, crenate-ribbed; hilum basal.

12. Euphrasia. Cal. tubular or bellshaped,4-fid or 4-toothed. Cor. tubular, 2-lipped. Caps. obtuse or emarginate; cells many-seeded. Seeds rather angular, longitudinally ribbed: hilum subapical.

13. Sibthorpia. Cal. in 5 deep spreading segments. Cor. rotate, irregularly 5-cleft. Caps. compressed, orbicular, 2-seeded, 2-valved.

\section{*** Stamens 2.}

14. Veronica. Cal. 4-5-parted. Cor. rotate, unequally 4-lobed, lower lobe the smallest. Caps. compressed, 2celled.

1. Verbascum Linn. Mullein.

* Leaves strongly decurrent.

1. V. Thapsus (L. ?); l. ovate-oblong crenate densely woolly on both sides all decurrent, st. simple, spike dense, pedicels 
shorter than the calyx, cor. rotate, segments oblong obtuse, filaments woolly 2 longer nearly glabrous, anth. all nearly equal. - E. B.549. V. Schraderi Koch. - St. 4-5 feet ligh. Fl. about twice as long as the calyx. Filaments with white wool, the 2 glabrous ones about 4 times as long as their slightly decurrent anthers.-Waste ground. B. VII. VIII. Great Mullein.

[2. V. thapsiforme (Schr.); "l. decurrent crenulate woolly, upper ones acuminate, racemes spiked, segments of the cor. unequal obovate, 2 of the anth. oblong." Fries.-Fl. much larger than those of $V$. Thapsus, about 4 times as long as the calyx. "The 2 glabrous filaments scarcely twice as long as their greatly decurrent anthers." Koch.-Kent. Hudson. B. VII. VIII.] E.

\section{** Leaves not decurrent, flowers in clusters.}

$\dagger$ Flowers yellow or whitish; hairs on the filaments white.

3. V. Lychnitis (L.); l. crenate nearly glabrous above woolly and powdery beneath, lower l. elliptic-oblong wedgeshaped below scarcely stalked, upper 1 . sessile ovate-acuminate with a rounded base, st. angular panicled above with ascending branches, stam. equal, filaments all with white hairs.-E. B. 58.-Fl. on short stalks, small, many, cream-coloured or rarely white.-Roadsides and waste places. B. VI.-VIII. White Mullein. E.

4. V. pulverulentum (Vill.); $l$. obscurely crenate clothed with mealy deciduous wool on both sides, lower 1. oblong-elliptical attenuated into a stalk, upper 1 . sessile acuminate, st. terete panicled above with patent branches, stam. nearly equal scarlet with white hairs. - E. B. 487. - Fl. on very short stalks; which, as well as the calyx, are densely covered with wool, bright yellow. Cal.-teeth often glabrous.-It is now believed that V. floccosum is the same plant as $V$. pulverulentum.-Roadsides in Norfolk and Suffolk. Den of Cullen, Scotland. B. VII. Hoary Mullein.

E. S.

†† Flowers yellow; hairs on the filaments purple.

5. V. nigrum (L.); 1. doubly crenate nearly glabrous above subpubescent beneath, lower l. cordate or ovate-oblong with long stalks, upper l. cordate-ovate nearly sessile, st. angular, raceme elongated, pedicels twice as long as the calyx, stam. equal with purple hairs. - E. B. 59.-Fl. in clusters on a nearly simple long spike, small, bright yellow. $-\beta$. tomentosum (Bab.); l. subpubescent above woolly beneath, $f$. smaller. $-\gamma$. nigro-lychnitis; lower l. ovate-oblong or lanceolate attenuated into a stalk subpubescent above downy beneath.-Banks and way-sides. $\beta$. Alderney. $\gamma$. Sussex. P. VII. VIII. Dark Mullein.

E. S. 
*** Leaves all decurrent; flowers solitary or in pairs.

6. V. Blattaria (L.); 1. crenate glabrous, lower l. ovate-oblong obtuse sinuate at the base attenuated, upper l. oblong or subcordate semiamplexicaul, pedicels solitary nearly twice as long as the bract, stam. and anth. unequal.-E. B. 393.-Panicle glandular pilose. Fl. yellow. Filaments with purple hairs, the 2 longer hairy only on the inside.-On gravelly banks, rare. B. VIII. Moth Mullein.

7. V. virgatum (With.); 1 . doubly serrate slightly glandularhairy, lower 1. oblong-lanceolate sublyrate lobate-crenate-serrate the base attenuated, upper 1 . oblong acuminate semiamplexicaul, pedicels $1-5$ together shorter than the bracts, stam. nearly equal. -E. B. 550.-Panicle glandular-pilose. Fl. yellow. Filaments with purple hairs, 2 rather longer and hairy only within.-On gravelly banks, rare. B. VIII.

E. I.

\section{Digrtalis Linn. Foxglove.}

1. D. purpurea (L.); 1. ovate-lanceolate crenate downy beneath, lower l. attenuated into footstalks, sep. ovate-oblong acute 3-veined downy, cor. obtuse glabrous externally, upper lip scarcely cloven, segments of the lower lip ovate rounded. $-E . B$. 1297. St. 11.-L. often crenate-dentate or -serrate. Fl. sometimes white or flesh-coloured. St. 3-4 feet high.-Hedge-banks and woods. P. VI.-VIII.

\section{Antirrhinum $\dot{L}$ inn. Snapdragon.}

*1. A. majus (L.); 1. lanceolate opposite or alternate glabrous, fl. racemose, sep. ovate obtuse much shorter than the cor., upper lip bifid. $-E$. B. 129.-Height $1-2$ feet. Cor. $1 \frac{1}{2}$ in. long, purplish-red or white.-Old walls and calcareous cliffs. P. VII. -IX. Great Snapdragon.

2. A. Orontium (L.); 1. linear-lanceolate opposite or alternate, f. loosely spiked distant, sep. linear longer than the corolla.E. B. 1155. St. 27.-About a foot high. Fl. purple--Dry sandy and gravelly fields. A. VII. VIII.

E. 1.

\section{Linaria Mill. Toadflax.}

*1. L. Cymbalaria (Mill.); 1. roundish-heartshaped 5-lobed glabrous, st. procumbent.-Antirrhinum Sm., E. B. 502. St. 70. 10.-Stems slender, rooting. Fl. solitary, axillary, upon long stalks, pale blue.-Old walls. P. V.-X. Ivy-leaved Toadflax.

2. L. Elatine (Mill.); l. ovate-hastate, lower 1. ovate, spur 
straight, peduncles glabrous, st. procumbent.-Antirrhinum Sm., E. B. 692. St. 70. 11.-Fl. solitary, axillary, upon long slender stalks, small, yellow, with the upper lip purple.-Gravelly and chalky corn-fields. A. VII.-IX.

E. I.

3. L. spuria (Mill.); l. roundish-ovate, spur curved upwards, peduncles hairy, st. procumbent.-Antirrh. Sm., E. B. 691. St. 70. 12.-Fl. similar to the last but larger. $L$. with here and there a small tooth.-In this species and the two preceding some of the fl. are often regular with 5 spurs or partially so with 2, 3, or 4.-Gravelly and sandy corn-fields. A. VII.-IX. E.

4. L. minor (Desf.); l. linear-lanceolate obtuse-glandularpubescent mostly alternate, $f$ l. solitary axillary, peduncles 3 times as long as the calyx, segments of the upper lip diverging, seeds oblong sulcate.-Antirrhinum Sm., E. B. 2014. St. 70. 15.Fl. small; the tube, upper lip, and spur of the cor. purplish; lower lip yellowish. St. erect, 4-10 in. high, branched, glandular-pubescent.- Sandy and gravelly fields. A. VI.-VIII.

[5. L. Pelisseriana (Mill.); glabrous, 1 . linear, the lower ternate or quaternate upper alternate, sterile branches radical prostrate with ternate lanceolate or ovate l., fl. racemose, peduncles as long as the bracts, sepals linear acute twice as long as the capsule, seeds discoidal with a fimbriated wing smooth externally tubercular within.-E. B. S. 2832.-Fl. purple with darker veins. St. one or more from each root, erect, about a foot high. Caps. bilobed.-Jersey. A. VI.]

*6. L. supina (Desf.); glabrous, rachis ped. and sep. glandular-hairy, l. linear blunt mostly whorled, sep. linear-spathulate shorter than the caps. or spur, seeds smooth discoidal with an orbicular striated margin.-L. maritima DC. Icon. Gall. 12.Fl. capitate-racemose, yellow; throat and spur with slender purple lines. Style entire.-Catdown Quarries, Plymouth ; and Poole, Dorset; a ballast plant. Perhaps a native at Hayle, and St. Blazey's Bay, Cornwall. A. VII. VIII.

[L. purpurea (Mill.); glabrous, 1. linear-lanceolate scattered, lower 1. irregularly in fours, fl. narrowly racemose, sep. linear shorter than the caps. and long incurved spur, seeds angular with a network of elevated lines.-Fl. purple or yellow with the lips purple; spur two or three times longer than the ped. which is usually shorter than the bract. St. erect, leafy.-Old walls : an escape from gardens. P. VII. VIII.]

E.

7. L. repens (Ait.); glabrous, 1. linear scattered or partly whorled, fl. racemose, sep. lanceolate as long as the spur but shorter than the caps., seeds angular with transverse elevated lines. -E.B. 1253. L. striata DC., Koch, R. I. t. 423.-FI. white with 
blue veins. St. erect, branched, leafy, $1-1 \frac{1}{2}$ foot high, slender. Seeds much smaller than those of $\dot{L}$. vulgaris. L. italica and L. sepium nay be hybrids between this and $L$. vulgaris.-Calcareous soils, particularly near the sea, rare. P. VII.-IX.

8. L. vulgáris (Mill.); glabrous, rachis and peduncles glandular-hairy, 1. linear-lanceolate scattered crowded, fl. racemose imbricated, sep. ovate acute glabrous shorter than the caps. or spur, seeds tubercular-scabrous with a smooth orbicular margin. - E. B. 658. St. 18. 13.-Fl. large, yellow, rarely milk-white with an orange palate. St. erect, 2 feet high, as well as the 1. glabrous. Common and partial flower-staiks occasionally glabrous.-The var. Peloria with 5 spurs and an equal and regular cor. is rarely found. E. B. 260.- $\beta$. latifolia (Bromf.); 1. narrowly lanceolate, $\mathrm{fl}$.-l. often lanceolate very glaucous, $\mathrm{fl}$. twice as large in a few-fl. lax raceme, ped. glabrous, spur directed perpendicularly downwards. $L$. speciosa Ten.?-Hedges on a gravelly soil. $\beta$. Isle of Wight. P. VI. VII. Yellow Toadflax.

5. Scrophularia Linn. Figwort.

* Cal. of 5 rounded lobes. Cor. purplish; upper lip with a scale on its inner side (staminode).

1. S. nodosa (L.); l. ovate acute subcordate glabrous doubly and acutely serrate, lower serratures largest, st. acutely 4-angular, cymes lax, sep. roundish-ovate with a narrow membranous margin, staminode transversely oblong slightly emarginate.E. B. 1544. St. 23. 14.-Root tuberous, thick, knotty. St. $2-3$ feet high. Bracts small, lanceolate, acute. Fl. greenish-purple, lurid, sometimes milk-white. Caps. ovate.-Moist hedges and thickets. P. VI. VII. Knotted Figwort.

2. S. Ehrharti (C. A. Stev.); l. ovate-lanceolate acute subcordate glabrous sharply serrate, lower serratures smaller, st. and petioles winged, cymes lax few (4-8)-flowered, sep. roundish with a broad membranous margin, staminode bifid with diverging lobes.-E. B. S. 2875. S. aquatica St. 23. 15.-St. tall. Bracts leaflike, lanceolate, acute. Fl. dark purple. Caps. subglobose, obtuse.-Wet places. P. VIII. IX. E. S.

3. S. aquatica (L.!); $l$. cordate-oblong rounded-obtuse glabrous crenate-serrate, st. and petioles winged, cymes dense corymbose many (8-15)-flowered, sep. roundish obtuse with a broad membranous margin, staminode roundish-reniform entire.-E. $B$. 854. S. Balbisii Horn., Koch.-St. 2-5 feet high. Bracts linear, obtuse. Fl. dark purple, occasionally milk-white. Caps. ovate, pointed.-In wet places. P. VII. VIII.

4. S. Scorodonia (L.); l. cordate-triangular with large double 
teeth downy on both sides, st. bluntly quadrangular downy, cymes lax few-flowered, sep. roundish downy with a membranous margin, staminode roundish entire.-E. B.2209.-St. $2-3$ feet high. L. wrinkled. Bracts leaflike, lower exactly like the leaves. Fl. purple. Caps. ovate, acute.-In moist places. West of Cornwall. Tralee, Kerry. Jersey. P. VII.

** Cal. of 5 deep acute segments. Cor. yellow; no staminode.

5. S. vernalis (L.); $l$. downy cordate-acute doubly serrate, st. winged hairy, cymes axillary corymbose with leaflike bracts, sep. oblong with a recurved apex.-E. B.567. St.23. 16.-St. about 2 feet high. Fl. yellow, inflated; the mouth much contracted. Caps. ovate, acute. Differing greatly from the other species and allied in appearance to some of the Calceolaria.-Waste places, rare. P. IV. V.

E. S.

\section{Limosella Linn. Mudwort.}

1. L. aquatica (L.) ; l. lanceolate spathulate on long stalks, ped. axillary crowded shorter than the petioles.-E. B.357. St. 30. 15.-St. 0, except the naked stcles. Fl. small, white, or rose-coloured. Caps. minute, ovate.-Muddy places where water has stagnated. A. VII.-IX.

E. S.

\section{Melampyrum Linn. Cow-wheat.}

1. M. cristatum (L.); spikes densely imbricated 4-sided, bracts heartshaped acuminate pectinate-dentate lower ones with a long leaflike recurved point.-E. B. 41.-Bracts rose-coloured at the base. Fl. yellow, tinged with purple. L. linear-lanceolate, acute, entire, with netted veins beneath.-Woods and thickets in the eastern counties. A. VII. Crested Cow-wheat.

E.

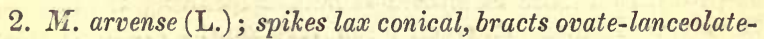
attenuate pinnatifid with subulate segments and with a few large glandular points beneath, cal. hispid equalling the cor.-tube with elongate-lanceolate-attenuate teeth from an ovate base, cor. closed.-E. B. 53 (bad).--Bracts purple-rose-colour. Fl. variegated with yellow, rose-colour, and purple. L. linear-lanceolate, acute, rough-edged, slightly downy on both sides, entire.-Cornfields and dry banks in the eastern counties and the Isle of Wight. A. VII. Purple Cow-wheat.

E.

3. $M$. pratense (L.); fl. axillary secund in distant pairs, upper bracts lanceolate with 1 or 2 teeth at the base, cor. 4 times as long as the glabrous calyx closed, lower lip protruded.-E. B. 113. -Teeth and tube of the cal. about equal in length. L. lanceolate, or ovate-lanceolate, or with a cordate base, entire, varying greatly in size. Fl. large, pale yellow.- $\beta$. ericetorum (D. Oliv.); 
lispid, l. lanceolate or linear-lanceolate, bracts toothed, fl. approximate, cor.-tube whitish (Phytol. iv. 678). - $\gamma$. M. montanum (Johnst.); smaller in all its parts, bracts quite entire, l. linearlanceolate bispid, the 2 lowest obovate-lanceolate blunt. - Woods and thickets. $\beta$. West of Ireland. $\gamma$. Mountains. A. VI.VIII.

4. M. sylvaticum (L.); fl. axillary secund in distant pairs, bracts all entire linear-lanceolate, cor.about twice as long as the glabrous calyx open, lips equal in length.-E. B. 804.-Teeth of the cal. longer than the tube. L. linear-lanceolate, entire. Fl. very small, deep yellow.-Alpine woods. A. VII.

[Mimulus luteus (Willd.); l. roundish ovate veined, lower ones stalked, uppermost clasping, st. creeping; fl. yellow; a native of America, is naturalized in many boggy places. P. VI.-IX.]

\section{Pedicularis Linn. Louse-wort.}

1. P. palustris (L.); st. solitary erect branched throughout, 1. pinnatifid, segments oblong blunt lobed, cal. ovate pubescent 2-lobed, lobes incise-dentate crisped.-E. B. 399.-Upper lip of the cor. with a short truncate beak with a triangular tooth on each side. Fl. large, crimson. St. 12-18 in. high, angular, with alternate branches. Crown of the root with a whorl of ovate-acute scales.-Marshy and boggy places. A.? V.-VII. Red Rattle.

2. P. sylvatica (L.); st. branched at the base erect, branches long spreading prostrate, l. pinnatifid, segments ovate lobed, cal. oblong glabrous irregularly 5-lobed, upper lobe lanceolate, other lobes with 3 leaflike divisions. - E. B. 400. St. 13. 14.-Upper lip of the cor. as in the last. Fl. large, rose-colour. Summit of the ped. with a loose membranous cuticle inclosing the base of the calyx. Primary st. erect, often very short; branches prostrate. Crown of the root with a whorl of ovate-lanceolate crenate undivided reflexed leaves.- Wet heathy and rather hilly pastures. A. ? V.-VIII.

\section{Rhinanthus Linn. Yellow Rattle.}

1. R. Crista-galli (L.); l. oblong-lanceolate serrate, fl. in lax spikes, cal. glabrous, lobes of the upper lip of the cor. short roundish, bracts ovate incise-serrate, seeds with a membranous border.-E.B. 657. R.I.! f. 974.-Lateral lobes of the upper lip. of the cor. very blunt, shorter than broad, bluish. Bracts green throughout, nectary ovate. St. $1-2$ feet high.-Meadows and pastures. A. VI.

2. R. major (Ehrl..); 1. linear-lanceolate serrate, fl. in crowded 
spikes, cal. glabrous, lobes of the upper lip of the cor. oblong, bracts with an attenuate point incise-serrate.-Cal. often slightly downy on its edges. Lateral lobes of the upper lip of the cor. longer than broad, purple; the central part truncate. Anth. very villose. Bracts yellowish with green points.-Mr. Bentham calls this $R$. angustifolia (Gm.), and applies the name of $R$. major (Ehrh.) to the foreign $R$. hirsutus (Lam.). The latter plant has never been found in Britain.-a. platypterus (Fries); seed not twice as broad as its wing. R. major Koch. R. I. f. 975.-B. stenopterus (Fries); seed quite twice as broad as its wing. R. major E. B. S. 2737.- $\gamma$. apterus (Fries); seed not winged but rounded and longitudinally ribbed or furrowed on the back. R. Reichenbachii Drej.-Cultivated land. a. Hastings. $\beta$. North of England and Scotland. $\gamma$. Forfarshire. A. VII. VIII. E. S.

\section{Bartsia Linn.}

1. B. alpina (L.) ; l. opposite ovate slightly clasping bluntly serrate. - E. B. 361. St. 17. 15.-St. square, 4-8 in. high, simple. Root ereeping. Fl. forming a short dense leafy spike, purplish-blue, downy. Cal. purplish, viscid. Anth. hairy.Alpine pastures, rare. P. VI. VII.

\section{Eufragia Griseb.}

1. E. viscosa (Benth.); l. opposite, upper l. alternate ovatelanceolate sessile acutely-serrate.-E. B. 1045. Bartsia Sm.-L. sometimes linear-lanceolate. St. round, $3-12$ in. high, simple. Root fibrous. Fl. distant, axillary, upper ones crowded, yellow. Anth. hairy. St., 1., and cal. viscid.-Damp places in the west of England, south-west of S., and south of I. A. VII.-IX.

\section{Euphrasia Linn. Eye-bright.}

i. Eimphrasia. Anthers unequally mucronate.

1. E. officinalis (L.); l. ovate or oblong-lanceolate nearly sessile serrate (3-5 teeth on each side), lobes of the lower cor.-lip emarginate, of the upper lip patent sinuate-dentate, anth. hairy. -E. B. 1416. - St. 1 -8 in. high. Fl. axillary, solitary, sessile, crowded towards the ends of the branches. A peculiarly variable plant, perhaps including 2 species.-1. E. officinalis (L.); cal. downy and glandular, teeth of upper l. acute, caps. oblong-obovate emarginate mucronate, seeds ovate (greyish) with white winged ribs and fine transverse lines between them.-2. E. nemorosa (Pers.) ; cal. glabrous or pulverulent not glandular, teeth of upper l. long cuspidate, caps. linear-oblong truncate mucronate, seeds fusiform (yellowish) with white winged ribs and very slight traces of transverse lines. See Fl. de France, ii. 605.Pastures, woods, heaths. A. VI.-VIII. Common Eye-bright. 
ii. Odontites (Duby). Anthers with 2 equal points.

2. $E$. Odontites (L.); $l$. narrowed from near the base opposite linear-lanceolate-attenuate remotely serrate, floral $l$. usually longer than the fl. with 2-4 teeth and an entire end, cal.-segments as long as their tube lanceolate acute, cor. pubescent, lobes of the lower lip oblong-obtuse, anth. with 2 equal points hairy, caps. oblong.-Bartsia Sm., E. B. 1415.-St. about a foot high, much branched. Fl. many, pink, in leafy unilateral spikes. Filaments, anth., and stam. hairy. $-\beta$. E. rotundata (Ball); 1. sessile lanceolate crenate-serrate, fl.-l. nearly entire equalling or falling short of the fl., cal.-segments $\frac{1}{2}$ as long as their tube broadly triangular, cor. pubescent, lobes of lower lip broadly rounded nearly equal, caps. broadly oval almost rounded. Filaments, anth., style, and stigma nearly glabrous. $A$. N.H. ser. 2 . iv. 30.-Corn-fields and waste places. A. VII. VIII.

\section{Sibthorpia $\operatorname{Linn}$.}

1. S. europaa (L.).-E.B. 649.-An elegant trailing plant with slender filiform creeping stems, and alternate long-stalked roundish reniform leaves with a few large crenatures. Fl. very small, axillary, solitary, on short stalks, pinkish, inconspicuous.-Damp shady places in the south and south-west. P. VI.-IX. R. I.

\section{Veronica Linn. Speedwell.}

* Racemes axillary.. (Root perennial.)

1.V. scutellata (L.); l. linear-lanceolate acute sessile minutely denticulate, racemes alternate, fruitstalks reflexed, caps. of 2 flattish orbicular lobes, st. erect.-E. B. 782. St. 58. 3.-Stoloniferous. St. weak, elongated. Fl. pale flesh-coloured, with darker lines. Sep. small, lanceolate, acute, shorter than the capsule.- $\beta$. pubescens (Koch); st. hairy. V. Parmularia "Poit." -In boggy places. P. VI.-VIII.

2. V. Anagallis (L.); l. lanceolate serrate acute sessilc, racemes opposite, fruitstalks spreading, caps. elliptical slightly notched, st. erect.-E. B. 781.- Stoloniferous. St. thick, hollow, varying much in height. Fl. pale blue. Sep. lanceolate, longer than the capsule. Racemes sometimes clothed with glandular hairs. Whole plant usually glabrous.- In stagnant water. P. VI.-VIII. Water Speedweil.

3. V. Beccabunga (L.); l. stalked elliptical obtuse crenateserrate, racemes opposite, fruitstalks spreading, caps. roundish tumid slightly notched, st. procumbent at the base rooting.- $E$. B. 655. St. 12. 1.-Fl. bright blue. Whole plant glabrous. - $\beta$. $V$. limosa (Lej.); bracts longer than the pedicels, fl. pink or flesh- 
coloured.-Ditches and streams. $\beta$. Dalkeith Park near Edinburgh. Prof. Balfour. P. V.-VIII. Brooklime.

4. V. Chamadrys (L.); 1. nearly sessile cordate-ovate inciseserrate, racemes opposite, fruitstalks ascending, caps. flat obcordate deeply notched ciliate shorter than the cal., st. bifariously hairy ascending.-F.B.623. St. 58. 6.-Fl. large, many, handsome, blue. Sep. lanceolate, acute.-Hedge-banks. P. V. VI. Germander Speedwell.

5. V. montana (L.); l. stalked broadly ovate serrate, fruitstalks ascending, caps. orbicular notched their margins crenulate and ciliate longer than the cal., st. diffuse hairy all round procumbent. -E. B. 766. St. 58. 5.-Racemes lax. Fl. few, pale blue. Caps. very large, quite flat. Sep. ovate-lanceolate, acute. -Woods and thickets in hilly districts. P. V. VI.

6. V. officinalis (L.); l. shortly stalked elliptical serrate, $r a$ cemes spikelike many-flowered, fruitstalks erect, caps. obcordate truncate obtusely notched longer than the cal., st. prostrate creeping hairy.-E. B. 765. St. 58.4.-Racemes erect, much longer than the leaves. Caps. not always notched.- $\beta$. glabra; st., l., and calyx smooth. Not V. Allionii (Vill.). - $\gamma$.V. hirsuta (Hopk.); 1. ovate-lanceolate, caps. abrupt undivided. E.B.S. 2673. Much smaller than the true $V$. officinalis. I have not seen wild specimens.-Dry banks and heaths. $\beta$. Mountains. $\gamma$. Dry heath, Carrick, Ayrshire. P. VI.-VIII. Common Speedwell.

** Racemes terminal; cor.-tube longer than broad.

7. V. spicata $(\mathrm{L}$.); 1. ovate or lanceolate crenate-serrate entire at the end, lower l. obtuse stalked, raceme spiked elongate dense, bracts longer than the pedicels, caps. ovate emarginate with a very long style.-St. erect, branching at the base. Spike nearly always solitary. Fl. blue. Lower l. oblong with a wedgeshaped. base, or ovate with a rounded or slightly cordate base. E. B. 2 . V. hybrida (L.) E. B. 673.-Rare. On chalky heaths near Newmarket and Bury; and on limestone cliffs. P. VII. VIII. Spiked Speedwell.

*** Racemes terminal; cor.-tube very short. † Seeds flat.

[8. V. fruticulosa (L.); l. elliptical or lanceolate obtuse subcrenate, lower l. smaller, raceme glandular-pubescent few-flowered (many-flowered Sm.), caps. elliptical abrupt, valves bifid.-E. B. 1028. St. 56. 1.-FI. flesh-coloured. I have not seen native specimens. - Ben Cruachan. Dr.Walker. Ben Lawers. Mr.R. Brown. P. VII.]

9. V. saxatilis (L.); 1. elliptical serrate at about the middle; 
lower 1 . smaller, raceme pubescent with crisped hairs not glandular few-flowered, caps. ovate-attenuate, valves bifid.-E. B. 1027. St. 56. 2.-Fl. bright blue. St. much branched, decumbent, woody.-Exposed alpine rocks. P. VII.

10. V. alpina (L.); l. elliptical or ovate dentate or entire, lower l. smaller, raceme hairy with patent hairs not glandular few-flowered, caps. oblong-obovate emarginate crowned with the very short persistent style.-E. B. 484. St. 56. 3.-Fl. bright blue. St. ascending, simple except at the base, $4-6$ in. high. Hairs jointed.-Summits of Highland mountains. P. VII. VIII.

11. V. serpyllifolia (L.); l. ovate or elliptical slightly crenate, lower 1 . smaller and rounder, raceme elongate many-flowered, caps. obcordate broader than long crowned with the long persistent style.-E. B. 1075. St. 58. 1.-Fl. whitish with blue veins. St. rooting below, afterwards erect. $-\beta$. $V$. humifusa (Dicks.); stems quite prostrate, racemes shorter.-Roadsides and damp places. $\beta$. Highland mountains. P. V.-VII.

12. V. arvensis (L.); l. cordate-ovate crenate, lower l. stalked, uppermost 1. lanceolate entire resembling bracts exceeding the flowers, raceme slightly spiked many-flowered lax, ped. very short, caps. obcordate broader than long compressed ciliate on the keel.-E. B. 734. St. 58. 11.-St. ascending, 2-6 in. or rarely a foot long. Fl. pale blue. Caps. smooth, with rounded lobes which exceed the style. Seeds 12-14. Sep. lanceolate, unequal.-Gravelly and sandy places. A. IV.-VII.

13. V. verna (L.); l. pinnatifid, lower l. stalked ovate serrate, upper l. lanceolate entire resembling bracts, raceme slightly spiked many-flowered lax, ped, very short, caps. obcordate compressed ciliate on the keel.-E.B.25.St.13.1.-St. erect, 1-3 in. high, simple, or branched in the lower part. Caps. smooth or downy, with rounded lobes. Style very short. Seeds 12-14. Sep. linear-lanceolate, unequal. - Sandy heaths. Bury, Thetford and Mildenhall, Suff. A. V.

† Seeds concave.

14. V. triphyllos (L.); l. fingered, lower l. ovate entire or dentate stalked, raceme slightly spiked lax many-flowered, ped. exceeding the calyx, caps. obcordate compressed smooth ciliate on the keel.-E.B.26. St.8.1.-St. erect with spreading branches, $4-5$ in. high. Fl. deep blue. Ped. usually louger than the leaves. Sep. oblong, obtuse. Known by its spreading st., deeply fingered l., and dark blue flowers.-Sandy fields. Bury and Mildenhall, Suff. Iork. A. IV.

E. 
**** Flowers axillary, solitary; seeds concave.

15. V.agrestis (L.); l. all stalked cordate-ovate incise-serrate, sep. oblong-obtuse, stam. inserted at the very bottom of the cor., caps. of 2 turgid keeled lobes, seeds about 6 in a cell.-E. B.S. 2603. St. 58. 14. R. I. f. 440.-St. procumbent. Caps. hairy all over, or only ciliate on the keel; hairs all straight and glandular. L. usually exceeding the peduncles. Lower cor.-lip white.- $[V$. opaca (Fries) with spathulate sep., fewer seeds, "hairs on caps. incurved short with a few longer and glandular," stam. inserted in the throat of cor.; is probably British.]-Fields and waste places. A. IV.-IX. Green Field Speedwell.

16. V. polita (Fries); 1. all stalked cordate-ovate incise-serrate, sep. broadly ovate acute, stam. inserted at the very bottom of the cor., caps. of 2 turgid lobes, seeds $8-12$ in a cell. $-E$. $B$. 783. St.58. 16. R. I. f. 404. 405.-St. procumbent. Caps. with short dense glandless hairs and other shorter glandular ones, rarely glabrous. L. usually falling short of the peduncles. Fl. wholly blue.- $\beta$. grandiflora; cor. as large as that of $V$. Buxbaumii.-Fields and waste places. $\beta$. Berwickshire. Cambridge. Bury St. Edmonds. A. IV.-IX. Gray Field Speedwell.

*17. V. Buxbaumii (Ten.); 1. all stalked cordate-ovate inciseserrate, sep. lanceolate acute, stam. from the bottom of the cor., caps. of 2 divaricate lobes compressed upwards and sharply keeled, seeds about 8 in a cell.-E. B. S. 2769. St. 56. 5. R. I. 430. 431.-St. long, procumbent. L. falling short of the peduncles. Fl. twice the size of those of the preceding, as large as those of V. Chamadrys, blue.-Fields. A. IV.-IX.

18. V. hederifolia (L.); l. with 5-7 large toothlike lobes all stalked, sep. cordate ciliate, caps. of 2 turgid lobes, seeds 2 in each cell.-E. B.784. St. 56.6.-St. procumbent. Fl. pale blue. -Fields and banks. A. IV.-VI. Ivy-leaved Speedwell.

[Acanthus mollis, belonging to the Order Acanthacer, has been introduced by unknown agency into the isle of St. Agnes, Scilly ( $A$. N. H. ser. 2. viii. 505$)$; but having very slender claims to be included in the British Flora, it is not described here.]

\section{Order LVIII. LABIATA.}

Cal. tubular, regular or 2-lipped, persistent. Cor. 2-lipped, upper lip entire or bifid, lower 3-cleft. Stam. 4, didynamous, rarely 2. Ovary free, 4-lobed. Style 1 , from the base of the lobes ; stigma bifid. Fr. in $1-4$ small nutlike portions.-Figures of all the genera will be found in G. F. G. Gam. ii. 
Tribe I. MENTHOIDEAE. Cor. bellshaped, nearly regular. Stam. distant, straight, diverging upwards.

1. Mentha. Cor. 4-fid, tube very short. Cal. equal, 5toothed. Stam. 4 ; anth.-cells parallel.

2. Lycopus. Cor. 4-fid, scarcely longer than the equal 5 toothed calyx. Stam. 2; anther-cells parallel or ultimately divergent; 2 upper stam. 0 or rudimentary, or rarely perfect.

Tr. II. MONARDEAE. Cor. 2-lipped. Stam. 2, fertile, parallel under the upper lip of the corolla.

3. Salvia. Two upper stam. wanting or rudimentary; filaments with 2 diverging branches, one bearing a perfect antl..cell, the other barren. Cor. ringent. Cal. tubular, 2-lipped.

Tr. III. SATUREIINEAE. Cor. 2-lipped. Stam. 4, distant ; cells of anth. separate, divergent; connective dilated.

4. Origanum. Stam. divergent; connective subtriangular. Upper lip of cor. straight, nearly flat; lower patent, 3-fid. Cal. with 5 equal teeth and 10-13 veins; throat hairy. Spikes 4-sided, resembling catkins, imbricated with bracts.

5. Tнymus. Tips of stam. patent. Anth.-cells at first nearly parallel, afterwards divergent; connective subtriangular. Upper lip of cor. straight, nearly flat; lower patent, 3-fid. Cal. 2-lipped and 10-13-veined; throat hairy. Fl. whorled, axillary or spiked.

6. Calamintha. Tips of stam. connivent under the upper lip of the corolla. Anth.-cells at length divergent; connective subtriangular. Upper lip of cor. straight, nearly flat; lower patent, 3-fid. Cal. 2-lipped.

[Tr. IV. MELISSINEAE. Cor. 2-lipped. Stam. distant; anth.cells connected above.

7. Melissa. Tips of stam. connivent under the upper lip of the cor. Anth.-cells divergent. Upper lip of cor. concave; lower patent, 3-fid. Cal. 2-lipped; upper lip flat, with 3 teeth, the lateral teeth folded at their midrib.]

Tr. V. SCUTELLARIEAE. Stam. approaching, parallel under the upper lip of the cor. Cal. 2-lipped, closed in fruit.

8. Scutellaria. Tips of stam. incurved. Filaments simple. Anth. of the 2 longer and inferior stam. 1-celled, of the shorter and superior 2-celled. Cor. 2-lipped, upper lip concave. Cal. ultimately closed and compressed; lips entire, upper one with a concave scale on its back. 
9. Prunella. Two inferior stam. longest. Filaments bifid, one branch barren. Anth. all 2-celled. Cor. ringent; upper lip concave, entire. Cal. ultimately closed and compressed; upper lip flat, truncate, 3-toothed; lower bifid.

Tr. VI. NEPETEAE. Stam. approaching, parallel under the upper lip. of the cor., 2 inferior shortest. Cal. tubular.

10. Nepeta. Anth.-cells diverging. Cor. ringent; upper lip flat, straight, emarginate or bifid. Cal. 5-toothed.

Tr. VII. STACHYDE AE. Stam. approaching, parallel under the upper lip of the cor., 2 inferior longest. Cal. tubular or bellshaped, spreading in fruit.

\section{* Stamens exceeding the tube of the corolla.}

11. Melittis. Anth. approaching in pairs and forming a cross, bursting longitudinally. Upper lip of the cor. flat, entire, straight ; lower lip with 3 rounded nearly equal lobes. Cal. membranous, bellshaped, ample, variously lobed.

12. Lamium. Anth. approaching in pairs; cells diverging, bursting longitudinally. Upper lip of the cor. arched; lateral lobes of the lower lip minute toothlike or obsolete rarely elongated. Cal. bellshaped, 5 -toothed; teeth nearly equal. -Galeobdolon (Huds.) has the lobes of the lower lip of the cor. nearly equal and acute.

13. Leonurus. Anth. approaching; cells nearly parallel, bursting longitudinally. Upper lip of cor. nearly flat, lower with 3 obtuse lobes. Cal. tubular, 5 -toothed, 2 lower teeth rather the longest. Nuts flatly truncate.

14. Galeopsis. Anth. approaching in pairs; cells opposite, bursting by 2 valves transversely. Upper lip of cor. arched, lower lip 3-lobed with 2 teeth on its upper side, lobes unequal. Cal. tubular, 5-toothed; teeth equal or 2 upper ones longest. Nuts rounded at the end.

15. Stachys. Anth. approaching in pairs; cells diverging, bursting longitudinally. Upper lip of cor. concave, lower of 3 unequal lobes. Cal. tubular-bellshaped with 5 equal teeth. Nuts obtuse and convex at the end.

16. Ballota. Anth. approaching in pairs; cells diverging, bursting longitudinally. Upper lip of cor. erect, concave; lower 3-lobed, middle lobe cordate. Cal. funnel-shaped with 5 equal teeth. Nuts convex and rounded at the end. 
** Stamens included in the tube of the corolla.

17. Marrubium. Anther-cells diverging, bursting longitudinally. Upper lip of cor. straight, erect, flattish, cloven; lower 3-lobed, middle lobe the largest. Cal. tubular; teeth nearly equal or 2 longer. Nuts flatly truncate.

Tr. VIII. AJUGOIDEAE. Cor. with the upper lip very short, or deeply bifid and appearing as if wanting.

18. TeuCrium. Stam. parallel, protruding between the deeply divided lobes of the upper lip of the cor., inferior longest; cells bursting longitudinally. Cor. with the upper lip deeply bifid, lobes long; lower lip 3-lobed. Cal. tubular, 5-toothed; teeth equal or the upper one larger.

19. AJUGA. Stam. parallel, protruding far beyond the upper lip of the cor., inferior longest ; cells bursting longitudinally. Cor. with the upper lip very short, 2-lobed; lower 3-lobed, much longer than the upper. Cal. ovate-bellshaped, nearly equally 5-cleft.

\section{Tribe I. Menthoidea.}

\section{Mentha Linn. Mint.}

* Throat of the calyx naked. Inflorescence determinate. Fl.in spiked whorls or terminal heads.

1. M. rotundifolia (L.); l. sessile elliptic-obtuse crenate-serrate wrinkled shaggy beneath, spikes linear-cylindrical dense, bracts lanceolate, "fr.-cal. not contracted at the mouth."-E. B. 446. Sole Menth. 3. - Viscid. L. usually with a cordate base. Whorls of spike nearly all close together. Scent acrid.-Waste places, rare. P. VIII. IX. Round-leaved Mint. E. I.

2. M. sylvestris (L.) ; $l$. subsessile ovate or lanceolate serrate silky beneath, spikes linear-cylindrical dense, bracts subulate, "fr.-cal. contracted at the mouth."-E.B.686. Sole 1. and 2.L. sessile, rarely cordate below. Whorls of spike nearly all close together. Scent sweet.- $a$. L. lanceolate, acute, rather narrowed below.- $\beta$. M. velutina (Lej.) ; l. elliptical-cordate. M. rotundifolia Sole 4.-Waste ground in damp places. P. VIII. IX. Horse Mint.

E. $\mathrm{S}$.

3. M. viridis $(\mathbf{L}) ;$.$l . glabrous sessile lanceolate acute serrate,$ spikes lax cylindrical, bracts subulate.-E. B. 2424 . Sole 5.Cor. glabrous. Whorls of the spike rather distant. L. glandular beneath. $-\beta$. crispa (Benth.). - In marshy places, rare. $\beta$. Glen Farg, Perthshire. Hooker. P. VIII. Spear Mint. 
4. M. piperita (L.); l. stalked ovate-lanceolate or oblong serrate, upper l. smaller, bracts lanceolate, spikes lax short blunt interrupted below, cal. tubular glabrous below with lanceolate subulate teeth.-E. B. 687.-St. and l. nearly glabrous or hairy on the nerves beneath. Cal. glandular. - $\beta$. sylvestris (Sole); l. ovate rounded and almost heartshaped below, spikes elongated. Sole 24.-Wet places, rare. P. VII. VIII. Pepper Mint.

5. $M$. aquatica (L.); $l$. stalked ovate serrate rounded or slightly cordate below, uppermost $l$. like bracts and falling short of the fl., whorls few subglobose capitate the uppermost terminal, cal. tubular with triangular subulate teeth hairy as well as the pedicel.-M. hirsuta Sm., E. B. 447.-Cal. glandular. Inflorescence capitate, determinate. Fl. in terminal and axillary stalked clusters rather than whorls.-M. citrita Ehrh., M.odorata Sole 9, $E$. B. 1025, is a glabrous variety of this species; and $M$. crispa E. B. S. 2785 a form with cut and crisped leaves.-In wet places. P. VII. VIII. Capitate Mint.

** Throat of cal. naked. Inflorescence indeterminate. Fl. in axillary, distant whorls; none amongst the uppermost l., or shorter than them.

6. M. pratensis (Sole); l. nearly sessile ovate-lanceolate acute serrate, floral $l$. similar the smaller ones exceeding the fl., whorls distant subglobose, pedicels glabrous, cal. bellshaped, teeth hairy. -Sole 17. M. gentilis E. B. 449. M. gracilis Sm-St. and 1. usually glabrous. L. paler beneath, glandular. Cal. glandular. - [M.rubra (Huds.), M.gentilis (Sole), is considered as distinct from nos. 6 and 7 by Fries.]-Marshy places, rare. P. VIII. IX.

7. M. sativa (I..); l. stalked ovate or elliptical serrate, upper ones similar but smaller all exceeding the fi., whorls all distant dense, cal. tubular or bellshaped, teeth triangular-lanceolate acuminate.-Uppermost leaves often barren.-a. vulgaris; cal. and pedicels hairy. M. sativa Sm., E. B. 448.- $\beta$. M. rubra (Sm. not Fr.); pedicels and lower part of the calyx glabrous, st. slightly branched reddish, whole plant nearly glabrous. $E$. $B$. 1413. $-\gamma$. M. gentilis (Sm.); pedicels and lower part of the cal. glabrous, teeth shorter triangular, whole plant nearly glabrous, st. much branched green, l. all of nearly the same size. The characters of this variety closely approach $M$. arvensis. $-\delta$.? $M$. acutifolia (Sm.) ; pedicels and cal. hairy all over, 1. ovate-lanceolate tapering at each end. $E$. B. 2415. A specimen from near Settle, Yorkshire, only differs from Smith's plant by having glabrous pedicels.-Var. $a, \beta$, and $\gamma$ are closely connected by intermediate forms.-Wet places. $\delta$. Banks of the Medway, but not found for many years. P. VII. VIII. Whorled hairy Mint. 
8. $M$. arvensis (L.); $l$. stalked ovate or elliptical serrate, upper l. similar and equally large, whorls distant, cal. bellshaped, teeth triangular as broad as long. - a. vulgaris; 1 . narrowed below. M. arvensis Sm., E. B. $2119 .-\beta$. M. agrestis (Sm.); 1. somewhat cordate below, upper ones nearly sessile. E.B. 2120. -Corn-fields. P. VII.-IX. Corn Mint.

*** Throat of the calyx closed with hairs. Pulegium Opitz.

9. M. Pulegium (L.); l. stalked elliptical obtuse slightly crenate all similar, whorls all distant globose many-flowered, cal. tubular hispid closed with hairs in the throat.-E. B. 1026. Sole 23.- St. prostrate. L. often recurved, uppermost axils empty. The smallest of our species and remarkably different in habit.-Wet places. P. VIII. IX. Penny-royal. E. I.

\section{Lycopus Linn. Gipsy-wort.}

1. L. europaus (L.); 1. stalked ovate-oblong sinuate-dentate or pinnatifid, sterile stam. wanting, nuts within the tube of the calyx.-E. B. 1105.-L. glabrous or pubescent, opposite. Fl. small, in dense whorls. [L. exaltatus is distinguished by having 2 barren stamens and much longer seeds.] -Banks of streams and ditches. P. VII. VIII.

\section{Tribe II. Monardea.}

\section{Salvia Linin. Sage.}

1. S. verbenaca (L.); l. oblong obtuse cordate below sinuate and crenate or dentate stalked, upper $l$. short broad cordate sessile clasping, bracts cordate acuminate, tube of the cor. equalling the calyx.-E. B. 154.-Varies with the l. incise-dentate. Remarkable for its enlarged very broad sessile upper leaves. Upper cor.-lip concave, laterally compressed, straight except at the tip. Upper cal.-lip broad; teeth small, converging.-Dry gravelly banks. P. V. VI. English Clary.

2. S. clandestina (L.) ; 1. oblong cordate below sinuate-dentate or incise-dentate stalked, upper l. oblong acute sessile scarcely cordate or clasping, bracts cordate acuminate, tube of the cor. exceeding the calyx.- Upper cal.-lip very broad, teeth very small. - Probably distinct from the preceding but very difficult to distinguish on paper.-Dry gravelly banks, rare. Lizard Point, Cornwall. Jersey. P. VII.

E.

3. S. pratensis (L.); 1. oblong-ovate cordate below crenatedentate stalked, upper 1 . small sessile lanceolate acute, bracts cordate acuminate, cor. thrice as long as the calyx.-E. B 153. 
-Known by its large flowers.-Near Cobham, Kent. Near Middleton Stoney, Oxfordshire. P. VII.

\section{Tribe III. Satureiinece.}

\section{Origanum Linn. Marjoram.}

1. O. vulgare (L.); 1. stalked broadly ovate obtuse, bracts ovate exceeding the cal., heads of $\mathrm{fl}$. roundish panicled crowded. -E. B. 1143. St. 3. 13.-Bracts usually purple. L. often slightly toothed.-Dry uncultivated places. P. VIII.

\section{Thymus Linn. Thyme.}

1. T. Serpyllum (L.); st. prostrate creeping, 1. oblong or lanceolate narrowed into the flat fringed stalks, fl.-1. similar, flowering shoots ascending, $\mathrm{fl}$. capitate, upper cal.-lip with 3 short triangular teeth, lower of 2 subulate teeth, upper cor.-lip oblong.-E. B. 1514.- St. producing in its second year the erect fl.-shoots from its lower joinings and prolonged at the end. L. narrowed below, their lower half and the stalk often fringed, rather conspicuously veined beneath, often narrow. Seeds globose, mealy. Upper cor.-lip conspicuously notched. The hairiness of the stem, although variable, is usually in $2-4$ rows with or without pubescence on the faces.-Dry heaths. P. VI.-VIII.

2. T. Chamcedrys (Fr.) ; stems similar diffuse ascending 2-4fariously hairy, l. broadly oblong with flat fringed stalks, fl.-l. similar, fl. whorled or capitate, upper cal.-lip with 3 triangular teeth, lower of 2 subulate teeth, upper cor.-lip semicircular.-Flowering and growing shoots springing intermixed from the old wood. L. less narrowed into the stalks than in No. 1, usually only the stalk is fringed, less prominently veined beneath, broad. Seeds roundish, subcompressed, with a basal apiculus. Upper cor.-lip slightly and obscurely notched. In the larger forms the st. is stronger; it is not so in No. 1.-Heaths. P. VI.-VIII.

\section{Calamintha Moench. Calamint. \\ * Fl. in whorls of 2 dichotomous cymes.}

1. C. Nepeta (Clairv.); l. ovate serrate pale beneath shortly stalked, cal. subcampanulate obscurely 2 -lipped its teeth shortly ciliate all nearly the same shape the upper ones slightly shorter, cymes dichotomous many-flowered, common stalk about as long as the primary partial stalk.-E. B. 1414. St. 70. 3. Thymus Sm.- St. usually many from the crown of the root. Hairs in the throat of the cal. protruded.-Dry banks, rare. P. VII. VIII. Lesser Calamint. 
2. C. officinalis (Moench?); 1. broadly ovate slightly serrate green on both sides on longish stalks, cal. tubular ventricose in front distinctly 2 -lipped its teeth with long cilia those of the upper lip triangular and ascending of the lower twice as long and subulate, lower lip of the cor. with distant segments the middle one longest, cymes scarcely dichotomous few-flowered, common stalk not $\frac{1}{2}$ as long as the primary partial stalk.-Thymus Calamintha Sm., E. B. 1676 . C. menthafolia G. and G.-St. usually solitary, or few from the root. Hairs in the throat of the cal. included. Larger in all its parts than the preceding.-Dry banks, rare. P. VII.-IX. Common Calamint. E. I.

3. C. sylvatica (Bromf.); 1. broadly ovate sharply serrate, cal. tubular distinctly 2-lipped, teeth with long cilia those of the upper lip patent or reflexed, lower lip of the cor. with overlapping segments all nearly equally long, cymes many-flowered, common stalk about as long as the primary partial stalk.-E. B. S. 2897. C. officinalis G. and G.-Hairs in the throat of the cal. few, included. Root slightly creeping. L. large. Cal.-teeth tinged with purple. Cor. very large, tube much protruded, middle lobe of lower lip short and broad.-Isle of Wight. P. VIII.-X. E.

\section{** Whorls of 6 simple separate peduncles. Acinos Moench.}

4. C. Acinos (Clairv.); 1. ovate subserrate acute with revolute margins, cal. tubular gibbous below distinctly 2-lipped, upper lip with short triangular teeth lower with subulate teeth all converging in fruit.-E.B. 41]. St.70.5. Thymus Sm.-St. $6-8$ in. long. Fl. blue.-Dry gravelly places and limestone rocks. A. ? VII. VIII. Basil Thyme.

\section{*** Fl. in dense axillary whorls. Bracts forming a kind of involucre. Clinopodium Linn.}

5. C. Clinopodium (Spenn.); 1. ovate obtuse rounded below slightly crenate, whorls equal many-flowered, bracts setaceous as long as the calyx.-E. B. 1401. Clinopodium vulgare Sm.-St. $1-1 \frac{1}{2}$ foot high. Fl. purple in 2 or 3 dense whorls, the uppermost terminal.-Dry bushy places. P. VII. VIII. Wild Basil.

Tribe IV. Melissinea.

\section{Melissa Linn. Balm.}

[*1. M. officinalis (L.); 1. ovate crenate-serrate acute paler beneath, cal. subcampanulate slightly ventricose in front distinctly 2-lipped, upper lip flat truncate with 3 short broad teeth, lower 
with 2 lanceolate teeth.-St. 11.-St. 2 feet high. Fl. in axillary secund whorls. - Naturalized in the south. P. VII. VIII.]

E. I.

\section{Tribe V. Scutellariea.}

\section{Scutellaria Linn. Skull-cap.}

1. S. galericulata (L.); l. shortly stalked all oblong-lanceolate cordate below crenate-serrate, fl. axillary opposite secund, calyx without glands. - E. B. 523.-Cor. large, blue. St. 6-12 in. high, stout. Distinguished from S. hastifolia by wanting the glandular hairs on the calyx, even when that part is downy, and the different shape of the leaves, and fl. not racemose. This genus has a curved elongated support (carpophore) to its nuts.Banks of rivers and ditches. P. VII. VIII.

2. S. minor (L.); l. shortly stalked, lower l. broadly ovate, intermediate ovate-lanceolate with the base cordate, upper 1 . lanceolate with a rounded base, $\mathrm{fl}$. axillary opposite secund, cal. pubescent.-E. B. 524.-Cor. sinall. St. 4-8 in. high, slender. -Moist heaths and boggy places. P. VII.-IX.

\section{Prunella Linn. Self-heal.}

1. P. vulgaris (L.); l. stalked oblong-ovate obtuse, upper lip of the cal. with short truncate mucronate teeth, lower lip with ovate-lanceolate mucronate teeth, longer stam. with a straight spinous tooth at their apex.-E.B.961.-L. nearly entire or slightly toothed; on continental specimens they are sometimes pinnatifid. Fl. blue, rarely white, whorled, crowded into a dense spike, with 2 broad obcordate acuminate bracts under each whorl. Cal. reddish-purple.-In damp pastures. P. VII. VIII.

\section{Tribe VI. Nepetea.}

\section{Nepeta Linn.}

1. N. Cataria (L.); l. stalked cordate acute incise-serrate whitish-pubescent beneath, whorls dense many-flowered rather stalked spiked, nuts smooth and glabrous.-E. B. 137.-Fl. white. St. $2-3$ feet high, downy or mealy. Stam. at length curved outwards. - Waste places. P. VII. VIII. Cat-mint. E. I.

2. N. Glechoma (Benth.); 1. cordate-reniform crenate, whorls axillary stalked secund 3-4-flowered, cal.-teeth ovate aristate, nuts oblong with impressed dots.-E. B. 853 . Glechoma hederacea Sm.-St. procumbent, creeping. Anth. in pairs forming a 
cross.- $\beta$. hirsuta; cal.-teeth elongate linear-lanceolate.-Hedges and thickets. $\beta$. Scotland. P. IV.-VI. Ground-ivy.

\section{Tribe VII. Stachydea.}

\section{Melittis Linn. Bastard Balm.}

1. M. Melissophyllum (L.).-E. B. 577 and 636.-L. oblongovate or slightly cordate. Upper lip of the cal. with 2 or 3 teeth. Fl. purple with a white margin or variegated in different ways, large. St. 1-2 feet high.-M. grandiflora (Sm.) is only a slight variety.-Woods in the south. P. V. VI.

\section{Lamium Linn. Dead Nettle.}

* Lower lip of cor. with one large obcordate lobe with $1-2$ teeth on each side of its base.

1. L. amplexicaule (L.); l. roundish-cordate obtusely incisecrenate, lower l. stalked, upper sessile clasping, cal.-teeth longer than their tube (green) at length connivent, cor.-tube straight.E. B. 770. R.I. f. 373.-Nuts small, three times as long as broad, with a small triangular oblique terminal space. Cor.-tube much exceeding the calyx, slender, naked within. The cor. does not always expand, but still the anth. are fertile and fr. is produced. - Sandy and chalky fields. A. V.-VIII. Henbit.

2. L. intermedium (Fries); l. incise-crenate, lower 1. stalked, upper reniform-cordate sessile, cal.-teeth longer than their tube hispid always spreading, straight cor.-tube with a faint hairy ring within.-E.B.S.2914.-Nuts twice the size of those of the preceding, as broad as but longer than those of the following, with a large triangular terminal rather oblique space. Tube of the cor. equal, cylindrical. Cal.-teeth usually purple, rigid.-Common in Scotland, rare in England and Ireland. A. VI.-IX.

3. L. incisum (Willd.); $l$. cordate incise-dentate all stalked, upper broadly ovate crowded, cal.-teeth as long or longer than their tube always spreading, tube of the cor. straight naked within.-E. B. 1933.-Uppermost 1. wedgeshaped below. St. few slender and elongated or many thick and short. Tube of the cor. equal, cylindrical, sometimes with a faint ring of hairs within.-Cultivated and waste ground. A. IV.-VI.

4. L. purpureum (L.); l. cordate crenate-serrate all stalked, upper ovate crowded, cal--teeth as long as their tube always spreading, cor.-tube a little curved below with a ring of hairs within.-E. B. 769.-Cor. pale purple, lip spotted with red; tube narrowed below. Nut about twice as long as broad. A 
form of this plant with more deeply cut leaves is often taken for L. incisum. - Waste and cultivated ground. A. V.-VIII. Red Dead-nettle.

5. L. album (L.); 1. cordate-ovate acuminate deeply serrate stalked, cal.-teeth as long as the tube all separated by acute angles, upper one distant from the others, cor.-tube exceeding the calyx with an oblique ring of hairs within.-E. B. 768. St.8. -St. 12-18 in. high. Fl. large, white. The separation of one tooth from the others in the calyx of this species is remarkable. -Waste ground. P. V. VI. White Dead-nettle.

†6. L. maculatum (L.) ; 1. cordate-ovate acuminate deeply serrate stalked, cal.-teeth longer than their tube 3 upper ones separated from the other 2 by broad obtuse angles, cor.-tube exceeding the calyx with a transverse ring of hairs within.E. B. 2550.-St. 12-18 in. high. Fl. purple. L. marked with white, cordate-ovate (L. maculatum $R$. I. t. 215); or green, triangular-cordate (L. lævigatum R. I. t. 216).-Fifeshire. Clova. P. VI.-.VIII.

E.? S.

** Lower lip of cor. in 3 entire nearly equal acute lobes. Galeobdolon Linn. Archangel.

7. L. Galeobdolon (Crantz); 1. ovate acuminate truncate below coarsely serrate stalked, upper l. lanceolate attenuated below, helmet of the cor. elongated entire, lower lip in 3 entire nearly equal lobes.-E. B. 787. G. luteum Sm. G. montanum Reich.! -Fl. yellow. St. 12-18 in. high. Lower l. coarsely and even doubly serrate. [-G. luteum Reich.! has the l. all ovate-acuminate and the lower ones simply crenate with a minute apiculus.] -Woods and thickets. P. V. VI.

\section{Leonurus Linn. Motherwort.}

†1. L. Cardiaca (L.); lower 1. palmately 5-fid incise-dentate, upper ones 3-lobed entire wedgeshaped below, tube of the cor. with an oblique ring, helmet nearly flat, lip spreading its middle lobe entire.-E. B. 286. St.9.2.-St. 3 feet high. Cor. hairy externally, purple. Fl. in crowded whorls. Cal.-teeth sharp.Hedges and waste places, rare. P. VIII.

\section{Galeopsis Linn. Hempnettle.}

1. G. ochroleuca (Lam.); st. softly pubescent with deflexed hairs not thickened at joinings, 1. ovate-lanceolate serrate soft and downy on both sides, upper l. ovate, cal. glandular shaggy, upper cor.-lip deeply notched.-E. B. 2353. St.62.5. G. villosa Sm.-Cor. large, pale yellow. St. 10-12 in. high.-Sandy corn-fields, rare. A. VII, VIII. 
2. G. Ladanum (L.) ; st. softly pubescent with deflexed hairs not thickened at joinings, 1 . lanceolate or ovate-lanceolate serrate or nearly entire downy on both sides, cal. shaggy with adpressed hairs and a few gland-tipped hairs intermixed, upper cor.-lip slightly notched.-E. B. 884.-Cor. purple variegated with crimson and white, shaggy externally. St. about a foot high.- $\beta$. G. canescens (Schult.); l. narrow nearly entire, bracts often reflexed at the end, cal. and upper part of st. clothed with patent hairs. - In gravelly and sandy districts. $\beta$. Southampton, on shingles. A. VIII. IX.

3. G. Tetrahit (L.) ; st. hispid thickened at joinings, l. oblongovate acuminate serrate, cal. tubular, cal.-teeth and tube nearly equal, cor.-tube equalling the cal., upper lip ovate.-E.B. 207. St. 62. 6.-Cor.-tube slender, slightly inflated. Fl. purplish, variegated or white. Cal.-teeth as long as their tube, which is shorter but quite as broad and more strongly ribbed than in the next species, rather inflated below the mouth. Nuts wholly green, the oblique top longitudinally marked with veins all springing from the wholly acute inner angle of the nut. L. slightly pubescent above. Fl. large ; middle lobe of lower cor.-lip subquadrate, flat, crenulate, obtuse or slightly emarginate.- $\beta$. G. bifida (Boenn.); middle lobe of lower cor.-lip oblong entire emarginate, margins at length revolute. A more slender plant with paler 1 . and smaller $\mathrm{fl}$. The middle lobe of the lower lip purple with a pale margin, its base with a yellow 2-lobed spot and several minute dots.-Woods and cultivated ground. A. VII.-IX.

4. G. versicolor (Curt.); st. hispid thickened at the joinings, 1 . oblong-ovate acuminate serrate, cal. bellshaped, cal.-teeth shorter than the tube, cor.-tube much exceeding the cal., upper lip roundish-oval.-E. B.667. St.62. 8.- Cor.-tube inflated above. Fl. very large, yellow, usually with a broad purple spot upon the lower lip. Cal.-teeth shorter than their tube. Nuts with the oblique top dark brown, inner angle rounded off almost to the base. Difficult to distinguish upon paper from G. Tetrahit. -Cultivated ground. A. VII. VIII.

\section{Stachys Linn. Woundwort.}

1. S. Betonica (Benth.); spike oblong interrupted below, whorls many-flowered, st. erect, lower l. ovate-oblong with a cordate base crenate obtuse with long stalks, upper l. oblong-lanceolate serrate acute sessile, bracts linear-lanceolate equalling the cal., cal. nearly glabrous, stam. falling short of the lip.Betonica officinalis Sm., E. B. 1142.-Whorls sometimes separated considerably. Cor.-tube exserted. The English plant 
has the subulate-spinous cal.-teeth of B. officinalis (R.); and the round crenate not emarginate lower lip of B. hirta (R.).-Woods and thickets. P. VII. VIII. Betony.

2. S. germanica (L.); whorls many-flowered, st. erect woolly, 1. oblong-ovate or ovate-lanceolate with a cordate base crenateserrate stalked, upper l. lanceolate acute sessile, all densely silky, cal. silky, teeth acute mucronate spinous, bracts equalling the calyx.-E.B.829.-Fl. purple.-Chalky soil in Oxfordshire and Bedfordshire. P. VII. Downy Woundwort.

E.

3. S. sylvatica (L.); whorls 6-8-flowered, st. erect, l. cordateovate serrate with long petioles, floral l. linear entire, cal.-teeth lanceolate very acute, bracts minute.-E. B. 416.-Cal.-teeth rather spinous. Petioles and 1 . nearly equal. Fl. reddish purple. Nuts opaque, punctured and irregularly tubercular. $\mathbf{L}$. clothed with scattered adpressed hairs or densely silky on both sides.-Woods and thickets. P. VII. VIII. Hedge Woundwort.

4. S. palustris (L.); whorls 6-10-flowered, st. erect, l. linearor ovate-lanceolate subcordate below acute crenate-serrate nearly sessile, cal.-teeth lanceolate very acute, bracts minute.-E. $B$. 1675. St. 18. 10.-Cal.-teeth rather spinous. Lower 1 . with very short stalks, uppermost sessile. Fl. dull purple. Nuts shining, very minutely dotted.- $\beta$. S. ambigua (Sm.); 1. stalked ovatelanceolate cordate below serrate. Petioles sometimes half as long as the leaves.-River-sides and damp places. P. VII. VIII. Marsh Woundwort.

5. S. arvensis (L.); whorls 4-6-flowered, st. decumbent or ascending, $l$. ovate-cordate obtuse crenate stalked, floral $l$. ovateoblong sessile acute, cal.-teeth lanceolate-aristate, cor. scarcely exceeding the cal., bracts minute.-E. B. 1154.-Fl. pale purple. Nuts covered with minute dots and scattered tubercles.Corn-fields. A. VIII. IX.

*6. S. annua (L.); whorls 4-6-flowered, st. erect, lower I. ovate-oblong obtuse crenate-serrate stalked, floral l. lanceolate acute, cal.-teeth lanceolate very acute, tube of the cor. exceeding cal., bracts minute.-E. B.S. 2669.-Fl. yellowish. Nuts minutely rough.-Near Gadshill, Kent. A. VIII. IX. E.

\section{Ballota Linn. Horehound.}

1. B. fotida (Lam.) ; l. crenate-serrate, bracts linear-subulate, cal.-tube funnelshaped, cal.-teeth broadly ovate short suddenly acuminate mucronate carinate-reflexed.-E. B. 46. R. I. f. 1041 !. - St. 2-3 feet high. Lower l. cordate; upper ovate. Fl. purple or white. $-\beta$. borealis (R.); cal.-teeth with very short points, 
whole plant including the cor. covered with thick down.-Waste places. $\beta$. St. Vincent's Rocks, Bristol. Mr. Borrer. Bray, Wicklow. Mr.J. Ball. P. VII. VIII.

2. B. ruderalis (Sw.); l. crenate-serrate, bracts linear-subulate, cal.-tube narrow and elongate, cal.-teeth ovate gradually acuminate aristate erect-patent. $-R$. I. f. 1039 !.-St. $2-3$ feet high. Lower 1. cordate; upper ovate. Fl. purple or white.-Waste places, rare. P. VII. VIII.

\section{Marrubium Linn. White Horehound.}

1. M. vulgare (L.); st. erect hoary, 1. ovate and attenuated into a petiole or roundish-cordate crenate hoary rough, whorls many-flowered, cal.-teeth 10 subulate recurved-patent woolly below their upper half glabrous. - E. B. 410 .- St. $1-2$ feet high with many whorls of small flowers. My Scottish specimen has the 1. rather dentate than crenate. $-\beta$. M. apulum (Ten.); 1. roundish-cordate densely woolly.-Waste places, "frequent." P. VIII. IX.

\section{Tribe VIII. Ajugoidea.}

\section{Teucrium Linn. Germander.}

1. T. Scorodonia (L.); st. erect, l. oblong-ovate with the base cordate crenate-serrate green on both sides, racemes lateral and terminal one-sided, floral 1 . ovate acute rather longer than the pedicels, upper cal.-lip undivided ovate, lower 4-toothed, cor.tube exserted.-E.B.1543.-St. 1-2 feet high. L. wrinkled; sometimes oblong, truncate below or subcordate, coarsely and unequally dentate. Fl. yellowish.-Woods and shady places. P. VII. VIII. Wood Sage.

2. T. Scordium (L.); st. procumbent below, $l$. sessile oblong dentate green on both sides, floral $l$. similar, whorls 2 - 6 -flowered axillary distant, cal.-teeth short equal.-E. B. 828.-More or less hairy or woolly. L. attenuated or broad or even cordate below. Fl. purple. - T. scordioides is only a state of this caused by situation. (Phytol. ii. 129.) - Wet places, rare. P. VII. VIII. E. I.

3. T. Chamadrys (L.); st. ascending, l. ovate incise-crenate wedgeshaped and entire below green on both sides, floral 1 . similar smaller nearly entire, whorls racemose 5-flowered, cal.-teeth lanceolate nearly equal.- E. B. 680.-St. much branched, lower part woody. Fl. purplish with darker lines. Lower floral 1. exactly like the stem-1., upper 1. gradually smaller and broader below-Ruined walls and dry banks, rare. P. VII. 
[T. regium (Schreb.) is said to have been found on the Blorenge near Abergavenny. I fear some mistake has occurred.]

4. T. Botrys (L.); st. ascending, l. trifid or pinnatifid green on both sides, segm. oblong entire or cut, flural l. similar, whorls axillary 4-6-flowered, cal. gibbous at base inflated-tubular, cal.teeth lanceolate equal.-Central st. erect; branches ascending. Fl. many, pale purple.-Box Hill, Surrey. A. VIII. IX. E.

\section{Ajuga Linn. Bugle.}

1. A. reptans (L.); fl. whorled, st. solitary with creeping stoles, l. ovate or obovate entire or crenulate stalked, stem-l. sessile.-E. B. 489.-Lower whorls distant, upper ones spicate. Cor.-tube with a ring of hairs within. Fl. blue, rarely white.Wet places. P.V.VI. Common Bugle.

2. A. pyramidalis (L.); fl. whorled, most or all of the whorls spiked, st. solitary without stoles, l. ovate-oblong entire or crenulate, radical 1 . attenuated below, stem-l. sessile upper $l$. exceeding the fl.-E. B. 1270.-Cor.-tube with a ring of hairs within. Fl. bluish-purple. Whorls crowded in a pyramidal and tetragonal form. Plant often hairy. Increasing by offsets from the root.-Highland pastures, very rare, Scotland. South Isles of Arran, Ireland. P. V. VI.

S. I.

3. A. alpina (L.); fl. whorled, whorls distinct, st. solitary "without scions" (Sm.) "stoloniferous" (Fries), l. ovate-lanceolate obtuse dentate-serrate stalked, floral l.3-lobed the uppermost entire.-E. B. 477.-L. all nearly of the same size. Whorls all distant. Cor.-lip 3-lobed; central lobe entire. I have not seen native specimens.-Mountains, very rare. Derbyshire. Cave Hill, Belfast. P. VII.

E. I.

4. A. Chamapitys (Schreb.); fl. solitary axillary, st. much branched spreading, l. deeply trifid, segments linear entire, floral 1. similar exceeding the flowers.-E. B. 77.- Hairy. Lowest 1. much broader and toothed rather than 3-lobed. Fl. yellow with dark spots. St. reddish-purple.-Sandy and chalky fields in Kent, Essex, Surrey. A. V.-VII. Ground Pine. E.

\section{Order IIX. VERBENACE $Æ$.}

Cal. tubular, persistent. Cor. irregular, tubular. Stam. didynamous, or 2. Ovary 2-4-celled; style 1, terminal; stigua bifid. Fr. a caps. or berry, with $2-4$ nucules more or less adliering.

1. Verbena. Cal. 5-fid. Cor. irregular, 5-lobed, slightly 
2-lipped. Stam. included, 4, didynamous, or 2. Capsule dividing into 4 nuts.-G. F. G. Gam. ii. 50.

\section{Verbena Linn. Vervain.}

1. V. officinalis (L.); st. erect solitary 4-angular, l. ovate-oblong trifid or laciniate-multifid rough, spikes filiform somewhat panicled, stam. 4.-E.B. 767. St.3. - St. rather hispid, 1-2 feet high. L. lobed and serrate. Spikes long, slender, with small distant pale purple flowers.-Waste ground. P. VII. VIII.

\section{Order LX. LENTIBULARIACEAE.}

Cal. permanent, inferior, divided. Cor. irregular, 2-lipped, spurred. Stam. 2. Ovary free, 1-celled of 2 carpels. Stigma 2-lipped; lower lip smaller or obsolete. Caps. 1-celled; placenta large, free, central.

1. Pinguicula. Cal. 2-lipped, lower of 1 bifid, upper of 3 segments. Cor. ringent, spurred.-G.F.G. Gam. i. 24.

2. UTRICUlaria. Cal. 2-leaved, lower often notched, upper entire. Cor. personate, spurred.-G. F. G. Gam. i. 25.

\section{Pinguicula Linn. Butterwort.}

1. $P$. vulgaris (L.); spur subulate shorter than the veinless border of cor., cor.-segments very unequal oblong-obovate rounded. separated entire.-E. B. 70.-L. all radical, fleshy, covered with minute crystalline points, pale green; when the plant is gathered they curve backwards so as to hide the root. Fl. purple. Caps. ovate, acute.-Bogs. P. V. VI.

2. $P$. grandiflora (Lam.); spur subulate cylindrical often notched as long as veined border of cor., cor.-segments very unequal broadly obovate rounded contiguous " the middle one of the lower lip notched."-E. B.2184.-Much larger than P. vulgaris. Fl. very large, deep purple. Caps. oval, rounded at the end. Length of spur variable-Bogs. Kerry and Cork. P. V. VI. I.

3. P. alpina (L.); spur conical shorter than unequal border of cor. and curved towards lower lip, caps. acuminate, scape glabrous. - E. B. S. 2747.-Fl. small, yellowish; spur remarkably short and conical.-Bogs. Skye. Black Isle, Ross. P. VI. S.

4. P.lusitanica (L.); spur cylindrical obtuse decurved shorter than the nearly equal limb of the cor., caps. globose, scape downy. $-E$. B. 145.-Fl. small, pale, yellowish, spur short and cylindrical. [P. villos $\alpha$, distinguished from this by its acute spur and 
obconical capsule, may be expected in the north of Scotland.]Bogs in the western parts of the country. P. VI.-IX.

\section{Utricularia Linn. Bladderwort.}

1. U. vulgaris (L.); spur conical deflexed at tip, roundish 3-lobed upper cor.-lip about equalling the bilobed palate, anth. cohering, 1. pinnate-multifid, bladders upon the leaves. $-E . B$. 253.-Fl. bright yellow, rather large. Ped. scarcely 3 times as long as the bract, patent with fruit. Scape $4-6$ in. high. St. floating in the water.- $[U$. neglecta (Lem.); spur adpressed more slender, ovate-oblong blunt or emarginate upper cor.-lip nearly 3 times as long as the subrotund palate, anth. free, ped. 4-5 times as long as the bract erect with fr., l. more distant, bladders on both stem and leaves; is apparently a native of the Fen country.] P. VI.-VIII. Greater Bladderwort.

2. U. intermedia (Hayne); spur conical adpressed, upper lip twice as long as the inflated palate, 1. 3-parted, segments linear dichotomous, bladders separate from the leaves.-E. B. 2489.Fl. paler with a much longer upper lip than in No. 1. Bladders on leafless shoots. Increasing by buds at the end of the shoots and seldom flowering.-Ditches and pits, rare. P. VIII.

3. U. minor (L.); spur very short obtuse, upper lip equalling the palate, lower lip ovate with reflexed sides, l. dichotomously multifid, bladders upon the leaves.-E. B. 254.-Scarcely any spur. Fl. small. Sep. subrotund, acuminate. Plant much smaller than either of the others. [U. Bremii (Heer); a rather stronger plant with an "orbicular flat lower lip and subrotund subreniform minutely apiculate sep.;" is probably a native.] Ditches and pits. P. VI.-VIII. Smaller Bladderwort.

\section{Order LXI. PRIMULACEA.}

Cal. 4-7-cleft, permanent, inferior. Cor. regular, 4-7-fid. Stam. upon the cor., opposite to its segments. Ovary free, 1celled, with a free central placenta. Style 1. Stigma capitate. Fr. a capsule. Seeds peltate; embryo transverse in fleshy albumen.-For fig. of genera see G. F. G. Gam. i.

1. Primula. Cal. tubular, 5-fid. Cor. salvershaped, tube cylindrical up to the insertion of the stamens. Stam. 5, inserted and included in the tube of the cor. Caps. manyseeded, 5 -valved with 10 teeth.

2. Hotronia. Cal. 5-parted, divided almost to its base. Valves of caps. remaining connected at the top. Seeds with the hilum close to one end. Otherwise like Primula. 
3. Cyclamen. Cal. bellshaped, half 5-cleft. Cor. with a short bellshaped tube and 5-partite reflexed limb. Stam. 5, inserted at the bottom on the tube of the cor., included. Caps. many-seeded, opening with 5 teeth.

4. Lysimachia. Cal. 5-parted. Cor. rotate, scarcely any tube, limb 5-parted. Stam. 5, at the base of the cor. Caps. with 5 valves (in $L$. nemorum sometimes 2 -valved or indehiscent, in L. thyrsiflor a few-seeded).

5. Avagallis. Cal. 5-parted. Cor. rotate, tube none, limb 5-parted. Stam. 5, at the base of the cor. Caps. manyseeded, opening all round transversely.

6. Centunculus. Cal. 4-5-parted. Cor. with a subglohose inflated tube and spreading 4-5-parted limb. Stam. 4 or 5 , inserted in the throat of the cor. Caps. manyseetled, opening all round transversely.-Fl. usually 4parted.

7. Trientalis. Cal.7-parted. Cor. rotate, 7-parted, tube none. Stam. 7, inserted at the base of the cor. Caps. manyseeded, opening with 5 revolute fugacious valves. Seeds invested with a reticulated tunic.

8. Glaux. Cal. bellshaped, 5-parted, coloured. Cor. none. Stam. 5, inserted at the base of the calyx. Caps. few-seeded (about 10), opening with 5 valves.

9. Samolus. Cal.5-parted, its tube adhering to the lower half of the germen, persistent. Cor. salvershaped, tube short, limb 5-parted with interposed converging scales. Stam. 5, inserted near to the base of the tube of the cor. Caps. $\frac{1}{2}$ inferior, many-seeded, opening with reflexed teeth.

\section{Primula Linn. Primrose.}

I. P.vulgaris (Huds.); $l$. oblong-ovate wrinkled crenate, ped. obsolete, pedicels villose sessile single-flowered, cal. tubular, teeth linear-lanceolate attenuate very acute, cor.-limb flat with a circle of scalelike folds at the slightly contracted mouth, caps. ovate $\frac{1}{2}$ the length of cal., long straightish teeth of fr.-cal. meeting at top.-E. B. 4. St. 14.6. P. acaulis Jacq.-L. narrowing gradually downwards. Fl. erect. Cal. villose.- $\beta$. caulescens; 1. slightly contracted below, ped. umbellate, fl. erect. Often taken for P. elatior. - Woods and thickets. P. IV. V. Primrose.

2. P. veris (L.); l. ovate abruptly contracted below then attenuate wrinkled crenate, ped. tomentose umbellate manyflowered, cal. bellshaped, teeth short ovate, cor.-limb concave with a circle of scalelike folds at the slightly contracted mouth, 
caps. elliptical $\frac{1}{2}$ the length of inflated cal., short teeth of fr.cal. converging. - E. B. 5. St. 14. 4. P. officinalis Jacq.-Cal. tomentose. Cal. teeth $\frac{\mathrm{r}}{3}$ of the length of the tube, obtuse or slightly acute. Cor.-segments cordate.-Probably hybrids are formed between this and $P$. vulgaris, which are mistaken for $P$. elatior.-Meadows and pastures. P. IV. V. Cowslip. Paigle.

3. P. elatior (Jacq.) ; l. ovate abruptly contracted below then attenuate wrinkled denticulate, ped. umbellate many-flowered, cal. tubular, teeth lanceolate acute, cor.-limb concave, segments obcordate-oblong, tube not crowned nor contracted at the mouth, caps. linear-oblong equalling cal., teeth of fr.-cal. patent.-E. B. 513. St. 14. 5.- Segments of the corolla almost square. Cor.limb rarely flat. Outer fi. nodding. Fr. erect.-Woods and meadows in the eastern counties. P. IV. V. Oxlip. E.

4. P. farinosa (L.) ; $l$. obovate-lanceolate mealy, cal. oblongovate, teeth linear, limb. of cor. flat, segments obcordate rounded below distant as long as the tube--E.B.6. St. 14.-Umbellate. Fl. pale lilac with a yellow centre; but the colour and breadth of segments very variable. Germen obovate. Stigma capitate. Rarely the ped. is obsolete and the fl. amongst the leaves.North of England and south of Scotland. P. VI. VII. Bird'seye Primrose.

E. S.

5. P. scotica (Hook.); $l$. obovate-lanceolate mealy, cal. swollen, teeth short ovate obtuse, limb of cor. flat, segments broadly obcordate approximate half the length of the tube.-E. B.S. 2608. - Half as large as the preceding. Umbellate. Fl. bluish-purple with a yellow centre. Germen globose. Stigma with 5 points. -Sandy heaths of the extreme north of Scotland. P. VII. S.

\section{2. Ноттомr Linn. Water-violet.}

1. H. palustris (L.); fi. whorled stalked upon a long solitary cylindrical stalk, cor. exceeding the calyx, l. pectinate.-E. $B$. 364.-L. submerged, crowded. Fl. rising above the water, purple and yellow. Style exceeding the cal., stam. inserted in tube, anth. and filaments about equal in length; or style falling short of cal., stam. inserted at top of tube, filaments 3 or 4 times as long as the anthers. The former of the varieties is apparently barren.-Ponds and ditches. P. V. VI. E. I.

\section{Cyclamen Linn. Sow-bread.}

1. C. hederifolium (Ait.) ; l. cordate-ovate angular denticulate, cor.-throat 5-angled, sep. ovate acuminate denticulate. $-R$. xvii. 1538. C. europaum Sm., E. B. 548.-St. a large depressed tuber. L. after the fl., with wavy white blotches above. Fl. 
more or less pink with darker spots, 2-horned spots at the mouth. Fr.-ped. rolled up spirally.-Woods near the borders of East Sussex and Kent! Mr.W.W. Saunders. P. VIII.

E.

\section{Lysimachia Linn. Loose-strife.}

1. L. thyrsiflora (L.); racemes axillary stalked dense, 1. opposite lanceolate.-E. B. 176.-St. 1-2 ft. high. Fl. small, very many. Cor. divided almost to its base into narrow segments separated by minute teeth, yellow and as well as the cal. spotted with orange. Stam. combined below into a short ring.-Marshes in the north. P. VI. VII.

E. S.

2. L. vulgaris (L.); st. erect, panicles compound terminal and axillary, $l$. ovate or ovate-lanceolate nearly sessile opposite or 3 or 4 in a whorl, cor.-segments entire with glabrous edges, stam. 5 combined through half their length.-E. B. 761.-St. $2-3$ feet high. L. variable in size, shape and pubescence. Panicle much branched or nearly simple.-Sides of rivers and pools. P. VII.

[L. punctata (L.); st. erect, ped. axillary opposite or whorled 1-fl., l. ovate-lanceolate slightly stalked opposite or whorled, upper 1. narrower, cor.-segm. orate glandular-ciliate, stam. 5 combined through half their length. - L. westphalica Gardn.

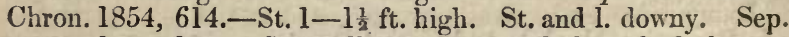
narrow-lanceolate. Cor. yellow. Pet. rarely branched, downy, falling short of leaves.-Dulverton, Devon! P. VI. VII.]

*3. L. ciliata (L.); st. erect, ped. axillary opposite or whorled racemose, $l$. opposite or 4 in a few of the uppermost whorls ovatelanceolate subcordate with ciliated stalks, cor.-segments roundish crenate obtuse cuspidate, filaments 10 free 5 sterile.-E. B. S. 292\%. - Fl. yellow. Ped. nodding at the end. St. 3 feet high? - Near Serbergham, Cumb. Mr.W. Backhouse. P. VII. E.

4. L. Nummularia (L.); st. prostrate creeping, fl. solitary axillary, sep. ovate acute, filaments glandular connected at the base, 1. opposite roundish or ovate shortly stalked.-E. B. 528. - Peduncles shorter than the leaves. Fl. occasionally in pairs. -Damp places. P. VI. VII. Moneywort.

- 5. L. nemorum (L.); st. prostrate, fl. axillary solitary, sep. linear-lanceolate, filaments smooth distinct, l. opposite ovate acute shortly stalked.-E. B. 527.-Peduncles longer than the 1. Caps. 5-valved but usually dividing longitudinally into 2 parts, sometimes indehiscent. Stam. distinct.-Woods and damp shady places. P. VI.-VIII.

\section{Anagallis Linn. Pimpernel.}

1. A. arvensis (L.); st. procumbent or erect, fl. axillary soli- 
tary, 1. opposite sessile ovate or ovate-oblong.-Cor. rotate. Pet. slightly exceeding the cal., crenate. Filaments distinct.- $a . A$. arvensis (Sm.); st. mostly procumbent, pet. fringed with minute glandular hairs (usually scarlet), l. ovate. E. B.529. Fl. sometimes flesh-coloured ( $A$. carnea Schrank), wholly white or white with a pink eye.- $\beta$. A. carulea (Sm.); st. mostly erect, pet. without glandular hairs (usually blue), 1. ovate-oblong. $E$. $B$. 1823.-Probably distinct; Mr. Borrer suspects that each varies with red or blue flowers.-Corn-fields. A. VI. VII. Scarlet Pimpernel.

2. A. tenella (L.); st. procumbent rooting, fl. axillary solitary, 1. opposite stalked roundish, cor. funnelshaped, pet. much exceeding the calyx entire, filaments connected below.-E. B. 530 . -Ped. long. Fl. rather large, rose-coloured. L. nearly sessile. -Spongy bogs. P. VII. VIII. Bog Pimpernel.

\section{Centunculus Linn. Bastard Pimpernel.}

1. C. minimus (L.) ; 1. alternate ovate acute, fl. nearly sessile, cor. without glands at the base.-E. B. 531.-Usually very minute. St. usually prostrate. Cor. very small, pale rose-colour. -Damp sandy and gravelly places. A. VI. VII.

\section{Trientalis Linn.}

1. T. europea (L.); 1. oblong-obovate obtuse.-E. B. 15.St. 4-6 in. high, with the l. mostly collected at the top. Fl. on slender peduncles, white with a yellow ring. Parts of the fl. and fr. varying from 7 to 9 in each whorl. Valves of the caps. soon falling off.-North of E.; Highlands of S. P. VI. E. S.

\section{Glaux Linn. Black Saltwort.}

1. G. maritima (L.).-E. B. 13.-St. mostly procumbent. L. opposite, ovate, glabrous. Fl. axillary, sessile, pink, with blunt segments. Remarkable in this order by its want of petals. -Sea-shores and salt marshes. P. VI.-VIII.

\section{Samolus Linn. Brook-weed.}

1. S. Valerandi (L.); l. obovate or roundish blunt, upper 1 . blunt with a point, racemes many-flowered ultimately elongated, caps. subglobose.-E. B. 703.-Remarkable in this order by its cal. adhering to the germen and by having a crown to the corolla. -Damp watery places. P. VII. VIII. 


\section{Order LXII. PLUMBAGINACEA.}

Cal. 5-cleft, persistent, inferior, plicate. Cor. regular, 5-fid or nearly 5-petalous. Stam. 5, hypogynous, or aanate to the base of the pet. Ovary free, of 5 carpels, 1-celled, 1-seeded; ovule 1, pendulous by a stalk arising from the bottom of the cell. Styles 5. Fr. a utricle. Seed inverted. Embryo in the axis of farinaceous albumen. Radicle superior.

1. Statice. Fl. spiked. Cal. scarious above. Cor.5-parted. Caps. not bursting.-G. F. G. Gam. i. 4.

2. Armeria. Fl. in a head with an inverted cylindrical sheath. Caps. not bursting.-G. F. G. Gam. i. 3.

\section{Statice Linn. Sea-Lavender.}

1. S. Limonium (L.); l. elliptic-oblong stalked mucronate 1-ribbed strongly veined, scape subterete branched above corymbose, spikelets 1-3-flowered ascending forming dense 2-ranked patent or recurved spikes, cal.-segments entire acute with intermediate teeth, outer bract pointed rounded on the back.-E. B. 102. $R$. xvii. 1111.-Scape usually not branched in its lower half, often not until near the corymbose top. Spikes short; spikelets densely imbricate.-Muddy salt marshes. P. VII.IX.

2. S. Bahusiensis (Fries); 1. oblong-lanceolate stalked mucronate 1-ribbed faintly veined, scape slightly angular usually branched from below the middle panicled, spikelets 1 -3-flowered unilateral rather distant forming lax erect or incurved spikes, cal.segments acute denticulate with intermediate teeth, outer bract pointed keeled on the back. $-R$. xvii. 111l. S. ruriflora Drej., E. B. S. 2917.- Scape not corymbose, much branched below. Spikes long; spikelets often I-flowered, not imbricate.-Salt marshes. P. VII. VIII.

3. S. Dodartii (Gir.); 1. obovate-spathulate narrowed into a broadly winged stalk 3 -ribbed below, scapes rigid alternately branched, no sterile branches, spikelets 2-4-flowered densely imbricate 2-ranked forming linear thick suberect spikes, cal.segments blunt entire without intermediate teeth.- Scape usually not branched in its lower half; branches often simple, short. Bracts with white margins or slightly pink. Anth. oblong. -Rocky shores. P. VII. VIII. E. I.

4. S. occidentalis (Lloyd); l. lanceolate-spathulate rather acute narrowed into a long winged stalk obscurely 3 -ribbed below, scapes slender wavy dichotomously brancher from near the base, few lowest branches sterile, spikelets 2-4-flowered imbricate 2- 
ranked forming linear slender suberect spikes, cal.-segments blunt entire without intermediate teeth.-S. binervosa G. E. Sm., E. B. S. 2663.-Scape usually branching quite from the base; branches repeatedly forked, elongate. Bracts deeply' tinged with pink. Anth. oval.-Rocky shores. P. VII. VIII. E. S.

5. S. caspia (Willd.); 1. obovate or lanceolate spathulate narrowed into a petiole, scapes branched from near the base granularscabrous, branches many slender repeatedly and acutely forked uppermost alone bearing dense terminal spikes of $2-3$-flowered 2 -ranked spikelets, cal.-segments ovate-cuspidate denticulate- S. reticulata Sm., E. B. 328.- Remarkable by its much divided sterile branches which fork at an acute angle. L. small.-Muddy sea-shores of Norf. and Suff. P. VII. VIII.

\section{Armeria Willd. Thrift.}

1. A. maritima (Willd.); l. linear l-veined, scape downy, inv.bracts very obtuse $1-3$ outer ones mucronate, cal.-segments acute, cal.-tube hairy or pilose-striate.-L. all radical, many, narrow. Fl. rose-coloured or white.-a. A. maritima (Boiss.); 1. flattish above, inv.-scales broadly green on the back outer ones ovate-mucronate, cal.-tube uniformly hairy equalling the primary pedicel. R. xvii. 1148.- $\beta$. A. pubescens (Link); l. flattish above, inv.-scales broadly green on the back outer ones triangular-ovate acute, cal.-tube hairy on the ribs otherwise glabrous equalling the primary pedicel. Statice Armeria Sm., E. B. 226. Pedicels shorter in the mountain plant. $-\gamma$. A. pubigera $\beta$. scotica (Boiss.) ; l. subtriquetrous channeled and dotter above, inv.-scales scarious a little thickened on the back, cal.tube uniformly hairy twice as long as the primary pedicel.$\delta$. A. duriuscula (Bab.); l. subtriquetrous channeled above, inv.scales broadly green on the back, cal.-tube only hairy on the ribs equalling the primary pedicel.-Muddy and rocky seashores. $\delta$. rare. $\beta$. also on mountains. P. IV.-IX.

[2. A. plantaginea (Willd.); l. all similar 3-5-veined linearlanceolate with a narrow membranous margin, scapes glabrous rough, outer inv.-bracts triangular or lanceolate cuspidate others ovate or obovate with a broad membranous margin obtuse, pedicel not $\frac{1}{2}$ as long as the pilose-striate cal.-tube.-E. B. S. 2928.Distinguished by its leaves.-Jersey. P. VI. VII.]

\section{Order LXIII. PIAANTAGINACEA.}

Cal. 4-parted, persistent, imbricate, inferior. Cor. 4-parted, regular, scarious. Stam. 4, hypogynous, or at the base of the tube, alternate with the segments of the cor.; filaments at first 
doubled inwards. Ovary free, of 1 carpel, 1-celled, or with a central compressed 2-4-winged placenta and thus 2-4-celled. Ovules 1 or 2. Style 1. Caps. opening transversely. Seeds peltate or erect. Radicle inferior.-G. F. G. Gam. i. 1 and 2.

1. Plantago. Fl. perfect. Cal. 4-cleft. Cor. with an ovate tube and 4-parted reflexed limb. Stam. on the corolla. Caps. bursting transversely, 2-4-celled, 2-4-seeded.

2. Littorella. Monœcious. Male fl. stalked; sep. 4; tube of the cor. cylindrical, limb 4-parted; stam. hypogynous; filaments very long. Fem. fl. sessile ; sep. 3; cor. oblong, narrowed at both ends; style long; caps. 1 -seeded.

\section{Plantago Linn. Plantain.}

\section{* Placenta 3-4-winged, thus forming 3-4 cells. Seeds 1 in each cell.}

1. P. Coronopus (L.); l. linear pinnatifid or dentate, scape round, spike slender, bracts subulate from an ovate base erect, midrib of lateral sep. with a ciliated membranous wing.-E.B.892. -Tube of the cor. glabrous. Extremely variable in size and amount of pubescence, woolly or nearly glabrous. L. varying in width, nearly entire, or even doubly pinnatifid. Spikes slencler, $1 \frac{1}{2}$ in. long, many-flowered; or spherical with $2-6$ flowers.Gravelly barren spots near the sea and inland. A. ? VI. VII. Buck's-horn Plantain.

** Placenta 2-winged. Seeds 1 in each cell. Cor.-tube pubescent.

2. P. maritima (L.); l. linear channeled fleshy convex on the back, scape round, spike cylindrical, bracts ovate mucronate, sep. not winged. $-E$. B. 175. St. 88. 4.- L. usually woolly at their base, nearly flat and broad or linear, toothed or quite entire, glabrous or hairy; 3-veined, veins equidistant. Scape glabrous or hairy. Caps. oblong-conical. Very variable in size. In a Cornish variety the 1 . are only $1-2$ lines in length and semicylindrical, scapes very short, spikes sometimes only 3 - or 4flowered. - The mountain plant is apparently P. serpentina (Vill.); its caps. is ovoid and blunt, bracts lanceolate acute perhaps not keeled, l. not channeled. It is probably a distinct species. - Seacoast and on mountains. P. VI.-IX.

*** Placenta 2-winged. Seeds 1 in each cell. Cor.-tube glabrous.

3. P. lanceolata (L.); l. lanceolate attenuated at both ends 5-veined, scape furrowed, spike ovate or oblong-cylindrical, 
bracts ovate acute or cuspidate, 2 lateral sep. keeled.-E. B. 507. -L. nearly glabrous, lanceolate, length 4-12 times the breadth. Anth. and filaments yellow. A very variable plant. Spikes globose, scape and l. silky, neck woolly, in sandy places; spikes very long, l. very long and broad, in rich damp soil.-Neadows, pastures and sandy places. P. VI. VII. Ribwort.

4. P. media (L.); $l$. elliptical sessile or with short broad stalks pubescent, scape round, spike cylindrical, bracts ovateacuminate, sep. not keeled.-E. B. 1559. St. 87. 8.-L. usually lying flat on the ground, sometimes shortly lanceolate and ascending. Anth. yellow, filaments purple.-Meadows and pastures. P. VI.-IX.

**** Placenta 2-winged. Seeds $2-4$ in each cell. Cor.-tube
glabrous.

5. P. major (L.); l. broadly ovate on longish channeled stalks, scape round, spike long, bracts ovate-obtuse keeled about as long as the cal., sep. with a prominent dorsal rib.-E. B. 1558. St. 87. 6. R. xvii. 1127.-L. ascending. Anth. purple. Seeds about 8.- $\beta$. microstachya (Koch); scape weak shorter than l., spike lax, 3-6-flowered.-Fields and waste places. $\beta$. Turfbogs, Cunnamara, Ireland. P. VI.-VIII.

\section{Littorella Linn. Shore-weed.}

1. L. lacustris (L.).-E. B. 468.-Fl. white. Fertile fl. sessile. Stalks of the male fl. $1-2$ in. long. L. all radical, linear, fleshy, somewhat channeled.-Margins of lakes. P. VI. VII.

\section{Subdivision IV. MONOCHLAMYDEસ.}

With only a single perianth, that is the cal. and cor. not distinguishable, or wanting.

\section{[Order LXIV. AMARANTHACEF.}

Perianth 3-5-parted, scarious, persistent. Stam. hypogynous. Ovary free, 1-celled; ovule 1 or several, suspended from a free central seed-stalk. Style l or (). Stigma simple or compound. Embryo curved round central farinaceous albumen.-L. without stipules or sheaths.-G. F. G. Monochl. 71.

1. Amaranthus. Fl. monœcious. Perianth 3-5-parted. Stam. 3-5. Styles 3. Caps 1-celled, l-seeded, bursting transversely.] 


\section{Amaranthus Linn.}

[1. A. Blitum (L.) ; fl. 3-fid 3-androus, clusters small lateral the upper ones in a small naked spike, st. diffuse glabrous.E. B. 2212.-Waste places near towns. A. VIII.] E.

\section{Order LXV. CHENOPODIACEE.}

Perianth 5-parted, persistent. Stam. from the base of the perianth. Ovary free or cohering with the tube of the perianth ; ovule 1, attached to the base of the cell. Styles divided, or rarely 1. Fr. not bursting, dry, membranous, included in the perianth which often becomes enlarged or fleshy. Embryo curved round farinaceous albumen, or spiral, or doubled together without albumen; radicle next the hilum.- L. without stipules or sheaths.-For figures of the genera see G. F. G. Monochl.

Tribe I. SALSOLEAE. Fl. uniform, perfect. Seeds without albumen. Embryo spiral. St. continuous. L. semicylindrical or terete.

1. SUæDA. Perianth 5-parted, without appendages. Stam. 5 , from the receptacle. Stigmas $2-3$. Pericarp membranous. Seed horizontal or vertical; testa crustaceous.-Bracteated.

2. SALsola. Perianth 5-parted, segments ultimately with a transverse dorsal appendage. Stam. 5, from an hypogynous ring. Styles 2. Pericarp membranous. Seed horizontal; testa membranous.-Bracteated.

Tr. II. BETEAE. Fl. uniform, perfect. Seeds with albumen. Embryo curved round the circumference of the seed. St. continuous. L. flat.

3. Chenopodium. Perianth 3-5-parted, persistent, unaltered. Stam. 5, from the receptacle. Stigmas 2-3. Pericarp thin, free. Testa crustaceous. Seed vertical or horizontal.-Without bracts.

4. Beta. Perianth 5-parted, persistent. Stam. 5, from a fleshy ring. Styles 2-3. Pericarp immersed and adhering to the tube of the perianth. Seed horizontal, attached laterally. Testa membranous.

Tr. III. SALICORNIEAE. Fl. uniform, perfect. Seeds and embryo as in Tr. II. St. jointed.

5. Salicornia. Perianth fleshy, tumid, undivided, imbedded in an excavation of the rachis. Stam. 1-2. Style very 
short, stigma bifid. Pericarp membranous. Seed vertical, covered by the persistent perianth.

Tr. IV. ATRIPLICEAE. Fl. monœcious, of two forms, rarely perfect. Seeds and embryo as in Tr. II. St. continuous.

6. Atriplex. Perianth 3-5-parted. Stam. 5. Style 0.Perigone compressed, of 2 more or less connected parts. Stigmas 2. Pericarp membranous, free. Testa crustaceous. Seed vertical, attacher by a lateral hilum either near the base or by means of a long seed-stalk in the middle of the side; radicle basal.

7. Oвrone. Perianth 3-5-parted. Stam. 5. Style 0.Perigone of 2 parts connected to their extremity, 3-toothed, wedgeshaped below. Stigmas 2. Pericarp very thin, ultimately adhering to the tube of the perigone. Testa membranous. Seed vertical, pendulous from a long seed-stalk; radicle terminal.

\section{Tribe I. Salsolea.}

1. Su

1. S. fruticosa (Forsk.); st. erect shrubby, l. obtuse semicylindrical, styles 3 , seeds smooth and shining.-E. B. 635. Salsola Sm. Schoberia Mey.-St. 2-3 feet high, with many erect leafy branches and axillary flowers. Seed horizontal.On the south and east coasts, rare. P. VII. VIII.

2. S. maritima (Dum.); st. herbaceous, $l$. acute semicylindrical, styles 2 , seeds reticulate-striate shining. $-E$. B. 633.-Chenopodium Sm. - St. erect or procumbent with many spreading branches. Seed horizontal.-Sea-shore. A. VII.-IX.

\section{Salsola Linn. Saltwort.}

1. S. Kali (L.) ; minutely hairy, st. diffuse, 1. subulate spinous rough, $f$. axillary solitary, segments of the enlarged perianth cartilaginous as long as their patent rather coloured roundish wings.-E. B. $634 .-$ St. angular, rigid, much branched.-Sandy sea-shores. A. VIII.

\section{Tribe II. Betea.}

3. Chenopodium Linn. Goose-foot.

* Perianth covering the fruit; seed horizontal.

$\uparrow$ Leaves undivided.

1. C. olidum (Curt.); l. ovate-rhomboidal entire mealy, fl. in 
leafless dense spikes, seed shining slightly rough (very small), st. diffuse.-E. B. 1034. St. 75. 14.-L. stalked. Whole herbage covered with a greasy pulverulent fetid substance.-Waste places by road-sides. A. VIII. IX.

2. C. polyspermum (L.); l. ovate-elliptical, fl. in axillary leafless cymose racemes, seeds shining minutely punctulate blunt at the edge.-E.B. 1480 and 1481. Leight.t. 5. St.75. 12 and 13. - Racemes more or less cymose or spicate. St. erect or procumbent. L. acute or obtuse. C. acutifolium and C. polyspermum are undistinguishable.-Damp waste places. A. VIII. IX.

† Leaves toothed angled or lobed.

3. C. urbicum (L.); l. triangular sinuate-dentate or nearly entire their base contracted into the petiole, spikes erect nearly leafless compound, seeds very minutely rough blunt at the edge. -L. with short triangular teeth. Spikes approaching the stem. Seed almost as large as Rape-seed.- $\beta$. C. intermedium (M. and K.); l. with large acute teeth. E. B. 717.-Near Oxford. Sm. $\mathrm{Fl}$. Br. $\beta$. Waste places. A. VIII.

4. C. album (L.); 1. rhomboid-ovate sinuate-dentate entire below, upper ones lanceolate nearly entire, fl. in compound branched nearly leafless racemes, seeds smooth and shining blunt but keeled at the edge.-E. B. 1723. St.75.6.-Axillary racemes spicate dense, 1. mealy. $-\beta$. C. viride (L.); racemes cymose, 1. green often quite entire. St. 75. 7.-Waste places. A. VII. VIII.

5. C. ficifolium (Sm.); l.unequally 3-lobed from a wedgeshaped base, lobes ascending, middle lobe elongate oblong-lanceolate dentate obtuse, upper l. linear-lanceolate entire, fl. in erect nearly leafless cymose racemes, seeds excavate-punctate shining blunt and not keeled at the edge.-E. B. 1724. St. 75. 10.-Mealy. L. blunt ; middle lobe nearly equally broad throughout. Seeds smaller than in C. album.- Waste ground, rare. A. VIII. IX.

6. C. murale (L.); l. rhomboid-ovate unequally and osharply toothed entire below, $\mathrm{fl}$. in divaricately-branched leafless cymes, seeds elevate-punctate opaque acute and keeled at the edge.-E.B. 1722. St. 75. 5.-Waste ground near towns and villages. A. VIII.

7. C. hybridum (L.); l. subcordate angulate-dentate acuminate, teeth large distant, $\mathrm{A}$. in aggregated panicled leafless cymes, seeds excavate-punctate opaque blunt and not keeled at the edge.E. B. 1919. St. 75. 2.- Seeds very large. L. with 2-4 large teeth on each side.-Waste places, rare.

A. VIII. 
** Perianth not covering the fruit; seed mostly vertical.

\section{$\dagger$ Stigmas short.}

8. ' rubrum (L.) ; l. rhomboid irregularly toothed and sinuate tire below, fl. in erect compound dense leafy spikes, seeds very minute smooth shining blunt and slightly keeled at the edge. -E. B. 1721.-St. erect, often a foot high. Pericarp very loose. Seed vertical, or horizontal in the terminal fl. Fl. generally incomplete. Cal. 4- rarely 5-cleft. Stam. 1 or 2. Mr. Leighton has sent a variety with much more triangular l., shorter spikes and larger seeds, grown from seed obtained near London.Waste places, particularly salt marshes. A. VIII. IX.

9. C. botryoides ( $\mathrm{Sm}$.); l. triangular somewhat toothed, $\mathrm{fl}$. in compound dense leafy spikes, seeds very minute smooth shining acutely keeled at the edge.-E.B. 2247.-St. prostrate, spreading, 4-5 in. long. Pericarp loose. Seeds vertical.-Moist sandy places near the sea. Cornw., Suff., Northumb. A. IX.

10. C.glaucum (L.); l. oblong sinuate-dentate, fl. in erect nearly simple leafless spikes, seeds very minute reticulate-rugose acutely keeled at the edge.-E. B. 1454 ? (C. botryoides?) St. 75. 1.St. spreading, often prostrate. Seeds reddish, vertical or horizontal. - Waste sandy soil. A. IX.

\section{†† Stigmas long.}

11. C. Bonus-Henricus (L.); l. triangular-hastate entire, fl. in compound leafless spikes, seeds smooth and shining.-E. $B$. 1033. St. 74. 13.-St. a foot high. L. large, dark green, used instead of Spinage.--Waste places near villages. P. V.-VIII.

\section{Beta Linn. Beet.}

1. B. maritima (L.); st. many from the crown of the root prostrate, l. triangular-ovate narrowed into a petiole, spikes long simple leafy, bracts lanceolate exceeding the 2-3-flowered clusters, segments of the perianth with entire keels.-E. B. 285 . B. vulgaris (H. and A.), but the weight of evidence is against their identity.-Root thick, fleshy. St. 6-12 in. long, prostrate below, spreading in a circle, afterwards ascending.--Sea-shore. P. VII.-IX.

\section{Tribe III. Salicorniea.}

\section{Salicornia Linn. ${ }^{1}$ Glasswort.}

1. S. herbacea (L.); herbaceous, joints of st. compressed

1 See a paper on this genus by Mr. Woods in Proc. Linn. Soc. iii. 111. 
rather thickened upwards notched, spikes cylindrical tapering stalked, fl. 3 on each side middle fl. placed highest, seed oval or oblong.-E. B. 415.-St. usually erect, branched, 3-12 in. high. Fl. placed in triangles. Stam. 1 or 2.- $\beta$. S. procumbens (Sm.) ; st. procumbent. E. B. 2475.-Muddy sea-shores. A. VIII. IX.

2. S. radicans (Sm.); joints of st. compressed deeply notched scarcely thickened, spikes oblong obtuse nearly sessile, middle fl. scarcely higher than the others, seed nearly globular.-E. B. 1691. S. fruticosa Sm. (not L.), E. B. 2467.-St. procumbent or ascending, rooting.-Muddy sea-shores. P. VIII. IX. E. I.

\section{Tribe IV. Atriplicea.}

\section{Atriplex Linn. ${ }^{1}$ Orache.}

A. Polygamous; sep. of fem. fl. distinct, seed vertical; perfect fl. 3-5-parted, seed horizontal.

[*1. A. nitens (Rebent.); st. erect, 1. triangular-cordate-hastate sinuate-dentate shining above glaucous beneath, upper l. elongatetriangular, fr.-perigone ovate-acuminate entire separate to the base.-A large coarse plant introduced by accident. Sea-shore near Ryde, Isle of Wight. A. VIII. IX.]

B. Monccious; sepals of fem. fl. united below.

* Stem with resinous stripes. - + Leaves not lobed.

2. A. littoralis (L.); st. erect, $l$. linear-lanceolate entire or rarely toothed, fr.-perigone ovate-rhomboid acute toothed tubercled on the back with spreading points.-E.B.708. St.79. 12. -Distinguished by the form of its open-pointed perigone, and 1. usually entire.-Salt marshes. A. VII.-IX.

3. A. marina (L.) ; st. erect, $l$. oblong-lanceolate irregularly toothed or rarely entire, fr.-perigone obcordate-triangular obtuse toothed tubercled on the back with adpressed points.-St. 80. 1 . -Distinguished by its toothed 1. and form of perigone.- Salt marshes. A. VII.-IX.

+† Lower leaves with lateral spreading or ascending lobes.

4. A. angustifolia (Sm.!); st. erect or prostrate, 1. lanceolate entire from a wedgeshaped base, the lower l. with 2 ascending lobes, fr.-perigone rhomboidal acute entire with prolonged lateral

1 See Woods in Phytol. iii. 587, and Tourist's Flora, 315. 
angles longer than the fr. and collected into nearly simple interrupted spikes the larger leaflike and not tubercled, seeds black and polished.-E. B. 1774. A. patula Wahl., Koch, St. 79.5. -Spikes wandlike with distant clusters of fl., valves of the fr. perigone netted.-Common. A. VII.-X.

5. A. erecta (Huds.) ; primary st. mostly erect, lower 1 . ovateoblong with 2 ascending lobes from a wedgeshaped base irregularly sinuate-dentate, upper 1 . lanceulate, fr.-perigone rhomboidal denticulate acute more or less muricated on the back scarcely exceeding the fr. and collected in branched dense many-flowered spikes, seeds black and polished.-E.B.2223! Koch in St.79.6. -Branches ascending or prostrate. Upper l. mostly entire.Common upon cultivated land. A. VII.-X.

6. A. deltoidea (Bab.); st. mostly erect, l. mostly opposite nearly all hastate-triangular with spreading lobes, fr-perigone ovate-triangular muricated on the back scarcely exceeding the fr. united only at the base, fr. panicled in dense spikes, seeds thick black and polished, or a few dark brown and larger and with large perigones.- a. A. deltoidea (Bab.) ; 1. all hastate-triangular toothed, fr.-perigone toothed muricated on back, spikes dense. E. B. S. 2860.-[ [ . A. microspermu (W. and K.) ; l. often alternate, upper l. subulate-hastate entire, fr.-perigone entire its back rough. $P l$. Hung. rar. t. 250 . A. ruderalis St. 79. 8.-] $\gamma . A$. triangularis (Willd.); st. and branches prostrate, l. often alternate, uppermost 1 . lanceolate entire, fr.-perigone slightly toothed or entire. A. prostrata Bab.-Cultivated and waste ground. $\gamma$. Sea-coast. A. VI. -X.

7. A. hastata (L.); st. mostly erect, lower l. hastate-triangular with spreading lobes, uppermost l. lanceolate entire, fr.-perigone triangular-rhomboidal slightly muricated on the back exceeding the fr. united only at base, fr. in nearly simple interrupted spikes, larger seeds dark brown shagreened compressed, smaller black and shining.-A. patula Sm., E. B. 936. A. latifolia St. 79. 7.-Cultivated and waste ground. A. VI.-X.

8. A. Babingtonii (Woods); st. spreading procumbent or ascending with spreading branches, $l$. mealy ovate-triangular somewhat 3-lobed unequally sinuate-dentate, upper l. lanceolate dentate and often 3-lobed at the base, fr.-perigone rhomboidal-acute toothed tubercled on the back united on both sides, clusters axillary and terminal few-flowered, seeds minutely tubercular-rugose. -A. rosea Bab., E. B.S.2880, not L. A. crassifolia Fries, probably not of Mey.-A very variable plant. Fr.-perigone large, typically forming a diagonal square a little rounded at the lateral angles.-Sea-shore, common. A. VII.-IX. 
** Stem buff-coloured, nearly without stripes. Perigone of fr. hard and thick.

9. A. arenaria (Woods); st. spreading procumbent with spreading branches, $l$. triangular-rhomboidal sinuate mealy beneath, spike of male $f$. dense naked, fertile $\mathrm{fl}$. axillary, fr.-perigones rhomboidal-3-lobed with the lateral lobes truncate the back 3ribbed the 2 lateral ribs often terminating in tubercles, seeds rough opaque.-A. laciniata $\mathrm{Sm}$. (L. in part) E. B. 165.-Plant hoary throughout. Fr.-perigones large, very broad.--Sea-shore. A. VII.-IX.

\section{Obione Gaert. Sea Purslane.}

1. O. pedunculata (Moq.); st. herbaceous wavy branched, 1. obovate entire attenuated below, upper l. narrower, fr.-perigone long-stalked inversely wedgeshaped 2-lobed with a small intermediate tooth.-E. B. 232. St. 80. 5. Atriplex Sm.-Muddy salt marshes near the east and south coasts of England, and Cunnamara, Ireland; very rare. A. VIII. IX.

2. O. portulacoides (Moq.); st. woody, 1. obovate-lanceolate entire attenuated below, $f r$.-perigone inversely triangular rounded below subsessile with 3 equal lobes above and muricated on the back.-E. B. 261. St. 80.4. Atriplex Sm.-Common on the sea-shore. P. VIII.-X.

\section{Order LXVI. POLYGONACEE.}

Perianth 3-6-parted, imbricate. Stam. definite, from the base of the perianth. Ovary 1 , free, with 1 erect ovule. Styles and stigmas several. Fr. not bursting, a nut, naked or covered by the enlarged perianth. Embryo inverted, usually on one side of farinaceous albumen; radicle remote from the hilum.- Stipules usually cohering in the shape of ochrex.-For figures of the genera see G. F. G. Monochl.

1. Rumex. Perianth 6-parted; 3 inner segments large, connivent. Stam. 6, disposed in pairs. Styles 3. Stigmas multifid. Nut triquetrous, covered by the enlarged inner segments of perianth; embryo lateral.

2. Oxyria. Perianth 4-parted; 2 inner segments larger. Stam. 6. Stigmas 2, multifid. Nut compressed, with a membranous wing, larger than the persistent segments of perianth ; embryo central.

3. Polygonum. Perianth 5-parted. Stam. 5-8. Styles 2-3. Nut trigonous or compressed; embryo lateral, incurved; cotyledons not contorted. 
4. Fagopyrum. Perianth 5-parted. Stam. 8. Styles 3. Nut trigonous; embryo central; cotyledons large, leaflike, contort-plicate.

\section{Rumex Linn. Docks.}

* Fl. perfect. Herbage not acid. Lapathum Tourn.

1. R. maritimus (L.); enlarged pet. rhomboidal narrow, each with a lanceolate entire point a prominent narrow oblong tubercle and upon each side 2 setaceous teeth as long as the pet., whorls crowded many-flowered leafy, 1. all linear-lanceolate.-E.B.725. - Nut very small; faces elliptical. L. equally narrowed at both ends.-Marshes principally near the sea. P. or B. VII. VIII.

[R. limosus (Thuil.); enlarged pet. ovate-oblong on each side 2 setaceous teeth, whorls distant, 1 . all linear-lanceolate narrowed at both ends. R. palustris Koch, St. 73.2. Gold Dock Pet. t. 2. f. 7. 'A plant having this character should be looked for. See Bot. Gaz. i. 296.]

2. R. palustris (Sm.); enlarged pet.ovate-oblong, each with a lanceolate entire point a prominent narrow oblong tubercle and upon each side 2 or 3 setaceous teeth shorter than the pet., whorls distant many-flowered leafy, root-l. narrowly lanceolate rounded or slightly decurrent below.-E. B. 1932.- Nut 3 times as large as that of $R$. maritimus; faces ovate. Upper l. linear-lanceolate, narrowed below.-Marshy places, rare. P. VII.-IX.

E.

3. R. conglomeratus (Murr.); enlarged pet. linear-oblong obtuse, each bearing a large tubercle and entire or obscurely toothed at the base, whorls distant leafy, l. oblong pointed, lower l. cordate or rounded at the base.-E. B. 724. R. acutus Sm. R. glomeratus R. I. f. 552.-Nut ovate, acute. Enlarged pet. broadest near the base; the sides nearly parallel. Unopened anth. white. Branches mostly spreading. Nearly every whorl is accompanied by a leaf.-Wet places. P. VI.-VIII.

4. R. sanguineus (L.); enlarged pet. narrowly oblong blunt entire only one bearing a tubercle, whorls distant leafless, l. ovatelanceolate, lower l. cordate or rounded at the base.-E.B. 1533. -Nut ovate-elliptical, acute. Enlarged pet. broadest above their middle. A very few of the lower whorls are often each accompanied by a leaf. Veins of the l. bright red. Branches ascending.- $\beta$. R. viridis (Sibth.); veins of the l. green. Unopened anth. pale yellow. R. nemorosus Schrad.-Woody places, rare. $\beta$. Woods and road-sides, frequent. P. VI.-VIII.

5. R. pulcher (L.); enlarged pet. triangular-ovate netted with raised nerves toothed below one principally tubercled, branches spreading, whorls mostly leafy, lower $l$. fiddleshaped or cordate- 
oblong obtuse, upper l. lanceolate acute, st. procumbent.-E. B. 1576. - St. straggling. Whorls distant. Nuts ovate, acute.Dry waste places. P. VII.-IX. Fiddle Dock.

6. R. obtusifolius (L. ?); enlarged pet. ovate-blunt-triangular subulate-dentate below with raised veins and an oblong or ligulate entire point one principally tubercled, lower $l$. cordate-ovateoblong blunt, upper 1. oblong or lanceolate, branches ascending. -E. B. 1999. - Height $2-3$ feet. Whorls distant, leafless. Nut elliptical, acute, nearly twice as long as broad.-All the British specimens that I have seen are $R$. Friesii (Gren.), R. divaricatus (Fr.). They are probably not the true $R$. obtusifolius (L.) which is said to be the $R$. sylvestris (Wahlr.) and has only slightly toothed small triangular and less strongly veined enlarged pet., and a nut scarcely longer than broad; and appears to grow only in the north of Europe. It may be expected to occur in Scotland.-Pastures and waste ground. P. VII.-IX.

7. R. pratensis (M. and K.); enlarged pet. unequal cordate dilated and toothed at the base with a small entire triangular point one principally tubercled, 1. oblong-lanceolate acute, lower 1. slightly cordate below.-E. B. S. 2757.- Whorls approximate but not crowded, mostly leafless. Unopened anth. white. Nut elliptical. One enlarged pet. larger than the others, sometimes all 3 equally tubercled.-Marshy places, rare. P. VI.-IX. E.

8. R. crispus (L.); enlarged pet. cordate entire or crenulate one principally tubercled, 1. lanceolate acute wavy crisped.-E. B. 1998.-Height $2-3$ feet. L. narrowed or truncate below. Nut elliptical. Enlarged pet. equal, sometimes all equally tubercled. -Road-sides, fields, \&e. P. VI.-VIII. Curled Dock.

9. R. aquaticus (L.) ; enlarged pet. broadly cordate membranous entire or wavy without tubercles, 1 . lanceolate, lower 1. somewhat cordate, petioles flat and margined above.-E. B. S. 2698. R. domesticus Hartm., Fries, Koch.-Height $3-4$ feet. L. very large. Whorls crowded, mostly leafless, forming a large dense lobed panicle. Nut elliptical, acute.-Ir the north of E. and in S., preferring spots liable to be flooded. P. VII. VIII. E. S.

[Dr. Arnott finds what "seems to be $R$. conspersus (Hartm.)" in Kinross-shire. It has membranous netted broadly cordate toothed enlarged petals. I have only seen a few fruits and do not consider it to be the $R$. conspersus.]

10. R. Hydrolapathum (Huds.); enlarged pet. ovate-triangular nearly entire all tubercled, $l$. lanceolate acute tapering below, petioles flat but not margined above.-E. B. 2104.-St. 3-5 feet high. L. often more than a foot long. Whorls crowded, mostly 
Fl. white, sometimes very few in number.-Mountain pastures. P. VI. VII.

** Ochrea truncate. Root fibrous. Nut compressed or triquetrous. Stam. 4-8. Styles 2-3. Fl. spiked, rarely capitate.-Fl. purple or white. L. without or with a central dark spot. Persicaria.

3. P. amphibium (L.); spike dense ovate-cylindrical, l. stalked ovate-oblong (floating) or oblong-lanceolate or narrow-lanceolate rough at the margins, ochreæ membranous close, nut compressed smooth shining, stam. 5, root creeping.-E. B. 436.St. long when floating. Spikes generally solitary and terminal. Fl. rose-coloured. Very variable in the form of its leaves according to its habitation.-Floating or growing upon mud or on boggy ground. P. VII.-IX.

4. P. lapathifolium (L.); spikes oblong cylindrical dense, 1. oblong-lanceolate or ovate attenuated at both ends glandular beneath, ochrea close not fringed the upper ones shortly fringed, peduncles and perianth glandular-scabrous, nut compressed its faces roundish acuminate concave smooth shining scarcely covered by the perianth, styles distinct at length divergent and reflexed.-E.B. 1382.-a. P.pallidum (With.); 1. all oblong-lanceolate wavy, spikes axillary or terminal solitary, bracts auricled glandular, joinings of the st. scarcely thickened. P. lapathifolium R. I. f. 688. - $\beta$. P. nodosum (Pers.); lower l. ovate or elliptical even, spikes usually 2 together, bracts auricled glabrous, joinings of the st. tumid. R.I.f. $689,-$ Fries.-These varieties are quite connected by intermediate forms. According to Fries, in var. $a$. the veins of perianth are arcuated and recurved; in var. $\beta$. branched and converging at the end. Height $1-2$ feet. Fl. pale. St. sometimes spotted and 1. hoary.-Waste and damp places. A. VII.-IX.

5. P. laxum (R.) ; spikes elongated slenỉer, 1. lanceolate much attenuated at both ends wavy glandular beneath, ochrece loose shortly fringed the floral ones horned, ped. and perianths glandular scabrous, nut compressed its faces roundish acuminate concave shining covered by the perianth, styles connected below at length divergent and reflexed.-E.B. S. 2822. R. I. f. 685.Smaller than the preceding. St. often prostrate. Spikes slender and interrupted (the typical form); or spikes thicker and contiunous (represented in E.B.S.), and 1. white and woolly beneath.-Damp gravelly places. A. VII.-IX. E. I.

6. P. Persicaria (L.); spikes compact ovate-oblong cylindrical, 1. lanceolate plane minutely tubercled, ochrea loose strongly fringed, ped. and perianths smooth, nut compressed and gibbous on one side or trigonous its faces roundish acuminate smooth 
scarcely covered by the perianth, styles connected half-way up at length patent.-E. B. 756. -St. 1-2 feet high. L. more or less covered with hairs on both sides, sometimes woolly on the under side, when it is $P$. incanum of authors. Ped. sometimes slightly hairy, never glandular.-Waste and damp ground. A. VI.-X.

7. P. mite (Schrank); spikes erect filiform interrupted, 1. lanceolate slightly wavy, ochrea loose funnelshaped pilose strongly fringed without glands, perianths without glands, nut (large) compressed its faces roughish ovate acute rather shining convex, stam. 5, styles connected half-way up "arrect." E.B.S. 2867. - St. 1-3 feet high, often much branched. Ochreæ all fringed. Spikes thickening upwards. - Wet places. A. VIII. IX. E.

8. P. Hydropiper (L.); spikes drooping filiform interrupted, 1. lanceolate wavy, ochrea ventricose glabrous fringed glandular, perianths glandular, nut (large) compressed its faces ovate acute rugose-punctate opaque convex, styles 2 nearly distinct.-E. $B$. 989. - St. 1-3 feet high. Upper ochreæ funnelshaped, scarcely fringed. Nut rounder than in P. mite. Spikes sometimes erect. -Wet places. A. VIII. IX. Water Pepper.

9. P. minus (Huds.); spikes erect filiform slender lax, 1. linearlanceolate plane, ochrea close pilose all fringed without glands, perianths without glands, nut (small) compressed its faces ovate acute smooth shining convex, styles connected for at least half their length.-E. B. 1043.-St. usually procumbent, diffuse. Spikes ascending. Much smaller than $P$. Hydropiper, fl. and fr. only half the size.-Wet gravelly places. A. VIII. IX.

*** Ochrea 2-lobed. Root fibrous. Nut triquetrous. Stam. 8. Styles 3. Fl. axillary, 1-3 together. Avicularia.

10. P. aviculare (L.); l. lanceolate or elliptical stalked, ochrece lanceolate acute with few distant simple veins at length torn, nut striated with raised points opaque about equalling the perianth.-E. B. 1252.-L. usually blunt, sometimes acute. Fl. either very distant and scattered, or so much collected as almost to form a leafy spike. St. erect or procumbent. Ochreæ sometimes long and much torn. Extremely variable. A form with a long st. and fleshy broad 1 . is sometimes found on the seashore, which Reichenb. and Koch call P. littorale (Link).Waste places. A. V.-IX. Knot-grass.

11. P. Raii (Bab.) ; l. elliptic-lanceolate flat, ochrece lanceolate acute with few distant simple veins at length torn, nut smooth shining exceeding the perianth. $-E$. B. S. 2805 . P. Roberti Hook., not Loisel. P. littorale Link?, Gren. P. dubium Deak.-St. long, straggling, prostrate. L. bending towards the stem. Resembling $P$. aviculare in habit, but $P$. maritimum in 
fruit. Filaments broader at the base. It varies with smaller 1 . and fl.-Gren. says that the $P$. Roberti (Lois.) has the small fr. and almost the 1 . and st. of $P$. aviculare, with the ochreæ and smooth polished fr. of $P$. maritimum.-Sandy sea-shores. A. VIII. IX.

12. P. maritimum (L.); $l$. elliptical-lanceolate coriaceous with revolute edges, ochrece lanceolate with many branched veins at length torn, nut smooth shining exceeding the perianth.E. B. S. 2804.-St. procumbent, quite woolly below, often much buried. L. convex above, diverging from the stem. Filaments broader at the base.-Sands of the sea-shore. Christchurch Head, Hants. Channel Islands. P. VIII. IX.

**** Ochrea semicylindrical. Root fibrous. Nut triquetrous. Stam. 8. Styles 3. Fl. racemose. Tinaria.

13. P. Convolvulus (L.); st. twining angular, 1. cordate-sagittate, segments of perianth bluntly keeled, nut opaque striated with minute points.-E. B. 941.-St. climbing or prostrate, much shorter than in the next species. The perianth is sometimes winged, when the plant is often taken for $P$. dumetorum.-Cultivated and waste land. A. VII.-IX.

14. P. dumetorum (L.); st. twining striated, l. cordate-sagittate, segments of perianth winged, nut very smooth and shining. -E. B. S. 2811.-St. wiry, climbing to the height of 4 or 5 feet.-Thickets in the south. A. VII.-IX.

E.

\section{Fagopyrum Gaert. Buck-wheat.}

*1. F. esculentum (Moench); st. erect without prickles, $\mathrm{fl}$. in cymose panicles, stam. 8 , l. cordate-sagittate acute, nut triquetrous acute with entire angles.-E. B. 1044. Polygonum Fagopyrum Sm.-Naturalized. Sown as food for game. A. VII. VIII.

E. S.

\section{Order LXVII. ELÆAGNACEÆ.}

Mostly diœcious. Perianth tubular; limb 2-4-toothed, in male fl. 4-parted. Stam. 3 or more, inserted in the throat. Anth. 2-celled, nearly sessile, bursting on the inner side longitudinally. Ovary free, 1-celled, with 1 erect ovule. Fr. crustaceous, irclosed within the fleshy persistert perigone. Albumen thin and fleshy. Radicle inferior.-See G. F. G. Monochl. 44.

1. Hrppophä. Diøcious. Male fl. in a sort of catkin; scales ovate, 1 -flowered. Perianth of 2 leaves adhering by their points. Stam. 4 with very short filaments. Female 
68. THYMELACEAE.-69. SANTALACEA.

fl. solitary. Perigone tubular, cloven at the summit. Style short. Stigma long. Nut 1-seeded, in the large coloured berrylike perigone.

\section{Hippophä̈ Linn. Sea Buckthorn.}

1. H. rhamnoides (L.).-E. B. 425.-A thorny shrub with linear-lanceolate silvery leaves. Fl. appearing with the young leaves. Fr. orange. Height 4-6 feet.-Sandy spots and cliffs of the south-east and east cuasts chiefly. Sh. V.

\section{Order LXVIII. THYMELACE AL.}

Perianth tubular, inferior, often coloured, 4-5-cleft. Stam. definite, in the orifice of the tube. Anth. 2-celled, bursting longitudinally. Ovary free, 1-celled; ovule 1, pendulous. Fr. a nut or drupe. Albumen 0 or thin and fleshy. Radicle superior.

1. Daphne. Perianth 4-fid, deciduous. Berry fleshy, l-seeded. Stam. 8, falling short of the perianth, inserted in the tube in 2 rows.-G.F. G. Monochl. 46.

\section{Daphne Linn.}

1. D. Mezereum (L.); fl. subternate lateral sessile, tube hairy, segments ovate acute. $-E$. B. 1381. St. 8.-Fl. purple, or pale red, appearing before the lanceolate 1 . which are narrowed below. Berries red. A small shrub.-Woods, rare. Sh. III. Mezereon.

E.

2. D. Laureola (L.); racemes axillary of about 5 glabrous drooping bracteated fl., 1. lanceolate attenuate below glabrous evergreen.-E. B. 119.-A small shrub, 1-3 feet high, slightly branched, naked below. Fl. yellowish-green, funnelshaped. Berries bluish-black.-Woods and thickets. Sh.II.-IV. E. S.

\section{Order LXIX. SANTALACEA.}

Perianth adnate to the ovary; limb $3-5$-fid; æstivation valvate. Stam. 4-5, opposite to and inserted at the base of the segments. Ovary 1-celled; ovules $1-4$, pendulous from near the apex of a central placenta. Style 1. Fr. drupaceous, 1-seeded. Embryo in the axis of fleshy albumen.

1. Thesium. Perianth 4-5-cleft, top- or funnel-shaped. Stam. 5, with a fascicle of hairs at their base. Style 1 . Stigma simple. Nut drupaceous, crowned with the persistent perianth.-G. F. G. Monochl. 48. 


\section{Thesium Linn.}

1. T. humifusum (DC.); st. procumbent or ascending racemose, racemes branched or simple, fl.-stalks as long or longer than the fl., fr.-stalks patent, angles of fr.-stalks and edges of bracts and upper 1. denticulate-scabrous, fr. oval-oblong, 1. 1-veined linear. -R. xi. 542. T. linophyllum Sm., E. B. 247.- Parasitical. Root woody. St. nearly always procumbent. L. very slender; veins usually obscure. Middle bract in lower part of racemes exceeding flowers. Tube of perianth very short, open, funnelshaped; segm. triangular, spreading, a tooth on each side. Fr. oval, exceeding perianth which is usually inflexed only at the end, strongly ribbed, slightly netted, persistent.-Chalky and limestone (oolite) bills. P. VI. VII.

E.

[T. intermedium (Schrad.); st. more erect panicled, panicle pyramidal, lowest branches longest, 1. linear-lanceolate 3-veined; is said to be a native of Britain, but all the specimens which I have seen belong to $T$. humifusum.]

[2. T. humile (Vahl); racemes spiked, fl. nearly sessile, fr. strongly ribbed and netted sessile crowned with the very short inflexed perianth, $l$. fleshy linear 1 -veined.-R. xi. 542.-Fr. 4 or 5 times as long as the persistent inflexed perianth. Middle bract much exceeding the flowers. - I gathered 2 specimens of this plant somewhere near Dawlish in Devonshire, in 1829, but it was probably not indigenous. P. VII. VIII.]

E.

\section{Order LXX. ARISTOLOCHIACEA.}

Perianth adnate to the ovary below, tubular above, with a lobed dilated usually irregular limb. Stam. 6-12, epigynous. Ovary 3-6-celled. Style simple ; stigma radiant. Fr. manyseeded. Seed with a minute embryo at the base of fleshy albumen.-For fig. of genera see G. F. G. Monochl. 50,5l.

1. Aristolochia. Perianth tubular, swelling at the base; mouth dilated on one side. Anth. 6 , adnate to the short columnar style under the 6-lobed stigma. Caps. 6-celled.

2. Asarum. Perianth bellshaped, 3-fid. Stam. 12, inserted at the base of the style. Anth. attached to the middle of the flaments. Stigma 6-lobed. Caps. 6-celled.

\section{Aristolochia Linn. Birthwort.}

*1. A. Clematitis (L.) ; root creeping, st. erect simple, 1. cordate stalked glabrous, fl. aggregate.-E. B. 398. St. 6. 16.-Fl. pale yellow.-Naturalized near old ruins. P. VII. VIII. E. 


\section{Asarum Linn. Asarabacca.}

1. A. europaum (L.); 1. reniform obtuse.-E. B. 1083. St. 2.7. -St. short, with 2 leaves, between which there is a solitary drooping dull green $\mathrm{fl}$. Segments of the perianth ovate and incurved. Filaments extending beyond the anthers.-Woods in the north, rare. P. V.

E.

\section{Order LXXI. EMPETRACEA.}

Diœcions. Perianth of hypogynous scales imbricated in several rows. Stam. equal in number to the inner row of scales and alternate with them, free. Ovary free, on a fleshy disk, 2-9celled. Ovules solitary, ascending. Style 1. Stigma radiant. Fr. fleshy with bony cells. Embryo in the axis of fleshy albumen. Radicle inferior.

1. Empetrum. Cal. 3-parted. Pet. 3. Stam. 3 in the male fl. Style short; stigma dilated, peltate, with 6-9 rays. Berry globose, 1-celled. Seeds $6-9 .-$ G.F.G. Monochl. 42.

\section{Empetrum Linn. Crowberry.}

1. E. nigrum (L.); procumbent, l. linear-oblong their margins meeting in a white line beneath. $-E$. B. 526.-A small procumbent leafy heathlike shrub. Fl. axillary, small, purple. Stigma with 9 rays. Berries black.-Mountain heaths. Sh. V.

\section{Order LXXII. EUPHORBIACEA.}

Fl. usually monœcious. Perianth lobed or 0 . Male flowers of 1 or more stamens. Anth. 2-celled. Fem. fl. of 1 superior 2-3-celled ovary. Styles 2-3. Stigma compound or simple. Caps. opening with elasticity ; cells $2-3$, with 1 or 2 suspended seeds in each. Embryo in fleshy albumen. Radicle superior.For fig. of genera see G. F. G. Monochl.36. 40.41.

1. Buxus. Fl. monœcious.-Male. Cal. 3-parted. Pet. 2. Stam.4.-Fem. Cal. 4-parted. Pet. 3. Caps. with 3 horns, 3 -celled, 6 -seeded.

2. Eurinorbia. Fl. incomplete, collected into monœcious heads consisting of 1 female and many male flowers. Involucre campanulate, with 5 divisions and 5 alternate glands. - Males consisting of a single stamen upon a pedicel, intermixed with scales and surrounding the female.-Fem. a single pistil. Styles 3. Stigmas bifid. Caps. 3-celled, bursting at the back. Seeds solitary, pendulous. 
3. Mercurialis. Fl. diœcious or monœcious. Perianth 3-parted.-Male. Stam.9-16.-Fem. Style short, forked. Caps. 2-celled. Cells 1-seeded, bursting at the back.

\section{Buxus Linn. Box.}

1. B. sempervirens (L.); 1. ovate-oblong coriaceous shining above, petioles ciliated, anth. ovate-sagittate.-E. B. 1341.-A small bushy tree of $10-12$ feet in height.-Dry chalky hills, rare. T. IV.-VI.

\section{Euphorbia Linn. Spurge.}

A. Leaves with stipules. Heads axillary.

1. E. Peplis (L.); st. procumbent forked, heads solitary, caps. keeled, seeds smooth, 1. opposite stalked half-oblong-heartshaped nearly entire glabrous.-E. B. 2002.--St. usually much tinged with purple, glaucous. Inv.-glands rounded.-Loose sand. Southern sea-coast. A. VII.-IX.

B. Stipules wanting.

* Involucral glands roundish or transversely oval.

2. E. Helioscopia (L.); umbel 5-fid then 3-fid and 2-fid, bracts and 1 . membranous obovate-wedgeshaped serrate upwards, caps. smooth glabrous, seeds netted rugose.-E. B. 883.-Waste and cultivated ground. A. VI.-IX. Sun Spurge.

3. E. stricta (Koch); umbel twice 3-5-fid then bifid, general and first partial bracts and 1. oblong clasping, other bracts broadly cordate blunt with a minute apiculus, inv.-glands oval, stam. rarely more than 2 in each inv., caps. with prominent cylindrical tubercles, seeds smooth oval brown and shining, seed-stalk cordate. - St. erect, 2-3 ft. high, much branched. Umbel moderate. Inv., caps., and seeds small.-Limestone woods. Gloucestershire and Monmouthshire. P.? VII. VIII. E.

4. E. platyphylla(Koch); umbel 3-5-fid then repeatedly bifid, l. and general bracts long-obovate with a cordate base, partial bracts all cordate apiculate, stam. $7-8$ in each inv., inv.-glands oval, caps. with shortly conical tubercles, seeds obovate brown and shining, seed-stalk nearly reniform.-E. stricta Sm., E. B. 333 (starved).-Plant more diffuse than, and quite distinct from, the preceding, erect, slightly branched. Inv., caps., and sceds twice as large.-Fields. A. VI.-VIII.

5. E. hiberna (L.); umbel about 5 -fid, bracts and 1. ovate or elliptical entire blunt, inv.-glands reniform, caps. warted glabrous, seeds obovate smooth somewhat shining brownish. $-E$. B. 
1337. - Height $1-2$ feet. L. broad, usually pilose beneath. -S.W. of Ireland and N. Devon. P. VI.

E. I.

6. E. palustris (L.); umbel irregular about 5-fid then 3-fid and 2 -fid, bracts all elliptical glabrous, 1 . broadly lanceolate minutely serrate slightly hairy, inv.-glands transversely oval, caps. warted, seeds obovate minutely punctate smooth.-E. pilosa L. E. B. S. 2787. - St. $2-4$ feet high, leafy throughout, annual. Caps. usually hairy.-The form with glabrous l., the original $E$. palustris (L.), has not been found in Britain.--Shady places near Bath. P. V. VI.

E.

*7. E. coralloides (L.); umbel 5-fid then 3-fid and 2-fid, bracts ovate-oblong the tertiary ones ovate all hairy, l. lanceolate minutely serrate woolly, inv.-glands transversely oval, caps. nearly smooth woolly, seeds obovate minutely punctate and with faint reticulate bands. - E. B. S. 2837 . - Height $2-3$ feet. Usually naked below.-Slinfold, Sussex. Introduced. B. ? V. VI. E.

** Involucral glands triangular-lunate or with 2 horns.

$\dagger$ Seeds smooth. Bracts united.

8. E. amygdaloides (L.); umbel 5- or many-fid then 2-fid, bracts rounded connate, l. ovate-lanceolate hairy beneath entire, inv.-glands lunate (yellow) with 2 horns, caps. with very minute tubercles glabrous, seeds roundish-ovate.-E. B. 256 . E. sylvatica L.-St. 2-3 feet high, leafy, purple below, biennial.Woods and thickets. P. III. IV. Wood Spurge. $\quad$ E. I.

[E. Characias (L.) E. B. 442. has no claim to be considered as a native. It does not grow in Needwood Forest.]

† Seeds smooth. Bracts separate.

[E. Cyparissias (L.); umbel many-fid then 2-fid, partial bracts reniform or cordate blunt entire, 1 . linear entire on the barren shoots setaceous, inv.-glands with 2 horns, caps. tubercular.It is probably a native at Whitbarrow in Westmoreland. Rev. W. H. Hawker.]

E.

9. E. Esula (L.); umbel many-fid then 2-fid, partial bracts cordate obtuse mucronate, $l$. lanceolate or sublinear narrowed helow glabrous denticulate, inv.-glands with 2 horns, "caps. scabrous, seeds obovate." $-E$. B. 1399. and 840 ? R. v. 146.St. $12-18$ in. high, leafy, with a few axillary leafy branches without flowers. Root creeping.-Woods, rare. P.VI.VII. E. S.

10. E. Paralias (L.); umbel usually 5 -fid then 2 -fid, bracts rather reniform, $l$. coriaceous elliptic-oblong, inv.-glands 5 with 3 or 4 short points, caps. wrinkled.-E. B. 195.-Root woody, tough. Flowering st. about a foot high ; barren stems shorter, 
many. L. closely imbricated.-Sandy sea-coast. P. VIII. IX. Sea Spurge.

$+\dagger$ Seeds rough, tubercled or pitted. L. alternate, scattered.

11. E. portlandica (L.); umbels 5 -fid then 2 -fid, bracts broadly rhomboidal acuminate, $l$. obovate or obovate-lanceolate blunt subapiculate, inv.-glands 4 lunate with long horns, caps. rough at the angles, seeds pitted and netted almost white.-F. B. 441.-Glaucous, smooth. Scarcely a foot high. L. spreading. Seed-stalk conical, booded.-Sea-coast. P. V.-IX.

12. E. Peplus (L.); umbel trifid then forker, bracts ovate blunt mucronate, $l$. broadly ovate stalked, lower l. suborbicular, inv.-glands 4 lunate with long horns, caps. smooth with thickened rough keels, seeds oval pitted.-E. B. 959.-Light green, smooth, erect, 6-10 in. high.-A common weel. A. VII. VIII. Petty Spurge.

13. E. exigua (L.); umbel trifid then forked, bracts lanceolate acute unequal below, l. linear blunt with a mucro or acute, inv.glands rounded with 2 horns, caps. smooth with slightly thickened and tubercled angles, seerls angular wrinkled.-E. B. 1336. - Height 3-6 in., usually branched at the base. Seeds small, white-Corn-fields. A. VI-VIII.

$++\dagger$ Seeds rough. Leaves opposite.

14. E. Lathyris (L.); umbel 3-4-fid then 2-fil, bracts oblong-ovate attenuate acute, -1 . linear-oblong sessile, upper 1 . cordate at the base, inv.-glands lunate with blunt horns, caps. smooth with a dorsal line.-E. B. 2255.- St. solitary, 2-3 feet ligh, purplish. L. many, in 4 rows. - Truly wild in a few stony and rocky woods, where it appears for 2 or 3 years after the bushes have been cut. Also naturalized on cultivated ground. B. VI. VII. Caper Spurge.

E. S.

\section{Mercurialis Linn. Mercury.}

1. M. perennis (L.); st. simple, 1. stalked oblong-lanceolate rough, female fl. on long common stalks, root creeping.- $E$. B. 1972. - St. a foot high, usually naked below. All the fl. in lax spikes. - $\beta$. M. ovata (Steud.); 1. nearly sessile ovate.-Woods and thickets. $\beta$. Hurstpierpoint, Suss. Mr. Mitten. P. IV. V.

2. M. annua (L.); st. branched, l. stalked ovate or ovate-oblong smooth, female fl. nearly sessile, root fibrous. $-E$. B. 559. St.29. 16. - Height 6-12 in. Bright green. Much branched - . M. M. ambigua (L.); 1 . lanceolate, fl. whorled male and fernale intermixed. E. B. S. 2816. - Waste and cultivated land. $\beta$. Jersey. Isle of Wight. Dr. Bromfield. A. VIII. IX. 


\section{Order LXXIII. CERATOPHYLLACEA.}

Fl. monocious. Perianth free, in many divisions. Anth. 12 -20, sessile, 2-celled, 2-pointed ; cells again partially divided.Perigone none. Ovary l-celled. Seed 1, pendulous. Embryo straight; cotyledons 4 , alternately smaller.-Only one genus.

\section{Ceratophyllum Linn. Hornwort.}

1. C. demersum (L.); segments of 1 . linear-filiform, fr. not winged with a spine on each side near the base and tipped with the curved subulate style.-E. B. 947.-L. 2-4 times forked, dark green; segments of uppermost l. broader and more rigid. - Ponds and ditches. P. VI. VII.

2. C. submersum (L.); segments of 1. setaceous, fr. destitute of spines corered with cylindrical tubercles and tipped with the short curved style. $-E$. B. 679 . - L. palc green. Young $f$ r. smooth.-Ponds and ditehes. P. VI. VII.

\section{Order LXXIV. CALLITRICHACEE.}

Fl. mostly monøcious, solitary, minute, usually with 2 white bracts, no perianth. Stam. 1. Filament long. Anth. reniform, 1-celled, opening transversely at the top.-Perigone none. Ovary 1, 4-angled, 4-celled. Styles 2, subulate. Fr. dry, 4-celled, 4lobed: separating into 4, 1-seeded, indehiscent carpels. Embryo in axis of fleshy albumen. Radicle superior, long. Cotyledons short, terete.-Only one genus.

\section{Callitriche Linn. Water Starwort.}

1. C. verna (L.); fr. nearly sessile, lobes parallel in pairs bluntly keeled on the back, styles erect deciduous, bracts falcate. $-E$. B. 722. R.v. 129.-Lower l. linear; floating l. ovate-spathulate, in a rosette, rarely wanting. Fr. small; keels of each pair of lobes converging. Bracts falling short of fruit.-Common in stagnant and slowly running water. A. or P. IV.-IX.

2. C. platycarpa (Kütz.); fr. nearly sessile, lobes parallel in pairs slightly winged on the baek, styles erect in flower persistent and reflexed closely with fruit, bracts falcate.-E.B.S. 2864 . R. v. 129.-Lower $l$. of st. and branches linear; floating l. roundobovate-spathulate, in a close rosette, often wanting. Fr. twice as large as that of C. verna, pale when dry. $-[\beta$. C. stagnalis (Scop.); lobes of fr. more spreading, $i$. all round obovate-spathulate.] -Common, especially on mud. A. or P. V.-IX.

3. C. pedunculata (DC.); fr. stalked or nearly sessile, lobes 
parallel in pairs bluntly keeled on the back, styles divaricate and reflexed over the sides of the fruit, bracts $0 .-E$. B. S. 2606.L. linear, upper ones broader in the middle. Fr. stalked, small, the size of that of C. verna. $-\beta$. sessilis (Bab.); l. linear, upper floating 1 . ovate-spathulate, fr. sessile. I have never been able to find any bracts to the $\mathrm{fl}$. of this plant. It is only in that respect that it differs from $C$. hamulata (Kütz.) which has falcate deciduous bracts.-Marshes. $\beta$. Lakes. A. or P. VI.-IX.

4. C. autumnalis (L.); fr. nearly sessile, lobes spreading in a star broadly and acutely winged at the back, styles spreading, bracts 0,1 . all linear and broadest at the base.-E. B. S. 2732.Fr. 4 times as large as in C. verna, dark brown, 1 or 2 of the lobes often abortive. L. dark green, all submersed, very abrupt at the end.-Rare. Anglesea. Several Scottish lakes. Cong, Mayo. A. or P. VI. -IX.

\section{Order LXXV. URTICACEÆ.}

Fl. monceious, diøecious, or rarely perfect. Perianth inferior, 4-3-6-parted, imbricate or entire in the female flowers. Stam. definite, free, inserted at the base of the perianth and opposite to its lobes. Ovary free, 1-celled; ovules solitary. Stigmas 1-2. Fr. not bursting.-See G. F. G. Monochl. 28.29. 30.

1. Parietaria. Fl.polygamous, surrounded by an involucre. Perigone bellshaped, 4-parted. Stam. 4. Style filiform.

2. Urtica. Fl. monœcious or diœcious. Males in loose racemes; perianth 4-parted; stam. 4. Females in capitate racemes; perigone 2-parted; stigma sessile.

3. Humulus. Fl. diœecious. Males with the perianth 5parted; stam.5. Females with the perigone scalelike, open, hidden by the scales of an oval catkin; stigmas 2, elongated.

\section{Parietaria Linn. Wall Pelletory.}

1. P. erecta (Koch); 1. oblong-oval attenuate at both ends tripliveined, perianth bellshaped equalling the stamens.-St. mostly erect and simple or with a few short branches falling short of the leaves. Inv. of two 3-lobed 3-flowered segments with a female $\mathrm{fl}$. between them, and two small simple segments alternating with them; each lateral lobe of each segment bearing a pair of small leaves on its face with the lateral $\mathrm{fl}$. between them.-Old walls. P. VI.-IX.

2. P. diffusa (Koch); l. oval acute at both ends tripliveined, perianth. of perfect $\mathrm{fl}$. ultimately elongated and twice as long as the stum. (red).-P. officinalis Sm., E. B. 879.-St. prostrate or 
ascending, diffuse, much branched. Inv. of two 3-lobed 1flowered segments with a fem. $\mathrm{fl}$. between them and a simple lobe in front.-Old walls. P. VII.-IX.

\section{Urtica Linn. Nettle.}

$\dagger$ 1. U. pilulifera (L.); $l$. opposite ovate ovate-lanceolate or cordate-acuminate coarsely toothed, clusters of fr. globose stalked. -E. B. 148.- B. U. Dodartii (L.); l. ovate or ovate-lanceolate nearly entire.-About towns or villages in the east of England. A. VI.-VIII. Roman Nettle.

2. U. urens (L.); 1. opposite elliptical serrate, spikes axillary nearly simple two together falling short of the petiole, seeds smooth opaque.-E. B. 1236.-Common weed. A. VI.-IX.

3. U. dioica (L.); 1. opposite cordate serrate, spikes axillary panicled exceeding the petiole, seeds smooth opaque.-E.B. 1750.- $\beta$. angustifolia (W. and G.) ; l. ovate-lanceolate rounded but not cordate at the base.-Common. P. VI.-IX.

\section{Humulus Linn. Hop.}

1. H. Lupulus (L.). - E. B. 427.-Well known by its long climbing stems, opposite rough 3-5-lobed serrate leaves, ani remarkable catkins. Male fl. in loose panicles.-A true native in many parts of England. P. VII.

\section{Order LXXVI. ULMACEE.}

Fl. perfect, not in catkins. Perianth inferior, bellshaped, 3-8-cleft, imbricate. Stam. definite, inserted at the base of the perianth and opposite to its segments. Ovary free, 1-2-celled; ovules solitary. Stigmas 2. Fr. not bursting.

1. Ulmus. Fl. perfect. Perianth bellshaped, 4-5-cleft, persistent. Stam. 5. Styles 2. Caps. compressed, winged all round.

\section{Uluus Linn. Elm.}

1. U. suberosa (Ehrh.); 1. shortly acuminate more or less doubly serrate, ped. short, fl. 4-5-fid, lobes ciliate, fr. obovate or oblong notched, seed-cavity chiefly above the middle of fr. and near the notch. $-U$. campestris (L.) includes this species and the following.- $-a$. $U$. campestris (Sm.); l. scabrous above pubescent beneath. E.B. 1886 . U. suberosa E. B. 2161.- $\beta$. U. glabra (Sm.); 1. rather coriaceous shining smooth or subscabrous above glabrous except in the axils of the veins beneath, young l. stip. and fr. with subsessile glands. E. B. 2248. $U$. stricta (Lindl.) which has rigid erect close branches is a form 
of this variety.-a. Throughout England. $\beta$. South of England and Ireland. T. III.-V. Common Elm.

2. U. montana (With.); 1. much acuminate doubly serrate scabrous above rather downy beneath, ped. short, fl. 5 -7-fid, lobes ciliate, fr. oblong or roundish notched, seed-cavity chiefly below the middle of fr. and distant from the notch. - E. B. 1887. U. major Sm., E. B. 2542 ?.-Branches large, spreading. L. broad. Fr. hoplike.-Woods and hedges. T. III.IV. Wych Elm.

\section{Order LXXVII. AMENTIFERE.}

Fl. monœcious or diœecious, rarely perfect. Barren fl. capitate or in catkins; sometimes with a membranous perianth. Fertile fl. clustered, solitary or in catkins. Ovary usually simple. Stigmas 1 or more. Fruit as many as the ovaries, bony or membranous. Albumen usually wanting. Embryo straight or curved, plain. Radicle mostly superior.-Young leaves with stipules.-For figures of the genera see G. F. G. Monochl.

Tribe I. SALICINEAE. Fl. all in catkins. Fr. naked, 2-valved, l-celled, many-seeded. Seeds erect, comose.

1. SALIX. Catkins consisting of imbricate entire scales. Stam. 1-5. Fr. a 1-celled follicle with $1-2$ glands at its base. Perianth 0 .

2. Populus. Catkins with lacerate scales. Stam. 4-30, from a little oblique cupshaped perianth. Fr.almost 2-celled, with a cupshaped perigone.

Tr. II. MYRICEAE. Fl. all in catkins. Fr. drupaceous, surrounded by the scales of the ovary become fleshy and adherent.

3. MYrica. Catkins with concave scales. Stam. 4-8. Stigmas subulate. Drupe 1-celled, 1-seeded. Perianth 0.

Tr. III. BETULINEAE. Fl. all in catkins. Ovary 2-celled, each with 1 ovule. Fr. naked, indehiscent, l-celled, 1 -seeded. Seeds pendulous, not comose.

4. Betula. Scales of the barren catkins ternate, the middle one bearing the stamens. Perianth 0 . Scales of the fertile catkin 3-lobed, 3-flowered, membranous, deciduous. Styles 2 , filiform. Fr. with a membranous margin.

5. Alnus. Scales of the barren catkins 3-lobed, 3-flowered. Perianth 4-parted. Scales of the fertile catkin ovate, 2 flowered, coriaceous, persistent. Styles 2. Ovary compressed, 4 minute scales at its base. Fr. not winged. 
Tr. IV. CUPULIFERAA. Male fl. in a catkin. Fem. solitary or aggregate or spiked. Perigone adnate to the ovary, with a denticulate limb, sometimes evanescent, surrounded by a coriaceous involucre.

6. FAGUs. Barren fl. in a globose catkin. Perianth 5- or 6fid. Stam. $8-15$. Fertile fl. 2 together within a 4-lobed prickly involucre. Stigmas 3. Ovaries 3-cornered and 3celled. Nut by abortion 1-2-seeded.

7. Castanea. Barren $f$. in a long cylindrical catkin. Perianth 6-parted. Stam. 8-20. Fertile fl. 3 within a 4lobed muricate involucre. Stigmas 6 . Ovary 5-8-celled. Nut 1-celled with $1-3$ seeds.

8. Quercus. Barren catkin long, pendulous, lax. Stam. 5-10. Perianth 5-7-cleft. Fertile fl. solitary with a cupshaped scaly involucre. Stigmas 3 . Ovary 3-celled. Nut 1-celled, 1-seeded, surrounded at the base by the enlarged cupshaped involucre.

9. Corylus. Barren catkin long, pendulous, cylindrical. Scales 3-lobed, middle lobe covering the 2 lateral lobes. Stam. 8. Anth. l-celled. Perianth 0. Fertile fl. several, surrounded by a scaly involucre. Styles 2 . Nut 1-seeded, inclosed in the enlarged coriaceous laciniate involucre.

10. Carpinus. Barren catkin long, cylindrical. Scales roundish. Stam. 5-14. Anth. 1-celled. Fertile $\mathrm{tl}$. in a lax catkin. Scales large, leaflike, 3-lobed, 2-flowered. Styles 2. Nut ovate, 1-seeded.

\section{Tribe I. Salicinea.}

\section{SALtx Linn. ${ }^{1}$ Willow.}

\section{Pedunculate laterales.}

Catkin and its leafy stalk deciduous together, lateral, appearing with the leaves. Scales of uniform colour.

* Scales of the catkins soon falling.

i. Pentandra (Borr.). Stam. more than 2. L. glossy, glabrous. Trees or large shrubs. - Stipules soon falling.

1. S. pentandra (L.); l. ovate-elliptical or ovate-lanceolate acuminate glandular-serrate, "stip. ovate-oblong straight equal,"

1 I have ventured to place many plants as varieties which are considered as distinct by my able friend Mr. Borrer. I do so with hesitation, being very imperfectly acquainted with many of them, but follow the example of most modern botanists. 
stam. 5 or more, caps. ovate-attenuate glabrous, stalk twice as long as the gland, style short, stig. bifid.-E. B. 1805.-Height 6 - 20 feet. Top of petioles glandular. L. fragrant.-Riversides in the north. T. V. VI. Bay-leaved Willow.

†2. S. cuspidata (Schultz?); l. oblong-lanceolate acuminate glandular-serrate, stip. half-cordate oblique, "stam. 3 or 4," caps. ovate attenuate glabrous, stalk 3 or 4 times as long as the gland, style short, stig. emarginate.-Loudon's Arboretum 1439. S. Meyeriana Willd.-Height 20-30 feet. Top of the petioles glandular.-Near Shrewsbury. T. VI.

E.

ii, Fragiles (Borr.). Stam. 2, distinct. L. glabrous. Trees.

3. S. fragilis (L.); l. lanceolate pointed serrate, stip. $\frac{2}{2}$-cordate, caps. obovate-lanceolate stalked glabrous, stigmas rather thick bifid.-a. S. decipiens (Hoffm.); caps. tapering, style longer than the cloven stigmas. E. B. 1937. Branches smooth, highly polished, reddish-brown; young shoots often crimson. $-\beta$. S. fragilis (L.) ; caps. oblong-ovate, style short, stigm. bifid. E. B. 1807. Branches round, very smooth, brown, brittle in the spring. Crack Willow. - . S. Russelliana (Sm.); caps. stalked lanceolate acuminate, style as long as the bifid stigmas. E. B. 1808. Branches polished, round, smooth. L. gradually attenuate, very glaucous beneath. Wood and bark highly valuable. Bedford Willow.-Damp meadows and osier-grounds. T. IV. V.

iii. Albc (Borr.). Stam. 2. L. hairy with adpressed silky hairs when young. Catkins lax. Trees.

4. S. alba (L.); l. elliptic-İanceolate glandular-serrate acute silky on both sides when young, stip. minute, caps. nearly sessile ovate-acuminate glabrous, style short, stigmas thick recurved bifid.-E. B. 2430.-Height 50-80 feet. Scales shorter than stam., as long as caps. in $a$. and $\beta$, exceeding them both in $\gamma$. Branches silky.- $\beta$. S. carulea (Sm.); l. less silky beneath. $E . B$. 2431. - . S. vitellina (Sm.); branches bright yellow, 1. shorter and broader.-Wet places. T. V. White Willow.

$$
\text { ** Scales of the catkins persistent. }
$$

iv. Triandra (Borr.). Stam.3. L. lanceolate approaching to ovate, glabrous. Catkins lax. Osiers, naturally trees.

*5. S. undulata (Ehrh.); 1. lanceolate much acuminate serrate glabrous except when young, stip. $\frac{1}{2}$-cordate acute, caps. stalked ovate acuminate, pedicel twice as long as the gland, style elongate, stigma bifid, scales very shaggy. - S. lanceolata Sm., E. B. 1436. - Height 12-15 feet. L. sometimes wavy, often quite silky when young. Germ. glabrous in S. lanceolata (or downy in the foreign S. undulata).-Near Lewes, Suss. T. IV. V. 
6. S. triandra (L.); 1. oblong-lanceolate acute serrate glabrous, stip. $\frac{1}{2}$-cordate blunt, caps. stalked oblong-ovate glabrous, stigma nearly sessile, scales glabrous.-E. B. 1435.-Height 20 30 feet. Germen not furrowed. L. narrowing down to the stalk, somewhat paler beneath, or (S. triandra Curt.) lanceolate wavy paler and glaucous beneath.- $\beta$. S. Hoffmanniana (Sm.); 1. somewhat rounded below ovate-lanceolate, stip. larger, scales shaggy towards their base. E.B.S. 2620.- - . S. amygdalina (L.); l. oblong-ovate acute rounded below, caps. ovate tumid furrowed, young shoots furrowed. E. B. 1936.-Wet woods and osier-grounds. T. IV. V.

E. S.

[S. petiolaris (Sm.) E. B. 1147. is stated by Lindley not to be a European plant and is therefore omitted.]

\section{Sessiles laterales.}

Catkins lateral, sessile, without leaves or with two or three small leaves or leaflike bracts at the base, stalk sometimes elongated in fruit so as to resemble a leafy shoot but deciduous with the catkin. Scales discoloured or purple at the end.

v. Acutifolice (Borr.). Filaments 2. Anth. ultimately yellow. Catkins persistently sessile. Scales discoloured at the end. Style long. Bark of young shoots pruinose.

†7. S. acutifolia (Willd.); 1. linear-lanceolate acuminate crenate-serrate glabrous glaucous beneath, stip. lanceolate acute sub- $\frac{1}{2}$-cordate below, "caps. ovate-conic glabrous sessile, stig. linear-oblong." - Shoots purple with a glaucous bloom. Male catkins short, thick, very hairy. Fertile plant not yet found in England.-North Yorkshire. T. IV.

E.

vi. Purpurea (Koch, Borr.). Filament 1 with a 4-celled anther, or forked with 2 anthers each of 2 cells. Anth. purple, ultimately black. Catkins bracteated at the base.

8. S. purpurea (L.); l. lanceolate broader upwards acuminate attenuate below finely serrate glabrous, caps. ovate very downy sessile, style very short, stigm. ovate, anth. 1, stip. 0.a. S. purpurea (Sm.); decumbent, twigs purple, fertile catkins very compact. E. B. 1388.- $\beta$. S. Woolgariana (Borr.) ; erect, twigs yellowish-gray, l. cuneate-lanceolate glaucous beneath, stigmas blunt. E. B. S. 2651.- - . S. ramulosa (Borr.); erect, twigs pale yellowish, l. oblong-lanceolate paler beneath, stigmas sessile bifid. - $\delta$. S. Lambertiana (Sm.) ; erect, twigs purplishglaucous, l. oblong-linear-lanceolate slightly narrowed and somewhat rounded below, stigmas ovate emarginate. E. B. 1359.-є. S. Helix (L.); caps. oblong-ovate, stigmas almost linear 


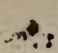

emarginate, twigs pale yellowish or tinged with purple polished. E. B. 1343. Rose Willow.-Marshes and river-banks. 'T. III. IV.

9. S. rubra (Huds.); 1. linear-lanceolate acuminate glabrous green on both sides, caps. oblong-ovate very pubescent, style elongated, stigmas ovate undivided, anth. 2 (yellow?), filaments combined below, stip. linear.-E. B. 1145.-Height 10-20 feet. Twigs usually tawny. L. like those of S. viminalis but without the white pubescence.- $\beta$. S. Forbyana $(\mathrm{Sm}$.$) ; 1$. lanceolateoblong, style nearly as long as the linear "divided stigmas, anth. 1." E. B. 1344. Twigs grayish-yellow. L. rather paler and somewhat glaucous beneath. Stip. broader, variable. Stigma entire.in all that I have seen.-Low meadows. T. IV. V.

vii. Viminales (Borr.). Stam. 2. Anth. becoming yellow or brown. Catkins bracteated at the base; scales discoloured at the end. Stigmas not sessile. Pubescence of the l. silky.

\section{* Capsules nearly or quite sessile.}

10. S. viminalis (L.); l. linear or linear-lanceolate obscurely crenate white silky and shining beneath, stip. small sublanceolate, capsule very shortly stalked lanceolate-subulate, style elongate, stigmas undivided. $-E$. B. 1898.-Height 10-20 feet. Branches wandlike, long, slender. Gland longer than the stalk of the caps.- $\beta$. intricata (Leefe); 1. broader, caps. shorter and broader, style very short, stigmas from the first cloven reflexed and entangled. $-\gamma$. stipularis (Leefe); l. lanceolate, stip. linearlanceolate denticulate or $\frac{1}{2}$-cordate acuminate, stigmas elongated. -Wet places. Sh. IV. V. Common Osier.

11. S. stipularis $(\mathrm{Sm}$.$) ; 1. lanceolate very obscurely crenate$ white and downy beneath, stip. $\frac{1}{2}$-cordate acute, caps. ovate nearly sessile, style very short $\left(\mathrm{Sm}\right.$.) elongate $\left(H_{0 o k}\right.$.), stigmas linear undivided. - E. B. 1214. - Height 10-20 feet with upright brittle reddish-brown twigs.-Wet places. Sh. III.

\section{** Capsules shortly stalked.}

12. S. Smithiana (Willd.); l. elongate-lanceolate obscurely crenate white satiny beneath, stip. reniform $\frac{1}{2}$-cordate, caps. stalked lanceolate-subulate, pedicel about as long as the gland, style elongate, stigmas long linear mostly entire.-Twigs erect, somewhat downy, brittle.-a. S. Smithiana (E. B. 1509); 1 . rounded at base white with satiny down beneath, stip. small narrow $\frac{1}{2}$-lunate.- $\beta$. S. rugosa (Leefe); l. greenish-white and rather silky beneath, stip. $\frac{\frac{1}{2}-c o r d a t e}{2}$ acute, style moderate, stigmas linear broad undivided. - $\gamma$. S. ferruginea (And.); l. greenish-white and rather silky beneath, stip. $\frac{1}{2}$-ovate or reni- 


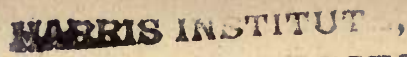 \\ ERTSTON. \\ SALIX.

form, style elongate, stigmas linear-oblong undivided. E. B.S. 2665. Bushy.-Wet places. Sh. IV. V.

viii. Caprece (Koch). Stam. 2. Anth. becoming yellow or brown. Catkins bracteated at the base. Stalks of the caps. at least twice as long as the gland. Trees or shrubs with an exposed trunk.

A. Cinerece (Borr.). L. rugose, not turning black; pubescence crisped, not silky. Stigma subsessile. Stip. without basal glands.

13. S. acuminata $(\mathrm{Sm}$.$) ; l$. lanceolate-oblong pointed finely toothed glaucous ashy and downy scarcely silky beneath, stip. $\frac{1}{2}$-cordate, caps. ovate tapering, style conspicuous, stigmas ovate undivided, buds downy. -E. B. 1434. Loud. 1464. - Height 2530 feet.-Damp woods and hedges. Sh. or T. IV.

14. S. cinerea (L.); 1. elliptic- or lanceolate-obovate pointed subserrate downy and ashy beneath, stip. $\frac{1}{2}$-cordate, caps. lanceolate-subulate, stigmas simple or bifid, buds downy. - E. B. 1897. - Height 20-30 feet.-a. S. cinerea (Sm.); l. obovatelanceolate rather thick reddish beneath, stip. $\frac{1}{2}$-cordate acute, style very short thick. E. B. 1897.- - . S. aquatica (Sm.); l. obovate-elliptical thinner downy and rather glaucous beneath, stip. reniform, style obsolete. E. B. 1437.-y. S. oleifolia; l. obovate-lanceolate rather rigid downy and rather glaucous beneath, stip. small roundel. E. B. 1402. - Varies greatly; varieties scarcely distinguishable. - Wet places. T. or Sh. III. IV. Sallow.

15. S. aurita (L.); l. obovate repand-dentate recurved-apiculate much wrinkled more or less downy above pubescent beneath, stip. roundish or reniform large stalked, caps. lanceolate-subulate, stig. generally entire, buds glabrous or slightly downy.-E. $B$. 1487. - Height 3-4 feet. Edges of l. deflexed, point hooked. Stigmas and scales often reddish.-Damp woods. Sh. IV. V.

16. S. Caprea (L.); l. ovate or elliptical flat acute crenateserrate wavy at the margins deep green with a downy midrib whitish above and cottony beneath, stip. subreniform, caps. lanceolate-subulate, style very short, buds glabrous.-E. B. 1488. S. sphacelata E. B. 2333.-A small tree, 15-30 feet high. Catkins very thick, blunt. L. mostly large and broad, rarely sublanceolate; spring l. nearly entire.-Woods and hedges in dryish places. $\beta$. subalpine. T. IV. V. Great Sallow.

B. Nigricantes (Borr.). L. punctate beneath, turning black in drying. Style very long. Stip. with basal glands.

17. S. nigricans (Fries); young shoots and 1. downy, l. ovate- 
elliptical or lanceolate more or less glaucous beneath thin, point of stip. straight.- $a$. germen and stalk silky, st. erect.-a. S. cotinifolia (Sm.); 1. roundish elliptical or subcordate. E. B. 1403 . -b. S. nigricans (Sm.); 1. elliptic-lanceolate. E. B. 1213.c. S. Forsteriana (Sm.); 1. elliptic-obovate acute, stip. vanlted, catkins long. E. B. 2344.- $\beta$. S. rupestris (Donn); awlshaped germ. and stalk silky or glabrous below, st. trailing, l. ellipticobovate. E. B. 2342. - $\gamma$. germen glabrous, stalk downy or glabrous, st. erect.- - a. S. Andersoniana (Sm.); 1. elliptic-oblong acute, caps. awlshaped not wrinkled. E. B.2343.-b. S. damascena (Forbes); 1. broadly elliptical or subrhomboidal acute, caps. not wrinkled. E. B. S. 2709.-c. S. petrcea (And.); 1. oblong or sublanceolate, caps. wrinkled near the top. E. B. S. 2725.? S. hirta (Sm.) ; l. elliptic-cordate pointed, "caps. very pubescent" (Leefe) "glabrous" (Arnott) not wrinkled.-The varieties are scarcely distinguishable.-Sides of streams, osier-grounds, mountains. Sh. IV.-VI.

C. Virentes (Fries). L.smooth, scarcely any crisped pubescence beneath, not turning black. Style manifest.

18. S. laurina (Sm.); young shoots and 1. densely downy or hairy towards the end, l. afterwards glabrous dark dull green above glaucous beneath (young 1 . turning black).- $a$. stalk of germ. hairy.-a. S. propinqua (Borr.); l. elliptical acute, germ. silky towards the end, style longer than stigmas. E. B. S. 2729. -b. S. tenuior (Borr.); 1. elliptic-oblong acute, germ. silky, style as long as stigmas. E.-B.S. 2650.-c. S. laurina (Sm.); 1. obovate-lanceolate narrow acute, germ. silky, style longer than stigmas. S. bicolor (Sm.), E. B. 1806.- $\beta$. S. tenuifolia (L.); germ. and style quite glabrous, l. elliptical acute. E. B. S. 2795. -Thickets and river banks, chiefly in England. Sh. IV. V.

19. S. phylicifolia (L.); shoots and 1. soon quite glabrous, 1. rigid dark shining green above glaucous beneath not turning black.-a. germ. and stalk silky or hairy. -a. S. radicans (Sm.); 1. oblong or elliptic-lanceolate, style elongate. S. phylicifolia E. B. 1958.-b. S. Davalliana (Sm.); 1. oblong-lanceolate pointed, style as long as stigmas. E.B.S.2701 - - c. S.Weigeliana (Willd.); l. roundish or elliptical obscurely crenate (acute at both ends in fertile plant), style longer than stigmas cloven. $E . B . S$. 2656.--d. S. nitens (And.); l. elliptic-lanceolate acute at both ends turning rather blackish, style longer than stigma undivided. E. B. S. 2655.-e. S. Croweana (Sm.); 1. elliptic-obovate rather acute at both ends, style as long as stigmas, stam. free below. E. B. 1146.-f. S. Dicksoniana (Sm.); l. elliptic rather acute, style about as long as stigmas, catkins short. E. B. 1390.- $\beta$. lower part of germ. and stalk glabrous.-a. S. laxiflora (Borr.); 1. broadly obovate narrowed to the base, stigmas cloven. $E . B S$. 
2749.-b. S. tetrapla (Walk.); 1. lanceolate narrowed to both ends, stigmas undivided. E. B. s. 2702.- $\gamma$. germen glabrous. -a. S. Borreriana (Sm.); l. lanceolate narrowed to both ends, stalk of germ. hairy, style elongate. E.B. S.2619.-b. S. phillyreifolia (Borr.); 1. elliptic-lanceolate narrowed at both ends, stalk of germ. glabrous, style as long as stigmas. E.B. S. 2660. - Small branching shrubs. Mountain valleys. IV. V.

ix. Fusca. Stam. 2. Anth. fuscous-yellow when empty. Catkins bracteated at the base. Stalks of the caps. very rarely not longer than the gland. Shrubs with a subterranean creeping trunk. L. silky beneath.

\section{A. Rosmarinifolia (Borr.). Small erect shrubs.}

20. S. rosmarinifolia (L.) ; 1. linear-lanceolate silky beneath quite entire or remotely glandular toothed, stip. lanceolate, germens silky lanceolate-acuminate, scales short hairy, "style about as long as the linear-divided stigmas."-E. B. 1365.-A slender upright shrub, 3 feet high. Catkins very short, at first drooping. Whole plant becomes nearly black in drying. Style short. "Several parts of the north." Sm. Sh. IV.

21. S. angustifolia (Wulf. ?); l. linear-lanceolate silky beneath when young afterwards nearly glabrous remotely glandulartoothed, stip. very minute, germens densely silky ovate-acuminate, scales very villose and nearly as long as the young germens, style as long as the erect lanceolate entire stigmas.-S. Arbuscula Sm., E. B. 1366 (excl. large 1.), not Koch, Fries.-A shrub about a foot high. L. very much attenuated at both ends.-Clova. Dumfries. Sh. IV.

S.

22. S. Doniana (Sm.); l.lanceolate or obovate-lanceolate acute slightly serrate livid with scattered silky hairs beneath, stip.linear, germens very silky ovate-oblong longer than the bearded oblongovate scales, style very short, stigmas short emarginate.-E. B. S. 2599. - Shrub about 6 feet high. "Stam. monadelphous, anth. ultimately luteo-fuscous not black." (Koch.) Closely allied to the Purpurec.-Forfarshire. Sh. V.

S.

B. Repentes. Small procumbent shrubs.

23. S. repens (L.); 1. elliptical or elliptic-lanceolate acute entire or minutely glandular-serrate glaucous and silky beneath, germens lanceolate silky, style moderate, stigmas ovate bifid.a. S. repens (Sm.); l. elliptic-lanceolate with a straight point, st. depressed with short upright branches. $E . B .183$. - $\beta$. S.fusca (Sm.) ; l. oblong-oval straight, st. decumbent below then erect much branched. E.B. 1960.- - . S. prostrata (Sm.); 1. ellipticoblong with a twisted point, st. prostrate with elongated straight branches. E. B. 1959.- - . S. ascendens (Sm.); 1. elliptical with 
a recurved point, st. recumbent with long somewhat ascending branches. E. B. 1962. S. parvifolia Sin., E. B. 1961.-є. S. incubacea (L.); 1. elliptic-oblong with a twisted point, stip. stalked

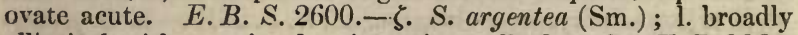
elliptical with a twisted point, stip. stalked oval. E.B.1364. - Fries thinks that S. fusca (L.) is different.-Heaths at various elevations. Sh. III. IV.

24. S. ambigua (Ehrh.) ; l. oval obovate or lanceolate slightly toothed with a recurved point somewhat rugose above soft and silky beneath, stip. stalked half-ovate acute, germens lanceolatesubulate silky, style very short, stigmas short at length cloven. -E. B. S. $2733 .-\alpha$. 1. oval or obovate moderately hairy. $-\beta$. major; 1 . obovate very silky on both sides. $-\gamma$. spathulata; $1 . \mathrm{ob}-$ ovate or ovate-lanceolate moderately hairy or silky, style somewhat elongate. - $\delta$. undulata; 1 . ovate-lanceolate. - Gravelly heaths. Sh. V.

x. Arbuscula. Stam. 2. Anth. yellow or brown when empty. Catkins subsessile, bracteated at the base; scales discoloured at the end. Stalks of the capsules 0 or shorter than the gland. Shrubs with an exposed trunk.

25. S. Arbuscula (L., Fries); $l$. lanceolate-ovate or ovate glabrous smooth glaucous and opaque beneath finely serrate, germens oblong-ovate silky, stigmas bifid.-a. S. carinata (Sm.); l. ovate finely toothed minutely veined folded into a keel, catkins cylindrical with rounded hairy scales. E. B. 1363:- $\beta$. S. prunifolia (Sm.); l. broadly ovate toothed smooth on both sides, st. erect much branched. E. B. 1361. $-\gamma$. S. venulosa (Sm.); 1 . ovate toothed naked reticulated with prominent veins above, st. erect much branched. E. B. 1362.- - S. vacciniifolia (Sm.); 1. lanceolate-ovate serrate smooth and even above silky beneath, st. decuinbent. E.B. 2341.-Highlands. Sh. IV.-VI. S.

26. S. Lapponum (L.); 1. lanceolate or elliptical subacuminate entire cottony or silky beneath with crisped hairs wrinkled above and wheu young downy, germens ovate-lanceolate silky, stigmas linear.-a. S. arenaria (L.); l. ovate-lanceolate reticulated and somewhat downy above veined and woolly beneath, style as long as the sessile woolly germen, stigmas linear. E. B. 1809. Germen with a long slender reddish style.- $\beta$. S. Stuartiana (Sm.); 1. ovate-lanceolate shaggy above densely silky almost cottony beneath, style as long as the almost sessile woolly germen, stigmas capillary deeply divided. E. B.2586. $-\gamma$. S. glauca (Sm.); 1. ovate-lanceolate even and nearly smooth above woolly and snow-white beneath, germens sessile woolly, style very short with thick ovate stigmas. E. B. 1810. Germen blunter. Style elongating and the stigmas becoming linear and deeply cloven as 
the fruit ripens. [S. glauca L., Wahl., Koch, has subterminal catkins with very long leafy stalks and belongs to the next section.]-Breadalbane and Clova Mountains. Sh. VI. VII. S.

xi. Hastata. Stam. 2. Anth. permanently yellow. Catkins appearing before the 1. , sessile, terminal and lateral with very sliaggy and silky scales. L. broadly elliptic or roundish.

[27. S. hastata (L.); 1. broadly elliptic wavy thin and crackling quite glabrous beneath, stip. unequally heartshaped longer than petioles, catkins with silvery hairs, germ. subulate glabrous stalked.-S. malifolia Sm., E.B. 1617.-A very doubtful native. Sands of Barrie. Sh. V.]

S.

28. S. lanata (L.) ; l. broadly oval pointed entire shaggy beneath, stip. oval, catkins with yellow silky hairs, germ. conical glabrous. - E. B.S. 2624. - A low (2 ft.) and very beautiful shrub.-Clova and Glen Lochay Mountains. Sh. V. VI. S.

\section{Pedunculate terminales.}

Catkins on long leafy persistent shoots from the terminal or subterminal buds. Chamely $x$ Fries.

xii. Myrsinites (Borr.). Catkins at the extremity of the terminal shoot, or of those from the last but one or two of the buds, but in such a manner as to appear to be an elongation of the branch. Small bushy plants.

29. S. Myrsinites (L.); 1. elliptical or lanceolate serrate shining: often hairy with prominent veins, germens subsessile ovate-subulate downy, style long.-St. much branching.-a. S. arbutifolia (Sm.); l. ovate or lanceolate rather acute. S. Myrsinites $\beta$. Sm.- $\beta$. S. Myrsinites (Sm.); l. elliptical serrate nearly smooth, catkins short, style short, stigmas cloven. E. B. 1360.-Highlands. Sh. VI.

30. S. procumbens (Forbes); 1. oval minutely serrate bright green and shining on both sides, catkins elongated cylindrical, germens subsessile ovate lanceolate downy, style short deeply cloven, stigmas bifid.-E.B.S. 2753.-Scales of the catkin nearly black, longer and more hairy than in S. Myrsinites. A low procumbent much branched shrub.-Highlands. Sh. VI. S.

[Fries states that S. retusa (L.) was found by Mr. Winch in Scotland, but there is no such plant in his Herb.]

xiii. Reticulate (Borr.). Catkins opposite to the terminal leaves with a bud between them.

31. S. reticulata (L.); $l$. nearly roundly-elliptical very obtuse entire reticulated with veins and glaucous beneath, germens sessile oblong-ovate downy, style short, stigmas bifid.-E. B. 1908.- 
A procumbent much branched shrub. Catkins on long stalks.Lofty mountains. Sh. VI.

xiv. Herbacea (Borr.). Catkins exactly terminal.

32. S. herbacea (L.); l. round or oval obtuse or retuse serrate shining glabrous reticulated with veins, germens subsessile ovateconical glabrous, style short, stigmas bifid.-E. B. 1907.-A very minute herblike shrub; the stems extend far amongst loose stones on the tops of mountains. Edges and veins of 1 . hairy. -Alpine situations. Sh. VI.

\section{Index to the Salices.}

S. acuminata, 13. acutifolia, 7. alba, 4 . ambigua, 24. amygdalina, 6 . Andersoniana, 17. angustifolia, 21. aquatica, 14 . Arbuscula, 21, 25. arbutifolia, 29. arenaria, 26. argentea, 23. ascendens, 23. aurita, 15. bicolor, 18. Borreriana, 19. cærulea, 4. Caprea, 16. carinata, 25. cinerea, 14. cotinifolia, 17 . Croweana, 19. cuspidata, 2. damascena, 17. Davalliana, 19. decipiens, 3 . Dicksoniana, 19. Doniana, 22. ferruginea, 12. Forbyana, 9.

\begin{tabular}{ll} 
Forsteriana, 17. & propinqua, 18. \\
fragilis, 3. & prostrata, 23. \\
fusca, 23. & prunifolia, 25. \\
glauca, 26. & purpurea, 8. \\
hastata, 27. & radicans, 19. \\
Helix, 8. & ramulosa, 8. \\
herbacea, 32. & repens, 23. \\
hirta, 17. & reticulata, 31. \\
Hoffmanniana, 6. & retusa, 30. \\
incubacea, 23. & rosmarinifolia, 20. \\
intricata, 10. & rubra, 9. \\
Lambertiana, 8. & rugosa, 12. \\
lanata, 28. & rupestris, 17. \\
lanceolata, 5. & Russelliana, 3. \\
Lapponum, 26. & Smithiana, 12. \\
laurina, 18. & sphacelata, 16. \\
laxiflora, 19. & stipularis, 10, 11. \\
malifolia, 27. & Stuartiana, 26. \\
Meyeriana, 2. & tenuifolia, 18. \\
Myrsinites, 29. & tenuior, 18. \\
nigricans, 17. & tetrapla, 19. \\
nitens, 19. & triandra, 6. \\
oleifolia, 14. & undulata, 5. \\
parvifolia, 23. & vacciniifolia, 25. \\
pentandra, 1. & venulosa, 25. \\
petiolaris, 6. & viminalis, 10. \\
petræa, 17. & vitellina, 4. \\
phillyreifolia, 19. & Weigeliana, 19. \\
phylicifolia, 19. & Woolgariana, 8. \\
procumbens, 30. & \\
\hline
\end{tabular}

Forsteriana, 17. fragilis, 3 . fusca, 23. glauca, 26. hastata, 27. Helix, 8 . herbacea, 32 .

hirta, 17.

Hoffmanniana, 6 incubacea, 23. intricata, 10. Lambertiana, 8 . lanata, 28. lanceolata, 5 . Lapponum, 26. laurina, 18. laxiflora, 19. malifolia, 27. Meyeriana, 2. Myrsinites, 29. nigricans, 17 . nitens, 19. oleifolia, 14 parvifolia, 23. pentandra, 1. petiolaris, 6 . petræa, 17. procumbens, 30 . propinqua, 18. prostrata, 23. prunifolia, 25. purpurea, 8 . radicans, 19. ramulosa, 8 . repens, 23. reticulata, 31 . retusa, 30 . rosmarinifolia, 20. rubra, 9. rugosa, 12. rupestris, 17. Russelliana, 3. Smithiana, 12. sphacelata, 16. stipularis, 10, 11. tenuifoli, 18. tenuior, 18. tetrapla, 19. triandra, 6 . undulata, 5 . vacciniifolia, 25. venulosa, 25. viminalis, 10 . vitellina, 4. Weigeliana, 19. Woolgariana, 8.

\section{Populus Linn. Poplar.}

1. P. alba (L.) ; 1.-buds downy, 1. roundish-cordate angularly toothed cottony and snowy-white beneath, 1 . of the young shoots cordate palmately 5-lobed, stig. 2 linear bifid crosslike (yellow). -E. B. 1618. - With suckers. L. generally lobed. Catkin- 
scales notched at the end.-Damp woods. T. IV. White Poplar. Abele.

2. P. canescens $(\mathrm{Sm}$.$) ; 1.-buds downy not viscous, l. roundish$ angularly toothed cottony and white beneath, l. of young shoots cordate-ovate undivided, stig. 2 wedgeshaped 3-4-lobed (purple).-E. B. 1619.-With suckers. L. not lobed, except occasionally the youngest. Catkin-scales deeply cut at the end.Damp woods. T. IV. Gray Poplar.

3. P. tremula (L.) ; 1.-buds glabrous slightly viscous, l. nearly round acute serrate glabrous on both sides, young l. slightly downy, stig. 2 bifid erect. - E. B. 1909.-A rather large tree, with suckers. Ped. laterally compressed. Catkin-scales deeply palmately cut.-Woods. T. III. IV. Aspen.

4. P. nigra (L.); l. triangular acuminate serrate glabrous, "catkins lax cylindrical, stig. 2 roundish 2 -lobed."-E. B. 1910. -A large tree without suckers. L. remarkably triangular. Young shoots glabrous. Catkin-scales palmately cut, glabrous.-Damp places, river-banks. T. III. Black Poplar.

\section{Tribe II. Myricea.}

3. Myrica Linn. Sweet Gale.

1. M. Gale (L.) ; 1. lanceolate broader upwards serrate, st. shrubby.-E. B. 562.--Height 3-4 feet. Bushy. Catkins sessile, erect. Fr. with resinous glands. L. fragrant when bruised. -Bogs. Sh. V.

\section{Tribe III. Betulinea.}

\section{Betula Linn. Birch.}

1. B. alba (L.); 1. rhomboid-triangular doubly serrate abruptly acuminate, scales of the fem.catkins 3-lobed, lateral lobes falcatereflexed, fr. obovate-elliptical.-E. B. 2198 (upper fig.). B. alba Koch. B. odorata R. xii. 626. B. verrucosa Fries!-L. usually glabrous often covered with resinous spots above, always having a manifest tendency to a rhomboidal form. Young shoots mostly with resinous tubercles. Stip. ovate-lanceolate, acute, thrice as long as broad, circinate ; sides not deflexed. Buds conical. Young twigs often very long and pendulous. The catkin-scales distinguish this from the next; the shape of the l. also is different.Rather common. T. IV. V. White Birch.

2. B. glutinosa (Fries!); l. rhomboid-ovate or cordate unequally serrate acute, scales of the fem. catkins 3-lobed, lateral lobes ascending, fr. broadly obovate.-E. B. 2198 (lower fig.). $B$. alba R. xii. 623 . B. pubescens Koch.-L. usually glabrous, 
always more or less ovate. Stip. ovate, blunt, twice as long as broad; siles deflexed. Buds ovate. Not so elegant a tree as the preceding and often little more than a bush. Twigs sometimes pendulous. - $\beta$. B. pubescens (Ehrh.); 1. peduncles and young twigs downy.-Common. T. IV. V. Common Birch.

3. B. nana (L.); $l$. roundish crenate glabrous, crenatures obtuse, scales of the fem. catkin digitate-trifid, lobes equal, fr. orbicular with a very narrow membranous margin.-E. B. 2326.A small procumbent shrub. L. minute. Catkins subsessile, small.-Turfy places in the Highlands. Sh. V. Dwarf Birch. S.

\section{Alnus Tourn. Alder.}

1. A. glutinosa (Gaert.); 1. roundish obtuse wavy serrate glutinous rather abrupt with a wedgeshaped base, axils of the veins beneath downy. - E. B. 1508. R. xii. 631. St. 29. 15.Trunk and branches crooked. Male catkins long and pendent; fem. ones short, ovate or oblong, very persistent. A moderately large tree.- $\beta$. incisa; leaves deeply cut. - Wet places and riverbanks. $\beta$. Galloway. S. Dr.Balfour. T. III.

\section{Tribe IV. Cupulifera.}

\section{FAGUS Linn. Beech.}

1. F. sylvatica (L.); l. ovate glabrous obsoletely dentate ciliate on the edges. $-E$. B. 1846. $R$. xii. 639.-A large tree.-Woods, particularly on calcareous soils. T. III. IV.

\section{Castanea Tourn. Chestnut.}

$\dagger$ †. C. vulgaris (Lam.); l. oblong-lanceolate acuminate mucronate-serrate glabrous on each side.-Fagus Sm., E. B. 886. $R$. xii. 640.-Height 50-80 feet. A magnificent tree. A doubtful native, often planted. T. V. Swcet Chestnut.

E.

\section{Quercus Linn. Oak.}

1. Q. Robur (L.); 1. deciduous stalked obovate-oblong sinuate, lobes blunt, inv. much shorter than the ripe nut its scales adpressed.-a. Q. pedunculatu (Ehrh.) ; young branches glabrous, petioles short, fr.-catkins long-stalked, fr. scattered. E. B. 1342. - . Q. intermedia (D.Don); young branches glabrous, petioles short, l. stellate-downy beneath, fr.-catkins shortly stalked, fr. approximate. Mart. Rust. 11. - . Q. sessiliflora (Sm.); young branches downy, petioles long, l. glabrous beneath, fr.-catkins subsessile, fr. approximate. $\mathscr{E}$. B. 1845 .- It is generally supposed by foresters that there are two species of Oak in Britain. I have failed in learning how to distinguish them.-Woods. T. IV. V. 


\section{Corylus Linn. Hazel.}

1. C. Avellana (L.); stip. oblong obtuse, 1. roundish-cordate acuminate, involucre of the ovoid fr. bellshaped spreading torn at the margin.-E. B. 723.-A shrubby tree. Young twigs hairy and glandular. L. downy beneath. Male catkins long, pendulous. Fem. fl. in ovate buds. Stigmas bright crimson.-Hedges and copses. Sh. III. IV. Hazel Nut.

\section{Carpinus Linn. Hornbeam.}

1. C. Betulus (L.); scales of the fruit 3-parted, segments lanceolate the middle one longest.-E. B. 2032.-A small tree. L. ovate, acute, plaited when young, deeply and sharply doubly serrate.- Damp clayey woods and hedges. T. V.

\section{Subclass II. GYMNOSPERM E.}

Seeds quite naked.

\section{Order LXXVIII. CONIFERA.}

Fl. monœcious or diœcious. Barren fl. of one or more monadelphous stamens, in a deciduous catkin, about a common axis. Anth. of 2 or more lobes bursting outwards, often terminated by a scalelike crest. Fertile fl. usually in cones, sometimes solitary. Ovary spread open in the shape of a scale and placed in the axil of a membranous bract; in the solitary $\mathrm{fl}$. apparently wanting. Ovules naked in pairs on the face of the ovary and inverted; or (in the solitary fl.) erect. Fr. a cone, or solitary naked seed. Testa hard, crustaceous. Embryo in the axis of fleshy albumen. Radicle next the apex. Woody tissue marked with circular disks.

Tribe I. TAXINEAE. Male fl. in catkins. Fem. fl. solitary, naked or bracteated.

1. Taxus. Catkins of male fl. oval, scaly below, flowering at the top. Stam. many. Anth. peltate, 3-8-celled. Fem. fl. scaly below. Style 0. Ovule surrounded at the base by a ring which becomes a fleshy cupshaped disk surrounding the seed.-G. F. G. Monochl. 14.

Tr. II. CUPRESSINEAE. Male fl. in eatkins. Anth. 4-7, inserted on the edge of the subpeltate scales. Fem. fl. few, in a small catkin. Ovules pointing from the axis.

2. Juniperus. Anth. 4-7, 1-celled, inserted on the lower edge of the scales. Scales of the fem. catkin imbricate, lower ones barren. Ovules 3 , surrounded by a 3 -fid fleshy 
involucre formed of the 3 uppermost connate scales of the catkin.-G. F. G. Monochl. 12.

Tr. III. ABIETINE $E$. Fl. in catkins. Anth. 2, l-celled, adnate to the underside of the scales. Fem. $f$. a flat scalelike open ovary in the axil of a membranous scale. Ovules in pairs on the inner face of the ovary, pointing towards the axis.

3. Pinus. Male catkins crowded, racemose. Scales of the cone (carpels) thickened and angular at the end. Seeds with a crustaceous coat, winged.-G. F. G. Monochl. 6.

\section{Tribe I. Taxinea.}

\section{Taxus Linn. Yew.}

1. T. baccata (L.) ; 1. 2-ranked crowded linear acute, fl. axillary sessile.-E. B. 746.-A low tree, trunk often attaining a very considerable bulk. Fr. roundish.- $\beta$. T. fastigiata (Lindl.); 1 . scattered, fr. oblong, branches fastigiate.-Mountainous woods and limestone cliffs. $\beta$. North of Ireland. T. III. IV. Yer. $\beta$. Irish Yew.

\section{Tribe II. Cupressinea.}

\section{Juniperus Linn. Juniper.}

1. J. communis (L.); 1.3 in each whorl spreading linear subulate mucronate keeled exceeding the ripe fruit. $-E$. B. 1100.Fruticose, erect. L. with a broad flat shallow channel above, the keel beneath with a slender furrow. Berries black, tinged with blue, about half the length of the leaves.-Dry hills, especially on a calcareous soil. Sh. V.

2. J. nana (Willd.); 1. 3 in each whorl incurved linear-lanceolate mucronate keeled equalling the ripe fruit.-E. B. S. 2743. -A prostrate shrub with longer berrics and shorter leaves than the last.-Mountains. Sh. V.

\section{Tribe III. Abietinea.}

\section{Prnus Linn. Scotch Fir.}

1. P. sylvestris $($ L.); l. in pairs, young cones stalked recurved ovate-conical, wing thrice as long as the seed.-E. B. 2460.-A lofty tree. Cones referred by the late Prof. Don to P. Mughus (a variety of this species) have been found at considerable depths in the Irish bogs.-Highlands. T. V. VI. 


\section{Class II. MONOCOTYLEDONES.}

Stems destitute of medullary rays, consisting of cellular tissue amongst which the vascular tissue is mixed in bundles, increasing by the addition of new matter within. Leaves mostly alternate and sheathing, with parallel simple veins connected by smaller transverse ones, rarely netveined. Cotyledon one, or if more they are alternate.

\section{Subdivision I. DICTYOGEN E.}

Leaves net-veined, deciduous. Floral envelopes whorled.

\section{Order LXXIX. TRILLIACEÆ.}

Perianth inferior, 6- or 8-parted; in 2 whorls; outer whorl or calyx herbaceous; inner or corolla coloured, or in our plant herbaceous. Stam. 6-10. Anth. linear; filaments subulate. Ovary superior, 3-5-celled. Ovules indefinite, in two rows in each cell. Styles as many as the cells, distinct; stigmas inconspicuous. Fr. succulent, not bursting. Seeds with a leathery skin. Embryo minute, in fleshy albumen.

1. Paris. Perianth subherbaceous, 8-parted; 4 inner divisions narrower than the others. Stam. 8-10. Anth. on the middle of the subulate filament.-G. F. G. Monocot. ii. 58.

\section{Paris Linn. Herb Paris.}

1. P. quadrifolia (L.); 1. usually 4 in a whorl.-E. B. 7.-St. $1 \mathrm{ft}$. high, from the end of a long rlizome, usually with 4 , rarely from 3-6, ovate l. at its summit. Fl. solitary, terminal. Sep. lanceolate. Pet. subulate. Styles 4. Berry 4-celled; cells with 4-8 seeds. No root-leaves.-Damp woods. P.V.

\section{Order LXXX. DIOSCOREACEA.}

Perianth superior, petaloid, 6-parted. Stam. 6, inserted into the base of the segments of the perianth. Anth. bursting inwards. Ovary inferior, 3-celled. Ovules 2 in each cell, erect. 
Style 1. Stigmas 3, reflexed. Fr. baccate, or dry and flat. Embryo minute, quite inclosed in the albumen.

1. Tamus. Perianth bellshaped; limb 5-parted. Male with 6 stamens. Fem. with the perigone adhering to the ovary and persistent. Stam. very short, abortive.

\section{Tamus Linn. Black Bryony.}

1. T. communis (L.); 1. undivided cordate acute.-E. B. 91 . -Diœcious. Root large, thick, fleshy. St. very long, twining. Racemes axillary, on long stalks. Fi. yellowish-green, regular; small. Berry red.-Hedges and thickets. P. V. VI. F.

\section{Subdivision II. FLORID 玉:}

Leaves parallel-reined, persistent. Floral envelopes whorled.

\section{Order LXXXI. HYDROCHARIDACEE.}

Sep. 3, herbaceous. Pet. 3, regular, coloured. Stam. epigynous. Ovary solitary, inferior; placentas parietal, sometimes projecting into the centre of the ovary. Stigmas 3-6. Fr. dry, or succulent, not bursting, 1- or spuriously many-celled. Seeds many. Albumen 0. Embryo straight, cylindrical.

1. Hydrocharis. Diøcious. Cal.3-parted. Pet.3. Male with $9-12$ stamens in 3 rows surrounding 3 abortive styles. Fem. with 3 abortive filaments and 3 fleshy scales surrounding the 6 deeply bifid styles. Caps. 6-celled, many-seeded.

2. Stratiotes. Diøcious. Cal. 3-parted. Pet. 3. Male with 12 or more stamens surrounded by many abortive ones. Fem. with 6 deeply bifid styles Berry 6-celled, manyseeded.

3. Avacharis. Diœcious. Cal.3-parted. Pet. 3. "Male. Sep. ovate-oblong. Pet. linear or none. Stam.9; filaments combined into a column below." Fem. with a long filiform tube, 3 abortive filaments and ligulate stigmas. Caps. 1celled, few-seeded.

\section{Hydrocharis Linn. Frog-bit.}

1. H. Morsus-rance (L.).-E. B. 808. St. 44. 16. R. vii. 62.Floating. Creeping. L. stalked, roundish-reniform, entire. Fl. white, delicate, springing from a pellucid membranous sheath. Seeds covered with beautiful prominent spirally twisted cells.-Ponds and ditches. P. VII. VIII. 


\section{Stratiotes Linn. Water Soldier.}

1. S. aloides (L.) ; 1. swordshaped-triangular ciliate-spinous. $-E$. B. 379. R. vii. 61 . - Creeping extensively in the mud. L. many, rigid like those of an Aloe. Stalk compressed, 5 or 6 in. high, with 2 l. near its summit. Fl. white, delicate. The plant rises to the surface of the water to flower and sinks again afterwards. - Fen-ditches in the east of England; naturalized in Scotland. P. VII.

\section{Anacharis Rich. Water Thyme.}

*1. A. Alsinastrum (Bab.); 1.3 in a whorl oval-oblong blunt serrulate, fem. fl. with a tubular bifid spath many times longer than the sessile germen, sep. and pet. broad nearly equal, stigmas reflexed.-A. N. H. Ser. 2. i. t. 8.-St. long, branching, whorls of leaves many, close together. Fl. subtended by a leaflike bract placed within the whorl of leaves, very small, but with a very long tube. Sep. tinged with green and pink externally, incurved, hooded. Pet. flat, diaphanous, recurved, oblong. Filaments at first curved outwards, their points placed under the hood of the sepals, afterwards erect, linear, blunt, diaphanous. Anth. 0 . Stigmas recurved, linear, or deeply bifid. Sep. pet. and stigmas of about equal length. Style adnate on 3 sides to the tube. Male fl. unknown in England.-In water. Probably introduced from America where the same or closely allied species are found. Dunse Castle. Whiteadder River. S. Canals and rivers in England. P. VII.-IX. $\quad$ E. S.

\section{Order LXXXII. ORCHIDACEÆ.}

Sep. 3, usually coloured. Pet. 3, 2 above, 1 below (lip) frequently lobed and spurred and unlike the others. Stam. 3, united in a central column, 2 lateral abortive, or (in Cypripedium) the middle one abortive. Pollen powdery or adhering in masses. Ovary 1-celled, inferior, with 3 parietal placentas. Style forming part of the column with the stamens; stigma a viscid space in front of the column. Caps. 3-valved. Seeds very many, minute. Testa loose, netted.

Tribe I. OPHRYDINEAE. Anther wholly adnate to the column. Pollen-masses in divisible lobes which are indefinite in number and waxy, stalked.-Root with 2 fleshy entire or palmate knobs below the fibres.

* Cells of the anther with a rostellate process between their bases.

1. Orchis. Perianth ringent, hooded. Lip 3-lobed, spurred. Glands of the stalks of the pollen-masses in a common pouch. 
2. Gymnadenia. Glands of the pollen-masses withunt a pouch. Otherwise like Orchis.

3. Aceras. Lip without a spur. Otherwise like Orchis.

** Cells of the anther without any process between their bases.

4. Ha Benaria. Perianth ringent, hooded. Lip 3-lobed or entire, spurred. Glands of pollen-masses naked.

5. Ophrys. Perianth patent. Lip variously lobed, without a spur. Glands of pollen-masses each in a distinct pouch.

6. Herminium. Perianth bellshaped, segments all erect. Lip 3-lobed, tumid beneath at the base, without a spur. Glands of the stalks of the pollen-masses exserted, naked.

Tr. II. NEOTTIDE $A$. Anther attached by its base, persistent. Pollen-masses granular; granules only in a slight state of cohesion; no stalks. - Root of many fleshy fibres, rarely of 2-4 much thickened ones.

\section{* Stigma rostellated.}

7. Goodyera. Perianth ringent. Lip saccate at the base, entire, included. Stigma subcordate. Rostellum erect, bipartite, with a large squarish appendage between its slender segments.

8. Spiranthes. Perianth ringent. Lip channeled, clawed, fringed. Stigma roundish. Rostellum straight, bifid, with an elongate linear appendage between its points.

9. Listera. Perianth ringent. Lip deflexed, 2-lobed. Stigma transverse. Rostellum long, entire, acute, with a minute globose appendage at its somewhat reflexed apex. Column very short.

10. Neotria. Perianth hooded. Lip deflexed, 2-lobed, saccate at the base. Stigma transverse. Rostellum flat, broad, prominent, entire, without an appendage. Column long.

11. Epipactis. Perianth patent. Lip interrupted; the basal division concave ; terminal one(label) larger with 2 projecting plates at its base above. Stigma nearly square. Rostellum short, terminated by a globose appendage. Anth. terminal, erect, sessile, 2-celled; cells without septa. Column short. Germen straight, on a twisted stalk.

$$
\text { ** Stigma without a rostellum. }
$$

12. Cephalanthera. Perianth converging (in C. rubra spreading). Lip interrupted, the basal division saccate, 
jointed to the recurved label. Stigma transverse. Anth. terminal, erect, moveable, shortly and thickly stalked, 2celled; cells with imperfect septa. Column long. Germen sessile, twisted.

Tr. III. ARETHUSEAE. Anther ultimately free, opercular, deciduous. Pollen in many granules, pulpy or powdery, cohering in 2 stalked masses.-Root (in our plant) of fleshy much branched fibres.

13. Epipogium. Perianth patent. Lip posterior, erect, large, entire, with a small patent lobe on each side of its base. Spur erect, inflated. Anth. tumid, seated in the lobed top of the column. Stigma transverse, tabular. Germen and stalk not twisted.

Tr. IV. MALAXIDE E. Anther terminal, free, usually opercular. Pollen cohering in a definite number of granules and at length waxy and confluent; no stalks.-Root fibrous, with or without a superior bulb.

14. Corallorhiza. Perianth converging. Lip with 2 prominent longitudinal ridges at the base, 3 -lobed; lateral lobes small; middle lobe large, slightly emarginate. Spur short or obsolete. Stigma triangular. Rostellum obsolete, but with a large globose appendage. Anth. terminal, 2celled, opening transversely. Column long. Germen slightly stalked, straight.

15. Malaxis. Perianth patent. Lip posterior, erect, entire, similar to the pet., smaller than the sepals. Spur 0. Stigma rhomboidal. Rostellum short, entire, acute. Anth. terminal, continuous with the short column out of the apex of which it appears as if it was excavated, with 2 imperfect cells. Pollen-masses connected at their apex. Germen upon a twisted stalk.

16. Sturuia. Perianth patent. Lip anterior, erect or oblique, entire, dilated, much larger than the sepals. Spur 0. Stigma roundish. Rostellum obsolete, but with an appendage consisting of 2 tubercles. Anth. terminal, deciduous, moveable like a lid, with 2 distinct cells. Column long. Germen on a twisted stalk:

Tr. V. CYPRIPEDIEAE. Intermediate anther barren petaloid, 2 lateral anthers perfect.

17. Cypripedium. Perianth patent. Lip ventricose, inflated. Column trifid above; the lateral lobes bearing stamens; middle lobe sterile, dilated. Two lower (lateral) sepals combined. Germen straight. 


\section{Tribe I. Ophrydinea.}

\section{OrChis Linn. Orchis.}

* Glands of the pollen-masses separate, lip erect in astivation.

+ Bracts mostly 1-veined, root-knobs undivided.

$\ddagger$ Lip 3-lobed, lobes broad and short.

1. O. Morio (L.); lip crenulate, middle lohe truncate-emarginate, spur ascending subclavate rather shorter than the germen, sep. and pet. obtuse connivent, anth. obovate rather acute.-E.B. 2059. R. xiii. 363. - St. 6-12 in. high. L. lanceolate, lower spreading, upper adpressed. Fl. few, in a lax spike, purple; sep. (rarely patent) and pet. marked with green veins, converging so as to form a sort of helmet; lip pale in the middle, spotted with purple. Fl. sometimes white.-Meadows and pastures. P. V. VI. Green-winged Meadow Orchis. E. I.

2. O. mascula (L.); lip crenate, middle lobe emarginate, spur ascending rather longer than the germen, sep. acute, 2 outer reflexed upwards, pet. converging, anth. obcordate apiculate.E. B. 631. $R$. xiii. 390.-St. a foot high. L. mostly radical, elliptic-lanceolate, usually spotted with purple. Lowest bract often 3-veined. Fl. in a lax spike, purple; centre of the lip whitish at the base, spotted and downy. Sep. and pet. veinless. -When the sep. and pet. are very acute and the plant luxuriant it is the O. speciosa Host.-Woods and pastures. P. V. Early purple Orchis.

\# Lip 3-lobed, middle lobe dilated bifid and often with an intermediate tooth (that is, pinnately 4-lobed).

3. O. purpurea (Huds.); lip with raised rough red points, basal lobes linear-oblong, term. lobes broader and shorter with an interm. tooth, spur about $\frac{1}{2}$ as long as the germen, sep. connivent into an ovate helmet including the pet., bracts minute.$R$. xiii. 378. O. fusca Jacq. O. militaris Sm., E. B. 16.-St. l-2 ft. high. L. ovate-oblong, obtuse. Fl. in a rather dense spike; helmet dark purple, variegated; lip paler.-Chalky bushy hills in Kent. P. V.

E.

4. O. militaris (L.); lip with raised rough red points, basal lobes linear, term. lobes broader and shorter with an interm. tooth, spur about $\frac{1}{2}$ as long as the germen, sep. comnivent into an ovate-lanceolate helmet including the pet., bracts minute.E.B.S. 2675. R. xiii. 376.-Smaller than the preceding. Helmet ash-coloured or pale purple. Lip purple, white in the middle, 
spotted, with a linear space between the pairs of lobes.-Chalky hills. Berks., Oxf., Bucks., Herts. P. V.

5. O. Simia (Lam.); lobes of lip all long narrow 1-veined linear with an interm. setaceous tooth, spur $\frac{1}{2}$ as long as the germen, sep. connivent into an ovate-lanceolate helmet including the pet., bracts minute.-O. tephrosanthos E. B. 1873 . R. xiii. 373.-More slender than the preceding. Helmet dark purplish. Lip with remarkably slender segments, dark purple, with or without small rough raised points; a linear space between the pairs of lobes which are about equal in length.-Chalky hills in Berks., Oxf., and Kent. P. V.

E.

6. O. ustulata (L.); lobes of lip linear-oblong, spur $\frac{1}{3}$ the length of the germen, sep. connivent into a roundish helmet including the pet., bracts long.-E. B. 18. R. xiii. 368.-St. 4-6 in. high. L. lanceolate, acute. Spike oblong, dense. Fl. small, many. Helmet dark purple. Pet. linear-lanceolate, obtuse. Lip white with purple spots.-Calcareous hills. P. VI. E.

† Bracts with 3 or more veins, root-knobs undivided.

[7. O. laxiflora (Lam.); lip 3-lobed, lateral lobes rounded and crenulate in front longer than the truncate slightly emarginate interm. lobe, spur shorter than the germen cylindrical, 2 lateral sep. reflexed upwards, pet. connivent, anth. obcordate apiculate. -E. B. S. 2828. $R$. xiii. 393.-St. 1-2 feet high, round, angular and rough upwards. L. lanceolate or linear-lanceolate. Bracts 3-5-veined. Spike long, lax. Fl. bright purple.-Wet meadows and bogs in Jersey and Guernsey. P. V. VI.]

$+\dagger+$ Bracts with 3 or more veins, root-knobs palmate.

8. O. maculata (L.); lip 3-lobed flat crenate, spur subulate shorter than the germen, 3 sep. patent, pet. connivent, st. solid. $-E$. B. 632. R. xiii. 407.-St. about a foot high. L. usually spotted with purple, lower obtuse or rarely acute, upper linearlanceolate resembling the bracts. Spike ovate, afterwards elongate; lower bracts exceeding the germen, upper equalling it. Fl. pale purple, more or less streaked with purple. Lateral veins of bracts inconspicuous. Middle sep. with a flat acute point. Lip usually flat, deeply 3-lobed, lateral lobes rounded, middle lobe longer and narrower.-Damp pastures and heaths. P. V. VI. Spotted palmate Orchis.

9. O. latifolia (L.); lip obscurely 3-lobed its sides reflexed crenate, spur subulate shorter than the germen, two lateral sep. patent, middle sep. and pet. connivent, st. hollow, $l$. lanceolate acute.-E. B. 2308. R. xiii. 402.-About a foot high. L. seldom spotted, spreading, lowest oblong and blunt. Lower bracts 
exceeding the flowers. Middle sep. usually hooded at the end. - Marshes and damp meadows. P. VI. Marsh Orchis.

10. O. incarnata (L.); lip obscurely 3 -lobed its sides reflexed crenate, spur subulate shorter than the germen, two lateral sep. patent, middle sep. and pet. connivent, st. hollow, $l$. narrowed from a broad base hooded at the end.-R. xiii. 397.-L. erect and approaching the stem, hooded at the end. Bracts all usually exceeding the flowers. Middle sep. hooded. $-\beta$. O. angustifolia (R.) ; l. erect-patent linear-lanceolate, upper l. erect, lower bracts equalling the flowers upper ones shorter. R. xiii. 394. $O$. Traunsteineri Koch.-Marshes. P. VI.

** Glands of the pollen-masses united, root-knobs undivided. Anacamptis Rich.

$+\mathrm{Lip}$ erect in æstivation.

11. 0 . pyramidalis (L.); lip with 3 equal lobes and 2 tubercles at the base above, lobes oblong truncate, middle lobe sometimes emarginate, spur filiform longer than the germen, lateral sep. ovate-lanceolate acute spreading, bracts 3 -veined.-E. $\boldsymbol{B}$. 110. - St. 12-18 in. high. L. linear-lanceolate, acute. Spike pyramidal, afterwards cylindrical. Fl. rose-purple, sometimes white.-Calcareous pastures. P. VII. Pyramidal Orchis.

\section{† Lip spiral in æstivation. Himantoglossum Spr.}

12. O. hircina (Scop.); lip 3-parted downy, segments linear, middle one very long twisted, lateral much shorter wavy, spur very short. -E. B. 34. R. xiii. 359. 360.-St. $2-3$ feet high. "Cal. green, spotted with dull purple internally." Lip purplish white and spotted at the base.-Bushy chalk hills. Kent. Surrey. Gt. Glenham, Suff.! P. V. Lizard Orchis. E.

\section{Gymnadenia $R, B r$.}

1. G. conopsea (R. Br.); lip 3-lobed, lobes equal entire obtuse, lateral sep. spreading, spur filiform twice as long as the germen, root-knobs palmate.-Orchis Sm., E.B.10.-St. a foot high. L. linear-lanceolate. Spike cylindrical, elongated. Bracts 3-veined. Fl. rose-purple, fragrant. Pollen-cells open in front and below, stopped below by oblong glutinous valves quite distinct from the stigma, and to the broader ends of which the glands of the pollen-masses are attached.-Hilly pastures. P. VI. VII.

2. G. albida (Rich.); lip 3-lobed, lobes unequal entire, middle lobe longest and broadest, sep. and lateral pet. connivent, spur much shorter than the germen, root-knobs clustered.-Habenaria R. Br. Orchis Sm., E. B. 505. Peristylus Lindl.-St. 6-12 in. 
high. L. oblong, obtuse ; upper lanceolate, acute. Spike elongated, cylindrical, dense. Bracts 3-veined. Fl. small, yellowishwhite, fragrant.-Mountain pastures. P. VI. VII.

\section{Aceras $R$. Br.}

1. A. anthropophora (R. Br.) ; lip 3-parted, segments linearfiliform, middle one bifid and often with an intermediate tooth. -E. B. 29. R. xiii. 357.-Root-knobs ovate. Height 8-12 in. Spike long, lax. Fl. greenish-yellow. Sep. ovate, acute, connivent, margined with purple, including the linear-lanceolate obtuse petals.-Dry chalky places. P. VI.

E.

\section{Habenaria $\boldsymbol{R} \cdot \boldsymbol{B r}$. Frog Orchis.}

* Spur very short, usually inflated. Coeloglossum Hartm.

1. H. viridis (R. Br.) ; spur 2-lobed, lip linear flat 3-pointed middle point the shortest.-Orchis Sm., E. B. 94. R. xiii. 434. Peristylus Lindl.-Lip with 3 tubercles at its base, 1 central, 2 lateral. Stigma oblong, slightly emarginate above. Glands of the pollen-masses connected by an elevated transverse line. Sep. and pet. connivent. Root-knobs palmate. Fl. green, lip browner. St. 6-8 in. high.-Pastures. P. VI. VII. Frog Orchis.

\section{** Spur slender. Platanthera Rich. Butterfly Orchis.}

2. H. bifolia (R. Br.) ; spur twice as long as the germen, lip linear entire, pet. connivent obtuse, anth. oblong truncate its cells parallel.-E. B. S. 2806. R. xiii. 429.-About a foot high. Root1. usually 2, elliptical. Stem-l. small, lanceolate, resembling the bracts. Spike slender. Fl. white. Central line between the cells of the anther a furrow in front and a keel behind. Stigma truncate, emarginate with pointed lobes.-Heathy places. $P$. VI. VII.

3. H. chlorantha (Bab.); spur twice as long as the germen, lip linear entire, pet. connivent obtuse, anth. truncate its cells twice as distant at the base as at the top.-Orchis bifolia Sm., $E$. B. 22. $R$. xiii. 430.-Usually taller and stouter than the preceding. Spike usually lax, but sometimes dense. Fl. larger. Central line between the cells of the anther a prominent ridge in front and a groove behind. Space between the bases of the anth.-cells usually, not always, spread open. Stigma very broad, slightly pointed in the middle.-Moist woods and thickets. P. V. VI.

\section{Ophrys Linn.}

1. O. apifera (Huds.); lip tumid 5-lobed, 2 lower lobes prominent and with a hairy base, 2 intermediate reflexed truncate, 
terminal acute long reflexed, anth. with a hooked point, pet. oblong bluntish downy.-E. B. 383. R. xiii. 457.-About a foot high. Fl. few, large, rather distant. Sep. whitish, tinged with purple. Lip velvety, brown variegated with yellow. "All the lobes of the lip sometimes reflexed, interm. overlapping term. one."-On calcareous soils. P. VI. VII. Bee Orchis. E. I.

2. O. arachnites (Reichard); lip somewhat tumid entire or with 4 shallow marginal lobes and a terminal inflexed flat rather heartshaped appendage, anth. with a straight or hooked point, pet. deltoid downy.-E. B. S. 2596. R. xiii.461.-Sep. pinkish. Lip velvety, dark purple, variegated with yellow; appendage green, never reflexed.-Chalk downs. Folkestone and Sittingbourne, Kent. P. IV.-VI. Late Spider Orchis. E.

3. O. aranifera (Huds.); lip tumid obscurely 3 -lobed, middle lobe large emarginate without an appendage, anth. acute, pet. linear glabrous. - E. B. 65. R. xiii. 449.-Smaller than the two preceding and with fewer flowers. Sep. green. Pet. green, quite glabrous. Lip deep brown, hairy with paler or yellowish glabrous lines often resembling the Greek letter $\Pi$, entire at the end or notched with a central point. $\beta$. O. fucifera (Sm.); lip usually undivided often with a gland in the notch, pet. scabrous. E. B. S. 2649.-Chalky places. $\beta$. Kent and Sussex. P. IV. V. Spider Orchis.

E.

4. O. muscifera (Huds.); lip oblong trifid with a broad pale spot in the centre, middle lobe long bifid, anth. short obtuse, pet. filiform.-E. B. 64. R. xiii. 447. St. 40. 15.-Slender, about a foot high. Sep. green. Lip brownish-purple ; central spot subquadrate, bluish. Pet. very narrow, purple.-Damp calcareous thickets and pastures. P. V. VI. Fly Orchis.

\section{Herminium $R$. Br. Musk Orchis.}

1. H. Monorchis (R. Br.) ; lip 3-lobed, central lobe longest, pet. with a lobe on each side.-E. B. 71.-Root-knobs very unequal and distant. L. usually 2. St. about 6 in. high. Sep. ovate, greenish. Spike dense, slender.-Calcareous soil in the south. P. VI. VII.

\section{Tribe II. Neottidea.}

7. Goodyera $R . B r$.

1. G. repens (R. Br.); l. ovate stalked netted, sep. pet. and lip ovate-lanceolate.-E. B. $289 .-$ St. $6-8$ in. high, bearing linear adpressed bracts. Root creeping. Whole upper part of the plant covered with minute stalked glands. L. netted with brown.-Fir forests of the north. P. VIII. 


\section{Spiranthes Rich. Lady's Tresses.}

1. S. autumnalis (Rich.) ; root-fibres few ovate-oblong thick, root-l. ovate-oblong in a lateral cluster, stem-l. like bracts, spike dense.-E. B. 541. Neottia Sm.-St. 4-6 in. high. Spike spiral. Fl. greenish-white. Column and operculum acute ; an obtuse ovate membranous process between them on each side.Dry calcareous and gravelly places. P. VIII. IX. E. I.

2. S. astivalis (Rich.) ; root-fibres few long cylindrical, rootl. oblong-lanceolate round the base of the st., stem-l. narrowly lanceolate, spike lax.-E.B.S.2817.-Spike spiral. Fl. with a larger lip. Column and operculum acute ; the interm. processes lanceolate acute.-Bogs. Between Lyndhurst and Christchurch, Hants. Wire Forest, Worcest. St. Owen's Pond, Jersey. P. VII. VIII.

3. S. cernua (Rich.); root-fibres few long-cylindrical, root-l. linear-lanceolate, stem-1. triangular-lanceolate surrounding the base of the st., bracts shorter than the fl., spike dense 3-ranked, sep. and pet. equal obtuse adhering together, lip blunt spathulate.-Linn. Trans. xix. t. 32. Neottia gemmipara Sm.-Spike about $1 \frac{1}{2}$ in. long. Fl. fragrant.-Castleton Bearhaven, Co. Cork. P. VIII. IX.

\section{Listera $R . B r$. Tway-blade.}

1. L. ovata (R. Br.); l. 2 opposite ovate, lip bifid, column with a crest which includes the anther. $-E$. B. 1548. St.29. 14. -St. $1 \mathrm{ft}$. high. Spike long, very lax. Fl. small, greenish. L. large.-Woods and pastures. P. V. VI. Tway-blade.

2. L. cordata (R. Br.); 1. 2 opposite cordate, lip 4-lobed, column without a crest. $-E$. B. 358.-Height $3-5$ in. St. slender. Fl. very small, in a lax spike, greenish. Lip with 2 basal and 2 terminal linear lobes.-Turfy mountain moors. P. VI.-VIII.

\section{Neоtтia Linn. Bird's-nest.}

1. N. Nidus-avis (Rich.).-E. B. 48. Listera Hook., Sm.Whole plant pale reddish-brown. Root formed of many short thick fleshy fibres from the extremities of which the young plants are produced. (See Leight. Fl. Shrop. 434.) St. a foot high, with sheathing brown scales. L. none. Spikes dense, cylindrical, many-flowered. Lip linear-oblong with 2 spreading lobes.This is the original Neottia of Linnæus. Act. Ups. 1740, p. 33. - Shady woods. P.? VI. 


\section{Epipactis Rich.}

1. E. latifolia (All.); 1. broadly ovate exceeding the joints, upper 1. ovate-oblong, lower bracts exceeding the fl., label roundish-cordate with a small recurved point falling short of the broadly ovate sep. and pet., basal hunches smooth.-E. B. 269. - L. ovate, very broad, the very uppermost sometimes lanceolate-attenuate; lowermost leafless sheaths close. Lower bracts leaflike, lanceolate, attenuate. Fl. green with the lip purple, sometimes all purple. Peduncle shorter than the downy germen. Label of the lip broader than long, crenate. In a slender form of this plant the upper 1 . are lanceolate, label cordate blunt with a minute apiculus, and sep. ovate-lanceolate.-Mountain woods. P. VII. VIII.

2. E. media (Fries); l. ovate-oblong the upper ones lanceolate acute, lower bracts exceeding the $\mathrm{fl}$. and fr., label entire triangular-cordate acute equalling the lanceolate sep. and pet., basal hunches plicate-1ugose.- Narrower and longer in all its parts than E. latifolia. Only the very lowest 1 . ovate, intermediate lanceolate, upper l. lanceolate-attenuate and merging gradually into the linear-lanceolate bracts; sheaths funnelshaped. Fl. green tinged with purple. Peduncles shorter than the downy germen. Label longer than broad, crenate.- $\beta$. E. purpurata (Sm.); 1. ovate lanceolate the upper ones narrower, label falling short of the ovate-lanceolate sep. and pet., hunches plicate-crenate. E. B. S. 2775 . R. xiii. 486. Fl. "yellow-green tinged with pink." St. and l. much tinged with purple. Peduncle shorter than the downy germen. Label longer than broad, entire, exactly like that of $E$. media but with a more attenuate point.-Woods. Salop. Mátlock. Abberley, Wors. $\beta$. Woburn. Reigate. Crawley, Suss. P. VIII. E. I.

3. E. ovatis (Bab.); l.ovate-oblong acute the upper ones lanceolate, 1 or 2 lowest bracts exceeding the fl. but falling short of the fr., label transversely oval mucronate equalling the ovate acute sep. and pet., basal hunches plicate-rugose.-E. B.S. 2884. Helleborine \&c. No. 2. Ray. 383.-L. small; sheaths funnelshaped, rather close. Bracts all much smaller than even the uppermost leaf. Fl. varying from a dark yellow to blackishred, peduncle shorter than the downy germen. Label transversely oval, crenate, with a small acute point, and elevated folded and tubercularly crenate hunches above. St. 6-18 in. high.Settle, Yorkshire. Little Doward Hill, Herefordshire. Ormes Head. P. VII.

4. E. palustris (Sw.); l. lanceolate, bracts falling short of the somewhat drooping fl., label roundish obtuse crenate equalling the perianth.-E.B.270.-St. 12-18 in. high. Cal. purplish- 
green, pet. and lip white tinged with purple.-Moist places, not rare. P. VII. VIII.

\section{Cephalanthera Rich.}

1. C. grandiflora (Bab.); 1. ovate or ovate-lanceolate, bracts exceeding the glabrous germen, lip obtuse included.-E. B. 271. C. pallens Koch.-Fl. white; lip marked with several elevated longitudinal lines. Sep. erect, blunt.-Woods, usually on a caleareous soil. P. VI.

E. I.

2. C. ensifolia (Rich.); 1. lanceolate, bracts much falling short of the glabrous germen, lip obtuse included.-E. B. 494.-Fl. white; lip with several elevated white lines and a yellow spot in front. Outer sep. acute.-Woods, rare. P. V. VI.

3. C. rubra (Rich.); l. lanceolate acute, bracts exceeding the downy germen, lip acute equalling the pet. - E. B. 437. Epipactis Sm.-Fl. purple; lip white with a purple margin, marked with many wavy longitudinal lines.-Woods, very rare. "Bank sloping to the south of Hamptou Common, Gloucestershire." Sm. P. VI. VII.

E.

\section{Tribe III. Arethusea.}

\section{Epipogium $G m$.}

1. E. aphyllum (Sw.).-R. xiii.468. St. 18. 16.-St. 3-7 in. high, sheathed. L. none. Sep. and pet. narrowly lanceolate, acute, flavescent. Middle lobe of lip ovate, furrowed, white with 4 rows of purple tubercles. Spur very thick. Column short, dilated above the stigma to receive the base of the anther. Appendage triangular.-Damp woods. Tedstone Delamere, Herefordshire. Rev.W.A. Smith. P. VIII.

E.

\section{Tribe IV. Malaxidea.}

\section{Corallorhiza Hall.}

1. C. innata (R. Br.); spur very short or wanting.-E. B. 1547.- Root of thick fleshy much branched fibres. Spike of few yellowish flowers. Sep. and pet. lanceolate, acute. Lip oblong, white, with a few purple spots, sometimes with 3 equal lobes. $\frac{-}{\text { s. }}$ Boggy woods, rare. P. VII.

S.

\section{Malaxis Sw.}

1. M. paludosa (Sw.) ; st. with 3-5 oval concave leaves, lip concave acute. - E. B. $72 .-$ St. $1-4$ in. high, 5-edged. Sep. 
ovate, spreading, 2 turning upwards. Lip above, erect, 3-veined, its base surrounding the column. L f fringed at the end with bulbous gemmæ. Forming a small bulbous hybernaculum.This plant and the next rather grow upon the moss as epiphytes than amongst it.-Spongy bogs. P. VIII. IX.

\section{Sturmia Reich.}

1. S. Loeselii (R.); 1. oblong-lanceolate, st. triangular, lip obovate exceeding the petals.-Malaxis Sm., E. B. 47. Liparis Rich., Hook., Lindl.-St. $6-10$ in. high. Fl. $6-12$, in a lax spike, yellowish. Sep. lanceolate. Pet. linear. Hybernaculum large, ovate, inclosed in the whitish sheaths of the decayed leaves. An epiphyte?-Liparis is the name of a genus of insects, and also of fish. I follow Koch in adopting Sturmia here.Spongy bogs in Norf., Suff., and Camb., very rare. P. VI. E.

\section{Tribe V. Cypripediea.}

\section{Cypripedium Linn. Lady's Slipper.}

1. C. Calceolus (L.); st. leafy, middle lobe of the column nearly ovate obtuse deflexed, lip slightly compressed falling short of the calyx.-E. B. 1.-St. 12-18 in. high, downy, bearing 3 or 4 large ovate pointed leaves. Fl. usually solitary, or 2, large ; sep. $1-1 \frac{1}{2}$ in. long, dark brown; pet. dark brown, rather narrower than sep.; lip 1 in. long, inflated, yellow, netted with darker veins.-Dense woods in the north, very rare. P. V. VI.

\section{Order LXXXIII. IRIDACEA.}

Perianth tubular, 6-parted, petal-like, in 2 often unequal rows. Stam. 3, epigynous, opposite the outer segments of the perianth. Anth. bursting outwards. Ovary inferior, 3-celled. Style 1. Stigmas 3, dilated, often like petals. Caps. 3-celled, 3-valved; valves bearing the dissepiments in the middle. Seeds many. Embryo cylindrical, inclosed in horny or fleshy albumen. Radicle pointing towards the hilum.

1. Sisyrinchium. Perianth 6-cleft; segments nearly equal, patent. Stigmas 3, involute, filiform. Filaments connate below.

2. IRIs. Perianth 6-cleft; alternate segments reflexed. Stigma 3-parted, like petals, covering the stamens.

3. Trichonema. Perianth regular, 6-cleft; segments spreading. Stigmas 3, bifid; lobes slender. 
4. Crocus. Perianth regular, funnelshaped with a long tube ; limb bellshaped. Stigma 3-fid or 3-parted; lobes widening upwards.

\section{Sisyrinchium Linn.}

1. S. anceps (Lam.); scape 2-edged nearly simple nearly leafless, spath about 4-flowered "longer than the flowers," segments of perianth emarginate mucronate.-Redoute Lil. v. 282.-St. about 1 foot high. L. grasslike. Spath with lanceolate valves, falling short of the $\mathrm{fl}$. in my Irish specimens. Perianth blue; segments narrowed below.-Woods near Woodford, Galway. Mr. Jas. Lynam. P. VII.

\section{Iris Linn. Flag.}

1. I. Pseud-acorus (L.); 1. swordshaped, st. roundish, perianth beardless its inner segments narrower and falling short of the stigmas.-E. B. 578. R. ix. 344.-Fl. yellow. Caps. oblong, trigonous, apiculate.-Wet places. P. VI. VII. Yellow Flag.

2. I. fxtidissima (L.) ; 1. swordshaped, st. compressed, perianth beardless its inner segments about equalling the stigmas. -E. B. 596. R. ix. 347.- Herb green, not glaucous, yielding an unpleasant smell when bruised. Fl. lead-coloured or bluish, rarely yellow.-Woods and thickets. P. V.-VII. Gladdon.

[*I. tuberosa (L.); l tetragonal, segments of the perianth acute, root tuberous.-Penzance. Cork.-E. B. S. 2818.]

\section{Trichonema $K e r$.}

1. T. Columne (R.); scape 1-flowered usually solitary slightly nodding, l. filiform compressed furrowed recurved, spath exceeding the tube of the cor., style falling short of the stam., stigmas bifid.-E. B. 2549. R.ix. 354. T. Bulbocodium Sm.A small bulbous plant not more than 4 in. high. Fl. pale purple or violet, yellow in the lower part within.-Sandy places. Dawlish Warren, Devon. Jersey and Guernsey. P. III. IV. E.

\section{Crocus Linn.}

* Scapes enveloped in a tubular sheath.

*1. C. vernus (Willd.); 1 . and fl. at the same time, spath simple, throat of the cor. fringed with hairs, stigma shortly 3-fid, lobes erect wedgeshaped jagged at the end, bulb clothed with slender anastomosing fibres.-E. B. 344.-Fl. violet-purple.Near Nottingham; and Mendham, Suff. P. III.

E.

[C. sativus (L.); 1. succeeding the fl., spath double, throat 
bearded, stigma in 3 deep linear divisions drooping, bulb clothed with slender anastomosing fibres.-E. B. 343.-Fl. purple. L. usually appearing just before the $\mathrm{fl}$. fades.-Formerly cultivated near Saffron Walden : not naturalized. P. IX. Saffron.]

2. C. nudiflorus (Sm.); l. succeeding the fl., spath simple, stigma in 3 deeply laciniate divisions erect, bulb with a membranous coat.-E. B. 491. C. speciosus Hook., E. B. S.2752, not Bieb.-L. linear, appearing in March. Fl. purple. Stigmas only a little higher than the anthers, or rising considerably above them.-Meadows. P. IX.

E.

\section{** Scapes naked.}

[C. biflorus (Mill.); l. and fl. at the same time, spath double, stigma longer than the stam. erect deeply trifid, divisions truncate and slightly notched at the end, bulb with a membranous coat.-E.B.S.2645. C. pracox Haw. C. minimus Hook.-Fl. pale lilac with yellow and purple stripes.-In the park (site of old garden) at Barton, Suff. Not indigenous. P. III.]

[C. aureus (Sib.); 1. and fl. together, spath simple, stigma shorter than the stam. shortly 3-fid, segments truncate or slightly notched at the end, bulb coated with compact fibres.- $E$. B. S. 2646.-Fl. yellow.-With the preceding. P. III.]

\section{Order LXXXIV. AMARYLLIDACEA.}

Stam. 6. Anth. bursting inwards. Otherwise like IRIDACEAE.

1. NArcissus. Perianth 6-parted, spreading, with equal segments, and a bellshaped crown within. Stam. alternately shorter, within the crown.

2. Leucojum. Perianth 6-parted, bellshaped, the segments all equal and thickened at their points. Stam. equal.

3. Galantuus. Perianth 6 -parted, 3 outer segments spreading, 3 inner shorter erect emarginate. Stam. equal, subulate.

\section{Narcissus Linn.}

*1. N. biflorus (Curt.); 1. linear obtuse "acutely" $(\mathrm{Sm}$.) "obtusely" (Koch) keeled, scape compressed 2-edged striated 1-2-flowered, crown very short concave crenate at the pale (ultimately white) margin.-E. B. 276. R. ix. 365.-Pet. of a pale sulphur-colour.-Sandy fields in the south. P.IV.V. E. I.

[2. N. poeticus (L.); 1. linear obtuse obtusely keeled, scape compressed 2-edged mostly l-flowered, crown very short concave crenate at the red margin.-E. B. 275. R. ix. 364.-Pet. 
white, broadly ovate, crown yellow.-Heathy open fields on a sandy soil. Norf., Kent. P. V.]

3. N. Pseudo-narcissus (L.); 1. linear obtuse not keeled, scape 2-edged 1-flowered, perianth-segm. scarcely exceeding tube, crown bellshaped crisped at the margin and crenate equalling the perianth, pedicel within the spath short.-E.B. 17. R. ix. 369.-Fl. large, yellow.-Woods and thickets. P. III. IV. Daffodil.

[N. lobularis (Schult.); "perianth-segm. exactly twice as long as tube, crown 6-lobed." Tenby.-N. minor (L.); "crown 6-lobed equalling the perianth, pedicel long." Penrice Castle, Glam. - N. incomparabilis (Curt.); crown erect $\frac{1}{2}$ as long as perianth, otherwise like No. 3. In several places in the south. -These are not native plants.]

\section{Leucojum Linn. Snowflake.}

†1. L. astivum (L.); spath many-flowered, style thickened upwards.-E. B. 621. R. ix. 362.-Bulbous. Height 2-21 feet. Fl. white, drooping; tips greenish. L. broadly linear, keeled. Scape 2-edged.-Wet meadows. P. V.

E.

\section{Galanthus Linn. Snowdrop.}

1. G. nivalis (L.).-E. B. 19. R. ix. 363.-Fl. solitary, white, drooping; inner segments greenish. L. 2, keeled, broadly linear, glaucous. Bulbous.-Thickets. P. II. III.

\section{Order LXXXV. ASPARAGACEA.}

Perianth inferior, petaloid, 6-parted or 4-8-parted. Stam. 6 or $4-8$, inserted into the receptacle or on the perianth. Anth. bursting inwards. Ovary superior, 3-celled. Ovules 1 or many in each cell. Styles 1-3. Fr. succulent, not bursting. Root not bulbous.-In this and the two succeeding Orders I follow Koch, who appears to have paid great attention to them. For figures of the genera see G. F. G. Monocot. ii.

1. Asparagus. Perianth 6-parted, bellshaped, tubular below. Stam. 6. Ovary 3-celled; cells 2-ovuled. Style 1. Stigmas 3, reflexed.-Fl. by abortion dicecious.

2. Convallaria. Perianth bellshaped, 6-parted, deciduous. Ovary 3-celled; cells 2-ovuled. Stigma blunt, trigonous. Berry with 1-seeded cells. Fl. jointed to pedicel.

3. Polygonatum. Perianth tubular, 6-toothed, tardily deciduous. Ovary 3-celled; cells 2-ovuled. Stigma blunt, 
trigonous. Berry with 1-seeded cells. Fl. not jointed to pedicel.

4. Mainantemum. Perianth 4-parted; segments horizontally patent or reflexed, deciduous. Stam.4. Style 1. Stigma blunt. Berry 2-celled; cells 1-seeded.

5. Ruscus. Perianth 6 -parted to the base, persistent. Male with the filaments connected into a tube on the top of which the 3 anth. are placed. Fem: the same, but the anthers barren. Style 1. Stigmas capitate. Berry 3-celled; cells 2-seeded.

\section{Asparagus Linn.}

1. A. officinalis (L.); st. herbaceous mostly erect without spines branched, l. fasciculated terete flexible setaceous. $-E . B$. 339. - Root creeping. Stems many, scaly, erect, or rarely procumbent, scarcely more than a foot high (in cultivation 3 feet).-Sea-coast, rare. Kynance Cove, Cornwall. South coast of Anglesea. Giltar Point, Pemb. Gosford Links, Scotl. P. VIII.

E. S.

2. Convallaria Linn. Lily of the Valley.

1. C. majalis (L.).-E. B. 1035. St. 14, 10.-About a foot high. L. 2, ovate-lanceolate, radical. Scape semicylindrical. Fl. racemose, nodding, pure white, globose-bellshaped, fragrant. -Woods and thickets. P. V.

E. S.

\section{Polygonatum Tourn. Solomon's Seal.}

1. P. verticillatum (All.); l. linear-lanceolate whorled, st. erect angular. -E. B. 128. R. x. 435.-St. 2 feet high. L. 3-5 in a whorl. Berries red.-Woods. Den of Rechip and Craighall, Perthshire. Smalesmouth, Northumberland. P. VI. E. S.

2. P. officinale (All.); l. ovate-oblong half clasping glabrous alternate, st.angular, peduncles 1-2-flowered, filaments glabrous. -Convallaria Polygonatum (L.), E.B.280. R. x. 434.-Height $1-1 \frac{1}{2}$ foot. Berry bluish.-Woods, rare. P. V. E.

3. P. multiflorum (All.); l. ovate-oblong half clasping glabrous alternate, st. round, peduncles 1- or many-flowered, filaments downy. - E. B. 279. R. x. 433.-Height 2 feet. Berry bluish. -Woods. P. V. E. S.

\section{Maianthemum Wiggers.}

*1. M. bifolium (DC.); st. with 2 alternate stalked triangularcordate leaves.-Ger. Herb. p. 409. Convallaria L., St. 13. 6. 
R. x. 436. - St. 6-8 in. high. Root filiform. L. very deeply cordate. Raceme terminal, resembling a spike. Fl. small; segments reflexed. "Berry yellow with brown spots."-Woods. Howick, Northumb. (now eradicated). Mr. R. Embleton. Kenwood, Middlesex. Mr. E. Edwards. Dingley Wood, Preston; and Harwood near Blackburn. Gerard. P. V.

E.

\section{Ruscus Linn. Butcher's Broom.}

1. R. aculeatus (L.); l. (flattened shoots) ovate-attenuate very acute rigid bearing the fl. upon the middle of their upper surface, fl. 1 rarely 2 with a flat subulate scarious l-veined bract.-E. B. 560. R. x. 437.-Foliage evergreen. Fl. very minute.-Thickets. Sh. III. IV.

E. S.

\section{Order LXXXVI. LILIACEAE.}

Perianth inferior, petal-like, 6-parted. Stam. 6, inserted into the receptacle or on the perianth. Anth. bursting inwards. Ovary superior, 3-celled. Ovules many in each cell. Style 1. Stigmas 3 or 1 . Fr. dry, capsular, bursting with 3 valves bearing the dissepiment on their middle.-For fig. of genera see G. F. G. Monocot. ii.

Tribe I. TULIPEAE. Leaves of the perianth distinct. Cells of the caps. many-seeded. Seeds flat (in Lloydia angular), placed closely one above another; testa pale or fuscous, not crustaceous.-St. usually more or less leafy. Root bulbous.

1. Tulipa. Perianth-1. 6, without nectaries, deciduous. Anth. erect. Style 0. Stigma 3-lobed. Seeds flat.

2. Fritilllaria. Perianth-l. 6, deciduous; a nectariferous depression at the base of each. Anth. attached above their base. Style 3 -fid at the apex. Seeds flat.

[3. Lilium. Perianth-1. 6, deciduous, spreading or reflexed ; a longitudinal nectariferous furrow at the base of each. Anth. attached above their base. Stigma capitate. Seeds flat.]

4. Lloydia. Perianth-1. 6, persistent, patent. Stam. inserted at the base of perianth. Anth. erect. Style filiform. Stigma trigonous. Seeds angular above, flat beneath.

Tr. II. ASPHODELEAE. Fl. not jointed to their stalks. Leaves of perianth distinct. Cells of the caps. few-seeded. Seeds various in form, usually with a black crustaceous testa. -St. usually leafless. Root bulbous. 
5. Ornithogalum. Perianth-1. 6, spreading, persistent. Stam. on the receptacle and adhering only slightly to the perianth. Anth. incumbent, attached by their backs.-Fl. white or yellow, never blue.

6. Gagea. Perianth-1. 6, spreading, persistent. Stam. adhering to the base of the perianth. Anth. erect.-Fl. corymbose or umbellate.

7. Scilla. Perianth-1. 6, spreading, deciduous. Stam. on the base of the perianth. Anth. incimbent.-Fl. racemed, never white or yellow.

8. Allium. Perianth-1. 6, rather spreading. Stam. at the base of the perianth. Anth. incumbent.-Fl. umbellate. Spath of 1 or 2 leaves.

Tr. III. ANTHERICEAE. Fl. jointed to their stalks. Leaves of perianth slightly connected below. Cells of caps. fewseeded. Seeds various in form.-Root not bulbous.

9. Srmetris. Perianth-1. 6, spreading, deciduous. Stam. on the base of the perianth. Filaments bearded. Arth. incumbent. Caps. 3-celled, 6-seeded.

Tr. IV. HEMEROCALLIDEA. Leaves of the perianth combined below. Cells of the caps. few-seeded. Seeds various in form; testa (in our plants) black.

10. Endymion. Perianth tubular-bellshaped of 6 connivent leaves with reflexed points, combined below. Stam. inserted below the middle of the perianth; filaments decurrent.

11. Muscari. Perianth globose or subcylindrical, narrowed at the mouth, 6-toothed. Stam.inserted at about the middle of the tube; filaments not decurrent.

\section{Tribe I. Tulipea.}

\section{Tulipa Linn. Tulip.}

1. T. sylvestris (L.) ; st. 1-flowered glabrous, fl. at first drooping, inner segments of perianth and base of the stamens bearded. -E. B. 63. St.29.11. R.x. 446.-Fl. yellow, rarely produced in a wild state.-Chalk-pits in the eastern counties. Several places in Scotland. P. IV. V.

E. S.

\section{Fritrllaria Linn. Fritillary.}

1. F. Meleagris $\left(\mathrm{L}_{.}\right)$; st. single-flowered leafy, l. all alternate 
linear-lanceolate.-E. B. 622. St. 18. 4. R. x. 442.-About a foot high. Fl. flesh-coloured with many dark spots, rarely white.-Meadows and pastures in the east and south. P. V. E.

\section{Lilium Linn. Lily.}

[*1. L. Martagon (L.); l. whorled elliptic-lanceolate, st. pubescent-scabrous, fl. nodding, perianth reflexed.-E. B. S. 2799 . R. x. 451.-Height $1-1 \frac{1}{2}$ foot. Fl. violet-flesh-coloured with dark purple spots.-Copses. P. VI. VII. Turk's-cap Lily.] E.

[*2. L. pomponium (L.); 1. scattered linear-lanceolate, fl. nodding, perianth reflexed.-About $1 \mathrm{ft}$. high. Fl. yellow with black dots below.-Between S. Molton and Mollond, Devon.]

\section{Lloydia Salisb.}

1. L. serotina (R.); root-l. semicylindrical, st.-l. dilated below and sheathing, fl. mostly solitary, nectary a transverse plait.E. B. 793. St. 28. 2. R. x. 440. Anthericum Sm.-Height 5 or 6 in. St. and l. springing separately from the root. St.-l. several, short. Fl. white with reddish lines internally.-Welsh mountains, very rare. Snowdon. Glyder Fawr. P. VI. E.

\section{Tribe II. Asphodelea.}

\section{Ornithogalum Linn. Star of Bethlehem.}

†1. O. umbellatum (L.); fl. corymbose, peduncles exceeding the linear-lanceolate bracts, filaments lanceolate simple, 1. linear glabrous.-E. B. 130. R. x. 467.-L. exceeding the stem or filiform and shorter. Height 8-12 in. Fl. white with a broad green longitudinal band externally.-Meadows and pastures. P. V.

E. S.

2. O. pyrenaicum (L.); fl. in an elongated raceme, peduncles at first spreading afterwards erect, bracts lanceolate-acuminate, filaments dilated below with a long point, l. fugacious linear grooved.-E. B. 499.-St. leafless, $2-3$ feet high. Raceme very long. Fl. greenish-white; segments of the perianth variable in breadth. L. withering before the stalk appears, rarely contemporaneous. - Woods. Extremely common near Bath. Sussex. Bedfordshire. P. VI.

E.

*3. O. nutans (L.) ; fl. few in a lax nodding raceme, peduncles falling short of the bracts, filaments flat membranous trifid, the lateral points acute, middle one very short bearing the anther, $L$ linear-lanceolate.-E. B. 1997. Albucea R. x. 473.-Height 
9-12 in. Fl. large, white, greenish externally.-Fields and orchards, rare. P. IV. V.

\section{GaGEA Salisb.}

1. G. lutea (Ker); radical 1. usually solitary linear-lanceolate flat, bracts 2 opposite, peduncles umbellate simple glabrous, segments of the perianth oblong obtuse, bulb ovate solitary.$E . B .21$. R. x. 477 . Ornithogalum L.-St. about 6 in. high, shorter than the leaves. Bracts lanceolate, one often exceeding the yellow flowers. Bulb often inclosing many small round offsets.-Woods and thickets, rare. P. III. IV.

\section{Scrlda Linn. Squill.}

1. S. autumnalis (L.) ; 1. linear many, raceme lax, peduncles ascending, bracts $0 .-E$. B. $78 . \quad R$. x. 463.-Height 4-6 in. Fl. purplish-blue with a green line down the back, in perfection before the 1 . appear.-Dry pastures in the south and west. P. VIII. Autumnal Squill.

2. S. verna (Huds.); l. linear channeled hooded at the end many, raceme few-flowered corymbose, bracts lanceolate as long or longer than the peduncles.-E. B. 23. R. x. 463.-Height 4-5 in. Fl. blue. $L$. as long or longer than the stalk.Western and northern coasts. P. IV. V. Vernal Squill.

[S. bifolia (L.); 1. linear-lanceolate usually only 2 , raceme lax slightly corymbose, ped. erect, bracts $0 .-E$. B. 24. - Said to grow in the west of England. P. IV.]

\section{Allium Linn. Garlic.}

* Stam. alternately broader and 3-pointed, the middle point alone bearing an anther. PoRrum Tourn.

† Stem-leaves flat or keeled, not hollow.

*1. A. Ampeloprasum (L.); st. leafy below, 1. linear, spath long, umbel globose compact, stam. exserted, anther-bearing point of 3-pointed filaments as long as the undivided part, bulb compound of 2-4 divisions. - E. B. 1656.-Bulb with large offsets within its coats. St. 2-6 feet high. L. long, linear. Spath calyptriform, parting at the base, and falling off in one piece before the fl. open; horn 1-2 in. long. Fl. pale purple, the keel of the outer subemarginate segments greenish and roughish. Germen rather globose; nectarial projections at about the middle; lower spaces slightly excavated. Head-bulbs rare, when present small, the size of Peas.-Cliffs on Steep Holmes 
Island in the Severn (remains of former cultivation). Gt. Arran Island, Galway. Mr. Andrews. Cliffs in Guernsey. P. VIII. E. I.

2. A. Babingtonii (Borr.); st. leafy below, 1. acutely keeled, spath long-pointed, umbel loose irreguar with hemispherical bulbs, stam. exserted, anther-hearing point of 3-pointed filaments rather shorter than the undivided part and with an incurved apex when young, bulb compound of few (2) divisions.-E. B. S. 2906. A. Halleri Bab., not G. Don.-St. 4-6 feet high. L. long, linear, broad. Heads large, with many bulbs about as large as a Hazelnut. Spath usually deciduous in two pieces or persistent; horn $1-2$ in. long. Fl. pale reddish-purple, rather few, more conical than in the preceding, only slightly opening; outer segments with a green keel, ovate-oblong, with callous points, edges and back rough with minute pellucid points; inner segments slightly emarginate and without points. Lengthened stalks $1-2$ in. long, bearing secondary heads are usually present. Germen rather conical, nectarial projections below the middle, lower spaces rather deeply excavated.-Roundstone, and S. Isles of Arran plentifully, Galway. Cornwall. P. VIII.

3. A. Scorodoprasum (L.!); st. leafy below, 1. flat, sheaths 2-edged, spath short and broad with a very short point, umbel globose with many spherical small bulbs, stam. included or equalling the perianth, anther-bearing point of 3-pointed filaments shorter than the undivided part or the lateral points, bulb with many purple offsets.-E.B.S. 2905. A. arenarium L.!, Sm.-St. $2-3$ feet high. L. with scabrous margins. Heads small. Fl. few, purple; segments all with a minute apiculus, outer with the edges and keel rough. Head-bulbs deep purple. - Sandy woods and fields in the north. P. VI. VII. E. S.?

\section{+† Stem-leaves hollow.}

4. A. vineale (L.); st. leafy below, $l$. terete slightly channeled above, spath 1-valved short with a slender long point, umbel globose with many bulbs, stam. exserted, anther-bearing point of 3-pointed filaments equalling the undivided part and half as long as the lateral points.-E. B. 1974. R. I. t. 404. A. arenarium Fries.-St. 2 feet high. L. faded at the time of flowering. Heads of few pale rose-coloured fl. with green keels and long stalks. Head-bulbs small, oval, acute, greenish.- $\beta$. A. compactum (Thuil.); umbel without fl., head-bulbs with a leaflike point.-Waste ground and dry fields. $\beta$. is the more common. P. VII. Crow Garlic.

5. A. spharocephalum (L.) ; st. leafy below, 1. subcylindrical channeled above smooth, spath 2-valved short, umbel globose without bulbs, stam. twice as long as the perianth, anther-bearing 
point of 3-pointed filaments as long as the undivided part longer than the lateral points, bulb accompanied by stalked offsets.E. B. S. 2813.-St. 1-2 feet high. L. usually faded before the time of flowering. Heads of many rose-coloured or purple fl.; keels darker and rough.-St. Vincents Rocks, Bristol. Sands in Jersey. P. VII.

** Stam. all simple, not 3-pointed, connected at the base. Spath 2-valved, 1 valve with a long point. St.-l. narrow.

6. A. oleraceum (L.) ; st. leafy below, 1. channeled above ribbed beneath, spath with one of the points very long, umbel with bulbs, stam. equalling or shorter than the perianth.-E. B. 488.-Height $1-2$ feet. L. (of the Bristol plant) thick, fleshy, solid, nearly flat but slightly and broadly channeled above, with 4 ribs beneath. Segments of perianth obtuse.- $\beta$. complanatum (Fries); stam. shorter than the perianth, 1. of equal thickness throughout, curved upwards at the sides so as to appear channeled, with many ribs on each side. Perhaps a distinct species. A. carinatum Sm., E. B. 1658.-Borders of fields. B. Mountains in the north. P. VII. VIII. E. S.

[A. carinatum (L.) has protruded stamens.]

*** Stam. all simple and distinct. Spath 2-valved, short. Leaves hollow.

7. A. Schonoprasum (L.) ; st. leafless or with one leaf, 1. terete or slightly flattened above subulate, spath ovate pointed about equalling the flowers, umbel many-flowered globose without bulbs, stam. simple about half the length of the lanceolate segments of the perianth.-E. B. 2441 . - St. about 6 in. high. L. straight, mostly with even striæ. Pet. lanceolate. Barren bulbs with 2 leaves. Fl. pink. Bulbs forming dense tufts.- $\beta$. A sibiricum (L.); 1. curved and bent downwards with crenulate striæ, pet. lanceolate-attenuate, barren bulbs single-leaved, style longer than the young germen. E. B. S. 2934 . Height 6 in. to 2 feet. Heads large. This plant has retained its characters for several years in Mr. Borrer's garden and is probably a distinct species.Meadows and pastures in mountainous situations. $\beta$. Rocks and cliffs near the sea. Tintagel; between Kynance Cove and Mullion; Cornwall. P. VI. VII. Chives.

**** Stam. all simple. Leaves flat, all radical.

[8. A. triquetrum (L.); st. triquetrous, 1. linear acutely folded and keeled, spath 2-valved about equalling the erect bulbless lax umbel, stam. half as long as the oblong segments of the perianth. 
$-R$. x. 503.-Bulb ovate. L. angularly folded, acute. Segments of perianth white with a slender green midrib.-Hedges in Guernsey. P. V. VI.]

9. A. ursinum (L.); st. naked triangular, 1. stalked ovate-lanceolate, spath 2-valved ovate, umbel level-topped lax bulbless, stam. simple. - E. B. 122.-Bulb slender, oblong. L. few, broad, smooth, bright green. Stalk one, as tall or taller than the leaves. Fl. white. Smelling strongly of garlic when bruised.Damp woods and hedges. P. V. VI. Ramsons.

[A. ambiguum (Sm.); st. terete, l. broadly linear attenuate, umbels few-flowered with a few bulbs, spath 3-4-valved, stam. about half the length of the perianth.-Rochester. Eye Castle Hill, Suff. Not a native. E.B.S. 2803.]

\section{Tribe III. Anthericea.}

\section{Simethis Kunth.}

1. S. bicolor (K.).-E. B. S. 2952.-Root of fleshy fibres. L. linear, flat or a little keeled upwards. St. and l. inclosed in sheathing scales and surrounded by brown fibres. Fl. panicled. Pet. purple without, white within. Seed-stalks thick, white. Seeds black.-Sandy heaths. Near Bournmouth, Dorset. On hills and by sea-side, Derrynane, Kerry. P. V.

\section{Tribe IV. Hemerocallidec.}

10. Endymion Dumort. Blue Bell.

1. E.nutans (Dum.); l. linear, raceme nodding, fl. bellshaped cylindrical, apex of the sep. revolute, bracts 2 .-Scilla $S m ., E$. $B$. 377. Agraphis Link.-Scape about a foot high. Fl. blue, rarely white. Stam. united to the perianth half-way up. L. shorter than the scape.-Woods and thickets. P. V. English Blue-bell.

\section{Muscari Tourn. Grape Hyacinth.}

1. M. racemosum (Mill.); fl. ovate nodding crowded upper ones nearly sessile abortive, 1 . linear flaccid recurved.-Hyacinthus Sm., E. B. 1931.-Scape $1 \mathrm{ft}$. high. FI. dark blue, scented. -Sandy fields. Plentiful near Pakenham, Suffolk. P. V. E.

\section{Order LXXXVII. COLCHICACEÆ.}

Perianth inferior, 6-7-parted. Stam. 6, on the receptacle or 
perianth. Anth. attached below their middle, bursting outwards. Ovaries superior, 1 of 3 cells, or 3 of 1 cell more or less connected. Ovules many. Styles 1-3. Fr. bursting inwards, of 3 separate 1-celled follicles, or more or less combined into a 3-celled septicidal capsule.-See G. F. G. Monocot. ii.

1. Colchicum. Perianth funnelshaped with a very long tube; limb 6-parted, petal-like. Caps. 3, connected throughout, 1-celled, opening at the inner edge, many-seeded.

2. Tofinldia. Perianth 6-leaved. Caps. 3, connected to above the middle, 1-celled, opening at the inner edge, manyseeded.

\section{1. Соцснісum Linn. Meadow Saffron.}

1. C. autumnale (L.); 1. flat lanceolate erect.-E. B. 133.Root large, tuberous. $L$. a foot long and often an inch broad, dark green, smooth. Fl. several, bright purple, radical, with very long tubes; the germen remaining under ground and appearing in the spring with the leaves.-Meadows. P. IX. X.

\section{Tofieldia Huds. Scottish Asphodel.}

1. T. palustris (Huds.); pedicels with a 3-lobed bract at the base but none at the top.-E. B. 536 (not good). T. borealis Wahl. St. 78. 8. - St. 4-8 in. high. L. swordshaped, about 2 in. long, in 2-ranked radical tufts. Fl. in a short dense spike, at first sessile, afterwards slightly stalked. The true plant of Hudson.-Mountain bogs. P. ViI.

\section{Order LXXXVIII. ERIOCAULACEA.}

Fl. capitate, unisexual. Perianth glumaceous, 2-6-parted. Stam. 2-6, if in two rows the inner row most developed. Anth. 2-celled. Ovary superior, 2-3-celled. Ovules solitary, pendulous. Dehiscence of caps. loculicidal. Seeds coated with wings or rows of hairs. Embryo lenticular, on the outside of farinaceous albumen, at the end remote from the hilum.

1. Eriocaulon. Fl. in a compact scaly head. Barren fl. in the centre. Perianth 4-6-fid, the inner segments united nearly to their top. Stam. 4-6. Fertile fl. in the circumference. Perigone deeply 4-parted. Stigmas 2-3. Caps. 2-3-lobed, 2-3-celled; cells 1-seeded. 


\section{Eriocaulon Linn. Pipewort.}

1. E. septangulare (With.); scapes striated exceeding the cellular compressed subulate glabrous l., fl. 4-cleft hairy at the end as well as the scales, stam. 4, caps. 2-celled.-E. B. 733.-Roots of many white jointed fibres. St. varying in height according to the depth of the water, usually with 6 or 8 rarely 7 or 10 angles, each corresponding with a bundle of vessels surrounding a central bundle. Fertile fl. 4-parted nearly to the base ; 2 lateral divisions keeled, compressed, obtuse, fringed, black. Each fl. with a broad blunt black scale in front which is shorter and broader than it.-Peaty pools in Skye and a few of the neighbouring islands. Cunnamara. P. VIII. S. I.

\section{Order LXXXIX. JUNCACE}

Perianth more or less glumaceous, 6-parted. Stam. 6, on the base of the segments; or 3, opposite to the outer series. Anth. 2-celled. Ovary $1-3$-celled, superior. Ovules 1,3 , or many in each cell. Style l, stigmas usually 3. Fr. capsular, 3-valved, loculicidal, sometimes not bursting. Embryo subcylindrical, very minute, within firm albumen, near the hilum.-For fig. of the genera see G. F. G. Monocot. ii. 28. 29. 30.

1. Narthecium. Perianth partly coloured, of 6 linear-lanceolate persistent leaves. Filaments woolly. Style undivided. Stigma simple, obtuse. Caps. pyramidal, 3-celled, 3-valved. Placenta extending only a short distance up inner edge of dissepiment. Seeds with a long filiform appendage at each end.

2. Juncus. Perianth glumaceous, 6-leaved. Filaments glabrous. Style undivided. Stigmas 3, filiform. Caps. 3celled, 3-valved. Seeds attached to the inner edge of the dissepiments.

3. Luzula. Caps. 1-celled, 3-valved, without dissepiments. Seeds 3 , at the base of the cell. Otherwise like Juncus.

\section{Narthecium Huds. Bog Asphodel.}

1. N. ossifragum (Huds.) ; l. linear-swordshaped, pedicels with 1 bract at the base and another above their middle, perianth exceeding the stam. and much falling short of the caps. $-E . B$. 535. St. 78. 3. R. x. 421.-St. $6-8$ in. high, slightly leafy, decumbent and rooting below. L. mostly in radical 2-ranked tufts, half the height of the stem. Cluster continuous. Fl. bright yellow.-Turfy bogs. P. VI. VII. 


\section{Juncus Linn. Rush.}

* Barren and fertile stems subulate with leafy sheaths below. L. long, resembling the stems, or reduced to a mucro. Seeds with a loose testa forming a sack at each end (appendaged).

1. J. maritimus (Sm.); st. naked, 1. radical terete sharppointed, panicle compound erect, segments of perianth equal lanceolate acute equalling the elliptical mucronate capsule.E. B. 1725. R. ix. 402--St. erect, $1-2$ feet high. Panicle long, lax.-Salt marshes, but not very common. P. VII. VIII.

2. J. acutus (L.) ; st. naked, 1. radical terete sharp-pointed, panicle very compound mostly compact, segments of perianth equal half the length of the roundish ovate caps., 3 inner ones obtuse with a membranous border.-E. B. 1614. St. 71.6. $R$. ix. 401.-St. erect, rigid, with a very sharp rigid point, 3-6 feet high. Panicle dense, corymbose. Fr. twice as large as that of the preceding.--Sands on the sea-coast, rare. P.VII.VIII. F. I.

** Barren and fertile stems subulate with sheaths at their bases which are either leafless or bear rudimentary leaves. Seeds with a close testa (not appendaged).

3. J. effusus (L.); st. naked faintly striate soft, pith continuous, pauicle close or diffuse, caps. obovate retuse not apiculate, stam. 3.-E. B. 836. $R$. ix. 413. - Height $1-2$ feet. L. none or reduced to minute slender filaments at the top of sheathing scales. Panicle diffuse, branched; or more or less dense, globose. Anth. oval, short.-Marshy ground. P. VII.

4. J. conglomeratus (L.); st. naked faintly striate soft, pith continuous, panicle close or diffuse, caps. obovate retuse apiculate, stam. 3.-E. B. 835. St. 71. 3. R. ix. 408.-Height $1-2$ feet. $L$. none or reduced to minute slender filaments at the top of the sheathing scales. Panicle globose, dense; or more or less diffuse. Anth. linear.-Marshy ground. P. VII.

5. J. glaucus (Sibth.); st. naked deeply striate rigid, pith interrupted, panicle loose much branched erect, segments of perianth lanceolate-subulate rather exceeding the elliptic-oblong mucronate capsule, stam. 6.-E.B.665. St. 71.5. R. ix. 415. -Panicle ascending, diffuse. Fr. black. St. rigid, attenuate, ylaucous. Sheaths dark. L. none or reduced to minute slender tilaments at the top of the scales. - Wet places. P. VII.

6. J. diffusus (Hoppe); st. naked finely striate rigid, pith continuous, panicle loose much branched crect, segments of perianth lanceolate-subulate exceeding the obovate-obtuse mucronate capsule, stam. 6.-St. 77. 10. R. ix. 414.-Very like the pre- 
ceding, but the caps. much smaller. St. green.-In wet places, rare? $P$. VII. VIII.

E. S.

7. J. balticus (Willd.); st. naked very faintly striate rigid, pith continuous, panicle erect slightly branched, segments of perianth ovate-lanceolate acute, caps. elliptical scarcely trigonous obtuse mucronate.-E. B.S.2621. St.71.2. R. ix. 411.-Root creeping widely. L. none or reduced to very minute points at the top of the sheathing scales.-Distinguished from J. arcticus by its rounded not trigonous capsules; from $J$. glaucus by its farcreeping root, scarcely striated st. and continuous pith.- Sandy and wet sea-coasts. P. VII.

8. J. filiformis (L.); st. naked filiform faintly striate, panicle simple of few (about 7) fl. placed near the middle of the st., segments of perianth lanceolate acute, caps. roundish-obovate obtuse mucronate. $-E$. B. 1175 . St. 36. 10. R. ix. 412.-L. none or as in the preceding plants. St. remarkably slender, about $1 \mathrm{ft}$. high ; small panicles placed very low.-Stony margins of lakes in the north. P. VII.

E. S.

\section{*** No barren stems.}

† Fl. capitate or solitary and terminal. Seeds appendaged.

9. J. castaneus (Sm.); st. bearing $2-3$ channeled $l$., heads terminal solitary or 2 or 3 , segments of perianth elliptic-lanceolate acute half as long as the ovate-oblong pointed trigonous capsules, root creeping.-E. B.900. St. 71. 14. R. ix. 393.-St. 8-12 in. high. Root with lax runners. Caps. chocolate-coloured. Filaments about twice as long as the anthers.-Micaceous mountain bogs at a great elevation, rare. P. VII. VIII. E.? S.

10. J.triglumis (L.) ; st. naked round, l. radical subulate channeled, head solitary terminal of $1-3$ erect $\mathrm{fl}$. usually equalling the membranous bract, segments of the perianth elliptical-oblong obtuse falling rather short of the ovate-oblong obtuse-mucronate caps., root cespitose.-E. B. 899. St. 28. 3. R. ix. 392.Scarcely creeping. St. several from one root, $3-6$ in. high, perfectly round. Caps. chestnut-coloured.-Boggy places on mountains. P. VII. VIII.

E. S.

11. J. biglumis (L.); st. naked channeled on one side, l. radical subulate compressed (not channeled), head solitary terminal of 2 unilateral $\mathrm{fl}$. one of which is stalked and usually falls short of the leaflike bract, segments of perianth oblong-obtuse falling rather short of the turbinate retuse caps., root fibrous.-E. $B$. 898. - St. 2-4 in. high, seldom more than one from each root. Caps. light brown with purple margins.-Boggy spots on mountains, rare. P. VIII.

S. 
12. J. trifidus (L.); st. with 1 leaf on its upper part, basal sheaths awned, upper sheath with a short l., head terminal of $1-3$ fl. with two setaceous leaflike bracts, segments of perianth acute falling short of the rounded elliptical beaked caps., root creeping.-E. B. 1482. St.71.12. R. ix. 394.-St. crowled, erect, slender, $2-6$ in. high. Occasionally the stem-l. is wanting and sometimes it has a second head in its axil. Remarkable for its long setaceous bracts. Perianth and caps. dark brown.-Damp rocky places on mountains. P. VII. VIII.

t十 Flowers in a terminal head, or 2 lieads one above the other, or in panicled heads. Seeds not appendaged.

[13. J. capitatus (Weigel); st. naked erect simple, l. radical filiform, head terminal mostly solitary falling short of the seta('eous bract, segments of the perianth unequal, outer ovate-lanceolate acuminate-aristate twice as long as the truncate apiculate caps., stam. 3.-E. B. S. 2644.-Plant 1-4 in. high. L. half as long as the stems. Heads large, of $3-6$ sessile flowers. Sandy ground in Guernsey and Jersey. A. VI. VII.]

14. J.obtusiflorus (Ehrh.); st. 2-leaved and as well as the internally jointed $l$. terete, panicle repeatedly compound spreading divaricate, segments of perianth equal obtuse equalling the ovate acute trigonous (pale brown) capsulc.-E. B. 2144. St. 77. 12. $R$. ix. 404.-Erect, $2-3$ feet high. St. and l. not compressed. Segm. of perianth pale, often purplish, quite blunt or with a small inflexed point.-Marshes, rather rare. P. VII.-IX.

15. J. acutiflorus (Ehrh.); st. 3-4-leaved and as well as the internally jointed $l$. subcompressed, panicle compound pyramidal, segments of perianth acuminate-aristate inner ones longest all falling rather short of the narrow ovate-acuminate rostrate triquetrous (pale brown) capsule.-E. B. 238. R. ix.406. J. sylvaticus $S t$. 78. 1.-St. erect, $1 \frac{1}{2}-2$ feet high. L. slightly compressed. Clusters 5-6-flowered.-Boggy places. P. VI.-VIII.

16. J. lamprocarpus (Ehrh.); st. 3-6-leaved and as well as the internally jointed $l$. compressed, panicle repeatedly compound erect forked, segments of perianth equal acute the inner ones obtuse all falling short of the ovate attenuate mucronate triquetrous (dark brown) capsule.-E. B.2143. St. 71.16. R. ix. 405. -St. erect, 12-18 in. high. L. compressed; many internal divisions. Clusters $4-8$-flowered.-Boggy places. P. VII. VIII.

[J. alpinus (Vill.), $R$. ix. 403, having an acute dorsal angle to the sheaths of its 1 . and blunt perianth-segm. mucronate below their summit ; - J. atratus (Krock.), $R$. ix. 407, having "more deeply striated l." than either of the 2 preceding species and the inner acute perianth-segm. about equalling the ovate-attenuate 
capsule; and J.nigricans (Drej.), R. ix.407, with unequal acute perianth-segm. and a subglobose eapsule; will probably be found in Britain.]

17. J. nigritellus (D. Don); st. 3-4-leaved and together with the internally jointed $l$. nearly cylindrical, panicle slightly compound ereet, segments of perianth nearly equal (3 inner rather longer and broader) all acute falling short of the linear-oblong trigonous rostrate (black) capsule. - E. B. S. 2643, not of Koch, nor Kunth.-St. erect, $6-12$ in. high. L. scarcely compressed. Clusters of more fl. than in No. 16. Caps. brown, at length black and glossy, more abruptly pointed than in J. lamprocarpus. -Boggy places in the north. P. VII. VIII.

18. J. supinus (Moench); st. filiform, l. setaeeous slightly channeled and faintly jointed internally, panicle nearly simple irregular long with few distant clusters, segments of the perianth equal acute ( 3 inner rather obtuse) nearly equalling the elliptical very obtuse mucronate (pale brown) eapsule, anth. as long as their filaments.-E. B. 801. St. 13.8. R. ix. 397. J.uliginosus and J. subverticillatus Sm.-Extremely variable in size and the direction of its stems, sometimes erect, at others prostrate and rooting at every joining, or floating. Fl. often viviparous. Stam. 3 or $6 .-\beta$. $J$. nigritellus (Koch); eaps. shorter, stam. 6 , filaments nearly twice as long as the elliptical anthers. St.78.2. - Boggy and wet places. $\beta$. Ivy Bridge, Devon (in a bog). Mr. Keys. Cunnamara, Galway. P. VI.-VIII.

$+\dagger+$ Flowers solitary, remote, or corymbose and forming a terminal paniele. Seeds not appendaged.

19. J. squarrosus (L.); st. leafless simple, l. linear channeled radical, panicle terminal compound with cymose branches, segments of perianth ovate-lanceolate acute or rather obtuse equalling the obovate obtuse mucronate capsule, anth. 4 times as long as their filaments.-E. B.933. St.36.11. R. ix. 400.-St. erect, 6-12 in. high. L. many, somewhat spreading, rigid, half as long as the stem. Caps. pale brown, shining.-Wet heaths and moors. P. VI. VII.

20. J. compressus (Jacq.); st. with 1 leaf in the middle, 1. linear channeled, panicle terminal compound subcymose usually falling short of the bract, segments of perianth oval-oblong obtuse falling short of the roundly ovate shortly mucronate capsule.-E. B. 934. St. 36. 13. R. ix. 399.-St. slender, erect, round and leafy below, naked and compressed above. Floral bracts usually pale. Style half the length of the ovary. Anth. oblong, about as long as the filaments.-Damp places. P. VI.VIII. 
21. J. Gerardi (Lois.); st. with 1 or more leaves, 1. linear channeled, panicle terminal compound subcymose usually exceeding the bract, segments of perianth oval-oblong obtuse about equalling the oval-oblong strongly mucronate capsule.-J. cœnosus Bich., Sm., E. B. S. 2680. St. 71. 8. R. ix. 398.St. trigonous in its upper part. Floral bracts usually shining brown. Style as long as the ovary. Anth. long, at least twice as long as the filaments.-Salt marshes. P. VI.-VIII. Mud Rush.

[22. J. tenuis (Willd.); "st. above shortly dichotomous panicled, 1 . linear-setaceous grooved, fl. solitary approximate mostly sessile, caps. nearly spherical shorter than the very acuminated leaves of the perianth."-E. B.2174.-Clova Mountains. Mr. G. Don. P. VII.]

23. J. bufonius (L.); st. leafy dichotomous, 1. setaceous, fl. solitary unilateral scattered mostly sessile, segments of the perianth unequal lanceolate-acuminate exceeding the oblong obtuse capsule.-E. B. 802. St. 36. 12. R. ix. 395.-St. 4-8 in. high, usually with only 1 leaf on the slender stems.- $\beta$. fasciculatus (Koch); st. shorter (2-3 in. high) and thicker, fl. 2 or 3 together.-Marshy and wet places. A. VII. VIII. Toad Rush.

[J. pygmeus (Thuil.), J. triandrus ( $R$. ix. 391) with a pyramidal caps., and like $J$. bufonius $\beta$, will probably be found in sandy places near the sea in Britain.]

\section{Luzula Cand. Wood-rush.}

1. L. sylvatica (Bich.); 1. linear-lanceolate hairy, panicle subcymose doubly compound, peduncles long, clusters about 3 flowered, segments of perianth bristle-pointed equalling the ovate-mucronate capsule, filaments very short, seeds minutely tubercled at the end.-E. B. 737. St. 36. 14. R. ix. 390. L. maxima DC., Koch. Juncus sylvaticus Huds.-Underground st. woody. St. $12-18$ in. high. L. broad, shining, striate, with hairy edges. Panicle much exceeding the leaflike bracts.Shady places. P. IV.-VI.

[L. nivea (DC.); pan. patent overtopped by bract, ped. mostly 4-fl., segm. of perianth acute exceeding caps., anth. subsessile.Fl. whitish.-Bromhall Woods, Dunfermline ; planted.]

2. L. Forsteri (DC.); l. linear hairy, panicle subcymose only slightly branched, ped. l-flowered erect with both fl. and fr., style equalling stam., filaments $\frac{2}{2}$ as long as the anth., caps. acute scarcely falling slort of perianth, seeds with a straight blunt crest.-E. B. 1293. St. 77.2.-St. slender, about a fout high. 
Caps. with 3 acute angles, not suddenly contracted above.Thickets, rather rare. P. V.

3. ? L. Borreri (Bromf. MS.); 1. linear-lanceolate hairy, pan. subcymose long very slightly branched, ped. 1-2-fl., upper ones reflexed after flowering, style equalling stam., filaments about $\frac{7}{2}$ as long as anth., caps. acute shorter (?) than the perianth, seeds with a straight blunt crest. - St. slender, more than a foot high. Bracts at base of pan. narrow, scarcely leaflike. Ovary not tapering into the style. Caps. perhaps equalling the perianth when ripe. Seeds as large as those of $L$. pilosa. See Phytol. iii. 983. -Isle of Wight. Sussex. Ross, Herefordshire. P. IV. V. E.

4. L. pilosa (Willd.); l. lanceolate hairy, panicle subcymose only slightly branched, peduncles $1-3$-fi., upper ones reflexed after flowering, fl. solitary, style (excluding stigmas) exceeding stam., filaments about half as long as the anth., caps. blunt exceeding the perianth, seeds with a falcate crest.-E. B. 736 . St. 77.3. - St. slender, $6-12$ in. high. Caps. ovoid, trigonous, suddenly contracted above.-Thickets. P. V.

5. L. campestris (Willd.); 1. linear hairy, panicle of 3 or 4 ovate dense sessile or stalked clusters, segments of perianth lanceolate-acuminate exceeding the obtuse apiculate caps., filaments much shorter than the anthers, seeds nearly globular with a basal appendage.-E. B.672. St. 77.5.-St. 4-6 in. high. Anth. linear, about 6 times as long as the filaments.-Pastures and dry places. P. IV. V.

6. L. multiflora (Lej.); 1. linear hairy, panicle of many ovate dense sessile or stalked clusters, segments of perianth narrowlylanceolate strongly acuminate exceeding the obtuse-apiculate caps., filaments nearly as long as the anthers, seeds nearly twice as long as broad with a basal appendage.-E. B. S. 2718. St. 77. 7. L. congesta Sm.-St. 8-20 in. high. Filaments more than half as long as the rather short small anth. and often as long as them. Panicle with the clusters nearly all stalked, or ( $\beta$. $L$. congesta, Lej., L. campestris $\beta$. Hook.) contracted into a rounded lobed head.-Moorish and turîy places. P. VI.

7. L. spicata (DC.) ; 1. narrow slightly channeled hairy, panicle an oblong lobed nodding spike, clusters falling short of their bracts, segments of perianth narrow acuminate bristlepointed, filaments half as long as the anthers, caps. obtuse apiculate, seeds oblong with a very slight basal appendage. $-E . B$. 1176. - St. 3-12 in. high. L. short, slender. Spike $\frac{1}{2}-1$ in. long, nodding. Partial bracts tapering, bristle-pointed.-Mountains. P. VII.

8. L. arcuata (Hook.); 1. channeled slightly hairy, panicle 
subumbellate of few 3-5-flowered clusters on long drooping peduncles, segments of perianth broadly-lanceolate bristle-pointed, filaments as long as the anthers, caps. roundish-ovate, seeds oblong obtuse or apiculate scarcely appendaged below.-E. B. S. 2688. - St. slender, $2-5$ in. long. L. short, curved, narrowly linear. Panicle of $3-5$ small clusters, one nearly sessile, the others on long deflexed stalks.-Highest summits of the Cairngorum and Sutherland mountains. P. VII. VIII.

S.

\section{Order XC. AIISMACE 2 .}

Perianth free, 6-parted, coloured. Stam. 6-9 or more. Ovaries 3-6 or many. Styles and stigmas the same. Fruit not bursting, 1- or many-seeded. Embryo straight or curved; albumen 0.-See figures of the genera in G. F. G. Monocot. ii.

\section{Suborder I. ALISMOIDEE.}

Three inner segments of the perianth like petals. Seeds $1-2$ in each cell, erect or ascending. Placenta sutural. Embryo cylindrical, doubled upon itself; radicle next the hilum.

1. Alisma. F. perfect. Stam.6. Carp. many, 1-seeded, not bursting.

2. Actinocarpus. Fl. perfect. Stam. 6. Carp. 6-8, 2-seeded, combined at the base and spreading in a radiant manner.

3. Sagittaria. Fl. monœcious. Male fl. with many stamens. Female fl. with many l-seeded compressed carpels upon a globose receptacle.

\section{Suborder II. BUTOMEE.}

Three inner segments of the perianth like petals. Seeds many, minute. Placenta ramified over the inner surface of each follicle. Embryo straight or curved; radicle next the hilum.

4. Butomus. Perianth 6-parted, coloured, resembling a corolla. Stam. 9,3 interior. Follicles 6 , connected below, bursting inwards.

\section{Suborder III. JUNCAGINEE.}

Perianth uniform, herbaceous, inconspicuous, or 0 . Seeds 1-2, erect, approximate at the base. Fmbryo straight; radicle at the opposite end from the hilum; plumule coning through a lateral cleft in the embryo.

5. Scheuchzeria. Perianth of 6 reflexed leaves. Stam, 6 , 
with slender filaments. Ovaries 3 . Stigma sessile, downy. Fruit compressed, inflated, diverging, 1-2-seeded.

6. Triglochin. Perianth of 6 erect deciduous leaves. Stam. 6 ; anth. almost sessile. Ovaries 3-6. Stigmas sessile, feathery. Carp. attached to an angular axis from which - they at length separate at the base.

\section{Suborder I. Alismoidea.}

\section{Alisma Linn. Water Plantain.}

1. A. Plantago (L.); fl.-stalk panicled with whorled compound branches, carp. ranged in a circle compressed blunt obovate, style below the top of inner edge of carp., l. cordate-ovate or lanceolate.-E. B. 837. R. vii. 57.-L. all radical, on long stalks. Submersed l. linear. Fl.-stalks $2-3$ feet high. Fl. pale rose-colour.- $\beta$. A. lanceolatum (With.); l. lanceolate narrowed below.-By water. P. VII. VIII.

2. A. ranunculoides (L.) ; fl.-stalks umbellate, carp. angular acute forming a globose squarrose head, style terminal, l. linearlanceolate acute. $-E$. B. 326 . R. vii. t. 55.-L. all radical, on long stalks. Fl.-stalks from 3 to $24 \mathrm{in}$. long, ending in 1 or $2 \mathrm{um}$ bellate whorls of simple peduncles. Fl. pale purple.- $\beta$. A. repens (Dav.); plant depressed, umbels rooting and proliferous, fl. larger. E. B. S. 2722.- Turfy bogs. $\beta$. By lakes in Wales and Scotland. P. VI. VII.

3. A. natans (L.); st. floating and rooting leafy, peduncles simple from the joinings of the stem, carp. striate beaked, floating l. stalked oblong obtuse, radical leafless petioles linear-tapering. - E. B. 775. R. vii. t. 54.- St. slender, the few lowest joinings rooting. Root-petioles in small tufts. Fl. rather large, white with a yellow spot.--Lakes, rare. P. VIII.

\section{Actinocarpus R. Br. Thrumwort.}

1. A. Damasonium (R. Br.); stalks with $1-3$ whorls of fl., carp. subulate compressed opening longitudinally, l. cordateoblong.-E. B. 1615. Alisma Sm. Damasonium stellatum Pers. -L. all radical, floating, on long stalks. Pet. white. Carp. large; with 2 stalked seeds, 1 from the lower angle erect, the other from the upper horizontal. - Ponds and ditches, rare. P. VI. VII.

\section{Sagittaria Linn. Arrowhead.}

1. S. sagittifolia (L.); aërial l. arrowshaped with lanceolate straight lobes, fl.-stalk simple, fl. whorled.-E.B. 84. R. vii. t. 53 . Q 5 
-Stoloniferous; each runner ending in a tuber. The l. that rise above the water are remarkably arrowshaped. The submersed leafless petioles are linear. Fl. white.-Ditches and rivers. P. VIII.

E. I.

\section{Suborder II. Butomea.}

4. Butomus Linn. Flowering-rush.

1. B. umbellatus (L.).-E. B. 651. R. vii. t. 58.-Flowerstalk radical, $2-3$ feet high, overtopping the leaves, bearing an irregular many-flowered simple umbel with scarious bracts and a membranous 3-leaved involucre. Fl. rose-coloured. L. all radical, linear, triangular.-Rivers and ponds. P. VI. VII.

\section{Suborder III. Juncaginea.}

\section{Scheuchzeria Linn.}

1. S. palustris (L.).-E. B. 1810. St. 78. 4. R. x. 419.-St. 6-8 in. high, erect. L. distichous, few, alternate, semicylindrical, obtuse, with a minute pore on the upper side at the apex. Raceme terminal, of about 5 greenish flowers. Caps. about 3 , much inflated.- Sphagnous parts of bogs. Lakely Car, and Thorne Moor, Yorkshire. Bomere, Shropshire. Wybunbury, Cheshire. Methvin, Perthshire. P. VII.

E. S.

\section{Triglochin Linn. Arrow-grass.}

1. T. maritimum (L.); fr. ovate of 6 combined capsules.E. B. 255. R. vii. t. 52.-L. radical, linear. Fl. in a lax simple spike or raceme, greenish.-Salt marshes. P. VII. VIII.

2. T. palustre (L.); fr. linear angular of 3 combined capsules. -E. B.366. R. vii.t. 51 l. - Taller than the preceding but closely resembling it. Stoloniferous.-Marshy places. P.VI. VII.

\section{Order XCI. TYPHACEE.}

Fl. monceious, many, closely placed on a spadix without a spath ; barren and fertile on different parts of the spadix. Perianth of 3 or more scales or bristles. Stam. 1-6, distinct or monadelphous. Anth. erect.-Fertile fl.: Ovary free, solitary, 1-celled; ovule 1, pendulous. Style short. Stigma simple. Fr. dry or spongy. Embryo with a cleft on one side.

1. Typha. Sterile and fertile spikes cylindrical. Stam. surrounded with bristles. Anth. 3 together on one filament. Ovary surrounded with bristles, at length stalked. 
2. Sparganium. Fl. in dense globose heads, each with a single 3-4-leaved perianth. Stam. free. Fruit dry, sessile.

\section{Typha Linn. Reed-mace.}

1. T. latifolia (L.); 1. linear nearly flat, sterile and fertile spikes contiguous, style exceeding the bristles, stig. oblique linear-subulate rounded below.- $\boldsymbol{E}$. B. 1455. $R$. ix. 323.-St. 6-7 feet high. L. overtopping the inflorescence, very broad. Spikes very long.- [In T. Shuttleworthii (Koch), R. ix. 322, the style equals the bristles.]-Ponds and lakes. P. VI. VII.

2. T. angustifolia (L.); l. linear channeled below, sterile and fertile spikes a little separated, style longer than the bristles, stig. long filiform.-E. B. 1456 . R. ix. 321 .-St. 5-6 feet high, much slenderer than in the preceding. L. very narrow, overtopping the inflorescence. Spikes very long, slender, separated by an interval of about an inch.- $[T$. gracilis (Suhr.), $R$. ix. 320, has a rounded spathulate stigma.]-Lakes and ponds. P. VI. VII.

[T. minor (Sm.); 1. linear-setaceous overtopped by the distant spikes.-E. B. 1457.- - Reported to have been found on Hounslow Heath. Dillenius. P. VII.]

\section{Sparganium Linn. Bur-reed.}

1. S. ramasum (Huds.); l. triangular at the base with concave sides, st. branched, stigma linear, fl. sessile.-E. B. 744. R. ix. 326.-St. erect, about 2 feet high ; lower branches with several heads, $1-3$ fertile, the rest barren. Heads spherical. L. long. -Ditches. P. VII.

2. S. simplex (Huds.); 1. trigonous at the base, st. simple, stigma linear, fr. slightly stalked subfusiform.-E. B. 745. $R$. ix. 325.-About 1 foot high. L. long, often floating; sheath slightly furrowed, not inflated. Heads many; barren several, sessile ; fertile shortly stalked, especially the lowest. Fr. oblong, narrowed into a long beak, elliptic-fusiform.-Ditches. P. VII.

3. S. natans (L.); st. simple flaccid, floating 1. very long linear from a dilated sheathing base, heads many panicled distant, fertile heads spiked, barren male heads several sessile, fr. stalked oblong not longer than its subulate beak.-S. affine Schn., R. ix.417.St. much thicker than in the next plant. L. grass-green, very long. Male heads fewer in our plant than in the Swedish.Lakes in Scotland. Cunnamara, Ireland. Mr. D. Moore. Snowdon. P. VIII. 
4. S. minimum (Fr.); st. simple flaccid, 1. linear floating blunt not enlarged at the base, heads few racemose or spiked distant, only 1 male head, fr. sessile ovoid shortly beaked.-S. natans Sm., E. B. 273. R. ix. 324.-St. slender. L. pale, pellucid, long.-Lakes and ditches. P. VII. VIII.

\section{Order XCII. ARACEÆ.}

Fl. monœecious or perfect, placed on a spadix and usually in a spath. Barren and fertile $f$. usually on different parts of the spadix. Perianth none, or of $4-8$ scales. Stam. many or definite. Anth. turned outwards. Ovary free, with 1 or more cells. Stigma sessile. Fr. succulent. Embryo slit on one side.

1. Acorus. Spath 0. Fl. on a sessile spadix. Perianth 6-leaved, inferior, persistent. Stam. 6, filiform.

2. Arum. Spath convolute at the base. Perianth 0. Male fl. of I sessile 2-celled anther. Fem. fl. placed lower, of 1 pistil. Top of spadix naked. Fr. succulent.

\section{Acorus. Sweet Flag.}

1. A. Calamus (L.); scape with a long leaflike prolongation beyond the spadix.-E. B. 356. R. x. 429.-St. 5-6 feet high, resembling the 1., swordshaped, flattened. Spadix completely covered by the flowers, $2-3$ in. long, lateral. St. and l. sweetscented when crushed.-In water, rare; more common in Norf. and Suff. P. VI.

E. S.

\section{Arum Linn. Cuckoo-pint.}

1. A. maculatum (L.); $l$. all radical hastate-sagittate with deflexed lobes green or spotted with purple, spadix clubshaped straight falling short of the spath.-E. B. 1298. R. vii. \&.Root tuberous. L.vernal, with branching veins. Spath ventricose below and above, constricted in the middle, with inflexed elges when open. Spadix blunt; with ovaries at the base; above them whorls of stamens; then a few filaments, probably abortive pistils ; club naked. Berries scarlet, many-seeded, remaining after the rest of the plant has disappeared.-Hedge-banks and thickets. P. IV. V.

2. A. italicum (Mill.); $l$. all radical triangular-hastate with divaricate lobes and yellow veins, spadix clubshaped straight falling short of the widely spread spath. $-R$. vii. 11.- L. appearing before the winter, of a dark blue-green. Spath ventricose below, opening nearly flat and very broad above. Abortive pistils very long, both above and below the stamens. Berries 
with not more than 3 large seeds. - Thickets in the Undercliff, Isle of Wight. Mr. Hambrough. P. VI.

E.

\section{Order XCIII. LEMNACEA.}

Fl. monœcious, 2, in a spath, but without a spadix. Perianth 0. Stam. 1-2, distinct. Ovary 1-celled. Style short. Stigma simple. Fr. bladdery, not bursting. Seeds with a coriaceous ribbed testa.-Floating, leaflike, small; no distinction of st. or leaf.

1. Lemna. Spath membranous, urn-shaped. Stam. 1-2. Anth. 2-celled, didymous (cells bilocular?).-Fl. from just below the edge of the frond. Increasing chiefly by buds.

\section{Lemna Linn. Duckweed.}

1. L.trisulca (L.); fronds thin pellucid elliptic-lanceolate tailed at one end serrate at the other, roots solitary.-E. B. 926. $R$. vii. 15.-Roots tipped with a sheath. Fronds half an in. long, proliferous at right angles. "Filaments recurved, filiform." Schleid. Plants truly annual, producing gemmæ which survive the winter as in the other species.-Stagnant water. A. VI.

2. L. minor (L.); fronds obovate compressed opaque, roots solitary.-E. B. 1095. $R$. vii. 14.-Fronds 1-2 lines long, nearly flat beneath, of a compact texture. Filaments recurved, filiform. -Stagnant water. A. VI. VII.

3. L. polyrrhiza (L.); fronds roundish-obovate compressed, roots many clustered. $-E$. B. 2458 . $R$. vii. 15 . Spirodela Schleid., Endl.-Fronds half an in. long, green above, purple beneath. "Filaments narrowed below." Schleid.-Stagnant water. A. Fl. have not been seen in Britain.

4. L. gibba (L.); fronds obovate nearly flat above hemispheri$c a l$ and spongy beneath, roots solitary.-E. B. 1233. R. vii. 14 . Telmatophace Schleid., Endl.-Fronds 1-2 lines long, remarkably gibbous and cellular beneath. "Filaments recurved, dilated in the middle." Schleid. See an excellent account of the germination of this plant, by Mr. Wilson, in Bot. Misc. i. 145. t. 42.Stagnant water. A. VI.-VIII.

\section{Order XCIV. POTAMOGETONACEÆ.}

Fl. perfect or imperfect. Perianth inferior, 4-parted, or 0, or repllaced by a membranous spath. Stam. free, 1,2 or 4 . Ovaries 4 , distinct, each with 1 ovule, and 1 sessile stigma. Fr. a drupe 
inclosing a hard nut, or a dry nut, not bursting, 1-seeded. Albumen 0. Embryo with a thin skin having a lateral cleft.

1. Potamogeton. Fl. perfect. Perianth 4-parted. Anth. 4 , sessile, opposite to the divisions of the perianth. Ovaries 4. Styles 0. Drupes 4, sessile.-Fl. sessile, spiked.

2. Ruppia. Fl. perfect. Perianth 0. Stam. 2, the cells considerably separated; filaments very short, scalelike. Ovaries 4. Styles 0 . Nuts 4, with long stalks.-Fl. about 2 together.

3. Zannichellia. Fl. imperfect, axillary. Barren with 1 stam., and no perianth. Fertile with a bellshaped perianth, persistent style, and peltate stigma. Nuts $3-5$ or more, very shortly stalked.

\section{Potamogeton Linn. Pondweed.}

* L. alternate, floral l. floating and sometimes opposite; stipules free.

1. P. nutans (L.); 1. all stalked, upper coriaceous floating ovate or elliptical plicate at the base, lower leafless petioles linear or setaceous, fr. (large) rounded on the back when fresh keeled when dry, peduncles equal.-E. B. 1822. R. vii. 50.-A creeping rhizome. Lowermost 1 . (phyllodes) often quite setaceous; upper 1. more or less cordate at the base, when pressed flat a ridge is formed on each side of the base, jointed to their stalks a little below the limb. Petioles plane-concave above. Sep. stalked, roundly rhomboidal. Anth.-cells not parallel. Fr. greenish, $1 \frac{1}{2}-2$ lin. long.-Ponds, ditches, and slow streams. P. VI. VII.

2. P. polygonifolius (Pourr.); 1. all stalked, upper subcoriaceous floating oblong-elliptical subcuspidate no leafless petioles, lower 1. linear-lanceolate, fr. minute obtuse and rounded on the back, peduncles equal.-P. oblongus Viv. E. B. S. 2849.St. creeping below. Petioles longer than leaves, plane-concave above. Lower 1 . often very narrow. Spikes rather short and irregular. Sep. transversely elliptical, stalked. Fr. reddish, I lin. long, having a faint keel and rather obscure lateral ridges when dry.-Ditches, small streams, ponds. P. VII.

3. P. plantagineus (Ducr.); $l$. all shortly stalked membranous and pellucid blunt not cuspidate nor plicate, upper elliptical, lower l. oblong, $f r$. minute rounded on the back when fresh keeled when dry, peduncles equal.-E. B. S. 2848 . R. vii. 45. - St. creeping below, branched, sometimes throwing out long stoles from its upper axils. L. all beautifully transparent and 
netted with veins, the upper often almost sessile and nearly orbicular, sometimes slightly cuspidate. Petioles plane-concave above. Spikes long, cylindrical. Anth.-cells nearly parallel. Sep. ovate. Fr. greenish, $\frac{3}{4}$ lin. long.-Stagnant peaty water. P. VI. VII.

4. P. rufescens (Schrad.); submersed 7 . lanceolate narrowed at both ends subsessile membranous pellucid entire not apiculate with chainlike network near the midrib, floating 1 . subcoriaceous obovate obtuse narrowed into a short petiole, stip. without wings, fr. acutely keeled, peduncles equal.-E.B. 1286. $R$. vii. 32. $P$. fluitans Sm. - St. simple. Upper 1. alone slightly coriaceous, often tinged with purple, longer than their stalks; submersed 1. all nearly, if not quite, sessile. Sep. "transversely oval."-Ditches and slow streams. P. VII.

5. P. lanceolatus (Sm.); submersed $l$. lanceolate narrowed at both ends entire not apiculate with chainlike network near the midrib, floating l. subcoriaceous elliptic-lanceolate stalked, stip. linear-lanceolate acute uppermost broader, fr......, peduncles equal.-E. B. 1285. (not R.) P. nigrescens Fries?-St. very slender, slightly branched. Floating 1. not always present. Uppermost stip. apparently with 2 stronger dorsal ribs. Fr. unknown.--Streams, rare. P. VII. VIII.

E. S. I. ?

[P. sparganiifolius (Laest. ?); submersed $l$. linear narrowed at both ends very long sessile entire not apiculate with many parallel veins next the midrib, floating 1 . subcoriaceous lanceolate long-stalked, stip. very long not winged, fr. unknown. - St. very slender, slightly branched. Floating 1 . often wanting. Submersed 1 . sometimes $2 \mathrm{ft}$. long, very narrow, few-veined with additional parallel veins closely placed next the midrib. $L$. very much longer than those of P.lanceolatus and without the chainlike network.-A remarkable plant requiring examination.-In the river at Ma'am, Galway. Mr. T. Kirk.]

6. P. heterophyllus (Schreb.); submersed l. lanceolate narrowed at both ends sessile denticulate and apiculate, floating l. subcoriaceous elliptical stalked, stip. broadly lanceolate obtuse with 2 stout prominent ribs, lower ones linear-lanceolate, fr. obtuse on the back, peduncles swelling upwards.-E.B. 1285. R. vii. 4143. P. gramineus, Fries, not Linn.--St. much branched below. Submersed l. wavy. Lower stip. without the two strong ribs and equally veined, upper ones widely spreading. Dry fr. slightly marked with 3 ridges on the back.- $[P$. nitens (Weber) has the submersed 1 . rounded and clasping at their base.]Ponds and ditches. P. VI. VII. 
** L. all submersed, membranous, lanceolate or broader: stipules free.

7. P. lucens (L.); $l$. pellucid oval or lanceolate stalked denticulate and apiculate, stip. winged, fr. obtuse on the back and slightly keeled when fresh, peduncles swelling upwards, spikes cylindrical densely flowered.-E. B. 376 . R. vii. 36.-All the stipules have two prominent wings on their back. Spikes long, about equalling the peduncles. According to Mr. W. Wilson "ovate-lanceolate moderately acute coriaceous l." sometimes occur. When the limb of the 1 . is much reduced in size and the midrib prominent and resembling a long spine, it is the $P$. acuminatus Schum.-Common in deepish water. P. VI.

8. P. longifolius (Gay?); l. pellucid elongate-lanceolate narrowed below entire apiculate, stip. winged, fr......., peduncles very long swelling upwards, spikes with few subverticillate distant flowers.-E. B. S. 2847.- St. long, slender. L. distant, not denticulate, nearly sessile with very short stalks. Stipules green, lanceolate, with 2 narrow wings on the back. Ped. $6-8$ in. long, much thicker than the stem, suddenly contracting at the spike which is about an inch long and has the fl. rather more whorled than they are represented in $E . B . S$. Fr. unknown.Deep water. Lough Corrib, Galway. Mr.J. Ball. P. VIII. I.

9. P. pralongus (Wulf.); $l$. pellucid élongate-oblong halfclasping blunt and hooded at the end entire, stip. not winged, fr. rounded (rarely keeled) on the back when fresh keeled or winged when dry, peduncles very long equal, spikes many-flowered.E. B. S. 2858 . R. vii. 33.-St. long, growing in deep water. Peduncles 6-12 in. long. Spikes $1-2$ in. long.-Rivers and ditches, rare. P. VI.

10. P. perfoliatus (L.); st. round, l. pellucid cordate-ovate clasping not hooded, fr. rounded on the back when fresh keeled when dry, perluncles equal.-E. B. 168. R. vii. 29.-St. long, slightly branched. Peduncles rather thick and short, Spikes short.-Lakes and streams. P. VII.

11. P. erispus (L.); st. compressed, l. pellucid linear-oblong blunt sessile serrate wavy, fr. with a long beak keeled on the back when dry, peduncles equal.-E. B. 1012. R. vii. $29-30$. - St. much branched. Ped. long. Spikes few-flowered. Beak as long as the nut. L. usually crisped at the edges, occasionally flat ( $P$. serratus Huds.).-Ditches and streams. P. VI.

*** L. all submersed, alternate, linear; stipules free.

12. P. zosterifolius (Schum.); st. flattened, $l$. linear-acuminate with 3 principal and many close parallel intermediate 
veins occupying the whole surface, spikes cylindrical upon long ped., sep. transversely oval, fr. obovate keeled, style terminal.E. B. S. 2685 . R. vii. 27. P. cuspidatus Sm., P. compressus Fries.-Ped. 2-4 in. long. Spikes 10-15-flowered. Inner edge of fr. rounded; faces a little convex. L. suddenly acuminate or apiculate.-Rivers and lakes. P. VI. E. S.

13. P. acutifolius (Link); st. flattened, $l$. linear acuminate with 3 principal and many close parallel intermediate veins occupying the whole surface, spikes ovate about as long as the short ped., sep. rhomboidal, fr. broadly $\frac{1}{2}$-obovate compressed inner edge straight with a tooth near its base keeled, style facial.E. B. S. 2609. R. vii. t. 26.-Ped. very short. Spikes 4-6flowered. L. gradually acuminate. Styles hooked, continuing the inner edge of the fruit.-Marsh ditches. Sussex. Hertf. Norfolk. P. VI.

14. P. gramineus (L.?, Sm.); st. slightly compressed with rounded edges, $l$. linear 3-veined, spikes ovate dense continuous about as long as the short ped., sep. rhomboidal, fr. obovate keeled.-E. B. 2253. P. obtusifolius Koch, $R$. vii. t. 25. - St. slender, much branched. Peduncles very short. L. rounded off to a slight point at the end, with oblong network near the midrib, wanting the fine parallel veins of the two preceding species. - Ponds and ditches, rare. P. VI. VII.

15. P. compressus (L.) ; st. slightly compressed, l. linear 5-veined suddenly apiculate, spikes short lax 2 or 3 times shorter than the compressed clavate ped., sep. transversely oval, fr. obliquely ovate bluntly keeled. $-E$. B. 418. R. vii. 24, not Fries, nor Koch.-Lateral veins nearer together and nearer to the margin of the l. than to the midrib, no intermediate veins.-Like No. 14 rather than 16.-Ditches. P. VI. VII.

16. $P$. pusillus (L.) ; st. subterete, l. linear 3-veined, spikes short rather lax 2 or 3 times shorter than the slender ped., sep. roundish-reniform, fr. obliquely ovate bluntly keeled.-E. $B$. 215. R. vii. 22.-St. slender. L. narrow, rather acute, without intermediate parallel veins, the lateral reins equidistant between the midrib and margin. Ped. scarcely compressed, not thickened. - [P.rutilus (Wolfg., Fries) has 3-veined attenuate-cuspidate l., semiterete st., and oblong-elliptical fr. without a keel.]-Ponds and ditches. P. VI.

[A plant found near Dunstanburgh, Northumberland, by $\mathbf{M r}$. D. Oliver, is probably $P$. gracilis (Fr.) which has l-veined attenuate-cuspidate 1., terete st., and globose-elliptical fr. without a keel.]

17. P. trichoides (Cham.); st. subterete, l. subsetaceous 1- 
veined finely pointed, spikes short lax long-stalked, fr. semicircular compressed obscurely keeled, straight inner edge with a tooth near its base.- $R$. vii. 21.-St. very slender, a little thickened below the joinings. L. not transversely veined. Floral stip. large. Ped. not thickened. Sep. roundish, stalked. Fr. often verrucose or the back and with a tubercle on each side at its base when fresh.-About Norwich. P. VII. VIII. E.

**** L. all submersed, alternate, linear, sheathing.

18. P. flabellatus (Bab.); lower $l$. broadly linear abruptly apiculate or acuminate $3-5$-veined with transverse veins, floating $l$. narrow acute 3-veined, fr. (2 lin. long) broadly $\frac{1}{2}$-obovate inner edge nearly straight but gibbous near the top rounded on the back, nut with a prominent keel.-Phytol.iv. 1158. P. zosteraceus Bab. (not Fr.).-Floating st. branched, spreading like a fan. Broad lower 1 . usually decayed at the time of flowering. Lateral veins of upper 1 . at the margin, of lower l. distant from it. Spikes slightiy interrupted. Back of fr. without ridges, rounded when fresh; inclosed nut with faint lateral ridges.Ponds and ditches. P. VI. VII.

E.

19. P. pectinatus (L.); $l$. formed of 2 interrupted tubes, lower narrowly linear flattened slightly grooved above, upper setaceous, fr. (2 lin. long) broadly $\frac{T}{2}$-obovate inner edge curved back rounded on the back, nut with 2 lateral ridges but (usually) no keel.-E.B. 323. $R$. vii. 19. - St. branched, forming linear masses. L. very gradually acute, all l-veined, no marginal veins and scarcely thickened there; upper l. with an oval section. Spikes slightly interrupted. Back of fr. without ridges and rounded when fresh; nut with strong lateral ridges. Varying greatly in length and size of st. and leaves.-Ponds and streams. P. VI. VII.

20. $P$. filiformis (Nolte!); $l$. linear-setaceous 1-veined with transverse veins, spikes greatly interrupted, fr. ( $1 \frac{1}{2}$ lin.) obovate rugose rounded on the back without keel or ridges when dry, nut round-backed.-L. like those of the preceding but longer. Fr. smaller. Whorls very distant on the spikes. Peduncles very long,-Rare. Forfarshire and Berwickshire. P. VI. VII. S.

***** L. all opposite, submersed; stipules none.

21. P. densus (L.); l. all opposite pellucid clasping ellipticallanceolate or lanceolate, spikes shortly stalked ultimately reflexed. -E. B. 397. R. vii.t. 28.-L. crowded, rather recurved. Spike 4-flowered. Sep. triangular.-Ditches. P. VI. VII. 


\section{Ruppia Linn. Tassel-Pondweed.}

1. R. maritima (L.) ; ped. long spirally twisted, anth.-cells oblong $1 \frac{1}{2}$ times as long as broad, nut ovoid rather obliquely erect. $-R$. vii. 17 . - Whole plant stronger than the next. $L$. very narrowly linear, formed as in Pot. pectinatus. Sheaths large, inflated.-Salt marshes in the south. P. VII. VIII. E.

2. $R$. rostellata (Koch); ped. short not spiral, anth.-cells squarish as long as broad, nut gibbous at base obliquely ascending when young. - E. B. 136 ? R. vii. 17. - Whole plant very slender. L. rather filiform than linear. Sheaths small, close. - Salt marshes. P. VII. VIII.

\section{Zannichellia Linn. Horned Pondweed.}

1. Z. palustris (L.); style at least half as long as the fruit.$E$. B. 1844. R. vii. 16.-Floating. L. slender, opposite, filiform. Fl. axillary, sessile. Anth. 2-4-celled. Style $\frac{1}{2}$ as long as fruit. Stigma generally notched at the margin. $-\beta . Z$. pedicellata $(\mathbf{F r}$.$) ;$ style as long as the fruit. Clusters usually stalked. Pedicels elongated.- [Z. polycarpa (Nolte), style scarcely a sixth of the length of the nut, has not been found in Britain.]-Stagnant water. $\beta$. Brackish water. A. or P. V.-VIII.

\section{Order XCV. NAIADACEA.}

Fl. monœcious or diœcious, in a spath. Perianth 0. Stam. free, $1-3$. Ovary 1 , superior, with 1 ovule. Style 1 ; stigmas 2-4, filiform. Fr. a nut inclosed in the persistent spath, 1-celled, 1-seeded, not bursting. Albumen 0. Embryo with a thin skin having a lateral cleft.

1. Zostera. Fl. imperfect. Stam. and pistils inserted in two rows upon one side of a spadix. Spath linear, leaflike. Fl. naked. Anth. 1. Ovary 1; style 1; stigmas 2.

2. NaIAs. Fl. imperfect, solitary, sheathed, no perianth. Barren fl. of 1 stamen. Fertile: style short; stigmas 2-4, filiform.

\section{Zostera Linn. Grass-wrack.}

1. Z. nana (Roth); 1. linear l-veined, ped. filiform, spadix short with clasping bands, nuts smooth.-E.B.S. 2931. R. vii. 2. -Plant small, scarcely $3 \mathrm{in}$. long. L. slender. Ped. quite as long as the inflated oblong-lanceolate spaths.-Muddy estuaries of the coast of England. P.? VII. VIII. 
2. Z. marina (L.); 1. linear $1-7$-veined, spadix without bands, nuts striated.-E. B. 467. R. vii. 4.-Plant long. L. broad. Ped. rather strong. $-Z$. angustifolia is a slender form, growing upon mud, which has fewer veins in its 1 . and rather longer perluncles.-In the sea. P.? VII. VIII.

\section{Naias Linn.}

1. N. flexilis (Rostk.); l. very narrow and very minutely denticulate, sheaths ciliate-denticulate. - L. ternate or opposite, 1veined, pellucid, remotely denticulate. Ovary solitary, axillary, sessile, oblong. Style short.-Near Roundstone, Cunnamara, Galway. Mr. D. Oliver, Jun. A. VIII.

\section{Subdivision III. GLUMIFER E.}

Leaves parallel-veined, persistent. Floral envelopes imbricated.

\section{Order XCVI. CYPERACEE.}

Fl. perfect or unisexual, each with a scale or glume imbricated on a common axis. Perigone 0, or rarely membranous. Stam. hypogynous, definite, with sometimes a row of bristles or abortive filaments. Anth. erect, entire at the apex. Ovary l-cellecl, l ovule at its base, often surrounded by bristles. Style simple, trifid or bifid. Embryo inclosed within the base of the albumen. -L. with entire sheaths. - For figures of the genera see G.F. G. Monocot. ii.

Tribe I. CYPEREAE. Fl. perfect. Gl. 2-ranked. Perigone 0.

1. Cyperus. Spikelets 2-ranked. Gl. of 1 valve, many, keeled, nearly all with flowers.

2. Schøevus. Spikelets 2-ranked, 2-4-flowered. Gl. 6-9; lower ones smaller, empty. Bristles few or 0 .

Tr. II. SCIRPEAE. Fl. perfect. Gl. imbricated on all sides. Perigone 0.

\section{* Lower glume empty or smaller.}

3. Cladium. Spikelets $1-2$-flowered. GI. 5 or 6 . Bristles 0 . Nut with a thick fleshy coat, tipped with the conical base of the jointless style.

4. Rhynchospora. Spikelets few-flowered. Gl. 6 or 7 . Bristles about 6. Nut compressed, convex on both sides, crowned with the dilated base of the jointed style. 
** Lowest glume empty or larger, sometimes all fertile.

+ Bristles scarcely equalling the glume or wanting.

5. Eleocharis. One or 2 lowest gl. larger, empty. Bristles $3-6$. Nut compressed, crowned with the persistent dilated hase of the jointed style.

6. Scirpus. Glumes nearly equal, or 1 or 2 lowest larger empty. Bristles about 6 or 0 . Nut plane-convex or trigonous; base of the style filiform, not dilated, jointless.

7. Blysmus. Two lowest gl. largest and empty. Bristles 3-6. Nut plane-convex, tipped with the not dilated base of the jointless style. Spikelets bracteated, alternate, forming a close distichous compound terminal spike.

$\dagger \dagger$ Bristles ultimately much exceeding the glumes.

8. Eriophonum. Glumes nearly equal, lowest sometimes empty. Bristles ultimately silky. Nut trigonous.

Tr. III. ELYNEAE. Fl. diclinous. Perigone 0 or formed of 1 or 2 scales.

9. КовRеsia. Spikes aggregate. Lower $f$ l. fem., perigone of 1 scale inclosing the germen and covered by the glume. Upper fl. male, without any perianth.

Tr. IV. CARICEAE. Fl. diclinous. Nut completely inclosed in the un-shaped perigone.

10. CAREX. Fl. in imbricated spikes, each covered by a glume. Female fl. with a single urn-shaped persistent perigone, 1 style and 2-3 stigmas. Male fl. of 3 stam., without a perianth.

\section{Tribe I. Cyperea.}

\section{Cyperus Linn. Galingale.}

1. C. longus (L.); spikelets linear-lanceolate in twice compound umbels, peduncles of partial umbels erect unequal, stigmas 3, root creeping.-E. B. 1309. St. 52.10.-St. triangular, $2-3$ feet high. Umbel very large, lax, unequal, its base with 2 or 3 long leaves. Glumes brownish-red, with green keels and pale margins.- South of England, rare. P. VIII. IX. E.

2. C.fuscus (L.); spikelets linear-lanceolate in small roundish heads at the extremities of the branches, gl. spreading, stigmas 3, root fibrous. - E. B.S. 2626. St.52.5.-A small nearly prostrate plant. Stems many, $2-5$ in. long. Heads with 3 un- 
equal 1. at the base. Glumes fuscous with green keels.-Little Chelsea, Middlesex. Shalford Common, Surrey. Guisborough Moor, Yorkshire. Jersey. A. VIII. IX.

\section{Schanus Linn. Bog-rush.}

1. S. nigricans (L.); st. round naked, spikelets 5-10 collected into a terminal roundish head overtopped by the lower bract, gl. scabrous at the keel.-E.B. 1121. St. 40. 9.-Root of strong black fibres. St. 8-12 in. high, clothed at the base with blackish-brown smooth shining scales some of which terminate in setaceous erect leaves which are shorter than the stem. Bristles variable in number, short, rough with upward spines. Stigmas 3. Anth. terminating in a point. Gl. dark-brown or black.-Turfy bogs. P. VI.

\section{Tribe II. Scirpea.}

3. Cladium Pat. Br. Sedge.

1. C. Mariscus (R. Br.); panicles lateral and terminal repeatedly compound, spikelets capitate, st. roundish leafy smooth, 1 . rough on the margins and keel.-E. B. 950.-Root creeping. St. 3-4 feet high. L. rery long, rigid, narrowed and triquetrous towards the end, the margins and keel with fine but very acute serratures. Fl. in each spikelet $1-3$, but usually only one nut is produced.-Bogs and fens, rare. P. VII. Common Sedye.

\section{RHYNCHOSPORA $V a h l$.}

1. R. alba (Vahl); spikelets in a compact corymb about as long as the outer bracts, stam. 2, bristles with declining teeth, base of the style without teeth.-E. B. 985. St. 40. 7.-Root slightly creeping. St. 6-12 in. high. L. narrowly linear. Spikelets whitish. Bristles $9-12$. Filaments slender.- $\beta$. sordida; spikelets brownish, in small oval clusters often overtopped by the outer bracts. - Turfy bogs. P. VII.

2. $R$. fusca (Sm.); spikelets in an oval head considerably shorter than the outer bracts, stam. 3 , bristles with ascending teeth, base of the style with erect teeth. $-E . B .1575$. St. 40.6. -Root creeping extensively. St. $6-8$ in. high. L. nearly filiform. Spikelets brown. Bristles 6. Filaments dilated.-Bogs, rare. South-west of England. Ireland. P. VII. VIII. E. I.

\section{Eleocharis $R$. $B r$.}

1. E. palustris (R. Br.); spikes terminal solitary oblong, glumes rather acute, lowest $\frac{1}{2}$-surrounding the spike, stigmas 2 , 
nut roundish plane-convex with rounded edges smooth crowned with the ovate base of the style and falling short of the 4 bristles, base of st. clothed with membranous almost transversely truncate sheaths. - E. B. 131. St. 9. R. viii. 297. - Often only slightly creeping. Sheaths with a very obtuse point on one side. -Wet and marshy places. P. VI.

[E. Watsoni (Bab.); spikes terminal solitary oblong, gl. acute?, lowest rather blunt surrounding the spike, stigmas 2 ?, nut oblong very blunt a little narrowed below compressed with rounded edges finely punctate-striate crowned with the broad depressed base of the style and exceeding the 4-6 bristles, base of st. clothed with abruptly truncate sheaths. $-A$. N. H. ser. 2. x. 52.- Sheaths with a blunt point on one side. Radical scales broad, blunt, reddish. St. 3-4 in. high. Requires examination.-Taynloan, Argyleshire. Dr.Balfour.]

2. E. uniglumis (Link); spikes terminal solitary oblong, glumes rather acute, lowest almost surrounding the spike, stigmas 2, nut pearshaped obtuse rather compressed with rounded edges smooth crowned with the conical base of the style and falling short of the bristles, base of st. clothed with transversely truncate sheaths. - $R$. viii. 296. - Far-creeping. - Wet sandy places, especially near the sea. P. VI. VII.

3. E. multicaulis (Sm.); spikes terininal solitary oblong, glumes blunt, stigmas 3, nut topshaped triquetrous smooth crowned with the broad triquetrous base of the style equalling the 6 bristles, base of st. clothed with obliquely truncate rather acute sheaths.-E. B.1187. St.78.11. R. viii. 296.-Slightly creeping.-Marshy places. P. VII.

4. E. acicularis (Sm.); spike terminal solitary ovate, glumes obtuse, stigmas 3, nut obovate-oblong compressed longitudinally ribbed and transversely striate crowned with the turbinate base of the style, bristles short deciduous.-E. B.749. St. 10. R. viii. 294.-Root fibrous with slender runners. St. many, slender, erect, 3-4 in. high. Spikes very small.-In damp places upon heaths. P. ?, A. (Koch) VII. VIIII.

\section{Scirpus Linn. Club-rush.}

* Bristles 6. Spikes many.- - St. triangular; panicle leafy.

1. S. maritimus (L.); spikes stalked or sessile in a dense terminal cluster, bracts several leaflike, gl. bifid with acute lobes and a central point, nut obovate trigonous smooth.-E. B. 542. St. 13.3. R. viii. 310, 311.-Root creeping, sometimes tuberous. St. 1-3 feet high, leafy. Spikes large, sometimes solitary. Stigmas 3, or rarely 2.-Salt marshes. P. VII. 
2. S. sylvaticus (L.); spikes clustered in a large cymose very compound terminal panicle, clusters stalked and sessile, general bracts several leaflike, gl. obtuse apiculate, nut obovate obtusely trigonous. - E. B. 919. St. 36. 8. R. viii. 313.-St. $2-3$ feet high. Spikes very many, small, greenish, ovate. L. broad, flat. Stigmas 3.- [S. radicans (Schk.), spikes all stalked, glumes not apiculate, stoles long and rooting, will probably be found.]Damp woods and banks. P. VII.

† Stem triangular; panicle naked.

3. S. carinatus (Sm.); st. round below bluntly trigonous upwards, spikes in a small cymose panicle, $g l$. notched mucronate slightly punctate-scabrous and pilose fringed, nut "corvex on the back smooth."-E. B. 1983. S. Duvalii St. 36. 2. R. viii. 308.- St. 2-4 feet high, convex-faced; with 1 or 2 long sheaths at the base, the uppermost terminating in a leaf of 3 or 4 in. long. Lower bract much overtopping the panicle. Stigmas 2. -By rivers, near London and in Sussex. P. VI. VII. E.

4. S. triqueter (L.); st. acutely triquetrous throughout, spikes in a small cymose panicle, $g l$.notched mucronate glabrous fringed with rounded obtuse lobes, nut " roundish-obovate plane-convex smooth." - E. B. 1694. St. 36. 3. R. viii. 305.-St. 3-4 feet high, with flat or concave faces; 1 or 2 long sheaths at the base, the uppermost terminating in a short broad triquetrous leaf. Lower bract long and rigid, resembling a prolongation of the stem. Spikelets small, stalked and sessile. Anth. with a short beardless point. Stigmas 2.-Muddy banks of the Thames near London; and the Arun, Sussex. P. VIII.

[5. S. pungens (Vahl); st. acutely triquetrous throughout, spikelets few sessile, gl. notched mucronate smooth with acute lobes, nut roundish-obovate plane-convex smooth.-E. B.S. 2819. R. viii.304. St. 36. 4. S. tenuifolius DC. - St. from a few inches to $1 \frac{1}{2}$ foot high, slender; with several sheaths at the base terminating in long narrow keeled leaves. Lower bract very long and rigid, resembling a prolongation of the stem. Spikelets large, ovate, obtuse, all sessile. Anth. with a subulate fringed point. Stigmas 2.-St. Ouen's Pond, Jersey. P. VI. VII.]

\section{+++ Stem terete.}

6. S. lacustris (L.); st. round, spikes in a terminal twice compound panicle, $g l$. notched mucronate glabrous fringed, nut $o b$ tusely trigonous obovate, stigmas 3.-E.B.666. St.36. 1. R. viii. 306.-St. 4- 6 feet high, naked; with 1 or 2 long sheaths at the base. Anth. bearded at the end. Panicle terminal. The bract sometimes resembles a continuation of the stem. Sometimes the 
sheaths bear long nearly flat floating leaves.-Rivers and ponds. P. VI. VII. Bull Rush.

7 ?. S. Tabernamontani $(\mathrm{Gm}$.); st. round, spikes in a terminal compound panicle, $g l$. notched micronate punctate-scabrous fringed, nut compressed roundish-oblong smooth, stigmas 2. $-R$. viii. 307. S. glaucus Sm., E. B. 232 l.-St. 2 feet high, with 1 or 2 long sheaths at the base. Anth. not bearded. Panicle smaller than in the preceding. Lower bract short. Fr. convex on one side.-Rivers and ponds. P. VI. VII.

** Bristles 4-6. Spike solitary, terminal. Basothryon Dietr.

8. S. caspitosus (L.); st. nearly round striate with imbricate leafless acute scales and sheaths with short subulate $l$. below, spike terminal solitary ovate few-flowered, gl. ovate membranous pointed, 2 outer gl. as long as the spike inclosing it and terminating in long rigid leaflike points, nut obovate oblong mucronate smooth, bristles longer than the nut with a few erect teeth near the tip.-E. B. 1029. St. 10. R. viii. 300.-St. 3-6 in. long, many, erect, many of them barren. Bristles 6.-Barren turfy heaths. P. VI.-VIII.

9. S. pauciflorus (Lightf.); st. round striated with a few thin narrow leafless scales and one tight abrupt leafless sheath below, spike terminal solitary ovate few-flowered, $g l$. ovate keeled membranous at their edges, 2 outer gl. obtuse shorter than the spike and inclosing it, nut obovate mucronate finely reticulate-striate, bristles shorter than the nut with declining teeth.-E. B. 1122. St. 10. R. viii. 299.-St. 3-10 in. long, erect, many of them barren. Bristles 6.-Boggy moors and heaths. P. VI.-VIII.

10. S. parvulus (R. and S.) ; st. round with one close-pressed leafless sheath, $l$. filiform acute radical slightly dilated at the base and clasping the st., spike terminal solitary oval few-flowered, gl. ovate obtuse keeled membranous, 2 outer ones rather longer, nut obovate-oblong mucronate smooth, bristles twice as long as the nut with declining teeth throughout.-St.85. 1. R. viii. 299. -Root fibrous with capillary stoles. St. about an inch high, several. St. and 1. with 2 or 3 longitudinal fibres and more or less perfect transverse lines. Bristles 4-6.-On a mud-flat near Lymington, Hants. Rev. G. E. Smith. A. VII. E.

*** Bristles 0.—† Spike solitary. Eleogitor Link.

11. S. fluitans (L.) ; st. floating branched leafy, l. fasciculate, fl.-stalks alternate with a sheathing l. at the base, spike terminal ovate few-flowered, gl. obtuse keeled membranous at their edges, 2 outer gl. larger shorter than the spike and inclosing it, nut ob- 
ovate, stigmas 2.-E. B.216. St. 85.2. R. viii. 298.--St. rooting from the lower joinings and spreading to a great extent in a zigzag manner.-Ditches and ponds. P. VI. VII.

\section{†† Spikes 1-3. Isolepis R. Br.}

12. S. setaceus (L.); st. round leafy at the base, spikes terminal, lower bract long so as to resemble a short continuation of the st., gl. obtuse mucronate, nut trigonous obovate longitudinally ribbed and transversely striated, stigmas 3.-E. B. 1693. St. 10. $R$. viii. 301.-St. tufted, slender, 3-6 in. high. Spikes small, sessile, considerably shorter than the lower bract. Gl. brown with whitish margins and a green keel.-Wet sandy and gravelly places. P.? VII.

13. S. Savii (S. and M.); st. round leafy at the base, lower bract shorter or slightly longer than the terminal spikes, gl. obtuse submucronate, nut subglobose rough with minute points, stigmas 3.-E. B. S. 2782. R. viii. 301.-Closely resembling $S$. setaceus. Spikes varying considerably in length, sometimes 1 in. long. Gl. scarcely mucronate, greenish, usually with a brown spot on the upper part of each side.- $\beta$. monostachys (Hook.); spike small solitary, bract very short. Isolepis pygmaa Kunth. -In many places near the coast. P.? VII.

t†† Spikes many, in heads. HoLoscharus link.

14. S. Holoschønus (L.); st. round, spikes in dense globular sessile or stalked heads, lower bract erect long, gl. obovate emarginate mucronate. $-E . B .1612$. - St. 3-4 feet high, round quite up to the cluster. Upper bract patent or ascending; lower very long, with a flat upen white channel. Gl. variegated with fuscous and white, pilose. Anth. with a long entire point.-Sandy coast of Somerset and Devon, rare. P. IX.

E.

\section{Blysmus Panz.}

1. B. compressus (Panz.); st. rather triangular, spikelets 6-8flowered, outer gl. shorter than the spikelet, bristles 3--6 strong persistent with declining teeth, 1 . flat rough on the edges and keel.-Scirpus Sm., E. B.791. St. 85. 6. R. viii. 293.-St. 6-s in. high. Outer gl. of lowest spikelet with a subulate leaflike point which often overtops the spike. Glumes reddish-brown, striated. Nut lenticular, shortly stalked, crowned with the long persistent style, shining.-Boggy pastures. P. VI. VII. E. S.

2. B. rufus (Link); st. round, spikelets 2-4-flowered, outer gl. as long as the spikelet, bristles $1-6$ slender deciduous with patent or ascending teeth, l. channeled not keeled smooth.- 
Scirpus Sm., E. B. 1010. St. 85. 7. R. viii. 293.-St. slender. Gl. dark-brown, polished, not striate. Nut ovate, with a long beak and very short stalk, opaque.-Marshes near the sea on the northern and western coasts. P. VII.

\section{Ertophorum Linn. Cotton-grass.}

* Bristles 4-6, at length crisped. Spike solitary.

1. E. alpinum (L.); st. triquetrous, scabrous, l. very short, spike oblong. - E. B.311 (excl. the leafy shoot). R. viii. 288. St. 10. - A slender elegant plant now nearly lost through the drainage of its place of growth,-Moss of Restenet, Forfar. Mr, Brown. Durness, Sutherlandshire. Prof. Balfour. P. VI.

S.

** Bristles very many, not crisped.- + Spike solitary.

2. E. vaginatum (L.); st. triangular above round below, spike oblong, nut obovate, 1. long setaceous triquetrous-channeled, upper sheath inflated leafless.-E. B. 873. R. viii. 289.-Bogs and moors. P. V. Hare's-tail Cotton-grass.

[E. capitatum (Sm.); "st. entirely round with a swelling sheath, spike roundish, glumes membranous."-E.B.2387.-Ben Lawers near perpetual snow. Mr. G. Don. Mr. Don's authentic specimen (Herb. Hook.) resembles E. capitatum, but the upper part of its st. is triangular. P. VIII.]

S.

\section{t† Spikes more than one.}

3. E. angustifolium (Roth); st. nearly round, peduncles smooth, l. linear channeled their upper half triangular, nut elliptic-acuminate or obovate triquetrous. $-E . B .564$. $R$. viii. 291. - Tall and rather slender. L. triangular through more than half their length. Bristles 3 or 4 times as long as the spikes.- $\beta$. minus; st. and.l. very slender. $E$. gracile $\mathrm{Sm}$., E.B. 2402 (not Koch). An alpine form has but one nearly sessile spike. $-\gamma$. elatius (Koch); st. strong tall, 1. $2-3$ lines broad the triangular part commencing above the middle. $E$. polystachion Sm.-Bogs. $\beta$. in mountainous districts. P. V. VI. Common Cotton-grass.

4. E. latifolium (Hoppe); st. triquetrous in its upper half, peduncles scabrous, l. linear nearly flat contracted above the middle into a triangular point, nut obpyriform triquetrous. $-R$. viii. 292 . E. pubescens Sm., E. B. S. 2633 . E. polystachion E. B. 563.-A tall rather slender plant. L. about 2 lines broad; triquetrous point short. Several of the elegant spikes upon longish stalks which are not downy but scabrous. Bristles 2 or 3 times as long as the spikes. Bogs, rather rare.

P. V. VI. 
5 E. gracile (Koch); st. subtriquetrous, peduncles downy, $l$. narrowly linear triquetrous, nut oblong-linear triquetrous. E. B. S. 2886 . R. viii. 290 . E. triquetrum Hoppe, St. 10.2. -A tall slender plant. Spikes about 4, most of them on downy not scabrous stalks. Gl. with many ribs. Bristles about twice as long as the spike.-Bogs. Halnaby, Yorkshire. Whitemoor Pond, Guildford. P. VI. VII.

E.

\section{Tribe III. Elynea.}

\section{Kobresia Willd.}

1. K. caricina (Willd.).-E.B. 1410. Schk. Rrr. 161. R. viii. 193.-St. erect, $6-12$ in. high. L. slender, falling short of the stem. Spikes $4-5$, aggregated at the summit of the stem, 6-8-flowered. There is an abortive stam. (?) at the base of the nut; but some authors, considering each fl. as a separate spike, think that this represents a second flower.-Moors. Yorkshire. Durham. Perthshire. P. VII. $\quad$ E. S.

\section{Tribe IV. Caricea.}

\section{Carex Linn. ${ }^{1}$}

i. Monostachya. Spike simple, solitary.

* Diøcious. Stigmas 2.

1. C. dioica (L.); fertile spike ovate dense, fr. ascending ovate many-veined angles rough near the top, nut roundish oral, terete st. and l. roughish, stoloniferous.-E. B. 543. Schk. A. 1. H. a. 1. R. 194.-About 6 in. high. Sometimes the barren spike has fruits at its base.-Spongy bogs. P. V. VI.

2. C. Davalliana (Sm.); fr. deflexed ovate-lanceolate angles rough near the top, nut "linear-oblong," st. and margins of the 1. rough, cæspitose.-E.B. 2123. R. 194.-About 6 in. high.-Lansdown near Bath: now lost by drainage. P. VI. E.

${ }^{1}$ In the following descriptions fruit means the persistent bottleshaped perigone, including the ripe nut or true capsule. The glume is always taken from the fertile spike unless it is otherwise stated. Schk. refers to the plates of Schkuhr's Riedgräser; H. to Hoppe's Caricol. Germ. in Sturm Deutschl. Flora; and R. to Reichenbach Ic. Fl. Germ. Cent. viii. See also for excellent Monographs Andersson's Pl. Scand., and Lang in Linncea, xxiv. 481. 


\section{** Spike barren at the top. Stigmas 2.}

3. C. pulicaris (L.); half of spike barren, fr. remote at length deflexed oblong-lanceolate compressed, nut oblong-obovate planeconvex.-E. B. 105l. Schk. A. 3. H. a. 3. R. 195.-St. slender, 6-12 in. or more in height, erect, smooth. L. slender, erect. Glumes deciduous. Fr. dark brown.-Bogs. P. VI.

\section{*** Spike barren at the top. Stigmas 3 .}

4. C. rupestris (All.); half of spike barren, fr. obovate trigonous with a very short beak adpressed scarcely longer than the persistent gl., "nut obovate acutely triquetrous." - E. B.S. 2814. H. b. 4. R. 198.-Stoloniferous. St. 3-6 in. high, triquetrous, rough upwards. $L$. flat, ending in a tortuous rough slender triangular point. Gl. fuscous. Fr. paler.-Lofty mountains. P. VII.

S.

5. C. pauciflora (Lightf.); $1-3$ terminal fl. barren, fr. $2-4$ lanceolate-subulate terete patent or reflexed longer than the deciduous gl., nut linear-oblong trigonous.-E. B.2041. Schk. A. 4. H. b. 1. R. 196.-Stoloniferous. St. usually about 5 inches high, slender. L. 2 or 3 , much shorter than the stem. Fr. pale yellow.-Bogs in the north. P. VI. VII. E. S.

ii. Homostachya. Spikelets barren at one or both ends in a compound continuous or interrupted spike. Nut plane-convex or compressed. Stigmas 2.

+ Spikelets barren at the top.- $\ddagger$ Rhizome far-creeping.

6. C. incurva (Lightf.); spikelets in a roundish head, fr. inflated broadly ovate acuminate-rostrate, beak split externally, nut obovate, st. smooth about equalling the leaves.-E. B. 927. Schk. Hh. 95. H. a. 5. R. 199.-St. 2-3 in. high, usually recurved so as to bring the large head down to the ground. Beak of fr. usually rather scabrous.- Sandy shores of the north. P. VI.

7. C. divisa (Huds.); spikelets in a somewhat ovate head, $f r$. plane-convex ovate many-veined, beak acutely bifid with finely serrated edges, nut broadly oblong, gl. with an excurrent rib, lowermost bract leaflike, st. roughish at the top.-E. B. 1096. -St. slender, a foot high. Fr. veined on both sides. Spike often interrupted below.-Near the sea on the southern and eastern coasts. P. V. VI. $\quad$ E. I.? S.?

8. C. disticha (Huds.); spikelets in an oblong interrupted spike upper and lower ones fertile intermediate barren, fr. ovate- 
lanceolate veined narrowly margined bifid with serrated edges above, nut elliptical, gl. shorter than the fr. acute the midrib not reaching the top, st. with scabrous angles.-C. intermedia Good., E. B. 2042. Schk. B. 7. H. a. 14. R. 210.-Height 1-2 feet. Fr. about as long as gl.; usually abortive and twice as long. Lower bract with a slender leaflike point.-Marshy places. P. V. VI.

9. C. arenaria (L.); spikelets in an oblong interrupted spike upper barren lower fertile intermediate barren at the end, $f r$. ovate veined winged and finely serrate from the middle to the bifid top of the beak, nut bluntly ovate, glumes longer than the fr. acuminate, st. scabrous above.-E. B.928. Schk. B. and Dd. 6. H. a. 13. R. 209.-Height 1 foot. Rhizome superficial. Lowermost bracts with slender leaflike points.-Sandy places. P. VI.

\section{++ Caspitose. Spike simply compound. Fr. squarrose, not gibbous.}

10. C. vulpina (L.); spikelets compound in a cylindrical oblong crowded spike, fr. ovate-acuminate plane-convex veined, beak bifid finely serrate, nut oval tipped with a beak slightly thickened upwards, gl. mucronate shorter than the fruit, st. triquetrous with scabrous angles, bracts setaceous. $-E$. B. .307. Schk. C. 10. R. 217.-Height 2 feet. St. firm; faces concave. L. broad. Fr. palish green. Beak of the nut constricted, its base narrower than the base of the style.- $\beta$. nemorosa (Reb.); spikelets greenish, bracts long. R. 216.-Wet places. P. VI.

11. C. muricata (L.); spikelets approximate, spike oblong dense or interrupted below, $f r$. ovate-acuminate plane-convex obsoletely veined bifid finely serrate above divergent, nut ovate its beak extremely short, gl. mucronate shorter than the fruit, st. triquetrous with rough angles.-E. B. 1097. R. 215.-Height 1-2 feet. St. slender but strong. L. narrow. Lowermost spikelets not more than their own length distant from each other. Fr. much larger than that of No. 12, with a broad flat beak with very sharp edges.-Gravelly pastures. P. VI.

12. C. divulsa (Good.); spikelets distant the upper ones approximate, $f r$. ovate acute plane-convex obsoletely veined bifid smooth ascending, beak roughish at the edges, nut ovate-oblong compressed its beak extremely short, gl. mucronate shorter than the fruit, st. triquetrous with rough angles above, bracts short setaceous. $-E$. B. 629. Schk. Dd. and Ww. 89. H. a. 16. R. 220 . -Height 1-2 feet. St. lax, slender, flaccid. Spikelets grayish, usually distant, 1 or 2 lowest often lengthened into a short branch. 
Fr. with a thick green margin slightly rough near the top.Moist shady places. P. VI.

¥++ Caspitose. Spike compound, often panicled. Fr. ascending, gibbous on its back.

13. C. teretiuscula (Good.); spike compound oblong, spikelets densely aggregated, fr. ovate with $2-5$ central ribs on the convex side (back), beak bidentate serrulate split to its base and overlapping on the back, nut turbinate with a very short beak convex, style not thickened at the base, st. trigonous and scabrous above.-E. B. 1065 . Schk. D. 19. T. 69. H. a.9. R.222.Root forming scattered sirnple tufts. St. $1-2$ feet high, slender. - . C. Ehrhartiana (Hoppe); root more cæspitose, spike long, spikelets rather loosely aggregated, nut narrowed from below the middle, st. triquetrous above--Boggy meadows, rare. $\beta$. near Manchester. P. VI.

14. C. paradoxa (Willd.); spikes narrowly panicled lower branches rather distant, fr. ovate with many short elevated ribs near its base, beak obliquely bidentate serrulate not split nor winged on its back, nut rhomboidal constricted below doubly convex with a short beak, style slightly enlarged at the base, st. trigonous and scabrous above.-E. B. S. 2896 . Schk. E. 21. $H$. a. 12 . R. 222 .- Root densely tufted, crowned with the fibrous remains of decayed leaves. St. 1-2 feet high, slender. -Bogs. Near Mullingar, Ireland. Near York. Hoveton, Norfolk. P. VI. VII.

E. I.

15. C. paniculata (L.); spikes panicled with long diverging branches, $f r$. ovate faintly many-veined with a bifid fringed beak split to its base and overlapping on the back, nut ovate obtuse narrowed below plane-convex, beak slightly thickened upwards, st. triangular. - E. B. 1064 . Schk. D. 20. Ttt. 163. H. a. 19. R. 223.- Root forming dense elevated tufts. St. stout, $2-3$ feet high. Panicle usually large and spreading or reduced to a slender compound (or even simple) spike. Bracts all much shorter than the spike.-Bogs. P. VI.

+† Spikelets barren at their base (or at both ends).

\section{‡ Rhizome far-creeping.}

16. C. brizoides (L.); spikelets about 5 contiguous curved, fr. lanceolate plane-convex bifid at the end deeply split on the back serrulate from near the base, gl. rather shorter than the fruit.-H. a. 23 . R. 207 . - St. 1 ft. high. Gl. acute, silvery brown. L. long, slender, equalling or overtopping the spikes. -Studley Wood, Yorkshire. Mr. W. MacIvor. P. VII.? E. 
¥¥ Caspitose. Bracts leafike. Lower spikelets distant, simple or compound.

17. C. Boenninghauseniana (Weihe); spikelets several upper ones simple crowded lower distant alternately branched, fr. lanceolate plane-convex tapering strongly serrate from below the middle, beak deeply split on one side, nut ovate-elliptical pointed, gl. equalling the fruit, root tufted, lower bract at least equalling the spike.-E. B. S. 2910 . H. a. 34. Kunze Riedg. 22. R. 219. - St. 1-2 feet high, triangular with slightly convex faces and rough edges. Inflorescence often a foot long. Rachis straight, with 3 rough edges. Gl. ovate, membranous, silvery brown, smooth. Lower spikelets wholly barren, barren at both ends or at either end. Bracts, except the lowest, short. L. channeled.-Marshes and pond-sides. P. VI.

18. C. axillaris (Good.); spikelets several upper ones simple crowded lower distant densely compound, fr. ovate-lanceolate plane-convex tapering deeply bifid serrate above, nut obovate with a beak, gl. shorter than the fruit, root tufted, lower bract as long as or longer than the spike.-E. B. 993. H. a. 33 . -St. I-2 feet high, acutely triangular. Rachis straight, with 3 rough angles. Gl. ovate, membranous, brownish; midrib often rough, extending to the point. Divisions of the lower spikelets crowded into the axils of the bracts. Bracts, except the lowest, short. L. flat. Spikelets barren at the base or at both ends.-Marshes. P. VI.

- 19. C. remota (L.); spikelets several all simple upper ones crowded lower distant, fr. ovate-acuminate plane-convex notched at the end serrate above, nut ovate with a beak, gl. shorter than the fr., root tufted, bracts long.-E. B. 832. Schk. E. 23. H. a. 35. R. 212.-St. 1-2 feet high, trigonous. Rachis with 2 rough angles in its upper part. Gl. ob'ong, membranous, greenish-white; midrib smooth, usually not reaching the point. Several of the bracts long. L. channeled. Sometimes with a thick rooting densely proliferous rhizome.-C. tenella $(\mathrm{Sm}$.) is sair to differ by its small spikelets with a terminal sterile $f$. and $f r$. equally convex on both sides. It should be looked for " in a wood by the Esk, Angusshire."-Damp places. P. VI.

$\$+$ Caspitose. Bracts not leafike. Spikes approximate or
rather distant. + Spikes and leaves glaucous or dusky.

20. C. stellulata (Good.); spikelets about 4 roundish rather distant, fr. divergent broadly ovate acuminate plane-convex striate, beak bifid with serrate edges, nut ovate obtuse tapering 
below, gl. shorter than the fruit.-E.B.806. Schk. C. 14. H.a. 28. R. 214.- St. $6-12$ in. high, triquetrous, nearly smooth. Lowermost spikelet often with a short bract. Gl. ovate, membranous, reddish with a green keel and white edges. Ripe fr. greenish, stellate.-Boggy places. P. V. VI.

21. C. elongata (L.); spikelets many oblong approximate, fr. patent oblong-acuminate plane-convex with many ribs on both sides, beak almost entire with rough edges, nut linear-oblong tapering below beak very short style persistent, gl. shorter than the fruit, bracts none or one very short.-E. B. 1920. Schk. E. 25. H. a. 32. R. 218. - St. $1-2$ feet high, triquetrous. Gl. ovate, dark brown with a green keel and whitish edges, obtuse, sometimes apiculate. Upper spikelets crowded, lower lax but not distant.- $\beta$. C. Gebhardi (R.); smaller, spikelets short panicled. - Marshes, rare. P. VI.

E. I.

22. C. curta (Good.); spikelets 4-6 elliptical approximate, fr. erect acute plane-convex faintly striate, beak short notched not split rough at the edges, nut elliptical beak very short style persistent, glumes ovate shorter than the fruit.-E. B. 1386. Schk. C. 13. C. canescens Linn.? R. 206.-St. a foot high, triquetrous, smooth except at the top. Lowermost spikelet often with a setaceous bract. Glumes membranous, whitish with a green keel, blunt, apiculate. Fr. whitish.-Bogs. P. VI.

23. C. vitilis (Fr.) ; spikelets $4-8$ ovate or oblong approximate, fr. erect ovate plane-convex faintly striate, beak short split to its base externally rough at the edges, " nut elliptical," glumes ovate shorter than the fruit.-C. curta $\beta$. alpicola $W a h l$. C. Persoonii Sieb., R. 206.-Creeping. St. 6-12 in. high, triquetrous, smooth except at the top. Lowermost spikelet often with a setaceous bract. $G l$. membranous, brown with a white margin. -Mountains. P. VII. VIII.

E. S.

\section{+ Spikes fuscous.}

24. C. lagopina (Wahl.); spikelets $3-4$ roundish-elliptical contiguous terminal one longer, fr. erect elliptical acuminate plane-convex narrowed below nearly entire at the point with smooth edges, nut elliptical tipped with the persistent style, gl. ovate nearly as long as the fruit.-H. a. 24 . $R$. 204 . C. leporina Linn. Fl. Lap. not Fl. Suec. E. B. S. 2815.-St. 4-8 in. high, smooth, triangular. Glumes reddish with the edges paler. Fr. yellow.-Loch na Gar, and Cairn Toul, Aberdeenshire. P. V'III.

S.

25. C. ovalis (Good.); spikelets about 6 oval contiguous, $f r$. erect ovate-attenuate plane-convex narrowed below bifid at the 
point with membranous edges serrulate above, nut elliptical with a short cylindrical beak terminating in the persistent style, gl. lanceolate as long as the fruit.-E.B.306. Schk. B. 8. C. leporina $H$. a. $22, R$. 211.-St. $1-2$ feet high, triangular, smooth or roughish above. Gl. lanceolate, acute, brown with a paler membranous margin. Fr. yellowish.-Meadows. P. VII.

iii. Heterostachya. Spikes separate, one or more terminal wholly or rarely only partially barren, the others fertile.

* Beak of fr. short, entire or emarginate or shortly 2-toothed.

+ Nut plane-convex. Stigmas 2, rarely 3. Barren spikes 1 or more.

+ Stigmas 2. Sheaths of leaves webbed. Fertile spikes erect. L. ultimately revolute-edged; lowest sheaths usually leafless.

26. C. stricta (Good.); fertile spikes erect elongate-cylindrical, bracts auricled lowermost leaflike short, fr. oblong-elliptical acute compressed veined closely imbricated, nut nearly round shortly beaked, sheaths of 1 . with filamentous network.-E. $B$. 914. R. 230. C. caspitosa H. and A.-Densely crespitose. St. 2-3 ft. ligh, triquetrous, rigid. L. short, narrow. Fertile spikes often barren at the top Gl. blunt or acute, equalling or shorter than the fr, narrow, dark purple; keel green. Fr. in 6-9 regular rows.-Marshes. P. VI.

[27. C. caspitosa (L.); fertile spikes erect subsessile oblong, bracts with long narrow auricles lowest slender leaflike short, fr. elliptical lenticular not veined rather patent, sheaths of 1 . finely webbed.-R. 229. C. pacifica Drej.-Cæspitose. St. slender, acutely triangular. St. lax. L. shorter downwards. Spikes close together. GI. lanceolate, dark purple; keel rather paler.-"Britain. Dr. Greville." Fries. P. V.]

\#+ Stigmas 2. Sheaths not webbed, usually all bearing leaves.

L. ultimately revolute-edged. Stoloniferous.

28. C. acuta (L.); barren spikes $1-3$, fertile $2-4$ slender cylindrical-acuminate erect with fruit, lowermost bract leaflike often overtopping the stem with elongate auricles, fr. oblong lenticular veined, nut roundish-obovate with a short skender beak, gl. acute. - E. B. 580. Schk. Fe. Ff. 92. H. a.44. R. 231, 232. -St. $2-3$ feet high, triquetrous, rough at top. L. broad. G1. narrow-lanceolate, acute, on the male spikes spathulate-lanceolate, purple with a green keel. Fr. pale, blunt or acute, round or oval, spherical or flattened. Fertile spikes usually with a few barren $\mathrm{fl}$. at the end, nodding with flowers. - Wet places. P. VI. 
29. C. rigida (Good.); spikes erect, barren 1, fertile oval or shortly cylindrical dense subsessile, lower bract leaflike, $f r$. elliptical lenticular without veins, nut roundish blunt with a slender beak, st. triquetrous rough towards the top, $l$. curving outwards with deflexed edges.-E.B. 2047. H. a. 40. R.225. C. saxatilis L. ?-St. 6 in. to a foot or more high. L. broad, flat, keeled, rigid. Bracts without sheaths. Spikes near together, short, rarely narrowed and laxly flowered below. Gl.about exceeding the fr., purple with a green keel. Nut rather longer than broal. -In wet and stony places on mountains. P. VI. VII.

+++ Stigmas 2. Sheaths no webbed. Fertile spikes erect. Edges of leaves ultimately involute. Gl. narrower than fruit.

30. C. aquatilis (Wahl.); spikes erect, barren 1 or more, fertile 3 or 4 long narrowed below lower ones stalked, bracts leaflike erect overtopping the stem, fr. elliptical lenticular without veins broader than the gl., nut oblong narrowed below with a short slender beak, st. trigonous smooth.-E. B. S. 2758.-St. l-4 ft. high, with convex faces. Spikes rather distant. Gl. usually short, narrower than the yellowish-green fr., reddishpurple with a pale midrib.-Alpine boggy table-lands of the Clova mountains and in the valley by the bridge at Clova." P. VII.

31. C. vulgaris (Fries); spikes erect, barren 1 or 2 , fertile 3-4 subsessile cylindrical, bracts with short auricles leaflike, fr. elliptical plane-convex with many veins below and a short entire beak, nut roundish very blunt, st. triquetrous rough towards the top.-C. caspitosa Sm., E. B. 1507. C. Goodenovii Gay._St. about a foot high. L. slender, not keeled. Bracts without sheaths. Spikes near together, short. Gl. blunt, shorter than fr., purple; keel slender, pale green. Fr. greenish or with a purple tinge. Nut rather broader than long.-Marshes. P. V.VI.

32. C. Gibsoni (Bab.); spikes erect, barren 1, fertile 2-4 oblong narrowed downwards slightly stalked, bracts with short auricles leaflike, fr. lanceolate acute with many veins not reaching the summit, nut broadly obovate very blunt with a short thick beak, st. triquetrous rough towards the top.-A. N. H. xi. t. 5.-St. 6-8 in. high. L. flat, not keeled; sheaths not filamentous, lowest leafless. Lowest bract long. Spikes lax below. Glumes falling short of the fr., oblong, blunt, purplish-brown with a broad green band up the midrib; on the barren spike paler, obovate-lanceolate. Perigone nearly twice as long as the nut, gradually narrowed from below the middle to the top. Nut rather broader than long.- Nearly allied, I think, to C. vulgaris 
rather than $C$. acuta.-Hebden Bridge, Yorkshire : said to be now lost by drainage. P. VI.

E.

†† Nut with 3 angles. Stigmas 3, rarely 2.

‡Fruit glabrous. Terminal spike barren at its base.

33. C. Vahlii (Schk.); spikes 1-4 roundish or oblong contiguous nearly sessile, fr. obovate veinless scabrous above with a short notched beak, gl. acutish falling short of fr., nut obovate triquetrous blunt with a short cylindrical beak, bract scarcely overtopping the spikes, st. triangular rough towards the top.E. B. S.2666. Schk. Gg. 94. and Ppp. 154. R.235.-St. 6-12 in. high, erect. Gl. brown or black.-Glen Callater and Glen Fiagh, Clova. P. VII.

S.

34. C. Buxbaumii (Wahl.); spikes $3-4$ oblong sessile contiguous, the lowest shortly stalked rather distant, fr. oval obtuse compressed (ultimately irigonous) bidentate subscabrous above veined, gl. cuspidate lower exceeding fr., nut obovate trigonous blunt apiculate, lower bract leaflike.-E. B. S. 2855 . H. b. 11. Schk. X. and Gg. 76. R. 235. C. canescens, Linn. Herb.-St. $1-2$ feet high, triquetrous, rough. Sheaths of the $l$. connected by netlike filaments. Gl. nearly black, with a green keel prolunged into a cuspidate point. Fr. glaucous-green.-Island near Toom bridge in Lough Neagh. P. VI.

35. C. atrata (L.); spikes $3-4$ ovate-oblong shortly stalked contiguous ultimately drooping, the lowest rather distant and with a longer stalk, fr. elliptical vcinless with a short terete slightly notched beak, glumes acute, nut elliptical triquetrous blunt apiculate, lower bract leaflike.-E. B.2044. Schk. X. 7T. H. b. 8. R. 237 . St. $1-1 \frac{1}{2} \mathrm{ft}$. high, triangular, smooth. L. flat, broad. Gl. dark purple; midrib slender, pale. Fr. yellowish. -Alpine rocks. P. VI. VII.

\section{++ Fruit glabrous. Terminal spike wholly barren, solitary.}

36. C. pallescens (L.); fertile spikes subpendulous ovate or oblong with exserted stalks approximate, bracts leaflike, gl. mucronate, fr. ovate-oblong convex on both sides veined obtuse, beak 0 , nut linear-elliptical narrowed at both ends trigonous.E. B. 2185. Schk. Kk.99. H. b. 44.-St. slender, triquetrous, rough above, $1-1 \frac{1}{2}$ foot high. Spikes blunt, pale green; the barren one sessile, darker.-Marshy places. P. VI.

37. C. panicea (L.); fertile spikes erect remote subcylindrical on exserted stalks with distant fl., bracts leaflike sheathing, gl. rather acute, fr. orate-subgloliose inflated veinless with a short terete truncate beak, nut obovate-oblong trigonous with a cylin- 
drical beak.-E. B. 1505. Schk. Ll. 100. H. b. 33.-St. 1-2 ft. high, erect, smooth. Fertile spikes about 2. Gl. oblong, more or less acute, dark brown with a green keel and membranous pale margins. Lowermost bract about as long as its spike, the rest shorter, sheaths close.-Marshy places. P. VI.

38. C. vaginata (Tausch !); fertile spikes erect remote on exserted stalks with distant fl., bracts sheathing scarcely leaflike, gl. bluntish, fr. ovate triquetrous glabrous veinless with a short terete smooth very obliquely truncate and emarginate beak, nut elliptical triangular " with a beak slightly thickened upwards." H. b. 17. Kunze Riedg. 15. C. phæostachya Sm., E. B. S. 2731. C. Meilichoferi Sm., E. B. 2293. - St. 5-6 in. high, smooth. Fertile spikes $1-2$. Glumes bluntish. Bracts with funnelshaped sheaths.-Highland mountains. P. VII.

39. C. limosa (L.); fertile spikes 1 or 2 upon very long stalks drooping ovate densely-flowered with occasionally a few barren $f$. at their top, bracts auricled slender strongly keeled, gl. ovate mucronate, fr. roundish-obovate compressed strongly ribbed with a very short entire beak, nut obovate bluntly trigonous with a beak, $l$. narrow linear complicately-channeled rough at the edges throughout.-E. B. 2043. Schk. X.78. H. b. 49. R. 238.Creeping. St. $1 \mathrm{ft}$. high. L. and bracts very slender. Gl. purple, with a green keel, about as long as the pale fr. which is broadest above the middle. Nut pale.-Spongy bogs. P.VI.

40. C. irrigua (Hoppe); fertile spikes 2 or 3 drooping upon long stalks oblong densely-flowered with occasionally $a$ few barren $f$. at their base, bracts auricled leaflike rather broad nearly flat, gl. ovate-lanceolate attenuate acute, fr. roundish-ovate compressed faintly ribbed with a very short entire beak, nut elliptical triangular with a beak, $l$. linear flat smooth at the edges except near the tip.-E. B. S. 2895. H. b. 48. R. 238.-Creeping. St. a foot or more in height. L. and bracts 2 or 3 times as broad as in the preceding. Gl. wholly purple, usually longer than the pale fr. which is broadest below the middle. Nut pale. - Spongy bogs. Muckle Moss, Northumb. Terregles, Dumfries. Ben Mime near Loch Lomond. P. VI.

41. C. rariflora (Sm.); fertile spikes 2 or 3 drooping upon long stalks oblong few-flowered lax, bracts with very short sheaths, gl. very broad blunt as long as the fr., fr. oblong with 3 blunt angles, beak extremely short entire, nut roundish-oblong, l. flat rough-edged towards the tip.-E. B. 2516.-Creeping. St. $6-8$ in. high, smooth. Gl. folded round the fr., dark brown ; midrib pale, terminating in a minute apiculus. Fr. pale, faintly veined; nut darker.-Elevated bogs. Highlands, rare, P. VI. 

++ Fruit glabrous. Several barren spikes. Fertile spikes
drooping.

42. C. capillaris (L.); fertile spikes upon long stalks half included few-flowered lax, one bract sheathing several flowerstalks, gl. blunt, fr. oblong trigonous turgid narrowed below veinless terminating in a slender membranous beak, nut obovate triquetrous blunt with a short beak.-E. B. 2069. Schk. O. 56. H. b. 53. R. 241.- St. very slender, $2-6$ in. high, smooth. Peduncles rough, several usually inclosed in one sheath. Gl. short, broad, blunt, midrib not reaching the tip, falling short of the small smooth brown fruit. Nut pale. Root tufted.-Teesdale. Scottish Highlands. P. VI.

E. S.

43. C. strigosa (Huds.); fertile spikes about 4 distant rather long slender lax lower with exserted stalks, bracts leaflike sheuthing, fr. oblong-lanceolate narrowed at both ends trigonous veined with an obliquely truncate mouth, nut elliptical triangular punctured, 1. broad.-E. B. 994. Schk. N. 53.-St. 2 feet high. Sheaths covering nearly the whole length of the peduncles. Gl. elliptic-lanceolate, diaphanous, greenish down the back.-Groves and thickets, rare. P. V. VI.

44. C. pendula (Huds.); fertile spikes about 5 distant cylindrical very long densely-flowered, bracts leaflike lower ones with sheaths nearly equalling the flowerstalks upper scarcely sheathing, fr. elliptical subtrigonous tumid with a short trigonous emarginate beak, nut elliptical narrowed at both ends triangular.-E. B. 2315. Schk. Q.60. R.243. C. Agastachys Ehrh. H. b. 57. C. maxima Scop. - St. 3-6 feet high, rough at the angles above. Fertile spikes often 3 or 4 in. long, arched; upper ones frequently with barren $\mathbb{A}$. at the tip. Gl. ovate, mucronate, brown with a green keel. Fr. green, ciliated at the mouth.Damp woods. P. V.

++++ Fruit downy, hairy or scabrous. Bracts sheathing. L. in sterile tufts. Barren spike 1.

45. C. humilis (Leyss.); fertile spikes 2 or 3 remote about 3flowered inclosed in the membranous sheathing leafless bracts, fr. obovate subtrigonous narrowed below with an entire oblique mouth, "nut obovate triangular with a short beak." - H. b. 15. C. clandestina Good. E.B. 2124. Schk. K. 43. R. 239.-St. about 2 in. high, erect, concealed amongst the leaves. Bracts large, wholly membranous, nearly hiding the fertile spikes. L. all radical, linear, channeled, rough.-Limestone hills in Wilts and Somerset. P.IV.

E.

46. C. digitata (L.); fertile spikes 2 or 3 distant linear erect lax, bracts membranous sheathing obliquely truncate lowermost 
with a setaceous leaflike point, fr. obovate trigonous narrowed below equalling gl., beak short nearly entire, " nut elliptic-oblong triangular shortly-stalked and shortly-beaked." -E. B. 615 . Schk. H. 38. H. b. 14.-St. $6-8$ in. high, erect, sheathed at the base, leafless, taller than the flat radical leaves.-Woods on limestone, rare. P. IV. V.

E.

++++ Fr. hairy or downy or scabrous. Bracts not sheathing (except slightly in No. 50). - + Barren spike 1.

47. C. pracox (Jacq.); fertile spikes $1-3$ oblong-ovate near together sessile, bracts clasping the lowest leaflike and slightly sheathing, gl. broadly ovate-acuminate, $f r$. ovate-rhomboidal trigonous with an entire mouth, nut obovate narrowed below trigonous, base of the style surrounded by a prominent ring, stoloniferous. - E. B. 1099. Schk. F. 27. H. b. 24.-St. 3-12 in. high. Lowermost spike sometimes slightly stalked.-Dry places. P. IV. V.

48. C. montana (L.) ; fertile spikes $1-3$ ovate crowded sessile, bracts small membranous the lowest with an awlshaped point, gl. of fertile spikes obtuse notched and mucronate, fr. narrowed below oblong-obovate trigonous with a short notched beak, nut oblong narrowed below with a pyramidal beak, root fibrous from a shaggy thick branched rhizome.-E. B S. 2924. Schk. F. 29. H. b.21. R. 262. C. collina H. and A.-St. about a span long, slender. L. narrow; sheaths of lower 1. red. Gl. very dark; midrib narrowly yellowish. Fr. hairy, its beak purple.-Near Tonbridge Wells. Wynd Cliff, Chepstow. P. IV. V. E.

49. C. pilulifera (L.); fertile spikes about 3 roundish near trgether sessile, bracts small lowest scarcely leafike awlshaped not sheathing, gl. broadly-ovate mucronate, fr. stalked subglobose with a short bifid beak, nut subglobose subtrigonous narrowed below, roct fibrous.-E. B. 885. Schk. I. 39. H. b. 20. R. 260. -St. 6-1:2 in. long, slender, at length decumbent. Base of the style enlarged.-Wet heaths. P. V.

50. C. tomentosa (L.); fertile spikes 1 or 2 nearly sessile $c y$ lindrical blunt, lowermost bract leaflike with a very short sheath, gl. broadly ovate acute, $f r$. obovate subtrigonous scarcely beaked slightly emarginate, nut obtuse trigonous narrowed below with a short beak constricted at its base, stoloniferous.-E. B. 2046. Schk. F. 28. H. b. 28. R. 263.-St. a foot high, with 3 sharp angles, rough upwards, erect. Beak of nut slightly swelling upwards. Fr. with copious white down, mouth very broad.Water-meadows at Merston Measey, Wilts. P. VI. 


\section{4+ Barren spikes usually more than 1.}

51. C. glauca (Scop.) ; fertile spikes 2 or 3 erect or drooping cylindrical densely flowered long-stalked, bracts leaflike scarcely sheathing, gl. ovate acute, fr. obtuse elliptical veinless slightly scabrous entire at the small point, nut roundish-ovate triangular.-H.b. 67. Schk. O.P. 57. R. 269. C. recurva Huds., E. B. 1506.- Stoloniferous. St. a foot or more in height. Barren spikes variable in number. Fertile spikes often with a barren $\mathrm{fl}$. at the summit. $-\beta$. C. Micheliana (Sm.); gl. blunt, fr. smaller. E. B. 2236.- . C. stictocarpa (Sm.); fertile spikes ovate, fr. obovate dotted. E. B. S. 2772.-Damp places. P. VI.

** Beak of fr. long, 2-toothed or bifid. Nut with 3 angles. Stigmas 3, rarely 2.

+ Beak of fruit terete. Terminal spikè barren.

52. C. ustulata (Wahl.); fertile spikes 2 or 3 upon short stalks ovate densely flowered, bracts scarcely leaflike or sheathing, gl. ovate acute, $f r$. elliptical compressed rough-edged with a cloven beak, nut elliptical triangular on a long stalk, root fibrous. $-E$. B. 2404. Schk. Y. 82. H. b. 47.-St. 3-10 in. high. L. very short, broad. Gl. dark purple with a slender pale midrib. Fr. dark purple, paler below. Nut fuscous. I have seen no specimens.-Ben Lawers. Mr. G. Don. P. VII.

itt Beak of fruit plane-conrex. Barren spike 1, or rarely 2. Fruit glabrous. Bracts sheathing, leaflike.

53. C. flava (L.); fertile spikes roundish-oval subsessile, lowest spike witlı a nearly included-stalk, bracts leanlike with short sheaths, gl. obtuse, fr. ovate inflated ribbed smooth narrowed into a deflexed rough-edged bifid beak, nut obovate trigonous punctate-scabrous, st. trigonous smooth. - E. B. 1294. Schk. II. 36. H. b. 22. R. 273. - St. 6-l2 in. high. L. broad. Barren spike cylindrical, obtuse; gl. obtuse. Fertile spikes usually near together and near the barren spike, sometimes distant; gl. with a green midrib slightly rough and often excurrent at the end. Beak of the fr. curved downwards. Lowest fr. declining. - $\beta$. C. lepidocarpa (Tauseh !); barren spikes usually long-stalked, beak of fr. often nearly straight. I unze Riedgr. 13. R.272.-Wet places. P. V. VI.

[C. Mairii (C. and G.!), point of gl. scabrous, fr. obsoletely veined narrowed into a setose-ciliated beak, may occur.]

54. C. Gideri (Ehrh.); fertile spikes roundish-ovate subsessile near together, lowest spike with an included stalk, bracts leaflike with short sheaths, gl. obtuse (?), fr. subglobose inflated ribbed. 
smooth suddenly contracted into an erect narrow rough-edged bifid beak, nut obovate-trigonous punctate-scabrous, st. trigonous smooth.-E. B. 1772. H. b. 23. R. 272.-Much like, but distinct from, C. flava. Fertile spikes smaller. Fr. much smaller than those of C. flava, more in number, with a shorter and narrower-based beak. Very variable in height.-Bogs. P. VI. VII.

55. C. extensa (Good.); fertile spikes oblong near together subsessile lower one rather distant with a short included stalk, bracts very long leaflike with short sheaths, $g l$. mucronate triangular ribbed narrowed into a straight smooth-edged bifid beak, nut oblong-elliptical narrowed at both ends triangular smooth.E. B. 83.3. Schk. V. Xx. 72. H. b. 32. R. 274.-St. usually curved, $8-12$ in. high, trigonous, smooth. Barren spike nearly sessile, blunt; gl. blunt. L. and bracts very narrow, convolute, long.--Marshes chiefly near the sea. P. VI.

56. C. fulva (Good.) ; fertile spikes oblong-oval distant with exserted stalks, bracts leaflike with long sheaths, gl. aeute not mucronate, $\mathrm{fr}$. ovate triquetrous ribbed smooth with a straight rough-edged bifid beak, nut obovate trigonous nearly smooth.E. B. 1295. ? R. 252.-St. triangular, rough-edged, about a foot high. Barren spike spindles爪aped, acute; gl. obtuse. Lowest bract frequently, but not always, reaching up to the barren spike. Root sometimes creeping. $-\beta$. ${ }^{C}$. Hornschuchiana (Hoppe); fertile spikes oblong on longer stalks more distant, fr. more inflated and more strongly ribbed, st. trigonous smooth except sometimes near the top, lowest bract longer than its own spike. H. b. 40. R. 252. C. speirostachya Sm., E. B. S. 2770. -Boggy places. $\beta$. Peaty bogs, chiefly on mountains. P. VI.

57. C. punctata (Gaud.); fertile spikes erect cylindrical with slightly exserted stalks particularly the lowest, bracts sheathing, gl. ovate shortly awned, $f r$. ovate tumid obsoletely veined pellucidly punctate with a linear bidentate smooth beak, nut ovaterhomboidal narrowed at both ends triangular rough. $-H$. b. 37 . Kunze Riedg. 6. R. 251.-St. smooth, 1-2 feet high, slender. Spikes distant or the upper ones near; stalks slightly (the lowest often greatly) exserted, rough; lowest spike often very distant. Gl. pale red with a broad green longitudinal dorsal band. Fr. pale. Nut brown. Gl. of barren spike blunt.-Marshy places near the sea. Charlestown, Cornwall. Dingle, Kerry. Bantry Bay, Cork. Guernsey. P. VI.

E. I.

58. C. distans (L.); fertile spikes remote erect oblong, upper with included stalks, bracts with sheaths, gl. mucronate, $f r$. ovate trigonous equally ribbed pellucidly punctate smooth, edges of the bifid narrow beak rough, nut triquetrous roughish oblongelliptioal narrowed at both ends.-E. B. 1234. Schk. T. 68. 
H. b. 42. R. 253.-St. smooth, seldom exceeding a foot high, slender. Spikes distant, short; lower ped. half exserted. Gl. brownish. Fr. greenish-brown. Nut yellowish. Barren spike cylindrical, clavate, with blunt glumes.-Marshy places especially near the sea. P.V.

59. C. binervis $(\mathrm{Sm}$.$) ; fertile spikes remote, upper ones nearer$ cylindrical their stalks mostly included, lower long with exserted stalks, bracts sheathing, gl. mucronate, fr. ovate triquetrous with 2 principal green submarginal ribs on the back, beak broad bifid rough at the edges, nut obovate narrowed below roughish.-E. B. 1235. Schk. Rrr. 160. H. b. 39. R. 255.-St. triangular, smooth, 1 foot high. Spikes often very distant; upper stalks often quite included, never much exserted, lower often greatly exserted. Gl. dark purple; midrib greenish-yellow. Fr. brown or deeply tinged with purple, 2 prominent ribs always green; nut brown. Barren spike with blunt glumes.-Dry heaths. P. VI. VII.

60. C. lavigata (Sm.); fertile spikes remote cylindrical, stalks more or less exserted, bracts sheathing, gl. acute, fr. ovate-attenuate striate, beak long deeply bifid with scabrous edges, nut subpyriform narrowed below triangular smooth.-E. B. 1387. Schk. Bbb. 1l6. and Sss. 162. H. b. 38. R. 254.-St. smooth, $2-3$ feet high. Spikes distant, erect or drooping. Gl. often acute on the barren spike, always so on the others, purple with a paler dorsal longitudinal band. Rarely 2 barren spikes. Fr. green; not yellowish. L. broad.-Marshes and wet thickets, rather rare. P. VI.

61. C. depauperata (Good.); fertile spikes erect remote 3 or $4 f l$., stalks exserted, bracts sheathing leaflike, gl. acute, fr. large nearly globose, beak long bifid with rough edges, nut elliptical trigonous with bluntish angles.-E. B. 1098. Schk. M. 50.St. 1-2 feet high, trigonous, smooth. Gl. of the barren spike blunt. Fr. very large and few with many ribs. Spikes very distant.-Dry woods, very rare. P. VI. $\quad$ E. S.?

$+\dagger$ Beak of fr. glabrous, terete or compressed. Barren spikes 1 (rarely more). Stigmas 3.

62. C. sylvatica (Huds.); fertile spikes about 4 distant slightly drooping linear with long half-exserted stalks, bracts leaflike sheathing, fr. elliptical trigonous obscurely veined narrowed into a long cloven smooth beak, nut obovate-elliptical triangular, 1. narrower than in the preceding.-E. B. 995. Schk. Ll. 10l. H. b. 55. R. 242.- - St. about 2 feet high, smooth, its top and the fr.-beak rarely a little rough. Sheaths scarcely half equalling the peduncles. Gl. ovate, acute, diaphanous with a green keel. -Damp woods. P. V. 
63. C. Pseudo-cyperus (L.); fertile spikes about 5 drooping cylindrical densely-flowered upon long stalks near together, bracts leaflike scarcely sheathing, gl. setaceous scabrous dilated at the base, fr. ovate-lanceolate ribbed narrowed into a deeply bifid beak, nut elliptical triangular, st. with acute rough angles. -E. B. 242. Schk. Mm. 102. H. b. 56. R. 275.-St. $2-3$ feet high. Fertile spikes $1 \frac{1}{2}-2$ in. long.-Damp places, rare. P. VI.

$+t^{\prime}+$ Beak of hairy fr. terete or compressed with patent cusps.

Barren spikes 2 or more.

64. C. filiformis (L.); barren spikes 2 , fertile 3 or 4 remote erect sessile oblong, bracts leaflike lowermost slightly sheathing, gl. oblong-ovate cuspidate and ciliate at the point, $f r$. downy oblong-ovate narrowed into an obliquely truncate beak with 2 lateral points, nut narrowly elliptical narrowed at both ends subtrigonous, l. slender channeled.-E. B. 904. Schk. K. 45. H. b.31. R. 265.-St. 2 feet high. L. with filamentous sheaths below. Lowest spike rarely stalked.-Peat-bogs. P. V.

65. C. hirta (L.); barren spikes 2 or 3 , fertile 2 or 3 remote erect oblong-cylindrical stalked, bracts leaflike the lower with long sheaths nearly equalling the peduncles, gl. elliptic-lanceolate with long slender ciliated points, fr. hairy oblong-ovate narrowed into a deeply divided beak, nut obovate narrowed below triangular, l. flat hairy.-E. B. 685. Schk. Uu. 108. H. b. 58. R. 257. - St. $1 \frac{1}{2}-2$ feet high, leafy. L. and sheaths shaggy, rarely glabrous. Fr. tawny. Occasionally the spikes are compound at the base and very long-stalked, and the gl. much lengthened. -Wet places. P. IV. Hammersedge.

$+1++\dagger$ Beak of fr. glabrous, terete, striate, with patent cusps, or 2 -toothed. Barren spikes many, rarely 1. Bracts not sheathing.

$\ddagger$ Barren spike 1. Stigmas 2 . Beak of fr. 2-toothed.

66. C. pulla (Good.); barren spikes 1 (rarely 2 ), fertile $1-3$ roundish-ovate lower one stalked bracteated sheathless erect, $f r$. ovate obscurely veined inflated, beak short, nut roundish mucronate, gl. bluntish. - E. B. 2045. Schk. Cc. 88. - St. 6-8 in. high. Gl. dark purple tipped with white, midrib dark purple. Fr. dark purple paler at the base, longer than the gl., stalked. C. saxatilis (Linn. Herb.), but Andersson says that the true plant is C. rigida. - Wet parts of the higher Scottish mountains. P. VI.

67. C. Grahami (Boott); barren spikes 1 or 2 slender acute, fertile 2 or 3 ovate obtuse lower one stalked bracteated sheath- 
less, fr. oblong-ovate strongly ribbed inflated narrowed into a short bifid beak, gl. acute.-E. B. S. 2923.-St. 1-2 ft. high. GI. fuscous, with the tip and midrib pale. Fr. pale or darkish brown, nearly twice as long as the gl., with several strong ribs on each side. Nut too young in all my specimens.-Glen Fiadh, Clova. Ben Cruban, Killin. P. VII.

\section{++ Barren spikes many. Stigmas 3. Bracts not sheathing.}

68. C. ampullacea (Good.); fertile spikes $2-4$ remote cylindrical erect stalked, bracts leaflike, fr. subglobose inflated suddenly narrowed into a long slender beak, nut obovate triangular, st. smooth with obtuse angles. - E. B. 780. Schk. Tt. 107. H. b. 65 . R. 277. - St. $1-2$ feet high, with rounded faces and 3 slight angles. L. glaucous, channeled.-Very wet bogs. P. VI.

69. C. vesicaria (L.) ; fertile spikes $2-4$ remote cylindrical, bracts leaflike, fr. ovate-conical inflated gradually narrowed into a subulate bifid beak, nut elliptical triangular, st. with acute angles. -E. B. 779. Schk. Ss. 106. H. b. 64. R. 276.-St. 2 feet high, with flat faces and 3 strongly marked angles, roughish near the top. L. rather broad, green. $\beta$. involuta; 1 . narrow folded into a $\frac{1}{2}$-cylinder, midrib of gl. apiculate, fr. narrower. - Wet bogs. $\boldsymbol{\beta}$. Hale Moss, Manchester. Mr. J. Sidebotham. Congletou, Chesh. Mr. E. Wilson. P. V.

70. C. paludosa (Good.); gl. of the barren spikes blunt, anth. apiculate, fertile spikes cylindrical blunt, bracts leaflike, fr. oblong-obovate compressed with a short bifid beak, nut roundishobovate triangular, -st. with acute angles.-E. B. 807. Schk. Oo. 103. - St. $2-3$ feet high, angles rough. L. broad.- $\beta$. spadicea; gl. of fertile spikes with a long scabrous beak.-Wet places. $\beta$. Littlehampton, Suss. Mr. Mitten. P. V.

71. C. riparia (Curt.); gl. of the barren spikes acute, anth. with a long point, fertile spikes acute cylindrical, bracts leaflike, fr.oblong-ovate convex on both sides narrowed into a short broad cloven beak, nut pyriform triangular, st. with acute angles.E. B. 579. Schk. Qq. and Rr. 105. H. b. 66.-St. 3 feet high, angles rough. L. broader than in the preceding. - Wet places. P. V.

\section{$+_{++}^{++}$Barren spikes many. Bracts sheathing.}

[72. C. hordeiformis (Wahl.); barren spikes 2 , fertile 3 oblong remote with short exserted stalks, bracts overtopping the spikes long leaflike flat, fr. large ovate plane-convex scabrous winged ciliate-serrate narrowed into a long bifid beak. $-S c h k$. Ddd. 121. C. secalina Sm., not Willd.-Fr. very large, twice as long as the glumes. - Forfarshire, but doubtless an error. P.VI.] $\$$. 


\section{Index to the Carices.}

C. acuta, 28.

Agastachys, 44. ampullacea, 68. aquatilis, 30 . arenaria, 9. atrata, 35 . axillaris, 18. binervis, 59 . Boenninghauseniana, 17. brizoides, 16. Buxbaumii, 34. cæspitosa, 27. caspitosa, 26, 31 . canescens, $22,34$. capillaris, 42 . clandestina, 45 . collina, 48 . curta, 22. curta, 23. Davalliana, 2. depauperata, 61 . digitata, 46. dioica, 1. distans, 58. disticha, 8. divisa, 7. dirulsa, 12. Ehrhartiana, 13. elongata, 21. extensa, 55 . filiformis, 64 . flava, 53 . fulva, 56 .
Gebhardi, 21 .

Gibsoni, 32.

glauca, 51. Goodenovii, 31. Grahami, 67. hirta, 65. hordeiformis, 72. Hornschuchiana, 56. humilis, 45 . incurva, 6 . intermedia, 8. involuta, 69 . irrigua, 40. lævigata, 60 . lagopina, 24. lepidocarpa, 53. leporina, 24, 25. limosa, 39 . [Mairii, 53.] maxima, 44. Meilichoferi, 38. Micheliana, 51. montana, 48. muricata, 11. nemorosa, 10. Ederi, 54. ovalis, 25. pacifica, 27. pallescens, 36 . paludosa, 70. panicea, 37. paniculata, 15. paradoxa, 14 . paucifiora, 5. pendula, 44.

Persoonii, 23.

phroostachya, 38 .

pilulifera, 49 .

præcox, 47.

Pseudo-cyperus, 63.

pulicaris, 3.

pulla, 66 .

punctata, 57.

rariflora, 41 .

recurva, 51 .

remota, 19.

rigida, 29.

riparia, 71.

rupestris, 4 .

saxatilis, 29,66 .

secalina, 72.

spadicea, 70.

speirostachya, 56.

stellulata, 20.

stictocarpa, 51 .

stricta, 26.

strigosa, 43.

sylvatica, 62 .

tenella, 19.

teretiuscula, 13.

tomentosa, 50.

ustulata, 52.

vaginata, 33 .

Vahlii, 33.

vesicaria, 69 .

vitilis, 23.

vulgaris, 31 .

vulpina, 10.

\section{Order XCVII. GRAMINEA.}

Fl. perfect or unisexual, 1,2 or more seated on a common axis which is contained within an involucre of 2 (or l) valves (glumes) or rarely none, the whole forming a locusta or spikelet. Each fl. of 1 or 2 scales (pales) of which the outer or lower is simple and usually keeled, the inner with 2 veins or keels. Hypogynous scales 2, 3, or none. Stam. hypogynous, $1-6$. Anth. versatile, notched at both ends. Ovary l-celled. Styles usually 2, rarely 1 or 3 . Einbryo on the outside of the albumen and at its base.-L. with split sheaths ${ }^{1}$.

1 Nearly all the genera of this Order are beautifully figured in the Gen. Fl. Germ. Monocotyl. vol. i. Andersson's Pl. Scand. fasc. ii. contains a valuable account of this Order. 


\section{Suborder I. CLISANTHEÆ.}

Flowers closed. Styles or stigmas long, protruded at the top of the flower.

Tribe I. PANICEAE. Spikelets dorsally compressed, l-flowered, or with $1 \mathrm{fl}$. and an inferior glumelike rudiment or a neuter flower. Lower gl. much the smaller.

1. Drgitaria. Spikes fingered. Spikelets in pairs on one side of the flattened rachis, awnless, 1-flowered with an inferior rudiment. Gl. 2, lower minuter or 0, upper 3-veined. Sterile fl. of one $5-7$-veined pale equalling the flower.

[2. Echinochloa. Spikes compound, secund in the whole and in each part. Spikelets on one side of the flattened partial rachis, 2-flowered, inferior fl. rudimentary. Gl. 2, lower 3-veined, upper equalling fl. 5-veined mucronate or awned. Lower pale of sterile fl. like and equalling upper glume.]

3. Setaria. Spike cylindrical, compound. Spikelets surrounded by an involucre of bristles, 2 -flowered; inferior $\mathrm{fl}$. rudimentary. Gl. 2, lower 3-veined, upper equalling fl. many-veined. Sterile fl. of 1 pale, like and equalling upper glume.

Tr. II. CHLORIDEAE. Spikelets laterally compressed, 1 flowered in our plants and sometimes with a superior rudiment, placed in 2 rows on one side of a flattened rachis, or alternate and unilateral.

4. Cynodon. Spikes fingered, spreading. Spikelets 1flowered, awnless, with a superior rudiment. Gl. nearly equal, patent. Pales equal; lower boatshaped, compressed, embracing the inner. Styles long, distinct. Stigmas feathery.

5. Spartina. Spikes upright, in a raceme. Spikelets 1flowered, awnless. Gl. unequal; upper lanceolate. Pales unequal; lower boatshaped, compressed. Styles long, united half-way up. Stigmas feathery.

6. KNAPpIA. Inflorescence a somewhat 1-sided raceme. Gl. not keeled, blunt. Fl. 1. Pale 1, scarious, very hairy, obtuse, not awned.

Tr. III. PHAIJARIDEAE. Panicled. Spikelets laterally compressed, 1-flowered, with 1 or 2 or more glumelike inferior rudiments; or 1 or 2 inferior male flowers. Gl. equal, covering the flowers. Styles long. Stigmas filiform.

7. Phalaris. Gl.2, boatshaped, keeled, membranous, nearly 
equal, exceeding the flower. Pales coriaceous, unequal, closely investing the fruit. Rudimentary fl. $1-2$, scalelike.

8. Anthoxanthum. Gl. 2, unequal, membranous; lower small, l-veined; upper exceeding the fl., 3-veined. Pales scarious. Stam. 2. Rudimentary fl. 2, scalelike, bifid, awned on the back.

9. Hierochlog. Gl. 2, nearly equal, membranous, about equalling the spikelet. Fl. 3; 2 lower male, 3-androus, upper pale with 2 keels ; upper perfect, 2 -androus, upper pale with 1 keel.

Tr. IV. PHLEINE $A$. Inflorescence dense, spikelike. Spikelets laterally compressed, l-flowered or with a superior rudiment. Gl. nearly equal, covering the flowers. Styles long. Stigmas filiform.

10. Phleum. Gl. compressed, keeled, parallel at the midrib, truncate, with a terminal seta, or acute. Fl. 1. Pales 2, membranous; lower 3-veined, obtuse, without awns, or with a minute central point.

11. Alopecurus. Gl. compressed, connate below, membranous, awnless. Fl. 1. Pale 1, scarious, 5-veined, awned on the back.

Tr. V. SESLERIEAE. Panicle spikelike. Spikelets laterally compressed, with 2 or more flowers. Styles 0 or very short. Stigmas very long, filiform.

12. Sesteria. Spikelets sessile, tiled all round. Gl. 2-6flowered, nearly or quite equalling the spikelet. Lower pale keeled, membranous, with a scarious margin, ending in 3 or 5 points; dorsal rib excurrent.

Tr. VI. NARDEAE. Spikelets sessile in hollows of the rachis, 1-flowered. Gl. 0. Style short. Stigma filiform.

13. Nardus. Spikelets in 2 rows on one side of the rachis. Lower pale keeled, tapering into a subulate point. Stigmas long.

\section{Suborder II. EURYANTHE王.}

Flowers open. Styles short. Stigmas protruded at the bottom of the flower.

* Inflorescence panicled or racemose.

Tr. VII. ORYZEAE. Spikelets laterally compressed, l-flowered. 
Glumes 0. Stigmas plumose. Pales inclosing but free from the nut.

14. Leersia. Pales 2, chartaceous, compressed, keeled, awnless; lower much broader.

[Tr. VIII. STIPACE AE. Spikelets not compressed, l-flowered, without any rudiment. Gl. unequal, membranous, inclosing the flowers. Pales hardening, inclosing but free from the nut.]

[15. Sripa. Spikelets stalked. Pales coriacenus; outer cylindrical, convolute, evidently jointed to the kneed twisted feathery awn.]

16. Milium. Spikelets stalked. Pales chartaceous, awnless; lower ventricose, convex.

Tr. IX. AGROSTIDEAE. Spikelets laterally compressed, Iflowered, or with a superior rudiment, or many-flowered. Gl. and pales membranous.

† Gl. falling short of the outer pale. Style long. Stigmas often protruded at the middle of the flower.

17. Phragmites. Pan. diffuse. Gl. unequal; lower much smaller. Fl. 2-6, awnless, with silky hairs at their base; lower imperfect. Lower pale acuminate, much exceeding the inner, awuless.

† Gl. exceeding the flowers. Style short or none.

18. Psamma. Pan. spikelike. Gl. nearly equal; lower rather the shorter. Fl. 1, with silky hairs at its base, with a superior rudiment. Lower pale with a very short awn.

19. Ca lamagrostis. Pan. diffuse. Gl. nearly equal; lower rather the longer. Fl. 1, with silky hairs at its base, with or without a superior rudiment. Lower pale awned.

20. Apera. Pan. loose. Gl. membranous, acute, unarmed; lower the smaller. Fl. 1, with hairs at its base, and a pedicel-like rudiment. Pales unequal, scarious; lower with a long subterminal awn.

21. Agrostrs. Pan. loose. Gl. membranous, acute, unarmed; upper smaller. Fl. 1, with hairs at its base; no rudiment. Pales unequal, scarious; dorsal awn falling short of the glumes, or $0 .-A$. canina wants the inner pale. 
[22. Lagurus. Pan. spikelike. Gl. scarious, ending in a long fringed bristle. Fl. 1, with a peduncle-like rudiment. Lower pale ending in 2 long bristles and with a dorsal kneed twisted awn.]

23. Polypogon. Pan. close, spikelike. Gl. scarious, each with a long bristle from just below the notched tip. Fl. 1. Lower pale usually awned from just below the tip.

24. Gastridium. Pan. close, spikelike. Gl. membranous, acute, awnless, ventricose at the base, much exceeding the flower. Fl. 1. Lower pale truncate or toothed at the end, with or without a dorsal awn.

Tr. X. $A V E N E A E$. Spikelets with 2 or more flowers; upper often barren. Gl. equalling or overtopping the flowers. Lower pale awned. Style short or 0.

25. Holcus. Fl. 2 ; lower perfect, awnless (or very rarely awned); upper usually male, with a dorsal awn. Pales hardening on the fruit; tip of lower entire.

26. Corynephorus. Fl. 2, perfect, awned. Awn straight, jointed in the middle; the upper portion clavate; a tuft of hairs at the joint. Tip of lower pale entire.

27. Arra. Pan. lax. Fl. 2, with or without the rudiment of a third (sometimes perfected in A. caspitosa). Lower pale denticulate or bifid at the tip, terete on the back. Awn dorsal, kneed (in $A$. caspitosa straight). Ovary glabrous. Fr. not crested.

28. Trisetum. Spikelets crowded. Fl. 2-6. Lower pale keeled with faint lateral veins, ending in 2 acute teeth, awned. Awn dorsal, kneed and twisted. Ovary glabrous. Fr. neither crested nor furrowed.

29. Avena. Fl. 2 or more. Lower pale not keeled with lateral veins, awned, ending in 2 points. Awn dorsal, kneed and twisted. Ovary hairy at the top. Fr. crested and furrowed.

30. Arrhenatherum. Fl. 2, with a rudiment; lower $f$. male with a long dorsal kneed and twisted awn; upper with a short straight awn. Pales herbaceous, ending in 2 points. Ovary hairy at the top. Fr. .....

Tr. XI. FESTUCEAE. Spikelets with 2 or more flowers, upper often barren. Gl. falling short of the lowest flower. Styles short, or 0 . 
+ Lower pale with nearly parallel veins which do not join to form an awn. Awn 0. Stylesterminal.

$$
\text { + Lower pale 2-3-fid. }
$$

31. Triodia. Fl. 2-4. Lower pale rather coriaceous, rounded on the back, bifid with an intermediate broad point. Nut free.

+4 Lower pale nearly or quite entire.

32. Korleria. Gl. unequal ; upper 2-3-ribbed. Spikelet compressed, 2-5-flowered. Lower pale keeled, acuminate, or with a straight subterminal bristle. Nut free.

33. MELiCA. Gl. nearly equal, with lateral ribs, nearly as long as the ovate spikelet consisting of 1 or 2 flowers rounded on the back and a clublike rudiment. Pales hardening on the free nut.

34. Molinia. Gl. unequal, without lateral ribs, falling short of the lanceolate spikelet of 2 or 3 semicylindrical flowers and a subulate rudiment. Pales hardening on the free nut.

35. PoA. Gl. rather unequal. Lower pale 3-5-veined, membranous below, scarious at the tip, compressed, keeled.

36. Glyceria. Gl. unequal, submembranous. Lower pale with $5-7$ strong prominent ribs and a scarious margin, subcylindrical.

37. Sclerochloa. Gl. unequal, membranous. Lower pale with 5 faint veins, membranous, cylindrical below, often keeled at the tip or with-a very minute mucro.

38. Briza. Gl. nearly equal, broad, 3-ribbed. Fl. 3-8, densely imbricated in a short distichous spikelet. Lower pale boatshaped, heartshaped, obtuse, rounded on the back. Gl. and pales membranous with a scarious margin. Fr. free. -Lower pale with 7-9 faint veins.

4.4 Lower pale truncate and erose-denticulate.

39. Catabrosa. Gl. unequal, very short, 1-veined. Flowers usually 2 , rounded on the back, distant. Lower pale membranous, with 3 veins ending in teeth which do not quite extend to the edge of the scarious margin. Upper gl. often with 2 short and faint lateral veins.

+† Lower pale with converging veins, all or $1-3$ of which combine in the awn.

40. Cynosurus. Gl. nearly equal, scarious, strongly keeled, 
1- or more flowered. Lower pale rounded on the back with a terminal bristle. Each spikelet with a pectinated bract at its base. Panicle spicate, 1-sided. Nut closely coated witn the pales.

41. Dactylis. Gl. unequal, herbaceous, many-flowered; lower keeled. Lower pale compressed, keeled, 5-veined; dorsal vein fringed and excurrent just below the tip as a short awn. Spikelets crowded, subsecund.

42. Festuca. Gl. unequal, herbaceous, many-flowered. Lower pale rounded on the back, very acute, or with the dorsal vein excurrent at or just below the tip as a short awn; lateral veins slightly converging and vanishing below the tip. Upper pale minutely ciliated on the ribs. Styles terminal.-Rachis with acute angles. Sheaths of the leaves divided to the base.

43. Bromus. Gl. unequal, herbaceous, many-flowered; lower 1-veined, upper 3-5-veined. Fl. lanceolate, compressed. Lower pale with a long awn, (usually) founded on 3 veins, from below the tip. Styles below the top of the fruit.Sheaths of the l. divided half-way down.

44. Serrafalcus. Gl. unequal, herbaceous, many-flowered, lower 3-5-veined, upper 7-9-veined. Fl. oblong, turgid. Lower pale with a short awn, (usually) founded on 3 veins, from below the tip. Styles below the top of the fruit.Sheaths of the 1. scarcely divided half-way down. Spikelets narrower upwards.

Tr. XII. HORDEIEAE. Spikelets solitary or 2 or 3 together, subsessile on opposite sides of a channeled and toothedjointed rachis. Uppermost $\mathrm{fl}$. often barren. Style very short. (Lateral spikelets often stalked in Hordeum.)

$\uparrow$ Spikelets very shortly stalked or subsessile.

45. Brachypodium. Spikelets solitary. Gl. opposite, unequal, many-flowered, their sides towards the rachis. Upper pale coarsely fringed on the ribs. - The unequal gl. distinguish this from Triticum.

$\dagger \uparrow$ Spikelets quite sessile.

+ Glumes 2.

46. Tritricum. Spikelets solitary. Gl. opposite, nearly equal, many-flowered, their sides towards the rachis. Inner pale minutely ciliate on the ribs.

47. Elymus. Spikelets 2 or 3 together. Gl. 2 , both on the 
same side of the spikelet, without awns or bristles, with 2 or more perfect flowers.

48. Hordeum. Spikelets in threes, often partially barren. Gl. 2, ending in long bristles; 1 perfect flower and a stalklike rudiment.

49. Lepturus. Spikelets solitary, imbedded alternately on opposite sides of the rachis. Gl. $1-2$, opposite to the rachis, cartilaginous, covering the $1 \mathrm{fl}$. and superior rudiment. Pales scarious. Stigmas feathery.

+t Glume solitary, bractlike, or the upper very small.

50. Lourum. Spikelets solitary, placed edgewise on the rachis. Gl. solitary, or that next the rachis very small, with 3 or more flowers.

\section{Suborder I. Clisanthea. Tribe I. Panicea.}

\section{Digitaria Scop.}

[1. D. sanguinalis (Scop.); 1. and sheaths hairy, fl. oblonglanceolate glabrous with downy margins (?). $-E . B .849$. P. 70 . - St. ascending, a foot long.-Not a native. A. VIII.] E.

2. D. humifusa (Pers.); l. and sheaths glabrous, fl. elliptical downy with glabrous veins.-E. B.S.2613. P.71.-St. mostly procumbent, $4-8$ in. long. Spikes usually 3 or 4 , springing from nearly the same point. Spikelets in pairs, one on a longer stalk than the other.-Sandy fields, rare. A. VII. VIII. E.

\section{Echinochloa Pal. de Beauv.}

[1. E. Crus-galli (Beauv.); spikes alternate or opposite, spikelets near together, upper gl. and sterile floret awned or mucronate hispid, rachis hispid.-E. B. 876. P. 67. Panicum Sm. Oplismenus Kunth.-A strong coarse grass; found occasionally on cultivated land. Near London. A. VII.] E.

\section{Setaria Pal. de Beauv.}

1. S. viridis (Beauv.); pan. spikelike, involucral bristles with forward teeth, lower pale smooth.-Panicum Sm., E. B. 875 . P. 68.-London and Norwich. A. VII. VIII.

E.

[2. S. verticillata (Beauv.); pan. spikelike, involucral bristles with declining teeth, lower pale smooth.-Panicum Sm., E. B. 874. P. 69.-London and Norwich. A. VII. VIII.] E. 
[3. S. glauca (Beauv.); pan. spikelike, involucral bristles with ascending teeth, pales transversely rugose.-Weybridge, Surrey. Mr. Borrer. A. IX.] E.

\section{Tribe II. Chloridece.}

\section{Cynodon Rich.}

1. C. Dactylon (Pers.); spikes $3-5$ digitate, pales smooth edges and keel slightly ciliate, l. downy beneath, barren shoots prostrate. $-E$. B. 850. P. 72.-Creeping. Flowering st. 4-6 in. high, ending in a cluster of spreading many-fl. slender spikes. Spikelets purplish. L. on the long branched barren shoots flat, spreading; on the others usually folded.-Sandy shores. Dorset. Devon. Cornwall. P. VIII.

E.

\section{Spartina Schreb.}

1. S. stricta (Roth); 1. jointed to their sheaths falling short of the spikes, spikes $2-3$, rachis scarcely extending herond the last spikelet, outer gl. hairy.-E. B. 380.-St. 1-2 feet high. L. narrowing to the base where they easily separate from their sheaths. Spikes pressed close together. A remarkably rigid plant.-Muddy salt marshes. P. VIIII.

E.

2. S. alterniflora (Loisel.); 1. continuous with their sheaths equalling or exceeding the spikes, spikes many, rachis produced beyond the spikelets and flexuose, outer gl. glabrous. $-E$. B. S. 2812. P. 75.-St. $2-3$ feet high. L. broadest at the base and not separating from their sheaths more easily than at any other part. Spikes pressed close together.-Mud-flats in the river Itchin at Southampton. P. VIII.

E.

\section{KNappia $S m$.}

1. K. agrostidea (Sm.).-E.B.1127. P.73. Sturmia minima Hoppe in St. 7.1. Chamagrostis Koch. Mibora verna R.-An elegant but very small grass. Root small, fibrous. St. many. L. short, rough. Spikes slender; spikelets 5-10, sessile. Pale shorter than the glumes, hairy, truncate, ragged. Mibora (Adans.) is the oldest name, but İ have thought it better to follow Smith.-Sandy maritime pastures, rare. A. III.-V. E.

\section{Tribe III. Phalaridea.}

\section{Phalaris Linn. Canary-grass.}

*1. P. canariensis (L.); pan. ovate spikelike, gl. winged on 
the keel, wing entire, rudimentary fl. 2 half as long as the fertile fl., pales pilose.-E. B. 1310. P. 9.-St. $1-2$ feet high, terminating in a compact compound panicle. Gl. large, pale yellow variegated with green lines and remarkably winged at the back. - Scarcely naturalized. A. VII. True Canary-grass.

[P. paradoxa (L.); pan. spikelike, gl. of fertile fl. with a blunt tootlied wing on the keel many-veined, rudimentary $\mathrm{fl}$. several much shorter.- St. decumbent below, then ascending, l-3 ft. high, branched. Lower part of pan. usually barren; branches with about 6 spikes.-Swanage, Dorset. A. VII.] E.

2. P. arundinacea (L.); pan. upright with spreading branches, fl. clustered, $g l$. not winged, rudimentary $f$. 1 or 2 small hairy. -E. B. 402. P. 9.-St. 4-5 feet high. Root creeping. Pan. $3-4$ in. long. Gl. ketled. L. sometimes rariegated with white lines.-By water. P. VI. VII.

\section{Anthoxanthum Linn. Vernal-grass.}

1. A. odoratum (L.); pan. spikelike oblong compound, gl. about as long as the awns.-E. B. 647. P. 8.-About a fout high. Spike lanceolate, dense, or rather interrupted below.Very common in pastures. P. V. VI.

\section{Hierochloe Gmel. Holy-grass.}

1. $H$. borealis (R. and S.); pan. divaricate, pedicels glahrous, fl. awnless, l. flat, root creeping.-E. B. S.2641. P.31.-About a foot high. Spikelets ovate, brown.-Glen Kella or Cally, Forfarshire. Mr.G.Don. Thurso, Caithness. Mr.R.Dick. P.VII. S.

\section{Tribe IV. Phleinea.}

\section{Phleum Linn. Cat's-tail-grass.}

1. P. asperum (Jacq.); pan. cylindrical, gl. wedgeshaped truncate swelling upwards, keels rough, rudimentary $\mathrm{fl}$. subulate. - E. B. 1077. St. 26. 5. P. 79. -St. often branched, leafy almost up to the panicle. Lower pale entire, not awned.-Dry open fields, rare. A. VII.

2. P. Boehmeri (Wibel); pan. cylindrical, gl. linear-lanceolate obliquely truncate mucronate, keel ciliate above, rudimentary $\mathrm{f}$. subulate.-E. B. 459. P. 80.-St. leafy below, the upper half naked, with sterile leafy shoots. Lower pale entire, not awned. -Dry chalky fields, rare. P. VII.

[3. P. Michelii (All.); pan. nearly cylindrical, gl. lanceolate 
acuminate, keel ciliate throughout. - E.B. 2265 . P. 7.-St. with sterile leafy shoots.- On the rocky parts of the Clova mountains. Mr. G. Don. P. VII. VIII.]

$\mathrm{S}$.

4. $P$. arenarium (L.); pan. oblong somewhat narrowed below, gl. lanceolate acuminate, keel ciliate above, rudimentary fl. subulate minute.-E. B. 222. St. 29.1. P. 7.-St. varying greatly in height. Sheaths inflated. Lower pale notched at the summit, $\frac{\pi}{3}$ the length of the glumes. "Stigma very short."-Sandy places near the sea. A. VI.

5. P. pratense (L.); pan. cylindrical, gl. oblong truncate with an awn of less than half their length, keel ciliate above, no rudimentary flower.-E.B. 1076. P.77 and 78.--Root slightly creeping, in dry places rather tuberous ( $P$. nodosum L.). Pan. $1-5$ in. long. Awns sometimes longer. Lower pale jagged at the summit.-Meadows and pastures. P. VI. Timothy-grass.

6. P. alpinum (L.); pan. oblong, gl. truncate glabrous ciliate on the back with a scabrous awn of nearly their length, keel ciliate, upper sheath inflated.-E. B. 519. P. 6.-Root somewhat creeping. St. 6-12 in. high. Our plant is the P. commutatum (Gaud.) and differs from the true $P$. alpinum by its shorter panicle, not ciliate awn, much inflated upper sheath and short blunt upper ligule.-Wet alpine moors at an elevation of $2500-3500$ feet. P. VII.

S.

\section{Alopecurus Linn. Fox-tail-grass.}

1. A. pratensis (L.); st. erect smooth, pan. cylindrical obtuse, gl. acute connected below ciliate downy, pale equalling the glumes, awn projecting more than half its own length beyond the pale.-E. B. 759. St. 8. 1. P. 4. - Root fibrous, scarcely creeping. St. $1-3$ feet high. In salt marshes the base of the st. becomes fleshy and the plant may be taken for $A$. bulbosus. Upper sheath slightly inflated. Ligule short, obtuse. Spike 1-3 in. long, branches 4-6-flowered. Anth. yellow. Styles combined.-Rich pastures. P. IV.-VI.

2. A. alpinus $(\mathrm{Sm}$.$) ; st. erect smooth, pan. oblong, glumes$ acute connected below hairy, pale equalling the glumes, awn projecting $\frac{1}{3}$ of its length beyond the pale.-E. B. 1126 . P. 4.Root somewhat creeping. St. decumbent at the base, then erect, 9-12 in. high. Ligule short, obtuse. Uppermost 1. usually (not always) short and broad, $\frac{1}{8}$ of the length of its inflated sheath. Awn from about the middle of pale, sometimes wanting. Styles combined. Spike not exceeding an inch in length ; silky branches 4-6-flowered.-On mountains at an elevation of 2500-350) feet. Loch-na-Gar. Ben Lawers. Clova. P. VII. 
3. A. geniculatus (L.); st. ascending bent at the knots smooth, pan. cylindrical, gl. obtuse connected below ciliate rather exceeding the pale, awn from near the base of the pale and projecting half its length beyond it, anth. linear.-E. B. 1250. P. 5 . - Root fibrous. St. about a foot long, branching below. Knots generally (in dry places) oval and fleshy. Upper sheath inflated. Ligule oblong. Gl. membranous at the top except the midrib, often villose or hairy below. Pale when laid open oblong, obtuse, slightly notched. Anth. ultimately violet-yellow. Styles mostly combined. Spikes 1-2 in. long.-Wet places. P. VI. VII.

4. A. fulvus (Sm.); st. ascending bent at the knots smooth, pan. cylindrical, glumes connected below ciliate rather falling short of the pale, awn from just below the middle of the pale and scarcely extending beyond it, anth. short and broad.-E.B. 1467. P. 5. - St. 1-2 feet long, procumbent below. Ligule oblong. Spikes $2-3$ in. long. Anth. at first white, afterwards orangecoloured.-Wet margins of ponds. P. VI.-IX.

5. A. bulbosus (L.); st. smooth, pan. cylindrical acuminate, gl. distinct abruptly acute downy exceeding the pale, awn from near the base of the pale and projecting half its length beyond it. -E.B. 1249. P. 76.-St. I foot long, ascending or decumbent, in a circular tuft, kneed, the lowermost knots forming ovale fleshy knobs. Upper sheath inflated. Ligule oblong. Pale when laid open truncate, emarginate, with 2 small teeth in the middle. Styles combined. Pan. about 1 in. long, less decidedly racemose than in our other species; pedicels usually 1-flowered.-Salt marshes in the south, rare. P. VI.

E.

6. A. agrestis (L.); st. erect scabrous upwards, pan. tapering slender, gl. acute connected bèlow nearly glabrous, awn from near the base of the pale and projecting half its length beyond it.-E. B. 848. P. 3.-St. $1-2$ feet high, slencler. Sheaths roughish. Ligule prominent, obtuse. Gl. glabrous, but with a row of fine short cilia on the back. Styles combined.-A very troublesome weed. A. IV.-XI. $\quad$ E. S.?

\section{Tribe V. Sesleriea.}

\section{Sesleria Scop. Moor-grass.}

1. S. carulea (Scop.); raceme ovate slightly 1-sided, outer pale ending in 4 teeth, midrib rough with a short excurrent point, l. abrupt with a minute rough point. $-E$. B. 1613. P. 27. - R oots tufted. St. 6-12 in. high. Raceme about half an in. long' bluish-purple. Anth. purple-tipped. Stigmas very long, linear.-Mountains. Banks of the Shannon, I. P. IV. V. 


\section{Tribe VI. Nardece.}

\section{Nardus Linn. Mat-grass.}

1. N. stricta (L.).-E. B. 290. P. 2.-Tufted. St. and 1. erect, slender, rigid. Height 5-8 in. Spike close, slender. Lower pale with a short rough awn, coriaceous, often purplish ; upper membranous.-Moors and heaths. P. VII.

\section{Suborder II. Euryanthea. Tribe VII. Oryzea.}

\section{Leersia Soland.}

1. L. oryzoides (Sw.); pan. patent with wavy branches, spikelets 3 -androus half-oval, keel ciliate. - E. B. S. 2908. Creeping. St. 1-2 ft. high. L. broad, rough-edged; uppermost horizontal at the flowering season. Pan. rarely, if ever, protruded in this country, mostly inclosed in the sheath of the uppermost leaf.-Marsh-ditches in Sussex, Surrey and Hampshire. P. VIII. IX.

\section{Tribe VIII. Stipacea.}

\section{STipa Linn. Feather-grass.}

[1. S. pennata (L.); awn very long twisted feathery its base glabrous.-E. B. 1356.-A beautiful plant with remarkably long awns, common in gardens.-Long Sleadale, Westm. Dillenius. P. VI.]

E.

\section{Mrirum Linn. Millet-grass.}

1. M. effusum (L.); pan. diffuse, pales acute, st. smooth, I. lanceolate-linear.-E. B. $1106 . \quad P, 17$. - Stoloniferous. St. 3-4 feet high. Branches of the panicle long, in distant alternate tufts, in flower horizontal, afterwards deflexed.Damp shady woods. P. VI.

\section{Tribe IX. Agrostidea.}

\section{Phragmites Trin. Reed.}

1. P. communis (Trin.) ; pan. diffuse, spikelets 3-5-flowered, fl. exceeding the glumes.-Arundo Sm., E. B. 40l. P. 29.St. 5-6 feet high, erect. Pan. large, purplish. L. flat, broad. 
Stoloniferous; stoles rarely aërial, $20-40 \mathrm{ft}$. long (Phytol. i. 146).-Marshes. P. VIII.

\section{Psamma Pal. de Beauv. Marram.}

1. P. arenaria (R. and S.); pan. cylindrical thickest at the middle, gl. and pales linear-lanceolate acute, lower pale 5 -ribbed, hairs $\frac{1}{3}$ of the length of the pales.-Arundo Sm., E. B. 520 . Ammophila $R$. P.8.-St. erect, stiff, $2-3$ feet high. L. rigid, involute, acute, glaucous. Panicle straw-coloured.-The name of Ammophila was given to a genus of Hymenopterous insects by Kirby in 1798. - Sandy sea-shore, binding the shifting sandis. P. VII.

\section{Calamagrostis Adans. Small-reed.}

1. C. lanceolata (Roth); pan. loose erect, awn very short from the bottom of the noteh of the lower pale and scarcely extending beyond it, hairs longer than the pales, no rudimentary fl. -P. 84.-Arundo Calamagrostis E. B. 2519.-St. slender, $3-4$ feet high. - Wet places, rare. P. VII.

E.

2. C. Epigejos (Roth); pan. rather close lobed, straight awn from about the middle of the lower pale, hairs longer than the pales, no rudimentary fl. $-E$. B. 403 . P. 16.-St. $3-5$ feet high.-Damp shady places. P. VII.

3. C. stricta (Nutt.); pan. close, gl. lanceolate rough on the keel one (at least) 3-ribbed, lower pale nearly as long as the upper gl. deeply notched at the top longer than the hairs, straight awn from below the middle of the pale and scarcely extending beyond it, a rudimentary flower, 1 . of the barren shoots slender.E. B. 2160.-St. erect, $2-3 \mathrm{ft}$. high. L. broad; on the barren shoots much narrower. Uppermost ligule short, blunt; longer and acute in the Irish plant, which has shorter pan.-branches.-Bogs. Formerly found near Forfar. Oakmere, Cheshire. Lough Neagh. P. VI. VII.

[C. lapponica (Wahl.). “In Scotiâ adest forma nostræ pl. valde similis." Anders. 88. I cannot learn anything about this.]

\section{Apera Adans. Wind-grass.}

1. A. Spica-venti (Beauv.); pan. spreading, anth. linearoblong.-Agrostis Sm., E. B. 951. Anemagrostis (Trin.) P. 17. -St. 1-2 feet high. Pan. very light and elegant; branches spreading horizontally with flowers. Awn 3 or 4 times exceeding the pale. Ruclimentary fl. pedicelliform. A tuft of hair on each side of the inner pale.- Sandy fields, rare. A. VI. VII. 
2. A. interrupta (Beauv.); pan. close, anth. oval.-E. B. S. 2951. - St. $1-2 \mathrm{ft}$. high. Pan.-branches dividing from their base, never spreading. Awn 3 or 4 times exceeding the pale.Sandy fields. Pampisford and Chippenham, Cambridgeshire. Thetford, Suffolk. A. VI. VII.

E.

\section{Agrostrs Linn. Bent-grass.}

1. A. setacea (Curt.); panicle close oblong, branches and pedicels scabrous, gl. unequal acute, lower pale erose at the top 4-ribbed, lateral ribs terminating in short setæ, kneed and twisted awn from the base of the pale and twice its length, $l$. setaceous, sheaths rough, ligule oblong acute.-E.B. 1188. P. 83. - Root tufted. L. short, involute, almost capillary. Pan.branches short. Midrib of lower glume scabrous in its upper half, slightly excurrent. Upper pale very minute, a tuft of hairs at its base.-Dry heaths in the south-west. P. VII.

E.

2. A. canina (L.) ; pan. spreading when in flower otherwise close, branches and pedicels scabrous, gl. unequal acute, lower pale erose at the top 4-ribbed, kneed and twisted awn from below the middle of and exceeding the pale, lower l. setaceous tufted, stem-l. narrow, sheaths smooth, ligule oblong acute.E. B. 1856. P. 15.-Trailing leafy shoots. St. decumbent below, then erect. L. narrow; radical involute. Pan.-branches long, slender. Fl. green or purplish. Lower gl. not erose at the top; midrib scabrous from rather below the middle. Upper pale 0 , or very minute. Awn sometimes very short or rarely absent.-Peaty heaths. P. VII. VIII.

3. A. vulgaris (With.); pan. spreading during and after flowering, gl. nearly equal, lower toothed on the upper part of the keel, ligule short truncate--E. B. 1671. P. 12. 13.-St. long, ascending or decumbent below and rooting at the knots, sometimes with long prostrate stoles. Sheaths mostly smooth. Pedicels toothed. Fl. rarely awned.- $\beta$. A. pumila (Lightf.); cæspitose, st. $2-3$ in. high, fl. often awned usually infested with smut.-Rather dry places. P. VII.

4. A. alba (L.); pan. compact after flowering, glumes nearly equal, lower toothed throughout its keel, ligule long acute.E. B. 1199. P. 13. 14.-St. procumbent and rooting below, then erect, often with long prostrate stoles. Sheaths roughish. Pan. spreading with flowers, afterwards close. Pedicels very much toothed. Florets rarely awned.- $\beta$. maritima; st. procumbent, rooting at the knots, panicle lobed. $E$. B. 1532.Fields, \&c. $\beta$. Sea-sands. P. VII. 


\section{LAGURUS Linn. Hare's-tail-grass.}

[1. L. ovatus (L.).-E. B. 1334. P. 88,-St. 4-12 in. high. L. broad, lanceolate. Spikes ovate, soft, with long protruded awns.-Sandy places in Guernsey. A. VI. VII.]

\section{Polypogon Desf.}

1. P. monspeliensis (Desf.); awns more than twice as long as the rather obtuse glumes. $-E . B .1704$. P. 11.-Root fibrous. St. a foot or more high. Pan. dense, lobed, pale, silky, often 2 in. long. Gl. linear, hairy. A most beautiful grass.-Salt marshes. A. VI. VII.

E. S.

2. P. littoralis $(\mathrm{Sm}$.$) ; awns as long as the acute glumes.-$ E. B. 1251. P. 81. R. vii. 75.-Somewhat creeping. St. a foot or more ligh. Pan. close, lobed, purplish. Gl. linear-lanceolate.-Muddy salt marshes, rare. P. VI. VII.

E.

\section{Gastridium Pal. de Beauv.}

1. G. lendigerum (Gaud.); gl. lanceolate acuminate, lower pale awned, awn rather exceeding the glumes. $-E . B .1107$. P. 86 . -St. 3-12 in. high. L. rougbish at the edges. Ligule oblong. Pan. close, almost spiked, lobed. Gl. remarkably ventricose and shining at the base. Pales very small.-Damp places especially near the sea, rare. P. VI.-IX.

F.

\section{Tribe X. Avenea.}

\section{Houcus Linn. Soft-grass.}

1. H. lanatus (L.); upper gl. obtuse apiculate, awn smooth except near the tip.-E.B.1169. P.21.- Root fibrous. Height 1-2 feet. Knots not hairy. St. and l. villose. Inflorescence panicled, often piukish. Gl. rough. Lower fl. awnless. Awn at length curved like a fish-hook and included within the glumes, quite smooth or slightly rough at the point.-Meadows and pastures. P. VII.

2. H. mollis (L.); upper gl. acute, awn rough throughout.E. B. 1170 . P. 21, 22.-Creeping. Height $1-2$ feet. Knots of st. usually hairy. St. and l. subglabrous or slightly hairy. Inflorescence not so compact as in the preceding, whitish. Gl. smooth. Lower fl. awnless. Awn at length kneed, protruding beyond the glumes. Sometimes the lower $\mathrm{fl}$. has an awn; rarely the upper is perfect. Occasionally the spikelets are much smaller and the plant only $12-18 \mathrm{in}$. high.-Thickets or open places on a light soil. P. VII. 


\section{Corynephorus Pal. de Beauv.}

1. C. canescens (Beauv.); pan. rather dense long, gl. exceeding the fl. acuminate, awn from near the base of the pale, l. setaceous. - Aira Sm., E. B. 1190. P. 110. - St. tufted, slender, 6-8 in. high. L. many. Pan. close, spreading with flowers; branches short. Spikelets variegated with purple and white. Anth. dark purple. Lower portion of the awn dark yellow, straight, cylindrical, longitudinally striated and slightly twisted; upper part clavate, white tinged with purple.-Sandy coasts of Norf., Suff., and Jersey. P. VI. VII.

E.

\section{Arra Linn. Hair-grass.}

* Lower pale truncate, jagged. Nut free, not furrowed on the back.

$\dagger$ Awn straight. Deschampsia Beauv.

1. A. caspitosa (L.); pan. spreading, l. flat, gl. slightly rough at the midrib, awn from below the middle of the pale and scarcely extending beyond its tip.-E. B. 1453. P. 23.-Root tufted. St. $1-4$ feet high. L. rigid, roughish; their margins involute when dry. Pan.-branches rough. Lower pale with 4 veins in addition to that which ends in the rough awn. Rudiment of third $\mathrm{fl}$. often scarcely, if at all, distinguishable; or, half the length of the upper fl. and somewhat clavate.- $\beta$. brevifolia (Parn.); radical l. short, sheaths and st. smooth, panicle small. $P$. 106. Viviparous states are often called A. alpina; they produce stoles and sometimes have the awn from the upper part of the pale. $-\gamma$. longiaristata (Parn.); awns exceeding the fl., sheatlis rough. P. 105. - Meadows, thickets, \&c. $\quad \beta$. and $\gamma$. Mountains. P. VII.

H Awn bent, twisted at the base.

2. A. alpina (L.) ; pan. close, l. mostly involute, gl. smooth on midrib, awn from above the middle of the pale and scarcely extending beyond its tip.--E. B. 2102. P. 23.-Height 6-12 in. L. narrow, rigid, roughish on the upper surface. Pan.branches quite or nearly smootll; lower lax; upper erect. Fl. often viviparous.-Tops of Highland mountains. P. VIII. S,

3. A. flexuosa (L.) ; pan. spreading triply forked with wavy branches, l. very narrow subsetaceous, awn from near the base of the pale and extending considerably beyond its tip, pedicel of the second $\mathrm{fl}$. less than $\frac{1}{4}$ of its length, ligule truncate.-E. B. 1519. P. 107.-St. erect, slender, about a foot high. L. solid, nearly terete. Upper sheaths rough from above downwards. Lower pale notched at the tip.-Heathy places. P. VII. 
** Lower pale bifid. Nut adnate to the pales, "furrowed on the back." AIropsis Fries.

4. A. caryophyllea (L.) ; pan. spreading triply forked, spikelets rounded below, awn from below the middle of the pale and extending considerably beyond its atteuuate deeply bifid tip.E. B. 812. P. 24. Avena Koch.-St. 6-12 in. high. L. short and narrow. Sheaths roughish from below upwards. Spikelets small, rounded below, chiefly collected at the ends of the branches; no rudiment of a third floret.-Dry gravelly places. A. VI.

5. A. pracox (L.); pan. spikelike oblong, spikelets scarcely rounded below, awn from below the middle usually near the base of the pale and extending considerably beyond its attenuate deeply bifid tip.-E. B. 1296. P. 25. Avena Koch.-Height $1-6$ in. Pan. close, oval or oblong. No rudiment of a third floret. L. very narrow.-Dry and sandy places. A. IV. V.

\section{Trisetum Pers.}

1. T. flavescens (Beauv.); pan. much branched diffuse equal, gl. very unequal about 3-flowered.-P. 54. Avena Sm., E. B. 952. - St. about a foot high. Radical 1. and sheaths hairy. Spikelets yellowish. Upper gl. oblong-lanceolate, acuminate. Floral axis hairy, hairs short.-Fields. P. VII.

[T. subspicatum (Fr.); pan. spikelike ovate-cylindrical dense. "In alpibus Anglix." Anders. 69. Should be looked for. I cannot obtain information from Sweden.]

\section{Avena Linn. Oat.}

* Upper gl. 5-9-veined. Spikelets ultimately drooping. Root annual. No lateral clusters of leaves.

1. A. fatua (L.); pan. erect, spikelets of about $3 \mathrm{fl}$., $\mathrm{fl}$. falling short of the gl. hairy at the base, lower pale bifid at the end.E. B. 2221. P. 27.- Height 3 feet. 11. with long fulvous hairs at their base by which it may be distinguished from $A$. sativa, the cultivated Oat.-Corn-fields. A. VII. Wild Oat.

2. A. strigosa (Schreb.); pan. secund, spikelets of about $2 \mathrm{fl}$., fl. equalling the gl., lower pale ending in 2 long straight bristles. -E. B. 1266. P.26.-Height 3 feet. Very like A, sativa, but readily distinguished by the bristles at the end of the fl.-Cornfields. A. VII.

** Upper gl.3-veined. Spikelets erect. Root perennial. Lateral clusters of $l$. barren.

3. A. pratensis (L.); pan. erect with simple or slightly divided 
branches, $f$. erect $3-6$ exceeding the glumes, 1. scabrous.$E$. B. 1204. P. 52.-Height nearly 2 feet. St. usually nearly round. L. usually short, narrow, acute. Pan.-branches usually simple with only one spikelet. - $\beta$. longifolia (Parn.); l. much longer. $-\gamma$. alpina; st. often compressed and sheaths keeled, pan.-branches often with several spikelets, spikelet with more fl., upper pale less acute, 1 . broader. I believe that none of these characters are permanent. E.B.2141. P.53.-A. planiculmis of $E$. B.S. 2684 appears to belong to this species, differing in its greatly compressed st., strongly keeled sheaths and more branched panicle. In $a$. and $\beta$. the lowest fl. sometimes slightly falls short of the longer gl., in $\gamma$. exceeds it.-Dry pastures and mountainous places. P. VI.

4. A. pubescens (L.); pan. erect nearly simple, fl. erect 2 or 3 scarcely exceeding the glumes, lower $l$. and sheaths hairy.E. B. 1640. P. 53.-Height 1-2 feet. L. short, rounded behind the tip.-Chalky and limestone districts. P. VII.

30. Arrhenatherum Pal. de Beauv. Oat-grass.

1. A. avenaceum (Beauv.); 1. flat.-Holcus Sm., E. B. 813 . P. 25.-Height $2-3$ feet. Root fibrous. Knots of the st. glabrous, sometimes downy. Pan. long, ultimately close. Spikelets greenish.- $\beta$. A. bulbosum (Lindl.); base of the st. with swollen knobs, knots downy. P. 26.-Hedges and pastures. P. VI.

\section{Tribe XI. Festucea.}

\section{Triodia $R . B r$. Heath-grass.}

1. T. decumbens (Beauv.); pan. racemose, spikelets few oval, fl. about 4 scarcely extending beyond the glumes without awns. -E. B. 792. P. 30.-St. $6-12$ in. high. L. flat. Sheaths rather hairy. Ligule a tuft of hairs. Spikelets few, 1-7. Gl. smooth, coriaceous, hiding the fl. Lower pale with 3 points, 5 -ribbed, hairy at the base.-Mountain pastures. P. VII.

\section{Kocleria Pers. Crested Hair-grass.}

1. K. cristata (Pers.) ; pan. compact spikelike interrupted below, lower pale acute, 1 . narrow rough at the edges ciliate.Aira Sm., E. B. 648. P. 19.-Root crowned with the undivided sheaths of the old leaves. St. 6-18 in. high, downy particularly in the upper part. I., gl. and pales downy or glabrous. G1. finely toothed on the keel. Lower pale finely toothed on the midrib. Sometimes the 1 . become convolute. In dry places the 1. are much shorter than the st., in damper places long and often 
.e.

nearly equalling the stem.-Dry pastures. A large form on Ben Bulben, Co. Sligo. P. VI. VII.

\section{Melica Linn. Melic.}

1. M. uniflora (Retz); pan. branched slightly drooping, spikelets erect with 1 perfect glabrous $\mathrm{fl}$., l. flat, ligule short obtuse with a slender acuminate lobe on one side. $-E$. B. 1058. P. 18. - Shady and rocky woods. P. VI.

2. M. nutans (L.); pan. a nearly simple lax secund raceme, spikelets drooping with 2 perfect glabrous fl., l. flat, ligule short obtuse.-E. B. 1059. P. 18.-Damp shady woods in hilly districts. P. V. VI.

\section{Molinia Schrank.}

1. M. carulea (Moench); pan. erect long narrow, spikelets 1-3-ff., lower pale 3- (rarely 5-) veined awnless, upper part of the st. naked.-E. B. 750. P. 20.-St. $1-2$ feet high, with only one knot placed near to its base. L. long, linear, attenuate, all from near the base of the stem. Panicle purplish, close. $-\beta$. $M$. depauperata (Lindl.); spikelets 1-fl. few, outer pale often 5-

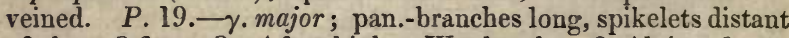
of about $3 \mathrm{fl}$., st. $3-4$ feet high. - Wet heaths. $\beta$. Alpine places. P. VII. VIII.

\section{Poa Linn. Meadow-grass.}

* Root fibrous, annual; no stoles. Base of stem sometimes prostrate and rooting. Pan.-branches solitary or in pairs.

1. $P$. annua $($ L. $)$; pan. spreading erect with a triangular outline, spikelets ovate-oblong of 5 or 6 free fl., lower pale with 5 veins all more or less silky, upper sheath longer than its leaf, ligule oblong acute.-E. B. 1141. P. 40, 41.-St. ascending or prostrate. L. flaccid, often wavy, broad. Spikelets subsecund with patent or divaricate branches. - $\beta$. supina ; lower pale glabruus or with a very few hairs on the midrib, pan.-branches erect-patent, 1. narrow.-Very common. A. III.-X.

** Root fibrous, perennial; no stoles.

+ Lower pan.-branches solitary or in pairs. Dorsal and marginal veins of the lower pale hairy.

2. P. bulbosa (L.); pan. close erect, spikelets ovate of 3 or 4 acute webbed fl., lower pale with 3 silky veins, upper sheath below the middle of the st. much longer than its leaf, ligule prominent acute.-E. B. 1071. P. 89.--Root fibrous. Base of 
POA.

the st. and offsets swollen bulblike. L. with a narrow white serrate edge. The st. soon wither and the bulbs lie loose until the autumn.-Sandy sea-shores of the south and east. P. IV. V.

3. P. minor (Gaud.); pan. oblong subovate, spikelets of 3 or 4 webbed $f$., lower pale with 5 veins but only 3 hairy, upper sheath longer than its leaf which is folded and slightly incurved but tapering at the tip, uppermost knot covered, upper ligule long acute, lower ones short rather blunt. $-P$. flexuosa Sm., E. B. 1123. ? not of others.-Root fibrous. St. 6-8 in. bigh. Fl. often viviparous.-Lofty mountains. Loch-na-Gar. Ben Nevis. P. VII. VIII.

S.

4. P. laxa (Haenke!); pan. lax slightly drooping, spikelets oblong-ovate of 3 free fl., lower pale with 3 hairy veins, upper sheath longer than its leaf which is flat and taper-pointed, uppermost knot covered, ligules all long acute.-P. 38.-Root fibrous. St. 6-12 in. high. Fl. often viviparous.-Lofty mountains. Ben Nevis. Loch-na-Gar. P. VII. VIII. S.

5. $P$. alpina (L.); pan. erect spreading when in flower, spikelets ovate of 3 or 4 free fl., lower pale with 3 hairy veins, upper sheath longer than its leaf which is folded and rounded behind the tip, uppermost knot exposed, ligule long pointed.-E. B. 1003. P. 37 and 94.- Root fibrous, tufted. St. $6-12$ in. high, basal sheaths common to it and the tuft of leaves. Fl. often viviparous.-Lofty mountains. P. VI. VII.

6. $P$. cresia $(\mathrm{Sm}$.) ; pan. erect slender, spikelets ovate of $2-5$ acute free fl., lower pale with 5 veins but only 3 hairy, upper sheath about as long as its leaf which is folded and slightly incurved but tapering at the tip, uppermost knot near to the base of the stem, ligule obtuse. - Root fibrous. St. 6-12 in. high. Lowest fl. longer than the large glume.-a. casia; spikelets of 4 or $5 \mathrm{fl}$., pan. rather spreading. P. casia Sm., E. B. 1719. P. 40.- $\beta$. glauca; spikelets of 2 or $3 \mathrm{fl}$., pan. rather close, 1 . broader.-Mountains. $a$. Ben Lawers. Clova. $\beta$. Ben Nevis. Snowdon. P. VII.

E. S.

t十 Lower pan.-branches in fives or 2 or 3 together. Dorsal and marginal veins of the lower pale hairy.

7. P. nemoralis (L.); pan. rather drooping slender, spikelets ovate-lanceolate of 3 or 4 webbed $f$., lower pale with 5 veins but only 3 hairy, upper sheath not longer than its leaf, uppermost knot at about the middle of the st. exposed, ligule extremely short truncate.-E. B. 1265 . P. 36.-Root slightly creeping. St. slender, $1-2$ feet high. Sheaths smooth: $-\beta$. angustifolia; st. and pan. very slender, 1 . long and narrow, uppermost knot 
near the pan., spikelets few $1-2$-flowered.- $\gamma$. glauca; st. slender, pan. with many long-stalked spikelets, plant glaucous.

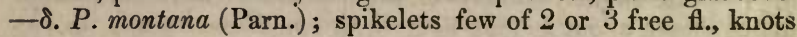
4 or 5 uppermost rather above the middle of the stem. $P .39$. -Shady places. $\gamma$. and $\delta$. Mountains. P. VI. VII.

8. P. Parnellii (Bab.); pan. erect large rather close oblong, spikelets ovate of 2 or 3 acute free fl., lower pale with 5 veins but only 3 hairy, upper sheath usually longer than its leaf, upper knot at about the middle of the st. exposed, ligule very short truncate. -E. B. S. 2916. P. 93.-St. ascending, $1 \mathrm{ft}$. or more high, compressed; knots 5 or 6 , uppermost not above the middle of the stem. Ligule 6 times as broad as long, but longer than that of $P$. nemoralis, to which this is perhaps too nearly allied. Occasionally there is a slight trace of a web to the florets.-Higti Force and other parts of Upper Teesdale. P. VII.

E.

9. P. Balfourii (Parn.); pan. erect rather spreading, spikelets ovate of 3 or 4 webbed fl., lower pale with 5 veins but only 3 hairy, upper sheath about as long as its leaf, upper two-thirds of the stem without knots, ligule prominent obtuse.-P. 66 . E. B. S. 2918.-Root creeping. St. $3-15$ in. high; knots about 3 , uppermost within the lower third of the stem. Lower fl. as long as the larger glume. I cannot join this to $P$. nemoralis without more proof of their identity than has yet appeared.-Tops of mountains. P. VII.

+† Lower pan.-branches subverticillate. Dorsal vein of the lower pale hairy ; marginal glabrous.

10. P. trivialis (L.); pan. diffuse, spikelets ovate of 2 or 3 acute webbed $\mathrm{fl}$., lower pale with 5 veins, upper sheath much longer than its leaf, ligule acute long. - E. B. 1072. P. 35.Root tufted. St. $1-2 \mathrm{ft}$. high. Sheaths slightly rough. $-\beta$. parviflora (Parn.); spikelets small 1-2-flowered, plant slender.Moist and shady places. P. VI.

*** Root creeping by long stoles.

11. P. pratensis (L.); pan. diffuse, spikelets ovate of 3 or 4 webbed fl., lower pale with 5 prominent veins but only 3 hairy, upper sheath much longer than its leaf, ligule prominent obtuse. -E. B. 1073. P. 31-34.-Very variable in size. St. compressed and sheaths nearly always smooth. Fl. strongly webbed. - $\beta$. subcarulea; spikelets broader, l. broad and short, upper 1 . compressed rounded at the end behind.-E. B. 1004. - - . angustifolia; spikelets small, l. slender long, lower l. involute.Common. P. VI. VII.

12. P. compressa (L.); pan. rather unilateral spreading when 
in flower otherwise close, spikelets ovate or oblong-ovate of 5-7 obtuse slightly webbed fl., lower pale 3-veined, veins hairy, upper sheath about as long as its leaf, uppermost knot at about the middle of the stem, ligule short truncate.-E. B. 365. P.37. $-S t$. decumbent at the base, then erect, very much compressed, $1-1 \frac{1}{2} \mathrm{ft}$. high. - $\beta$. subcompressa (Parn.); lower pale with 2 faint intermediate veins. P. 90.-Dry situations. P. VII.

13. P. polynoda (Parn.); pan. erect ovate-lanceolate, spikelets ovate or ovate-lanceolate of 4 or 5 not webbed fl., lower pale 5-veined but only 3 hairy, upper sheath not longer than its leaf, uppermost knot above the middle of the stem, ligule prominent obtuse.-P.91.-St. decumbent at the base, then erect, compressed, 1-1 $\frac{1}{2} \mathrm{ft}$. high; knots 7 or 8 , the second at about the middle of the stem. L. acute. Pan. with short branches. Lowest fi. not longer than the large glume.- $\beta$. denticulata (Parn.); midrib of lower pale not hairy but denticulate throughout, ligule shorter, often one convolute hair at the base of the fl. P.92. -Dry stony places. P. VI. VII. E. S.

\section{Glyceria $R$. Br.}

1. G. aquatica (Sm.); pan. erect repeatedly branched spreading, branches scabrous, spikelets linear oblong of 5-10 fl., lower pale obtuse, 1. smooth with terete sheaths. - E. B. 1315. P. 44. - Creeping. St. 3-6 feet high, smooth, slightly compressed. Sheaths very long. L. long, rough on the edges and keel, never tloating. Ligule short. Pan. large; branches angular, slender, branched.-Watery places. P. VII.

2. G. fluitans (R. Br.); pan. secund slightly branched very long, branches nearly simple roughish, spikelets linear of 7-12 adpressed lanceolate-oblong acute fi., outer pale nearly thrice as long as broad, sheaths compressed.-P.95.- St. ascending, rooting below, or floating. Sheaths nearly smooth, striate. L. pale green, acute, often floating. Ligule long. Pan. very long, often nearly simple; branches without callosities, ascending, lowermost usually in pairs. Spikelets adpressed. Lower pale rather the shorter, with a triangular central point. Anthers about five times as long as broad, purple, pale yellow when empty.-Watery places. P. VI.-IX. Flote-grass.

3. G. plicata (Fries); pan. compound, branches compound nearly smooth erect with flowers divaricate with fruit, spikelets linear of 7-20 oval-oblong rather acute fl., lower pale twice as long as broad, sheaths compressed.- $R$. vii. 79. G. fluitans Sm., E. B. 1520. P. 45.-St. ascending, rooting below. Sheaths rough, furrowed. L. glaucous, bluntish, plicate when young. Ligule shorter. Pan. much branched; branches with callosi- 
ties at the base, lowermost about in fives. Lower pale with 3 teeth at the end. Anth. about 3 times as long as broad, creamcoloured, fuscous when empty.- $\beta$. G. pedicellata (Towns.); pan.-branches simple roughish, spikelets of 9-12 blunt florets. L. more acute, simply folded when young. Lowermost pan.branches about in threes. Anth. about 4 times as long as broad, yellow when young. $A$. N. H. ser. 2. v. 105.-Stagnant water and wet places. P. VI.-VIII.

\section{Sclerochloa Pal. de Beauv. * Glumes with 3 veins.}

1. S. maritima (Lindl.); pan. branched, lowermost branches in pairs or simple, branches ultimately erect, spikelets linear adpressed 4-8-flowered, rachis terete, lower pale obtuse apiculate, midrib reaching the tip, stoloniferous.-Glyceria Sm., E. B.1140. $P$. 42.-Root fibrous with rooting or ascending stoles. $L$. involute; the central ridge on their upper surface strongly marked, the others faint. Anth. about 6 times as long as broad. Lower pale with involute edges. Ligule bluntish.- $\beta$. hispida (Parn.); st. compressed, rachis furrowed on one side and as well as the pan.-branches rough. P.99.- Sea-coast, in damp places. P. VI. VII.

2. S. distans (Bab.); pan. branched, branches long ultimately spreading or deflexed lowermost in fours or fives, spikelets linear 3-6-flowered, rachis semiterete rather flat on one side, lower pale obtuse, midrib not reaching to the tip, root fibrous. - Glyceria Sm., E. B. 986. P. 41.-Without rooting stoles. St. decumbent below. L. flat, short, with 8-10 equally prominent ridges upon their upper surface. Ligule short and truncate. Edges of lower pale not involute. Spikelets and $\mathrm{fl}$. half the size of those of the preceding.- $\beta$. obtusa (Parn.); pan. more compound, spikelets about 7 -flowered, lower pale truncate and broader, ligule shorter. P.96 and 97.- Sea-shores and waste sandy places. $\beta$. Leicestershire. P. VI.-VIII.

3. S. Borreri (Bab.); pan. branched, branches ultimately erect-patent lowermost generally in fours, spikelets linear 4-7fl., rachis terete, lower pale with a rigid apiculus formed by the tip of the dorsal vein, cæspitose.-Glyceria E. B. S. 2797 (1837). P. 98. G. conferta Fries (1839).-St. 6-12 in. high. L. short, flat, with very long sheaths. Ligule short, truncate. Edges of the lower pale not involute. Spikelets and $\Theta$. half the size of those of S. maritima and S. procumbens. Pan.-branches short, scarcely elongated after flowering, hispid.-Muddy salt marshes. A.? VI.-VIII. 
4. S. procumbens (Beauv.); pan. ovate-lanceolate compact distichous rigid, spikelets linear-lanceolate of about $4 \mathrm{fl}$., rachis angular, lower pale obtuse with an apiculus formed by the tip of the dorsal vein, root fibrous.-Glyceria Sm., E. B. 532. P. 42.St. procumbent (rarely when growing in water erect), rigid. L. flat, with inflated sheaths. Pan. about 2 in. long, with very short rigid branches spreading in 2 rows. Fl. large.-Salt marshes. A. VI. VII.

\section{** Glumes 1- (rarely 3-) veined.}

5. S. rigida (Link); pan. lanceolate rigid distichous, spikelets linear acute of 7-10 fl., lower pale obtuse witl a mucro, upper gl. reaching to the base of the third fl., root fibrous.Glyceria Sm., E. B. 1371. P. 43.-St. slender, wiry, erect. L. nearly flat, acute. Pan. $1-2$ in. long, nearly simple. Lower pale indistinctly veined. Fl. small.-Dry places. A. VI.

6. S. loliacea (Woods); pan. racemose narrow rigid secund, spikelets oblong of 8-12 fl., lower pale obtuse with a mucro, upper gl. reaching to the base of the fourth $\mathrm{fl}$., root fibrous.-Triticum Sm., E. B. 221. P. 43.-St. stout, slightly curved, ascending. L. flat, convolute when dry. Spikelets usually solitary, alternate, all directed to one side; footstalks very short and stout. Lower pale with well-marked marginal veins.-Sandy sea-coast. A. VI. VII.

\section{BrizA Linn. Quaking-grass.}

1. B. minor (L.); spikelets triangular of about 7 fl., gl. exceeding the lowest $f$., pan. diffuse, ligule long lanceolate acute. -E. B. 1316. P. 101. - St. very slender, about 1 foot high. Spikelets pale green. Lower pale roundish-cordate, cartilaginous, very gibbous in the middle of the back.-Dry and sandy fields in the south-west. A. VII.

2. B. media (L.); spikelets broadly ovate of about $5 \mathrm{fl}$., $g l$. falling short of the lowest $f$., pan. diffuse, ligule truncate very short.-E. B. 340. P. 30.-St. slender, erect, $1-1 \frac{1}{2}$ foot high. Panicle light and elegant, with slender branches. Spikelets usually purplish. L. linear-acuminate. Lower pale roundish oval, cartilaginous, not gibbous.-Pastures. P. VI.

\section{Catabrosa Pal. de Beauv.}

1. C. aquatica (Presl); pan. long-pyramidal with half-whorls of patent branches, lower pale 3-ribbed, 1. broad linear obtuse. -E. B. 1557. P. 20.-Creeping. St. long, procumbent or floating below. L. flat. Pan.-branches in alternate threes or fives. Spikelets usually 2- (or 3-5-) flowered. Gl. very thin, 
often purplish. Fl. distant. - $\beta$. minor; st. $2-3$ in. high, spikelets mostly 1 -flowered.-Ponds and ditches. $\beta$. Wet seasands. P. VI. VII.

\section{Cynosurus Linn. Dog's-tail-grass.}

1. C. cristatus (L.); raceme spikelike linear, fl. with a very short awn.-E. B. 316. P. 28.-Spike unilateral, plane-compressed. Spikelets closely placed. Bract pectinate.-Pastures. P. VIII.

[2. C. echinatus (L.); raceme contracted close ovate, awns about as long as the pales.-E. B. 1333. P. 28 and 129.-St. erect, 1-2 feet high. Bract pectinate with long points.-Sandy places in Guernsey and Jersey. A. VII.]

\section{Dactylis Linn. Cock's-font-grass.}

1. D. glomerata (L.); pan.-branches with ovate clusters of spikelets, st. erect, l. linear flat with scabrous margins, roots cæspitose.-E. B. 335. P. 29.-A coarse grass. Pan.-branches long, spreading or divaricate with fl., afterwards adpressed, distant; each bearing an ovate cluster of spikelets; or wanting, and the panicle of one cluster.-Meadows. P. VI. VII.

\section{Festuca Linn. Fescue-grass.}

* Root-leaves very narrow. Ligule with round auricles. Awn terminal.

† Usually monandrous. Awn longer than the pale. Gl. very unequal. VULPIA.

1. F. uniglumis (Sol.); raceme 2-ranked secund close, lower gl. very small, fl. compressed keeled.-E. B. 1430. P. 112.St. 6-12 in. high, erect, leafy nearly to the top. Raceme close. Lower gl. usually scarcely distinguishable.-Sandy sea-shores. A. VI.

E. I.

2. F. sciuroides (Roth); st. mostly naked above, pan. erectpatent short, lower branches often equalling $\frac{1}{2}$ the panicle, upper gl. equalling the lowest $\mathrm{fl}$., fl. terete scabrous. $-F$. bromoides $\mathrm{Sm}$., E. B. 1411.-Slender, 6-12 in. high. L. linear, involute.Walls and sandy places. A.? VI. VII.

3. F. myurus (L.); st. usually leafy to the arcuate long narrow pan., lower branches short, upper gl. falling short of the lowest fl., fl. terete scabrous.-E. B. 1412. F. pseudo-myurus Soy.-Will. -Known from the preceding, to which it is very closely allied, 
by its long narrow spikelike pan. and narrower spikelets.-Walls and sandy places. A. ? VI. VII.

t† Triandrous. Awn shorter than the pale.

4. F. ovina (L.) ; pan. narrow subsecund close with fr., spikelets 4-6-fl., fl. mostly awned, $l$. all setaceous, sheaths glabrous, cæspitose.-E. B. 584. P. 56, 57.-Very variable. L. short, slightly curved, densely tufted. Fl. glabrous or hairy. Spikelets soinetimes changed into leafy shoots. F. vivipara Sm., E.B. 1355.- $\beta$. F. tenuifolia (Sibth.); l. very long setaceous, fl. awnless. - $\gamma$. F. duriuscula (L.); pan. pyramidal, branches spreading, lower sheaths downy, l. filiform channeled, st.-l. broader. St. and l. stouter. Fries thinks that it is a distinct species. Dry hilly pastures. $\beta$. On mountains. $\gamma$. Damper places. P. VI. Sheep's Fescue-grass.

5. F. rubra (L.); pan. broadish below subsecund, spikelets 4-10-fl., l. involute-setaceous, st.-l. flat, lowest sheaths hairy, stoloniferous, stoles ending in erect shoots with distichous leaves. $-E$. B. 2056. F. duriuscula $P .58,59,60, \mathrm{Sm}$. (in part). Very variable. Always stoloniferous. St.-l. rarely (F. sabulicola Duf.) involute-setaceous. Fl. shortly awned, glabrous, hairy or villose. $L$. variable in length and breadth and the fl. in size. - Common in dry sandy, rarely in wet places. P. VI.

** Root-leaves broad and flat. Ligule not auricled. Awn 0 , or dorsal. Schedononus, Beauv.

† Uppermost ligule prominent. Lower pale 3-veined.

6. F. sylvatica (Vill.); pan. erect diffuse much-branched, branches rough, spikelets of 3-5 awnless acute $f$., lower pale scabrous, dorsal rib serrulate throughout, l. lanceolate-linear with scabrous margins.-Poa P. 44 and 100. F. Calamaria Sm., E. B. 1005.-Scarcely creeping. St. 2-4 feet high, covered at the base with imbricated broad acute leafless sheaths, tufted. L. very long, broad, roughish on both sides; uppermost l. smaller. Lower pale very acute; midrib extending nearly to the tip or slightly beyond it. Ovary pilose at the top.- $\beta$. F. decidua (Sm.); 1. narrower, fl. about 2. E. B. 2266.-Woods in mountainous districts. P. VII.

†† Uppermost ligule very short. Lower pale 5-veined. Bucetum Parn.

7. F. gigantea (Vill.); pan. drooping branched, spikelets of about 5 awned fl., dorsal rib of lower pale nearly smooth not extending to the tip but ending in a scabrous awn twice as long as the pale, l. linear-lanceolate.-E. B. 1820. P. 47.-St. 3-4 
feet high. L. very long, broad, roughish on both sides, except near the base on the under side. Ligule unequal, auricled. Lower pale roughish, nnembranous, often bifid at the tip. Top of the ovary glabrous. $-\beta$. F. triflora (Sm.); pan. smaller and more erect, spikelets scattered of about 3 flowers. E. B. 1918.Moist woods and thickets. P. VII.

8. F. arundinacea (Schreb.); panicle diffuse patent, branches mostly in pairs each bearing 2 or more ovate-oblong spikelets divaricate with $\mathrm{fl}$. or afterwards, spikelets very many of 5-6 closely placed fl., dorsal rib of lower pale ending at or just below the tip or forming a short awn, l. linear-lanceolate. $-\boldsymbol{F}$. elatior Sm., E. B. 1593. P. 46, 47.--St. 2-6 ft. high, forming large tufts. L. broad.-There seem to be two forms of this plant, or perhaps two species. - a. F. arundinacea (Schreb.); pan.branches divaricate after flowering. A very large plant, 3-6 ft. high.- $\beta$. F. elatior (L.?); pan.-branches shorter " divaricate with $\mathrm{fl}$. afterwards ascending." $-\boldsymbol{\alpha}$. Banks near the sea. $\beta$. Damp pastures. P. VI. VII.

9. F. pratensis (Huds.); pan. close subsecund, branches in pairs one bearing a single spikelet the other several never divaricate, spikelets linear-oblong of 5-10 rather distant fl., dorsal rib of lower pale ending at or just below the tip or forming a very short awn, 1. linear-lanceolate.-E.B. 1592. P.46. F. elatior Koch.-A smaller plant than the preceding. Pan.-branches ascending; one of each pair nearly always reduced to a single spikelet. In this and the preceding the pale is obtuse or acute according as the miabib is or is not attached up to the tip. $-\beta$. $F$. loliacea (Huds.); spikelets solitary alternate long slender truly distichous, lower ones stalked, upper sessile, fl.distant. E.B. 1821. P. 45, 113 and 114. Mr. Borrer considers these plants to be distinct. They deserve careful study.-Wet meadows. P. VI. VII.

\section{Bromus Linn. ${ }^{1}$}

* Spikelets broader upwards when in flower. Ribs of upper pale finely fringed.

1. B. erectus (Huds.); pan. erect nearly simple, spikelets linear-lanceolate, fl. remote subcylindrical, lower pale indistinctly 7-veined, lowest $f$. $\frac{1}{3}$ exceeding the upper $g l$. and longer than its awn, root-l. very narrow ciliate.-E. B. 471. P. 51.-St. $2-3$ ft. high, erect. Root.-l. convolute; upper 1. broadest; sheaths somewhat hairy with upward hairs. - $\beta$. villosus; lower pale hairy.-On dry sandy and chalky soil. P. VI. VII.

1 Synonymous with the genus Schedonorus (Fries), not Beauv. 
2. B. asper (L.) ; pan. drooping with long slightly divided branches, spikelets lanceolate, fl. remote linear-lanceolate, lower pale hairy 5-7-ribbed, lowest fl. twice exceeding the upper gl. and longer than its awn, l.broad hairy.-E. B. 1172 . P. 51.St. 4-5 feet high. L. flat; lower ones broadest; sheaths with downward hairs.-Damp woods and thickets. A. or B. VII.

** Spikelets always broader upwards. Ribs of upper pale strongly fringed. Awn long.

3. B. sterilis (L.) ; pan. drooping, branches long slightly divided, spikelets linear-lanceolate, $\mathrm{f}$. remote, lower pale glabrous shorter than its awn with 7 distinct equidistant ribs, l. pubescent. -E. B. 1030. P. 50. - Height $1-2$ feet. L. broad, flat. - Waste places. A. VI.

4. B. diandrus (Curt.); panicle erect, branches short scarcely divided, spikelets lanceolate, fl. linear remote subcylindrical, lower pale about as long as its awn 7-ribbed, 2 lateral ribs close together, interm. rib faint.-E. B. 1006. P.50.-a. B. madritensis (L.); st. glabrous, rachis and pedicels scabrous. St. 6-12 in. high. Remarkable for its erect panicle. Upper pale but little shorter than the lower.- $\beta$. B. rigidus (Roth); pan. compact, pedicels very short, upper part of st., pedicels, rachis and gl. pubescent.-Dry sandy places, rare. $\beta$. Channel Islands. A. VI. VII. E. S.

- [B. tectorum (L.); like B. diandrus, pan. secund drooping, upper pale much the shorter.-Hoddesdon, Herts : introduced.]

[5. B. maximus (Desf.); pan. erect lax at length nodding, branches slightly divided elongated after flowering, spikelets downy, lower pale 7-ribbed about half as long as its awn.E. B. S. 2820. P. 115. Parnell's figure misrepresents the styles as terminal. - Height $1-2$ feet. A most beautiful grass. -Sandy places. Channel Islands. A. VII.]

\section{Serrafalcus Parlatore 1 .}

[*1. S. secalinus (Bab.); pan. loose drooping in fr. slightly compound, simple peduncles about as long as the oblong glabrous spikelets, $\mathrm{fl}$. at first loosely imbricated afterwards distinct and cylindrical about as long as the straight awn, lower pale not overlapping the next fl., l. hairy.-Bromus Sm., E. B. 1171. P. 49,121 and 122 . - In fr. the $f$. are quite separate and the spikelets droop. Top of upper gl. $\frac{1}{2}$-way between its base and the top of fourth $f$. (second on same side). Lower pale not twice as long as broad, longer than the upper, 7-ribbed.-B.B.velutinus (Sm.);

1 Corresponds to the genus Bromus of Fries. 
pan. nearly simple, fl. larger downy. $\quad$ P. 123. $E$. B. 1884 ?Corn-fields. $\beta$. Between Edinburgh and Newhaven. Sm. A.? VI. VII.]

2. S. commutatus (Bab.); pan. loose slightly drooping compound, simple peduncles as long or longer than the oblong-lanceolate spikelets, fl. loosely imbricated about as long as the straight awn, l. and sheaths hairy.-Bromus Schrad. P. 124. B. pratensis Sm., E. B. 920.-Lower pale only slightly overlapping the next $\mathrm{fl}$. at the base when in fruit. Top of upper gl. $\frac{1}{2}$-way to top of fourth $f$. Lower pale twice as long as broad, longer than the upper, glabrous or downy, 7-ribbed. Anth. 6 times as long as broad.- $\beta$. multiflorus (Parn.); fl. more numerous, top of upper gl. rather higher. P. 125.-Common. B. VI. VII.

3. S. racemosus (Parl.); pan. close or long erect usually simple, spikelets ovate somewhat compressed glossy, fl. closely imbricated about as long as the straight awn, midrib of the gl. and pales scabrous towards the top, 1. and sheaths slightly hairy. -Bromus Sm., E. B. 1079. P. 119.-Top of the upper gl. halfway to the top of the sixth floret. Simple ped. not longer than the spikelets. Lower pale longer than the upper. Anth. four times as long as broad.- $\beta$. arenarius; pan. nearly or quite simple, ped. very short.-See Parnell (Brit. Grasses) and Watson (Lond. Journ. Bot. i. 82.) on these species.-Common. B. Sandy ground in the south. B. VI.

4. S. mollis (Parl.); pan. close erect compound or simple, spikelets ovate somewhat compressed pubescent, fl. closely imbricated about as long as the straight awn, midrib of $g l$. and pales downy not scabrous, 1. and sheaths hairy or downy.Bromus Sm., E. B. 1078. P. 116.-Top of the upper gl. halfway to the top of the sixth fl., or a little higher (ovalis Parn. 117, with short oval spikelets), or about halfway to the top of the eighth fl. (pratensis Parn. 118, with longer spikelets). Lower pale longer than the upper. Simple ped.not longer than the spikelets.- $\beta$. velutinus; pan. quite simple, ped. very short, spikelets and 1. densely pubescent.-Common. $\beta$. Sandy ground in Devon and Cornwall. A.? V. VI.

[S. arvensis (Godr.); pan. spreading erect compound, spikelets linear-lanceolate, pales equal in length, outer 7-ribbed with 2 prominent ribs near each margin, anth. 4 times as long as broad.-E. B. 1984. P. 126.-Top of the upper gl. halfway to the top of the fourth flower.-Southampton; Durham; Hebden Bridge. Not even naturalized. A. VII. VIII.]

[S. patulus (Parl.); pan. spreading compound at first erect, spikelets lanceolate, pales unequal 7-9-ribbed, 2 lateral ribs prominent, anth. twice as long as broad.-P. 127.- Not naturalized. Yorkshire. A. VI.] 
[S. squarrosus (Parl.); pan. drooping simple, spikelets ovatelanceolate subcompressed, fl. nearly glabrous imbricated compressed, awn divaricate, l. pubescent. $-E . B .1885$. P. 128.Somerset and Sussex, introduced. A. VI. VII.]

\section{Tribe XII. Hordeiea.}

\section{Brachypodium Pal. de Beauv.}

1. B. sylvaticum (R. and S.); spike drooping, spikelets (at first) terete alternate distichous, awns of the upper fl. longer than their pales, 1. flat linear-lanceolate flaccid, root fibrous.-E. B. 729. $P$. 61.-St. usually solitary or 2 or 3 from the same root, erect, 1-2 feet high. Sheaths hairy. Ligule short, blunt, notched or torn. L. ciliate. Pales hairy.-Woods and hedges. P. VII.

E. I.

2. B. pinnatum (Beauv.); spike erect, spikelets (at first) terete alternate distichous, awns of the upper fl. shorter than their pales, 1. flat linear-lanceolate rigid, root creeping.-E. B. 730. P.132137.- St. several, erect, $1-2$ feet high. Pales scabrous or hairy. Sheaths subglabrous. Ligule short, truncate. L. not ciliate.$\beta$. caspitosum; l. very narrow and involute, st. very many, spikelets small smooth.-On dry limestone soil. P. VII.

\section{Triticum Linn. Wheat-grass.}

1. T. caninum (Huds.); spikelets $2-5$-flowered, 3-5-ribbed gl. and 5-ribbed lower pale awned, axis and edges of the racbis hispid, l. flat rough on both sides, root fibrous.-E. B. 1372. P. 62. Agropyrum $R$.- - Spikelets approximate.- $a$; spikelets 4-5-flowered, lower pale shorter than its awn.- $\beta$. alpinum; spikelets 2-4-flowered, lower pale much longer than its awn, 1 . nearly smooth.-Banks. $\beta$. Rocks on Ben Lawers. Mr. G. Don. P. VII.

2. T. repens (L.); spikelets 4-8-flowered, gl. acute 5-7ribbed, lower pale acute, axis scabrous, rachis with rough angles, 1. flat roughish a single row of hairs upon each ridge above, root creeping.- E. B. 909. P. 62.-The lower pale often has an awn which is seldom more than half its length. Rachis glabrous or downy, but always with small ascending rigid bristles on its angles. $\beta$. littoreum; rachis nearly or quite smooth, $f$. awned, edges of glaucous 1. involute.-Common. $\beta$. Sea-shores. P. VII. Couch-grass.

3. T. laxum (Fr.) ; spikelets 5-8-flowered, gl. obtuse or apiculate about 7 -ribbed, lower pale blunt apiculate, axis downy, rachis smooth or slightly rough at the angles not brittle, $l$. scabrous above with very many acute points flat involute when dry, 
root creeping.-L. having a deciduous row of hairs on the ridges as in T. repens, not keeled. Spikelets often approximate. St. prostrate or ascending. Producing decumbent barren leafy shoots. -Sandy sea-shores, probably not rare. P. VII. VIII. E. S.

4. T. junceum (L.) ; spikelets 4-6-flowered, gl. obtuse or apiculate 6-11-ribbed, lower pale blunt, axis smooth or slightly downy, rachis smooth brittle, $l$. involute finely and closely downy above, root creeping.-E. B. 814. P. 63.-Spikelets distant. Rachis easily separating at the knots. Producing decumbent barren leafy shoots.-Sandy sea-shores. P. VII. VIII.

[T. cristatum (Schreb.); spikelets 4-5-flowered closely imbricated, gl. with a terminal awn, outer pale with an awn about as long as itself, rachis and axis slightly downy, l. hairy above, st.rough. - E.B. 2267 . - “ On steep banks and rocks by the seaside between Arbroath and Montrose." Mr. G.Don. P. VII.] S.

\section{Elymus Linn.}

1. E. arenarius (L.); spike upright close, rachis flat not winged, gl. lanceolate downy not longer than the spikelets. $-E . B .1672$. P. 64.-Closely resembling Psamma arenaria, but readily distinguished by its broad 1. and short ligule. St. $3-4$ feet high. - Sandy sea-shores. P. VII.

2. E. geniculatus (Curt.); spike lax, rachis winged, gl. awlshaped glabrous longer than the spikelet. $-E$. B. 1586. P. 131. -St. 3-4 feet high. Spike 1-2 feet long, usually remarkably bent downwards at the second or third spikelet.-In a salt marsh near Gravesend. Mr. Dickson. P. VII.

E.

\section{Hordeum Linn. Barley.}

1. H. sylvaticum (Huds.); gl. all awlshaped not ciliate rough, lateral fl. perfect, middle fl. often barren, lower pale with an awn of twice its length. - P. 130. Elymus europaus Linn., Sm., E. B. 1317.-Middle fl., if barren, with shorter gl. having involute edges, thus appearing setaceous. The spikelets have a second fl. occasionally.-Woods and thickets on a calcareous soil. P. VII. VIII.

2. H. pratense (Huds.); gl. all setaceous not ciliate rough, lateral fl. imperfect, lower pale of fertile middle fl. with an awn of about its length. $-E$. B. 409. P. 11.-Spike erect. Gl. of lateral fl. shorter.-Damp meadows. P. VII.

3. H. murinum (L.) ; gl. of the middle spikelet linear-lanceolate ciliate, of the lateral ones setaceous rough, lateral fl. imperfect.-E. B. 1971. P. 10.- Spike often slightly nodding. Awn longer than the lower pale. Lateral gl. sometimes slightly 
ciliate.- $\beta$. arenarium (Bab.); lower part of the st. buried, lengthened and rooting, thus appearing to creep.-Waste places. $\beta$. Sands of the sea-shore. A. VI. VII.

4. H. maritimum (Wither.); gl. scabrous, inner one of the lateral $\mathrm{fl}$. half-ovate, the rest setaceous, lateral $\mathrm{fl}$. imperfect.E. B. 1205. P. 10.-The smallest species.-Sandy pastures near the sea. A. VI.

\section{Lepturus $R$. $B r$.}

1. L. incurvatus (Trin.); spike cylindrical-subulate, gl. 2 equalling or slightly exceeding the flowers.-Rottboellia Sm., E. B. 760. P. 2.-St. 2-6 in. long. Spike long, curved when dry.- $\beta$. L. filiformis (Trin.); spikes much more slender filiform scarcely at all curved. P. 3.-Sandy salt marshes. A. VII.

\section{Lolium Linn. Rye-grass.}

1. L. perenne (L.) ; with leafy barren shoots, edges of young l. simply folded, spikelets 3-11-flowered, gl. equalling the lowest fl., lower pale usually awnless. $-E$. B. 315. P. 65.-

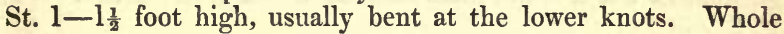
plant rather dark green.- $\beta$. aristatum; lower pale with a long awn. $-\gamma$. L. tenue (L.); spikelets few-flowered, l. slender.Sometimes the spikelets become converted into branches; occasionally the rachis is so much shortened as to form a broad ovate close distichous spike-Common. P. VI. Rye-grass.

[*2. L. italicum (A. Braun); with leafy barren shoots, edges of young $l$. involute, spikelets 9-14-flowered, outer pale with a long awn.-R. vii. 77. L. perenne. P. 138-141. L. multiflorum H. and A. (not Lam.).-St. many, straight, in close tufts, 1 $\frac{1}{2}-3$ feet high. Whole plant, especially the spikelets, paler than in the preceding. Ligule short, abrupt.-Probably the true L. multiflorum (Lam.) is confounded with this in Britain; it has no barren shoots and is annual.-Cultivated fields. B. or P. VI. Italian Rye-grass.

[3. L. linicola (Sond.); no barren shoots, spikelets 7-11flowered exceeding the gl., lower pale longer than its awn or awnless.-E. B. 2955. - St. erect. Lower pale cartilaginous below, narrower than the upper, tumid in fruit.-Cultivated fields. Sussex. Yorkshire. A. VI. VII.]

4. L. temulentum (L.); no barren shoots, spikelets about 6-flowered equalling or shorter than the $g l$., lower pale as long as its awn.-E.B.1124. P.142.-St. erect. Ligule short. Upper gl. usually present, often bifid. $-\beta$. $L$. arvense (With.); fl. $4-5$ without or with short awns. E. B. 1125.-Cultivated fields. A. VI.-VIII. Darnel. 


\section{FLOWERLESS PLANTS.}

Substance of the plant wholly of cellular tissue (excepting in the Subclass Ductulosa which has a few ducts). No woody fibre. No true flower with stamens and pistils. No distinct embryo nor cotyledons.

\section{Class III.}

\section{CRYPTOGAME王 DUCTULOS正。}

Plants with a few ducts amongst the cellular tissue ${ }^{1}$ :

\section{Order XCVIII. EQUISETACEÆ.}

Leafless branched plants with a striated fistular stem, joints sheathed above each joining. Sporules surrounded by elastic clavate filaments and inclosed in capsules arising from the peltate scales of terminal cones or spikes.-Vernation straight. Cuticle abounding in silex. Only one genus.

\section{Equisetum Linn. Horse-tail.}

* Fertile stems mostly unbranched and succulent; barren stems with whorled branches, appearing later.

1. E. arvense (L.); sterile st. with few furrows slightly seabrous, branches rough with 3 or 4 simple angles, teeth of sheaths long acute l-ribbed at the tip, fertile st. simple with few lax distant sheaths.-E. B. 2020. S. 1. N. 77.-Sterile st. many, procumbent or ascending; with many whorls of roughish usually simple branches, having 3- or 4-toothed sheaths; general

${ }^{1}$ (N.) refers to Newman's History of British Ferns, ed. 2. (S.) to Sowerby's Ferns of Britain and Fern-allies. Moore's Handbook of British Ferns may be consulted with advantage. 
outline narrowed upwards. Fertile st. short, with few (4-5) sheaths, appearing before the sterile ones. Sterile and fertile st. always distinct.-Damp meadows. P. IV.

2. E. umbrosum (Willd.) ; sterile st. with about 20 striæ very scabrous with prominent points particularly above, branches simple with 3 or 4 simple angles, teeth of sheaths blunt 1-ribbed but not to the tip, fertile st. simple with many crowded deeply toothed sheaths. - S. 2. N. 63. E. Drummondii Hook., E. B. S. 2777. - Sterile st. $1-1 \frac{1}{2} \mathrm{ft}$. high, nearly naked below; with many whorls of slender branches in the upper part, having 3- or 4toothed sheaths; general outline remarkably blunt at the top. Branched fertile st. with larger sheaths and whorls of about 6 branches ; simple fertile st. short (4-6 in.), with many loose and still larger yellowish-white sheaths with black prominent ribs upwards and 12-20 teeth.-Wet places, rare. P. IV.

3. E. Telmateia (Ehrh.); sterile st. nearly smooth with about 30 striæ and branches, branches rough doubly-angular simple, teeth of sheaths 2-ribbed, fertile st. simple with many crowded large deeply toothed sheaths.-S. 3. N.67. E. fuviatile Sm., E. B. 2022.-Sterile st. $3-6 \mathrm{ft}$. high; occasionally bearing a small terminal spike; furnished from top to bottom with whorls of slender branches which have 4 angles each with a longitudinal furrow, and 4-toothed sheaths. Fertile st. stout, 1 foot or more in height, with many pale brown sheaths with $30-40$ teeth; spike large.-Wet places. P. IV.

** Sterile and fertile stems similar, simple or branched.

4. E. sylvaticum (L.) ; sterile and fertile st. with about 12 furrows and many whorls of slender compound spreading or deflexed branches, sheaths lax ending in 3 or 4 blunt lobes.E. B. 1874. S. 4. N. 59.-St. 12-18 in. high. Sheaths of the branches with 3 long acute teeth each 1-ribbed to its tip. Fertile st. occasionally simple. Spike blunt. General outline of sterile st. pyramidal, of fertile abrupt.-Wet shady places. P. IV. V.

5. E. limosum (L.); stem nearly smooth with many slight furrows, teeth of sheaths short rigid acute, branches simple whorled or none.-St. 2-4 ft. high. Sheaths rather short. Spike blunt.-a. E. limosum (L.); st. smooth, barren st. narrowing gradually upwards, branches short rigid slightly tapering upright and equalling the joints of the st. from green sheaths often wanting.- $\beta$. E. fluviatile (L.) ; st. subglabrous, barren st. with a lax whiplike end, branches long slender tapering lax exceeding the joints of the st. from dark brown sheaths rarely wanting.-In stagnant water. P. VI. VII. 
6. E. palustre (L.); st. with 4-8 deep furrows branched throughout, sheaths loose pale with acute wedgeshaped teeth tipped with brown and membranous at the edges.-E.B. 2021. S. 6. N. 43, 47 and 49.-St. slightly rough. Barren st. whipshaped at the end. Spike blunt. Sheaths coloured like the st. or paler; teeth brown with nearly transparent edges, rib furrowed on the back. Branches usually barren or ( $\beta$. polystachion) each ending in a catkin. Occasionally $(\gamma \cdot$ nudum DC. $)$ the angles and teeth are fewer and the st. nearly or quite simple and dwarf. -Spongy bogs. $\gamma$. Sandy places. P. VI. VII.

7. E. hyemale (L.); st. simple very rough with $14-20$ slender furrows, sheaths close whitish but the top and bottom black, teeth slender black deciduous.-E. B.915. S.8. N. 17.-St. I-2ft. high, simple, biennial. Spike with an apiculus. Sheaths widest at their top, at first green with a black crenate rim after the teeth have fallen, then entirely black, and ultimately pale in the middle and black above and below.-Damp banks and woods. P. VII. VIII.

8. ? E. Moorei (Newm.); st. simple "annual" very rough with about 12 furrows, sheaths "loose" white with the base black, teeth black-based rather persistent.-Phytol. v. 19. S. 12.-St. 1-2 ft. high, never branched. Spike with an apiculus. Sheaths loose, pearly white; teeth long, whitish above, more persistent and longer than those of $E$. hyemale.-Probably not distinct from $E$. trachyodon, from which the annual st. and loose sheaths alone seem to separate it.-Wicklow. P. VIII. I.

9. E. trachyodon (A. Br.); st. simple or very slightly branched very rough with $8-12$ furrows, sheaths close ultimately wholly black, teeth slender persistent.-E. Mackaii N. 24. S.9.-St. 1-3 feet high, simple or with solitary distant branches, biennial. Spike with an apiculus. Sheaths quite cylindrical, pale green with a black band beneath the teeth but ultimately wholly black. Teeth more persistent than in the two preceding, usually black. Certainly the plant of A. Braun.-Mountain glens. P. VII. VIII.

10. E. variegatum (Weber and Mohr); st. simple or slightly branched very rough with 4-10 furrows, sheaths slightly enlarged upwards green below black above, teeth blunt each tipped with a deciduous bristle. $-N$. 31.-St. about a foot high, erect, usually simple except at the base. Lower half of the sheaths green like the stem, upper part black; teeth persistent ovate, black in the centre, with a white membranous margin. Spike apiculate. $-\beta$. arenarium; st. procumbent, usually more slender, teeth of the sheaths wedgeshaped. E. variegatum Sm., $E$. $B$. 1987. S. 11. E. Wilsoni (Newm.39. S. 10.) is probably a large form of this variety. - Wet places, or in water. $\beta$. Sandy places near the sea. P. VII. VIII. 


\section{Order XCIX. FILICES.}

Leafy plants with a rhizome or trunk. L. or fronds with a circinate vernation (Tribe VII. excepted), simple or divided. Fructification springing from the veins on the under side or at the edge of the l., of l-celled capsules (thecæ) which are stalked and have an elastic ring or sessile and without a ring.

* Capsules with an elastic marginal ring.

\section{Suborder I. POLYPODIACEE.}

Capsules in clusters on the back of the frond, opening transversely; ring vertical, usually incomplete.

Tribe I. POLYPODIE EE. Clusters nearly circular, without an indusium, seuted upon the back of the lateral veins.

1. Allosorus. Clusters circular, at length confluent, concealed by the reflexed margin of the frond.

2. Poly podium. Clusters circular, naked; edge of the frond flat, not reflexed.

3. Woodsia. Clusters circular, with an inferior involucre divided at the edges into many capillary segments.

Tr. II. ASPIDIEAE. Clusters nearly circular, covered by an indusium, seated upon the back of the lateral veins.

4. Lastrea. Indusium reniform, attached by the sinus. Veins distinct after leaving the midrib, not uniting with those of the adjoining lobe.

5. Polystichum. Indusium circular, attached by the centre. Veins distinct after leaving the midrib.

6. Cystopteris. Indusium attached by its broad hooded base under the clusters, with a long fringed free extremity at first covering the capsules.

7. Pseudathyrium. "Indusium crescentic, oblique, attached across the vein by its inner edge." (Newm.)

Tr. III. ASPLENIEAE. Clusters oblong or linear, usually covered by an indusium opening longitudinally on one side, placed on the side of the lateral veins.

8. Атнy rium. Clusters oblong-reniform. Indusium opening towards the central vein or midrib, margin fringed.

9. Asplenium. Clusters long, straight. Indusium opening towards the central vein or midrib, nearly flat. 
10. Scolopendrium. Clusters long, straight, 2 together. Indusia of each pair opening towards each other.

11. Ceterach. Lateral veins anastomosing, clusters attached to their middle on the side next the midrib, except in the lowest. Indusium (?) a narrow nearly erect membrane on the back of the vein. Whole back of the frond covered with chaffy scales.

[12. Gym nogramma. Clusters oblong or linear on both branches of the forked vein, becoming confluent and covering the back of the frond. Indusium wanting.]

Tr. IV. ADIANTE EE. Capsules covered by a marginal or submarginal elongated part of the frond, or by a separated portion of the cuticle resembling an indusium.

13. Blechnum. Capsules in a continuous line parallel to the midrib upon a longitudinal anastomosing part of the transverse veins, covered by a continuous scarious indusium.

14. Pteris. Capsules in a continuous marginal line covered by a continuous indusium formed of the reflexed margin.

15. Adrantum. Capsules marginal, oblong or roundish, covered by distinct reflexed portions of the margin of the frond.

\section{Suborder II. HYMENOPHYLLACEE.}

Capsules opening irregularly ; ring oblique, excentric, transverse, complete; receptacle terminating a vein at the margin of the frond.

Tr. V. HYMENOPHYLLEAE.

16. Trichomanes. Capsules on a long filiform receptacle within a cupshaped involucre of the same texture with the frond.

17. Hymenophyllum. Capsules on a narrow subclavate receptacle within a two-valved involucre of the same texture with the frond.

** Capsules without an elastic ring.

Suborder III. OSMUNDACEA.

Vernation circinate. Rachis woody. Capsules regularly 2 valved, stalked, in clusters at the extremity of the frond. 


\section{Tr. VI. OSMUNDEAE.}

18. Osmunda. Capsules clustered, arranged in a branched spike terminating the frond.

\section{Suborder IV. OPHIOGLOSSACEE.}

Vernation straight. Rachis succulent. Capsules regularly 2-valved, sessile, in clusters on a separate branch of the frond.

Tr. VII. OPHIOGLOSSEAE.

19. Botrychium. Capsules distinct, disposed in a compound spike attached to a pinnate or bipinnate frond.

20. Ophioglossum. Capsules connate, disposed in a simple distichous spike attached to an undivided frond.

\section{Suborder I. Polypodiacea. Tribe I. Polypodiea.}

\section{i. Allosonus Bernh. Rock-brake.}

1. A. crispus (Bernh.) ; barren fronds 2-3-pinnate, leaflets wedgeshaped or linear-oblong often bifid at the end, leaflets of the fertile fronds oblong.-N. 103. Pteris Sm., E. B. 1160. Cryptogramma R. Br., Hook.-Fertile frond nearly triangular. Veins alternate, often forked and each branch ending in a cluster having no indusium but concealed by the reflexed edge of the leaflet. Height $6-12$ in. St. slender, very brittle. - Stony places on mountains. P. VII.

\section{Polypodium Linn. Polypody.}

* Clusters at the end of a veinlet, other veinlets knobbed at the end and not reaching the edge. CTENopteris Newm.

1. P.vulgare (L.); fronds deeply pinnatifid, lobes linear-oblong somewhat serrate all parallel upper ones gradually smaller. $-E . B .1149$. N. 111.-Rhizome brown, densely sealy, creeping. Fronds strapshaped. Clusters large, on the upper part of the frond. Lateral veins of the pinnæ with 4 branches. Pinnæ occasionally bifid at the end, sometimes deeply serrate or even $(P$. cambricum L.) doubly pinnatifid.-Shady banks, walls and old trees. P. VIII.-X. Common Polypody.

** Veinlets not knobbed but reaching the edge, all usually fertile, clusters near the end of each. Gymnocarpium Newm.

2. P.? Phegopteris (L.) ; fronds pinnate, pinnæ linear-lanceo- 
late united at the base pinnatifid with linear-oblong blunt lobes, lowest pair of pinnce turned downwards and forwards the rest upwards, clusters marginal.-E. B. 2224. N. 115.- Rhizome nearly black, wiry, slightly scaly, creeping extensively. Fronds triangular. Pinnæ very acute, pointing upwards, rather hairy, connected by their whole width with the rachis; lowest pair quite distinct, with a minute stalk, standing forwards and pointing from the others.-Roth (Fl. Germ. iii. 73) found an evanescent indusium, which no other person appears to have seen.Damp places, loving the spray of waterfalls. P. VII.-IX.

3. P.? Dryopteris (L.); fronds ternate glabrous, divisions pinnate, pinnæ pinnatifid blunt uppermost nearly entire, clusters marginal.-E. B.616. N. 123.-Rhizome black, wiry, creeping, slightly scaly. Stalk slender, brittle. The three divisions of the frond loosely spreading, the middle one rather the largest. Vernation resembling 3 little balls on wires. Not at all glandular. -Shady mountainous places. P. VI. VII.

4. P.? Robertianum (Hoffm.); fronds triangular subternate glandular-mealy, lower branches pinnate, pinnæ pinnatifid blunt uppermost nearly entire, clusters marginal. $-P$. calcareum Sm., E.B. 1525. N.131.-More erect and rigid than the preceding, always covered with very minute stalked glands giving a mealy character to the surface. Frond scarcely 3-fid, the lower branches being much smaller in proportion to the middle one; all the 3 erect, rigid. - On broken limestone ground. P. VII. VIII.

E.

\section{Woodsia $R$. Br.}

1. W. ilvensis (R. Br.) ; frond lanceolate or oblong pinnate hairy beneath. $-N .137$ and 147.- Our plants seem to me to form only one species although they present three different appearances, viz.- - a. ilvensis; fronds lanceolate, pinnæ oblong deeply lobed or pinnatifid blunt, lobes ovate crenate. $W$. ilvensis E. B. S. 2616 . In the continental plant the pinnæ are narrowed from the base and rather acute. $-\beta$. gracilis; frond linear-lanceolate, pinnæ triangular pinnatifid, lobes $5-9$ oval entire or the lowest crenate. W. hyperborea E. B. 2023, Tausch! Pol. hyp. $\beta$. gracile Wahl. $\rightarrow \gamma$. alpina; fronds oblong, pinnæ triangular-oval lobed, lobes $3-5$ rounded very blunt. Pol. hyperboreum Wahl. Acrost. alpinum Bolt. t. 42.-A very small plant; fronds $1-3$ in. long, hairy and scaly. Rhizome tufted. - Exposed alpine rocks, very rare. a. Glyder-Fawr, N. Wales. Falcon Clints, Teesdale, Durham. $\beta$. Ben Lawers. Mr. Dickson! $\gamma$. Ben Lawers. Mr. W. Wilson! Clogwyn y Garnedd, Snowdon. P. VII. E. S. 


\section{Tribe II. Aspidiea.}

\section{Lastrea Presl.}

1. L. Thelypteris (Presl); fronds pinnate, pinnæ linear-lanceolate pinnatifid slightly downy but without glands, lobes oblong, clusters submarginal.-Aspidium Sm., $N$. 183.-Fronds lanceolate; earlier barren with flat lobes; later fertile with revoluteedged lobes; 2 or 3 lowest pairs of pinnæ decreasing in size. Lateral veins alternate, forked, extending to the edge. Clusters at length confluent, midway between the midrib and edge. Rhizome creeping.-Marshy and boggy places. P. VII. VIII. Marsh Fern.

2. L. Oreopteris (Presl); fronds pinnate, pinnæ linear-lanceolate pinnatifid glandular beneath gradually decreasing from about the middle of the frond to near the root, lobes oblong flat, clusters marginal.-Aspidium Sm., E.B. 1019. N. 187.Fronds remarkably narrowed downwards, rising in a circle from a tufted rhizome, fragrant when bruised from their glandular under surface. Lobes blunt, entire; lateral veins simple or forked. Height $2-3$ feet. The indusium is often scarcely distinguishable.-Mountain heaths. P. VII. Sweet Mountain Fern.

3. L. Filix-mas (Presl); fronds subbipinnute, pinnæ linearlanceolate, pinnules oblong blunt or acutish serrate not spinulose subconfluent, lowest distinct, clusters near the mid-vein, lateral veins forked.-Aspidium Sm., E. B. 1458. N. 198.-Fronds only slightly narrowed downwards and the lowest leaflet of considerable size, rising in a circle from a tufted rhizome. Stipes and rachis nearly glabrous, yellow, or densely clothed with purple scales. Indusium very persistent, convex, with no marginal glands. Height $2-4$ feet.- $a$; pinnules crowded linear-oblong very blunt slightly confluent broad-based adpressed-serrate. $-\beta$. affinis; pinnules less crowded longer acutish narrow and often slightly auricled at their base, teeth patent lower ones notched. $-\gamma$. abbreviata (DC.); clusters near the base of the confluent crowded very blunt pinnules, about $1 \mathrm{ft}$. high.-Woods and banks. $\gamma$. Cumberland. Yorkshire. Wyck, Glouc. Glen Isla, Forfar. P. VI. VII. Male Fern.

4. L. cristata (Presl); fronds linear-lanceolate subbipinnate, pinnæ short triangular-oblong pinnatifid, pinnules serrate the lowermost lobed and almost pinnatifid, lateral veins of the lobes with several branches. -Aspidium Sm., E. B. 2125. N. 203.Height about 2 feet. Fronds long and narrow, quite erect, from a tufted rhizome. Stipes very loug, with scattered large brownish blunt scales. Indusium persistent, without marginal glands.- 
B. L. uliginosa (Newm.); pinnules of fertile fronds oblong pointed deeply lobed somewhat aristate-serrate, lowest sometimes scarcely decurrent. The barren and later fertile fronds resemble $L$. cristata; the earlier fertile $L$. spinulosa. The lateral veins of the lobes are much less branched than in $L$. cristata. I am very imperfectly acquainted with this plant, and know of no good character by which to distinguish it from $L$. cristata or L. spinulosa : it may perhaps connect them.-Bogs and boggy heaths. Norfolk. Notts. Cheshire. P. VIII. E.

5. L. spinulosa (Presl); fronds linear-lanceolate bipinnate, pinnules oblong incise-pinnatifid, segments serrate spinose-mucronate, indusium persistent without marginal glands, stipes clothed with broad roundish concolorous scales.-Aspidium Sm. L. spinosa N. 209.-Fronds nearly erect; the lowest pinnæ equalling those that follow. Clusters mostly in 2 rows.-Marshy places and wet woods. P. VIII. IX.

6. L. rigida (Presl); fronds triangular-lanceolate bipinnate glandular, pinnules oblong blunt lobed and serrate, segments 2-5-toothed not spinulose, lateral veins 3-fid, indusium persistent fringed, stipes clothed with long pointed concolorous scales. -Aspidium Hook., E. B. S. 2724. N. 191.-Fronds erect, lanceolate with the lower pinnæ rather short and triangular, or triangular with the lower pinnæ long; upper pinnæ narrow; all pinnate. Pinnules truncate below with a narrow attachment. Stipes short, scaly. Covered with minute stalked glands. Height 1-2 feet.-Ingleborough, Arnside Knot, and near Settle. P. VII. VIII.

E.

7. L. dilatata (Presl); frond ovate-lanceolate bipinnate, pinnules pinnate or pinnatifid, segments acutely serrate spinose-mucronate, indusium with marginal stalked glands, stipes clothed with long pointed scales with a dark centre and diaphanous margin.-Aspidium Sm. L. multiflora N.215.-Fronds arched, often drooping, convex; the lowest pinnæ shorter than the following; more or less clothed with stalked glands when young. Fronds of young or starved plants often triangular, of older and perfect ones never. Clusters scattered. The largest scales of the fullgrown plant should be examined. $-\beta$. L. collina (Newm.); frond lanceolate, pinnules ovate blunt bluntly mucronate-serrate. $N$. 223. - $\gamma$. L. glandulosa (Newm.) ; frond broadly lanceolate covered with stalked glands beneath, scales of stipes "without the dark centre." L. maculata Deak. Fl. Brit. f. 1612.-Woods, banks, \&c. $\beta$. Westmoreland. P. VIII. IX.

8. L. Fonisecii (Wats.); frond triangular bipinnate, pinnules pinnate or pinnatifid, segments serrate spinose-mucronate, indusium jagged at the edge, stipes clothed with long narrow laciniate concolorous scales. - Nephrodium Fœnisecii Lowe! L. re- 
curva N. 225.-Frond long, triangular, concave above ; the lower pinnæ much the largest. A smaller plant than the two preceding. Sweet-scented.-Damp places. P. VIII. IX.

\section{Polystichum Roth.}

1. P. Lonchitis (Roth); fronds rigid linear simply pinnate, pinnæ not lobed serrate spinous their base auricled above oblique below.-N.163. Aspidium Sm., E. B. 797.-Stipes very short. Fronds narrow, very rigid and leathery. Pinnæ overlapping and twisted (most in the Irish, much less so in the Welsh plant), lower ones usually auricled both above and below.-Young and simple pinnate fronds of the next species are often distinguished from this with difficulty.-Alpine rocks. P. VII. Holly-fern.

2. P. aculeatum (Roth); fronds rigid linear or lanceolate bipinnate, pinnules obliquely decurrent acute.-N. 169. A. lobatum Kunze. A. aculeatum and A. lobatum $\mathrm{Sm}$.- Stipes usually short. First upper pinnule of each pinna longer than the others, its lower side (next the main rachis) usually nearly straight, its upper acutely auricled and forming an acute angle with the lower and with the partial rachis at the point of attachment. In young plants the pinnæ are serrate or pinnatifid or with one or more pinnules distinct. A few of the lowest pinnules are often slightly stalked, but very differently from those of $P$. angulare.- $\beta$. A. lobatum ( $\mathbf{S m}$.$) ; pinnæ less divided than in the type of the species$ and the fronds linear-lanceolate and more rigid.-Hedge-banks. P. VII. VIII.

3. P. ungulare (Newm.); fronds lax drooping lanceolate bipinnate, pinnules truncate below distinctly stalked bluntish. $-\mathrm{N}$. 173. Aspidium Sm., E. B. S. 2776. A. aculeatum Kunze.Stipes usually long. First upper pinnule scarcely longer than the others, its lower side rounded below, its upper with a large bluntish auricle and forming an obtuse angle with the lower at the top of the short stalk which is nearly at right angles with the partial rachis, similar or rather more deeply serrate than the others; all short, broad and bluntish ; or first upper pinnule deeply pinnatifid, all more acute; or pinnules all narrower and acute. - Sheltered woods and hedge-banks, chiefly in the west. P. VII. VIII.

\section{Cystopteris Bernh. Bladder-fern.}

1. C. fragilis (Bernh.); frond lanceolate bipinnate, pinnæ ovate or ovate-lanceolate, pinnules oblong-ovate rather narrowed below acute or bluntish pinnatifid or cut serrated.-Clusters rarely confluent. Pinnæ rather wedgeshaped at their base. "Sporules echinate." - a. C. anthriscifolia (Roth); pinnules 
ovate acute cut, segments oblong toothed. Cystea fragilis $\mathrm{Sm}$., N.155. C. angustata E. B.S. 2790 ? - B. C. cynapifolia (Roth); pinnules obovate cut, segments obovate toothed or retuse at the end. C. fragilis E. B. 1587. $-\gamma$. C. angustata $(\mathrm{Sm}$.$) ; pinnules$ lanceolate acute cut, segments lanceolate-oblong cut, teeth acute. N.156. C. regia Roth.-The varieties are intimately connected. -Rocks and walls. $\gamma$. Craven and N. Wales. P. VII.

2. C. dentata (Sm.); frond lanceolate bipinnate, pinnæ ovate or ovate-lanceolate, pinnules cordate-ovate or ovate blunt broad below bluntly toothed or rarely pinnatifid.-E. B. 1588 (bad). N. 154. C. fragilis Roth.-Clusters more marginal than in the preceding species, ultimately confluent. Pinuæ of young fronds reflexed. In well-grown plants the pinnæ are suddenly widened to their full extent just above their narrow stalklike base. "Sporules verrucate."-C. Dickieana (Sim, S. 22.) which has overlapping pinnæ, broad blunt pinnules, and scattered clusters, is a form of this plant found in a damp cave near Aberdeen.Rocks and walls. Breadalbane Mountains and Cumberland. P. VII. E. S:

[C. alpina (Desv.); frond lanceolate bipinnate, pinnæ ovate, pinnules ovate deeply pinnatifid with broadly and shortly linear segments partly cloven and slightly toothed at the end.-E. B. 163. - Fronds very much divided, but compact and close.-On a wall at Low Layton, Essex. P. VII.]

3. C. montana (Link); fronds triangular tripinnate, pinnæ and pinnules spreading, lobes pinnatifid with linear notched segments. -S. 24.-Fronds in shape like those of Polypodium calcareum, small, short, very finely divided.. Lower pair of pinnæ much the largest ; their lower larger than their upper pinnules. Stipes long, slender. Rhizome creeping extensively, black.-Breadalbane and Grampian Mountains. P. VIII. ?

S.

[Onoclea sensibilis is naturalized in one spot near Warrington.]

\section{Pseudathyrium Newm.}

1. P. alpestre (Newm.); fronds lanceolate bipinnate, pinnæ contiguous, pinnules widest at their base acute pinnatifid with serrate lobes. - S. 49.-Fronds suberect. Much like Athyrium Filix-foemina.-High mountain valleys. P. VII. VIII.

S.

2.? P. flexile (Newm.); fronds linear-lanceolate bipinnate, pinna distant, pinnules narrow at their base obovate bluntish serrate. - N. ed. 3. 203.-Fronds much less divided, narrow, spreading horizontally. A doubtful species.-Glen Prosen, Forfarshire. P. VII. VIII. 


\section{Tribe III. Aspleniece.}

\section{8. Аthyrium Roth. Lady-fern.}

1. A. Filix-fcemina (Roth); frond lanceolate pinnate or pinnatifid, pinnæ linear, pinnules linear-oblong deeply serrate or pinnatifid.-a. A. convexum (Newm.); frond bipinnate, pinnules toothed narrowly triangular-lanceolate convex remote not connected toothed, upper ones minute confluent, clusters ultimately confluent. N. 245. A. rhoticum Roth. Pinnules long, narrow, with deflexed edges, inclosing the clusters; their attachment broad; segments gradually decreasing from the base of pinnule. $-\beta$. A. Filix-fcemina (Roth); frond bipinnate, pinnules pinnatifid oblong-lanceolate bluntish flat remote not connected, seg. ments oblong patent with lateral and terminal sharp teeth. N.237. Frond much divided, dark green. Pinnules much narrowed at their base. Clusters distinct. A. latifolium (Bab.) is apparently only an extreme state of this. $-\gamma$. A. molle (Roth); frond pinnate, pinnules toothed oblong blunt or slightly pointed flat remote all connected by wing of midrib or lower ones distinct, segments ovate bidentate lowest with 3 uppermost with 1 tooth. N. 245. Frond scarcely more than pinnate, bright green. Pinnules attached by a broad decurrent base. Clusters distinct, in 2 rows. Sometimes ( $A$. trifidum Roth ?) the pinnules are nuch less connected, moderately cut, have a narrow attachment, and lobes with more but connivent teeth.-Wet shady places. P. VI. VII.

2. A. fontanum (Presl); frond linear-lanceolate bipinnate, pinnæ oblong-ovate, pinnules obovate-cuneate with few spinosemucronate teeth.-E. B. 2024.-Fronds about 4 in. long. This plant does not associate well with the genus. - Formerly on Amersham church, Bucks. Above Wybourn, Westmoreland, Hudson. Between Tan y Bwlch and Tremadoc, Merionethshire. Ashford, Hants. P. VI.-IX.

E.

\section{Asplentum Linn. Spleenwort.}

* Ultimate subdivisions with a distinct midvein. Asplenium Newm.

1. A. lanceolatum (Huds.); fronds lanceolate bipinnate, pinnules ovate deeply and sharply toothed or lobed, clusters short nearly marginal.-E. B. 240. N. 249.-Fronds sometimes nearly linear and simply pinnate, always narrowed at the base. Clusters oblong, ultimately rather confluent into roundish masses. Rocks and walls, rather rare. P. VI.-IX.

2.? A. acutum (Bory); fronds long-triangular repeatedly di- 
vided much shorter than the stipes, pinnæ and pinnules lanceolateattenuate, ultimate subdivisions very acute, clusters long. $-N$. ed. 3. 231.-I have no acquaintance with this plant.-Southwest of Ireland, plentiful. P. VI.-IX.

I.

3. A. Adiantum-nigrum (L.); fronds ovate-triangular twice or thrice pinnate about as long as the stipes, pinnæ and pinnules triangular, ultimate subdivisions blunt sharply toothed, clusters long central.-E.B. 1950. N. 255.-Clusters 2 or 3 times as long as in the preceding, placed near the midrib and ultimately confluent in oblong masses often covering the whole under surface of the pinnule.-Rocks and walls. P. VI.-IX. Black Spleenwort.

4. A. Trichomanes (L.); frond linear pinnate, pinnæ roundishovate crenate, veins forked below the clusters. - E. B. 576. N. 285.-Rachis black, keeled beneath. Pinnæ scarcely oblique; both edges rounded and crenate except at the base, upper often bluntly auricled below.- $\beta$. A. anceps (Sol.?); pinnæ oblong blunt wedgeshaped below upper edge and end crenate-dentate lower entire. Pinnæ oblique, lower edge nearly straight; lower pinna much the smaller.-A curious variety is occasionally found with its pinnæ deeply but irregularly pinnatifid with linear hotched segments. - Rocks and walls. $\beta$. Killarney. P. V.-X. Common Spleenwort.

5. A. viride (Huds.); fronds linear pinnate, pinnæ roundishovate or rhomboidal crenate, veins simple or forked beyond the sori.-E. B. 2257. N. 281.-Rachis green, not keeled. Sori at length confluent. - Rocks on mountains. P. VI.-X.

6. A. marinum (L.); frond linear simply pinnate, pinnæ stalked ovate or oblong serrate unequal and wergeshaped at the base.E. B. 392. N. 275.-Varying greatly in size. Sori not confluent. -Maritime rocks. P. VI. $-\mathbf{X}$.

** Ultimate subdivisions without a distinct midvein. Amesium Newm.

7. A. Ruta-muraria (L.); fronds bipinnate, pinnules rhomboidwedgeshaped notched or toothed at the end, indusium jagged.E. B. 150. N.261.-Fronds $3-4$ in. long.-Rocks and old walls. P. V.-IX. Wall Rue.

8. A.germanicum (Weiss); fronds simply and alternately pinnate, pinnules narrow-wedgeshaped the lowermost ternate, indusium entire at the edge.-N.265. A. alternifolium Sm., E. B. 2258.-Fronds 3-4 in.long. - Rocks, very rare. P. VI.-IX.-S.

9. A. septentrionale (Hull); fronds 2- or 3-cleft, segments elongate-lanceolate bifid.-E. B. 1017. N.269.-Segments of 
the fronds very narrow, narrowing gradually downwards, with 1 or 2 short bifid lateral teeth, and bifid at the end.-Dry clefts of rocks, rare. P. VI.-X.

E. S.

\section{Scolopendrium $\mathbf{S} m$. Hart's-tongue.}

1. S. vulgare (Sym.); frond oblong strapshaped smooth simple with a cordate base, stipes shaggy.-E. B. 1150 . Phyllitis N. 289.-Fronds $1-2$ feet long, acute, often crisped and multifid.-Damp shady places. P. VII. VIII.

\section{Ceterach Willd.}

1. C. Officinarum (Willd.); fronds pinnatifid covered beneath with dense scales, pinnæ alternate or opposite obtuse sessile.Notolepum N. 293. Scolopendrium Sm., E. B. 1244.-Fronds $3-6$ in. long, green and smooth above, wholly covered by very many scales beneath, amongst which the thecæ are almost hidden. -Old walls and rocks. P. IV.-X.

\section{Gymnogramma Desv.}

[1. G. leptophylla (Desv.); fronds pinnate or bipinnate glabrous, pinnules wedgeshaped deeply lobed. $-N$. ed. 3.11. S. 48. -Frond 1-4 in. high. Stipes purple. Pinnæ and pinnules alternate.-Banks. Jersey. A. IV.]

\section{Tribe IV. Adiantea.}

\section{Blechnum Linn. Hard-fern.}

1. B. boreale (Sw.); barren fronds pectinate-pinnatifid with broadly-linear rather obtuse pinnæ, fertile frond pinnate with linear acute pinnæ.-E. B. 1159. Lomaria Spicant N. 89.-Each lateral vein of the fertile pinnæ extends half-way to the edge, then turns at right angles and proceeds up the pinna until it reaches the next vein. Capsules attached in a continuous row to the longitudinal portions of the combined lateral veins. Rather a Blechnum than Lomaria. - Stony and heathy places. P. VII.

\section{Pteris Linn. Brakes.}

1. P. aquilina (L.); fronds tripartite, branches bipinnate, pinnules linear-lanceolate the lower ones usually pinnatifid, segments oblong obtuse.-E. B. 1679. N. 93. Eupteris Newm.Fronds annual, $1-5$ feet high, very much divided, with spreading branches. Capsules attached to the marginal vein, lying 
upon a fine membrane and covered by the membranous continuation of the epidermis. Inferior pinnules pinnatifid or sinuate or entire.-Wonds and heaths. P. VII.

\section{Adiantum Linn. Maiden-hair.}

1. A. Capillus-Veneris (L.); frond irregular, branches and roundish-wergeshaped lobed thin pinnules alternate, lobes of the fertile pinnules terminated by a transversely linear-oblong reflexed lobe covering several roundish clusters, sterile lobes serrate.-E. B. 1564. N.83.-Rhizome blackish, shaggy. Fronds 6-12 in. high. Stipes and rachis slender, nearly black. Pinnules not jointed to the partial stalks.-Damp rocks near the sea. P. V.-IX.

Subord. II. Hymenophyllacea. Tr. V. Hymenophyllea.

\section{Trichomanes Linn.}

1. T. radicans (Sw.); frouds 3 or 4 times pinnatifid glabrous, segments uniform linear, involucres solitary in the axils of the upper segments, seta at first included ultimately very prominent. -E. B. 1417. T. speciosum Willd., N. 305.-Fronds rather triangular, very much divided, $4-8$ in. long, formed of hard wiry branched ribs each with a rather membranous wing. Rhizome black, downy, very long. Involucres scarcely winged.ß3. Andrewsii (Newm.); fronds lanceolate, involucres winged. N. 315.-Very damp shady places, rare. Formerly at Bellbank, Yorkshire, from whence I have an old specimen exactly like Bolton's figure t. 30 . South and south-west of Ireland. P. IX. $\mathrm{X}$.

E. I.

\section{Hymenophyllum Sm. Filmy-fern.}

1. H. tunbridgense $(\mathrm{Sm}$.$) ; fronds pinnate, pinnæ distichous,$ segments linear undivided or bifid spinosely-serrate, involucre compressed spinosely serrate, rachis broadly winged.-E.B. 162. N.321.-Slender and delicate. Rhizome very long, threadshaped. Pinnæ, rachis and involucres in the same plane. Valves of the involucre adpressed throughout the greater part of their length, slightly gibbous at the base.-Amongst moss in damp and shady places. P. VII.

2. H. Wilsoni (Hook.); fronds pinnate, pinnæ recurved, segments linear undivided or bifid spinosely-serrate, involucre inflated entire, rachis slightly bordered.-E. B. S. 2686.-Resembling the preceding, but the pinnæ curve backwards and the 
involucres forwards. Valves of the involucre convex or gibbous throughout, touching only by their edges which are quite entire. -Amongst moss in damp and shady places. P. VII.

\section{Suborder III. Osmundacea. Tribe VI. Osmundea.}

18. Osmunda Linn. Flowering-fern.

1. O. regalis $(\mathrm{L}$.); fronds bipinnate, pinnules oblong nearly entire dilated and slightly auricled at the base, clusters panicled terminal.-E. B. 209. N. 331. Fronds erect or drooping, 1-8 feet high.-Boggy places. P. VII.-IX.

Subord. IV. Ophioglossacea. Tr. VII. Ophioglossea.

19. Вотrychium $S w$. Moon-wort.

1. B. Lunaria (Sw.); frond pinnate solitary, pinnæ lunate or fanshaped notched or crenate.-E. B. 318. N. 137.-Height $3-6$ in. Pinnæ with veins radiating from the petiole, sometimes deeply notched. Fronds usually solitary, but sometimes two on the same stalk.-Pastures. P. VI. VII.

[B. rutaceum ( $\mathrm{Sw}$. ); frond triangular-rhomboidal pinnatifid solitary, pinnæ 7-9 linear incise-serrate decreasing upwards. $-N$. ed. 3. 322.-Veins not radiating. The species is doubtful. -Sands of Barry, Forfar. P. VIII.]

\section{Ophioglossum Linn. Adder's-tongue.}

1. O. vulgatum (L.); frond ovate obtuse.-E. B. 108. N. 349. -Height 4-12 in., erect. Spike clubshaped, usually rather longer than the frond, sometimes very long.-Pastures. P.V. VI.

[2.? O. lusitanicum (L.) ; frond linear-lanceolate.-N. ed. 3 . 331. S. 47.- Height l-2 inches, erect.-Petit Bo Bay, Guernsey. Mr. G. Wolsey. P. I.]

\section{Order C. MARSILEACEE.}

Creeping plants with alternate erect leaves having a circinate vernation. Fructification consisting of globular nearly sessile coriaceous bodies with 3 or 4 cells and containing sacs including either other bodies that germinate or loose granules. 
1. Pilularia. Involucres solitary, nearly sessile, globose, coriaceous, 4-celled. Cells containing bodies of two kinds ; granules, and membranes containing minute grains.

\section{Pilularia Linn. Pillwort.}

1. P.globulifera (L.).-E. B.521. N. 393.-Rhizome slender, creeping, producing leaves and roots at regular intervals. L. very slender, erect. Inv. slightly stalked, axillary, nearly spherical, hairy.-Margins of ponds and lakes. P.

\section{Order CI. LYCOPODIACEA.}

Leafy plants with simple imbricated leaves; or stemless with erect subulate leaves. Fructification of axillary sessile capsules with 2 or 3 valves and no ring, including minute powdery matter or sporules.

* Capsules not opening.

1. Isoetes. Fructification inclosed within the swollen base of the leaves. Sporules of two kinds attached to filiform receptacles.

** Capsules bursting.

2. Lycopodrum. Caps. 1-celled, 2-valved, containing powder; or 3-valved, containing $1-4$ granules.

\section{Isoetes Linn. Quillwort.}

1. I. lacustris (L.); 1. subuläte roundish-quadrangular with 4 longitudinal jointed tubes. $-E . B .1084$. N. 381. R. vii. t. 1 . - Rhizome a blunt tuber. L. slender, broad and flat at the base, but elsewhere between cylindrical and quadrangular.-Bottom of lakes and ponds in hilly districts. P. VI.

\section{Lycopodium Linn. Club-moss.}

* Caps. all 1-celled. Sporules like powder. Lycopodium Koch.

1. L. clavatum (L.); 1. scattered incurved with a filamentous point, spikes stalked 2 or 3 together cylindrical, scales ovatetriangular membranous finely incise-serrate.-E. B. 224. N.353. -St. prostrate, long. Branches short, ascending. Spikes on long stalks, pale yellow. Scales on the stalks irregularly disposed in whorls.-Heaths. P. VII. VIII. Common Club-moss.

2. L. annotinum (L.); 1. scattered lanceolate mucronate serrulate, spikes sessile solitary terminal, scales roundish with an 
attenuated point membranous and jagged.-E. B. 1727. N.361. -St. prostrate, long. Branches rather loug, erect, each year's growth marked by a spot where the leaves are adpressed. Spikes cylindrical, greenish-yellow, not persistent.-Stony mountains. Rare in Caernarvonshire and Cumberland. Common in the Highlands of Scotland. P. VIII.

E. S.

3. L. alpinum (L.); $l$. in four rows imbricated acute keeled entire, spikes sessile solitary terminal, scales ovate-lanceolate flat, branches erect clustered forked level-topped.-E. B. 234 . N.365.-St. prostrate, long. Fertile branches usually twice dichotomous, each division ending in a short cylindrical yellowishgreen spike rather thicker than the branch.-Elevated mountains. P. VIII. Savin-leaved Club-moss.

4. L. Selago (L.); $l$. in eight rows crowded uniform linearlanceolate acuminate, caps. not spiked but in the axils of the common leaves, st. erect forked level-topped.-E.B.233. N.375. - St. short, erect or slightly decumbent, densely leafy. No separate spikes. At the extremity of the stems a few curious viviparous buds may usually be found; they are well illustrated by Mr. Newman (p. 378). Occasionally the stems in sheltered situations become much elongated.-Heaths, chiefly on mountains. P. VI.-VIII. Fir Club-moss.

5. L. inundatum (L.) ; l. scattered linear acute turned upwards, spikes terminal sessile leafy solitary upon short erect branches. -E. B. 239. N. 369.- St. short, prostrate, rooting. Branches few, simple, short, erect, fertile.-Boggy heaths. P. VIII. IX.

** Caps. of 2 kinds. Selaginella Koch.

6. L. selaginoides (L.); 1. scattered lanceolate ciliate, spikes terminal solitary sessile leafy upon short erect branches.- $E$. $B$. 1148. N.371. S. spinulosa Koch.--St. prostrate, much branched, rooting, slender. Flowering branches simple, short, erect. In addition to the 2 -valved capsules, this plant produces others which contain 2-4 large grains.-Boggy spots chiefly in mountainous places. P. VIII.

\section{Order CII. CHARACEÆ.}

Leafless branched plants with stems formed of one or more parallel tubes. Two kinds of fructification : round red globules (anthers?) formed of 8 valves, inclosing cells containing granular matter and spiral filaments; oval nucules formed of 1 cell with 5 filaments folded spirally round it and containing minute granules which appear at last to unite into a single seed.-Plants green, aquatic.-The position of this Order is very doubtful, and 
opinions are various concerning its structure. It is placed here simply from convenience.

1. Chara. The only genus.

\section{Chara Linn.}

I. Nitella Ag.- Orown of nucule of 10 cells forming 2 circles lying upon each other, never spreading, generally falling off before the seed is ripe. Stems more or less pellucid, composed of one tube.

i. Nitella. Globules terminal at the forks of the branchlets.

* Branchlets only once divided into 1-jointed segments, 6-8 in a whorl, similar.

1. C. flexilis (L.) ; monœcious, st. slender equal flexible transparent, branchlets pointed not mucronate nearly equally forked or trifid, nucules and globules together in the forks of the branchlets without bracts.-E. B. 1070. Atl. Fl. Par. 40 C.Rather slender, green, pellucid. Primary branches seldum more than once divided. Sometimes the axillary branchlets are much more divided and clustered (C. nidifica of collectors). Nucules with 6 striæ.-Ditches. P. V.

2. C. syncarpa (Thuil.); diœcious, st. slender equal flexible transparent, branchlets bluntish apiculate nearly equally forked or trifid, nucules or globules at the forks of the branchlets without bracts. - Atl. Fl. Par. 39 (not good).-Slender, diaphanous, resembling $C$. flexilis. Nucules with 5 striæ and scarcely any crown.- Stagnant water. Sussex ; Cambridgeshire ; Caernarvonshire. Galway. A. V.

E. I.

** Branchlets usually repeatedly divided, terminal segments of 2 joints, last joint usually like a mucro. Branchlets $6-8$ in a whorl, similar.

3. C. translucens (Pers.); monœcious, st. thick equal flexible transparent, sterile branchlets simple not jointed, upper ones ending in 2 or 3 short points, fertile whorls of small trifurcate branchlets very small and closely placed, nucules small oblong usually in threes just below the 3 bracts surrounding the terminal globule.-E. B. 1855. Atl. Fl. Par. 40 B.-Strong. Fertile whorls appearing capitate. Globules solitary. Nucules with 7 striæ.-Deep stagnant pools. A. VII.

4. C. mucronata (A. Br.); monœcious, st. slender equal flexible transparent, branchlets strongly mucronate nearly equally forked or trifid, nucules and globules together at the forks of the 
branchlets without bracts.-Atl. Fl. Par. 40 D.-Rather thick. Secondary branchlets once or twice forked, terminal subdivisions rather shorter than the others. "Nucules with 4 or 5 striæ." Marsh ditch, W. Grinstead, Suss. Mr. Borrer. A. VII. E.

5. C. gracilis (Sm.); monceious, st. slender equal flexible transparent, branchlets in lax whorls repeatedly divided into 3 or 4 segments, terminal segments mucronate shorter than the others, globules and nucules each solitary but together at the subdivisions of the branchlets without bracts.-E.B.2140. R.I. 793. Atl. Fl. Par. 41 E.-Small, slender, branching in a lax open manner. Nucules subglobose, with 4 or 5 striæ, large in proportion to the plant.-St. Leonard's Forest, Suss. Mr. Borrer. A. IX.

E.

6. C. tenuissima (Desv.); monœcious, st. slender equal flexible transparent, branchlets short in dense compact subglobose whorls repeatedly divided into $3-7$ segments, terminal segments mucronate longer than the others, globules and nucules each solitary but together at the subdivisions of the branchlets without bracts. -R. I. 792. Atl. Fl. Par. 41 E. - Very small and slender. Branchlets very much divided, forming little globose compact masses which are often much incrusted. Nucules subglobose, with $6-8$ strix, minute but 3 times the diameter of the branchlets and placed outside of them. Globules much larger than the nucules.-Peaty ditches. Cambridgeshire. A. VII. VIII. E.

ii. Tolypella. Globules lateral on the joinings of the chief ray of the branchlets between the lateral rays (bracts) which are always shorter than the chief ray.-Rays of many decreasing joints.

7. C. Smithii (Bab.); diœcious, st. slender equal flexible transparent, branchlets blunt those forming the primary whorls simple sterile long jointed (?), others on axillary branches many densely crowded baving 3 short and 1 long bract at their first joining, globules stalked subtended by the 3 shorter bracts, nucules unknown. - C. nidifica Sm. (not Müll.), E. B. 1703 (principal figure).-Small. Branchlets in bird's-nest-like masses, springing from the axils of the simple branchlets of the primary whorl. -Lancing, Sussex. Mrr. Borrer. A. IX.?

E.

8. C. prolifera (A. Br.); monœcious, st. slender equal flexible transparent, branchlets blunt those forming the primary whorls simple sterile long usually of 3 or 4 joints, others on axillary branches many densely crowded bearing 3 short and 1 long bract at their first joining, globules sessile in company with one or more nucules and subtended by the 3 shorter bracts.-Small. Like the preceding. Nucules small, faintly striate. Granules 
sessile (?). The presence of true bracts distinguishes this species, C. Borreri, and C. Smithii from C. polysperma and C. flexilis.-Ditches. Cley, Norfolk. Copford, Essex. A. IV.

E.

9. C. Borreri (Bab.); monœcious, st. slender equal flexible transparent, branchlets strongly mucronate those of the primary whorls simple sterile long jointed, others on axillary branches many densely crowded bearing 3 short and 1 long bract at their first and sometimes second joining, globules stalked or sessile in company with several nucules and subtended by the 3 shorter bracts.-C. nidifica Borr., E. B. S. fol. 2/62, note. See A. N. H. ser. 2. v. 87.- Like but larger than Nos. 7 and 8 . Branchlets suddenly contracted below the acute apiculus. Larger "bract" occasionally bearing a cluster of bracts.-Marsh ditch, Henfield, Sussex. Mr. Borrer. A. VII.

10. C. polysperma (A. Br.); monœeious, st. slender equal flexible transparent, barren and fertile branchlets of the primary whorls once or twice unequally branched, middle branch longest, branchlets of axillary branches many densely crowded much subdivided into short joints mostly finely pointed, nucules and globules placed at the joinings of the branchlets between the lateral rays.-Small. Branches with 2 or 3 ascending branchlets, often again branched, at their first joining; often but not always there is a simple branchlet beneath and at right angles to the main branch at that point. Globules stalked, directed downwards, few. Nucules clustered, sessile, directed upwards.Running water. Bury St. Edmonds. Cambridge. Dublin. A. IV.

E. I.

II. Chara Ag.-Crown of the nucule of 5 cells forming a single circle, sometimes spreading, persistent. Stems usually coated with smaller tubes.-Granule taking the place of one of the bracts. A double row of spines at the base of each whorl.

* Stem coated with as many tubes as there are branchlets in each whorl.-Branchlets coated.

11. C. crinita (Wallr.); diœcious, st. slender coarsely striated thickly beset with setaceous patent clustered spines, branchlets abbreviated, bracts whorled slender equal, nucules narrowly oblong shorter than the bracts.-Wallr. Ann. Bot. t. 3.-Slender. St. erect, flexible, smooth, densely crowded, slightly branched, pale green. Whorls of $8-10$ short branchlets, each of 7 joints with 6 bracts at each joining. Nucules solitary with 13 strix and a prominent crown.-Stagnant brackish pools. Burdoch Pool, Falmouth, Cornwall. Rev.W. L. P. Garnons. A. VIII. 
** Stem coated with twice as many tubes as there are branchlets in each whorl, those opposite to the branchlets bearing spines or tubercles, the others not.

12. C. vulgaris (L. ?); monœcious, st. scabrous finely striate brittle, upper part of the branchlets without external tubes, bracts only on the inner side of the branchlets, four long, two $2-4$ times as long as the nucules, two equalling them.-E. B. 336 . C. foetida A. Br., Atl. Fl. Par. 37. - Diffuse, usually incrusted. The spinose or tubercular (primary) cortical tubes less prominent than the secondary ones, collapsing when dry so as to place the spines in furrows. Branchlets seeming of one joint. Nucules with 13 striæ and a short crown, with the globule.-Ditches and streams. A. VI.-VIII.

13. C. hispida (L.); monœcious, st. thickened upwards spirally sulcate rough brittle with setaceous spines, branchlets long, bracts whorled (inner ones longer), nucules ovate shorter than the bracts solitary with a globule.-E. B. 436 . Atl. Fl. Par. $38 \mathrm{~B}$. -Opaque, greenish-white, usually incrusted. St. covered with minute tubercles; spines very many, sometimes few, upon the depressed primary tubes. Branches long, acuminate, of 7 joints, with $4-5$ short bracts at each joining.-Ditches and pits. A. V.-VIII.

14. C. tomentosa (L.); diœcious (?), st. thickened upwards spirally sulcate rough brittle with scattered obtuse papilla, branchlets incurved, bracts unilateral ovate-oblong mucronateacute, nucule shorter than the bract on each side of it longer than the three in front.-C. latifolia Willd., Hook. Icon. 532.Opaque, whitish-green. St. covered with minute tubercles; papillæ distant, rather whorled, short, blunt, on the prominent primary tubes.-Belvidere Lake, Westmeath, Ireland. A.VII.?-I.

\section{*** Stem coated with 3 times as many tubes as there are branchlets in each whorl, two rows of secondary between each pair of primary tubes on which latter alone the spines or tubercles are placed.}

15. C. aspera (W.); diœcious, st. finely striate smooth flexible with setaceous patent spines, branchlets short, bracts whorled slender (2 inner longer), nucules narrowly oblong shorter than the bracts. - E. B. S.2738:-Not opaque, pale green. St. densely crowded; spines scattered, often very short, or irregularly whorled. Branchlets $6-9$ in a whorl, of 7 joints, $4-5$ bracts at each joining.- Nucules solitary, striæ 12 or 13 , crown prominent.-Stagnant water. A. VIII.

16. C. fragilis (Desv.); monœcious, st. slender finely striate u 2 
smooth not spinous, last 1-3 joints of branchlets without external tubes, bracts on the inner side of the branchlets about as long as or longer than the oblong nucules.-Atl.Fl.Par. 38 C. C. Hedwigii $E . B . S .2762$. C. pulchella $E$. B. S.2824.-Slender, green and remaining so through the winter, not incrusted. Nucule with 13 or 14 striæ and a long crown, with the globule. Bracts usually shorter than the nucules, one equalling them; or all longer.-Stagnant water. A. VI.--VIII.

E.

"Quanquam multas observaverim plantas et sedulo quidem, tamen non confido me semper veritatem invenisse." - LINK, Philos. Bot. iv.

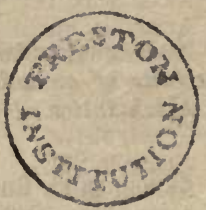




\title{
ALPHABETICAL INDEX
}

\author{
or \\ THE ORDERS AND GENERA.
}

* * The names in italics are synonymous.

Acanthus, 249.

Acer, 62.

Aceraceæ, 62.

Aceras, 319.

Achillea, 175.

Achyrophorus, 192.

Acinos, 256.

Aconitum, 12.

Acorus, 348.

Actæa, 12.

Actinocarpus, 345 .

Adiantum, 428.

Adonis, 5.

Adoxa, 152.

Egopodium, 141.

Ethusa, 145.

Agraphis, 335.

Agrimonia, 91.

Agropyrum, 411.

Agrostemma, 48.

Agrostis, 395.

Agrostis, 394.

Aira, 397.

Aira, 397, 399.

Airopsis, 398.

Ajuga, 263.

Albucea, 331.

Alchemilia, 92.

Alisma, 345 .

Alisma, 345.

Alismaceæ, 344.

Alliaria, 26.

Allium, 332.

Allosorus, 419.

Alnus, 308.

Alopecurus, 391. Alsinanthe, 51 .

Alsine, 50.

Alsine 48.

Althæa, 58.

Alyssum, 28.
Alyssum, 28.

Amaranthaceæ, 273.

Amaranthus, 274.

Amaryllidaceæ, 326.

Ambrosiaceæ, 208.

Amentiferæ, 296.

Amesium, 426.

Ammophila, 394.

Amygdaleæ, 89.

Anacamptis, 318.

Anacharis, 313.

Anacyclus, 175 .

Anagallis, 268.

Anchusa, 228.

Anđ̆romeda, 213.

Androscemum, 59.

Anemagrostis, 394.

Anemone, 4.

Angelica, 146.

Antennaria, 180.

Anthemis, 174.

Anthericum, 331.

Anthoxanthum, 390.

Anthriscus, 149.

Anthyllis, 80.

Antirrhinum, 240.

Antirrhinum, 240.

Apargia, 192.

Apera, 394 .

Aphanes, 92.

Apium, 140.

A pocynaceæ, 219.

Aquifoliaceæ, 218.

Aquilegia, 12.

Arabis, 23.

Araceæ, 348.

Aracium, 198.

Araliaceæ, $15 i$.

Arbutus, 213.

Arbutus, 213.

Archangelica, 146.
Arctium, 184.

Arctostaphylos, 213.

Arenaria, 52.

Arenaria, 51, 124.

Aristolochia, 288.

Aristolochiaceæ, 288.

Armeria, 271.

Armoracia, 30.

Arnoseris, 191.

Arrhenatherum, 399.

Artemisia, 177.

Arthrolobium, 86 .

Arum, 348.

Arundo, 394.

Asarum, 289.

Asparagacex, $32 \%$.

Asparagus, 328.

Asperugo, 227.

Asperula, 155.

Aspidium, 421-423.

Asplenium, 425 .

Aster, 171.

Astragalus, 81 .

Astragalus, 81.

Astrantia, 139.

Athamanta, 145.

Athyrium, 425.

Atriplex, 278.

Atriplex, 280.

Atropa, 233.

Atropeæ, 233.

Avena, 398.

Avena, 398.

Azalea, 216.

Baothryon, 361.

Baldingera, 378.

Ballota, 261.

Balsaminaceæ, 67 .

Barbarea, 22.

Barkhausia, 196.

Bartsia, 244. 
Bartsia, 244, 246. Batrachium, 5.

Bellis, 172.

Berberidaceæ, 13.

Berberis, 13.

Berula, 142.

Beta, 277.

Betonica, 260.

Betula, 307.

Bidens, 173.

Blechnum, 427.

Blysmus, 362.

Boraginaceæ, 226.

Borago, 228.

Botrychium, 429.

Brachypodium, 4]l.

Brassica, 26.

Breea, 189.

Briza, 405.

Bromus, 408.

Bromus, 409, 410.

Bryonia, 121.

Bucetum, 407.

Buffonia, 48.

Bunium, 142.

Bupleurum, 143.

Butomus, 346.

Buxus, 290.

Cakile, 34 .

Calamagrostis, 394 .

Calamintha, 255.

Callitrirhaceæ, 293.

Callitriche, 293.

Calluna, 214.

Caltha, 11.

Calycifloræ, 68.

Calystegia, 224.

Camelina, 30.

Campanula, 209.

Campanula, 211.

Campanulaceæ, 208.

Caprifoliacere, 153.

Capsella, 33.

Cardamine, 24.

Carduus, 188.

Carduus, 190.

Carex, 364.

Carlina, 184.

Carpinus, 309.

Carum, 141.

Carum, 142.

Caryophyllaceæ, 42.
Castanea, 309.

Catabrosa, 405.

Caucalis, 148.

Celastraceæ, 68.

Centaurea, 185.

Centranthus, 160 .

Centunculus, 269.

Cephalanthera, 323.

Cerastium, 54 .

Cerastium, 54.

Cerasus, 90.

Ceratophyllaceæ, 293.

Ceratophyllum, 293.

Ceterach, 427 .

Chærophyllum, 150.

Charophyllum, 149.

Chamayrostis, 389.

Chara, 432.

Characeæ, 431.

Cheiranthus, 21.

Cheiranthus, 27.

Chelidoniım, 16.

Chenopodiaceæ, 274.

Chenopodium, 275.

Chenopodium, 275.

Cherleria, 51.

Chlora, 221.

Chrysanthemum, 176.

Chrysocoma, 172.

Chrysosplenium, 133.

Cicendia, 222.

Cichorium, 191.

Cicuta, 140,

Cineraria, 183.

Circrea, 119.

Cirsium, 188.

Cistaceæ, 35 .

Cistus, 35, 36.

Cladium, 358.

Clematis, 3.

Clinopodium, 256.

Cnicus, 188.

Cnidium, 146.

Cochlearia, 29.

Cochlearia, 30.

Coeloglossum, 319.

Colchicaceæ, 335.

Colchicum, 336.

Comarum, 94.

Compositæ, 163.

Coniferæ, 309.

Conium, 150.
Conringia, 25.

Convallaria, 328 .

Convallaria, 328.

Convolvulaceæ, 224.

Convolvulus, 224.

Conyza, 172.

Corallorhiza, 323.

Coreopsis, 174.

Coriandrum, 151.

Cornaceæ, 152.

Cornus, 152.

Corollifloræ, 153.

Corrigiola, 123.

Corydalis, 16.

Corylus, 309.

Corynephorus, 397.

Cotoneaster, 113.

Cotyledon, 128.

Cracca, 82.

Crambe, 34 .

Crassulaceæ, 125.

Cratæegus, 113.

Crepis, 196.

Crithmum, 146.

Crocus, 325.

Cruciferæ, 18.

Cryptogameæ, 414.

Cryptogramma, 419.

Ctenopteris, 419.

Cucubalus, 44.

Cucurbitaceæ, 121.

Cuscuta, 225.

Cyclamen, 267.

Cynodon, 389.

Cynoglossum, 228.

Cynosurus, 406.

Cyperaceæ, 356.

Cyperus, 357 .

Cypripedium, 324 .

Cystea, 424.

Cystopteris, 423.

Cytisus, 73.

Dabeocia, 215.

Dactylis, 406.

Damasonium, 345.

Daphne, 287.

Datura, 234.

Daucus, 148.

Delphinium, 12.

Dentaria, 24.

Deschampsia, 397.

Dianthus, 44. 
Dicotyledones, 1.

Dictyogenæ, 311 .

Digitalis, 240.

Digitaria, 388.

Dioscoreaceæ, 311 .

Diotis, 176.

Diplotaxis, 27.

Dipsacaceæ, 162.

Dipsacus, 162.

Doronicum, 181.

Draba, 28.

Drosera, 39.

Droseraceæ, 39.

Dryas, 109.

Ductulosæ, 414.

Echinochloa, 388.

Echinophora, 150.

Echinospermum, 227.

Echium, 229.

Elæagnaceæ, 286.

Elatinaceæ, 41.

Elatine, 42.

Eleocharis, 358.

Eleogiton, 361.

Elodes, 61.

Elymus, 413.

Elymus, 413.

Empetraceæ, 289.

Empetrum, 289.

Endymion, 335.

Epilobium, 116.

Epimedium, 13.

Epipactis, 322.

Epipactis, 323.

Epipogium, 323.

Equisetaceæ, 414.

Equisetum, 414.

Eranthis, 11.

Erica, 214.

Ericacex, 211.

Erigeron, 171 .

Eriocaulaceæ, 336.

Eriocaulon, 337.

Eriophorum, 363.

Erodium, 65.

Ervum, 81.

Eryngium, 139.

Erysimum, 26.

Erythræa, 221.

Eufragia, 245.

Euonymus, 69.

Eupatorium, 170.
Euphorbia, 290.

Euphorbiaceæ, 289.

Euphrasia, 245.

Eupteris, 427.

Exacum, 222.

Fagopyrum, 286.

Fagus, 309.

Fagus, 309.

Farsetia, 28.

Fedia, 161 .

Festuca, 406.

Filago, 178.

Filices, 417.

Floridæ, 312.

Fœniculum, 145.

Fragaria, 95.

Frankenia, 41.

Frankeniaceæ, 41.

Fraxinus, 219.

Fritillaria, 330 .

Fumaria, 17.

Fumariaceæ, 16.

Gagea, 332 .

Galanthus, $32 \overline{7}$.

Galeobdolon, 259.

Galeopsis, 259.

Galium, 156.

Gastridium, 396.

Genista, 72.

Gentiana, 222.

Gentianaceæ, 220.

Geraniaceæ, 62.

Geranium, 62.

Geum, 109.

Glaucium, 16.

Glaux, 269.

Glechoma, 257.

Glumiferæ, 356.

Glyceria, 403.

Glyceria, 404.

Gnaphalium, 179.

Gnaphalium, 178, 179, 180.

Goodyera, 320 .

Gramineæ, 381.

Grossulariaceæ, 128.

Gymnadenia, 318.

Gymnocarpium, 419 .

Gymnogramma, 427.

Gymnospermæ, 309.

Gypsocallis, 215.

Habenaria, 319.
Habenaria, 318.

Haloragaceæ, 120.

Haloscias, 145.

Hedera, 152.

Helianthemum, 35 .

Helleborus, 12.

Helminthia, 194.

Helosciadium, 141.

Heracleum, 147.

Herminium, 320.

Herniaria, 123.

Hesperis, 25.

Hieracium, 198.

Hieracium, 197, 198.

Hierochloe, 390.

Himantoglossum, 318.

Hippocrepis, 86.

Hippophaë, 287.

Hippuris, 120.

Holcus, 396.

Holcus, 399.

Holoschœenus, 362.

Holosteum, 52.

Honkeneja, 50.

Hordeum, 413.

Hottonia, 267.

Humulus, 295.

Hutchinsia, 31 .

Hyacinthus, 335.

Hydrocharidaceæ, 312 .

Hydrocharis, 312.

Hydrocotyle, 139.

Hymenophyllaceæ, 418.

Hymenophyllum, 428.

IHyoscyamus, 233.

Hypericaceæ, 59.

Hypericum, 59.

Hypochœris, 191.

Hypopitys, 218.

Iberis, 31 .

Ilex, 218.

Illecebrum, 123.

Impatiens, 67.

Inula, 172.

Inula, 173.

Iridaceæ, 324.

Iris, 325 .

Isatis, 33.

Isnardia, 119.

Isoetes, 430 .

Isolepis, 362. 
Jasione, 209.

Juncaceæ, 337. Juncus, 338.

Juniperus, 310 .

Knappia, 389.

Knautia, 163.

Kobresia, 364.

Kœleria, 399.

Koniga, 28.

Labiatæ, 219.

Lactuca, 194.

Lagurus, 396.

Lamium, 258.

Lapsana, 191.

Lapsana, 191.

Larbrea, 54.

Lastrea, 421.

Lathræa, 237.

Lathyrus, 84 .

Lavatera, 58.

Leersia, 393.

Leguminosæ, 69.

Lemna, 349.

Lemnaceæ, 349.

Lentibulariaceæ, 264.

Leontodon, 195.

Leontodon, 192.

Leonurus, 259.

Lepidium, 32.

Lepigonum, 124.

Lepturus, 413.

Leucojum, 327.

Ligusticum, 145.

Ligustrum, 219.

Liliaceæ, 329.

I.ilium, 331.

Limnanthemum, 223.

Limosella, 243.

Linaceæ, 66.

Linaria, 240.

Linnæa, 155.

Linosyris, 172.

Linum, 66.

Liparis, 324 .

Listera, 321.

Listera, 321.

Lithospermum, 230.

Lithospermum, 230.

Littorella, 273.

Lloydia, 331.

Lobelia, 209.

Lolium, 412.
Lomaria, 427.

Lonicera, 154.

Loranthaceæ, 153.

Lotus, 79.

Luzula, 342.

Lychnis, 47.

Lycopodiaceæ, 430.

Lycopodium, 430.

Lycopsis, 228.

Lycopus, 254.

- Lysimachia, 268.

Lythracex, 115.

Lythrum, 115.

Maianthemum, 328.

Malachium, 54 .

Malaxis, 323.

Malaxis, 324.

Malcolmia, 25.

Malva, 57.

Malvaceæ, 56.

Marrubium, 262.

Marsileaceæ, 429.

Maruta, 174.

Matricaria, 177.

Matthiola, 21.

Meconopsis, 15 .

Medicago, 74.

Melampyrum, 243.

Melica, 400.

Melilotus, 75.

Melissa, 256.

Melittis, 253.

Mentha, 252.

Menyanthes, 223.

Menziesia, 215.

Mercurialis, 292.

Mertensia, 230.

Mespilus, 113.

Meum, 146.

Meum, 145.

Mibora, 389.

Microcala, 222.

Milium, 393.

Mimulus, 244.

Moehringia, 51.

Moenchia, 54 .

Molinia, 400.

Moneses, 217.

Monochlamydex, 273. Orobanchacex, 234.

Monocotyledones, 311 . Orobus, 82,86 .

Monotropa, 218.

Monotropeæ, 213.
Montia, 121.

Mulgedium, 196.

Muscari, 335.

Myosurus, 5 .

Myrica, $30 \%$.

Myriophyllum, 120.

Myrrhis, 150.

Myrrhis, 150.

Naiadaceæ, 355 .

Naias, 356.

Narcissus, 326.

Nardus, 393.

Narthecium, 337.

Nasturtium, 22.

Nasturtium, 30.

Neottia, 321.

Neottia, 321.

Nepeta, 257.

Nephrodium, 423.

Nitella, 432.

Notolepum, 427.

Nuphar, 14.

Nymphæa, 14.

Nymphracer, 13.

Obione, 280.

Odontites, 246.

Enanthe, 143.

Enothera, 119.

Oleaceæ, 218.

Onagraceæ, 116.

Onobrychis, 87.

Onoclea, 424.

Ononis, 73.

Onopordum, 187.

Ophioglossaceæ, 419.

Ophioglossum, 429.

Ophrys, 319.

Oplismenus, 388.

Oporinia, 192.

Orchidaceæ, 313.

Orchis, 316.

Orchis, 318, 319.

Origanum, 255.

Ornithogalum, 331.

Ornithogalum, 332.

Ornithopus, 86.

Orobanche, 234.

Osmunda, 429.

Osmundaceæ, 418.
Myosotis, 230. 
Oxalidaceæ, 67. Oxalis, 67.

Oxycoccus, 216.

Oxyria, 283.

Oxytropis, 80.

Pæonia, 13.

Panicum, 388.

Papaver, 15.

Papaveraceæ, 14.

Parietaria, 294.

Paris, 311.

Parnassia, 40.

Paronychiaceæ, 122.

Pastinaca, 147.

Pedicularis, 244.

Peplis, 115.

Peristylus, 318, 319.

Petasites, 170.

Petroselinum, 140.

Peucedanum, 147.

Phalaris, 389.

Phelipcea, 236.

Phleum, 390.

Phragmites, 393.

Phyllitis, 427.

Phyllodoce, 215.

Physospermum, 151.

Phyteuma, 209.

Picris, 193.

Pilularia, 430.

Pimpinella, 142.

Pimpinella, 140.

Pinguicula, 264.

Pinus, 310.

Pisum, 85.

Plantaginaceæ, 271.

Plantago, 272.

Platanthera, 319.

Plumbaginaceæ, 270.

Poa, 400 .

Poa, 407.

Polemoniaceæ, 223.

Polemonium, 224.

Polycarpon, 124.

Polygala, 40.

Polygalaceæ, 40.

Polygonaceæ, 280.

Polygonatum, 328.

Polygonum, 283.

Polygonum, 286.

Polypodiaceæ, 417.

Polypodium, 419.
Polypogon, 396.

Polystichum, 423.

Populus, 306.

Portulaceæ, 121.

Potamogeton, 350.

Potamogetonaceæ, 349 .

Potentilla, 93.

Poterium, 91.

Prenanthes, 194.

Primula, 266.

Primulaceæ, 265.

Prunella, 257.

Prunus, 89.

Psamma, 394.

Pseudathyrium, 424.

Pteris, 427.

Pteris, 419.

Pulegium, 254.

Pulicaria, 173.

Pulmonaria, 229.

Pyrola, 217.

Pyrola, 217.

Pyroleæ, 212.

Pyrus, 114.

Quercus, 308.

Radiola, 66.

Ranunculaceæ, 1.

Ranunculus, 5 .

Raphanus, 34 .

Reseda, 34 .

Resedaceæ, 34 .

Rhamnaceæ, 69.

Rhamnus, 69.

Rhinanthus, 244.

Rhodiola, 126.

Rhynchospora, 358.

Rhytispermum, 230.

Ribes, 128.

Robertsonia, 129.

Roemeria, 16.

Rosa, 110.

Rosaceæ, 87.

Roseæ, 90.

Rottboellia, 413.

Rubia, 159.

Rubiaceæ, 155.

Rubus, 95.

Rumex, 281.

Ruppia, 355.

Ruscus, 329.

Sagina, 49.

Sagittaria, 345.
Salicornia, 277.

Salix, 297.

Salsola, 275.

Salsola, 275.

Salvia, 254.

Sambucus, 154.

Samolus, 269.

Sanguisorba, 91.

Sanicula, 139.

Santalaceæ, 287.

Saponaria, 45.

Sarothamnus, 73.

Saussurea, 183.

Saxifraga, 129.

Saxifragaceæ, 129.

Scabiosa, 163.

Scandix, 149.

Schedonorus, 407, 408.

Scheuchzeria, 346.

Schoberia, 275.

Schœnus, 358.

Scilla, 332.

Scilla, 335.

Scirpus, 359.

Scirpus, 362.

Scleranthus, 124.

Sclerochloa, 404.

Scolopendrium, 427.

Scolopendrium, 427.

Scrophularia, 242.

Scrophulariaceæ, 237.

Scutellaria, 257.

Sedum, 126.

Selaginella, 431.

Selinum, 147.

Sempervivum, 127.

Senebiera, 33.

Senecio, 181.

Serrafalcus, 409.

Serratula, 185.

Serratula, 184.

Seseli, 145.

Sesleria, 392.

Setaria, 388.

Sherardia, 155.

Sibbaldia, 92 .

Sibthorpia, 246.

Silaus, 146.

Silene, 45.

Sileneæ, 44.

Silybum, 190.

Simethis, 335 . 
Sinapis, 27.

Sinapis, 27, 28.

Sison, 141.

Sison, 140.

Sisymbrium, 25.

Sisymbrium, 26.

Sisyrinchium, 325.

Sium, 142.

Sium, 141.

Smyrnium, 151.

Solanaceæ, 232.

Solanum, 233.

Solidago, 172.

Sonchus, 195.

Sonchus, 196.

Soyera, 198.

Sparganium, 347.

Spartina, 389.

Spartium, 73.

Spatularia, 130.

Specularia, 211.

Spergella, 50.

Spergula, 124.

Spergula, 50.

Spiræa, 90.

Spiranthes, 321.

S sirodela, 349.

Stachys, 260.

Staphylea, 68.

Statice, 270.

Statice, 271.

Stellaria, 52.

Stellaria, 56.

Stenhammaria, 230.

Stipa, 393.

Stratiotes, 313.

Sturmia, 324.

Sturmia, 389.

Suæda, 275.

Subularia, 33.
Swertia, 223.

Symphytum, 229.

Tamariscaceæ, 115.

Tamarix, 116.

Tamus, 312.

Tanacetum, 178.

Taraxacum, 195.

Taxus, 310.

Teesdalia, 31 .

Telmatophace, 349.

Teucrium, 262.

Thalamifloræ, 1 .

Thalictrum, 3.

Thesium, 288.

Thlaspi, 30.

Thlaspi, 33.

Thrincia, 192.

Thymelaceæ, 287.

Thymus, 255.

Thymus, 255, 256.

Tilia, 58.

Tiliaceæ, 58.

Tillæa, 125.

Tofieldia, 336.

Tordylium, 147.

Torilis, 148.

Tormentilla, 94.

Tragopogon, 193.

Trichomanes, 428 .

Trichonema, 325.

Trientalis, 269.

Trifolium, 75.

Triglochin, -346 .

Trigonella, 78 .

Trilliaceæ, 311.

Trinia, 140.

Triodia, 399.

Tripolium, 171.

Trisetum, 398.

Triticum, 411.
Triticum, 405.

Trollius, 11.

Tulipa, 330.

Turgenia, 148.

Turritis, 23.

Tussilago, 170.

Tussilago, 170.

Typha, 347.

Typhaceæ, 346 .

Ulex, 72.

Ulmaceæ, 295.

Ulmus, 295.

Umbelliferæ, 133.

Urtica, 295.

Urticaceæ, 294.

Utricularia, 265.

Vaccinieæ, 212.

Vaccinium, 216.

Valeriana, 160.

Valeriana, 160.

Valerianaceæ, 159.

Valerianella, 161.

Vella, 30.

Verbascum, 238.

Verbena, 264.

Verbenaceæ, 263.

Veronica, 246.

Viburnum, 154.

Vicia, 81.

Villarsia, 223.

Vinca, 219.

Viola, 36.

Violaceæ, 36.

Viscum, 153.

Vulpia, 406.

Wahlenbergia, 211.

Woodsia, 420.

Xauthium, 208.

Zannichellia, 355.

Zostera, 355. 


\section{N D E X}

TO THE

\section{POPULAR ENGLISH NAMES.}

Abele, 307.

Aconite, 11.

Adder's-tongue, 429.

Alder, 308.

Alexanders, 151.

Alkanet, 228.

Anemone, 4.

Archangel, 259.

Arrow-grass, 346.

Arrow-head, 345 .

Asarabacca, 289.

Ash, 219.

Aspen, 307.

Asphodel, 336, 337.

Avens, 109.

Awl-wort, 33.

Bald-money, 146.

Balm, 256.

Balm, bastard, 258.

Balsam, 67.

Bane-berry, 12.

Barberry, 13.

Barley, 413.

Barren Strawberry, 94.

Barren-wort, 13.

Basil, 256.

Bastard Pimpernel, 269.

Bed-straw, 156.

Beech, 308.

Beet, 277.

Bell-flower, 209, 211.

Bent-grass, 395.

Betony, 261.

Bilberry, 216.

Bindweed, 224.

Birch, 307.

Bird-cherry, 90.

Bird's-foot, 79, 86.

Bird's-nest, 321.
Bird's-nest, yellow, 218.

Birthwort, 288.

Bitter-cress, 24.

Bitter-sweet, 233.

Black Saltwort, 269.

Black-thorn, 89.

Bladder-nut, 68.

Bladder-wort, 265.

Blue-bell, 335.

Blue-bottle, 186.

Bog Asphodel, 337.

Bog-rush, 358.

Borage, 228.

Box, 290.

Brakes, 427.

Brakes, rock, 419.

Bramble, 95 .

Brooklime, 247.

Brookweed, 269.

Broom, 73.

Broom-rape, 234.

Bryony, red, 121.

Bryony, black, 312.

Buckbean, 223.

Buckthorn, 69.

Buck-wheat, 286.

Bugle, 263.

Bugloss, 228.

Bugloss, Viper's, 229.

Bullace, 89.

Bull Rush, 361.

Burdock, 184.

Burnet, 91.

Burnet-Saxifrage, 142.

Bur-reed, 347.

Butcher's Broom, 329.

Butter-bur, 170.

Butterwort, 264.

Cabbage, 26.
Calamint, 255.

Campion, 46, 47.

Canary-grass, 389.

Candy-tuft, 31 .

Caraway, 141.

Carrot, 148.

Catchfly, 45.

Cat-mint, 257.

Cat's-tail-grass, 390.

Celandine, 16.

Celery, 140.

Centaury, 221.

Chamomile, 174, 175.

Chamomile, corn, 174 .

Chamomile, wild, 177.

Charlock, 27.

Charlock, jointed, 34 .

Cherry, 90.

Chervil, 149, 150.

Chestnut, 308.

Chickweed, 53.

Chickweed, water, 54.

Chicory, 191.

Chives, 334 .

Cicely, 150.

Cinque-foil, 93.

Clary, 254.

Cleavers, 157.

Cloud-berry, 108.

Clover, 75.

Club-moss, 430.

Club-rush, 359.

Cock's-foot-grass, 406.

Cole-seed, 27.

Coltsfoot, 170.

Columbine, 12.

Comfrey, 229.

Coralwort, 24.

Coriander, 151.

Corn Cockle, 48. 
Corn Marigold, 176.

Corn Salad, 161.

Cotton-grass, 363.

Cotton-thistle, 187.

Couch-grass, 411.

Cowbane, 140.

Cowberry, 216.

Cow-parsnep, 147.

Cowslip, 267.

Cow-wheat, 243.

Crab tree, 114.

Cranberry, 216.

Crane's-bill, 62.

Crested Hair-grass, 399.

Crosswort, 156.

Crowberry, 289.

Crowfoot, 5, 9, 10, 11.

Cuckon-pint, 348.

Cudweed, 178.

Currant, 128.

Daffodil, 327.

Daisy, 172.

Dame's Violet, 25.

Dandelion, 195.

Danewort, 154.

Darnel, 413.

Dead-nettle, 258.

Deadly Nightshade, 233.

Devil's-bit, 163.

Dock, 281.

Dodder, 225.

Dog Rose, 112.

Dog's-tail-grass, 406.

Dog-wood, 152.

Dropwort, 91.

Duckweed, 349 .

Dwale, 233.

Dyer's-weed, 73.

Dyer's-woad, 33.

Elder, 154.

Elecampane, 172.

Elm, 295.

Enchanter's Nightshade, 119.

Eryngo, 139.

Evening Primrose,119.

Eye-bright, 245.

Feather-grass, 393.

Fennel, 145.

Fern, Bladder, 424.
Fern, Holly, 423.

Fern, Lady, 425.

Fern, Male, 422.

Fern, Marsh, 421.

Fern, Mountain, 421.

Fescue-grass, 406.

Feverfew, 177.

Figwort, 242.

Filmy-fern, 428.

Fir, 310.

Flag, 325.

Flax, 66.

Flax-seed, 66.

Fleabane, 171, 173.

Flixweed, 25.

Flote-grass, 403.

Flowering-fern, 429.

Flowering-rush, 346.

Fools' Parsley, 145.

Forget-me-not, 231.

Foxglove, 240.

Fox-tail-grass, 391.

Fritillary, 330 .

Frog-bit, 312.

Fumitory, 17.

Furze, 72.

Gale, 307.

Galingale, $35 \%$.

Garlic, 332.

Gentian, 222.

Germander, 262.

Gipsy-wort, 254.

Glasswort; 277.

Globe-flower, 11.

Goat's-beard, 193.

Gold-of-pleasure, 30.

Golden Rod, 172.

Golden Samphire, 173.

Golden Saxifrage, 133.

Goldilocks, 10.

Gooseberry, 128.

Goose-foot, 275.

Goose-grass, 157.

Gorse, 72.

Gout-weed, 141.

Grape Hyacinth, 335.

Grass-wrack, 355.

Gromwell, 230.

Ground-ivy, 258.

Ground Pine, 263.

Groundsel, 181.

Guelder-rose, 154.
Hairbell, 210.

Hair-grass, 397.

Hammersedge, 379 .

Hare's-ear, 143.

Hare's-foot, 76 .

Hare's-tail-grass, 396.

Hart's-tongue, 427 .

Hawkbit, 192.

Hawkweed, 198.

Hawk's-beard, 106.

Hawthorn, 113.

Hazel, 309.

Heartsease, 39.

Heath, 214, 216.

Heath-grass, 399.

Hedge Mustard, 25.

Hedge Parsley, 148.

Hellebore, 12.

Hemlock, 150.

Hemp Agrimony, 170.

Hemp-nettle, 259.

Henbane, 233.

Henbit, 258.

Hen's-foot, 148.

Herb Paris, 311.

Hog-weed, 147.

Holly, 218.

Holy-grass, 390.

Honewort, 141.

Honeysuckle, 154.

Hop, 295.

Horehound, 261.

Horehound, white, 262.

Hornbeam, 309.

Horned Pondweed, 355.

Horned Poppy, 16.

Hornwort, 293.

Horse-radish, 30

Horseshoe Vetch, 86.

Horse-tail, 414.

Hound's-tongue, 228.

Houseleek, 127.

Ivy, 152.

Jack-by-the-hedge, 26.

Jacob's Ladder, 224.

Juniper, 310 .

Knapweed, 185.

Knot-grass, 285.

Lady's Fingers, 80.

Lady's Mantle, 92.

Lady's Slipper, 324. 
Lady's Tresses, 321. Lamb's Lettuce, 161. Larkspur, 12.

Leopard's-bane, 181. Lettuce, 194.

\section{Lily, 331.}

Lily of the Valley, 328. Lime tree, 58. Ling, 214.

Live-long, 126.

London Pride, 129.

London Rocket, 25.

Loosestrife, 268.

Loosestrife, purple, 115.

Louse-wort, 244.

Lovage, 145.

Lucerne, 74.

Lungwort, 229.

Madder, 159.

Madwort, 227.

Maiden-hair, 428.

Mallow, 57.

Maple, 62.

Mare's-tail, 120.

Marjoram, 255.

Marram, 394.

Marsh Mallow, 58.

Marsh Marigold, 11.

Masterwort, 147.

Mat-grass, 393.

Meadow-grass, 400.

Meadow Rue, 3.

Meadow Saffron, 336.

Meadow-sweet, 90.

Medick, 74.

Medlar, 113.

Melic, 400.

Melilot, 75.

Mercury, 292.

Mezereon, 287.

Mignonette, 34 .

Milfoil, 120.

Milk Thistle, 190.

Milk-vetch, 81.

Milkwort, 40.

Millefoil, 176.

Millet-grass, 393.

Mint, 252.

Mistletoe, 153.

Money-wort, 268.

Monk's-hood, 12.
Monk's Rhubarb, 283. Pillwort, 430.

Moonwort, 429.

Moor-grass, 392.

Moschatel, 152.

Motherwort, 259.

Mountain Ash, 114.

Mountain Sorrel, 283.

Mountain Spignel, 145.

Mouse-ear, 54.

Mousetail, 5.

Mudwort, 243.

Mugwort, 178.

Mullein, 238.

Mustard, 27.

Navelwort, 128.

Navew, 26.

Needle Whin, 73.

Nettle, 295.

Nightshade, 233.

Nightshade, Enchanter's, 119.

Nipplewort, 191.

Oak, 308.

Oat, 398.

Oat-grass, 399 .

Orache, 278.

Orchis, 316, 319, 320.

Orpine, 126.

Osier, 300.

Ox-eye, 176.

Oxlip, 267.

Ox-tongue, 194.

Pæony, 13.

Paigle, 267.

Pansey, 39.

Parsley, 140.

Parsley Piert, 92.

Parsnep, 147.

Pasque-flower, 4.

Pea, 86.

Pear tree, 114.

Pearlwort, 49.

Pelletory, 294.

Penny cress, 30.

Penny-royal, 254.

Penny-wort, 139.

Pepper-wort, 32.

Periwinkle, 219.

Pheasant's-eye, 5.

Pig-nut, 142.

Pilewort, 10.
Pimpernel, 268.

Pink, 44.

Pipewort, 337.

Plantain, 272.

Plowman's Spikenard, 172.

Plum, 90.

Polypody, 419.

Pond-weed, 350.

Poplar, 306.

Poppy, 15.

Primrose, 266.

Privet, 219.!

Purslane, sea, 280.

Purslane, water, 115.

Quaking-grass, 405.

Quillwort, 430.

Radish, 34.

Ragged Robin, 48.

Ragwort, 181.

Rampions, 209, 211.

Ramsons, 335.

Rape, 27.

Raspberry, 95.

Red Bryony, 121.

Red Rattle, 244.

Reed, 393.

Reed-mace, 347.

Rest-harrow, 73.

Ribwort, 273.

Rock-brake, 419.

Rock-cress, 23.

Rock-rose, 35.

Rocket, 22.

Rose, 110.

Rose-bay, 117.

Rose-root, 126.

Rowan-tree, 114.

Rush, 338.

Rye-grass, 412.

Saffron, 326.

Sage, 254.

Saintfoin, 87.

Sallow, 301 .

Salsify, 193.

Saltwort, 275.

Samphire, 146.

Sandwort, 52.

Sanicle, 139.

Sauce-alone, 26.

Saw-wort, 185. 
Saxifrage, 129.

Scabious, 163.

Scorpion-grass, 230.

Scottish Asphodel,336.

Scurvy-grass, 29.

Sea Blite, 275.

Sea Buckthorn, 287.

Sea Heath, 41.

Sea Holly, 140.

Sea-kale, 34 .

Sea Lavender, 270.

Sea Pea, 86.

Sea Pimpernel, 50.

Sea Purslane, 280.

Sea Radish, 34 .

Sea-rocket, 34 .

Sedge, 358.

Self-heal, 257.

Service tree, 114.

Sheep's Scabious, 209.

Shepherd's Needle, 149.

Shepherd's Purse, 33.

Shore-weed, 273.

Silver-weed, 93.

Skull-cap, 257.

Sloe, 89.

Small-reed, 394.

Snakeweed, 283.

Snapdragon, 240.

Sneezewort, 175.

Snowdrop, 327.

Snowflake, 327.

Soapwort, 45.

Soft-grass, 396.

Solomon's Seal, 328.

Sorrel, 283.

Sorrel, mountain, 283.

Sorrel, wood, 67 .

Sow-bread, 267.

Sowthistle, 195.

Spearwort, 9.

Speedwell, 246.

Spindle-tree, 69.

Spleenwort, 426.
Spurge, 290.

Spurrey, 124.

Squill, 332.

St. John's-wort, 59.

St. Patrick's Cabbage, 129.

Star of Bethlehem, 331.

Star-thistle, 187.

Starwort, 171.

Stitchwort, 52, 53.

Stock, 21.

Stonecrop, 126.

Storksbill, 65 .

Strawberry, 95 .

Strawberry, barren,94.

Stra wberry tree, 213.

Succory, 191.

Sundew, 39.

Sweet Briar, 112.

Sweet-flag, 348.

Sycamore, 62.

Tamarisk, 116.

Tansy, 178.

Tares, 81 .

Teasel, 162.

Thistle, 188.

Thorn-apple, 234.

Thorow-wax, 143.

Thrift, 271.

Thrumwort, 345 .

Thyme, 255.

Timothy-grass, 391.

Toad-flax, 240, 242.

Toothwort, 237.

Tower-wort, 23.

Traveller's-joy, 3 .

Tree-mallow, 58.

Trefoil, 76, 79 .

Tulip, 330.

Turk's-cap Lily, 331.

Turnip, 26.

Tutsan, 60.

Tway-blade, 321.

Valerian, 160.

Vernal-grass, 390.
Vervain, 264.

Vetch, 81 .

Vetchling, 84.

Violet, 36 .

Wallflower, 21.

Wall Mustard, 27.

Wall Pepper, 127.

Wall Rue, 426.

Wart-cress, 33.

Water Chickweed, 54.

Water Cress, 22.

Water Hemlock, 140.

Water-lily, 14.

Water Milfoil, 120.

Water Pepper, 285.

Water Plantain, 345.

Water Soldier, 313.

Water Starwort, 293.

Water Thyme, 313.

Water-violet, 267.

Water-wort, 42.

Wayfaring trce, 154.

Weld, 35 .

Wheat-grass, 411.

Whin, 72, 73 .

White Beam tree, 114.

Whitlow-grass, 28.

Whortleberry, 216.

Willow, 296.

Willow Herb, 116.

Wind-grass, 394.

Winter-green, 217.

Woad, 33, 73.

Woodbine, 155.

Woodruff, 156.

Wood-rush, 342.

- Wood Sage, 262.

Wood Sorrel, 67.

Worm-seed, 26.

Wormwood, 177.

Woundwort, 260.

Yarrow, 175, 176.

Yellow Rattle, 244.

Yellow-wort, 221.

Yew, 310.

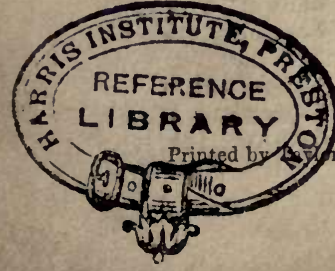

THE END. 


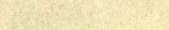

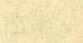





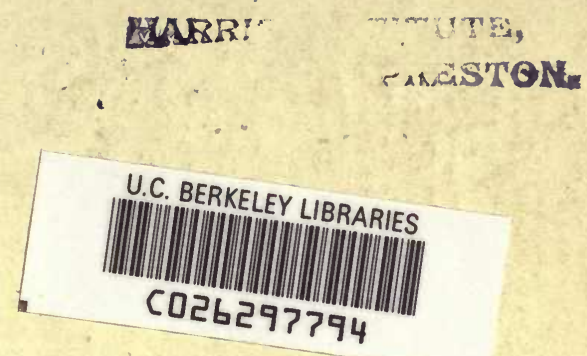


